\title{
LA DOCTRINA DE LOS ACTOS PROPIOS EN EL ÁMBITO CONTRACTUAL
}



TESIS DOCTORAL

\section{LA DOCTRINA \\ DE LOS ACTOS PROPIOS \\ EN EL ÁMBITO CONTRACTUAL}

- SIGNIFICADO Y PROYECCIÓN DE LA REGLA

VENIRE CONTRA FACTUM PROPRIUM NON VALET -

CARLOS IGNACIO JARAMILLO JARAMILLO

DIRIGIDA POR EL PROFESOR

Dr. D. EUGENIO LLAMAS POMBO

UNIVERSIDAD DE SALAMANCA, 2012 



\section{CAPítulo I}

LA DOCTRINA DE LOS ACTOS PROPIOS: CONSIDERACIONES GENERALES

1. SIGNIFICADO GENERAL Y APROXIMACIÓN A LA DOCTRINA

DE LOS ACTOS PROPIOS

3. FUNDAMENTOS GENERALES DE LA DOCTRINA DE LOS

ACTOS PROPIOS

4. FUNDAMENTACIÓN JURÍDICA DE LA DOCTRINA DE LOS ACTOS PROPIOS

5. LA BUENA FE Y SU ESTRECHA RELACIÓN CON LA DOCTRINA DE LOS ACTOS PROPIOS. INFRANQUEABLE LÍMITE AL EJERCICIO DE LOS DERECHOS SUBJETIVOS 
6. BIEN JURÍDICO TUTELADO POR EL DERECHO MEDIANTE LAAPLICACIÓN DE LA DOCTRINA DE LOS ACTOS PROPIOS (RATIO PROTECTIONIS).

7. JUSTIFICACIÓN DE LA PROTECCION BRINDADA Y UTILIDAD GENERAL DE LA DOCTRINA DE LOS ACTOS PROPIOS ......... 100

8. ANTECEDENTES Y EVOLUCIÓN HISTÓRICA 107

8.2.1. Generalidades 108

8.2.2. Derecho romano clásico. Casuística. 111

a) Emancipación: 112

b) Establecimiento de una servidumbre por parte de algunos condóminos:

c) Compra de un fundo ajeno 116

d) Alteración perjudicial del comportamiento previamente observado

8.2.3. Recapitulación

8.2.4. Derecho romano posclásico. Casuística.

8.3.1. Preliminares. 123

8.3.2. Escuela de los Glosadores. 
8.3.3. Escuela de los Comentaristas

8.3.4. Escuela de los Canonistas

8.3.5. Derecho histórico español 126

8.4.1. Preliminares 127

8.4.2. Escuelas Humanista y Clásica del Derecho Natural 128

8.4.3. Contribuciones de DOMAT y POTHIER 130

8.4.4. Aporte de J. SCHACHER 134

8.4.5. Síntesis 135

8.5.1. Preliminares 136

8.5.2. Revolución francesa 136

8.5.3. La codificación y el Derecho civil francés 138

8.5.4. La codificación y el Derecho civil italiano 145

8.5.5. La codificación y el Derecho civil español 148

8.5.6. La codificación y el Derecho civil alemán. Expansión generalizada de la regla venire contra factum proprium 
9. NATURALEZA JURÍDICA, CALIFICACIÓN Y CONFIGURACIÓN DE LA DENOMINADA 'DOCTRINA DE LOS ACTOS PROPIOS'. CARÁCTER ASIGNADO AL BROCARDO VENIRE CONTRA FACTUM PROPRIUM.

10. EXPANSIÓN Y ALCANCE DE LA DOCTRINA. GENERALIZADA PROYECCIÓN DISCIPLINAR, ESPECIALMENTE EN EL ÁMBITO PRECONTRACTUAL Y CONTRACTUAL

CAPítulo II

DELIMITACIÓN DE LA DOCTRINA DE LOS

ACTOS PROPIOS RESPECTO DE ALGUNAS FIGURAS AFINES

1. EL NEGOCIO JURÍDICO, EN GENERAL, Y LA

DECLARACIÓN DE VOLUNTAD, EN PARTICULAR 190

2. LARENUNCIA 202

3. LA BUENA FE 210

4. LA EXCEPCIÓN DE DOLO (EXCEPTIO DOLI GENERALIS)...... 213

5. ABUSO DEL DERECHO 236

5.4.1. Procedencia de oficio 257

5.4.2. Caracterización como principio general 258

5.4.3. La equidad como fundamento cardinal 259 
6. LA PROPIA CULPA O TORPEZA

7. EL ESTOPPEL Y LA VERWIRKUNG

CApítulo III

PRESUPUESTOS, CARACTERES Y EFECTOS DE

LA DOCTRINA DE LOS ACTOS PROPIOS

1. PRESUPUESTOS DE LA DOCTRINA DE LOS ACTOS PROPIOS

2. PRINCIPALES CARACTERÍSTICAS DE LA DOCTRINA DE LOS ACTOS PROPIOS

3. EFECTOS, CONSECUENCIAS Y SECUELAS JURÍDICAS DERIVADAS DE LAAPLICACIÓN DE LA DOCTRINA DE LOS ACTOS PROPIOS

Capitulo IV

PROYECCIÓN DE LA REGLA

VENIRE CONTRA FACTUM PROPRIUM

EN EL DERECHO COMPARADO.

ESPECIAL REFERENCIA AL ESTOPPEL Y A LA VERWIRKUNG 
2. EL ESTOPPEL 355

2.6.1 Estoppel by record 368

2.6.2. Estoppel by deed 369

2.6.3. Estoppel by facts in pais 369

2.6.4. Estoppel by representation 370

2.6.5. Estoppel by delay o Laches. 371

2.6.6. Estoppel by acquiesence 372

2.7.1. Su origen pretoriano 374

2.7.2. Su carácter procesal. 375

2.7.3. Es un medio defensivo y no procede de oficio 376

2.7.4. Es de doble vía y de efectos relativos. 377

2.7.5. Se fundamenta primordialmente en la apariencia jurídica 377

2.7.6. Su 'irradiación' al Derecho internacional 378

2.7.7. Es más limitado que la 'doctrina de los actos propios' 380

3. LA VERWIRKUNG 381 
3.9.1 Se trata de una figura de origen pretoriano 414

3.9.2. Es un instituto que sublima la buena fe y protege la confianza legítima

3.9.3. Entraña la inadmisibilidad del ejercicio de un derecho o, como lo afirma la doctrina mayoritaria, la materialización de un abuso del derecho. 416

3.9.4. Es una figura que difiere de la prescripción 417

3.9.5. No solamente es producto del trascurso del tiempo 417

3.9.6. No se exige una intención inequívoca de perjudicar. 418

3.9.7. Se trata de una institución que puede aplicarse de oficio 418

3.9.8. Se aplica en función del caso particular. 419

3.9.9. Su aplicación, es de doble vía.... 419

3.10. Limitaciones, peligros y cautelas. Somero juicio de pertinencia 420

Capítulo V

RECEPCIÓN NORMATIVA Y JURISPRUDENCIAL DE LA DOCTRINA DE LOS ACTOS PROPIOS. VISIÓN COMPARADA

1. PRELIMINARES Y RECEPCIÓN NORMATIVA EN EL CAMPO INTERNACIONAL 
2. RECEPCIÓN LEGAL Y JURISPRUDENCIAL EN EL CAMPO DE LOS ORDENAMIENTOS JURÍDICOS DE CARÁCTER NACIONAL 


\section{INTRODUCCIÓN}

Previamente a iniciar el examen individual del tema seleccionado, de acentuada significación, vigencia y pertinencia en la esfera jurídica contemporánea, en particular en sede contractual, norte primordial de la presente investigación, cumple poner de manifiesto que, en aras de la concreción, al mismo tiempo que en orden a una presentación panorámica de los principales aspectos que lo caracterizan, realizaremos un estudio descriptivo, esto es una aproximación más global y, de suyo panorámica, a fin de no concentrarnos en puntos que, aun cuando importantes, no se desconoce, resultarían excesivamente específicos, cercenado la posibilidad de hacer un escrutinio más transversal, lo que a nuestro juicio luce más aconsejable, habida cuenta que esta temática, por cierto no muy abordada sistemáticamente como se anotará de nuevo, exige por ello una visión de conjunto, con el propósito de que el cubrimiento temático sea más integral, sin que por ello dejemos de examinar, in concreto, su problemática más aguda y las tensiones que se general a su alrededor.

Expresado de otro modo, nos anima la idea de auscultar los aspectos más relevantes de la doctrina en referencia, a fin de podernos concentrar en ellos de modo más específico, procurando que la investigación en torno a los mismos refleje, en su real dimensión y alcance, su significado; su importancia; su fundamentación y justificación; su etiología y su evolución histórica en el Derecho comparado; su delimitación; sus presupuestos, características y efectos; la proyección más general y envolvente de la regla latina venire contra factum proprium, sus primordiales manifestaciones en la esfera internacional, su recepción normativa y jurisprudencial, entre otros.

Por ello, en obsequio a la concisión, es necesario puntualizar que el objeto de este laborío, reside en un tema de cardinal importancia científica, a fuer que 
palpitante actualidad y utilidad en la praxis, por lo demás, no muy estudiado -o por lo menos agotado- en la literatura jurídica moderna, incluso en la jurisprudencia, obviamente con elocuentes excepciones, cual es el relacionado con la apellidada teoría o 'doctrina de los actos propios', entre otras denominaciones, hija biológica del dominante postulado de la 'buena fe', circunscrito al ámbito negocial, en concreto al contractual, una de sus múltiples manifestaciones, como quiera que su radio de acción es muy amplio, lo que no impide reconocer sus orígenes y ancestros en un acto de la más mínima y genuina lealtad histórica, no siempre presente, puesto que hay casos en que, con diversas envolturas, presentaciones o razonamientos, algunos autores pretenden soslayar el jus sanguinis en relación con la bona fides, como si le fuera extraño, en una concepción completamente autonómica de la figura en cuestión, conforme se examinará en su oportunidad, la que estimamos inconveniente, y la que no puede contar con nuestra adhesión.

Muy por el contrario, abogamos por una postura llamada a intercomunicar la bona fides con la regla del venire contra factum proprium, incluidas todas sus manifestaciones, de suyo variopintas, pero hermanadas por el mismo propósito: el rechazo vehemente y sostenido de la incoherencia y de la contradicción comportamental, detonantes de la lesión de la confianza legítima y racional, materia de celosa y acentuada protección en la hora de ahora.

Es cierto que la doctrina de los actos propios ha sido objeto de referencia en la dogmática, y muy especialmente en la jurisprudencia de las últimas décadas, aun cuando no continúa y menos sistemática y orgánicamente, por cuanto buena parte de las contribuciones doctrinales atañen a aspectos más concretos y, por ende, insulares, que no siempre permiten una visión más panorámica, al mismo tiempo que articulada, la cual resulta fundamental en una materia que, no obstante los avances registrados, está aún en consolidación, como lo señalaremos de nuevo, pero no en 'obra gris', si el símil resulta de recibo, como quiera que es apreciable el terreno recorrido, así falte aún un trecho representativo por recorrer.

De hecho, en algunas naciones europeas y americanas ha comenzado a suscitar un gran interés en el siglo XXI, el que no se había registrado a lo largo de varios siglos, sobre todo a partir de la codificación del Derecho privado en el siglo XIX, la que no fue proclive a su consagración y a su ideario, retrasando por décadas -y en ocasiones por siglos- su recepción más generalizada, hoy 
una realidad en el concierto internacional, felizmente, aunque son diáfanos los antecedentes históricos del rechazo a la incoherencia a lo largo de los diferentes períodos de la historia, como se relata a espacio en el capítulo primero, gracias a los aportes del Derecho romano clásico, posclásico y, sobre todo, en el marco del Derecho medieval, merced a las memorables Escuelas de los Glosadores, Canonistas y Comentaristas.

Dicha importancia, conviene destacarlo por su significado, se ha evidenciado aún en aquellas naciones en las que, en el pasado, despertó más entusiasmo, pero que por disímiles razones se había perdido, el que ahora ha reverdecido, entre otras razones porque de él se están ocupando cada vez más legisladores y jueces: Italia y Francia, en el continente Europeo, son buen ejemplo de lo mencionado, en las que el estudio metódico y más detenido de la buena fe ha sido determinante, pues no obstante contar con normas expresas relacionadas con ella y con resonantes antecedentes, su análisis era episódico y algo general, lo que no deja de ser algo paradójico, v.gr: en Francia, en donde con tanta fuerza se enarboló la bandera de la libertad, de la fraternidad y de la igualdad, que son justamente las que abrazan la dogmática contemporánea de figuras como el venire contra factum proprium. $Y$ en Italia, tan íntimamente conectada con el legendario Derecho romano y con el enriquecido medieval, en donde despuntó.

Todo lo anterior justifica su anticipada y generalizada vigencia en la ciencia del Derecho, no sólo en el terreno del Derecho privado, siempre fecundo, sino también en el Derecho público, en especial en el ámbito del Derecho constitucional, administrativo, laboral, fiscal e internacional, en los que tiene cumplida y solvente aplicación, pues aunque buena parte de su estructura se ha tejido en el sacro telar de los jusprivatistas, no puede desconocerse que día tras día se amplía su radio de acción, en muestra de su dinámica y de su expansión, precisamente por sus efectos bienhechores, percibidos claramente en otras disciplinas, lo que luce muy positivo.

Por consiguiente, esta nueva realidad sirve entonces de acicate para que estudios como el presente, irrumpan en la escena académica, dado que, en honor a la realidad, no en todas las latitudes la doctrina se ha dedicado a su examen sistemático, en lo esencial, como se anticipó. Incluso en naciones como España, en donde se le examinó con vívido entusiasmo por la dogmática en la década 
de los cincuenta y en la de los sesenta, hace un importante número de lustros no se retoma el tema, in globo, con algunas puntuales excepciones, el que no puede entenderse agotado, por encumbrados que sean tales exámenes, como en efecto lo fueron y siguen siendo, ya que es muy conveniente que se ventilen ex novo, con mayor razón cuando se ha expandido tanto en el cosmos jurídico, y cuando los más granados proyectos y anteproyectos comunitarios y nacionales se ocupan del mismo, por primera vez, lo que no puede pasar desapercibido.

Nos referimos, muy especialmente, a los excelsos trabajos de autoría de los autores José Puig Brutau, y Luis Díz-Picazo. He ahí descrito, en tal virtud, uno de los objetivos de esta monografía: reexaminar una temática de penetrante trascendencia ético-jurídica, que antes que fenecida, superada, o agotada, requiere sostenidamente ser analizada, desde diversas perspectivas, por ser activa, y no pétrea, ejercicio que resulta muy conveniente, en especial después de que tales trabajos, de veras iluminantes, afloraran en las décadas del cincuenta y sesenta, respectivamente, sin perjuicio de las primeras incursiones en los albores del siglo XX (1913, Carlos DE HARO). Por ello creemos que el mejor homenaje a tan eruditos exponentes del Derecho privado español, es precisamente el de retomar el hilo de sus visionarias investigaciones, de gran valía en su momento y aún en los tiempos que corren, siempre de obligada consulta, a las que tanto debemos.

En palabras del profesor Compagnucci de CASO, el tema de los actos propios se ha vuelto "...a poner en la 'vitrina' "', como ha sucedido con la buena fe, objeto de un renovado "despertar" (GALLo), luego de un "...largo olvido" (FESTI), expirementando entonces un "...cambio evolutivo de gran relieve" (RINALDI), por ser un "....principio en expansión (MALAURIE y AYNES), entre otras calificaciones y reflexiones más.

En compendio, a emulación de la incidencia del Derecho romano en el medioevo jurídico, hoy podemos hablar, mutatis mutandis, de una 'segunda vida' de la buena fe. De ahí que en consonancia con lo afirmado, algunos aludan a un

Rubén Compagnucci DE CASo, La doctrina de los propios actos y la declaración tácita de voluntad, publicado en La Ley, Buenos Aires, 1985-A, 1000, p. 1. 
típico 'renacimiento' de la doctrina de los actos propios, ${ }^{2}$ sin dejar de reconocer que, en países como España ella ha tenido y sigue teniendo notable cabida y fértil desarrollo, al igual que en Argentina, en donde puede aludirse a una palmaria conciencia de su 'ser' y de su indiscutido reconocimiento en la academia y en el foro. Por eso en ambas naciones ha adquirido un sobresaliente protagonismo; en España, más de índole jurisprudencial, y en Argentina, doctrinal.

III

Nosotros, entonces, sin desconocer su carácter nuclear y su dilatado cubrimiento general, le pasaremos revista desde la perspectiva del contrato, primordialmente, en donde desempeña un papel estelar, más del que, prima facie pareciera, lo que quizá explique la moderada atención -con excepciones- por parte de ciertos jueces y doctrinantes, no así, empero, respecto de lo sucedido en algunas otras naciones, aún del cinturón latinoamericano, en el que su interés es manifiesto y reiterado. Tanto que se enseñorea no sólo en el civil law, sino también en el common law, en muestra de su proyección. Es así como en países como Alemania, España, Francia, Inglaterra, Portugal y Suiza -y más recientemente en Austria, Bélgica, Holanda e Italia, sólo para ubicarnos en el antiguo continente-, y en Argentina, Brasil, Chile, Colombia, Perú y Uruguay, para hacer lo propio en América Latina, se comprueba mayor interés.

El mismo interés se percibe en los Estados Unidos, en Canadá y en Australia, ad exemplum, en los que la figura del estoppel se ha expandido considerablemente. También, en lo pertinente, ha tenido lugar en el Japón, conforme se evidencia de la lectura de diversos y recientes estudios.

Edgardo AlbertI, Doctrina de los actos propios. Presentación, La Ley. Buenos Aires. 1986. p. X, autor que nos recuerda que, por un tiempo apreciable, ella permaneció en el 'ostracismo', y por fuera de los planes de estudio en las Facultades de Derecho, situación para nada distinta de lo acontecido en otras naciones, especialmente de América Latina, en muchas de las cuales, en rigor, no podría hablarse siquiera de un 'renacimiento', sino de un alumbramiento o floración, en sí mismo reciente, eso sí con singular fuerza y dinámica doctrinal y jurisprudencial. Cfr. Anderson SCHREIBER, A prohibiçao de comportamento contradictório. Tutela da confianca e venire contra factum proprium, Renovar, Rio de Janeiro, 2007, p. 125. 
Vivimos entonces, por decirlo así, un momento especial en la esfera jurídica respecto de esta doctrina que, con distintos nombres o manifestaciones, sin desconocer sus singularidades e identidades (venire contra factum proprium, doctrina de los actos propios, estoppel, verwirkung, rechtsverwerking, deber de coherencia, confianza legítima, tu quoque, manos limpias, etc.) persigue la protección de la confianza legítima, impidiendo que la incoherencia y la contradicción comportamentales, lesionen impunemente intereses ajenos, en manifiesta contravía de principios superiores, principalmente el de la buena fe objetiva, estrechamente vinculado y, de paso, vulnerado cuando aflora la incoherencia en mención.

Bienvenido pues su futuro escrutinio sistemático, merced a su paladino objetivo benéfico y arraigada importancia, con mayor razón si se tiene en cuenta su creciente relevancia. Por eso no exageramos al señalar que, efectivamente, como se corroborará a espacio, se trata de una de las instituciones o figuras más pródigas en resultados justicieros, al punto que puede decirse que transpira equidad, lógica y eticidad, claro está aplicada en su justa proporción (remedio), es decir con los límites y salvaguardas que le son consustanciales, como suele suceder en la ciencia jurídica, en donde los excesos o desbordamientos no son de recibo, por potísimas y numerosas razones. Cabida sí, entonces, pero con mesura, esto es ex abundante cautela, lo que no eclipsa, o relativiza su rol, repetimos protagónico, sobre todo en la actualidad en el que funge de típico límite al ejercicio de los derechos subjetivos, con todo lo que ello supone.

\section{IV}

Tal será la relevancia de la doctrina de los actos propios, que de ella no sólo se ocupa la doctrina y la jurisprudencia, sino que el legislador ha comenzado a mostrar especial interés, lo que justifica, de una parte, que en el plano supranacional Convenciones como la de Viena, le hayan reservado un sitial de preferencia. Lo mismo ha tenido lugar en el campo de la principialística internacional, v.gr: los principios de Unidroit, los Principios de Derecho Europeo de Contratos, el Marco Común de Referencia, entre otros. Y también en el terreno de los Anteproyectos de Códigos Civiles de algunas naciones, en concreto de Perú y Argentina, lo cual confirma que la mirada del legislador en el siglo XXI es muy diferente de la que 
otrora tenía, en donde la desconfianza y el celo se asomaban. Otro tanto puede decirse en la órbita judicial, específicamente con la confianza depositada en los jueces, cada vez más creciente, quienes tienen la elevada responsabilidad de aplicar con cautela y prudencia la regla del venire contra factum proprium, en su distintas vertientes, anotación extensiva a la tarea llevada a cabo por árbitros nacionales e internacionales.

Aun cuando no se trata de aventurar opiniones, a juzgar por el desarrollo alcanzado en el terreno de la doctrina de los actos propios, es de presagiar que su futuro será promisorio, obviamente si se procede con la cautela y cuidado necesarios, a fin de no desbordar su genuino cometido. En esta dirección, es de esperar que pueda cumplir una misión de enorme importancia en la esfera de la prevención (remedio preventivo), muy a tono con la mirada que la responsabilidad civil está dándole a la prevención, hasta el punto de que hoy se habla de una arquetípica función preventiva, al lado de las que tradicionalmente cumplía y sigue cumpliendo. Ello hace que en aras de asegurar una relación negocial más transparente, solidaria, coherente, límpida, ética y rodeada por la lealtad y la decencia, pueda acudirse a esta doctrina en procura de la evitación de perjuicios dimanantes del quiebre de la confianza legítima, más allá de que en otro plano, en un momento determinado, pudieran haber sido resarcidos o indemnizados, en cuyo caso esta nueva dimensión puede garantizarle un porvenir más estable y esperanzador, en armonía con el acelerado proceso que se ha iniciado en pos de una más profunda humanización del contrato y de una más patente justicia contractual.

En síntesis, la trascendencia contemporánea de la doctrina de los actos propios luce indiscutida, y su vigencia y proyección futura pareciera 'garantizada', merced a la significación que en el Derecho ha alcanzado, de un parte, la necesidad de que la relación jurídica sea absolutamente límpida y transparente, como decíamos en precedencia, a la par que escoltada por comportamientos probos y no sorpresivos y, por la otra, por el auténtico respeto en torno a los derechos de los demás, seriamente conculcados cuando se erosiona la confianza legítima suscitada (ratio protectionis). Eso explica, a nivel mundial, el vívido 
interés de la doctrina, de la jurisprudencia y, hasta de la propia normatividad internacional y nacional, encaminado a su recepción, aplicación y desarrollo, a lo que se agrega el hecho de que los más modernos proyectos legislativos del siglo XXI, en materia de obligaciones y contratos, expresamente se ocupan de ella, conforme se anticipó.

Por ahora, baste pues con señalar que, gracias a su grandilocuencia y a su talante justiciero, la doctrina de los actos propios -aún en proceso de decantación plena- ha adquirido un escaño privilegiado en el cosmos jurídico universal y a fe que lo preservará, en el entendido que se afianzará aún más en el curso de los próximos decenios, en prueba de la valía que hoy ya tiene y tendrá la conducta propia (factum proprium), considerada en función de los intereses de los demás, en el caso del contrato, de las partes contratantes, quienes deberán observar un comportamiento leal que, trascendiendo del simple e individualista interés personal, fije la atención en el otro extremo de la relación negocial, refractario a las sorpresas, a los cambios inopinados, a la lacerante incoherencia y a la urticante contradicción, antítesis del comportamiento esperado, no por ideal, irreal.

\section{VI}

Finalmente, en lo que dice relación con la metodología y plan seleccionados, hemos estimado de la mayor significación abordar los aspectos más salientes de la 'doctrina de los actos propios', con fundamento en la jurisprudencia, y en la doctrina comparadas, dado que, sobre el particular, hay un valioso material jurídico, tanto europeo, como americano, especialmente, en prueba de que los sistemas del civil law y del common law pueden interesarse, como se han interesado, alrededor de este tema que, al margen de sus diferencias y particularidades, que las tienen, están conectados por un mismo cometido: la estigmatización, de suyo frontal, de la incoherencia, la contradicción, y la incongruencia, percutores del resquebrajamiento de uno de los valores más caros a la humanidad, y al Derecho, en particular: la confianza, sin la cual todo se eclipsa, todo se diluye, todo se marchita.

Por eso, sin quiebres, jueces, autores y ahora legisladores, luchan denodadamente contra ese flagelo comportamental, cual es la transgresión 
mediata de la buena fe objetiva, como principio general y rector de toda la ciencia jurídica, y la vulneración de la referida coherencia y, por reflejo, de la confianza legítima, transfondo de la protección brindada por el ordenamiento.

En este orden de ideas, acudiendo al método deductivo los primeros capítulos se encargan de perfilar la base teórica adecuada para el cabal entendimiento de la doctrina sub examine, a fin de que en los siguientes, con arreglo a las bases sentadas, se puedan analizar puntos y aspectos muy concretos que, de otro modo, quizá no podrían asimilarse cabalmente. No en vano, en el primer capítulo, se analizan temas como los atinentes a la terminología empleada en el Derecho comparado; a los fundamentos generales de la misma, no sólo los jurídicos, sino también los de naturaleza social, filosófica, evangélica y económica, todos enlazados por un mismo denominador: la coherencia; a la buena fe y a su estrecha comunión con la doctrina de los actos propios; al bien jurídico tutelado; a la utilidad de la figura; a sus antecedentes históricos, y a su intrincada naturaleza jurídica.

En el segundo capítulo se aborda uno de los temas más espinosos, consistente en su delimitación con otras figuras afines, entre ellas la del negocio jurídico, en general, y la declaración de voluntad en particular; la renuncia; la buena fe; la excepción de dolo (exceptio doli generalis); el abuso del derecho; la propia culpa y torpeza, y el estoppel y la verwirkung, estas últimas de factura pretoriana.

En el tercer capítulo, se examinan los presupuestos, los numerosos caracteres y los singulares efectos emergentes del acto propio.

En el capítulo cuarto se analiza la proyección de la regla venire contra factum proprium en el Derecho comprado, y muy especialmente las instituciones del estoppel y la verwirkung, sin duda muy arraigadas en algunas latitudes.

Y en el último capítulo se escruta lo atinente a la recepción normativa internacional y jurisprudencial, en el que se hace en estudio comparativo en torno al factum proprium, al término del cual se estructuran dieciocho conclusiones que, en lo basilar, dan cuenta de la esencia de la investigación realizada sobre uno de los más apasionantes temas del siglo XXI, aún necesitado de mayor atención $y$, claro está, de mejores y más profundas disquisiciones que las realizadas por nosotros, sabedores de su no oculta dificultad, precisamente por su inespecificidad 
en muchos aspectos, ciertamente menos que en otros tiempos, hoy superados en parte, merced al progreso conseguido por el esfuerzo de académicos y jueces, y más recientemente de legisladores, quienes al unísono proclaman que la relación contractual, en cualquiera de sus fases, es refractaria a las malas prácticas comportamentales, una de ellas censurada severamente: la incoherencia y, por reflejo, la contradicción, binomio malhadado que origina la vulneración de la confianza legítima oportunamente despertada en el cocontratante (acto propio), en sí misma digna de tutela y salvaguarda, en procura de relaciones más probas, impolutas, solidarias y respetuosas de los intereses y expectativas de las partes. 


\section{CAPítulo I}

\section{LA DOCTRINA DE LOS ACTOS PROPIOS: CONSIDERACIONES GENERALES}

\section{SIGNIFICADO GENERAL Y APROXIMACIÓN A LA DOCTRINA DE LOS ACTOS PROPIOS}

Sólo con el propósito de realizar una aproximación al tema, el que será objeto de escrutinio más detallado a lo largo del presente escrito, importa manifestar anticipadamente que esta doctrina, llamada así por su fuerza e irradiación, al mismo tiempo que por su acogida y divulgación, quiere significar la existencia de coordenadas precisas que, en guarda de la evitación de actuaciones lesivas de intereses dignos de tutela y salvaguarda, proscriben que se pueda alterar la base o estado primigenio tomado en consideración en un momento determinado por uno o varios sujetos, esto es el acto original que, por su explicitud, eco o dinámica, suscitó confianza en cabeza suya, circunstancia que, por regla, debe ser preservada hasta donde sea posible. De allí que sea imperativo arbitrar mecanismos encaminados a privar de eficacia a la actuación o conjunto de actuaciones ulteriores constitutivas de sorpresa por parte de quien creyó, de buena fe, que dicha situación se mantendría, en consonancia con la coherencia comportamental que, en sí misma, se espera que se conserve inalterada (constantia).

Al fin y al cabo, los asociados aspiran a la regularidad y a la constancia, con todo lo que ello significa, habida cuenta que en sus relaciones anhelan estabilidad y no incertidumbre o volatilidad, generadoras, a su turno, de inseguridad. Los sobresaltos, los antagonismos, las alteraciones no son esperadas, y menos queridas. La aventura y el albur conductual, ciertamente, no son su deseo o genuina aspiración, tanto más en una relación de carácter negocial, comúnmente caracterizada por su reciprocidad y equilibrio prestacional y, de una manera más general, por la materialización de la justicia contractual, con todo lo que ella envuelve. 
De ahí que cuando súbitamente aflora un comportamiento inesperado, que troca y eclipsa por completo lo efectuado en precedencia, irrumpe la incoherencia y con ella la quiebra de la confianza legítima preexistente al nuevo acto que ensombrece la relación jurídica y que contamina, en tal virtud, su atmósfera, con graves o perturbadoras secuelas para el que confió, gracias a la existencia de conductas previas que hacían esperar un resultado muy diferente, en condiciones de regularidad y razonabilidad. Por ello es por lo que el acto incoherente, voluble, contradictorio, inconsonante, incongruente e inarmónico, entre otras calificaciones más, no puede contar con el exequatur del ordenamiento jurídico, en particular del juez, como su garante supremo, con las puntuales excepciones existentes, claro está, como quiera que de cara a específicos supuestos ex lege no siempre es censurado el cambio conductual, conforme se observará.

Sin embargo, la constante es aquella que, frontalmente, se encamina a rechazar la incoherencia y la contradicción en sede jurídica, detonantes de desconfianza, perplejidad e inseguridad, inadmisibles en un Estado Social de Derecho que aboga por el bienestar ciudadano, en nuestro caso el de los contratantes, arquitectos de la relación negocial.

El dilema que pudiese plantearse en el sentido de qué debe primar: si la situación creada ab initio, o la a posteriori, fruto de un cambio inopinado, debe entonces resolverse a favor de la primera actuación, generadora de un estado (confianza e impresión), urgido de tuición, ante lo cual el ordenamiento no puede permanecer pasivo e indolente, como si fuera un distante espectador. Muy por el contrario, debe estar vigilante, con el fin de actuar cuando fuere menester, dotando de poderes suficientes a las autoridades competentes para que, aún de oficio, esterilicen el actuar incoherente, voluble y contradictorio, antítesis de lo que demanda la bona fides, cabalmente entendida, el respeto de los derechos ajenos y por la sublimación de la lealtad, el buen gobierno relacional, la cooperación y el comportamiento ético.

Coherencia, razonabilidad y fidelidad a lo ejecutado, en suma, son pues las fiables coordenadas que deben ser tenidas en cuenta en esta materia, so pena de que se extravíe la conducta humana, a menudo con repercusiones de variada índole, tanto en la órbita jurídica, como en la patrimonial, en concreto. 
En este orden de ideas, el acto posterior (factum novum), per se, no puede servir de vehículo para que se lesionen intereses y prerrogativas ajenas, los que merecen tutela y, por ende respeto, en línea de principio rector, máxime si se considera que el ejercicio de los derechos, por lícitos que sean, conoce límites, lo que justifica que se deba proceder con arreglo a los cánones que escoltan a la buena fe, áureo postulado que gobierna esta temática, al igual que muchas otras, a fortiori en los tiempos que corren, signados por su lustre, potencia y expansión, según se realzará.

Como acertadamente lo explicita el ilustre tratadista don Luís DíEz- PICAZo, uno de los doctrinantes que, con su habitual agudeza, más se ha preocupado por perfilar este instituto en los últimos cincuenta años, "...el acto de ejercicio de un derecho subjetivo o de una facultad es inadmisible cuando con él la persona se pone en contradicción con el sentido que objetivamente y de acuerdo con la buena fe había que dar a su conducta anterior. La regla [venire contra factum proprium] veda una pretensión incompatible o contradictoria con la conducta anterior"1.

En palabras del profesor José PUIG BRUTAU, uno de los precursores en el Derecho español, del estudio sistemático de la doctrina o principio jurídico en cuestión, "...la base de la doctrina [de los actos propios] está en el hecho de que se ha observado una conducta que justifica la conclusión o creencia de que no se hará valer un derecho. Se supone, pues, cierta conducta que induce razonablemente a la creencia de que el derecho no existe o no se hará efectivo"2.

1 Luís Diez-Picazo. Prólogo a la obra de F. Wieacker, El principio general de la buena fe. Civitas. 1982, p. 21. Años más tarde, en la última edición de sus Fundamentos de derecho civil patrimonial, el Profesor DiEz-PICAZo también expresó que, "La interdicción de venire contra factum proprium significa que cuando una persona con su propio comportamiento ha creado en el sujeto pasivo la razonable, objetiva y fundada confianza en que el derecho no será ejercitado, o sólo lo será de una determinada manera, debe mantener un estándar de coherencia con su comportamiento, no defraudar la confianza que se pueda haber creado y, por consiguiente, no puede hacer valer unas pretensiones que resulten contrarias al sentido objetivo de su comportamiento anterior", Vol. III, Thomson-Civitas. Pamplona, 2007, p. 63.

José Puig BRUTAu. "La doctrina de los actos propios", en Estudios de derecho comparado. Ariel. Barcelona. 1951. En sentido similar, aun cuando más concluyente, el catedrático de la Universidad de Colonia, Heinrich LeHMAnN, puntualiza que, "A nadie le es lícito hacer valer un derecho en contradicción con su anterior conducta, cuando esta conducta, interpretada objetivamente según la ley, según las buenas costumbres o la buena fe, justifica la conclusión de que no se hará valer el derecho, o cuando el ejercicio posterior 
A su turno, según lo reseña el autor argentino Marcelo LóPEZ MESA, "Nadie puede variar de comportamiento injustificadamente, cuando ha generado en otros la expectativa de [un] comportamiento futuro"3, expectativa que, en sí misma, por tener una especie de vida propia, amén de legítima, no puede ser desconocida o burlada, como si no tuviera ninguna trascendencia o significado en el mundo del Derecho.

En consecuencia, el pasado, los actos propios realizados con antelación, generadores de confianza específica (legítima y razonable), no son un adorno, o un proceder incoloro y anodino, huérfano de toda virtualidad jurídica, el que puede ser desconocido a discreción, como si lo único trascendente, es cierto, fuera el nuevo comportamiento, con total prescindencia de si lesiona derechos ajenos, lectura ésta absolutamente inconsulta que exige del ordenamiento una respuesta disímil, llamada a garantizarlos y a tornarlos efectivos. Y esa es, justamente, la respuesta encarnada en la doctrina de los actos propios -y en otras instituciones hermanas o análogas-, como inequívoca manifestación de la regla latina venire contra factum proprium, a su vez emergente de un principio solar y, de suyo envolvente en el concierto internacional: la buena fe, omnipresente en el Derecho, en general, y penetrante en el Derecho de contratos, en particular.

choque contra la ley, las buenas costumbres o la buena fe". Tratado de derecho civil. La parte general, Editorial Revista de Derecho Privado, Madrid, 1956, p. 163. Cfr. Ludwig Ennecerus. Derecho civil. Parte general, Bosch, Barcelona, Vol. II, 1950, p. 495.

A su vez, a juicio del profesor José Luís DE LOS Mozos, lo determinante en esta regla estriba en la "...conducta contradictoria que implica la doctrina de los propios actos" El principio de la buena fe. Bosch, Barcelona, 1965, p. 184.

3 Marcelo López Mesa y Carlos Rogel Vide. La doctrina de los actos propios, Doctrina y jurisprudencia, Reus y B de F. Buenos Aires, 2005, p. 97, documentada monografía en la que ya se había resaltado que "...la doctrina de los propios actos importa una barrera opuesta a la pretensión judicial, por la cual se impide el obrar incoherente que lesiona la confianza suscitada en la otra parte de la relación e impone a los sujetos un comportamiento probo en las relaciones jurídicas, pues no es posible permitir que se asuman pautas que suscitan expectativas y luego se autocontradigan al efectuar un reclamo judicial", op. cit., p. 90. 


\section{TERMINOLOGÍA. DERECHO COMPARADO}

\subsection{Preliminares}

A continuación, de la manera más esquemática posible, nos ocuparemos de la terminología imperante en el concierto jurídico internacional, aspecto para nada trivial, pues de ordinario es manantial de confusiones y distorsiones, como se observará, razón por la cual hacer un esfuerzo en aras de precisión terminológica, amén de conceptual, resulta a todas luces conveniente.

Buena parte de la equivocidad reinante en este campo estriba en la terminología empleada, no simétrica y uniforme, y sabida es la significación que en una disciplina técnica, a fuer que especializada, como de antiguo lo es el Derecho, tienen los términos ${ }^{4}$, desde luego sin soslayar su pertinencia y proyección en lo social y sin hacer apología del 'preciosismo', sin freno alguno, muy cuestionado, cuando lo que se pretende es tornar confusa o ininteligible una idea, cuando lo que se quiere, con términos doctos y enrevesados, es limitar el acceso a una ciencia, o disfrazar la debilidad de un argumento. El éxito de una disciplina, en gran medida, depende de la real posibilidad de que sea entendida y asimilada por el mayor número de personas posible de una colectividad, en lo pertinente. Bien anotaba el reputado profesor Pietro PERLINGIERI que "... el discurso del jurista no es un discurso 'sobre' palabras o grupo de palabras; el hecho y no la palabra, es el objeto de la ciencia jurídica"5.

En tal virtud, iniciaremos esta exposición a partir de la denominación existente, no del todo afortunada, para luego revisar la terminología plural que a menudo se emplea por parte de la doctrina y la jurisprudencia, y finalmente para refrendar que sus variopintas denominaciones, es la regla, son inexpresivas de lo que realmente pretende y persigue la figura, evidenciándose un vacío que, en la praxis, ha sido llenado por la vía de la asociación intelectiva de un vocablo con el cotidiano significado jurídico atribuido, operación mental que mecánicamente

Cfr. Luís María Cazorla Prieto. El lenguaje jurídico actual, Thomson- Aranzadi, Pamplona, 2007, p. 34 y ss.

5 Pietro Perlingeri. // diritto civile nella legalitá constituzionale, Napoli, 1984, p. 37. 
tiene lugar, fundamentalmente, por la sistemática repetición del mismo, v.gr: acto propio, acto propio, y así sucesivamente.

\subsection{DenOMinación y PROYECCIÓN DEL término 'ACto PROPIO'}

Esclarecida preliminarmente la importancia que, en la hora de ahora tiene la doctrina de los actos propios -y sus figuras homólogas, hermanadas o próximas-, así como realzado y exaltado el rol grandilocuente que ha tenido y sigue teniendo en el concierto internacional, en muestra de su inequívoco y acerado compromiso con la equidad, con los sistemas jurídicos imperantes y, en general, con la sociedad toda, es aconsejable descender a la denominación y a la terminología comúnmente utilizada en este campo, en orden a evitar imprecisiones y yerros, no sólo semánticos, sino conceptuales, según se esbozó, lo que es aún más delicado, pues ello no es infrecuente en este temática, por las razones que seguidamente se señalarán.

En efecto, por más que en un extendido segmento del globo terráqueo se haya empleado y difundido la denominación de actos propios, y en menor proporción, la de propios actos: doctrina de los actos propios, o teoría de los actos propios, entre otras que indicaremos(venire contra factum proprium non valent; adversus factum summ quis venire non potest; venire contra factum proprium nulli conceditur; nemo potest venire contra factum proprium; nemini liceo adversus sua facta venire; etc.), no puede desconocerse que esta terminología empleada en el cosmos jurídico (legislación, jurisprudencia y doctrina), no resulta del todo feliz -o afortunada $-y$, por ende, precisa, ni tampoco reveladora, por sí misma, como tiene lugar en tratándose de otras instituciones, figuras, reglas, principios jurídicos, etc., lo cual conspira contra su entendimiento llano y fluido, como debiera ser en este campo. Esa es la tarea del lenguaje, la de permitir que propios y extraños, expertos y legos, en la medida de lo posible, conozcan cabalmente su significado, sin circunloquios, o laberínticos esfuerzos que terminan por oscurecerlo.

Es cierto que la ciencia del Derecho se caracteriza por ser técnica, pero debe procurar que no se convierta en un cenáculo o en una reservada y excluyente disciplina de doctos, en la que sólo los iniciados puedan participar, como si 
fuera una cofradía o una sectae, a sabiendas que en los tiempos presentes una profesión contará con mayor legitimidad y reconocimiento, se dice, cuando sea más próxima, conocida y entendida por el común denominador de los asociados, sus destinatarios naturales, sin que ello signifique que la precisión y el rigor se remplacen por lo pedestre, o vulgar. Una cosa, indefectiblemente no supone la otra. Sencillez y precisión, no son antagónicas.

Y decimos que no es precisa la expresión actos propios -o aún propios actos-, y tampoco en latín: factum proprium, habida cuenta que en diversas disciplinas del Derecho se alude al acto o hecho propio, indistintamente, en muestra de que en la ciencia jurídica, signada por su connotación práctica, todo o casi todo está determinado por una conducta o actuación humana ${ }^{6}$, a fortiori cuando se reconoce -y prudentemente recuerda- que el Derecho es para el hombre, y no al contrario, precisión que nunca sobra, pues de nuevo nos ubica en la realidad, sobre todo cuando se mora en el 'cielo de los conceptos' de lHERING, o cuando se sublima afanosamente el conceptualismo y se ejercita la teorización, en demasía. Por eso, cabalmente recordó el profesor E. DANZ, que "La vida no está al servicio de los conceptos, sino éstos al servicio de la vida"7.

Así sucede, sólo por vía de ilustración, en el campo de la responsabilidad civil -o del Derecho de daños-, concretamente con una de las formas vehiculares de obligar la responsabilidad de las personas. Nos referimos al llamado hecho propio (o acto propio), existente en contraposición al hecho ajeno, uno y otro, en lo pertinente, detonantes de responsabilidad o, si se prefiere, de la obligación de reparar el daño irrogado. Elocuente, al respecto, es el profesor Ricardo DE ÁNGEL, al manifestar que, "No sin fundamento...la doctrina acostumbra a tratar la génesis de la responsabilidad civil distinguiendo tres grandes grupos de daños: 1) los ocasionados por la actividad directa de la persona (responsabilidad por

6 En esta misma dirección, el profesor Carlos Cossıo diáfanamente expresó que "la conducta, es la propia vida humana (...) El Derecho siempre es vida humana, ni más ni menos; pero no toda vida humana es Derecho. Cuando nos referimos al Derecho como conducta no se trata de una conducta cualquiera, sino de la conducta humana en su interferencia intersubjetiva o conducta compartida". Radiografía de la teoría egológica del derecho, Depalma, Buenos Aires, 1987, p. 151.

Erich Danz, La interpretación de los negocios jurídicos, Editorial Revista de Derecho Privado, Madrid, 1955, p. 127. 
actos propios), 2) los producidos por otra persona, de la que se tiene el deber de responder (la llamada 'responsabilidad por hecho ajeno'), y 3) los causados por animales y cosas"8.

En este sentido, entre varios preceptos, se orienta el artículo 1903 del Código Civil español, el que reza que la obligación de reparar el daño “...es exigible no sólo por los actos $u$ omisiones propios, sino por los de aquellas personas de quienes se debe responder". Igual tiene lugar de cara al artículo 2347 del Código Civil colombiano, a voces del cual "Toda persona es responsable, no solo de sus propias acciones para el efecto de indemnizar el daño, sino del hecho de aquellos que estuvieren a su cuidado [...]" (el destacado es ajeno al texto original).

Ricardo De Ángel. Tratado de la responsabilidad civil, Universidad de Deusto y Civitas, Madrid, 1993, p. 255.

En este terreno de la responsabilidad civil, como lo confirma el profesor Javier TAMAYO JARAMILLO, el artículo 2341 del Código Civil colombiano, referente al centenario y capital axioma del neminem laedere, equivalente a otras normas similares en la legislación comparada, entre varias el artículo 1902 del Código Civil español, “...establece la responsabilidad delictual y cuasidelictual que se funda en la culpa probada del autor del daño. A ella nos referiremos con los nombres de responsabilidad por el hecho propio, responsabilidad directa o responsabilidad con culpa probada" De la responsabilidad civil, Tomo I, Temis, Bogotá, 1999, p. 37, observación complementada, años más tarde, cuando señaló en otra obra suya que la responsabilidad por el "hecho propio "...es la responsabilidad por los daños que en forma personal e inmediata una persona le causa a otra...”. Tratado de responsabilidad civil, Legis, Bogotá, 2009, p. 578.

Por su parte, el profesor español Jaime SANTOS BRIZ, aludiendo a la expresión 'actos propios', indica que "la obligación de reparar el daño causado por acción u omisión interviniendo culpa o negligencia, es exigible, según declara el artículo 1.903 del C. C., no sólo por los actos u omisiones propios, sino por los de aquellas personas de quienes se debe responder". La responsabilidad civil, Tomo I, Montecorvo, Madrid, 1993, p. 481. En sentido más genérico, el doctrinante chileno Enrique BARROS BoURIE, refiriéndose al régimen de la responsabilidad civil inmerso en el Código Civil chileno, equivalente al colombiano, en lo esencial, indica que, "La acción y la omisión pertenecen genéricamente a la categoría de actos libres. En tal sentido, acción y omisión pueden ser incluidas dentro del concepto genérico de la acción humana". Tratado de responsabilidad extracontractual, Editorial Jurídica de Chile. Santiago, 2006, p. 124. Finalmente, para culminar este parangón, el profesor español, Mariano YZQUIERDO TOLSADA, explícitamente se refiere a la expresión "responsabilidad por actos propios", en testimonio de lo ya afirmado en precedencia, aunque utilizando el vocablo 'actos propios'. Sistema de responsabilidad civil contractual y extracontractual. Dykinson, Madrid, 2001, p. 217. Cfr. Encarna Roca. Derecho de daños, Tirant lo blanch, Valencia, 1998, pp. 57 y ss. y José Ricardo León A. La categoría de la obligación 'in solidum', p. 190 y ss., Publicaciones de la Universidad de Sevilla, Sevilla, 1978. 
Es obvio que la locución acto propio, como manifestación de la regla venire contra factum proprium, no puede equipararse a la de hecho propio (o acto propio o acción propia) en el terreno de la responsabilidad civil, fundamentalmente por cuanto con su formulación, recta via, no se persigue la indemnización o el resarcimiento de un daño, propiamente dicho, amén que acaecido (prius), sino su evitación, y también por un sin número de particularidades y diferencias que hacen que ambas instituciones que comparten un nomen -y raíz-común tengan autogobierno y sustantividad propias, más allá de que la presencia de un daño o nocimiento tenga lugar cuando aflora el acto contradictorio, en cuyo caso se lesionará un interés legítimo, acicate para que se impida que se consolide o aún peor, aumente, según el caso. Ello no se opone, empero, a que con arreglo a las circunstancias especiales de cada asunto, la transgresión del principio de no contradicción, o el quiebre del deber de coherencia comportamental, pueda servir, en un momento determinado, de detonante de daños y perjuicios que ameriten ser resarcidos en sede patrimonial, hecho éste que no es suficiente, per se, para asimilar ambos institutos, de suyo disímiles, en rigor, tanto por su origen, como por su estructura, fundamentación, teleología, etc., más allá del prurito general y abstracto de hacer responsable a quien lesivamente mudó de comportamiento, hecho que no altera la sustantividad y autogobierno de la rega venire contra factum proprium, ni de ninguna de sus manifestaciones, una de ellas la doctrina de los actos propios ${ }^{9}$.

Hay otros supuestos legales en los que si bien no se acude, expressis verbis, al término 'propio', así se infiere de su texto y su construcción, v.gr: en relación con los denominados actos de heredero que, por definición, son propios, tal y como se desprende del artículo 1301 del Código Civil colombiano, el que, ad pedem literae, prescribe que "La enajenación de cualquier efecto hereditario, aun para objeto de administración urgente, es acto de heredero, si no ha sido autorizada por el juez, a petición del heredero, protestando éste que no es su ánimo obligarse en calidad de tal". Lo mismo sucede frente al artículo 1502 del C.C, el que reza, en lo pertinente, que "Para que una persona se obligue a otra por un acto o declaración de voluntad, es necesario...." También, sólo para citar

Cfr. Alessandro P. Scarso. "Venire contra factum proprium e responsabilitá", en Responsabilitá civile e previdenza, N³, 2009, pp. 533 y ss. 
un precepto más, con el artículo 1504 de la codificación civil, que dispone que, "Son absolutamente incapaces los dementes, los impúberes y sordomudos, que no pueden darse a entender. Sus actos no producen ni aún obligaciones naturales, y no admiten caución"10.

Por su parte, en el Derecho de bienes también se evidencia el empleo frecuente de la expresión actos propios, lo cual acontece en tratándose del fenómeno de la posesión, incluido el tema de la interversión posesoria, como quiera que para efectos de que él y ella se consoliden, se hace necesario, mejor imprescindible, que se ejecuten actos inequívocamente propios, por oposición a los ajenos, sin los cuales, ciertamente, no tendrían ninguna acogida en sede jurídica ${ }^{11}$.

En el plano del Derecho constitucional, importa traer a colación el contenido de algunos preceptos que se refieren a la actuación de la persona y del ciudadano. Así tiene lugar en el Derecho colombiano, específicamente, habida cuenta que el artículo 95 de su Constitución Política de 1991, en lo pertinente, dispone que "Son deberes de la persona y el ciudadano: 1. Respetar los derechos ajenos y no abusar de los propios", referencia que, de inmediato, refrenda la idea de que los derechos tienen y conocen límites, así sean propios, condición que no autoriza su desbordamiento y uso irracional; todo lo contrario.

10 Los referidos artículos 1502 y 1504, están ubicados en el Título II, del Libro Cuarto del Título I, del Código Civil, rotulado "De los actos y declaraciones de voluntad".

11 Cfr. Joaquín AtAz LóPEZ, quien manifiesta que “... el concepto posesorio significa la apariencia de titularidad que es resultado de una determinada conducta por parte del poseedor. Y esta apariencia de titularidad puede crearla el poseedor por sí mismo..., aunque no baste para producirla un simple 'querer', sino que solo cuando la voluntad del poseedor se manifiesta en actos inequívocamente propios del titular, puede considerarse cambiado el concepto posesorio...." "Sobre la interversión posesoria", en Homenaje al profesor Juan Roca J., Murcia, 1989, p. 38.

En el ámbito de la protección de la confianza circunscrita a la "fe pública registral", se resalta la importancia que revisten los "... actos propios del adquirente". Vid. Rafael BALLARIN HERNÁNDEZ. "Reflexiones sobre la referencia del artículo 22 de la ley 49/2003, de 26 de noviembre, de arrendamientos rústicos, al artículo 34 de la ley hipotecaria", en Estudios de derecho de obligaciones, Homenaje al Profesor Mariano Alonso Pérez, La Ley, T. I., Madrid, 2006, p. 90. 
En el campo de la filosofía del derecho, sólo para registrar un ejemplo adicional, se suele aludir por la doctrina del ramo a la visión de SCHELER, enderezada a relievar que la persona, centro de gravedad de sus reflexiones, es "...el depositario del valor", motivo por el cual se le considera como "...el ejecutor unitario de una serie de actos. La persona se define en sus actos. A través de ellos, cada cual engendra su propio mundo"12.

En otros dominios diferentes al del Derecho, también se utiliza el término en cita. Así, para comprobar este aserto, téngase en cuenta que en el Catecismo de la Iglesia Católica, se alude expresamente a "los actos [propios] del penitente"13, ejercicio que podríamos continuar, pero en aras de no extendernos en forma innecesaria, concluimos por ahora, para retornar de nuevo a lo jurídico.

\subsection{EQUIVOCIDAD E INEXPRESIVIDAD DEL VOCABLO 'ACTO PROPIO'. EMPLEO ALTERNATIVO DE LA EXPRESIÓN 'DEBER DE COHERENCIA'}

Como complemento a lo señalado, cumple manifestar que la expresión en cuestión tampoco es reveladora de su fisonomía, alcances, significado y efectos. Muy por el contrario, es algo incolora, insabora y hasta inasible. Poco transmite su mero enunciado, salvo para el que, por razón de su oficio, conoce bien su anatomía y sustrato, en cuyo caso se generará de inmediato la consabida asociación intrínseca. No acontece así, por vía de ejemplo, con otros principios, esos sí típicamente generales, como la buena fe, el abuso del derecho, grávidos de elocuencia, o con reglas como la de que no se podrá alegar su propia culpa, o nadie podrá enriquecerse sin justa causa, o la que reza que el primero en el tiempo es el primero en el derecho, o que lo particular deroga lo general, etc. Igualmente, por sus connotaciones, es un término como gelatinoso, algo resbaladizo que, de contera, no se puede asir fácilmente, conforme se expresó. Mutatis mutandis,

12 Martha Albert MÁrquez, Derecho y valor. Una filosofía jurídica fenomenológica, Universidad de Córdoba, 2004, p, 271, autora que transcribe el siguiente pasaje de SCHELER, alusivo al tema: "En la peculiar clase esencial de los actos propios singularizadores... el contenido de todo vivir de la especie de los actos singulares y del vivir para sí es el mundo de un individuo o un mundo particular...".

13 Catecismo de la Iglesia Católica, Librería Editrice Vaticana, Vaticano, 2009, p. 100. Dichos actos son el ".... examen de conciencia, la contrición...la confesión.... [y] la satisfacción”. 
se 'hace agua' y se desliza por nuestras manos cuando pretendemos tomarlo, lo que dificulta su comprensión inmediata.

No le falta pues razón de nuevo a Don Luís DíEZ-PICAZO, cuando asevera que, “...pocas reglas de derecho poseen una vaguedad y una falta de concreción tan grandes, hasta el punto de que es posible decir que su aplicación o inaplicación se fundan, la mayor parte de las veces, en convicciones intuitivamente formadas", a lo que agrega, a modo de conclusión, que "... la expresión 'ir contra sus propios actos', en su escueta desnudez, es muy poco orientadora"14.

Desde esta perspectiva, sin duda, comunica más la regla latina venire contra factum proprium non valet (no se podrá volver contra sus propios actos, o no es válido volver contra sus propios actos, o nadie podrá volver contra sus propios actos) ${ }^{15} \mathrm{y}$, mucho más, incluso, el señalamiento de un deber de conducta, específicamente de coherencia ('deber de coherencia') que, por ser construido en forma positiva y no negativa, es más diciente y penetrante, a fuer que revela mejor el mensaje que emana de la institución materia de examen, claro está. Lo mismo acontece con la expresión 'confianza legítima', la que se está abriendo camino cada vez más en algunas latitudes y áreas del conocimiento jurídico,

14 Luís DízZ-Picazo. La doctrina de los propios actos, Bosch, Barcelona, 1963, p. 13 y 108. En los albores del siglo XX, en concreto en el año 1913, Don Carlos L. DE HARO, uno de los primeros autores que del tema se ocupó en España, anotó sobre los actos propios que "Es una fórmula, que como axioma de derecho, continuamente se alega en los Tribunales sin conciencia de su contenido. Por su vaguedad, no se atiende a calificar previamente el acto, y se invoca la fórmula para cualquiera que el hombre realice....." "Los 'actos propios' en la jurisprudencia del Tribunal Supremo", en Revista de Derecho Privado, Madrid, 1913, p. 17.

15 Existen otras máximas latinas que, de ordinario, en la literatura jurídica, fungen como sinónimas o, por lo menos, equivalentes o muy próximas a la indicada, lo reiteramos: nemo potest venire contra factum proprium, nemo licet adversus sua facta venire, venire contra factum proprium nulla conceditur, adversus factum suum quis venire potest, nemo potest mutare consilium suum in alterius injuriam, mutare consilium quis non potest in alterius detrimentum, proprium factum nemo impugnare potest, etc. De todas ellas, en la actualidad, quizá es más frecuente el empleo de los brocardos venire contra factum proprium non valet, y nemo potest venire contra factum proprium. Por nuestra parte, empero, nos apoyaremos más en el primero de ellos, el que en ocasiones distinguiremos mediante la abreviatura venire, a secas.

En castellano, a menudo, se utiliza la expresión prohibición de ir contra los actos propios, indicativa de una proscripción. 
sobre todo en la esfera de los Derechos constitucional y administrativo, sin perjuicio que en naciones como Francia, ad exemplum, tiene expresa acogida en la doctrina jusprivatista, como se señalará más adelante en este escrito ${ }^{16}$. $\mathrm{Al}$ fin y al cabo, ella es el soporte de todas y cada una estas aplicaciones, y la ratio iuris de su sostenida y arraigada protección, aun cuando hay que reconocer que en algunas latitudes los juspublicistas han ampliado su radio de acción También es más reveladora la expresión principio de no contradicción o prohibición de ir contra los actos propios, en atención a que comunican de modo más frontal y explícito su real alcance, y lo hacen, además, en forma más llana y comprensible para la comunidad, en general.

En síntesis, expresado en positivo, aludir a un deber de coherencia, es más diciente, y en negativo, sucede lo mismo con el principio de no contradicción, vocablos que están estrechamente ligados a partir de la idea cardinal en esta temática: el interés en que las partes contratantes, a manera de regla rectora, sean coherentes a lo largo del iter ad contractum, evitando, por consiguiente, la contradicción en la órbita comportamental, obviamente con las excepciones toleradas por el Derecho positivo, como se registrará en su oportunidad, en el entendido de que el mutare factum -o el mutare consilium- están admitidos en casos muy puntuales, según se anticipó, y ahora se reitera por su importancia.

En consonancia con lo expresado, hay que reconocer entonces que el brocardo latino, así sea más elocuente y sonoro que la expresión doctrina de los actos propios, no es aún muy divulgado y acogido en el mundo del Derecho, por lo menos en su justa dimensión y en su auténtico significado, entre otros motivos por el desconocimiento que, en mayor o menor medida, conforme se expresó, existe en este campo, naturalmente con todas las excepciones que sea necesario realizar, hecho que, con creces, justifica el estudio continuo de esta

16 Ciertamente en el Derecho francés, a diferencia del italiano, el alemán, el español, el portugués, entre otros, el brocardo venire contra factum proprium, aun cuando algunos autores lo registran e identifican, no lo desarrollan propiamente, pues prefieren aludir a la coherencia, concretamente a un deber de coherencia; al estoppel, el que ha sido incluso recepcionado por su Corte de Casación, o al principe d'interdiction de se contredire au détriment d'autre. Vid. Benédicte FAUVARQUE-COSSON. "La confiance légitime et l'estoppel", "Rapport général", en La confiance légitime el l'estoppel, Societé de Législation Comparée, Paris, 2007, pp. 11 y ss. 
fascinante temática, a la vez que su sostenida divulgación, conforme acontecerá en el futuro, sin duda, en razón de que ella, así lo creemos, tiene reservado un escaño de privilegio. Lo propio sucede en punto al referido deber de coherencia (o de no contradicción, o de 'inadmisibilidad de la conducta contradictoria'), lo que no impide que, proceloso, día tras día se abra camino, según se afirmó. No es pues fortuito comprobar que en unas latitudes, más que en otras, se registra un fervoroso interés por su examen. v.gr: en Italia y en Francia, toda vez que la doctrina le está dando singular trascendencia, muy especialmente en el siglo $X X I^{17}$, al igual que en naciones como Perú y Colombia, en las que no en pocas

17 Vid. Paolo Gallo, Contratto e buona fede, UteT, Torino, 2009, p. 787, Francesco Astone, Venire contra factum proprium, Jovene, Napoli, 2006, Fiorenzo FESTI, II devieto di venire contra il fatto proprio, Giuffrè, Milano, 2007, p. 233. Este reciente entusiasmo por el tema en Italia, en gran medida, se explica por “...el generalizado despertar del interés por las cláusulas generales, en particular por el principio de la buena fe", según lo realza el profesor P. GAllo (Op. cit., p. 788), al igual que F. FESTI, al afirmar que "...la cláusula general de la buena fe, después de un largo olvido, está atravesando por un periodo de 'popularidad' "(Op. cit., p. 241). Cfr. Andrea D'Angelo. Buona fede e giustizia contrattuale, Giappicheli Editore, Torino, 2005, pp. 1 y 2, al confirmar que la "buena fe contractual" ha experimentado un "cambio evolutivo de gran relieve", acompañado en los últimos años de un "proceso de expansión"; Francesco RINALDI al constatar que "La buena fe objetiva es llamada a ejercer un nuevo y más activo rol en la experiencia jurídica contemporánea, evidenciándose una tendencia a expandirse a nuevos e inexplorados -o parcialmente explorados- espacios". Contratto in genere. "Dovere di buona fede"..., en NGCC, 2005, p. 449; Riccardo CARDILLI, de acuerdo con el cual "la buena fe en los últimos años ha experimentado una interesante renovación por parte de la doctrina". Bona fides. Tra storia e sistema, Giappichelli Editore, Torino, 2010, p. 100, y finalmente Guido ALPA, al concluir que la "Doctrina y jurisprudencia italianas subestimaron la cláusula de la buena fe por largo tiempo: por casi un cuarto de siglo de la entrada en vigor del Código civil [de 1942] la cláusula fue prácticamente ignorada, y los intérpretes no habían advertido la potencialidad operativa de la buena fe objetiva.... Transcurrido un cuarto de siglo, la situación comienza a cambiar". Manuale di diritto privato, Cedam, Padova, 2007, p. 152.

En Francia, por su parte, también la temática alusiva a la buena fe ha despertado mayor fervor, razón por la cual a menudo se expresa que es "Un principio en expansión". Philippe Maulaurie, Laurent Aynes, y Philippe Stoffel-Munnck. Les obligations, Lextenso Éditions, Paris, 2011, p. 379. En dirección similar, la autora Anne-Sylvie COURDIER-CUISINIER recuerda, ello es muy diciente, que "...la buena fe fue ignorada por generaciones en el sentido en el que ella hoy es admitida, es decir como una norma de comportamiento". Por eso, reitera que "La ignorancia por parte de la doctrina y la jurisprudencia de la buena fe lealtad duró casi dos siglos", motivo por el cual se ha pasado "... de la ignorancia a su reconocimiento", o como diría A. BENEBENT, que cita en apoyo de lo aseverado, se trata de un "...verdadero descubrimiento y no simplemente de una mera reanimación" (La foi dans les relations entre particuliers, dans l'exécutions du contrat). Le solidarisme contractuel, Université de Bourgogne, Litec, 2006, p. 290.

Y en Bélgica, con estribo en la misma normatividad gala, igualmente es incontrovertible que "El siglo XIX se caracterizó por un movimiento de desvalorización de la buena fe, en beneficio de la autonomía de la voluntad y de la fuerza de ley de las convenciones, lo cual 


\section{ocasiones, por el furor de la regla, no se entiende rigurosamente, trascendencia ésta que, tratándose de otros países, es el caso de Alemania, España, Portugal y}

las hipertrofió", generándose en el siglo XX”, muy especialmente gracias a Demogue, el “... retorno de la buena fe" en el Derecho francés, caracterizado por una "... real objetivación de su noción", de suyo relevante, por cuanto ha propiciado "...evoluciones recientes del derecho positivo contemporáneo, en materia contractual y extracontractual”, según lo anota Jean-François Romain. Théorie critique du principe général de bonne foi en droit privé, Bruylant, Bruxelles, 2000, pp. 165 y 167.

Es de resaltar que en algunas de tales naciones, a diferencia de lo que tiene lugar en Alemania, en Suiza, en Bélgica, en España, en Portugal, en Argentina, en Brasil, en Chile, en Colombia, en Perú, entre varias, la jurisprudencia se ha mostrado más refractaria a su adopción plena y frecuente utilización. Es en la doctrina, entonces, en la que se le ha brindado una mayor acogida, aunque es previsible que la judicatura se aproxime más a esta basilar institución (venire contra factum proprium), hijuela de la logicidad, la razonabilidad y la coherencia. Cfr. CRISTIÁN BOETSCH GILLET, quien también refiere a una "... revitalización del principio general de la buena fe", a lo que agrega el interés creciente alrededor del mismo, “...tanto en el llamado derecho continental como en el anglosajón...." La buena fe contractual, Editorial Jurídica de Chile, 2011, p. 47. Cfr. Gustavo Ordoqui CAstilla. La buena fe contractual, Universidad Javeriana y Grupo Editorial Ibáñez, Bogotá, 2012, pp. 139 y ss.

También es de mencionar que, como acontece con otros postulados e instituciones, determinadas coyunturas y situaciones precisas hacen que la buena fe adquiera más notoriedad, según tiene lugar en épocas de recesión, desaceleración, o crisis. Así lo corrobora la autora Ana QUIÑONEZ EsCAMEZ, al afirmar que “...en épocas de crisis económica el principio de buena fe suele recobrar cierto protagonismo", en cuyo caso "la cláusula general de la buena fe se ve revitalizada en época de crisis". "Buena fe y lealtad contractual", en Derecho contractual comparado, Civitas-Thomson, Pamplona, 2009, pp. 341 y 352.

Por su parte, no puede dejar de manifestarse que en el campo de la principialística internacional, muy especialmente la europea, se ha evidenciado la necesidad de sublimar la buena fe, lo que explica que diversos proyectos y normativas en materia de contratos le den un lugar de privilegio, v.gr: en tratándose de los Principios Europeos de Contratos, el Anteproyecto de los Contratos de la Academia de Pavía, el Marco Común de Referencia, los Principios Unidroit, entre varios. Por ello el profesor Cesare MASsIMO BIANCA, expresa en relación con la buena fe que "Un derecho contractual europeo que no otorgara espacio a esta exigencia conduciría al resultado de degradar tal derecho por debajo de aquél mínimo de ética contractual que el derecho privado de gran parte de los estados miembros ha expresamente receptado". "Técnicas de formación del contrato y tutela del contratante débil: el principio de la buena fe en el derecho privado europeo", en Tratado de la Buena Fe, T. II, La Ley, Buenos Aires, 2004, p. 204.

Paralelamente, importa subrayar que algo similar ha acontecido con la confianza, toda vez que día tras día adquiere más resonancia en sede jurídica, y cada vez es objeto de mayor protección (confianza legítima). En este sentido, como lo expone el profesor Laurent AYNES, ya no es aceptable partir de la desconfianza, como antes tenía lugar, pues en esta materia se ha registrado "...una evolución”, por cuanto en la actualidad se evidencia una "... restauración de la confianza en el contrato, en el mundo contractual". "La confiance en droit privé des contrats", en La confiance en droit privé des contrats, Dalloz, Paris, 2008, p. 155. Cfr. Rodolfo SAcco. "Affidamento", en Enciclopedia del diritto, Vol. I, Giuffrè, Milano, 1958, p. 661 y ss. Lo propio, en lo pertinente, ha tenido lugar con el denominado 'solidarismo contractual', al que nos referiremos de nuevo. 
Argentina, y más recientemente en Chile, Brasil y Uruguay, le ha sido ampliamente reconocida de tiempo atrás, como a espacio se resaltará. En una sola expresión, en esta materia, si se quisiera, bien podría hablarse de una prolongada primavera, y no de un gélido otoño, y menos de un período invernal.

\subsection{Precisión y Justificación terminológica}

En atención a la consabida falta de precisión terminológica, algunos más recientemente han pretendido sustituir todas las expresiones referidas por una nueva: relevancia jurídica de la conducta anterior, como respuesta al significado que el comportamiento primigenio, es la regla, suele tener en la ciencia jurídica, detonante de la confianza legítima que el ordenamiento se ve en la imperiosa necesidad de proteger ${ }^{18}$, aun cuando en rigor este giro, si bien hace énfasis en un eslabón de gran valía de la cadena del factum proprium, no trasmite derechamente el significado pretendido, y se puede confundir con un insumo o segmento de la trilogía de actos objeto de valoración en sede de la interpretación del contrato: actos anteriores, coetáneos y ulteriores a su celebración ${ }^{19}$.

Por lo tanto, así el vocablo acto propio (doctrina de los actos propios) no sea el más preciso, ni el más revelador, es uno de los más socorridos en la doctrina, en la jurisprudencia, y en la legislación internacional, lo que ha conducido a muchos a emplearlo, más por esta argumentación, eso sí, con algo de prevención, o con beneficio de inventario, como lo hacemos y haremos nosotros, movidos por la idea de que en tanto en cuanto no se configuren y arraiguen otros lo suficientemente exactos, creemos conveniente conservarlo con estas advertencias, amén de

18 Federico BERRO. La relevancia jurídica de la conducta anterior (Teoría de los actos propios), quien señala que "... dejamos constancia que el nombre de 'relevancia jurídica de la conducta anterior con que hemos rotulado este ensayo nos resulta más analítico, expresivo y científico que la denominación con que se le conoce en el derecho privado (teoría de los actos propios o de los propios actos)....." Ediciones Jurídicas Amalio Fernández, Montevideo, 1989, p. 9.

19 Vid. Carlos Ignacio JaRAmiLlo J. La interpretación de los contratos atípicos y valoración de la conducta de los contratantes. La valoración de la conducta de los contratantes y su incidencia en la interpretación del contrato. Alcance de la trilogía integrada por los actos anteriores, coetáneos y posteriores a su celebración. Coautor, Raúl Anibal ETCHEVERRY. Universidad de La Sabana y Grupo Editorial Ibáñez, Bogotá, 2012, pp. 79 y ss. 
reservas, toda vez que se nos sigue antojando insípido. Por eso su modificación, si no se hace en forma muy cuidosa y técnica, podría ser contraproducente, pues mal que bien hay un camino ya recorrido.

El ajuste, entonces, debe hacerse, a nuestro juicio, gradual y paulatinamente. De allí que a menudo en esta monografía, en forma complementaria, utilicemos el mencionado brocardo latino venire contra factum proprium que, rectamente entendido, luce más sonoro y diciente, a la vez que más fiel a la etiología del instituto en comento. No obstante, también hay que reconocer de nuevo, que términos como estoppel, verwirkung, confianza legítima, principio de prohibición de contradecirse en perjuicio ajeno, solidarismo contractual, entre otros, igualmente se han insertado en la ciencia jurídica contemporánea, como da cuenta el Derecho comparado, los que también adolecen de las mismas o similares vicisitudes, a lo que se agrega la dificultad lingüística en relación con los dos primeros, así se hayan expandido últimamente más.

Aclarado lo que antecede, importa memorar que para un sector autoral, y también jurisprudencial (español y argentino), es preferible aludir a los propios actos (doctrina de los propios actos), que al acto propio (doctrina de los actos propios), discusión o diferencia que, en puridad, no parece absolutamente sustancial y determinante, siendo quizá más un tema de preferencias y gustos, de suyo respetables, en una u otra dirección (logomaquia). Sin embargo, al margen de ello, y bajo el candil gramatical, que no jurídico, nos parece más exacto aludir primero al acto y después a su titular, toda vez que la calidad de propio o ajeno se predica es del 'acto', en sí mismo neutro o despersonalizado inicialmente: "Ejercicio de la posibilidad de hacer....resultado de hacer" (Diccionario de la lengua española), pero insistimos que ello no es esencial. Las dificultades de esta institución son muy otras; ellas, ciertamente, no residen en un cambio de palabras, luego este debate no amerita una cruzada.

Otra discusión que algunos han planteado, a primera vista igualmente adjetiva, dice relación con la pluralidad, o singularidad de la expresión. Para unos, no es fortuito que, en plural, ella se refiera a 'actos propios', siendo menester que irrumpa más de una conducta, de suerte que un sólo acto se tornaría insuficiente para la floración de un perjuicio o la amenaza del mismo, pues se exige una 
actuación inicial (prius) y otra ulterior (posterius), y contradictoria. Para otros, cuando se hace alusión al 'acto propio', en singular, se está haciendo énfasis en el comportamiento incoherente, posterior al primigenio. Con independencia de la verdadera importancia de esta polémica de raigambre semántica, que en principio parece exagerada, máxime si se tiene en cuenta el elevado número de temas ríspidos y complejos que gravitan a su alrededor, los que sí demandan una atención prioritaria -por encima de estas consideraciones gramaticales, no siempre trascendentes-, lo reiteramos, hemos optado por su utilización plural, con el objeto, ab origine, de hacer evidente la presencia de más de una actuación por uno de los sujetos de la relación jurídica, en particular del voluble, versátil o contradictorio, quien cambiara de rumbo a posteriori, con adversas secuelas para el destinatario de sus actuaciones, que bien pueden ser dos o más (haz conductual), según las circunstancias.

Un comentario final resta por hacer, relativo al uso del vocablo doctrina (doctrina de los actos propios), el que preferimos al de teoría (teoría de los actos propios), este último de menor usanza en la dogmática jurídica. $Y$ decimos que es de nuestra preferencia, sin pretender tampoco un prolongado e innecesario debate, merced a lo que aquél denota: "Enseñanza que se da para instrucción de alguien" (Diccionario de la Lengua Española), al paso que cuando se alude a una teoría, se insinúa más una lectura o mirada más individual o subjetiva y en ocasiones más especulativa. Dice efectivamente el mismo Diccionario que teoría es "Conocimiento especulativo considerado con independencia de toda aplicación". De allí que en nuestro entender case mejor la palabra doctrina, no para revelar un argumento de autoridad, o una construcción autoral, sino todo lo contrario: una directriz, fruto de la maduración y decantación de una regla, o un principio jurídico -que no general-, que se traduce en guía o faro para la colectividad, justamente por su fuerza intrínseca y su magnetismo, a lo que se añade su carácter instructivo, conforme lo explicita su definición ${ }^{20}$.

20 En similar dirección, Don Luís DíEz-PICAZo, ilustra muy bien el alcance de la mencionada expresión, pues con motivo del examen de la figura del enriquecimiento sin causa, para el que reserva el vocablo doctrina, manifiesta que la regla que lo tipifica y desarrolla puede ser "...calificada como 'doctrina', si entendemos por doctrina, como muchas veces se ha hecho, las elaboraciones de los tribunales o de los autores, que son derivación y consecuencia de los principios del Derecho, aunque no sean por sí mismos principios del Derecho, como ocurre con la máxima venire contra factum proprium nelli conceditur 


\section{FUNDAMENTOS GENERALES DE LA DOCTRINA DE LOS ACTOS PROPIOS}

\subsection{Planteamiento preliminar}

Diversos y muy variados, realmente, son los fundamentos que le sirven de explicación y estribo a la llamada doctrina de los actos propios, entre otras denominaciones más, pues no es correcto entender que en esta materia, según sucede con otras más, sólo un criterio es el escogido o el dominante, habida cuenta que la pluralidad o convergencia de varios soportes revela mejor su genuina esencia, determinada por la combinación armónica de varios basamentos, puesto que su arquitectura, mutatis mutandis, no se limita a una planta, sino a una edificación constituida por varias.

Dicho de otro modo, una lectura acentuadamente reduccionista, restringida a un sólo fundamento, entendemos que atentaría contra sus elementos vertebrales, por relevante que él sea, o pueda ser, ejercicio por lo demás subjetivo, carente de uniformidad, a la par que de toda utilidad, en atención a que la doctrina en referencia debe ser considerada como un tejido integrado por un número plural de fibras -o hilos-, cada uno dueño de una misión determinada, así individualmente no tengan idéntico valor, en gracia de discusión ${ }^{21}$.

En tal virtud, in abstracto, probablemente el más arraigado, o uno de los más arraigados en sede jurídica, desde luego reconociendo la importancia de los restantes, se anticipa, es la preservación de la coherencia comportamental,

o con la llamada cláusula rebus sic stantibus". La doctrina del enriquecimiento sin causa, Universidad Javeriana, Depalma y Grupo Editorial Ibáñez, Bogotá, 2011, p. 75.

21 Pese a su cercanía y comunicación, buena fe, coherencia, apariencia, confianza legítima -y racional- y seguridad jurídica, no son idénticas, o susceptibles de englobarse armónica y unánimemente en una sola figura, stricto sensu, sin perjuicio que, en su esencia, pueden llegar a compartir su teleología y de alguna manera su fundamentación última. Bien expresa el profesor Vittorino PIETROBON que, "A pesar de la diferencia que media entre estas hipótesis, sucede a veces que todas las disposiciones encaminadas a tutelar un estado fiduciario han sido reunidas por la doctrina en un mismo principio, llamado de buena fe, de la apariencia o de la confianza, por lo que los diversos criterios parecen tener un fundamento común". El error en la doctrina del negocio jurídico, Editorial Revista de Derecho Privado, Madrid, 1971, p. 248. 
e in concreto, la evitación de la contradicción lesiva y generalmente irreversible, coherencia que es el nervio y alma de este instituto y de un sin número de actuaciones de los individuos en sociedad, que se caracteriza por impedir que un sujeto, en desarrollo de una actuación ulterior, con éxito, desconozca o desdibuje el camino transitado por él con antelación, en perjuicio de otro que, por ello, confió en él. Confianza ésta que tendrá una relevancia capital y, de contera, ocupará un sitial de privilegio, hasta el punto que, en puridad, se traducirá en la ratio protectionis del factum proprium, mejor del venire contra factum proprium. Por eso, una y otra vez, se aludirá a un imperativo de coherencia, en particular a un deber de conducta que, en línea de principio rector, debe observar cada uno de los asociados, en nuestro caso los contratantes, so pena de resquebrajarse la citada confianza, pilar del Derecho, no de ahora, sino de vieja data.

Manifestado en términos más concisos, al igual que consonantes con la denominación de la doctrina objeto de análisis, a 'nadie', inicialmente, le está permitido volver -o ir- contra sus propios actos, o sea contrariarlos 0 contradecirlos (venire contra factum proprium, o venire contra factum proprium nulla conceditur, o nemo potest venire contra factum proprium, etc.), cuando ellos generaron, objetivamente, una confianza, creencia o certidumbre determinadas; un entendimiento racional diverso que, ex post, se vio trocado, y también truncado sorpresivamente, siendo entonces menester proceder a tutelar los intereses materia de amenaza o vulneración, a manera de plausible correctivo iuris (remedium). Lo anterior en clara sintonía con el acrisolado postulado general de la buena fe que, ab initio, es refractario a este tipo de comportamientos incoherentes y también contradictorios y huérfanos de razonabilidad intrínseca-y logicidad-, que originan inseguridad e incertidumbre jurídicas, todo de acuerdo con la necesaria preservación de la confianza generada o inculcada, clave de bóveda de esta institución, conforme se ha expresado.

En este orden de ideas, referir a la fundamentación de la doctrina de los actos propios, como se expresó esencialmente plural, supone aludir a un haz de pilares en los que se asienta, entre otros la coherencia comportamental, la buena fe, la razonabilidad conductual, la confianza legítima, la apariencia y la seguridad jurídica, todos ellos de un inconmensurable significado, a tal punto que necio sería negar su incidencia en la temática que nos ocupa, so pretexto de centrarnos en 
uno sólo de ellos, por de pronto el de mayor preferencia personal, en nuestro caso, la observancia de la buena fe, precisamente por su carácter envolvente y solar, incluida a la coherencia. Esto avala la riqueza de la figura del venire contra factum proprium, y correlativamente de cada una de sus manifestaciones, que igualmente son plurales, descartando, de plano, su pobreza o fragilidad ${ }^{22}$, lo que es positivo.

Anticipado lo que antecede, con el confesado propósito de reiterar la idea central ya delineada alrededor de la coherencia comportamental, le pasaremos somera revista al fundamento de la doctrina de los actos propios, desde varios ángulos: el filosófico, el social, el evangélico, el económico y de nuevo el jurídico, todos entrelazados, como quiera que dialogan en un mismo lenguaje y en armónica comunión. Al fin y al cabo, es tal la fuerza y logicidad de esta doctrina, que es más que natural que todo lo permee, hecho no ayuno de reveladoras connotaciones, habida cuenta que, a su manera, está inmerso en un apreciable

22 Un amplio sector de la doctrina moderna, al momento de ocuparse del fundamento del venire contra factum proprium, o de la doctrina de los actos propios, en concreto, lo circunscriben a la confianza -o lo derivan de ella-, tesitura que sin ser incorrecta, según se anunció, apunta a un sólo pilar, importante sí, si se quiere 'importantísimo', aun cuando no el único, por acerado que sea, como efectivamente lo es, tanto desde el punto de vista jurídico, como práctico, motivo por el cual no lo catalogamos como unicum. Sin embargo, cumple expresar que tal es la trascendencia de la protección de la confianza legítima que, aparte de servir de basamento, también se erige en la ratio protectionis del venire, y si fuera poco en su finalidad primordial, de naturaleza auténticamente tuitiva, aunque hay que reconocer que en los últimos años ha comenzado a suscitar un interés especial la razonabilidad como fundamento y explicación del deber de coherencia, a la vez que como directriz general del comportamiento contractual, según lo mencionaremos con mayor detenimiento en otro aparte. De hecho, se estima que la coherencia en mención, es una típica expresión de la exigencia de obrar razonablemente, por lo que se puede hablar de una "coherencia razonable". Incluso, modernamente también se alude a una "confianza razonable", al lado de la expresión "legítima": confianza legítima y razonable, con el fin de reafirmar que ella es calificada, puesto que no se protege cualquier confianza. Como concluyentemente lo expresa el Dr. IÑIGo DE LA MAZA GAZMURI, “....no cualquier confianza debe protegerse....sólo recibe protección jurídica quien la merece”. Los límites del deber precontractual de información, Civitas y Thomson Reuters, Pamplona, 2010, p. 315.

En una sola expresión, sin exacerbamiento, toda esta temática está influida por la razón, últimamente reivindicada y de paso rehabilitada; en últimas, ella es el sustrato y el báculo de la coherencia. En este sentido es que la Dra. Hobinavalona RAMPARANY-RAVOLOLOMIARANA igualmente señala que "La coherencia es obra de la razón", y es "una aplicación de lo razonable", de lo que desprende que "El comportamiento incoherente es pues considerado como un comportamiento irrazonable". Le raisonnable en droit des contrats, LGDJ, Paris, 2009 , pp. 319 y 320. 
número de campos y sectores de la vida en sociedad. De ahí que esta regla, no sea botín privativo del Derecho, pues evidentemente lo trasciende, y con razón, en prueba incontrastable de su amplio espectro y generalizada proyección. No en vano, es un axioma de vida, de lo que se colige que todas las disciplinas que se ocupen de su titular: el hombre, se interesen en una actuación coherente y, por reflejo, huérfana de contradicción, desconfianza, deslealtad, incorrección, inestabilidad, irrazonabilidad, insolidaridad e inseguridad.

\subsection{BREVE fundamento filosófico}

En el campo filosófico, brevemente lo anotamos para no desviarnos del propósito neurálgico de este estudio, según se delineó, la coherencia humana encuentra sólido respaldo, no de ahora, sino de antaño, a medida en que por milenios ha sido objeto de especial examen por los más ilustres pensadores.

Es así como en este plano de la filosofía, en general, encontramos granados exponentes de la epistemología clásica que dedicaron buena parte de sus profundas reflexiones a censurar la floración de comportamientos o conductas contradictorias, tal y como aconteció con el célebre ARISTóteLES, quien desarrolló, in extenso, el afamado principio de no contradicción, con arreglo al cual el filósofo griego, desde el olimpo de la lógica, afirmaba que “... es imposible que lo mismo convenga y simultáneamente no convenga a lo mismo bajo el mismo respecto ..."23 o "... es imposible que algo sea y no sea simultáneamente..." ${ }^{24}$. Por eso, desde el punto de vista de la lógica aristotélica, "los enunciados contradictorios no pueden ser simultáneamente verdaderos" ${ }^{\prime 25}$ y “... nadie puede creer que lo mismo sea y no sea simultáneamente, como, según algunos, habría dicho una vez Heráclito..."26.

23 Aristóteles. Metafísica, Espasa Calpe. Madrid, 2007, p. 30, en especial Libro Cuarto, Capítulo 4.

24 ARIStóteles. Metafísica, op. cit., pp. 13-14.

25 Aristóteles. Metafísica, op. cit., p. 23.

26 ARIstóteles. Metafísica, op. cit., 23. 
Tal fue, entonces, la fuerza que el filósofo de Estagira le dio, dicho principio de no contradicción, que lo calificó, nada menos, como "...el principio cierto por excelencia” (Libro cuarto, capítulo 4), calificación que denota la significación en sede filosófica ${ }^{27}$, disciplina con la cual, ab antique, el Derecho tiene inquebrantables lazos.

Así las cosas, de acuerdo con lo afirmado por Jorge Roettı, “... la fundamentación del principio de no contradicción (...) se discute al menos desde tiempos de Aristóteles...." ${ }^{28}$ y su trascendencia es estructural, como quiera que, en puridad, la coherencia resulta necesaria para la cabal convivencia del ser humano, puesto que como lo memoró el propio ARISTótelES, su artífice y difusor milenario, "No es posible...que pueda concebir nadie [ni los sujetos, ni el juez, ni la colectividad, etc., agregamos nosotros], que una cosa exista y no exista al mismo tiempo" (Libro Cuarto, G, capítulo 3). De hecho, concluye RoEtTI, “... la decisión de conducir un diálogo crítico o racional tiene como condición necesaria al menos en la forma débil del principio de no contradicción, y la decisión de

27 Como expresa el autor Eduardo Molina CANTÓ en torno al 'principio de no contradicción', "ARISTÓteles.... afirma que se trata del principio más firme. Esto es, no solo el principio más firme respecto de todas las cosas, sino también el más firme de todos los principios. Al parecer, su firmeza radicaría en el hecho de que el principio de no-contradicción debe ser supuesto necesariamente por todo conocimiento. Así, uno está tentado de interpretar tal principio, desde un punto de vista epistemológico, como "condición de posibilidad" de todo conocimiento particular, o aun como un principio de índole "trascendental", postura que, en lo esencial, coincide con revisiones muy posteriores en el plano de la filosofía, pues como lo señala el mismo autor, confirmando el linaje del principio que nos ocupa, si “... el principio más firme es aquel sobre el cual uno no puede engañarse y es el mejor conocido, esto quiere decir que semejante principio puede servir para explicar todos los otros, y como tal, resulta que es absolutamente primero e indemostrable. Es preciso, entonces, si se conectan los textos de la Metafísica con los de los Analíticos Posteriores, que todos los principios se funden, en cierto sentido al menos, en un solo principio fundamental, el que sería primero, inmediato e indemostrable en grado máximo. Se trata, pues, de una jerarquía inherente al orden de los axiomas y, por tanto, tal vez, inherente también a la ciencia que estudia ese axioma fundamental, ciencia que poseería, como todas las ciencias pero en grado eminente por su universalidad, una estructura jerárquica (cf. BERTI, 1996, pp. 7980)". "Principio de no-contradicción y usos del verbo ser en Aristóteles", en Onomazein. 7, Santiago de Chile, 2002, p. 264.

Vid. Eduardo López Villegas. Derecho y argumentación, Universidad Javeriana y Grupo Editorial Ibáñez, Bogotá, 2011, p. 193 y ss., quien eleva la coherencia a rango de "exigencia" y de "deber", todo a la luz de la doctrina aristotélica en mención.

28 Jorge Alfredo Roetti. "Aristóteles y el principio de no contradicción", en Anuario Filosófico. N. 32.1 Universidad de Navarra, 1999, p. 157. 
construir un sistema normativo que posibilite la convivencia pacífica de todos los miembros de un grupo tiene como condición necesaria la posibilidad de escapar a la sanción y a la contradicción...."29.

En fin, es tal la importancia que la coherencia ha adquirido en el ámbito de la filosofía y de la lógica, que algunos autores han elaborado la denominada teoría coherentista de la verdad, en virtud de la cual se hace depender la 'verdad' de la correspondencia entre los enunciados y los hechos, es decir un 'enunciado coherente' o consistente, en una suerte de visión holística que, como en la concepción de Cornelius Benjamin, integra la verdad y la coherencia ${ }^{30}$.

Por consiguiente, resulta diáfano que en esta área fundante del saber, no es admisible la contradicción o la incoherencia, pues sabido es que, al mismo tiempo, una cosa no puede ser y no ser, lo que significa, transpolando, que quien inicialmente adoptó una específica actuación que suscitó confianza, no puede, súbitamente, alterarla o mudarla, pues si lo hace, pretendiendo obtener réditos de ello, resquebrajará frontalmente dicho principio inspirador de la filosofía, no de ahora, sino desde tiempos inmemoriales, en el que descansa entonces la doctrina de los actos propios, al mismo tiempo que lo nutre ${ }^{31}$. Al fin y al cabo, ello es toral, ambos comportamientos no podrían simultáneamente, en principio, encontrar abrigo en la validez y, por ende, resultar válidos los dos ${ }^{32}$.

29 Jorge Alfredo Roetti. Aristóteles y el principio de no contradicción, op. cit., p. 190.

30 Sobre este particular, Vid. Benjamin A. CoRnelius. "Coherence Theory of Truth", en Dagobert D. Runes. Dictionary of Philosophy, Littlefield, Adams, and Company. Totowa, NJ, p. 58. También se habla, en este campo, de la teoría 'coherencial' de la verdad de Nicholas RESCHER.

31 Vid. Juan Pedro Colerio. "La Doctrina de los propios actos, la prueba conducente y el principio de congruencia", en Derecho Procesal en vísperas del Siglo XXI. Temas actuales en memoria de los profesores Isidoro EISNER y Joaquín Ali SALGADO. Ediar. Buenos Aires, 1997.

32 En similar sentido, refiriéndose al "principio lógico-jurídico de contradicción y su fundamento ontológico”, circunscrito al plano normativo, el profesor Eduardo GARCíA MÁYNES, expresa que "El juicio que afirma que dos preceptos jurídicos que se oponen contradictoriamente no pueden valer a un mismo tiempo, es de índole enunciativa. No se trata, pues, de una norma. Simplemente expresa que, si aquellos preceptos se contradicen, su validez simultánea es imposible", puesto que no es de recibo ostentar, “... a la vez, los atributos positivo y negativo- de la licitud y la ilicitud", lo que significa en que no pueden ser válidas, inexorablemente, todas las conductas observadas por un mismo contratante a lo largo 
En suma, de la mano del Dr. Isidoro EISNER, reafirmemos que la doctrina de los actos propios "....encuentra su sustento filosófico y racional en los conocidos principios lógico y ontológico de 'no contradicción', en virtud de los cuales una cosa no puede ser ella y a la vez su contraria ['una cosa no puede ser y no ser al mismo tiempo', puntualizamos nosotros] ni es posible afirmar su realidad y su inexistencia en forma simultánea. Por tanto, además del buen orden de los negocios y de los procesos, es la higiene mental la que impone su respeto" ${ }^{\prime 3}$.

\subsection{FUNDAMENTO SOCIAL}

En conexión con lo manifestado anteriormente, es meridiano que la doctrina de los actos propios, y todas las figuras a ella próximas o hermanadas, tienen también un fundamento humano, concretamente colectivo $y$, por ende, social, pues la coherencia se eleva a presupuesto y sirve de férreo fundamento de la convivencia ciudadana y de la pax socialis, incluido el Derecho, como prototípica explicitación o revelación de "cultura" 34 .

de la relación negocial, en caso de aflorar una palmaria contradicción. Si ello acontece, inicialmente, no podrá valer tanto la conducta primigenia, desencadenante de confianza legítima, y a la vez la conducta ulterior, enrutada por una vía enteramente diversa, detonante de sorpresa, desazón y perjuicios correlativos (factum novum), siendo entonces imperativo optar por una de ellas, hecho que supone la consecuente erradicación de la que está ensombrecida por la citada contradicción. Lógica del raciocinio jurídico, Fontamara, México D.F, 1997, pp. 102 y 103.

33 Isidoro EISNER, "La doctrina de los propios actos compromete también el obrar del tribunal ('venire contra factum proprium non valet')", publicado en La Ley, 1987-C, 280. Buenos Aires, p. 2. En sentido similar se manifiesta el autor. Rubén H. Compagnucci de CAso. La doctrina de los propios actos, op. cit., p. 3.

34 En esta dirección, corroborando el amplio radio de acción de las diversas modalidades encaminadas a la protección de la confianza, el profesor de la Universidad de Paris II, Benédicte FAUVARQUE-Cosson, concluye que la "La confianza legítima guía no solamente el derecho, sino también las relaciones humanas". La confiance légitime et l'estoppel. Rapport général, op. cit., p. 59. Cfr. Alexandre Pimenta BATISTA Pereira, quien apoyada en las ideas de LuHMANN, observa que "La confianza representa ciertamente el atributo de mayor relevancia en la sociedad...El confiar es condición elemental de convivencia.... Por eso se debe enfatizar en que el agente, por ser libre, responde por sus acciones. Un miembro adulto de la comunidad debe obrar con coherencia en sus conductas....." "Entre o individual e o social: o problema das expectativas negociais á luz da teoria dos sistemas (A vedaçao do venire contra factum proprium)", en Revista de direito privado, Vol. 24, 2005, p. 14. 
En este sentido, con arreglo a la formación académica básica impartida y recibida en las aulas, uno de los eslabones de la cadena formativa general, de vieja data, y atendido el modelo imperante en el ámbito sociocultural, se espera que los individuos de la especie humana, por regla, se comporten armónica y homogéneamente, sin sobresaltos y cambios súbitos de índole sustancial, o radical. Así sucede, por regla, en las diversas actividades en las que ser coherente es una especie de debitum personalis permanente; eso es lo que, $a b$ antique, se ha inculcado, aquí y allá. Por eso, quien no asuma una conducta consistente, continua, regular, constante, armónica o estable, se la reprochará, pues la cohaerentia vitalis se demanda sistemáticamente, hasta el punto que la expresión 'incoherencia' o también 'inconsistencia' o, incluso, 'incongruencia', 'inestabilidad', 'inarmonía' o 'contradicción', tienen asignado un alcance que va más allá de su lectura meramente semántica, de suerte que, recta via, se erigen en vocablos descalificadores (disvaliosos); en ellos, en puridad, hace presencia un manto de censura, cuestionamiento, reproche o reclamo ${ }^{35}$.

Hay casos, en consonancia con lo aseverado, que cuando se le dice a un congénere una de ellas, se le está formulando un juicio especial, comúnmente severo, máxime en una colectividad racional o en la que la lógica, así sea de raigambre empírica, impregna el actuar cotidiano. $Y$ por contraste, cuando se afirma que una persona lo es, y lo ha sido a lo largo de su existencia vital, se le está elogiando, o reconociendo una bondad, digna de ser tenida en cuenta por sus semejantes. No es fortuito que a un ser modélico, dentro del haz de virtudes objeto de reconocimiento, se le distinga mediante la elocuente locución ya mencionada: 'coherente', o que se le fustigue, pretextando que en su devenir se ha enquistado la 'incoherencia' y en su trasegar se ha paseado la 'contradicción' ${ }^{36}$.

35 Desde esta perspectiva, como lo corrobora el autor italiano Gianluca SICCHIERO, teniendo en cuenta que "se trata de un principio que aceptamos todos en la vida cotidiana, expresar que una persona se contradice significa desacreditarla; es decir que se genera pérdida de valor porque no se crea confianza". "L'interpretazione del contratto ed il principio contra factum proprium venire potest", en Studi in onore de Cesare Massimo BIANCA, Giuffrè, Milano, 2006, p. 507.

36 En el epílogo de su libro: La objetividad. Un argumento para obligar, el Dr. Humberto MATURANA enseña que, "Lo natural es que todo ser viva en coherencia con el ámbito de interacciones que lo hace posible, y que cuando esta coherencia se pierda, se desintegre. Eso corrientemente no nos sorprende, aunque a veces nos maraville y nos lleve a hablar de la sabiduría de la naturaleza". De allí que el autor entienda por sabiduría humana "... 
Tan cierto es lo aseverado que, en un plano psicológico y, aún psiquiátrico, se afirma que un sujeto -frecuentemente- incoherente, se torna indicativo de algún desarreglo, disfunción o desorden, por moderado, o acentuado que sea, o de alguna alarma especial. ${ }^{37}$ Muy por el contrario, quien se comporta coherente y ordenadamente, es la usanza, es tomado por una persona que se ajusta a estándares constitutivos de 'normalidad', constantia o regularidad, y que se le considera dentro de la media comportamental. Lo propio tiene lugar en punto tocante con la dialéctica y, en fin, con la argumentación, en las que la contradicción con lo esgrimido o aseverado antes o en su momento, asume el papel de leviatán, o de yerro catedralicio, por cuanto no permite que se asome, de lo que se colige que en este terreno, nada más cuestionable que se exprese, dentro de los 'pecados' probables, que se ha incurrido en ella ${ }^{38}$.

Análoga anotación, aún en un terreno más pragmático -y hasta pedestre-, cumple realizar en relación con la simple convivencia societaria o ciudadana, por cuanto en ella se anidan reglas o principios coloreados por la más elemental lógica cívica que, a su manera, y en un lenguaje más cotidiano y popular, con

la coherencia en el pensar, el sentir y la acción....en el vivir la estructura dinámica de los seres vivos permanece coherente con las circunstancias cambiantes que les toca vivir, y viven en tanto tal coherencia o acoplamiento estructural se conserva", Dolmen Ediciones, Bogotá, pp. 121 y 123.

37 Acerca de la incidencia del comportamiento contradictorio en el plano sociológico, en asocio del psicológico, ético y del social, véase la documentada obra del autor portugués, Antonio Manuel Da Rocha, Da boa fé no direito civil. Almedina, Lisboa, 2001, pp. 750 y ss. Así, en tratándose del primero de ellos, ad exemplum, recuerda que "Sociológicamente, el comportamiento contradictorio se configura como un atentado en contra de expectativas fundamentales de continuidad de autorepresentación que atañen también a identidades de parecer", op. cit., p. 750.

38 'No te contradigas'; 'hay una grave contradicción en lo que afirmas', 'cómo es posible que hoy sostengas una tesis cuando ayer defendiste precisamente la contraria', etc., expresiones de la cotidianidad mediante las cuales se pretende derruir la sindéresis individual, o descalificar al otro, lisa y llanamente, por tornarse inexplicable su comportamiento.

Al respecto, bien recuerda el profesor y exmagistrado de la Corte Suprema de Justicia de Colombia, Eduardo LóPEZ VILLEGAS, que ARISTÓTELES señalaba “....entre las pruebas retóricas de la persuasión, la del talante del orador que, especialmente, sea digno de crédito, la que no se tiene si se peca contra la coherencia consigo mismo. Una buena razón se demerita si está en boca de quien se le conoce por exponer ideas opuestas a la que ahora expone. En muchas ocasiones una idea brillante por su oportunidad, tiene que ser disociada del oportunismo del orador ofreciendo argumentos sobre como ésta no es el resultado de la coyuntura, sino de unos principios, de una postura mantenidos a través del tiempo". Derecho y argumentación, op. cit., p. 193. 
independencia del jurídico, no comulgan con actuaciones que minen la confianza, que pongan en entredicho la palabra empeñada, que se erijan en ambivalentes. No es infrecuente escuchar, a título de inequívoca alabanza, que un poblador es probo, honorable y correcto, por cuanto se comporta con regularidad o constancia, o que es 'de una sola pieza', queriendo expresar con ello que esa persona es de fiar, y que no se aprovecha de las circunstancias, dado que tiene muy en alto el significado íntimo de respetarse a sí mismo y también de respetar a los demás. Acierta entonces el profesor rosarino Juan M. DoBson, cuando indica que “...sostener que 'nadie puede obrar en contradicción con sus propios actos' constituye una regla de convivencia, y del sentido común, que en algunos casos ha sido recogida por el refranero popular", memorando, para recrear su aserto, el manido pero expresivo refrán: "No se puede borrar con el codo lo que se escribe con la mano" 39 , en adición a otro que revela, en términos aproximados, que hay quienes no la hacen a la entrada, pero sí a la salida ${ }^{40}$.

En este orden de ideas, es tal la relevancia funcional de la coherencia en la esfera social, que la convivencia colectiva, que la pax socialis, que la cohesión social, que la confianza ciudadana, y que la armonía cívica, en gran medida, dependerán de la misma, por cuanto la incoherencia se traduciría en percutor del desorden, de la inarmonía, de la desconfianza, de la desunión, de la beligerancia extrema, en una sola palabra del 'caos' o de la 'anarquía't1. Ello explica que se hable, con acierto, de la 'Trascendencia social de la doctrina de los actos propios', habida cuenta que "Cuando las personas integran una formación comunitaria, tienen conciencia de ciertas categorías conductuales y que la plena observancia

39 Juan Dobson. El abuso de la personalidad jurídica (en el Derecho Privado). Depalma. Buenos Aires. 1991, p. 283.

40 En rigor, esta lógica cívica, de ordinario sapiente, está en estricta sintonía con los más elementales y milenarios principios lógicos, uno de ellos el llamado principio de no contradicción, de raigambre aristotélica, en los que se asientan -y han asentado- varias disciplinas, como ya se anotó.

${ }_{41}$ Cfr. Dimitri Houtcieff. Le principe de cohérence en matiére contractuelle, Presses Universitaires D’Aix Marseille, Faculté de Droit, Aix-En-Provence, T. I, 2001, pp. 30 y 31, autor que expresa con rotundidad que "...la coherencia es un valor cultural....; es un factor de cohesión social. En efecto, una 'organización racional es...una condición necesaria para la continuidad de la sociedad. Es una de las exigencias de esa cohesión. Si ella no se preocupa por la predictibilidad, la sociedad cae en la anarquía, poniendo en duda toda base justa y legal". 
de las mismas produce un estado de seguridad, de mutuo conocimiento, de plena confianza social, todo lo que determina una virtual dependencia en su comportamiento para adecuarlo a esas reglas preestablecidas. De allí el nacimiento del principio que impide a un sujeto -en el ámbito de las relaciones humanas intersubjetivas-, desplegar conductas contradictorias con otras anteriores". Por ello, "El acto propio, como acto social, entraña como presupuesto la paz social"42.

Desde esta perspectiva, en síntesis, el binomio integrado por la coherencia, de un lado, y por la confianza, del otro, entendida esta última como reflejo -o corolario- (posterius) de aquella (prius), tiene asignado un protagónico papel en la comunidad, la que espera que no se alteren, negativamente, las bases mínimas de la convivencia pacífica y estable ${ }^{43}$.

42 Martín M. NolfI. "La doctrina de los propios actos como garantía de la solidaridad social", en La Ley. Buenos Aires. 1996-B. pp. 781 y ss., autor que continúa con su exposición, señalando que, "La solidaridad social, como referente dikelógico en las relaciones contractuales, aparece como un marco totalizante de conductas conocidas y asimiladas, que genera una esperanza de concreta realización en la actuación positiva de algunos de sus componentes... Afírmase que la base de la doctrina está en el hecho de que se ha observado una conducta que justifica la conclusión o creencia de que no se hará valer un determinado derecho. El interés de la comunidad, como pretensión innominada de índole ético-sociológica, persigue que la doctrina de los propios actos ofrezca la posibilidad de convertirse en un valladar paralizante de la actuación de un sujeto que asuma una conducta incoherente". Por todo ello, redondeando su planteamiento, asevera el Dr. NolfI, que "...el hecho de que un sujeto trate -en una determinada relación jurídica sustancial o procesalde situarse en función de la obtención victoriosa de un mejor resultado, poniéndose en manifiesta contradicción con su conducta anterior, constituye un proceder injusto y falto de lealtad que afecta la paz social y la convivencia armónica".

En esta misma dirección, ya había puesto de presente en la década del cincuenta el autor PUIG BRUTAU, que "Nuestra doctrina de los actos propios.... significa realmente un poderoso instrumento para aumentar el sentido de solidaridad y para dar cohesión al grupo social, pues cada miembro ve reflejado en sus propios intereses el perjuicio que su conducta podría haber inferido a los demás. Como se dice en una interesante obra, cuando las personas que integran un grupo social tienen conciencia de la existencia de un arquetipo de conducta, su acatamiento produce un estado de mutua dependencia en el comportamiento entre los individuos, hasta el punto de permitir cierto grado de previsión en el obrar, pues, el de una persona es la base de la conducta observada por la otra". La doctrina de los actos propios, op. cit., p. 115.

43 Análogo parecer es el expresado por la Dra. Silvia CALMES, de acuerdo con el cual el "...fenómeno de la confianza es objeto de numerosas disciplinas científicas -sicología, sociología, ética, derecho-. Este interés de las ciencias se explica por el hecho de que la confianza en sus propias actuaciones constituye un hecho elemental de la vida social; no solamente respecto de la existencia individual, sino especialmente de la coexistencia social de los hombres y las relaciones entre los Estados y los pueblos". Du principe de protection de la confiance légitime en droit allemand, communautaire et franç ais, Dalloz, Paris, 2001, p. 54. 


\subsection{Somero fundamento EVANGÉlico}

La doctrina en referencia, a su turno, tiene también un sólido fundamento y un respaldo evangélico, en razón a los numerosos pasajes de la Biblia, que en efecto, sirven de apoyatura a la 'coherencia humana' (deber ser), tanto que la doctrina cristiana, ab initio, en gran parte, se caracteriza por pregonar la armonía, la solidaridad, la equidad, el desprendimiento, la honradez, la tolerancia y, en fin, el amor por el prójimo, médula de su penetrante mensaje, en sí mismo refractario a todo lo que tenga la virtualidad de lesionar sus intereses. Por eso la incoherencia, la contradicción, los dobleces, la inconsecuencia, la hipocresía, el egoísmo, el afán de sacar provecho en perjuicio ajeno, están proscritos de raíz de su prédica, pues afectan el espíritu y el ser de los demás: la colectividad.

Numerosos fragmentos, ciertamente, podríamos traer a colación para corroborar este aserto. Empero, dos de ellos, quizá sean suficientes para encarnar la defensa de tan nobles propósitos y para condenar, correlativamente, la contradicción humana, fuente de tantos males, pasados y presentes. Nos referimos, en primer término, al Evangelio de SAN MATEO, en el cual se consigna lo siguiente: "23:27. "iAy de vosotros, escribas y fariseos hipócritas, pues sois semejantes a sepulcros blanqueados, que por fuera parecen bonitos, pero por dentro están llenos de huesos de muertos y de toda inmundicia! ${ }^{28}$ Así también vosotros, por fuera aparecéis justos ante los hombres, pero por dentro estáis llenos de hipocresía y de inequidad. ${ }^{29}$ "iy de vosotros, escribas y fariseos hipócritas, porque edificáis los sepulcros de los profetas y adornáis los monumentos de los justos, ${ }^{30} y$ decís: "Si nosotros hubiéramos vivido en el tiempo de nuestros padres, no habríamos tenido parte con ellos en la sangre de los profetas!" ${ }^{11} \mathrm{Con}$ lo cual atestiguáis contra vosotros mismos que sois hijos de los que mataron a los profetas. ${ }^{32}$ jColmad también vosotros la medida de vuestros padres!»».

Este texto de San MATEO, ha sido interpretado, justamente, como indicativo de la importancia de no asumir dobles o sinuosos comportamientos, en claro rechazo a la contradicción, al 'doble juego', a la existencia de dos caras, enteramente diversas, a una especie de disfraz que oculta una realidad disímil a la reflejada en el campo ontológico y cognoscitivo. La sola referencia a los sepulcros blanqueados, indiscutidamente elocuente, habla por sí sola (res ipsa loquitur). Lo propio acontece 
con la alusión a la apariencia externa de 'justos', antítesis de lo que sucede en el interior de algunos seres humanos, "...llenos de hipocresía y de inequidad"44.

Y en segundo término, nos referimos a otro texto de San MATEO de una gran profundidad y elocuencia en lo que atañe a su mensaje, al tenor del cual "Así que todas las cosas que queráis que los hombres hagan con vosotros, así también haced vosotros con ellos, pues esto es la Ley y los Profetas." (MATEO 7:12). Dicho texto, considerado como la "regla de oro", igualmente conocido a través de otras expresiones, v.gr: no hagas a los demás lo que no deseas que te hagan a ti, revela con diafanidad la trascendencia del significado de la referida regla de la coherencia, pues sería a todas luces contrario a ella reclamar para uno lo que no se está dispuesto a hacer respecto al prójimo, reflejando no sólo egoísmo, sino incoherencia ${ }^{45}$.

44 Lo mismo acontece con otro texto de SAN MATEO (23:1-7), el que reza: "Después de esto, Jesús dijo a la gente y a sus discípulos: Los maestros de la ley y los fariseos tienen la responsabilidad de interpretar a Moisés. Así que ustedes deben obedecerlos y hacer todo lo que les digan. Pero no hagan lo que hacen ellos, porque no practican lo que predican. Atan cargas pesadas y las ponen sobre la espalda de los demás, pero ellos mismos no están dispuestos a mover ni un dedo para levantarlas." Y decimos que lo mismo acontece con lo referido líneas atrás, habida cuenta que en este pasaje también se rechaza la dualidad comportamental existente entre decir y practicar. En este sentido, Samuel PÉrez MiLlos expresa, al hilo del texto en cita, que "Una disociación entre enseñanza y obediencia se manifestaba en muchos de los escribas y fariseos... Nuestro Señor advierte que aquellos enseñadores no ajustaban su conducta a lo que enseñaban. Es decir enseñaban una cosa y practicaban otra. Sus costumbres estaban habitualmente en contradicción con su enseñanza. El pecado que Jesús pone de manifiesto en esta conducta es esencialmente el de hipocresía. Aparentaban una cosa, pero realmente eran otra. Aparentaban piedad, pero negaban la eficacia de ella. Junto con el pecado de la hipocresía está también el de la inconsecuencia, porque 'dicen y no hacen'....". Comentario exegético al texto griego del Nuevo Testamento, Editorial CLIE, Barcelona, 2009, p. 1551.

Tal será la vigencia y la fuerza asignada en el texto de SAN MATEO a la inconsecuencia, utilizada por nosotros como equivalente a los términos incoherencia, contradicción e incongruencia, sin perjuicio de otros más, que p. R. SANTIDRIAN, comentándolo, anota que "La primera acusación de Jesús contra sus adversarios (pero no la única) es la de inconsecuencia: su enseñanza es válida, pero ni ellos mismos son fieles a ella". El Evangelio según San Mateo, Ediciones Cristiandad, Madrid, 1975, p. 499.

45 Tan penetrante será este pasaje que en el Derecho histórico francés, autores del prestigio de Jean Domat y Robert Joseph PothiER, como observaremos, se apoyaron en él para recrear y justificar la regla en comentario, en prueba de su vigencia en el marco del Derecho natural, dato este no muy conocido en sede jurídica, pero dueño de una singular importancia. Vid. Jean-François Romain. Théorie critique du principe général de bonne foi en droit privé, op. cit., p. 108 y ss. 
En todos los anteriores casos, queda en claro entonces que conductas del tenor expresado son ajenas a los cánones evangélicos y, por ende, alejados del mensaje de la Iglesia Católica, igualmente opuesta a ellas, como también se evidencia de algunas encíclicas papales, entre varias, la sollicitudo rei socialis ${ }^{46}$.

\subsection{Fundamento ECONÓMICO}

Abundando en razones que fungen como fundamento de la coherencia comportamental, y de su pertinencia, amén del respeto por la confianza suscitada en los individuos, no podemos dejar de considerar un aspecto que, en la actualidad, registra cada vez más protagonismo, a fuer de importancia, tanto en la esfera jurídica, como en la de las ciencias sociales, en general: se trata del análisis del impacto económico de las doctrinas y de las teorías que a diario se acuñan, tanto en sede legal, como jurisprudencial y doctrinal.

Ciertamente, no se puede soslayar la importancia que se ha atribuido al estudio de las consecuencias económicas de los diferentes institutos jurídicos, especialmente con sujeción a la -relativamente- reciente doctrina del análisis económico del Derecho (o law and economics, por su denominación en inglés, de suyo trascedente y reveladora, como quiera que ha servido para lograr interdisciplinariedad en los análisis en Derecho, los que antes resultaban más insulares y, de contera, menos universales, desde el punto de vista de las ciencias y las disciplinas académicas ${ }^{47}$.

46 Vid. Daniel Mario Rudi. "Aporte de la Encíclica 'sollicitudo rei socialis' a la doctrina de los actos propios". El Derecho. T. 138. Buenos Aires. pp. 969 y ss., quien indica que, "Estrictamente, la regla venire contra factum proprium non valet, engloba los deberes de la justicia clásica. Porque no es una doctrina sobre los derechos propios, sino sobre el fundamento del propio deber de respetar los derechos ajenos....Pues si ninguna duda hay que el hombre tiene libertad para actuar, no tiene el derecho de obrar mal....Pero además, la censura del acto incongruente, supone el reconocimiento en último término: (i) que al prójimo le pertenece algo inalienable, y (ii) que no puede depender absolutamente del arbitrio de un semejante (p. 973)".

47 No es invisible la difusión del análisis económico del Derecho, sobre todo en el siglo XXI. A partir de sus primeros desarrollos en la centuria pasada, particularmente por los pensadores de la Escuela de Chicago, la doctrina del law and economics ha venido ganando, en forma gradual, numerosos adeptos, que hacen de ésta una teoría de relevancia, con prescindencia de si a todos convence o concita su adhesión, por cuanto hay que reconocer que ha suscitado críticas. Anna Rita GeRmAnı señala sobre este particular que “... la razón por la 
Por eso, nos parece de la mayor importancia hacer una breve referencia al fundamento económico que soporta la coherencia comportamental, así no sea con la extensión y profundidad con la que quisiéramos hacerlo, pero sí simplemente con el propósito de enfatizar lo positivo de respetar los cánones de sindéresis y uniformidad en las conductas en la esfera económica (regularidad y estabilidad). Se trata, en lo medular, de exponer las razones por las cuales, desde la perspectiva en mención, la coherencia conductual y la confianza que de ella se deriva, no solamente resultan deseables, sino que, además, se erigen como convenientes, lo cual es corroborado por los referidos analistas económicos del Derecho, entre otros.

En efecto, si partimos de la base de que el fundamentum de una institución, es la "razón principal o motivo con que se pretende afianzar o asegurar" ella ${ }^{48}$, encontramos que, desde la colina económica, son varias las razones que afianzan la significación de la coherencia comportamental y, según se decía, la confianza que de ella se deriva en el circuito económico, detonante, a su turno, de seguridad, estabilidad, regularidad, y certidumbre, también clave de bóveda en la economía.

Realmente la doctrina, en forma casi unánime, coincide en señalar que el basamento económico a partir del cual se aboga por preservar la coherencia en el comportamiento (personas naturales y jurídicas), es variopinto. Así, entre otras cuestiones más, tradicionalmente se suele destacar la mitigación de los riesgos derivados de las operaciones, la previsibilidad de los comportamientos y, en consecuencia, la facilitación de las relaciones, la reducción de los costos

cual la economía se inmiscuyó en el campo del derecho, logrando importantes resultados, tiene que ver, fundamentalmente, con la combinación de dos factores; el primero, es que derecho y economía tienen una gran cantidad de aspectos comunes; el segundo, es que la economía ofrece una sólida base de análisis para el comportamiento humano, que el derecho no tiene..." "Environmental Law and Economics in U.S. and E.U.: A Common Ground?" en SOAS, Universidad de Londres, junio, 2004, pp. 4-5. Cfr. Hsiung BINYUANG, The Success of Law and Economics: A Methodological Interpretation, Universidad Nacional de Taiwan, 2000, pp. 3 y ss. Henry Manne. "Our Two Corporation Systems: Law and Economics", en Virginia Law Review, Vol. 53, N² 2, marzo de 1967, pp. 262 y ss.; Ronald COASE. "The Nature of the Firm", en Economica, No 4, 386, noviembre, 1937, pp. 386-495. 
asociados a las curvas de aprendizaje y la reducción de los costos de agencia con fundamento en la estabilidad de las relaciones ${ }^{49}$.

Las anteriores son contribuciones que constituyen parte de la ratio económica de la institución, y que están, todas ellas, referidas a la facilidad para la celebración de negocios, de una parte, y el aumento de la eficiencia a través de paliar los costos y el incremento de las utilidades, de la otra.

Pero donde radica el fundamento o soporte económico más saliente de la protección de la coherencia conductual, en adición a la preservación de la confianza de los actores y agentes económicos, es en el tema relativo a los costos: la coherencia comportamental, expresado en términos realistas, es sustancialmente menos costosa que la incoherencia y, en esa medida, económicamente se alcanza una mayor y sostenida eficiencia. Al fin y al cabo, los comportamientos abruptos, sorpresivos y contradictorios, minan la confianza e incrementan las erogaciones asociadas a cada actividad. La coherencia, por el contrario, estimula las relaciones, mitiga la necesidad de adoptar ciertas precauciones adicionales y reduce la aversión, con lo cual, naturalmente, se reducen costos y se aumentan las utilidades. De hecho, como se anticipó, la propia medición econométrica, devela que la incoherencia es más costosa que la coherencia, lo cual, entre otras proyecciones más, no solamente se irradia en el ámbito microeconómico, sino también en el macroeconómico. No es de extrañar que un país que propende por la estabilidad y la regularidad, genera menos riesgos, a la par que menores costos asociados a la inversión, con lo cual, a la postre, se propicia un mejor escenario que aquel que se generaría si la economía estuviera permeada por la volatilidad, los cambios, la inseguridad y la inestabilidad. Es en este sentido que se expresa, con apego a las relaciones contractuales, en particular al 'acuerdo racional', que "...la incertidumbre constituye la mayor amenaza para los mercados...."

49 Cfr. Lucia PIScitello. "Corporate diversification, coherence and economic performance", en Industrial and Corporate Change, Vol. 13, N 5 (ICC Association) 2004; Gary SAMPSON. "Greater Coherence in Global Economic Policymaking: A WTO Perspective", en The WTO as an International Organization, Universidad de Chicago, Chicago, 2000, pp. 257 y ss.; J. KRAFT y L. RAVIX. "Corporate Governance and the Governance of Knowledge: Rethinking the Relationship in Terms of Corporate Coherence", en Economics of Innovation and New Technology. Vol. 17. № 1-2, 2008.

50 Jules L. Coleman. Riesgos y daños, Marcial Pons, Madrid, 2010, p. 120. 
Lo propio sucede en la esfera de las relaciones individuales y grupales: contratar, por vía de ejemplo, con un individuo o entidad cuyas posturas varían abruptamente y del que no se puede esperar una razonable continuidad o regularidad (constancia), implica rodear al contrato de mecanismos más refinados de garantía y de equilibrio, a la vez que de controles más severos, lo cual se traduce en mayores costos de transacción. Por eso, no vacilamos en reafirmar que, in genere, la coherencia obviamente es menos costosa que la incoherencia, lo cual se manifiesta en dos particulares aspectos, a saber:

a. En primer lugar, en el hecho de que la coherencia comportamental, encarnada en la doctrina de los actos propios, favorece la confianza en el relacionar y el quehacer cotidiano, con lo cual se facilitan los negocios y se fomenta la transferencia eficiente de bienes. Estamos, gráficamente hablando, frente a un efecto en cadena: se fomenta la confianza en las relaciones humanas, lo que, a su turno, implica menores dificultades en la negociación y, por ende, menores costos de transacción - particularmente en relación con garantías, precauciones y remedios ante 'huidas' precontractuales-. Ello, en suma, conduce a facilitar la contratación y la eficiencia, la productividad, etc. Como bien lo advertía Ronald COASE, tales facilidades fomentan la transferencia eficiente de bienes, generándose valor agregado ${ }^{51}$.

b. Pero, adicionalmente, la confianza tutelada por figuras como la consabida doctrina del acto propio, contribuye a contrarestar problemas de agencia y, particularmente, los gastos derivados de la asimetría de la información. Realmente, las condiciones asimétricas existentes entre los individuos que se relacionan en la cotidianidad, suelen suponer la realización de una serie de cuantiosas erogaciones en aras de informarse y de igualar las ventajas informativas que el otro tiene a su disposición. Con ello, grosso modo, se procura equiparar la posición negocial de

$\overline{51}$ Sobre este particular son especialmente elocuentes las reflexiones planteadas por Richard POSNER, en el sentido de que los ordenamientos jurídicos deben propender por la transferencia eficiente de bienes, esto es, por su paso de manos de quienes menos los valoran, hacia quienes más los valoran, que es precisamente una de las ventajas que se logra con la reducción de los costos de transacción (Economic Analysis of Law. Aspen Publishers. Chicago. 2011, pp. 73 y ss.). Cfr. Ronald COASE. "The Problem of Social Cost", en Journal of Law and Economics, Vol. 3. Octubre de 1960. Vid., también, Guido CALABRESI. "Some Thoughts on Risk Distribution and the Law of Torts", en The Yale Law Journal. Vol. 70. 1967. 
todos los intervinientes, en aras de evitar comportamientos oportunistas y, por tanto, perjudiciales. Sin embargo, cuando la confianza prima, tales gastos se hacen menos necesarios $\mathrm{y}$, consecuentemente, se aminoran los problemas derivados de la mencionada asimetría de la información, como quiera que se tiene fe en la probidad y buena fe del otro sujeto, a pesar de su mayor información.

Las anteriores ideas confirman, de manera manifiesta, que es menos costoso para una economía el actuar coherentemente, lo cual, se itera, sirve de ratio económica para fundamentar la doctrina de los actos propios y la coherencia conductual, tal y como lo han reconocido, por lo demás, varios autores. En ese sentido, por vía de ilustración, Oliver WiLLIAmson expresa que “...Una forma de disminuir los costos de transacción es aumentando la confianza entre los agentes. La confianza es la base de la cooperación y por lo tanto a mayor confianza entre los agentes, existe más disponibilidad de parte de ellos de cooperar y de participar en acciones colectivas. Estas acciones, llevadas a cabo en la búsqueda de un beneficio común para las partes involucradas, permiten economizar tiempo y dinero..." 52 .

El Dr. Vladimir Monsalve Caballero, al respecto, es igualmente ilustrativo. En su entender, “... cierta parte de la doctrina económica-jurídica defiende que para poder corregir en parte dicha asimetría de la información y de sus costes, es necesaria la defensa y protección de la confianza. En un sentido más amplio, la salvaguarda de la confianza se refiere a la tarea general del ordenamiento jurídico de garantizar seguridad y agilidad del tráfico jurídico y especialmente el intercambio de bienes y servicios, desde una visión proteccionista hacia quien le es más costoso adquirir la información, de tal forma que, el problema de protección de la confianza desde un planteamiento económico es menester el gasto en coste de información al nivel más bajo posible, y para conseguir esa meta se requiere que las informaciones necesarias para la conclusión de un contrato perfecto las

52 Oliver WiLLIAMson. The Economic Institutions of Capitalism, traducción de Eduardo Suárez. Fondo de Cultura Económica. México. 1989, pp. 53-76. 
suministre quien le sea más barato adquirir la información, que por lo general coincide con la parte más fuerte de la relación contractual ..."53.

Mariano Nieto ANTOLín, por su parte, afirma que "... también se ha comprobado que en entornos institucionales - poco "susceptibles"- donde reina la confianza, las relaciones entre los agentes económicos son más fluidas. La confianza es un estado psicológico que reduce la incertidumbre a la que se enfrentan los individuos en relación con las intenciones y acciones futuras de otros con los que se relacionan. La confianza genera expectativas favorables y aumenta la probabilidad de que las acciones futuras de los otros sean beneficiosas $o$ al menos no vayan en detrimento de nuestros intereses. La confianza es una actitud de la que se deriva una conducta que opera acumulativamente a lo largo del tiempo. Cuando se confía y se coopera, los resultados positivos estimularán la confianza y el sentimiento de reciprocidad y facilitarán la cooperación posterior. Por esa razón, en relaciones económicas a largo plazo (relaciones laborales, contratos de aprovisionamiento con subcontratistas, adquisición de bienes de consumo duradero, operaciones de crédito, etc.), la confianza reduce el riesgo de comportamientos oportunistas y por lo tanto disminuye los costes de transacción y supervisión. La reducción de costes que induce la confianza puede cuantificarse a través del tiempo total que los agentes ahorran en verificar las acciones de los demás..." ${ }^{4}$.

Irene HAU-SI CHOW también coincide con la anterior idea, como quiera que sostiene que "... es una consecuencia naturalmente razonable que cuando las partes de un negocio confían recíprocamente el uno en el otro, los costos derivados de las transacciones celebradas entre ellos serán menores, ya que las garantías no serán necesarias. Estos menores costos de transacción contribuirán, obviamente, a mejorar la eficiencia (...) una estudio de casi 3000 empresas en

53 Vladimir Monsalve. Responsabilidad precontractual. Grupo Editorial Ibáñez. Bogotá. 2010, p. 245.

54 Mariano Antolín. Las ventajas económicas asociadas a las estructuras de confianza. Universidad de León y ACEDE. León. 2009, p. 7. 
diferentes ciudades de China, refleja que la confianza sí reduce los costos de transacción..." 55 .

Frank den BUTTER y Robert Mosch, de manera análoga, explican que "... es obvio que los costos de transacción en las diferentes fases de la negociación están íntimamente ligados al problema de la confianza. Este problema tiene que ver con el hallazgo de la información necesaria sobre las oportunidades de negocio, los potenciales contratantes y la mitigación de riesgos (fase precontractual). La confianza también es importante cuando se negocia sobre la distribución de las ganancias y las estipulaciones del acuerdo (fase contractual) y es un factor predominante en la determinación de la forma como se ejecutará y monitoreará el contrato (fase de control). De hecho, la confianza, en muchas ocasiones, permite soluciones cooperativas para el dilema del prisionero (...) los mecanismos que fomentan la confianza entre las partes, contribuyen en general a reducir los costos y a aumentar la eficiencia en la negociación..." ${ }^{.56}$.

Esta lectura es reiterada en múltiples estudios autorales que, como se puso de presente anteriormente, coinciden en que figuras que, como la doctrina de los actos propios, fomentan la coherencia comportamental, y correlativamente tutelan la confianza entre las partes, tienen un férreo basamento económico, toda vez que mitigan los riesgos y reducen los costos de transacción, con lo que facilitan la negociación y, de paso, la eficiencia, como se anotó. ${ }^{57}$. De hecho, los analistas económicos emplean una expresión que resulta, de suyo, elocuente para reflejar las ventajas asociadas a la estabilidad y la inmutabilidad de las circunstancias: se trata de la locución latina 'caeteris paribus', que traduce 'siendo las demás cosas igual' y que es utilizada en los casos en que se requiere que un conjunto de variables permanezcan constantes, estables o inalteradas. La inmutabilidad a

55 Irene $\mathrm{HAU}$-SIU CHOW. "How trust reduces transaction costs and enhances performance in China's businesses", en SAM Advanced Management Journal. 2008, p. 1.

56 Frank Den Butter, y Robert Mosch. Trade and Transaction Costs. Universidad de Amsterdam e Instituto Tinbergen. Amsterdam. 200, pp. 6-7.

57 Vid., entre otros, J.S. Coleman. Foundations of Social Theory. Harvard University Press, Cambridge, 1990; B. NоотевоOм. Trust: forms, foundations, functions, failures and figures. Edward ElgaR. Cheltenham, 2002; Oliver WilLIAMSON. "Transaction cost economics: the governance of contractual relations", en Journal of Law and Economics. $N^{\circ} 22,1979$, pp. 233 y ss. 
que se refiere esta expresión, facilita la comprensión de los modelos económicos abstractos y, con ello, se simplifican los análisis y se permite arribar a conclusiones más precisas frente a los problemas planteados.

De igual modo, en la esfera económica, como claro efecto reflejo de la ciencia del Derecho, algunos autores muestran preocupación por examinar cada vez más esta temática con equilibrio y cautela, a fin de no propiciar distorsiones y lecturas ajenas a la realidad social, enmarcadas únicamente en los beneficios, sin atender a los costos y secuelas de índole colectiva. Por ello, se habla de 'competencia y cooperación', términos que no son antagónicos, o irreconciliables. Bien expresa el autor J. ColEMAN, que "Sería insensato afirmar que el único valor de los mercados es el señalado: maximizar las relaciones sociales sin plantear los problemas relacionados con el ámbito y la medida del consenso subyacente lo que contribuye a la estabilidad social...El compromiso con la ventaja mutua como condición de estabilidad racional nos lleva nuevamente a la cooperación racional...."58.

En suma, como lo manifiesta de nuevo el Dr. MonsALVE, “... la protección de la confianza, como hasta aquí queda claro, no es una necesidad exclusiva de la ciencia jurídica sino también de la económica, ciencia que se ha ocupado en múltiples oportunidades sobre la materia con base en la triada MaximizaciónMercado-Eficiencia" ${ }^{\prime 2}$.

\section{FUNDAMENTACIÓN JURÍDICA DE LA DOCTRINA DE LOS ACTOS PROPIOS}

En sintonía con lo señalado en apartes anteriores, la coherencia, la congruencia, la regularidad, la continuidad, la constancia, la consistencia, la cadencia, la estabilidad, la armonía, la simetría, entre otras expresiones del

\footnotetext{
58 J.L. Coleman. Riesgo y daños, op. cit., p. 64, y 85, quien agrega que "La magnitud del problema de la cooperación, aproximadamente la distancia entre la curva de contrato y el punto de desacuerdo, refleja los beneficios sociales que se desaprovechan cuando fracasa la cooperación" (p. 125).

59 Vladimir Monsalve. La responsabilidad precontractual, op. cit., p. 246.
} 
mismo -o similar-tenor y alcance, son indicativas de lo que se espera de todo individuo, en general, y en el ámbito contractual, en particular, de cada una de las partes o extremos de la relación jurídico-negocial, con prescindencia de su status o ubicación en el contrato: acreedor, deudor; predisponente, adherente, etc., siendo absolutamente claro que, toda conducta opuesta, per se, no resultará admisible y, por tanto, procedente, en principio, ni en la etapa precontractual, ni en la pos-contractual. De ahí que la incongruencia, la irregularidad, la incoherencia, la inestabilidad, la discontinuidad, la inarmonía y la contradicción, sólo para aludir a algunos comportamientos fácticos, eclipsen el deber ser contractual, el cual, inicialmente, debe estar libre de toda oscilación, ondulación o cambio brusco e inopinado, por regla generalísima, desde luego con las excepciones de ley que indicaremos, pues categóricamente no puede decirse que la variación o cambio siempre es reprochable, ética y jurídicamente, así lo sea un apreciable número de casos, puesto que no es un estado conveniente, ni menos ideal; sería todo lo opuesto, porque se alteraría el 'programa contractual', en sentido lato, la armonía, la estabilidad y la convivencia negociales.

Admitir otra conclusión, nos situaría en un plano antijurídico, rayano en lo inequitativo, pues antes que el orden, que la certidumbre, la regularidad, la confianza y la seguridad, pulularía el desorden, la incertidumbre, la inestabilidad, la inarmonía, la desconfianza y la inseguridad, antítesis de lo que debe ser el Derecho, en todas sus manifestaciones y dominios, incluido el contractual, muy especialmente, en el que el componente relacional adquiere una dimensión particular. No en vano, la libertad, a menudo utilizada como argumento para fundamentar cualquier variación o cambio comportamentales, conoce límites; lo contrario, sería libertinaje, abusividad, al tiempo que causa de violaciones insostenibles e inadmisibles. Por ello el arbitrio y la voluntad, no son, no pueden ser absolutos, ni tampoco desafiantes de caros intereses. ¿Cuántas injusticias, en efecto, se han cometido y se siguen cometiendo en nombre de la 'justicia' y de la 'libertad'?

Desde esta misma perspectiva, no se equivocan los profesores Augusto Morello, y Rubén STIGLITZ, cuando aseveran que“...es un imperativo del sujeto observar un comportamiento coherente, como principio básico y en todos los 
órdenes de sus relaciones, no solamente las jurídicas", tanto que "la vida exige a los hombres un comportamiento coherente, no sólo en la faz negocial" ${ }^{\circ}$.

El voluble, el versátil, el contradictorio, el que va y viene como una veleta, el desorientado, el sinuoso, el que camina en círculo, el que se desplaza en zigzag, el que improvisa 'saltos de campana' -si el símil resulta aplicable-, el que comporta como un 'camaleón' iuris, el que se asemeja a un péndulo, no está llamado a servir de ejemplo en sede contractual, como quiera que su conducta -o conductasex novo, así suele acontecer, generan perplejidad, asombro, extrañeza extrema, desconfianza, sorpresa, contrariedad y, en no pocos casos, daños y perjuicios que, de no mediar específicos correctivos, quedarían en la sombría y desoladora impunidad, lo que no puede ser estimulado, al igual que tolerado, menos en un Estado social de Derecho, con todo lo que él implica.

En esta materia, ciertamente, no debe, ni puede haber contemplaciones, tolerancia o tipos contractuales inmunes a la incoherencia, a modo de irritante privilegio, como si algunos, ciertamente, fueran repúblicas independientes. E juez, en tal virtud, debe ser vigilante y estricto -que no injusto-y debe cerrarle el paso a un comportamiento tan deleznable y antiético como el que abruptamente desconoce la actuación previa, el proceder precedente: el acto propio (factum proprium). De otra manera, por apego a una lectura inconexa y alejada del deber ser jurídico, propia de una mal entendida 'libertad', o de una consideración benévola de cara a los cambios y alteraciones comportamentales, se estaría, de un lado, estimulando la gestación de conductas abiertamente transgresoras, en claro y manifiesto agravio de derechos ajenos, dignos de tutela y salvaguarda y, del otro, soslayando la relevancia que tiene la exigencia ética -que no necesaria y simétricamente moral- en el plano negocial, entre otras instituciones.

Un orden justo, ello es inconcuso, no puede ser indiferente ante este tipo de comportamientos que socavan los diáfanos estándares de la conducta humana

60 Augusto Morello y Rubén Stigltz. "La teoría del acto propio", en Dinámica del contrato. Enfoques, Librería Editora Platense, La Plata, 1985. pp. 58 y 79. Cfr. Philippe Le TourneAu, quien recuerda que, "Cada uno debe ser coherente consigo mismo o, para ver la otra cara de la moneda, nadie puede contradecirse a sí mismo...". La responsabilidad civil profesional, Legis y Republique Française, Bogotá, 2006, p. 173. 
que, in concreto, se desdobla en el tráfico jurídico, oscurecido con procederes de la indicada laya o temperamento. Ni tampoco, de modo más general, un Estado social de Derecho, en el que este tipo de actuaciones no son de recibo, empeñado en el respeto de una serie de aquilatados valores y garantías fundamentales, objeto de celosa y esmerada observancia por parte de la colectividad, conforme se anticipó61.

Ese es, para explicitarlo en una sola frase, el costo de la incoherencia o contradicción y, a su turno, en sede contractual, el corolario de la desconsideración con el cocontratante, un frater contractus, ese mismo que, de buena fe, no esperó, ni tenía porque esperar, un súbito y lesivo cambio conductual, como si el contrato fuera una especie de campo de batalla en el que todo puede suceder, así formalmente -y sólo formalmente- luzca legal, como se apreciará más adelante. ¿Qué sería del Derecho, si fuera menester, en todos los actos y actuaciones, desconfiar de los demás; pensar sórdidamente para sobrevivir; desconfiar de todos, y de todo? Sin duda, el caos, y la ruina jurídica, lo que explica que, con fuerza y justificada razón, se enseñoree la presunción contraria, esto es la de que la buena fe se presume, como mínima coordenada de la convivencia, seguridad y paz ciudadanas. ${ }^{62}$ Deplorable sería presumir la mala fe, así algunos, desventurada y apocalípticamente, procedan de esta manera, como si la corrección, la ortodoxia, la palabra empeñada, la transparencia, la honorabilidad, la decencia, la probidad, la lealtad, fueran alienígenas y, de contera, no fueran calidades terrenas. Felizmente, aquella pulula, y la mala fe, es sólo la excepción, así posea un eco sonoro y una recordación penetrante.

Como muy bien lo puso de manifiesto el célebre profesor de la Universidad de Múnich, Karl LARENZ -en lo pertinente-, "El ordenamiento jurídico protege la

${ }_{61}$ Véase con provecho la profunda investigación realizada por la Dra. Silvia CALMES. Du principe de protection de la confiance légitime en droit allemand, communautaire et français, op. cit., pp. 53 y ss., en la que se le da especial realce a esta temática, desde el Derecho constitucional y administrativo, principalmente.

62 No le falta entonces razón al autor chileno, Cristián BoETSCH GiLleT, cuando afirma que si la "...confianza no encuentra una protección jurídica, haría vivir a todo contratante en un constante estado de paranoia, pues significaría que defraudar esa confianza no acarrearía ninguna consecuencia práctica, lo que a todas luces aparece como indeseable y atentatorio a las reglas mínimas de toda convivencia". La buena fe contractual, op. cit., p. 110. 
confianza suscitada por el comportamiento de otro y no tiene más remedio que protegerla, porque poder confiar, como hemos visto, es condición fundamental para una pacífica vida colectiva y una conducta de cooperación entre los hombres y, por tanto, de la paz jurídica"63.

De igual modo, el autor portugués Joao BAPTISTA coincide en afirmar que "... el principio de confianza es un principio ético-jurídico fundamentalísimo y que el ordenamiento jurídico no puede dejar de tutelar la confianza legítima basada en la conducta del otro. Así tiene que ser, pues como se observó, poder confiar es una condición básica de toda convivencia pacífica y de cooperación entre los hombres....Nótese que, independientemente del precepto ético, contemplado como regla general de conducta, la falta de correspondencia sistemática con la confianza suscitada tornaría insegura, o paralizaría igualmente la interacción humana"64.

Y si ello es así en el quehacer cotidiano, como en efecto lo es, en el Derecho, y en concreto, en el cosmos contractual, con mayor razón no puede entenderse que sea disímil, habida cuenta que el voluble, el dueño de conductas o actuaciones que rayan en lo incoherente, el que transita por el sendero de la contradicción, a la vera de la incoherencia, no puede recibir el favor del ordenamiento, su conformidad o aplauso. Nó, toda vez que la seguridad jurídica, la estabilidad, la regularidad, la continuidad, la solidaridad y la justicia negocial, en gran medida, dependen de un adecuado equilibrio y constancia comportamental, de un adamantino e impoluto proceder (buena fe), de un buen gobierno in negotio (buenas prácticas), de una especie de juego limpio (fair play), y se quiere de una asepsia juris -o contractus-, hasta el punto que, como se anticipó, no se entenderá que una parte actuó

63 Karl LARENz. Derecho justo. Fundamentos de la ética jurídica, Civitas, Madrid, 1985, p. 91, autor que culmina su idea haciendo hincapié en que, "Quien defrauda la confianza que ha producido o aquella a la que ha dado ocasión a otro, especialmente a la otra parte en un negocio jurídico, contraviene una exigencia que el Derecho -con independencia de cualquier mandamiento moral- tiene que ponerse a sí mismo porque la desaparición de la confianza, pensada como un modo general de comportamiento, tiene que impedir y privar de seguridad al tráfico interindividual. Aquí entra en juego la idea de una seguridad garantizada por el Derecho", op. cit., p. 90.

64 Joao BAPtista MAchado. Obra dispersa, Vol. I, Tutela da confiança e venire contra factum proprium, Scientia luridica, Lisboa, 1991, p. 35. 
correcta, conveniente y coherentemente y, por tanto, de buena $\mathrm{fe}^{65}$, sino se ajusta a las pautas precedentemente esbozadas, sin las cuales debe responder, bien de una u otra forma. Y lo más importante, no podrá derivar provecho o beneficio de su inconstancia, a costa de su cocontratante, el que no tiene por que sufrir las consecuencias de su inconsistencia, zigzagueo, contradicción, inarmonía o vaivén factual. Allá él, quien no podrá aspirar a ganar con cara y cruz, a la vez, como si tan desmedida ventaja, ciertamente, fuera admisible. Bien decía VoltaIRE que "un derecho llevado demasiado lejos, degenera en injusticia".

El ordenamiento jurídico, para decirlo en apretada reflexión, no puede pues tolerar ese tipo de metamorfosis, de cambios repentinos, de transformismo extremo que, in radice, desluce y frustra la teleología negocial y que, de plano, erosiona los derechos o prerrogativas de uno de los contratantes, quien no tiene por qué ver afectado su derecho de crédito o su posición jurídica determinada, en cuyo caso podrá invocar este inusitado giro o molinete, en guarda de no perjudicarse, aun cuando el juzgador estará igualmente legitimado para proceder ex officio, con el objeto de evitar que emerjan atentados o lesiones injustas cuando -lato sensu- se toma por asalto un contrato, cuando se vacía su contenido o cuando se marchitan o esterilizan sus efectos, todo a despecho de la buena fe, y de su vibrante mensaje jurídico-ético, conforme se analizará en detalle más adelante, así como de la confianza legítima despertada, la que demanda tutela o protección sumas. Por ello, en todas las expresiones de la regla venire contra factum proprium, la misma ocupará un destacadísimo papel, puesto que servirá de factor de medición y evaluación objetivas de la entidad o relevancia de la incoherencia (prius).

Bien expresó el profesor de la Universidad de Roma, Emilio BETTI, con proverbial claridad, que "La buena fe, en fin, es considerada en cuanto que lleva a descubrir un abuso de derecho o conduce a prevenir el ir contra el propio acto,

65 En esta dirección, el profesor de la Universidad de París I, Jacques GHESTIN, expresa que la buena fe también se manifiesta "...como la consagración general de una exigencia de lealtad...la cual puede ser establecida por el legislador, o en su defecto determinada por la jurisprudencia a partir de los usos y más generalmente de las buenas prácticas contractuales". Traité de drot civil. Les obligations. Le contrat: Formation, L.G.D.J, Paris, 1988, p. 204. 
estableciendo una serie de limitaciones, conforme a una exigencia de coherencia en el comportamiento antecedente y en el subsiguiente" 66 .

A 'nadie', en consecuencia -con las excepciones de rigor-, le está permitido volver sobre -o ir contra- sus actos propios (venire contra factum proprium), en claro desmedro de los derechos de los demás, en especial del contratante que, con antelación, confió o creyó -o por lo menos no desconfió-, que no sería sorprendido de la manera en que lo fue posteriormente, generándole, y con potísima razón, sorpresa, extrañeza, desengaño, frustración, perplejidad y lesión a sus intereses, no siendo admisible esa irritante defensa que en ocasiones se escucha, de suyo insólita y a su turno poco responsable, a cuyo tenor: ¿por qué confió en el otro?; ¿por qué no desconfió, a sabiendas del adagio que indica 'que piensa mal y acertaras'? y que ¿por qué fue tan ingenuo de pensar que aún se honra la palabra empeñada?

¿Cómo entonces patrocinar este estado de cosas, evidentemente corrosivo y atentatorio de caros intereses y acerados postulados jurídicos, de indiscutida connotación ética (ethos contractus), rectamente entendida, según se esbozó, no sólo de cara al cocontrantante sorprendido, sino también, in globo, respecto del ordenamiento $-\mathrm{y}$ de la colectividad toda-, por la floración de inseguridad e inestabilidad jurídicas, e inequidad?

No se olvide, en un plano más general, que no es ni conducente, ni tolerable la abusividad -que no necesariamente supone intencionalidad-, así sea patrocinado por el titular de un derecho indiscutido, pues dicha titularidad jurídica no puede servir de rodela para justificar perjuicios, arbitrariedades o inequidades, menos en el presente, cuando el Derecho se ha 'humanizado' aún más, y cuando su carácter social, en buena hora, se ha realzado vivamente, en aras de un orden más justo, solidario, tolerante e incluyente, y respetuoso de los derechos de todos, como se pregona en el campo constitucional contemporáneo, en el que, expressis verbis, se alude a un 'Estado social de Derecho', con todo lo que ello envuelve en la esfera tuitiva, que no es de poca importancia, el que igualmente

66 Emilio BETTI. Teoría general de las obligaciones, Editorial Revista de Derecho Privado, Madrid, 1966, T. I, p. 100. 
es refractario a este tipo de malas prácticas negociales que terminan por lesionar a uno de los pilares de mayor significación en el ámbito constitucional y legal: el contrato, hoy revitalizado ${ }^{67}$.

Cuán aguda, a este respecto, sigue siendo la clásica -y aún vigente-opinión del profesor de la Universidad de Lyon, Luis JOSSERAND, con sujeción a la cual “...nuestros derechos no pueden realizarse en contravención o despreciando su misión social, a diestra y siniestra; se concibe que el fin pueda justificar los medios, al menos, cuando éstos son legítimos por sí mismos; pero sería intolerable que medios, aun intrínsecamente irreprochables, pudiesen justificar todo fin, hasta odioso e inconcebible"68.

En compendio, el fundamento medular de la doctrina en examen; su piedra de toque, como ya lo habíamos anticipado al momento de iniciar el numeral anterior (fundamentos generales de la doctrina de los actos propios), estriba en

67 Un sector de la doctrina contemporánea, encuentra en la solidaridad uno de los fundamentos constitucionales del nemo potest venire contra factum proprium. Es el caso del profesor Anderson SCHREIBER, quien manifiesta, con razón, que la regla "nemo potest venire contra factum proprium, concebida como un rechazo al comportamiento incoherente dirigida a la tutela de la confianza, no es sino un instrumento de realización de este valor constitucional. Hay, en otras palabras, una directa vinculación entre la solidaridad social y el principio de prohibición de comportamiento contradictorio". A prohibiçao de comportamento contradictório. Tutela da confiança e venire contra factum proprium, op. cit., p. 107. Es de señalar que en el Derecho italiano reputados doctrinantes como Francesco SANTORO PASSARELLI, desde hace varias décadas, le asignan a la solidaridad -o 'solidaridad'- un carácter envolvente, indicando que "Constituyen expresiones de la solidaridad, además del deber de lealtad, el deber de buena fe y el respeto de la confianza (affidamento)". Doctrinas generales de derecho civil, Editorial Revista de Derecho Privado, Madrid, 1964, p. 76. En términos similares, el profesor Massimo BIANCA indica que la buena fe "...es un principio de solidaridad contractual que se proyecta en dos fundamentales aspectos, el de la salvaguarda y el de la lealtad". Diritto civile. Il contratto, Giuffrè, Milano, 1987, p. 394.

Al lado de la solidaridad, reconociéndole un abolengo especial, igualmente se encuentra la buena fe, en aquellas naciones en que ella se ha constitucionalizado, v.gr: en Colombia (art. 83 C.P).

68 Luís Josserand. El espíritu de los derechos y su relatividad, José M. Cajica, Puebla, 1946, p. 15 , doctrinante que redondea su esclarecida afirmación, recordando, con tino, que "Todas las prerrogativas, todas las facultades jurídicas son sociales en su origen, en su esencia, y hasta en la misión que están destinadas a llenar; ¿cómo podría no ser así....puesto que la 'juridicidad', no es otra cosa que la regla social obligatoria....esta reflexión es exacta, no solo tratándose de las prerrogativas de carácter altruista....sino también, y a despecho de las apariencias, tratándose de las facultades más egoístas...., como el derecho de propiedad inmueble o el de un acreedor", op. cit., p. 312. 
la coherencia comportamental, elevada a la categoría de deber, y para otros de principio $^{69}$, como se anotó, la que no debe ser quebrantada, ni siquiera por parte del titular de un derecho legítimo que, a pretexto de su ejercicio, pretende obtener un beneficio jurídico a costa de otro que, en su oportunidad, por la conducta precedente asumida por su cocontratante, no imaginó que sería sorprendido -o emboscado, como lo anotan algunos-, en cuyo caso, merced a la fuerza inherente a esta regla o doctrina (de los actos propios), se tiene establecido que el derecho radicado en cabeza del voluble o incoherente, de por sí, no puede ser ejercido válidamente (limitación al ejercicio de un derecho subjetivo), así perviva in abstracto, motivo por el que se estima improcedente, habida cuenta de la confianza y seguridad primigenias suscitadas en el señalado sujeto (posterius), objeto de ulterior modificación y ultraje. He ahí también recreado su auténtico significado y alcance en la ciencia del Derecho, el que aboga por la armonía, la cadencia, la solidaridad y la estabilidad conductual, medulares en sede contractual, en la que por la connotación que adquiere el componente relacional la coherencia se torna indispensable, so pena de que altere su ratio y teleología ${ }^{70}$. Bien expresa F. Astone que la coherencia, sinónimo de cohesión, "...implica fidelidad a una línea de conducta, o sea la continuidad de una serie de comportamientos, de actos, de palabras que suponen el constante respeto de reglas y principios"71.

69 Vid. Benedicte FaUVARQUE-Cosson. La confiance légitime: et l'estoppel. Droit privé comparé et européen, op. cit., p. 12, y Dimitri HoutciefF. Le principe de cohérence en matiére contractuelle, op. cit., T. I, pp. 22 y ss.

70 De modo omnicomprensivo, el doctrinante argentino, Alejandro BoRDA, resume la esencia y proyección de esta figura señalando que, "Es dable exigir a las partes un comportamiento coherente ajeno a los cambios de conducta perjudiciales, desestimando toda actuación que implique un obrar incompatible con la confianza que -merced a actos anteriores- se ha suscitado en el otro contratante. Ello es así por cuanto no sólo la buena fe sino también la seguridad jurídica se encontrarían gravemente resentidas si pudiera lograr tutela judicial la conducta de quien traba una relación jurídica con otro y luego procura cancelar parcialmente sus consecuencias para aumentar su provecho. Nadie puede ponerse de tal modo en contradicción con sus propios actos ejerciendo una conducta incompatible con la asumida anteriormente". La teoría de los actos propios, Abeledo-Perrot, Buenos Aires, 2000 p. 53.

71 Francesco Astone. Venire contra factum proprium, op. cit, p. 38. A su turno, para Dimitri HOUTCIEFF, "...el término 'coherencia' designa 'ausencia de contradicción y disparidad entre las partes de una obra'. El evoca la 'consistencia', más específicamente la 'consistencia lógica'... El principio de la coherencia surge como proscripción de la contradicción..." Le principe de cohérence en matiére contractuelle, op. cit., T. I, pp. 41 y 43. 
Así entendida, entonces, la coherencia en el ordenamiento jurídico no es facultativa, potestativa, o ex gratia, como si dependiera del simple querer ( $s i$ voluero), o del deseo generoso u obsequioso de un sujeto determinado, en razón que se precisa de ella, invariablemente, en la esfera jurídica a modo de débito comportamental. Al fin y al cabo, ha sido considerada por algunos como prototípico deber, más específicamente de un 'deber de conducta', así no esté expresamente consignado en un texto legal, conforme tiene lugar con relación a muchos otros deberes que perviven en el sistema jurídico, merced a la buena fe, su dispensario, y cimiente, tesitura a la que delanteramente adherimos (encuadramiento jurídico) y, a la que de nuevo nos referiremos ${ }^{72}$. En tal virtud, ella es diamantina manifestación

\footnotetext{
72 Al respecto, con provecho, puede verse, entre otros, al profesor Arturo SOLARTE RODRÍGUEZ. "Buena fe contractual y deberes secundarios de conducta", en Revista Universitas, No 108, Universidad Javeriana, Bogotá, 2004; Mariana BERnAL FANDIÑO, "El deber de coherencia en los contratos y la regla del venire contra factum proprium", en Revista International Law. Universidad Javeriana, Bogotá, 2008, pp. 293 y ss., y Gianluca FALco. La buona fede e l'abuso del diritto, Giuffrè, Milano, 2010, p. 179. Por su parte, Francesco Astone refiere a la posibilidad de que se le considere como 'obligación' (Venire contra factum proprium, op. cit., p. XVIII); Fiorenze FESTI, a un “....deber de un sujeto de no asumir un comportamiento incoherente". II devieto di 'venire contra il fatto proprio', op. cit., p. 241, y Rodolfo SAcco. "Il fatto, l'atto, II negozio", in Trattato di diritto civile, UTET, Turín, 2005, p. 246, autor que expresamente alude a un "...deber de coherencia", el que "... no es extraño a la cultura italiana".
}

Del mismo modo, en su profunda y documentada investigación relativa al tema sub examine, el autor D. HoutCIEFF, no vacila en abogar por la existencia de un deber de coherencia, y más específicamente, en lo causal, por refrendar la existencia de un arquetípico principio de coherencia, que de la mano de B. CELICE (Les réserves et le non-valoir dans les actes juridiques), considera “... .autónomo y profundamente original", el que a su vez lo contempla como un "principio de continuidad". Además, recuerda "...que frente al término obligación, la doctrina prefiere el de deber", op. cit., pp. 22 y ss., y T. II, pp. 831 y 1041. A su turno, la autora Anne-Silvie COURDIER-CUISINIER, igualmente alude a ambos, aun cuando los diferencia, al expresar que "El deber de coherencia se distingue del principio de coherencia contractual....Mientras que el último asegura la coherencia del contenido del contrato, el otro impone la coherencia de los comportamientos contractuales". Le solidarisme contractuel, op. cit., p. 411. Vid. Pierre-Yves GAUTIER. "Confiance légitime, obligation de loyauté et devoir de cohérence", en La confiance en droit privé des contrats, Dalloz, Paris, 2008, pp. 109 y ss.; Jacques GHESTIN, doctrinante que emplea la expresión “...principio de coherencia”. Cause de l'engagement et validité du contrat, LGDJ, Paris, 2006, p. 186. Y Bertrand FAGES, también le asigna el status individual de "...obligación de coherencia”. Le comportement du contractant, Presses Universitaires D’Aix Marseille, Faculté de Droit, Aix-En-Provence, 1997, pp. 322 y ss.

Por su parte, Jean-Pascal CHAZAL, aboga por la utilización indistinta de los conceptos de obligación y deber en el campo comportamental, amén de contractual. "Les nouveaux devoirs des contractants. Est-on allé trop loin?", en La nouvelle crise du contrat, Dalloz, Paris, 2003, p. 105. Y en un ámbito más amplio, el profesor J. GHESTIN se ocupa de una "...exigencia de lealtad", acorde con la idea expresada previamente por el mismo autor en 
de un deber de conducta, en concreto, circunscrito a obrar coherentemente, cuyo venero se encuentra en la bona fides, en la norma jurídica, según el caso, y hasta en la misma razón, contemplada en tercera dimensión (regla o postulado de razonabilidad).

Obviamente, como señalamos en su momento, la coherencia, por importante que sea, como a nuestro juicio superlativamente lo es, no es el único basamento de la doctrina de los actos propios, ni de las manifestaciones vecinas de la regla del venire contra factum proprium, pues su fundamentación es plural, en prueba de que descansa en sólidos pilares, y no en uno sólo, lo que podría significar que no estuviese bien soportada, y que su peso estuviere mal distribuido. Empero, el más revelador, amén que estructural, nos parece que es la coherencia, se insiste, sin restarle fuerza, valor o protagonismo a los restantes; es más bien por hacer consonante la potísima regla de la coherencia, de tanta incidencia causal en el Derecho, y en otras áreas del saber y de la propia convivencia humana, como se resaltó. Además, desde una perspectiva etiológica, a fuer que racional, aquella es un prius, con todo lo que ello implica, expresada en positivo: regla o deber de coherencia, considerada entonces como imperativo, la que corre pareja con la regla de no contradicción, expresada en negativo, pero reveladora del mismo y elocuente mensaje de la regularidad comportamental y del respeto a los derechos y prerrogativas ajenos ${ }^{73}$.

el sentido de que "la buena fe se traduce en una exigencia de comportamiento...." Traité de droit civil. Les obligations. Le contrat: Formation, op. cit., pp. 203 y 204. Análogamente, los profesores Philippe MAULAURIE, Laurent AYNES, y Philippe STOFFEL-Munnck se refieren, en el marco de la buena fe, a "... un deber general de lealtad en el comportamiento, presente en numerosos campos del derecho: procedimiento penal y civil, reglas de mercados financieros, derecho de la competencia, teoría de la apariencia, prohibición de contradecirse en detrimento de otro..... Les obligations, op. cit., p. 379.

Finalmente, la autora Hobinavalona RAMPARANTY-RAVOLOLOMIARANA refiere a la coherencia como una "exigencia absoluta" ('exigencia de coherencia') y también como “... una exigencia de no contradicción". Le raisonnable en droit des contrats, op. cit., pp. 290 y 292.

73 No existe, en conclusión, unanimidad en lo que a los basamentos de la doctrina de los actos propios atañe, muy especialmente en lo que toca con el llamado pilar de la apariencia, de mayor aceptación en el Derecho anglosajón, como quiera que en el civil law, en general, se hace más hincapié en la coherencia, y también en la buena fe y en la confianza, no tanto en la referida apariencia. En esta dirección, recientemente, la profesora Mariana BERNAL FANDIÑO, críticamente ha expresado en su sólida investigación que "... se ha señalado por un sector que la doctrina de los actos propios tendrá su fundamento en la teoría de la apariencia, o en la buena fe y en la apariencia, como es el caso del tratadista español 
Habrá pues ocasión de escrutar algunos otros de los restantes fundamentos de la doctrina de los actos propios, sobre todo los relativos a la buena fe y a la confianza legítima, de especial acogida en la doctrina y en la jurisprudencia contemporánea, proclive a su señalamiento conjunto, binomio que, a su turno, servirá para justificar la protección brindada en desarrollo del venire contra factum proprium y de sus diversas manifestaciones o aplicaciones.

\section{LA BUENA FE Y SU ESTRECHA RELACIÓN CON LA DOCTRINA DE LOS ACTOS PROPIOS. INFRANQUEABLE LÍMITE AL EJERCICIO DE LOS DERECHOS SUBJETIVOS}

\subsection{Generalidades}

Como ha podido advertirse a lo largo del presente escrito, resulta insoslayable referirse a la buena fe en el marco de la institución de los actos propios, y en general con relación a innúmeras instituciones de carácter jurídico, sobre todo en los países del Derecho continental, en donde campea con tanta fuerza, no de ahora, sino de antaño, dado su inequívoco rol de principio general, al mismo tiempo que de postulado informador de la ciencia jurídica, pues todo lo permea, todo lo abraza, todo lo irradia, ora directa, ora indirectamente, incluida la doctrina en referencia, que no es la excepción, sin perjuicio de que en los últimos lustros se ha evidenciado un interés aún mayor en ella, como se señaló a espacio en precedencia, particularmente en Italia, Francia y Bélgica, en donde se alude a su renacimiento, reverdecimiento, rehabilitación, etc., aunque hay que reconocerle un protagónico papel en la historia del Derecho, sobre todo en sede del Derecho romano, en el que ocupó un destacado sitial. De ahí que la labor que desempeña

Santos Briz, quien manifiesta que 'nadie puede ir válidamente contra sus actos propios no sólo en la necesidad de proteger la buena fe, sino también las ideas de confianza y de la apariencia'. No coincidimos con esta visión, pues la teoría de la apariencia, como se explicó anteriormente, ha sido desarrollada principalmente para proteger a los terceros. Por esta razón, consideramos importante separar, en la conceptualización y en sus efectos, la teoría de la apariencia y la doctrina de los actos propios. Precisamente, la falta de precisión y de la debida delimitación entre las diferentes figuras que se desarrollan alrededor de la buena fe y de la coherencia es lo que ha llevado a confusión en la doctrina y la jurisprudencia.... El deber de coherencia en el derecho colombiano de los contratos, Bogotá, 2012 pp. 236 y 237. 
en la actualidad ciertamente es elocuente, en honor a la justicia y en franco reconocimiento genealógico, más allá de algunas voces disonantes -esas que nunca faltan- que estiman que la deuda existente no es tan elevada, o que el acto propio no abreva en la buena fe, así de categórico -y así de errado- ${ }^{74}$

Sin embargo, en función de dicho cometido no es nuestra pretensión auscultar en detalle la institución de la buena fe: génesis, concepto, estructura, características, tipología, alcances, diversas aplicaciones, etc., máxime teniendo en cuenta su vasta -y creciente- proyección en sede jurídica ${ }^{75}$, entendida como postulado, principio general del Derecho, cláusula general, etc., lo cual desbordaría el plan trazado primigeniamente, por manera que haremos una referencia más tangencial al mismo, y a su íntima conexión con la doctrina de los actos propios, en sí misma férrea y acerada, conforme se ha pincelado en diferentes apartes preliminares de este escrito, y como se reafirmará seguidamente. Al fin y al cabo, es tan amplia esta temática, de suyo, harto especializada, y cada vez más extendida, que la buena fe puede examinarse desde numerosas perspectivas, en la hora de ahora, a fortiori cuando se le considera altiva y en plena expansión, conquistando palmo a palmo todo el Derecho, si es que quedare, realmente, algún resquicio por conquistar, según ya se advirtió en precedencia. Por esto su primado es indiscutido, y sus raíces y ramificaciones son casi infinitas, hasta el punto que, en sede iuris, es omnipresente, sin pretender su aplicación ciega, totalitaria y desmedida, mejor aún la consagración de su tiranía, pues si funge en

74 Según lo expresa con acierto el profesor Sergio MuÑOz LAVERDE, sublimando su trascendencia, "La buena fe es quizás el más conspicuo de los principios generales del derecho. Sobre él se construyen los demás. Ninguna institución, regla de comportamiento o costumbre puede edificarse en su contra. Es pues principio rector de todo el ordenamiento jurídico". "El principio de buena fe y su incidencia en la interpretación del contrato. Nulidad de las cláusulas abusivas en el derecho colombiano", en Realidades y tendencias del derecho en siglo XXI, T.IV, Universidad Javeriana y Editorial Temis, Bogotá, 2010, p. 211.

75 Cfr. José María Miquel GonzÁlez, Observaciones en torno a la buena fe, op. cit., p. 497. 
esta materia como típico límite al ejercicio de los derechos subjetivos ${ }^{76}$, no por eso deja de tener los suyos ${ }^{77}$, sin que por ello se desdore.

Empero, como se advirtió, alrededor de ella haremos una somera lectura como prototípico principio rector e iluminante, circunscrito primordialmente al campo del Derecho de obligaciones y contratos, fértil, en grado sumo, no sólo en la actualidad, sino de antaño, ora expresa, ora tácitamente, sin quererlo limitar a un solo ámbito, pues sabido es que su espectro es muy amplio y que no hay área del saber jurídico en donde no intervenga, ni actividad humana, en la que, de alguna manera, esté ausente. Por ello en el plano cívico, amén que conductual, en general, igualmente ocupa un sobresaliente lugar (estándar de conducta), el que actúa como límite al ejercicio de los derechos subjetivos, como se anotó. De ahí que la bona fides esté en la atmósfera, en el aire que respiramos todos los mortales, en la sangre ciudadana. Y en el campo que detiene nuestra atención: el Derecho de contratos, está presente en todo el tejido y en el corpus negocial.

En efecto: la buena fe, en el terreno jurídico, de ordinario se inscribe como principio general, a fuer que cardinal -y como cláusula general o abierta, para un amplio sector-, pues domina todo el panorama del Derecho, y como dijimos, muy especialmente el Derecho de las obligaciones y de los contratos ${ }^{78}$, hasta tal punto

76 El artículo 7 del Código Civil español, es categórico, amén de diciente respecto de esta misión asignada a la buena fe, al estatuir que "Los derechos deberán ejercitarse conforme a las exigencias de la buena fe".

En opinión de la profesora María del Carmen GeTE-Alonso, este precepto “....significa -como ha destacado la doctrina a la hora de abordar el estudio del derecho subjetivo- que uno de los límites genéricos, institucionales o intrínsecos de todos derecho subjetivos viene constituido por el principio de la buena fe". "La buena fe", en Comentarios al Código Civil y Compilaciones Forales, Editorial Revista de Derecho Privado, Madrid, 1992, p. 889.

77 Véase, con provecho, el estudio del profesor peruano Fernando DE TRAZEGNIEZ G., por cuanto sin desconocer la grandilocuencia de la buena fe, reflexiona en torno a sus límites y al abuso que en ocasiones se comete cuando se aplica sin ningún freno, prudencia y cautela, cualidades que siempre son bienvenidas. "Desacralizando la buena fe en el derecho", en Tratado de la buena fe, La Ley, Buenos Aires, T. II, 2004, pp. 19 y ss.

78 Como lo ha reseñado el Tribunal Supremo Español, "La buena fe ha sido interpretada como principio general o como cláusula abierta, aunque en definitiva debe considerarse como principio positivizado que impone deberes a los titulares de los derechos. En el art. 7.1 CC se recoge uno de los aspectos principales de las consecuencias de la buena fe...." (Sentencia del 12 de diciembre de 2011, 8594). 
que, con acierto, como lo puntualizó don Florencio GARCiA GoYENA a mediados del siglo XIX, la buena fe se traduce en el alma de los contratos (Concordancias del proyecto de Código Civil Español).

De igual modo, al lado del carácter de principio general, puede la buena fe ser tomada en consideración, en concreto, como criterio orientador en materia de interpretación negocial, a la par que como límite o valladar al ejercicio de los derechos subjetivos que, no por derechos, debidamente consolidados y lícitos, pueden desplegarse arbitrariamente o en perjuicio ajeno, y también, dentro de otros roles más, como manantial de deberes de conducta y como criterio rector en el campo de la eticidad jurídica, ad exemplum, la contractual, en donde tiene irrestricta cabida. Por eso, cuando se habla de buena fe, hay que recordar que, merced a su condición de faro, tiene a su cargo numerosas misiones, unas más específicas que otras, pero todas de marcada significación. Lo cierto es que como agudamente lo revela el profesor Don MARIANo Alonso Pérez "...la buena fe no se puede reducir a una categoría unitaria: unas veces significará un estado de conocimiento, especialmente en los derechos reales....; otras un estado ético o de conducta, como sucede normalmente en el ámbito contractual; en algunas ocasiones, la buena fe es una manifestación del neminem laedere y, como preceptum iuris, implica un comportamiento"79.

En tal virtud, en el campo misional, particularmente en la esfera contractual, en donde reina con solvencia, como se acotó, se tiene establecido que la buena fe, indistintamente, gobierna las fases precontractual, contractual y pos-contractual, trinomio en el que, sin quiebres, matices y excepciones, se espera que cada uno de los interesados o partes contractuales, según el caso (in potentia o in actus), se comporten de la manera más proba, correcta, leal, considerada, transparente, decente y consistentemente posible, entre otras manifestaciones indicativas de un proceder diamantino y límpido, a la vez que ajustado a elevados estándares conductuales, muy sintonizados con plausibles exigencias de indiscutida raigambre ética (ethos contractus), no exentas de inequívocas connotaciones y secuelas jurídicas. Ello explica que, en general, cuando se alude a buena fe,

79 Mariano Alonso Pérez. "Traducción y extensas anotaciones y concordancias al Derecho español" de la obra El error en la doctrina del negocio jurídico, Vittorino PIETROBON, op. cit., p. 158. 
sin calificaciones especiales, se le vincule a honradez, a corrección, a rectitud, a lealtad, a respeto por lo ajeno (bonus vir), a proteger la confianza suscitada en los demás, aspectos centrales del presente estudio.

En esta última dirección, el respetado profesor Eugenio LLAMAS PoMBO, elocuentemente manifiesta que "...la buena fe constituye un canon de lealtad, rectitud, honestidad o corrección, una pauta de conducta que debe presidir el comportamiento de los contratantes, en el marco de la celebración, interpretación y ejecución de los contratos, y que viene integrado por todo un conjunto de reglas no escritas pero conocidas ( $y$, en general, observadas) por todos, lo que genera una confianza de que el otro contratante actuará con la misma honestidad y lealtad"80.

Como lo precisara la Corte Suprema de Justicia colombiana en los albores de la presente centuria, "principio vertebral de la convivencia social, como de cualquier sistema jurídico, en general, lo constituye la buena fe, con sujeción a la cual deben actuar las personas -sin distingo alguno- en el ámbito de las relaciones jurídicas e interpersonales en las que participan, bien a través del cumplimiento de deberes de índole positiva que se traducen en una determinada actuación, bien mediante la observancia de una conducta de carácter negativo (típica abstención), entre otras formas de manifestación".

"Este adamantino axioma, insuflado al ordenamiento jurídico - constitucional $y$ legal- $y$, en concreto, engastado en un apreciable número de instituciones, grosso modo, presupone que se actúe con honradez, probidad, honorabilidad, transparencia, diligencia, responsabilidad y sin dobleces. Identificase entonces, en sentido muy lato, la bona fides con la confianza, la legítima creencia, la honestidad, la lealtad, la corrección y, especialmente, en las esferas prenegocial y negocial, con el vocablo 'fe', puesto que "fidelidad, quiere decir que una de las partes se

80 Eugenio LlAmAS Pombo. "Buena fe y cláusulas abusivas en la contratación con consumidores", en Tratado de la buena fe, T. II, La Ley, Buenos Aires, 2004, p. 236. Vid. Riccardo CARDILLI, quien aludiendo al bonus vir, reafirma que "...la buena fe es un criterio que realza, a través de la regla de honestidad y corrección, un comportamiento humano asumido como modelo (bonus vir)." Bona fides. Tra storia e sistema, op. cit., p. 100. 
entrega confiadamente a la conducta leal de la otra en el cumplimiento de sus obligaciones, fiando que esta no lo engañará".

"De consiguiente, a las claras, se advierte que la buena fe no es un principio de efímera y menos de irrelevante figuración en la escena jurídica, por cuanto está presente, in extenso, amén que con caracterizada intensidad, durante las etapas en comento, tanto más si la relación objeto de referencia es de las tildadas de 'duración', v. gr: la asegurativa, puesto que sus extremos -in potentia o in concreto-, deben acatar fidedignamente, sin solución de continuidad, los dictados que de él emergen (prédica conductiva). Es en este sentido que los artículos 863 y $871 \mathrm{del}$ C. de Co y $1.603 \mathrm{del}$ C. C., en lo pertinente, imperan que "Las partes deberán proceder de buena fe exenta de culpa en el período precontractual..."; "Los contratos deberán celebrarse y ejecutarse de buena fe....", y "Los contratos deben ejecutarse de buena fe....".

"Quiere decir lo anterior que para evaluar si un sujeto determinado actúo o no de buena fe, resulta imperativo examinar, en cada una de las precitadas fases, la conducta por él desplegada, pero de manera integral, o sea en conjunto, dado que es posible que su comportamiento primigenio, en estrictez, se ciña a los cánones del principio rector en cita y ulteriormente varie, en forma apreciable y hasta sorpresiva, generándose así su inequívoco rompimiento. De allí que la buena fe no se pueda fragmentar, en orden a circunscribirla tan sólo a un segmento o aparte de una fase, por vía de ejemplo: la precontractual -o parte de la precontractual-, ya que es necesario, como corresponde, auscultarla in globo, según se indicó, valorando las diversas oportunidades que los interesados tuvieron para actuar con lealtad, corrección (correttezza) y diligencia, según sea el caso. Al fin y al cabo, sin excepción, ella se predica de la integridad de eslabones que, analizados en retrospectiva, conforman la cadena contractual (iter contractus), rectamente entendida...." (Sentencia de 2 de agosto de 2001, Sala de Casación Civil) ${ }^{81}$.

${ }_{81}$ Sin perjuicio de que más adelante se aludirá a esta providencia emanada de la Corte Suprema de Justicia, proferida en el año 2007, cumple destacar, por ahora, que la Sala Civil de la Corte, de una parte, reiteró que, "obrar de buena fe es proceder con la rectitud debida, con el respeto esperado, es la actitud correcta y desprovista de elementos de engaño, de fraude o de aprovechamiento de debilidades ajenas. Inclusive, bueno es destacarlo, desarrollo de estos parámetros es la regla que impide reclamar amparo a partir de la negligencia o descuido propios" y, de la otra, indicó que la conducta asumida por 


\subsection{BUENA FE, COHERENCIA, COOPERACIÓN JURÍDICA Y SOLIDARISMO CONTRACTUAL. RELACIÓN CON EL ACTO PROPIO}

Es en atención a la fuerza gravitacional del principio general en comento, un verdadero manantial y referente jurídico obligado, en asocio de las demás misiones a él asignadas, que brota la idea de que el deber de 'coherencia', por ser emanación suya -como que comparte un mismo material genético, un mismo $A D N-$, es un débito que le incumbe a todo sujeto que pretende entablar o preservar una relación jurídica. Nos referimos al deber de obrar coherentemente, es decir con plena y sistemática coherencia negocial, en sentido amplio, débito éste que hunde sus raíces en el propósito de no afectar el derecho de su cocontratante, de no erosionar su confianza, todo lo cual, si se quisiera, podría englobarse en otro deber, de insoslayable trascendencia y amplitud: el de cooperación, tan encumbrado por el Profesor Emilio BETTı a mediados del siglo pasado (ligado a la buena fe $)^{82}$, y también en el de la solidaridad, tan en boga en el Derecho

un sujeto voluble, que incurre en contradicción con sus "...antecedentes conductuales...., génesis....de la llamada Teoría de los Actos Propios”, “...puede constituir, y suele serlo, un acto contrario a los fundamentos de la buena fe y a la coherencia jurídica exigida a cualquier contratante..." Corte Suprema de Justicia - Sala de Casación Civil. Sentencia de 9 de agosto de 2007. Exp. 00254.01. Vid. Jorge Parra Benítez. Estudios sobre la buena fe, Librería Jurídica Sánchez, Medellín, 2011, pp. 186 y ss. y 306 y ss.

82 Vid. Emilio BetTI. Teoría general de las obligaciones, T. I, op. cit., pp. 70 y ss., quien ocupándose del 'deber de cooperación debido en interés ajeno' (buena fe contractual), manifiesta que, "...mientras la corrección se concreta normalmente en una conducta esencialmente negativa, esto es, como ya se ha dicho, en el abstenerse de indebidas injerencias en otra esfera de intereses; la buena fe, en sentido impositivo que asume en el ámbito de las relaciones de obligación consiste en una actitud de activa cooperación en interés ajeno, en una actitud de fidelidad al vínculo, por el cual una de las partes de la relación obligatoria está pronta a satisfacer la expectativa de prestación de la contraparte", expectativa que raya por completo con la incoherencia, la que de paso es antítesis de la cooperación y de la fidelidad en mención, a la vez que de otros valores. De allí que si un sujeto, realmente entendiera en su justa proporción lo que entraña este deber de cooperación, de plano, se abstendría de realizar conductas contradictorias y, por ende lesivas, in actus o in potentia, de los legítimos intereses de sus cocontratante, el que merece consideración y respeto, así esté en el otro lado negocial. Al fin y al cabo, de nuevo trayendo a colación el esclarecido pensamiento del maestro BETTI, en este contexto, sin sombra de mácula alguna "... si ha de considerarse como comportamiento incorrecto el desengañar a la otra parte, peor es todavía engañarla" (op. cit., p. 93), circunstancia que explica que el ilustre profesor italiano, luego de diversas disquisiciones en torno a esta problemática comportamental, termine vinculando buena fe, deber cooperación y coherencia, conclusión que justifica cuando señala que, “... .examinando con detenimiento el carácter más saliente de esa buena fe, consiste en que no está circunscrita a los actos singulares del contrato, sino que abarca por entero el comportamiento del mismo considerado en su intrínseca 


\section{contractual y constitucional moderno, en prueba de la constante búsqueda de la humanización del Derecho y, con él, de sus instituciones, ab initio, al servicio del}

coherencia y en su totalidad, es decir, como actitud de cooperación que es debida por cada parte a la otra, y la buena fe valora esta conducta en su totalidad, en la medida en que es más conforme al interés de la otra, el cual se trata de satisfacer con esa misma conducta" (op. cit., p. 101). Vid. Dimitri HoutcIEFF, pues en sentido similar observa que en desarrollo de esta forma de contemplar el débito en referencia "...el deber de lealtad o de colaboración absorbe claramente el principio de coherencia". Le principe de cohérence en matiére contractuelle, op. cit., T. II, p. 891.

Acerca de este importante deber, de insoslayable proyección contemporánea, tanto en al esfera nacional, como en la internacional del contrato, véase a Gloria ESTEBAN DE LA RosA, autora que no duda en señalar que “... .tanto el deber de cooperación como el deber de lealtad están relacionados -en su génesis- con el principio general de la buena fe, pudiéndose decir que el primero se deduce de la función normativa que cumple el referido principio... la función normativa del principio general de la buena fe permite que se deduzcan un conjunto de deberes para las partes con independencia de que estén previstos de forma expresa en el contrato o en el ordenamiento. Ahora bien, una vez admitida la existencia de deberes adicionales de comportamiento, el deber de cooperación es uno de los reconocidos ampliamente en el marco de los sistemas jurídicos del civil law. ...Por lo tanto, se trata de un deber aceptado y reconocido.....como deber accesorio o de colaboración". "El principio de cooperación en la contratación", en Derecho contractual comparado, Civitas Thomson, Pamplona, 2009, pp. 408 y ss. Vid, igualmente, a la autora brasilera Judith MARTINS-COSTA, la que indica que "... la cooperación, ligada a la conducta de los sujetos, no está reducida al cumplimiento del deber principal de prestación: ella requiere, en innumerables grados e innumerable tipología, la observancia de otros deberes, secundarios, anexos, colaterales o instrumentales, que encuentran su fuente ya sea en dispositivo legal o en cláusula contractual, o en el principio de la buena fe. Es que, si en todo el orden jurídico la cooperación es presupuesto abstracto y general, en el Derecho de obligaciones, centrado en la noción de prestación como conducta humana debida, la cooperación es nuclear....De este modo, el deber de colaboración está en el núcleo de la conducta debida, sirviendo para posibilitar, mensurar y calificar el cumplimiento". "La buena fe objetiva y el cumplimiento de las obligaciones", en Tratado de la buena fe, T. II, La Ley, Buenos Aires, 2004, p. 110.

En similar sentido, el profesor Gustavo ORDoQUI C., reafirma que "Hoy la buena fe no se refiere sólo a un no asumir determinadas conductas sino que impone deberes activos de cooperación y colaboración entre las partes, imponiendo un fin solidarista y personalista que en muchos casos asegura una verdadera justicia contractual. La buena fe exige que cada parte se preocupe por la otra y colabore en la realización de la prestación recíproca. Desde esta perspectiva la buena fe lleva a dejar de lado el individualismo egoísta con que se presentó en el contrato en los siglos XVIII y XIX, exigiéndose hoy la consideración prioritaria del interés del otro". La buena fe contractual, op. cit., p. 168.

Tal es la trascendencia de este deber en el Derecho contemporáneo, que expresamente, en el artículo 1.202 de los Principios del Derecho Europeo de los Contratos (PECL), se le da carta de ciudadanía, en los siguientes términos: "Cada una de las partes está obligada respecto de la otra, a cooperar para conseguir la plena efectividad del contrato", efectividad que, en rigor, desde una amplia perspectiva, supone la evitación de conductas o actuaciones volubles o contradictorias que asaltan la confianza depositada. No puede hablarse de efectividad negocial, en concreto contractual, cuando las expectativas de una parte, se truncaron por la conducta insolidaria e incoherente de la otra. De ahí que en este 


\section{ser humano, muy especialmente en sede civil, disciplina interesada en la persona, en torno a la cual ella gravita, y encuentra su ratio y explicación.}

plano, pueda aludirse a una especie de 'frustración del contrato', lato sensu, en lo que a esa parte burlada, sorprendida o afectada se refiere.

No sobra mencionar, por su elocuencia y significado, de ninguna manera nominal, que en algunos códigos decimonónicos, entre ellos el chileno, el colombiano, y el ecuatoriano, sólo por vía de ejemplificación, hay normas que literalmente refieren a la cooperación jurídica, v.gr: el artículo 1538 de la codificación civil colombiana -relativo a la condición suspensiva- (art. 1481 de Chile), que reza en su último inciso: "...si la persona que debe prestar la asignación, se vale de medios ilícitos para que la condición no pueda cumplirse, o para que la otra persona, de cuya voluntad depende en parte su cumplimiento, no coopera a él, se tendrá por cumplida".

Igualmente vale la pena mencionar que en la esfera de las obligaciones condicionales, en particular cuanto el obligado sub conditione impide su cumplimiento durante la fase de pendencia (conditio pendens), algunos autores entienden, con razón, que allí hay una clara demostración de un comportamiento incongruente, a la vez que incoherente y contradictorio, pues si por una parte el deudor se comprometió a honrar su palabra en el evento de que acaeciera el suceso futuro e incierto acordado ex ante, no se entiende, por la otra, que voluntaria y ulteriormente impidiera su cumplimiento, pues como puntualmente lo recuerda Don José Luis LACRUZ BERDEJO, "Durante la pendencia de la condición, los contratantes están obligados a observar el uno respecto del otro una conducta conforme a la buena fe (cfr. art. 1258) y, en particular, a no menoscabar la posibilidad de que las correspondientes expectativas lleguen a consolidarse en derechos y situaciones jurídicas definitivas" (Elementos de derecho civil. Librería Bosch, Barcelona, 1977, T.Il., p. 173). De allí que el artículo 1178 del Código Civil francés, y el artículo 1119 del Código Civil español, entre otros ejemplos más, estigmaticen tal actuación de raíz, estableciendo para el efecto una concreta secuela legis. Es así como uno y otro expresan, en su orden: "La condición se entenderá cumplida cuando el deudor, obligado bajo condición, impide su cumplimiento", y "Se tendrá por cumplida la condición el obligado impidiese voluntariamente su cumplimiento". El artículo 1394 del Código Civil uruguayo, sólo para referir a un caso más, consagra idéntica secuela.

En esta dirección, en lo tocante con el Derecho francés, en particular con el art. 1178 de su code, Dimitri HoutciefF observa que "La contradicción consiste para el deudor en obstaculizar espontánea y unilateralmente el cumplimiento de la condición El comportamiento del contratante es inconciliable con la ejecución del contrato...", la que se entiende materializada por "...la adopción por una misma parte de dos posiciones incompatibles...., la contradicción sancionada es puramente comportamental". Le principe de cohérence en matiére contractuelle, T. II, op. cit, pp. 830 y s.s. Y Bertrand FAGEs hace lo propio, al indicar que "... un deudor que impide el cumplimiento de la condición, contradice fatalmente su voluntad inicial de comprometerse...Su actitud, en el fondo, no es coherente... Ello es lo que sanciona el artículo 1178". Le comportament du contractant, op. cit, p. 326.

Y en lo atinente al Derecho colombiano, predicable de otros ordenamientos como el chileno y colombiano por su proximidad, entre otros latinoamericanos, la profesora Mariana BERNAL F. puso de manifiesto en su estructurada y reciente tesis doctoral, que "El deber de coherencia se puede presentar, así mismo, como un deber negativo, como ocurre en el caso del deber de no obstruir el cumplimiento de la condición, tema éste regulado en el artículo 1538 del Código Civil colombiano. Adicionalmente, por aplicación del deber de coherencia se puede ampliar el deber positivo de hacer lo posible porque la condición se cumpla si está en poder del deudor hacerlo, pues de lo contrario no sería coherente con 
Así concebida, grosso modo, la coherencia es un arquetípico deber jurídico, bien porque se considere como autonómico, o como inmerso en el deber de cooperación, concepciones en principio válidas, en términos generales, aun cuando sin desconocer la significación del deber de cooperación, que bien podría cobijar a la coherencia comportamental, no lo desconocemos, preferimos concebirla como deber propio: el deber de coherencia, entendido como un deber de conducta que, como todos los de este temperamento, emana de la buena fe, detonante de variados débitos de comportamiento, tesitura que ya hemos deslizado en algunos apartes de este escrito, por entenderla más precisa y, sobre todo, acorde con el revelador y elocuente mensaje que se quiere transmitir a quienes están llamados a observarlos ${ }^{83}$ : ser coherentes, no por capricho, sino por exigencia y requerimiento jurídicos a tono con lo que las partes -0 futuras partes- deben hacer en su beneficio, y en beneficio mutuo, como quiera que

el interés del contrato". El deber de coherencia en el derecho colombiano de los contratos, op. cit, p. 198.

Por último, cumple registrar que en el Derecho positivo italiano hay consciencia acerca de la conducta proba, leal y coherente que debe observarse en la fase de la condición pendiente (conditio pendens), lo que explica la expresa referencia a la plena observancia de la buena fe, con todo que ello supone. El artículo 1358 del C.C. al respecto manifiesta: "Comportamiento de las partes durante el estado de pendencia. El que se ha obligado o ha enajenado un derecho bajo condición suspensiva o lo ha adquirido bajo condición resolutoria debe, mientras pende la condición, comportarse de acuerdo con la buena fe para conservar íntegros los derechos de la otra parte".

83 Como lo explica el profesor Ricardo LoRenzetTI, Presidente de la Suprema Corte Argentina, los deberes especiales, secundarios o “... colaterales no son obligaciones en sentido técnico, sino deberes derivados de la buena fe. Su existencia abarca el período precontractual, contractual y poscontractual. Se distingue entre: deberes secundarios de finalidad negativa, cuya función es impedir invasiones arbitrarias en la esfera íntima del sujeto (deber de seguridad) y deberes secundarios de finalidad positiva, cuyo propósito es posibilitar el cumplimiento de la prestación: colaboración, información". "Esquema de una teoría sistémica del contrato", en Contratación contemporánea, Palestra y Temis, Bogotá, 2000, p. 22. Cfr. Mariana Bernal FAndiño, en otro de sus trabajos, al señalar que "... es bien conocido que en la actualidad la relación jurídica obligatoria no se limita a la correlación entre el deber del deudor de ejecutar la prestación y el derecho del acreedor a recibirla. La dogmática moderna considera que la relación obligatoria es compleja, y por tal razón, además de los deberes de prestación, que corresponden a la satisfacción de la finalidad principal perseguida por las partes y que éstas han acordado en virtud de la autonomía de la voluntad, se derivan de la relación otro tipo de deberes. En ese sentido, la situación de deuda no se agota en el deber central y primario, sino que para concretar y satisfacer el interés del acreedor, el plan de conducta futura del deudor incluye además deberes accesorios y complementarios, 'cuya entidad y denominación no ha sido pacífica hasta ahora'..." El deber de coherencia en el derecho colombiano de los contratos, op. cit, p. 114. 
así lo demanda la bona fides, su soporte genético y funcional, en armonía con coordenadas lógicas (coherencia y racionalidad) ${ }^{84}$.

Ha sido por ello, en consecuencia, que hemos catalogado a la coherencia, con antelación, como verdadero deber jurídico (deber especial, secundario o instrumental), y no de como arquetípica obligación (schuld y haftung), en sí misma coercible y, por tanto, ajena a su estructura y alcance, stricto sensu. Otros hablan de principio de coherencia, como se memorará. Y si ello es así, como en efecto para nosotros lo es, resulta diáfana su conexión con la buena fe, toda vez que es ella el sostén de este tipo de deberes, conforme se puntualizó, al margen que la ley no se refiera a ellos en forma expresa, pues precisamente emanan de la buena fe, que como se sabe, dentro de sus múltiples y granados oficios, tiene asignado el de servir de dispensario de deberes jurídicos de variada naturaleza y alcance a $^{8}$.

$\overline{84}$ Fiorenzo FESTI, reiterativamente se refiere en su obra a la existencia, “....en el ámbito jurídico”, de "un deber moral de coherencia". Il devieto di 'venire contro il fatto proprio', op. cit., p. 74.

85 F. Gómez Acebo. "La buena fe y la mala fe; su encuadramiento en la teoría general del derecho y su eficacia en el Código civil", en Revista de Derecho Privado, T. XXXVI, Madrid, pp. 101 y ss.; Delia Matilde FerReIRA R. La buena fe. El principio general en el derecho civil. Montecorvo, Madrid, 1984, p. 55, y ss.; y Jorge CuBIDES, "Los deberes de la buena fe contractual”, en Realidades y tendencias del Derecho en el Siglo XXI, Universidad Javeriana y Temis, T. IV, Vol. I, Bogotá, 2010, op. cit., p. 268, y Cristián BoETSCH Gillet. La buena fe contractual, Editorial Jurídica de Chile, 2011, op. cit., pp. 148 y ss.

Y de manera más particular, esto es inscribiendo estos deberes secundarios o especiales específicamente en el marco de la buena fe, véase también a Karl LARENZ. Derecho de obligaciones, T. II, op. cit., p. 22 y 24; Luís Díez-PICAZo. Fundamentos de derecho civil patrimonial, op. cit., pp. 63 y 64; Arturo SOLARTE RodRíGuez. Buena fe contractual y deberes secundarios de conducta, op. cit.; Fernando Hinestrosa. Tratado de las obligaciones, T. I, Universidad Externado de Colombia, Bogotá, 2002, p. 549; Mariana Bernal FAndIÑo. El deber de coherencia en los contratos y la regla del venire contra factum proprium, op. cit., pp. 293 y ss.; Rubén StıgLITZ. Contratos Civiles y comerciales. T. I. Abeledo Perrot. Buenos Aires. 1998. pp. 164 y 165, Jorge PARRA Benitez. Estudios sobre la buena fe, op cit., pp. 137 y ss., y Carlos Ignacio Jaramillo J., Responsabilidad civil médica, op. cit., pp. 195 y ss.

Acerca de los llamados deberes de protección, igualmente emanación de la buena fe, puede verse con provecho la obra del profesor Antonio CABANILLAS Sánchez: Los deberes de protección en el derecho civil, en el mercantil y en el laboral, en la que manifiesta que tales deberes, muy próximos a los especiales -o secundarios, o auxiliares, o instrumentales, etc.-, "Nacen del deber general de observar la conducta leal y recta, según la buena fe (art. 1.258 CC), pues entre las partes se establece con ocasión de un contrato una relación de confianza, sobre la que se basa el tráfico, debiendo, además, conducirse las partes según el sentido de la relación....", Civitas, Madrid, 2000, p. 258. 


\begin{abstract}
Por lo tanto, como sintéticamente lo revela el Profesor Luis Díez- Picazo, "Una de las consecuencias del deber de obrar de buena fe y de la necesidad de ejercitar los derechos de buena fe, es la exigencia de un comportamiento coherente....". Dicha "....exigencia jurídica del comportamiento coherente está de manera estrechamente vinculada a la buena fe y a la protección de la confianza" ${ }^{\prime 6}$, idea ésta que, en general, se reitera en la doctrina, plenamente
\end{abstract}

86 Luís Díez-PICAzo, La doctrina de los propios actos, op. cit., p. 142. Por su parte, el mismo autor, en otra obra suya, en lo atinente a la buena fe como 'fuente de especiales deberes de conducta', pone de presente que, "Al lado de la regla de la buena fe en lo que tiene de limitación del ejercicio de los derechos, existe también una proyección de la misma regla en lo que tiene de fuente de creación de especiales deberes de conducta entre las partes.... La necesidad de comportarse de buena fe en las relaciones obligatorias, en las relaciones contractuales y, en general, en todas las relaciones jurídicas, da lugar al nacimiento de una serie de deberes especiales de conducta y en ocasiones también a una ampliación de los deberes negocialmente asumidos". Fundamentos de derecho civil patrimonial, T. I, op. cit., p. 63.

Lo propio sucede con relación a lo señalado por Don Luís con motivo del prólogo por él realizado a la referida monografía del profesor CABANILLAS, a cuyo tenor, siguiendo a ESSER, “... junto al deber central de prestación, aparece, con frecuencia, como una ampliación o ensanchamiento de la situación de la 'deuda', una constelación de los que el autor citado denominaba 'deberes accesorios' y 'deberes de conducta', que, si las cosas se miran con detenimiento, en nuestro Derecho positivo tiene un fuerte fundamento en el artículo 1258 del Código Civil, según el cual, los contratos, una vez perfeccionados, no obligan sólo a cumplir aquello que los contratantes expresamente han pactado como objeto de su contrato, sino a una serie de 'consecuencias', como las llama nuestro Código Civil, que sólo exige que, según la naturaleza del contrato, sean conformes a la buena fe, al uso o a la ley. Hay que decir que, desde ahora, que el artículo 1.258 nos suministra un criterio seguro para situar las fuentes de estos deberes contractuales no pactados...". Los deberes de protección del deudor en el derecho civil, en el mercantil y en el laboral, op. cit., p. 17, criterio este que, sin duda, es basilar en tratándose del deber de coherencia, como deber especial que es, el que se anida entonces en diversas normas jurídicas que, aun cuando no se refieran a él expresamente, sí le sirven de apoyatura, v.gr: los artículos 7 y 1258 del Código Civil español, y los artículos 1603 del Código Civil y 863 y 871 del Código de Comercio de Colombia, a par que el 83 de su carta política, sólo para mencionar dos dicientes ejemplos.

Tan relevante es esta lectura de los señalados artículos 1258 del Código Civil español y del artículo 1603 del colombiano, existentes en la generalidad de legislaciones de los siglos $\mathrm{XIX}, \mathrm{XX}$ y XXI, que bien contextualizados sirven para extender el débito del deudor más allá de lo pactado nominalmente (concepción extra-textual), concretamente para cobijar deberes como el de coherencia, él no puede entonces ser soslayado, habida cuenta que, desde esta perspectiva, cuenta con una inequívoca carta de naturaleza.

En sentido similar, en lo pertinente, Antonio Manuel DA RocHA, reafirma que "...la regla venire contra factum proprium es una aplicación de la buena fe o, si se quiere, que asumir comportamientos contradictorios viola la observancia de la buena fe..., porque dotada de una carga ética, psicológica y sociológica negativa, necesariamente atenta contra la buena fe". Da boa fé no direito civil, Almedina, Lisboa, 2001, pp. 472 y 473, y Paulo MotA PINTo. Sobre a prohibiçao do comportamento contraditório (venire contra factum proprium) no direito civil, de acuerdo con el cual "...la buena fe constituye el patrón más próximo y tal 
consciente que buena fe y actos propios, están ligadas o conectadas, de una u otra forma, puesto que como lo expresa con rotundidad F. WIEACKER, acerca del venire contra factum proprium, "Esta máxima expresa de forma tan inmediata la esencia de la obligación de comportarse de acuerdo con la buena fe que a partir de ella se alumbra la totalidad del principio. La inadmisión de la contradicción con una propia conducta previa se basa en la misma exigencia de fides..." ${ }^{87}$. Lo mismo tratándose de la bona fides y la confianza (legítima y razonable), claro ${ }^{88}$ está. No es fortuito entonces que entre todas ellas existan lazos y hasta una cierta interdependencia, a la par que comunión en lo que a finalidades se refiere (teleología esencialmente común).

vez más adecuado para prohibir el venire contra factum proprium que la simple y genética invocación del abuso del derecho", pp. 321 y 322 . Cfr. Francesco AstonE, autor que señala que la referida fórmula latina encuentra asidero "... a través de la cláusula de la buena fe, justificando la calificación del comportamiento contradictorio como contrario a ella”. Venire contra factum proprium, op. cit., p. 59; Enrico DeLL'AqUILA. La correteza en el diritto privato, Giuffrè, Milano, 1980, p. 97 y ss.; Joaquín ATAz LóPEz. "La libertad contractual y sus límites", en Tratado de los contratos, Tirant lo blanch, Valencia, 2009, p. 168, y Mario CASTILLO FREYRE y Rita Sabroso MinaYa. La teoría de los actos propios, Palestra, Lima, 2006, pp. 71 y 78.

87 Franz WIEACKER. El principio general de la buena fe, op. cit., Vid. Fiorenzo FESTI. II devieto di 'venire contro il fatto proprio', op. cit., pp. 74 y 84, quien igualmente alude a su caracterización como sub principio. Vid. Giovanni CATTANEO, "Buona fede obbiettiva e abuso del diritto", en Riv. trim. dir. proc. civ., 1971, pp. 621 y ss.

De igual modo, el doctrinante español, José Luís De Los Mozos, enfatiza que “...no cabe dudar de la relación entre actos propios y buena fe..... El principio de la buena fe, op. cit., p. 183. G. ORDOQUI acertadamente precisa que, "De la vigencia plena del principio general de la buena fe se deduce la máxima de que "a nadie le es lícito hacer valer un derecho en contradicción con su anterior conducta". Buena fe contractual, op. cit., p. 230. Lo mismo ha expresado Cecilia O. NeIL De La Fuente, quien asevera que "el sustento de la doctrina de los actos propios es el principio de la buena fe porque su propósito es fomentar que las personas actúen de modo coherente sancionando a quienes incurren en contradicciones". El cielo de los conceptos jurídicos 'versus' la solución de problemas prácticos. A propósito de la doctrina de los actos propios, op. cit., p. 47. Cfr. María Laura EstigarRIBIA BIBIER. "La buena fe. Implicaciones actuales en las relaciones negociales", en Contratos. Teoría general, principios y tendencias, Grupo Ibáñez, Bogotá, 2011, p. 194 y F. FESTI. II devieto di 'venire contro il fatto proprio', op. cit., pp. 86.

Esta es pues, prácticamente sin reservas, la comunnis opinio en esta materia, la que no duda enlazar buena fe y actos propios, así puedan existir, es cierto, grados de conexión, y diferencias de intensidad en el vínculo: para algunos acerado, como para nosotros; para otros, menos intenso, pero en todo caso existente e indiscutido.

88 Ad exemplum, W. ERman y W. SiRp anotan, no sin razón, que "Atentaría contra la buena fe y minaría la confianza en el tráfico jurídico si a un sujeto se le permitiera incurrir en contradicción respecto a sus declaraciones y comportamientos anteriores", BGB, 1975, citados por Antonio Menezes Cordeiro. Tratado de direito civil portugués, Parte general, T. I, Almedina, Lisboa, 2005, p. 286. 
Análogamente, el profesor italiano Vincenzo RopPo, con motivo de la relación existente entre la buena fe y la doctrina en cita, afirma que "La buena fe impide a la partes ejercer sus propios derechos contractuales de modo lesivo, desleal y dañoso para la otra parte... La buena fe obliga a las partes a la coherencia de sus propios comportamientos....ello se funda en el antiguo precepto que prohíbe venire contra factum proprium ${ }^{89}$.

Otro tanto, por su parte, había expresado el profesor E. BETTI, de acuerdo con el cual, se reitera, "La buena fe, en fin, es considerada en cuanto que lleva a descubrir un abuso de derecho o conduce a prevenir el ir contra el propio acto, estableciendo una serie de limitaciones, conforme a una exigencia de coherencia en el comportamiento antecedente y en el subsiguiente" 90 .

Es en esa misma dirección, que el mencionado ordinal primero del artículo $7^{\circ}$ del Código Civil Español, reformado en el año 1974, lo memoramos de nuevo, atinadamente prescribe que, "los derechos deberán ejercitarse conforme a las exigencias de la buena fe". Y decimos atinadamente, por cuanto refrenda la idea de que la buena fe también se constituye en una especie de instrumento moderador o regulador de la conducta (estándar), pues siempre su ejercicio, aspecto crucial en tratándose de la doctrina de los actos propios, deberá realizarse con arreglo a la buena fe, como desde tiempo atrás viene sosteniéndolo la doctrina alemana y parte de la española y portuguesa, como se anotó, en el sentido de entender que la buena fe, dentro de sus diversas misiones, tiene la de servir de límite al

89 Vincenzo Ropo. I/ contratto. Giuffrè. Milano. 2000, p. 496.

90 Emilio BetTı. Teoría general de las obligaciones, op. cit., T. I., p. 100.

Similar criterio, en torno a la valía de la protección objetiva de la buena fe y su relación con el acto propio, expone el profesor emérito de la Universidad de Bonn, Werner FLUME, al señalar que, "La conducta jurídicamente relevante no es, como tal, jurídicamente decisiva, simplemente porque conforme al tráfico tenga para otro un sentido determinado, sino que la conducta alcanza relevancia jurídica solamente porque, dada la conducta precedente, el actual ejercicio de derechos y posiciones jurídicas es contrario a la buena fe. En consideración a la conducta precedente el actual ejercicio derechos y posiciones jurídicas es un venire contra factum proprium". Por eso el mismo autor, en su obra, más adelante señala que, lo determinante en esta materia es, aún "...considerando la conducta precedente, el ejercicio del derecho o de posiciones jurídicas es contrario a la buena fe. La negación de la contravención a la buena fe es decisiva". El negocio jurídico. Fundación Cultural del Notariado. Madrid. 1998. pp. 161 y 164. 
ejercicio de los derechos. No sólo es importante celebrar y ejecutar los contratos de buena fe, en sentido lato, sino también ejercer los derechos que de él afloran en forma proba, leal, solidaria y correcta, en cuyo caso el principio jurídico en cuestión obra como limitación, barrera o valladar al ejercicio de un derecho lesivo de los intereses del cocontratante, bien in actus, bien in potentia, tal y como se examinará más en detalle en el aparte reservado al análisis de los efectos y secuelas derivados de la citada regla (Cap. III).

Por su relevancia, cumple anotar que este criterio del ejercicio de un derecho con arreglo a la buena fe, entendida como límite o restricción, también se encuentra presente en diversos ordenamientos civiles. Es el caso, entre otros más, de Alemania (art. 226), Grecia (art. 281), Portugal (art. 334), Japón (art. 1), Provincia de Quebec (art. 6) y Paraguay (art. 272).

Aun cuando del tema nos ocuparemos más en detalle en otro aparte de este escrito (parte final del Cap. I), por su significado indiquemos anticipadamente que esta conexión de la buena fe y la doctrina de los actos propios, y sus figuras próximas, mejor aún con el rechazo a la contradicción e incoherencia, no es fruto lecturas o ejercicios contemporáneos, sino el resultado de análisis muy anteriores que corroboran que tal vínculo no es nuevo, pues la historia del Derecho da cuenta del mismo, muy especialmente en sede del Derecho romano, así la regla latina que conocemos (venire contra factum proprium) no haya sido acuñada literalmente en Roma, ni tampoco con un carácter general ${ }^{91}$.

91 Con esta aclaración anticipada, resulta de interés la opinión de la profesora Martha Lucía Nemen VilLareal, conforme a la cual “La prohibición de 'venire contra factum proprium' emana de la buena fe... así lo demuestran la totalidad de los elementos que conforman la regla...de suerte que la buena fe protege la confianza de las partes en que dichos acuerdos serán llevados a término, constituye garantía de que se respetará la palabra empeñada y de que, como consecuencia, serán preservadas las expectativas creadas, no sólo con la declaración contractual sino también con la conducta de la contraparte.... Pues como dice expresamente CELSO, contraría la buena fe quien pretende desconocer su conducta precedente en perjuicio de la contraparte....." La buena fe en el derecho romano. Extensión del deber de actuar conforme a la buena fe en materia contractual, Universidad Externado de Colombia, Bogotá, 2010, pp. 311 y 324. Cfr. Cristián BoETSCH GILLET, al afirmar que "...la doctrina de los actos propios", entre otras figuras, "...se nutren de un elemento estructural de la buena fe”. La buena fe contractual, op. cit., p. 70; René Ortiz Caballero. "La doctrina de los actos propios en el derecho civil peruano", Derecho, No 45, 1991, p. 266 y ss.; Cecilia O’NEILL DE LA FUENTE "El cielo de los conceptos jurídicos versus la solución de problemas prácticos a propósito de la doctrina de los actos propios", 
Ahora bien, en lo que concierne al referido solidarismo contractual, hay que señalar que la evolución que esta temática ha registrado en el Derecho comparado y muy especialmente en sede del Derecho francés, no es simétrica, habida cuenta que en los últimos lustros, sin la timidez inicial de los años treinta del siglo precedente, ha adquirido notorio protagonismo, hasta el punto que ciertos autores contemporáneos, abogando por dotarlo de singular status, lo han situado en la cúspide de la ciencia del Derecho, comprendida la temática contractual, incluso relativizando el rol de la buena fe, obviamente sin que esta lectura se haya generalizado, y menos aceptado sin reservas, so pretexto de una acendrada autonomía, de acuerdo con la cual se ha dicho que el "...solidarismo contractual no está sometido a su dependencia, ni tiene necesidad de ella para existir"92, postura que, así formulada, peca por extrema, merced al genuino alcance arropador de la bona fides, sobre todo en la actualidad. Por eso, sin inclinarnos por el pretendido divorcio, entendemos que buena fe y solidarismo están íntimamente vinculados.

Así las cosas, ciertos autores, atribuyéndole al solidarismo contractual un espectro más dilatado, amén que omnicomprensivo de diversas fenomenologías, han inscrito el deber de coherencia y, de paso la regla del venire contra factum proprium, en su propio marco, entendido aquél como un conjunto de coordenadas llamadas a sublimar los axiomas de la colaboración, la solidaridad y la cooperación en el campo negocial. Para los que adhieren a esta doctrina, no exenta de alguna controversia ${ }^{93}$, tal solidarismo se manifiesta en la imposición de diversos deberes contractuales, implícitos en el negocio jurídico, entre varios el deber de cooperación; el de lealtad, y el de coherencia conductual o comportamental.

En este orden, para algunos la mencionada coherencia es una expresión del solidarismo en referencia, de suyo más general y envolvente. De ahí que, con arreglo a una misma categoría, en esta tesis se cobijen varios deberes

en Themis, Revista de Derecho, Lima, p. 47; Rodrigo AlcAíno TorRes. "Comentario acerca de la naturaleza, efectos y orígenes de la regla venire contra factum proprium non valet, que impide contravenir las conductas pasadas", en Revista de Derecho y Tribunales, AMF, No 2, Montevideo, 2006, pp. 113 y ss.

92 Anne-Sylvie Courdier-CuIsINIER. Le solidarisme contractuel, op. cit., p. 247.

93 Vid. Christophe Jamin. "Le procés du solidarisme contractuel: bréve réplique", en Le solidarisme contractuel- Mythe o realité?, Economica, Paris, 2004, pp. 159 y ss. 
secundarios de conducta, en concreto el deber de coherencia. Como lo expresa el profesor Denis MAZEAUD, “... el solidarismo contractual consiste... esencialmente, en una exigencia de civismo contractual que se traduce, para cada contratante, en la consideración y el respeto del interés legitimo de la otra parte. Esta ética contractual se expresa concretamente, entre otras por las ideas altruistas, de decencia, de coherencia, de proporcionalidad y de cooperación, y excluye el egoísmo, la indiferencia, el atrevimiento y el cinismo..." ${ }^{94}$.

Por nuestra parte, sin auspiciar una concepción absorbente y desbordada del solidarismo, menos aún separada o desconectada de la buena fe, nos parece que racional y equilibradamente estructurada, reviste un papel de especial importancia en la ciencia jurídica contemporánea, la que no puede darle la espalda, enarbolando manidos argumentos que hunden sus raíces en el superado individualismo a ultranza. De ahí que bien delimitado, sea refractario a las conductas incoherentes y contradictorias, que de hacer presencia lo lacerarían de plano, comprobándose de este modo que buena fe y solidarismo, in radice, tampoco comulgan con el comportamiento voluble cuando se torna lesivo de la confianza legítima previamente suscitada.

\subsection{RECAPITULACIÓN}

En conclusión, conectado con el postulado general de la buena fe -sin desconocer la fuerza individual inherente a la confianza, muy por el contrario

94 Denis Mazeaud. "Solidarisme contractuel et réalisation du contrat", en Le solidarisme contractuel - Mythe ou réalité, Economica, Paris, 2004, pp. 60 y ss.

La profesora Mariana BERNAL, por su parte, afirma que uno de los deberes que suele estar presente en el solidarismo contractual, justamente es el deber de coherencia comportamental. Al respecto sostiene que “... El solidarismo busca adaptar las relaciones contractuales que no se encuentran en un pie de igualdad (...) Como consecuencia, se espera en el comportamiento de los contratantes una actitud de colaboración, de ayuda mutua independientemente de lo distantes que puedan estar sus intereses, rechaza las actitudes contradictorias que puedan tener los contratantes, por estar precisamente basado en principios como la buena fe, lealtad y coherencia contractual, entre otros... El solidarismo contractual rechaza las actitudes contradictorias que puedan tener los contratantes, por estar precisamente basado en principios como la buena fe, la lealtad y la coherencia contractual, entre otros..." "El solidarismo contractual. Especial referencia al Derecho francés", en Vniversitas. № 114, Universidad Javeriana, Bogotá, pp. 15-19. Vid. 
destacándola-, en su oportunidad afloraron la regla venire contra factum proprium, la doctrina de los actos propios, el deber de coherencia contractual, la confianza legítima, el estoppel, la verwirkung, la rechtsverwerking, el tu quoque, las manos limpias, entre varias manifestaciones contemporáneas de esta singular fenomenología en el Derecho comparado y también el solidarismo contractual, como se destacará en su oportunidad. Tanto que la jurisprudencia y la doctrina, es la constante, son contestes en aseverar que son una prototípica derivación, extensión, irradiación, subproducto, subcláusula y, en fin, hijas de la bona fides, sin perjuicio de que algunos adicionan o hacen énfasis en otros criterios. $Y$ lo mismo han hecho los Códigos Civiles que, como los mencionados, articulan buena fe y ejercicio de los derechos, todo sin perjuicio de lo anotado en relación con el referido solidarismo.

Es diáfano entonces que buena fe, y la doctrina de los actos propios, in complexu, forman parte de una misma dimensión global, así no sean, necesariamente, figuras idénticas, como no lo son, según también tendremos oportunidad de constatar en el Capítulo siguiente (Cap. II). Si así fuere, en puridad, se advierte que no habría para que distinguir la buena fe, in abstracto, del instituto de los actos propios, in concreto, pese a su inescindible vinculación, en cuyo caso, por sustracción de materia, sólo sería menester referir a la buena fe, para saber que todo, absolutamente todo lo relacionado con el acto propio (factum proprio), quedaría subsumido en ella, lectura que, habida cuenta del valor y el espectro tan amplio de este principio general, permitiría entender que la buena fe sería el único tema digno de ser tomado en consideración en la ciencia del Derecho, sobrando buena parte de los demás, tesitura maximalista que no resulta de recibo, ni tampoco equilibrada y razonable, sin restarle por eso trascendencia, pues la tiene toda. Lo mismo en relación con el solidarismo contractual, pues si indefectiblemente cobijara todo lo concerniente a la coherencia contractual, no sería necesario aludir a la doctrina en cita, y a la regla venire contra factum proprium.

Por ello, si bien se alimenta de la misma, y vive en virtud suya, y gracias a ella despuntó en el cosmos jurídico, existe cierta sustantividad que reclama autonomía -jurídica y dogmática-, sin que ello implique, claro está, dejar de reconocer inobjetables vasos comunicantes entre sí, como se señaló. Si no fuera 
de este modo, algo similar acontecería con otros institutos que, pese a su íntima relación con la buena fe, quedarían subsumidos por ella, se itera, como acontece con el abuso del Derecho, sólo para referir a un supuesto. Al fin y al cabo, la buena fe todo lo domina como lo hemos dicho, ora directa, ora indirectamente, lo que impediría el examen autonómico de este tipo de figuras que, no obstante su etiología, y ligamen con la bona fides, reclaman autogobierno, bien entendido, que no divorcio, o rompimiento pleno.

Una cosa es compartir el mismo material genético y, por ende, reconocer una génesis común, una línea parental, y otra muy distinta pretender desconocer la sangre iuris, el vínculo sanguíneo que es indeleble, como lo hemos advertido con antelación, en una actitud separacionista que no sólo conspira contra la realidad histórica, fáctica y jurídica, sino que pretende imprimir a la doctrina de los actos propios una supuesta e innecesaria autonomía que la dejaría en la más profunda orfandad y pobreza extrema.

La buena fe, por consiguiente, le brinda conveniente protección y salvaguarda, amén que le ofrece una familia y un apellido de gran ascendiente, a lo que se agrega algo fundamental, pues ha permitido, y seguirá haciendo por ahora hasta que los legisladores se ocupen directamente de ella-, que la judicatura, a partir de los preceptos que desarrollan el postulado de la buena fe, o de la simple consideración de ser un principio general, han elaborado la tesis de la procedencia de la doctrina de los actos propios, por lo que ella se ha traducido en su soporte cardinal. Difícil, amén de inseguro y riesgoso, sería para un juez aplicar las consecuencias, para nada triviales de esta doctrina, nada menos que el rechazo categórico y definitivo de una 'pretensión', en sentido lato, sin el apoyo o estribo de la buena fe, tan arraigada en la cultura jurídica contemporánea. Sería tanto como una especie de 'salto al vacío' pretender desnudar la doctrina de los actos propios, del cálido y confortable ropaje que la cubre toda, a fortiori, para quienes consideramos que, stricto sensu, ella no es un típico principio general, como si lo es la bona fides. Ad baculum, entonces, el juez conciente y reflexivamente se ha apoyado, y conviene que se siga apoyando en la buena fe, como pilar sobre el que descansa la figura de la apellidada doctrina de los actos propios, irradiación del axioma medieval venire contra factum proprium non valet, así cada día adquiera más fisonomía y perfiles acusadamente propios, no tantos, empero, para su estructuración aislada o insular. 
Expresado en términos más concisos, aspirar a romper el cordón umbilical de los actos propios, del deber de coherencia con la buena fe, aparte de ser contra natura, es negarse a sí mismo y a sus ancestros, obviamente en forma anodina, pues esta la ha tatuado para siempre con tinta indeleble. Por eso, consecuentes con todo lo expresado, reafirmamos el estrecho y perceptible vínculo reinante entre ellas, suficiente para entender que cuando se atenta contra la coherencia comportamental y, de paso, contra la confianza legítima, la buena fe se ha visto conculcada-directa o reflejamente-, pues no puede entenderse que obra de buena fe quien erosiona o socava la confianza legítima, quien es protagonista de la incoherencia y de la contradicción ilegítimas, con menoscabo de intereses ajenos ${ }^{95}$.

Para finalizar podemos entender que, como los adolescentes, y luego los mayores de edad, que reclaman libertad y autonomía, se peticione que buena fe y actos propios no se mezclen tanto, hasta el punto de que pierdan su arquitectura, en cuyo caso, como en familia, pueden tener independencia, pero no rompimiento, o aislamiento plenos, por lo menos a nivel genético. Sin embargo, lo que nos resulta inaceptable, es querer borrar, de modo contraevidente, la huella genética existente entre buena fe y actos propios, la que no impide vidas individuales, pero comunicadas, que no esclavizadas, como si el mencionado vínculo fuera vergonzante y hubiera que ocultarlo o callarlo. Ello es tanto, mutatis mutandis, como desear 'tapar' el sol con las manos, como desconocer y poner en duda el 'holocausto', escenario de horror y locura, como darle forma de cuadrado a la tierra.

\section{BIEN JURÍDICO TUTELADO POR EL DERECHO MEDIANTE LA APLICACIÓN DE LA DOCTRINA DE LOS ACTOS PROPIOS (RATIO PROTECTIONIS)}

Con apoyo en la expresión 'bien jurídico tutelado', en sentido lato, muy empleada en diversas disciplinas jurídicas, no sólo en el campo del Derecho

$\overline{95}$ Cfr. Salvatore PAtTI. "Verwirkung”, en Dig. Disc. Priv, Sez. Civ, XIX, Torino, 1999, p. 727. 
público, en particular del penal ${ }^{96}$, podemos señalar más en concreto que es la confianza, preponderantemente, la ratio protectionis de la institución de la doctrina de los actos propios, conforme hemos expresado, concretamente su ratio individual, por cuanto, in globo, merced a su carácter envolvente, será la buena fe la institución objeto de tuición o salvaguarda, pues insistimos que una concepción autonómica y también separatista, a ultranza, encaminada a negar los tejidos existentes con la bona fides, nos parece que desconoce su esencia y su genealogía, indisolublemente ligada a ella. Ya habíamos manifestado que algunas cosas se pueden negar, pero no todas; dos, precisamente, la sangre y los antepasados.

En efecto, sin perjuicio de reconocer el rol que desempeña -o puede desempeñar- la llamada teoría de la apariencia jurídica, entre otras más, es la confianza legítima la piedra de toque de la figura que comentamos; en ella reside su quintaesencia protectiva, su explicación última y, a nuestro entender, la más persuasiva y convincente en la esfera tuitiva, habida cuenta que sin su trasgresión, sin que se sobrepase su umbral, no podría censurarse la incoherencia o contradicción, dado que su quiebre, causalmente concebido, es el percutor de los efectos inherentes a la doctrina en mención, los que no son automáticos, per se. De allí el empleo de la expresión: bien jurídico tutelado -o protegido- o si se prefiere interés protegido, ${ }^{97}$ como quiera que, en puridad, es la protección de la confianza en la que descansa la prohibición o rechazo de obrar en contra de uno o varios actos propios anteriores, según sea el caso, sin dejar de soslayar, de una parte, su estrecha vinculación con la buena fe, como se precisó, y con otras instituciones o postulados, como el de la apariencia y seguridad jurídicas,

96 Por bien jurídico protegido “...debe entenderse, en un sentido amplio, cualquier objeto de satisfacción que genere un interés legítimo para su autor. Entonces puede comprender cosas, derechos, bienes inmateriales con valor económico...es decir puede tratarse de cualquier objeto de satisfacción, sea con valor económico o sin tal, como el cuerpo, la intimidad, etc.". Gastón Salinas UgarTe. Responsabilidad civil contractual, Abeledo-Perrot y Thomson Reuters, Santiago, T.I, 2011, p. 321.

97 El Art. 2:102 de los Principios de Derecho Europeo de la Responsabilidad Civil, aluden a los "intereses protegidos", en los siguientes términos: "(1) El alcance de la protección de un interés depende de su naturaleza; su protección será más amplia cuanto mayor sea su valor, la precisión de su definición y su obviedad....(6) Para establecer el alcance de la protección también deberán tenerse en cuenta los intereses del agente, en especial, en su libertad de acción y en el ejercicio de sus derechos, así como los intereses públicos". 
el deber de coherencia y regularidad, la fuerza vinculante de la declaración de voluntad (pacta sunt servanda), etc., las que, en un sentido lato o dilatado, podrían considerarse, en lo pertinente, como fundamento múltiple o justificación general de la doctrina de los actos propios, como ya se anotó, sin perjuicio que, stricto sensu, no tienen indefectiblemente el mismo abolengo, ni están situados en idéntico o simétrico sitial, pues no pueden confundirse ${ }^{98}$.

Todos ellos, sin embargo, están conectadas con el mismo ideario de rechazar, vehementemente, la irregularidad, el súbito e inesperado cambio comportamental; la incoherencia y la contradicción en el actuar ${ }^{99}$. Así sucede con elocuencia, por vía de ilustración, con la seguridad jurídica, específicamente con la apellidada seguridad del tráfico jurídico, capitales en un orden justo y en un Estado Social de Derecho, habida consideración que si “... la seguridad jurídica stricto sensu, se manifiesta como exigencia objetiva de regularidad estructural y funcional del sistema jurídico"100, ella se vulneraría cuando irrumpa la incoherencia

98 Como lo recuerda Pierre-Yves GaUtier en relación con "la confianza, la lealtad y la coherencia", hay entre ellas "familiaridades, pero no una identidad; hay lazos de parentesco". "Confiance légitime, obligation de loyauté et devoir de cohérence", en La confiance en droit privé des contrats, Dalloz, Paris, 2008, p. 110.

99 Vid F. Festi. II divieto di 'venire contro il fatto proprio', op. cit., p. 110, quien corrobora que la misma teleología acompaña a figuras e instituciones tales como la buena fe, el venire contra factum proprium, la exceptio doli generalis, la verwirkung, el abuso del derecho, entre otras.

100 Antonio-Enrique Pérez Luño. La seguridad jurídica, Ariel, Barcelona, 1994, pp. 10 y 29, quien agrega que la "seguridad del tráfico negocial mantiene su protagonismo en el Derecho privado". Por su parte, Don Luís DIEZ-PICAZo, en lo que dice relación con la 'seguridad del tráfico jurídico', señala que "La idea de seguridad jurídica cobra un matiz diverso cuando se habla de 'seguridad del tráfico jurídico'. Aquí lo que quiere decirse es que en el tráfico jurídico, en el mundo de los negocios jurídicos, merece protección la confianza razonable suscitada objetivamente por una situación jurídica: que quien de buena fe realiza un negocio jurídico fundado en la confianza razonable que objetivamente le suscita una situación de apariencia creada o mantenida por otra persona, debe ser protegido..... Fundamentos de derecho civil patrimonial. Teoría del contrato, Vol. I, op. cit., pp. 70 y 71.

Queda entonces claro que la regularidad y la continuidad conductuales, manifestaciones de la coherencia entendida como regla, o como deber, y la protección de la confianza legítima, no son ajenas a la seguridad jurídica; todo lo contrario, hasta el punto que el quiebre de aquellas, importa el quiebre de ésta, sin que ello suponga simetría o clonación, como se indicó en precedencia, en razón de que aunque entrelazadas, conocen diferencias. Cfr. Sylvia Calmes. Du principe de protection de la confiance légitime en droit allemand, communautaire et français, op. cit., p. 164, autora que se esfuerza por distinguir la seguridad jurídica y la confianza legítima, en ocasiones objeto de confusión, de suerte que insiste en 
comportamental en sede contractual y, por reflejo, se lastime la confianza legítima suscitada en uno de los cocontratantes, quien razonablemente esperaba que su relación no estuviera expuesta a alteraciones, desajustes, vaivenes; en una sola palabra a inestabilidad, menos si ella proviene del sujeto con quien concelebró el contrato (parte), y no de un extraño (mutualidad).

Lo anterior explica, en mayor o menor medida, que al unísono todas y cada una de las aludidas instituciones -exigencias o valores- se sumen a la brigada élite que lucha contra el ejercicio lesivo de derechos propios que, no por serlo, pueden contrariar la buena fe, desde una perspectiva general, y la confianza sembrada o suscitada en un determinado sujeto o sujetos, en especial, más allá de que, por efectos especulares, irradie a otros bienes dignos de tutela, como se anotó: la 'apariencia' - para algunos- y seguridad jurídicas, la regularidad, el solidarismo y la razonabilidad, entre varios más, estrechamente vinculadas entre sí, según se reiteró.

Expresado de otro modo, variadas son las fuerzas que, sin tregua o cuartel, combaten la volubilidad ilegítima o antijurídica, como quiera que, sin distingo, ellas pertenecen al mismo ejército guiados por la brújula de la fides, y por la constelación del ethos, aunque no todas, si de precisar se tratare su verdadero influjo e invariable incidencia, ocupan la misma posición. Por eso, como muy bien

\footnotetext{
"la necesidad de una diferenciación", porque "hay numerosas diferencias entre la lógica de la seguridad jurídica y la de la protección de la confianza legítima" (Op. cit., p. 166).

En sentido análogo, el profesor Jorge CuBIDES CAMACHO establece una relación entre coherencia y seguridad contractual. Así, cuando aborda el "Deber de conducta coherente", puntualiza que "La doctrina ha avanzado notablemente en señalar situaciones que suponen esa conducta y obligan a las partes a la coherencia... El avance y la tendencia de la doctrina consisten precisamente en deducir la coherencia de tales situaciones a fin de darle seguridad al convenio y evaluar consiguientemente la conducta de las partes en el marco de tal coherencia". No obstante, tan destacado autor colombiano, pese a reconocer "... de entrada la similitud existente entre la confianza legítima, la apariencia fundada, los actos propios", entre otras más, las distingue igual y detalladamente. Los deberes de la buena fe contractual, op. cit., p. 268.

Lo cierto, como lo resaltara en su oportunidad don Luís RECASENS SICHES, "No hay derecho sin seguridad; cuando una sociedad no asegura el repertorio de condiciones mínimas para su propia subsistencia y para la realización de sus proyectos colectivos, se produce la anarquía". "Estudios de filosofía del derecho", en Filosofía del derecho, T. I, Parte sistemática, Unión Tipográfica Editorial Hispano-Americana, México, 1946, p. 237.
} 
lo memoró el profesor José María MıQueL, “...no puede tolerarse la frustración de la confianza suscitada"101.

Una sinfónica, en efecto, está conformada por diversos músicos que, articuladamente, ejecutan numerosos instrumentos, todos alineados en función de un propósito común: interpretar fielmente una melodía, en el caso que nos ocupa, ciñéndose a la partitura de la coherencia, construida a partir del pentagrama de los derechos ajenos, refractarios al egoísmo, a la ausencia de cooperación y solidaridad, aún en tratándose de cocontratantes, que no contrapartes, quienes merecen no ser sorprendidos o asaltados, todo en el marco de un deber ser fraternal, en el que impere la corrección y el respeto por los demás, así se estime esta visión de romántica, ilusoria o idílica ${ }^{102}$. Aún a riesgo de ello, hay que reclamar del prójimo una conducta más considerada con su congéneres, ajena a esa corrosiva individualidad extrema que, antes que una cualidad humana, se traduce en un yerro que no debe ser repetido de generación en generación, a pretexto de que la sociedad es insolidaria, y que la vida es una 'selva' en la cual todos pueden sucumbir. Visiones tan negativas, que las hay, no deben eclipsar la idea de un Derecho incluyente, solidario, más humano y próximo a todos. Renunciar a ello, es morir un poco más todos los días; profundizar en la amargura y en la desesperanza.

Ya tuvimos ocasión de precisar en otro aparte que, al igual que la buena fe, en los tiempos que corren la confianza legítima, revitalizada, está en su apogeo, por de pronto en su mejor momento. Prueba de ello, de una parte, es el vigor reconocido por la doctrina y la jurisprudencia y, de la otra, que en el campo de la principialística internacional, expresamente se le confiera un destacado papel.

101 José María MıQuel. Acto propio, op. cit., p. 205.

102 Vid. Jean Pascal Chazal. Les nouveaux devoirs des contractants. Est-on allé trop loin?, op. cit., p. 120 y 121, quien entiende que la "...fraternidad, amistad, amor, generosidad", son constitutivas de una "utopía contractual", postura que, por radical, amén que desconocedora de la carga ideológica ínsita en el ordenamiento jurídico, incluida la temática contractual, no puede contar con nuestra adhesión, porque sin que se exageren en estas notas no puede desconocerse que, sin ellas, en su justo medio, el contrato estaría vacío de sustrato humanístico; sería como de piedra o de hielo, en clara contravía de caros valores, muchos de ellos de estirpe constitucional, incluso, como sucede con la solidaridad, dispensario de numerosos comportamientos (deberes de conducta) que exigen el más franco y sistemático respeto por el cocontratante, en concreto por sus aspiraciones y expectativas. 


\begin{abstract}
Baste simplemente recordar con Franz WIEACKER que "...el principio del venire es una aplicación del principio de la confianza en el tráfico jurídico"103, y que los Principios del Derecho Europeo de Contratos, a su turno, le asignan un destacado rol a la confianza razonable ${ }^{104}$.
\end{abstract}

103 F. WieAcker, El principio general de la buena fe, op. cit., p. 62. Cfr. Federico Procchi. "L'Exeptio doli generalis e il devieto di venire contra factum proprium", en L'eccezione di dolo generale, CEDAM, Milani, 2006, p. 111.

Tal es la importancia de la confianza en la actualidad, que más allá de la real pertinencia del aserto, la que se pone en duda por algunos sectores, se dice que la fuerza obligatoria de los contratos reside en ella, más que en la propia voluntad. Vid. Hugues KENFACK, "La consagration de la confiance come fondement de la force obligatoire du contrat?", en La confiance en droit privé des contrats, Dalloz, Paris, 2008, pp. 111 y ss.

104 De igual modo, cumple registrar que en esferas del Derecho privado aledañas al Derecho de obligaciones y contratos, acontece lo mismo. Es el caso de la responsabilidad civil, en donde comienza a ser objeto de escrutinio especial la temática atinente a los actos propios como modalidad de la regla venire contra factum proprium, en concreto el punto del interés que se protege a través suyo, que es el que nos ocupa. Al respecto, recientemente el profesor y Ex Magistrado Jorge SANTOS BALLESTEROS, con ocasión de un fallo emanado de la Corte Suprema de Justicia colombiana, expresó que "Según la Corte Suprema....el postulado venire contra factum proprium non valet puede enunciarse como "la coherencia exigida en el comportamiento de las personas, de tal forma que lo realizado en el pasado, que ha servido, a su vez, como determinante o referente del proceder de otras o que ha alimentado, objetivamente, ciertas expectativas, no pueden ser contrariadas de manera sorpresiva, caprichosa o arbitraria, si con ello trasciende la esfera personal y genera perjuicio a los demás". Desde luego que lo trascendente en el campo de la responsabilidad civil y al atender su función reparatoria es la indemnización plena de los perjuicios que se hayan ocasionado y por consiguiente dejar incólume la confianza fundada en el antecedente, lo que quiere significar que el interés jurídico prevalentemente protegido es el interés negativo o interés de confianza. La responsabilidad civil. Parte general, T. I, Universidad Javeriana y Temis, Bogotá, 2012, p. 59.

El artículo 2.106, numeral segundo, en efecto dispone que "En virtud de su declaración o de su conducta una parte puede quedar impedida para alegar una cláusula semejante en la medida en que la otra hubiere confiando razonablemente en aquéllos". Lo propio, en lo pertinente, hace el Anteproyecto de Código Europeo de Contratos (Proyecto GANDOLFI) en su artículo 6, a cuyo tenor: "Deber de corrección. 1. Cada una de las partes es libre para emprender negociaciones con vistas a la conclusión de un contrato, sin que se le pueda imputar responsabilidad alguna por la no celebración del mismo, salvo que su comportamiento haya sido contrario a la buena fe...3. Si, en el curso de los tratos preliminares, las partes han examinado ya los elementos esenciales del contrato, permitiendo ello prever la posible conclusión del mismo, la parte que haya hecho surgir en la otra una confianza razonable respecto de la conclusión del contrato, obra de modo contrario a la buena fe cuando interrumpe los tratos preliminares sin motivo justificado....".

En el reciente anteproyecto de Código Civil Argentino de 2012, artículo 1067, la temática en referencia se le reserva un lugar de preferencia, el que a la letra reza: "Protección de la confianza. La interpretación debe proteger la confianza y la lealtad que las partes se deben recíprocamente, siendo inadmisible la contradicción con una conducta jurídicamente relevante, previa y propia del mismo sujeto". 
En suma, puede decirse que, en sentido amplio, no por ello impreciso, existen diversos bienes jurídicos tutelados en punto tocante con la referida doctrina o teoría de los actos propios, comenzando por la buena fe, claro está, y continuando, in concreto, con algunas de sus expresiones, y también con otras instituciones y valores, en cuyo supuesto habría que traer a colación la confianza legítima, a la apariencia -para algunos- y a la seguridad jurídicas, al deber de coherencia y regularidad, a la fuerza vinculante del negocio jurídico, la solidaridad, etc. Empero, no todos están en un mismo plano, se itera, de suerte que, en nuestro entender, respetando toda otra opinión, es el primero de ellos, enlazado íntimamente con la buena fe, esto es, la confianza legítima, el que frontal y primeramente se afecta cuando se materializa un acto voluble capaz de erosionar las bases mismas de la relación jurídica, por vía de ilustración la negocial, caso en el cual, in toto, se resquebrajaría la 'justicia contractual', norte de todo contrato y deseo del ordenamiento jurídico, cimentado en un 'orden justo', connatural a un 'estado social de derecho', rectamente entendido. Desde este ángulo, una cosa es el fundamento de la doctrina, que en rigor es plural, y otra cosa su ratio protectionis, la que reside en la confianza legítima, amén que razonable.

En este sentido, cumple reiterar que en tratándose de otras instituciones, v.gr: el estoppel, objeto de ulterior y detallado escrutinio en este escrito, la doctrina se apoya de manera directa en la apariencia, más que en la confianza, recta via, muy al contrario de lo que tiene lugar, en sede del civil law, con la regla venire contra factum proprium, y sus manifestaciones más concretas, entre ellas, prevalentemente, la doctrina de los actos propios, e incluso la misma verwirkung, como se anotará a espacio, en las que la confianza, antes que la apariencia, se erige en la piedra angular de las mismas, toda vez que en el Derecho continental, sin soslayar la importancia que reviste la apariencia jurídica, la confianza desempeña un papel protagónico, lo que explica que tenga más arraigo en nuestro sistema ${ }^{105}$, especialmente en relación con los actos propios, en los que sobresale de manera notable, hasta el punto de ser su ratio protectionis o, si se prefiere, el

105 Como lo expresa Valérie LaserRe-Kielow, "Durante largo tiempo el derecho francés se refirió a la noción de apariencia. ... Pero la noción de confianza legítima presenta gran potencialidad de aplicaciones y se observa que ella se integra cada vez más en el derecho francés". "Contrat et morale", en Los contratos en el Derecho privado, Legis y Universidad del Rosario, Bogotá, 2007, p. 11. 
bien jurídico tutelado de mayor abolengo ${ }^{106}$, sin dejar de lado otros, como se anotó, que pueden converger también, pero en un plano diverso, no por ello adjetivo, se aclara. En el Derecho, de ordinario, bien se sabe que no todo es monopólico, o blanco o negro, tal y como tiene lugar en este campo, preferiblemente incluyente, que excluyente, así exista uno que se posicione más, según se indicó.

Así las cosas, claro entonces el sitial asignado a la confianza, en general, recordemos que ella es la base de un apreciable número de instituciones jurídicas, muy especialmente de la contratación privada. Al fin y al cabo, la confianza ocupa un papel estelar en la esfera del contrato, pues en ella descansa parte de su esencia y dinámica, como quiera que sin confianza se pierde la ratio negocial, todo aquello que condujo a los contratantes a celebrar el negocio jurídico (fase de la celebración), y proyectar o esperar su ejecución (fase ejecutiva) e, incluso, según el caso, su leal cesación ${ }^{107}$. De allí que, extraviada o perdida ella, el negocio jurídico se convierte en una carga, en un pesado yunque que, en sana lógica, no debería soportar el sujeto objeto de frustración: el burlado, el afectado.

Desde esta última perspectiva se tiene establecido que quien “...defrauda la confianza contraviene el derecho"108, el que no puede tolerar que tal defraudación

106 Cfr. Antonio Menezes CordeiRo. Tratado de direito civil portugués. Parte general, T. I, pp. 290 y 297, quien incluso le da más fuerza a la confianza legítima que a la propia buena fe. Por eso indica que "La confianza permite un criterio de decisión: un comportamiento no puede ser contrariado cuando ha suscitado la confianza de las personas....La confianza da el criterio a la prohibición del venire contra factum proprium...", el que "...claramente se asienta en la tutela de la confianza".

107 Vid. Pierre-Yves GAUTIER quien corrobora que la confianza "se encuentra presente en todas etapas de la vida de un contrato", especialmente en la etapa de formación, en el que "La confianza legítima ilustra la etapa de la integralidad del consentimiento y de su carácter esclarecedor". Confiance légitime, obligation de loyauté et devoir de cohérence, op. cit., pp. 110 y 111. En esta misma dirección, el Dr. Vladimiro Monsalve Caballero pone de presente, refiriéndose a la ecuación: "Relación precontractual-Relación de confianza", que "La relevancia de la confianza como elemento esencial no sólo del periodo de formación negocial, sino de todo el proceso contractual, está orientada en el propio concepto de buena fe objetiva, reconocida expresamente como norma dirigida a la tutela de la confianza y la lealtad en correlación al otro, con quien primero se entra en relaciones negociales....La confianza es el soporte de cualquier vínculo obligacional que puede regir las conductas humanas, de hecho es el fundamento del derecho de los negocios" Responsabilidad precontractual. La ruptura injustificada de las negociaciones, op. cit., pp. 135 y 144.

108 Gustavo Ordoqui. Reflexiones sobre la buena fe contractual, Academia Nacional de Derecho y Ciencias Sociales de Córdoba, Anales, Córdoba, 2008, p. 369, quien precisa que "Se 
quede impune, o se torne anodina, como si realmente no interesara su quiebre. Por ello bien se dice que la confianza es pilar insustituible sobre el cual se edifica la voluntas, la intentio, el asentimiento, rectamente entendidos, y el acicate para que, ab antique, se tutele de modo especial (fides), y para que en el Derecho contemporáneo legisladores y jueces se encarguen de su celosa protección a través de herramientas y figuras jurídicas de diversa estirpe y naturaleza ${ }^{109}$ siendo una de ellas, sin duda, la consabida doctrina de los actos propios.

No en vano, el profesor BARRos BouRIE refrenda que “... el bien jurídico cautelado por la doctrina de los actos propios es la confianza: el ejercicio del derecho resulta contrario a la buena fe, porque no se condice con su propio comportamiento. Quien hace valer el acto propio del titular del derecho subjetivo no tiene derecho a que éste se comporte de cierta manera, de modo que no se trata de un conflicto entre derechos..."110.

En resumen, así la línea o frontera sea tenue, como ciertamente lo es, el fundamento cardinal de la doctrina de los actos propios, conforme se expresó, estriba en la coherencia (deber de conducta), sin perjuicio del emplazamiento de otros más, y el bien jurídico tutelado por ella, por excelencia, es la confianza legítima. De la preterición del deber de coherencia (prius), como corolario, se sigue

protege la confianza para tutelar la seguridad, la buena fe, en poder creer legítimamente en apariencias tal como se presentan. Con la tutela de la confianza se evitan riesgos y se limita la industria del engaño", lo que explica que "la confianza se ha vuelto el fundamento del contrato en muchos casos cada vez con más evidencia y al proteger la confianza se posibilita un contrato ágil eficiente" (p. 375).

109 En desarrollo de la "buena fe y la concepción solidarista", el profesor Jorge MosSET ITURRASPE, no vacila en afirmar que "El juez moderno tiene una tarea 'cada vez más complicada', pues debe partir de la 'cuidadosa evaluación de los valores e intereses antagónicos que se hallan en juego' y para ello debe percibir con claridad los 'problemas de la sociedad contemporánea'". Interpretación económica de los contratos, Rubinzal-Culzoni, Santa Fe, 1994, p. 190.

110 Enrique Barros Bourie. Tratado de responsabilidad extracontractual, op. cit., p. 637. Cfr. Giovanni CATTANEO, profesor italiano que, con ocasión del escrutinio de la regla venire contra factum proprium, concluyó afirmando que "...el fin perseguido [por ella] es el de tutelar la confianza de la contraparte....." Buona fede obbiettiva e abuso del diritto, op. cit., p. 639. Cfr. Sara TodEsco, al expresar que "...la ratio y el ámbito de aplicación del venire contra factum proprium, como ya se ha dicho, tiende a sancionar una conducta contradictoria, legitimado...., más específicamente, en el principio de la tutela de la confianza". Per una riconstruzione teorico-generale del concetti di abuso del diritto, Padova, 2008, p. 54. 
la conculcación de ésta (posterius) y, de paso, también de la buena fe, sin que por ello medie antinomia, pues entre todas estas expresiones hay una acentuada interdependencia, de tal modo que se influyen recíprocamente ${ }^{111}$.

\section{JUSTIFICACIÓN DE LA PROTECCION BRINDADA Y UTILIDAD GENERAL DE LA DOCTRINA DE LOS ACTOS PROPIOS}

Al lado de la coherencia comportamental, la observancia de la buena fe (en sentido muy general) y el respeto por la confianza legítima suscitada, en lo medular (en sentido más particular), a su turno se erigen en fiable estribo para justificar la especial protección brindada a la parte que, por obra de la conducta contradictoria, e incoherente de la otra, lo perjudica -o puede perjudicar-, y a su turno, contribuirán para darle cimiente a su proscripción o interdicción, independientemente de otros bastiones que igualmente cumplen una decisiva misión, v.gr.: la seguridad jurídica, la apariencia, la razonabilidad, etc., como se anunció. Por ello, seguidamente, hemos estimado aconsejable dedicarle unas líneas más concretas a este significativo tema, en concreto al referido binomio: buena fe y confianza legítima y racional.

En sintonía con ello, expresemos que un segmento importante de la doctrina y de la jurisprudencia se refieren a ambas instituciones (buena fe y confianza legítima), en orden a justificar la prohibición del venire contra factum proprium -en veces en compañía de la apariencia y otras más, se reitera-, así algunos hagan más hincapié en una que en otra, y así sea claro que entre ellas medie una íntima y acerada relación, y que en ocasiones la segunda se englobe o la

\footnotetext{
111 Así sucede, ad exemplum, tratándose de la buena fe y la confianza legítima, y entre la primera y la seguridad jurídica. Por eso Silvia CALMES indica que “...la relación estrecha que liga a la buena fe y la protección de la confianza legítima, parece jugar en dos sentidos". Y que la "buena fe, 'por la vía de la protección de la confianza', es una emanación del principio de seguridad jurídica y también del Estado de derecho", expresando una opinión de HEUER. Du principe de protection de la confiance légitime en droit allemand, communautaire et français, op. cit., pp. 244 y 245.

En este último caso, si la seguridad jurídica propende por el orden y la regularidad, es diáfano que esté imanada por la doctrina de los actos propios, y naturalmente por la regla venire contra factum proprium y, claro está, ligada a una de las facetas de la buena fe, rectamente entendida (seguridad del tráfico jurídico).
} 
engloben en la primera, en sentido lato, o se le asocie, de alguna manera, pues entre todas existen vasos comunicantes, en mayor o menor medida, ya que un divorcio nos parece a todas luces inconsulto, puesto que media una inequívoca vinculación, como tantas veces lo hemos ya expresado ${ }^{112}$.

Lo cierto, es que, una y otra, en estrictez, son materia de quiebre en tratándose del acto incoherente o contradictorio (en forma mediata e inmediata, respectivamente), y sirven también para los fines de ilustrar muy gráficamente el atentado que, en la esfera negocial, se produce con motivo de la materialización de un comportamiento del señalado tenor. En este sentido, hay que reconocer que es la moderna doctrina alemana -y últimamente la portuguesa, la italiana, la francesa, la argentina, la brasilera, la chilena y la colombiana-, la que más se ha ocupado del tema, para la cual la confianza suele ser el valor que se estima más vulnerado por el advenimiento ulterior de la conducta contradictoria, muestra de una incoherencia previa. Eichler, WieAcker, Weber, Sieber, Canaris, Luhmann, ERMAn, Roth y TEUBner, entre otros distinguidos autores más, son una elocuente prueba de la corriente en cuestión. Y en Francia, por vía de ejemplificación, también lo son Mazeaud (D), Fauvarque-Cosson, Houtcieff, Moretau, Aubry (H), etc., así algunos de ellos, igualmente, hagan énfasis en el principio de la coherencia (principe de coherence) ${ }^{113}$, que consideran más general.

112 En el campo jurisprudencial sucede algo muy similar, pues ambas categorías o figuras se entrelazan y hasta retroalimentan. Es el caso de la jurisprudencia española, en particular del Tribunal Supremo, a juicio de quien "La doctrina de los actos propios tiene su fundamento último en la protección de la confianza y en el principio de la buena fe, que impone el deber de coherencia y autolimita la libertad de actuación cuando se han creado expectativas razonables". STS de noviembre 28 de 2000. Otro tanto tiene lugar en relación con lo señalado por el Tribunal Constitucional Español, de acuerdo con el cual, en Sentencia del 21 de abril de 1988, en el plano jurídico, hay una “... imposibilidad de adoptar después un comportamiento contradictorio, lo que encuentra su fundamento último en la protección que objetivamente requiere la confianza que fundadamente se puede haber depositado en el comportamiento ajeno y la regla de la buena fe que impone el deber de coherencia en el comportamiento y limita por ello el ejercicio de los derechos subjetivos".

Por su parte, la Corte Suprema de Justicia colombiana, censurando la conducta que se torne voluble y oscilante, observó que ella "... puede constituir, y suele serlo, un acto contrario a los fundamentos de la buena fe y a la coherencia jurídica exigida a cualquier contratante..." Corte Suprema de Justicia - Sala de Casación Civil. Sentencia de 9 de agosto de 2007. Exp. 00254.01.

113 Véase, al respecto, a Antonio Manuel DA Rocha. Da boa fé no direito civil, quien realiza un panorámico excursus alrededor de la dogmática alemana, en esta temática, realmente elocuente e ilustrativa, op. cit., p. 754. Lo propio a Denis MAZEAUD, "La confiance légitime et 


\section{A juicio del Profesor Díez-PICAzo, quien milita en una tesis que podríamos llamar bifronte, corroborante de lo ya señalado en líneas anteriores, "La buena fe tiene una estrecha relación con la confianza, pues es la raíz última de la}

l'estoppel'. Rapport Française, en 'La confiance légitime et l'estoppel'. Societé de Legislation Comparé, Paris, 2007, p. 247 y ss.; a Pierre-Yves GAUTIER. Confiance légitime, obligation de loyauté et devoir de cohérence, op. cit., p. 111, y a Dimitri HoutciefF. Le principe de cohérence en matiére contractuelle, op. cit., T. I, p. 21 y ss.

En el Derecho argentino, igualmente, "El principio de la confianza legítima ha sido receptado en forma práctica y directa....". Pedro José Coviello, "La confianza legítima”. El Derecho. T. 177. Buenos Aires, p. 911. En el Derecho colombiano, como lo habíamos expresado someramente en otro aparte, este tema ha sido objeto de especial atención por los Derechos constitucional y administrativo. Vid. María José VIANA CleVES. El principio de confianza legítima en el derecho administrativo colombiano. Universidad Externado de Colombia, Bogotá, 2007 y Gabriel Valbuena HeRnÁndez, La defraudación de la confianza legítima, Universidad Externado de Colombia, Bogotá, 2008.

Es de señalar, así sea de modo muy tangencial, que la dogmática no es conteste en asimilar la doctrina de los actos propios y la teoría de la confianza legítima, como quiera que, para algunos, esta es más general, y podría, incluso, cobijar supuestos que la primera no cobijaría, sin que por ello se pueda sostener que no tiene límites y fronteras, tesis que parece contar con el apoyo de la jurisprudencia de la Corte Constitucional, en razón de que en diversos fallos cuando acude a la confianza legítima, lo hace en condiciones aún más globales, ampliando su radio de acción frente al de aquella (doctrina de los actos propios), hasta el punto que, en ocasiones, pareciera que le asigna una misión especial y diferencial, así establezca puntos en común. De hecho, a menudo se confunden una y otra. Vid. Mariana BeRnal FAnDIÑo. El deber de coherencia en el derecho colombiano de los contratos, op. cit, pp. 315 y ss.

Y para otros, ambas, en el más estricto de los sentidos, pueden equipararse en función de su teleología, o porque "....no tienen en el fondo ninguna relevancia práctica, pues en últimas tanto la teoría de los actos propios como el principio de protección de la confianza legítima están orientados a la tutela jurídica del ciudadano cuando con el cambio sorpresivo e inopinado de posiciones precedentes adoptadas....resulten lesionados sus derechos e intereses particulares... Así las cosas, defendemos la tesis en virtud de la cual, el principio de protección de la confianza legítima no es más que una transmutación de la teoría de los actos propios...", Gabriel Valbuena HeRnÁNDEZ, La defraudación de la confianza legítima, op. cit., p. 123, posición compartida, también en sede del Derecho administrativo -en el que se ha difundido con fuerza, se itera-, por el Dr. Felipe DE VIVERo A., autor colombiano quien reconoce que hay autores que niegan "...la cercanía de la teoría de la confianza legítima con la teoría privatista de venire contra factum proprium, en razón de que no es posible alegar que una situación ilegal vincula a la administración de manera que tal que no puede en adelante actuar de manera legal ya que está ligada por el precedente ilegal.... Considero que la aplicación de la confianza legítima en el derecho público es la adecuación de la teoría de los actos propios en este campo". "La protección de la confianza legítima y su aplicación a la contratación estatal", en Revista de Derecho Público, Universidad de los Andes, Bogotá, 2004, p. 123. En contra, Pedro José Coviello. La confianza legítima, op. cit., p. 921. 


\section{expresión fides. Se viola la buena fe si se defrauda la confianza que se puede haber creado"114.}

114 Luís DıEz-PICAzo, Fundamentos de derecho civil patrimonial, op. cit., p. 67. Cabal análisis de la confianza y la buena fe realiza el connotado profesor Don Mariano Alonso Pérez, al reconocer que "La confianza implica protección de una situación diligente en el ámbito negocial: supuesto el deber de actuar honrada y correctamente en el tráfico jurídico, el Derecho debe otorgar amparo a aquellas personas que confiaron, de buena fe y fundadamente, en la honorabilidad ajena al celebrar negocios jurídicos". Traducción y extensas anotaciones y concordancias al Derecho español de la obra El error en la doctrina del negocio jurídico, Vittorino PIETROBON, op. cit., p. 328. En sentido similar, el profesor Karl LARENZ, indica que "El principio de confianza, como base de una 'responsabilidad por confianza', es sólo una entre varias configuraciones de este principio. Está contenido como incluido en el principio de la 'buena fe', donde a su vez ha encontrado una expresión especial en las doctrinas de la 'caducidad' y en la prohibición del 'venire contra factum proprium”'. Metodología de la ciencia del derecho, Ariel, Barcelona, 1994, p. 468.

Amplia referencia española a la fides realiza la profesora Amelia CASTRESANA, en su monografía Fides, bona fides: un concepto para la creación del derecho, Tecnos, Madrid, 1991.

De igual modo, véase el documentado estudio de la Dra. Martha Lucía NemE ViLLAREAL, titulado "Venire contra factum proprium, prohibición de obrar contra los actos propios y protección de la confianza legítima. Tres maneras de llamar a una antigua regla de la buena fe", quien anota que, "... podemos concluir que la buena fe al obligar al respeto de las mencionadas reglas, tutela, a su vez, la confianza suscitada en las partes de que serán observadas las consecuencias jurídicas que se derivan de la conducta adoptada por ellas en curso de la relación negocial, en apego a un deber de coherencia en el actuar y, por ende, preserva la apariencia de un estado jurídico creado por la conducta de una de las partes que determina ulteriores pasos de la contraparte; pues no concilia con la buena fe el que uno de los contratantes actúe de forma tal que contraríe su conducta precedente, desconociendo los actos o aseveraciones que haya realizado, los silencios u omisiones, que hayan hecho creer que actuará de determinada manera, al punto que la contraparte, haya adecuado su conducta contando con ello", en Estudios de derecho civil obligaciones y contratos. Libro homenaje a Fernando Hinestrosa. T. III, Universidad Externado de Colombia, Bogotá, 2003, p. 17.

También es de mencionar posturas más amplias y, de contera, omnicomprensivas, v.gr.: la cabalmente esbozada por el profesor y magistrado de la $\mathrm{H}$. Corte Suprema de Justicia colombiana, Arturo SolARTE Rodríguez, a juicio de quien "En lo relativo a la teoría de los actos propios, debe indicarse que ella se deriva del principio general de la buena fe y corresponde, en general, a una manifestación de la confianza legítima que tiene cualquier sujeto de derecho para esperar un actuar coherente de sus semejantes". "Relevancia jurídica del silencio en la contratación privada", en Estudios de derecho privado, Liber Amicorum en homenaje a César Gómez EstradA, T. II, Universidad del Rosario, Bogotá, 2009, p. 499. Y la adoptada por el profesor de la Universidad Católica de Uruguay, Gustavo OrdoQUI C., a cuyo tenor, la teoría de los actos propios" (...) se funda en la realidad, en la apariencia y en la tutela de la confianza y la buena fe. Se actúa en pos de la seguridad jurídica cuando se da firmeza a la confianza legitimada en una apariencia creada. La parte no puede actuar contra la apariencia creada por ella misma, pues se afectaría la seguridad jurídica y el deber de actuar con transparencia y de buena fe". Buena fe contractual. Ediciones del Foro y Universidad Católica del Uruguay. Montevideo. 2005, p. 231. Igualmente, en la segunda 
En esta última dirección, como bien lo recrea el profesor José María MıQUEL G., varias decisiones del Tribunal Supremo se apoyan en una y otra, dado que "Son muchas las sentencias que relacionan la doctrina de los propios actos con la buena fe y la protección de la confianza.... En la jurisprudencia constitucional la citada STC 21-4-88 afirma acertadamente que aquella doctrina 'encuentra su fundamento último en la protección que objetivamente requiere la confianza que fundadamente se puede haber depositado en el comportamiento ajeno y la regla de la buena fe, que impone deber de coherencia en el comportamiento y limita, por ello, el ejercicio de los derechos subjetivos"'115.

Así las cosas, es diáfano que la doctrina de los actos propios, en asocio de las figuras hermanadas o a ella muy próximas, se justifica porque se erige en un fiable mecanismo enderezado, por una parte, a conjurar la incoherencia $y$, por ende, la floración de contradicciones comportamentales lesivas y, por la otra, a contrarrestar los efectos negativos de su advenimiento, en caso de que no se puedan evitar, resquebrajándose de este modo, consecuentemente, tanto la buena fe, como la confianza legítima, por regla general, aunque la evitación, hay que registrarlo, es uno de sus cometidos neurálgicos. Coherencia, buena fe y confianza legítima, más allá de las matizaciones y de sus particularidades, están indisolublemente ligadas, amén que presentes en la regla venire contra factum proprium.

Esta figura actúa entonces como un benéfico remedio orientado a impedir que la contradicción conductual lesione caros intereses dignos de salvaguarda, concretamente limitando -o impidiendo- el ejercicio de derechos que, aun cuando lícitos, erosionan o pueden lesionar el comportamiento probo a cargo de uno de los extremos de la relación jurídico-negocial que, honorablemente, confío en su cocontratante, sin esperar sorpresas o desengaños ulteriores, en la medida en que la regularidad -o la continuidad- en el comportamiento tienden, en principio, a hacer previsible un resultado favorable, a tono con el fin práctico

edición de la misma obra, Universidad Javeriana y Grupo Editorial Ibáñez, Bogotá, 2012, p. 596 y ss.

115 José María Mıquel González, “Acto propio", en Enciclopedia Jurídica Básica, Civitas, Madrid, p. 204. 
que caracteriza todo contrato ${ }^{116}$. De ahí que empleando una elocuente expresión de Don Mariano Alonso Pérez, la inadmisión del ejercicio del referido derecho por parte de su titular tiene lugar, mutatis mutandis, por “...defraudar injustamente la confianza en la honorabilidad ajena"117, defraudación que no puede tornarse estéril o huérfana de secuelas en el mundo del Derecho, el que debe impedir que quien socava el deber de coherencia en comentario, en perjuicio de otro, pueda obtener réditos a costa de su congénere, nada menos que coparticipe del negocio jurídico celebrado con antelación, el que esperaba respeto, lealtad, solidaridad, cooperación, y no traición o defraudación.

Hay pues en la doctrina de los actos propios un claro carácter preventivo, como se anotó tangencialmente, y también correctivo, en el evento en que se materialice finalmente la contradicción, ese cambio inopinado de comportamiento, constitutivo de erosión a la buena fe, como principio supremo, y a la confianza legítima depositada primigeniamente, materia de resguardo, toda vez que "En su sentido estrictamente técnico, o lógico-formal, hablar de confianza es tanto como referirse, según la etimología de la expresión, a un estado subjetivo (sicológico) de carácter fiduciario y a su protección legal", como claramente lo puntualizó el profesor de la Universidad de Trieste, V. PIETROBon, quien agregó que en la confianza se evidencia un "... principio encaminado a tutelar un estado de fiducia en el hecho jurídico presente o pasado, no en un hecho o en una conducta futura"118, de modo que es menester honrar esa creencia pretérita, base en la que descansó, ab initio, el acuerdo de voluntades otrora celebrado.

Ahora bien, en lo que atañe a la utilidad, íntimamente ligada a la justificación de la figura objeto de escrutinio, es de memorar que la doctrina de los actos propios tiene asignada una tarea esencial en el ordenamiento jurídico, corroborando que

116 Como gráficamente afirma Dimitri HoutcIEFF, "La coherencia... proyecta un futuro previsible....La no contradicción es una condición de la previsibilidad... Ella coloniza un futuro jurídico a manera de prolongación estadística del pasado", Le principe de cohérence en matiére contractuelle, op. cit., pp. 61 y 62.

117 Mariano Alonso Pérez. "Traducción y extensas anotaciones y concordancias al Derecho español" a la obra titulada El error en la doctrina del negocio jurídico, Vittorio PIETROBON, op. cit., p. 163.

118 Vittorino Pietrobon. El error en la doctrina del negocio jurídico, op. cit., pp. 246 y 247. 
se trata de un instituto manifiestamente útil, amén de conveniente y constructivo, encaminado a propender porque la regularidad y la continuidad negociales, en lo posible, no se alteren en forma relevante, esto es en evidente desmedro de los intereses legítimos del otro extremo de la relación, procurando que la asepsia, el fair play y la eticidad imperen a lo largo de la misma, a fin de que no se interrumpa la cadencia y el ritmo contractual, como quiera que el contrato, teleológicamente considerado, no puede ser escenario de frustraciones, ni de comportamientos que traicionen su genuino objetivo, ni menos servir de patente de corso para que se enseñoree la injusticia contractual, so pretexto de que el acuerdo negocial es como el clima: variable u oscilante, en el que de repente llueve a cantaros, hasta inundar cultivos, bosques y praderas, después de soleadas y cálidas jornadas.

Tan útil será esta regla conductual, que cada vez con más frecuencia a ella acuden jueces y doctrinantes para conjurar las perturbaciones y desarreglos producidos por la incoherencia de una de las partes contratantes, e incluso el propio legislador, tanto en el campo nacional, como en el internacional, según daremos cuenta en capítulo separado, precisamente por la abundancia de pronunciamientos existentes, muy acordes con el llamado "renacimiento contemporáneo del nemo potest venire contra factum proprium"119, ya destacado por nosotros en la introducción de este escrito, a la par que por la rehabilitación o resurgimiento del principio de la buena fe, igualmente referido en apartes que anteceden, sobre todo en algunos países, v.gr: Francia, Italia y Brasil, sin perjuicio que en otros ha permanecido vigente y actuante, como ha sucedido en Alemania, España, Argentina, Colombia, etc.

Huelga manifestar, empero, que utilidad no significa infalibilidad, por cuanto si bien es cierto no pueden desconocerse los innúmeros beneficios que de su aplicación emergen, tampoco pueden sobredimensionarse, habida cuenta, de una parte, que no es una pócima mágica y, de la otra, que es un instituto subsidiario que sólo es de recibo en aquellos casos en los que no resulta aplicable otro, de suyo prevalente, según tendremos oportunidad de resaltar con detenimiento cuando nos ocupemos de sus características (Cap. III). Baste por ahora decir

119 Anderson SCHREIBER, A prohibiçao de comportamento contradictório. Tutela da confianca e venire contra factum proprium, op. cit., p. 125. 
que es una figura realmente trascendente, dueña de beneficios insoslayables, que como acontece en la praxis jurídica, debe ser recepcionada con cautela y buen juicio, lo que no le resta utilidad y merecidos aplausos.

En suma, la doctrina de los actos propios se justifica, al mismo tiempo que deviene útil por combatir decidida y frontalmente la incoherencia, el surgimiento de paladinas contradicciones que, por sus connotaciones intrínsecas, resquebrajan la buena fe y, por reflejo, la confianza legítima, entre otros criterios de celosa observancia, ad exemplum, la apariencia, la seguridad jurídica, la razonabilidad, etc. En tal virtud, la doctrina en referencia, prototípica manifestación de la regla venire contra factum proprium, se traduce en inequívoco límite el ejercicio de los derechos subjetivos por parte de su titular, evitando que se mancille el programa contractual, que se contamine su atmósfera, y que se pasee la injusticia negocial.

\section{ANTECEDENTES Y EVOLUCIÓN HISTÓRICA}

\subsection{Preliminares}

Ex professo, hemos reservado el examen histórico y evolutivo en torno a la doctrina de los actos propios para uno de los numerales finales de este primer capítulo, no porque la historia deba ocupar el último de ellos, claro está, sino por cuanto en testimonio de la trascendencia que ella reviste en la ciencia del Derecho, en particular respecto a la temática que detiene nuestra atención, hemos preferido que esté más próximo al cierre de este segmento introductorio, destinado a las generalidades de la doctrina en mención, a fin de que se pueda asimilar mejor, dada la no oculta dificultad que la rodea, manifestación especial de la regla jurídica venire contra factum proprium, hoy en franca y sostenida expansión, como en efecto también acontece con la buena fe, el deber de coherencia, la confianza legítima, el abuso del derecho, entre otras figuras más, estrechamente ligadas entre sí, dueñas de un aquilatado patrimonio común: su historia tuitiva. Por eso, felizmente, todas ellas pueden rastrear sus antecedentes, en mayor o menor medida, sobre todo en relación con el Derecho romano clásico y justinianeo, y ulteriormente en el marco del Derecho medieval (siglos XII y siguientes) y posmedieval (siglos XVI a XIX) primordialmente, en concreto en 
sede de las Escuelas Humanista y Clásica del Derecho Natural y también del movimiento codificador, sin perjuicio de los aportes doctrinales y jurisprudenciales enmarcados en los siglos XX y XXI, en atención a que aún sigue en formación, hecho que revela cómo todos los días, a su manera, continúa haciendo historia. De ahí que no sea un fósil, o un instituto senil, en cuyo caso no realizaremos su autopsia, sino su semblanza vital.

Por consiguiente, a fin de poder asimilar mejor el desenvolvimiento histórico de la doctrina en comento, creímos aconsejable examinar primero sus rasgos y aspectos de mayor significación en la actualidad, para luego centrarnos en su excursus, ciertamente peculiar, como se apreciará, para nada rectilíneo -o monótono-, según lo confirma su propia evolución, entre otros motivos por cuanto en nuestra materia se registraron puntuales avances, vacilaciones, estancamientos y hasta retrocesos, hoy por hoy ilustrativos, toda vez que se ha ido moldeando -y en ocasiones reinventando- a través de centurias, de suerte tal que, en rigor, no podemos decir que ha permanecido incólume y, por ende, intocada desde tiempos inmemoriales, como si fuera una institución absolutamente perfilada -y coagulada-, ni tampoco que no tiene pasado, sino sólo presente y futuro.

\subsection{Derecho Romano}

\subsubsection{Generalidades}

No es inusual asignarle al sapiente Derecho Romano, muy especialmente al de estirpe clásica, justamente por su riqueza y conocido esplendor, la paternidad de esta institución, más por intuición, suposición o creencia, que por razones técnicas y fundadas en todas las hipótesis, a pretexto del empleo de la máxima latina venire contra factum proprium non valet, entre otras de naturaleza muy similar, como si el latín, ciertamente, sólo hubiere sido empleado en el marco del precitado Derecho, stricto sensu, lo cual no sólo sucede frente a este instituto, sino frente a otros, como si todo, o por lo menos gran parte del Derecho, hubiera aflorado en tan fértil periodo, lo cual no es exacto, así nuestra deuda con él sea perenne, como efectivamente lo es. 
Sin embargo, dicha apreciación, por lo menos con un carácter en cierto modo más general, no resulta de recibo, por cuanto en puridad, su examen y planteamiento primigenios, tuvo lugar en sede del Derecho Medieval, así fuera en forma sucinta y algo global, también dueño de luces y significativos logros, en concreto en la afamada Escuela de Bolonia, o Escuela de los Glosadores, que se vistieron de gloria, no sin merecerlo, como quiera que fue el epicentro del denominado renacimiento de la cultura jurídica, en la que germinó la llamada 'segunda vida del derecho romano', aún perceptible, para fortuna nuestra, a la que igualmente le debemos rendir nuevo tributo, por su grandilocuente aporte ${ }^{120}$, perceptible en la actualidad, en virtud que sublimó la esencia romano-clásica. Y sabido es que "...toda la ciencia jurídica occidental no es más que una nota a pie de página al milagro de la jurisprudencia romana”121.

Lo anterior no significa, empero, que en la jurisprudencia clásica romana no se encuentren específicas y dicientes aplicaciones o concreciones de la regla en comentario como era la usanza ${ }^{122}$, en forma individual e inductiva, a la vez que casuística -a partir de la experiencia-, propia del momentum. $Y$ decimos que se encuentran aplicaciones particulares, habida consideración que el Derecho de la civitas, por regla, no fue conceptualista y, por tanto, proclive a las definiciones y estructuración de categorías privativamente abstractas, naturalmente con las excepciones de rigor, no tantas, sin embargo, como para desvirtuar -in radicesu mirada más casuista y, de suyo práctica (casus) alrededor de la temática constitutiva de la jurisprudencia de la época, entendida en su justo y verdadero alcance, o sea como un Derecho de juristas (jurisprudentes), por excelencia, cimentado en la utilitas y en la aequitas, que no puede ser evaluado y menos censurado a través del lente de las escuelas científicas de los siglos XIX y comienzos del XX, principalmente, en las que se arraigó, amén que se asiló la abstracción y la conceptualización, y en las que pretendió dividir el Derecho entre teóricos y prácticos, categorizaciones que, en sí mismas, a manera de antípodas,

\footnotetext{
120 Vid. Carlos Ignacio JaRAmillo J. El renacimiento de la cultura jurídica, op. cit., pp. 6 y ss.

121 Javier PARICIO, El legado jurídico de roma, El Faro Ediciones, Madrid, 2007, p. 21.

122 Vid. Carlos Rogel VIDE, La doctrina de los actos propios, obra conjunta realizada con Marcelo López Mesa, Reus B de F. Buenos Aires. 2005, p. 206.
} 
no se conocieron en el Derecho romano, ni siquiera en la etapa clásica (edad de oro), por lo menos deliberada y conscientemente

${ }^{123}$, sin abrirse entonces paso, como lo memora Aldo SCHIAVONE "...el constructivismo de una 'dogmática' perdida dentro de sí misma, sino un juego de conceptos resuelto por entero por la regla de los casos....."124. Por ello el “... jurista romano", lo confirma Theodor VIEHWEG, "plantea un problema y trata de encontrar argumentos"125.

Como lo ilustra el profesor alemán Fritz Schultz, "En el principio estaba el caso....La hostilidad de los romanos por la abstracción se revela además en la resistencia a fijar conceptos jurídicos...definir no es el fuerte de los juristas romanos.... a la antipatía por los conceptos generales se acompaña la resistencia a la formulación abstracta de normas jurídicas" ${ }^{126}$, lo que no se oponía, de ninguna manera, a la construcción o factura de reglas (regulae), ciertamente comunes en sede del Derecho romano clásico, sobre todo del tardío, tal y como lo atestigua

${ }^{123}$ Ya habíamos dicho en alguna oportunidad que "Se equivocan, en grado superlativo, quienes juzgan el pasado, con la lente del presente, mofándose o escandalizándose de las prácticas de nuestros antepasados... La historia, entendida como un devenir...., no siempre rectilíneo ... demanda respeto temporal y exige, en tal virtud, que se le valore con arreglo al momento experimentado, sin contaminarlo con la entronización de elementos extraños, que no se acompasan con él...". Carlos Ignacio JARAMILLO J. El renacimiento de la cultura jurídica, op. cit., p. X.

124 Aldo Schiavone. La invención del derecho en occidente, AH editora, Buenos Aires, 2009, p. 48 y 290, quien previamente había indicado que "... la permanencia del carácter casuístico del saber jurídico, que rechazaba por un lado la formación del sistema y, por el otro, el recurso regular al paradigma de le lex, estabilizaba definitivamente el intrínseco pluralismo de un mecanismo prescriptivo que, incluso habiendo aprendido a utilizar la potencia de la abstracción, no aceptaba someterse a la fuerza normativa de reglamentaciones universales, sino que requería cada vez -en el examen de cada caso- la renovación del contacto entre orden y vida, entre disciplina y eventos. Aquello que solemos llamar 'derecho romano' es, pues, sobre todo, su creación. Un 'derecho consuetudinario viviente', de estructura casuística, orientado por los expertos".

125 Theodor Vienweg. Tópica y jurisprudencia, Thomson Civitas, Pamplona, 2007, p. 83.

126 Fritz Schultz. Principios del derecho romano, Civitas, Madrid, 1990, pp. 61, 67 y 69.

Por su parte, el reconocido romanista ibérico, Joan MIQUEL, sobre esta misma realidad, precisó que, "El derecho romano, es, ante todo, un derecho de juristas. Ahora bien, la aportación de los grandes juristas clásicos no radica en que hayan elaborado conceptos jurídicos abstractos (....) o que hayan construido un completo y acabado sistema de conceptos jurídicos. Su aportación estriba, ante todo, en el magistral tratamiento del caso 
el Digesto justinianeo, contentivo de un apreciable número de ellas (Libro 50, título 17, de diversis regulis iuris antiqui), entendiendo por "... regla la que describe brevemente cómo es una cosa. No que el derecho derive de la regla, sino que ésta se abstrae del derecho existente. Así, pues, mediante la regla se transmite una breve descripción de las cosas, y, como dice Sabino, es a modo de resumen, que, si falla en algo, resulta inútil”'127.

\subsubsection{Derecho romano clásico. Casuística}

Así aconteció, por vía de reveladora ejemplificación, en tratándose de los siguientes supuestos vertidos en distintos pasajes y libros del Digesto justinianeo, aun cuando no abordados ordenada y sistemáticamente, como se indicó, sino en

concreto y en la seguridad con que resolvían los más complicados casos jurídicos", Historia del Derecho Romano, Madrid, p. 71.

Lo mismo hace el Dr. Fernando ReINoso BARBERo, quien con motivo del análisis de la técnica jurisprudencial en el Derecho romano, culmina su detenido estudio, in extenso, manifestando que, "En conclusión, podemos afirmar que, considerada la obra de la Jurisprudencia romana desde diferentes aspectos y distinciones, la técnica de los prudentes reviste caracteres propios, variados y mudables, como lo es la realidad y la práctica sobre la que trabajan. Siempre inspirados en la realidad, conveniencia y utilidad de las relaciones humanas a las que sirven, tanto su método, como su técnica, como su lógica son particularmente prácticas y vitalmente realistas. Crean y transforman el Derecho, llegando a importantes realizaciones, mediante una minuciosa e incansable elaboración casuística....evitando con sumo tacto la generalización abstracta e irreal....". Los principios generales del derecho en la jurisprudencia del Tribunal Supremo, Dikynson, Madrid, 1987, p. 25. Y el Profesor M. J. García GarRido, toda vez que en el Prólogo del libro del Dr. Reinoso, anteriormente mencionado, pone de relieve que, "Lo que no hicieron los juristas clásicos es aislar el principio del caso y mucho menos generalizarlo" (p. 7). El casus fue entonces el centro de gravedad de su metodología, toda vez que a juicio corroborante del profesor de la Universidad de Salzburgo, Max KASER, “...el nervio de la ciencia clásica del Derecho es la casuística, esto es el estudio exhaustivo y entusiasta del caso. El derecho romano es un derecho de casos". Derecho romano privado, Reus, Madrid, 1982, p. 18.

127 Como observa M. Jesús CASAdo CANDELAS, "...el jurisconsulto romano, apremiado por la urgencia del caso real, daba su responsum, con la solución que le parecía más justa; de estas soluciones se indujeron máximas, conceptos que, vendrían a nutrir el ordenamiento jurídico; de las máximas dedujeron figuras jurídicas que desbordarían el catálogo de tópicos y se convertirían a su vez en figuras de altísima precisión... La esencia del método casuístico romano viene constituida por una técnica de simplificación cuya finalidad consiste en lograr que una suma de resultados se plasme en formas abreviadas que sirvan a su vez para resolver futuros casos". Una introducción al estudio del origen de la jurisprudencia romana, Universidad de Valladolid, 1994, pp. 40 y 42 . Vid. Javier PARICIo y A. FernÁndez BARREIRO. Historia del derecho romano y su recepción europea, Centro de Estudios Ramón Areces, Madrid, 1995, p. 124. 
función de cada caso, lo que explica que estén consignados en disímiles libros -que como se recordará eran cincuenta-, y que se refieran a distintas hipótesis temáticas, sobre todo en el ámbito del Derecho de personas, bienes y contratos.

\section{a) Emancipación:}

"Después de la muerte de su hija que había vivido como madre de familia válidamente emancipada, y falleció dejando heredero instituidos en su testamento, se prohíbe que el padre mueva controversia contra su propio acto, como si no lo hubiese emancipado válidamente y en presencia de testigos...." (D. 1,7.25, ULPIANO.)

Como es sabido, se tiene establecido que en sede del Derecho romano la patria potestad era indicativa de un acentuado y generalizado poder del pater sobre el llamado filiusfamilias. Aunque se ha señalado que era necesario repetir varias veces la mancipatio y la manumisión, en concreto tres veces, a fin de quedare libre de la potestas, "Para las mujeres y para los filiafamilias descendientes de segundo o tercer grado (nietos y biznietos), los juristas consideraron suficientes una única mancipatio y la posterior manumisión", como lo refrenda el profesor Eduardo VOLTERRA, en cuyo caso, lo rememora el catedrático italiano, "El emancipado salía de su familia y perdía toda relación, también sucesoria con ella”128.

Por lo tanto, si se produjo la emancipación por decisión soberana del pater, ${ }^{129}$ este no podía luego de consolidada, desconociendo su actuación previa, en sí misma solemne, ulteriormente pretender, con ocasión del fallecimiento de su

128 Eduardo Volterra. Instituciones de derecho privado, Civitas, Madrid, 1991, p. 110. Cfr. Álvaro D'ors. Derecho privado romano, Eunsa, Pamplona, 1981, p. 221, y C. AccarIAs. Précis de droit romain, Librairie Cotillon, Paris, T. I, 1886, p. 304. Vid. Pelayo De LA RosA DíAz, quien afirma que, "Ante todo hay que señalar que el emancipado devenía sui iuris, es persona de derecho propio". "Reflexiones sobre la emancipatio", en Estudios jurídicos in memoriam del profesor Alfredo Calonge, Vol. I, Asociación Iberoamericana de Derecho Romano, Salamanca, 2002, p. 202.

129 En esta dirección, el romanista Rodolfo Soнm, pone de presente que bien“... puede el padre, espontáneamente, desprenderse del poder paterno por negocio jurídico convirtiendo al hijo en sui juris". Instituciones de derecho romano privado. Antigua Librería Robredo, México, 1951, p. 300. 
hija, que no la hubo y que, por ende, otrora no resultó plena de efectos (adversus factum suum). De ahí que el texto de ULPIANO, con meridiana rotundidad, proscriba la promoción de una "... controversia contra su propio acto", revelándose el inequívoco rechazo a la contradicción ${ }^{130}$, encarnada en el interés de desconocer el acto previo: la emancipación, tildada expresamente de válida en el referido pasaje.

Resulta entonces evidente que tratándose de una actuación realizada válidamente, en aras de la coherencia comportamental, no puede aspirar el sujeto a restarle virtualidad ex post, tanto más cuanto que el primer acto, concerniente a una mujer -y por ello suficiente-, generó unos precisos efectos en derecho: la confianza de haber sido liberada del poder paterno por libérrima decisión, detonante de un cambio relevante en su status y en sus derechos de índole patrimonial, los que no pueden ser borrados, ad libitum, por el respectivo pater, menos después de plurales mutaciones jurídicas, dignas de respeto y salvaguarda.

\section{b) Establecimiento de una servidumbre por parte de algunos condóminos:}

"El derecho de senda y el de paso de ganado a través de un fundo que es de varios, puede concederse separadamente. Así, sólo se hará mío este derecho, en rigor, si lo cedieran todos [los propietarios], y con la cesión del último se confirmarán todas las anteriores. Pero puede decirse, con mayor benignidad, que antes de que el último hubiese cedido el derecho, los que cedieron antes no pueden impedir que use de él" (D. 8.3.11, Celso).

Según lo expresa el profesor de la Universidad de Roma, Vincenzo ArangIORuíz, aludiendo a la tipología inmersa en el fragmento del jurisconsulto CeLso, quien en el mismo título III del libro 8 del Digesto, en asocio de otros togados, se ocupó de diversos aspectos de las servitutes -o jura praediorum-, "Los tipos más antiguos de servidumbre son los iura itinerum (servidumbres de pasaje)

130 Según lo avala Don Luís Diez-PıcAzo, en relación con este tema, "Todo el acento pesa y se hace recaer en la idea de la contradicción ('adversus factum suum'). No puede iniciar la controversia porque, al hacerlo, contradice su conducta anterior". La doctrinas de lo propios actos, op. cit., p. 26. 
y el de acueducto. Entre los primeros es antiquísima la via, nacida quizá de la imitación de muy antiguas convenciones de carácter internacional ajustadas entre las distintas aldeas para permitir al ejército de una atravesar el territorio de otra y trasportada después a los agri ocupados por las vastas posesiones patricias"131.

Al igual que en el supuesto anterior (emancipación), aflora de nuevo el propósito de hacer coherente una o varias conductas anteriores, llamadas a revestir alguna trascendencia real. Así sucede con relación a el carácter impeditivo atribuido a los cedentes, como quiera que, con prescindencia de la adquisición de los derechos de senda y de paso, sujeta a la verificación de una cadena de exigencias sucesivas, quienes a priori individualmente realizaron la cesión no pueden impedir que se haga uso del predio (acción negatoria), pues entrarían en flagrante incoherencia de cara a lo actuado con antelación y, por tanto, su actuación se tornaría incoherente, a la vez que incongruente, pues algún valor, así sea interino, provisional o embrionario, debe dársele a la cesión en cita, fuente generatriz de la confianza legítima y racional radicada en cabeza del interesado, aunque sea insuficiente en sede jurídica es cierto, por faltar aún una manifestación volitiva (meno uno) $)^{132}$.

Por eso, aparte de resaltar su carácter indivisible ${ }^{133}$ y su origen en un acto colectivo ${ }^{134}$, se ha entendido que dicho acto se "forma progresivamente", lo que

131 Vincenzo Arangio Ruiz. Instituciones de derecho romano, Depalma, Buenos Aires, 1973, p. 263.

132 Como lo confirma el profesor Pietro BonfanTE, en estricto Derecho, "Las servidumbres prediales no se pueden constituir por parte (por ejemplo por uno solo de los condóminos), ya que el goce que permiten de la cosa consiste en el ejercicio de facultades de uso, las cuales no se pueden naturalmente dividir". Instituciones de derecho romano, Reus, Madrid, 1979, p. 334. Al fin y al cabo, según se ha subrayado por la romanística, "Una servidumbre no podía ser constituida pro parte", como lo revela Giuseppe Grosso. Le servitu prediali nel diritto romano, Giappichelli Editore, Torino, 1969, p. 152.

133 Vid. Alessandro SACCH. Tratatto teorico-pratico sulle servitú prediale, Unione TipograficoEditrice, Torino, 1902, pp. 36 y ss.

134 Francesco Messineo. Le servitú, Giuffrè, Milano, 1949, p. 96. 
equivale", paralelamente, a la adquisición progresiva (acquisto progressivo) de la servidumbre por parte del titular"135.

Tan cierto será lo anterior, que el citado texto de CELSo refrenda la idea de que el derecho de dominio conoce límites, habida cuenta que la cesión consentida no puede ser soslayada después por los condueños en mención, sin entrar en el campo minado de la contradicción, del quiebre del deber de coherencia, ya apuntado, de lo que se desprende que cualquier rechazo, veda o hecho impeditivo se tornará frustráneo y, de paso, huérfano de conducencia ${ }^{136}$. De ahí que el pasaje, en forma por lo demás expresa, brinde protección prevalente, a fuer que objetiva al cesionario, lo que no es de poca significación, toda vez que refleja el vívido interés protectivo por parte del Derecho romano, aún en el caso en que sea ineficaz la servidumbre, stricto sensu, justamente por faltar un eslabón más, interés igualmente presente en el Derecho contemporáneo, según se constata en legislaciones del siglo XX, como el Código Civil Italiano, lo anticipamos ${ }^{137}$.

135 Francesco Messineo. Le servitú, op. cit., p. 97. En sentido similar, Guiseppe TAmBURINo, refiriendo a este mismo tema, expresa que en su opinión "...se está en presencia de una clásica y típica formación sucesiva", motivo por el cual "...sólo se producen plenos efectos cuando intervenga el último de los elementos constitutivos", de lo que colige que pueden asignarse entonces unos “...efectos prodrómicos”. Le servitú, Unione Tipografico-Editrice Torinese, Torino, 1968, p. 82. Crf. Giuseppe Grosso. Le servitú prediali nel diritto romano, op. cit., p. 153, y Salvatore DI MARzo. Instituzioni di diritto romano, Giuffrè, Milano, 1946, p. 266 , quien alude a la pluralidad de "...actos sucesivos", llamados a trascender, toda vez que se "...prohibió a los condóminos que ya habían consentido de impedir su uso, así faltare la cesión del último de ellos”.

136 Útil es recordar, como lo menciona el profesor Biondo BıONDI, que "Ninguna obligación de constituir una servidumbre existió en el derecho clásico, la que solo era el resultado de la voluntad expresa o tácita de las partes o del disponente", motivo por el cual sí se accedía a ella por la aceptación de un número plural de copropietarios, lo razonable y lo coherente era esperar que la actuación individual no fuera vulnerada luego, precisamente por parte de algunos de ellos. Corso de instituzioni di diritto romano, Siciliana Tipografica, Catania, 1929, p. 343. No sucedía lo mismo, claro está, con el condómino que no expresó su voluntad inicial, pues en este caso, precisamente, faltaría el factum proprium previo.

137 El artículo 1059 del Código Civil italiano, alusivo a las "Servidumbre concedida por uno de los copropietarios", dispone: "La servidumbre concedida por uno de los copropietarios de un fundo indiviso no está constituida sino cuando los otros la han concedido también unida o separadamente. Sin embargo, la concesión hecha por uno de los copropietarios, independientemente de los otros, obliga al concedente y a sus herederos o causahabientes a no poner impedimento al ejercicio del derecho concedido". El artículo 636 del Código Civil Italiano de 1865, igualmente se ocupó de esta misma temática, destacando que los concedentes "...no podían impedir el ejercicio del derecho concedido", así faltare el 
Esta es entonces una elocuente demostración de que en el fondo lo que realmente domina en el asunto escrutado es el afán de proteger la confianza, in futurum, encarnada en la inviabilidad de desconocer un hecho precedente (acto propio) y, de contera vinculante: la cesión en referencia por parte de dos o más propietarios del fundo, todo a partir de la demanda de un comportamiento coherente y leal, el que no se agota en un solo acto u momento sino que se proyecta en el tiempo (coherencia y buena fe sucesivas) ${ }^{138}$.

\section{c) Compra de un fundo ajeno}

"Si hubieras comprado a Ticio un fundo que era de Sempronio; te lo hubieran entregado, una vez pagado el precio; luego Ticio hubiera heredado de Sempronio y hubiera vendido y entregado ese mismo fundo a Mevio, dice Juliano que es lo más justo que el pretor te defienda [con una excepción de dolo], pues, si el mismo Ticio te reclamara el fundo, sería rechazado mediante una excepción redactada por el hecho o la del dolo malo, y si, poseyendo el fundo Ticio, se lo reclamara con la [acción] Publiciana, podrás servirte de una réplica contra la excepción de 'a no ser que sea propietario del demandado', de suerte que se entiende que había vuelto a vender un fundo que ya no tenía en su patrimonio" (D. 44,4.32, PomPonio).

asentimiento de uno de los condóminos. Vid. Matteo GaLDI. Delle servitú prediali, Unione Tipografico-Editrice Torinese, Torino, 1915, pp. 329 y ss.

Por su parte, como se mencionará en aparte especial de este excursus histórico, el Código Civil español en su artículo 597, también se ocupa del mismo tema.

138 Como lo refrenda Don Luís Diez-PICAzo "Ejercitar la acción negatoria después de haber consentido la constitución de la servidumbre es venir contra acto propio. Sería contrario a la equidad y el ordenamiento jurídico que no permite contradecirse; no es, dice PARDESSUS 'admisible atacar su propio hecho". La doctrina de los propios actos, op. cit., p. 32. Cfr. María Victoria SANSÓn RodRíguez. "La buena fe en el ejercicio de los derechos", en II ruolo della buona fede oggetiva nell'esperienza giuridica storica e contemporanea, Vol. III, Cedam, Milani, 2003, p. 336, autora que indica cómo es procedente la defensa del comprador ".... siempre que...haya pagado el precio, porque es inadmisible intentar la evicción de una cosa enajenada por uno mismo (D.21.2, 17, conducta contradictoria), la consecuencia es la convalidación pretoria.....Hay una previa relación de compraventa de la que surgió una obligación de entregar, y de responder por la evicción con la rei vindicatio el vendedor se pone en contradicción con ellas". 
En un todo de acuerdo con el citado texto de POMPONIO, es diáfano que en el Derecho romano, tuitivo por regla, de nuevo se brinda especial y definida protección al comprador de buena fe, con total prescindencia de la validez del acto primigenio, en cuyo caso se le protege con el reconocimiento de una excepción de dolo para preservar sus intereses, objeto de clara vulneración si le permitiere al vendedor (Ticio), que luego de adquirido el dominio de manos de Sempronio, pretendiera reclamar -reivindicar-el bien por él vendido con antelación, en franca contradicción comportamental, como quiera que estaría desconociendo su acto propio (factum proprium), por lo demás en perjuicio ajeno, en actitud rayana en la incoherencia ${ }^{139}$. ¿Como entonces conciliar la venta u acto originario y el reclamo posterior del fundo por parte del mismo sujeto? Ello explica la expresa concesión de una efectiva excepción llamada a defender al comprador, que se vio ex post sorprendido con el reclamo formulado por su vendedor, quien oportunamente pagó su precio, según relato del mismo PoMPONIO.

\section{d) Alteración perjudicial del comportamiento previamente observado}

"Nadie puede cambiar su voluntad en perjuicio ajeno". (D. 50, 17, 75, POMPONIO).

Prima facie, este pasaje de PomPonio, afamado exponente del clásico tardío, pareciera ser el equivalente al venire contra factum proprium non valet medieval, o a las demás expresiones similares empleadas en el medioevo. Tanto que su sólo enunciado en latín, ciertamente es diciente: nemo potest mutare consilium suum in alterius injurie, el que podría pensarse que hunde sus raíces en el

139 Se discute si en el Derecho romano era posible la apellidada venta de cosa ajena (venditio rei alienae), aunque la comunnis opinio se inclina por entenderla válida, a partir del hecho de que la compraventa, en sí, no era transmisora del derecho de dominio, de tal modo que se generaba simplemente la obligación de entregar la cosa en cabeza del vendedor, “... siendo indiferente que ésta sea suya o de otro", conforme lo puntualiza Ramón BADENES GASSET en el marco del Derecho romano. El contrato de compraventa, T. I, Bosch Editor, Barcelona, 1995, p. 131. En este sentido, el propio ULPIANo no vaciló en aseverar que "No hay duda que puede enajenarse una cosa ajena, porque hay en este caso compraventa pero la cosa puede ser quitada al comprador" (D. 18.1, 28). Cfr. Federico FERNÁNDEZ De BuJAN. Sistema contractual romano, Dykinson, Madrid, 2007, p. 175, y L. GuILLouARD. Traité sur la vente et d'échange, A Pedone, Paris, 1982, p. 198, cit. Mario CASTILlo FreYRe, La venta de bien ajeno, Ediciones Caballero Bustamante, Lima, 2010, p. 77. 
inequívoco deseo de formular una regla general, de aplicación indiscutida, amén de generalizada. Sin embargo, en puridad, con las excepciones que deben ser registradas, sabemos que los jurisconsultos romanos no eran proclives a la generalización y a la dogmática, según tuvimos ocasión de resaltar al comienzo de este numeral, tanto más cuanto que, en ocasiones estaba autorizado, o por lo menos no era objeto de reproche "...mudar de parecer" 140 . Por ello no le falta razón a Don Luís Diez-PıcAzo cuando asevera que su inclusión “...dentro de la recopilación de 'regulae iuris' que cierra el Digesto justinianeo, nos ha sido transmitido en... escueta formulación...., lo que le da un tono de generalidad que no es probable que en su origen tuviera. Cabe pensar que seguramente fue una razón dada por el jurisconsulto para resolver alguna cuestión concreta, como lo prueba el hecho de que el texto proceda del 'Libro Tertio Quastionum' del propio Papiniano. Aun así, ¿cuándo puede decirse que hay una mutación de consejo e injuria de otro? Es muy difícil aclarar el sentido de este texto", lo agrega el maestro con realismo, luego de haber hecho un recorrido por diversos pasajes del mismo jurisperito, que "En el pensamiento de PAPINIANo la regla de la inadmisibilidad del 'mutare consilium' no tiene, sin embargo, alcance general”'141.

$\overline{140}$ Es el propio PAPINIANO el que expresamente señaló que "Algunas veces, el pretor no rechaza al que muda de parecer, y no se desprecia la opinión del que varía en ella” (D. 37, 6.8).

141 Luís Diez-PICAZo. La doctrina de los propios actos, op. cit., p. 37. En sentido similar, la autora Laura GUTIERREZ-MASSON expresa de esta regla "nemo potest mutare consilium suum in alterius iniuriam, en cuyo enunciado pueden destacarse dos aspectos, uno formal como es la vaguedad y abstracción en claro contraste con la concreción y el casuismo de los juristas romanos y otro el material cual es de su vinculación al famoso precepto ulpianeo informador del entero ordenamiento romano alterum non laedere". Dicha autora, a su turno, con motivo del examen de la referida regla de autoría de PAPINIANo, la que entiende como basamento que le sirvió a "...glosadores como Azón para dar vida al brocardo voluntatem mutare non permittitur o como AccuRsio a adversum factum suum quis venire non potest", estima que no puede ser asimilada, per se, a aquella que se enuncia como "Nadie puede ir contra sus propios actos", puesto que la "... regulae papinianea y el principio actual presentan una notable diferencia en su enunciado: mientras que éste último sólo evidencia, lo que podríamos calificar de elemento objetivo, el mutare consilium o incongruencia con el acto anterior, la primera exige otro elemento tipificador, la alterius iniuria que en unos casos será de índole subjetiva cuando obedece a un animus iniuriandi o nocendi...." "Actos propios y buena fe. En torno a Papiniano 3 Quasestionum D. 50, 17, 25" (sic), en II ruolo della buona fede oggetiva nell'esperienza giuridica storica e contemporanea, Vol. III, Cedam, Milani, 2003, pp. 274 y 275. Cfr. Hernán CORRAL TALCIANI, "La raíz histórica del adagio 'venire contra factum proprium non valet'”, en Venire contra factum proprium, Universidad de los Andes, Santiago, 2010, p. 22. 


\subsubsection{Recapitulación}

A manera de recapitulación, en el Derecho romano clásico militan diferentes textos que corroboran la conclusión encaminada a rechazar la incoherencia, la contradicción y la incongruencia comportamentales. De ello, en efecto, dan fe los cuatro pasajes anteriormente referidos, cuya exégesis podemos resumir así:

En el primer pasaje, alusivo a la emancipación (D. 1,7.25, ULPIANO), se tiene establecido que el padre, bajo prohibición, no podía promover una acción luego de emancipada su hija, como quiera que ello, frontalmente, iría contra un acto anterior: “....su propio acto", esencia de la institución, toda vez que si ha permitido - de una u otra manera- que ella fuera tratada como sui juris, posteriormente no estaba legitimado para desconocer dicho status, a sabiendas de ello, de tal suerte que el testamento permanecería intocado.

En el segundo pasaje (D. 8.3.11, CELSO), por su parte, se evidencia que, en el terreno de la servidumbre constituida por condóminos, no se permitía que se afectare el derecho de senda por parte de los propietarios que, previamente, cedieron tal derecho a una persona, así aún no pudiera hablarse de un derecho pleno e integral. De allí que el acto contrario y ulterior de quienes separadamente lo confirieron en su oportunidad, no haya sido de recibo, justamente por las mismas consideraciones, lo que explica que no podían "....impedir que se use de él". Dicho de otro modo, los copropietarios debían respetar su voluntas previa, así no lo quisieran después.

En el tercer pasaje, (D. 44,4.32, PoMPONIO), a su turno, relativo a la adquisición posterior de la cosa vendida por parte del que la ha vendido con antelación, sin que para el momento de la venta fuera su verdadero propietario -operación ésta que, de acuerdo con este específico texto, para algunos, ciertamente no muchos, no estaba permitida a la sazón-, se observa un claro rechazo a quien pretende valerse de este hecho, en perjuicio ajeno, lo que justifica que la 'acción de dominio', en tales condiciones, no se abriera paso, por cuanto la actuación posterior: la reivindicación de la cosa vendida, lato sensu, reñiría abiertamente con la venta previa, más allá de su validez, en clara contradicción con su propio acto, realizado ex ante: el de la venta. Por ello, aspirar a que se devolviera el bien, 
por el que incluso se había "...pagado el precio", pretextando que inicialmente no era el dueño, no fue tolerado, y con sobrada razón, en franca sintonía con justicieros principios refractarios al quiebre de la fides, en dos de sus vertientes (constancia y confianza).

En el cuarto pasaje (D. 50,17,75, PomPoNIO), finalmente, sólo para referirnos a unos cuantos ejemplos ${ }^{142}$, el célebre jurista PoMPONIO, uno de los más reputados jurisprudentes del esplendente Derecho romano clásico, de modo más general, refiere a la conocida expresión, conforme a la cual: "Nadie puede cambiar su voluntad en perjuicio ajeno" ("Nemo potest mutare consilium suum in alterius injurie"), con el tiempo, elevada a una especie de canon romano, de suyo indicativo de uno de los aspectos nucleares de la doctrina sub examine: el cambio lesivo de actitud; la presencia de un comportamiento mutante en el marco de la relación jurídica, referido a la voluntas del actor -o emisor-, sin por ello erigirse, como se anotó, en equivalente de la regla venire contra factum proprium non valet, pero si en un antecedente suyo de importancia. Empero, como también mencionamos, hay que advertir, en aras de evitar equívocos, que esta regla romana no tuvo un carácter general, absoluto e irrestricto, como suele creerse en esta materia, hasta el punto que se cita como primordial, en ocasiones, como único fundamento histórico de la misma, lo que no es pertinente, en razón de que fue exceptuado, a través de otro diciente postulado, también del propio PAPINIANO, a cuyo tenor:

142 Según lo hemos expresado son numerosos los textos clásicos alusivos, in concreto, al rechazo de la incoherencia conductual, así no aludan a la fórmula medieval ya mencionada (venire). En adición a los mencionados con anticipación, sólo por vía de ejemplo, vale la pena traer a colación un emblemático pasaje de ULPIANO, indicativo de la protección o tutela de derechos ajenos brindada, gracias a la confianza suscitada, en sentido lato, a cuyo tenor "...si un acreedor hubiera cobrado intereses futuros y reclama la cantidad prestada, a pesar de ello, antes de haber transcurrido el plazo cuyos intereses cobró, podrá ser rechazado por la excepción de dolo..., ya que, al cobrar los intereses, se entiende que ha aplazado la reclamación para después del plazo de los intereses pagados, y que ha convenido no reclamar entre tanto", solución que claramente persigue salvaguardar las prerrogativas del deudor sorprendido por un mutare del acreedor, quien por un lado cobra intereses futuros y, por el otro, exige de inmediato la cantidad prestada, en ostensible contradicción, detonante lógico del rechazo de la pretensión que autoriza el Derecho romano en ese caso, y que para tornarla ex iure coherente con el factum proprium, parte del supuesto de que se ha "...convenido no reclamar entre tanto". Lo mismo tiene lugar, a juicio de Emilio BETTI -quien en este aspecto sigue a RIEZLER-, en relación con el pasaje consignado en el Digesto, atribuido al renombrado jurisconsulto JULIANO: D. 12, 1, 19.1, una específica manifestación de la regla conocida luego como venire contra factum proprium. Istituzioni de diritto romano, Vol II, Padova Cedam, 1960, p. 110. 
"Algunas veces, el pretor no rechaza al que muda de parecer, y no se desprecia la opinión del que varía en ella" (D. $37,6.8)$.

\subsubsection{Derecho romano posclásico. Casuística}

Por su parte, en el Derecho posclásico, específicamente en sede del Derecho justinianeo propiamente dicho, claramente se constata un recelo y desconfianza referida al cambio inopinado de parecer, no con un carácter absoluto o general, sino individual, a tono con la anunciada casuística romana, a menudo apreciable en la esfera contractual, en donde los contratantes, en consideración a la fuerza vinculante emergente del contrato y demás manifestaciones con virtualidad obligacional ("actus, negotium, conventio, contractus", etc.), resultaban ligados entre si $^{143}$, de tal suerte que debían honrar lo pactado y acatar lo convenido, en cuyo caso, si no lo hacían, estaban contrariando lo acordado primigeniamente y, de paso, tornándose incoherentes.

En esta dirección, entre varios, se enruta una constitución imperial de autoría del Emperador JUSTINIANO, conforme a la cual "Si alguno al otorgar un instrumento hubiere declarado que no usaría de la excepción de fuero por razón de su grado militar ó de su dignidad, ó aún de las prerrogativas de su sacerdocio, aunque antes se dudaba, si convendría que tuviera validez esta escritura, y si no debía el que pactó esto volverse contra su propio convenio, ó si se le debía facultar para apartarse de la escritura, y usar de su fuero; mandamos que a nadie le sea lícito ir contra sus pactos y a engañar a los que con él contrataron” "“...adversum suam conventione venire...; sancimus, nemini liceri adversum pacta sua venire et contrahentes decipere") $)^{144}$, mandamiento este del que se derrama elocuencia, justamente por su mensaje tan penetrante y preciso, en el sentido de rechazar el desconocimiento de lo pactado en precedencia, de nuevo como testimonio de la relevancia de lo realizado con antelación (respeto al pasado jurídico).

143 Vid. Alejandro GuzMÁn BRITo. "El vocabulario de la negocialidad jurídica en el derecho romano", en Acto, negocio, contrato y causa en la tradición del derecho europeo e iberoamericano, Thomson- Aranzadi, Pamplona, 2005, pp. 17 y ss.

144 Codex, II, III, 29. 
Otra elocuente Constitución bizantina inmersa en el Codex justinianeo, dispuso que "Así como en un principio tiene cada cual libre facultad para celebrar o no celebrar un contrato, así también nadie puede renunciar a una obligación una vez ya constituida, no consintiéndolo el adversario. Por lo cual debéis tener entendido, que, una vez sujetos vosotros a una obligación voluntaria, no podéis en manera ninguna separaros de ella, no consintiéndolo la otra parte, de la que hicisteis mención en las súplicas" (C. IV, X, 5), texto que corrobora lo ya señalado, y que servirá de preludio a concepciones más arraigadas y generalizadas en el Derecho medieval y en el Derecho revolucionario francés, defensores del pacta sunt servanda, finalmente incardinado en el art. 1134 del Código de Napoleón y en los códigos por él influenciados. ${ }^{145}$

En gran compendio, el Derecho romano, como se evidenció, si conoció diversas manifestaciones de lo que, siglos después, se conocería mediante el brocardo medieval "venire contra factum proprium", que no es propiamente romano-clásico, ni romano-bárbaro, ni romano-justinianeo, aun cuando no con un carácter general, y algo más abstracto, razón por la cual no se le puede adjudicar, como sucede con alguna frecuencia por las razones antedichas, lo que no quiere significar que en Roma tuviera cabida la contradicción, la incoherencia, la vulneración de la confianza legítima y razonable y, en fin, la ausencia de bona fides. Muy por el contrario, en forma por lo demás categórica, queda absolutamente diáfano que en el Derecho romano no se admitió el quebranto del factum proprium, ni la incoherencia, ni la transgresión del postulado de la no contradicción, entre otras manifestaciones de la misma idea: el rechazo, por regla, del comportamiento voluble, cambiante, sinuoso, contradictorio e inconsonante, así no haya sido elevado este parecer a regulae, o a principio jurídico expreso, lo que no le resta entidad, pues se puede extraer de numerosos textos que, a las claras, condenan proceder tan lesivo, y que sirvieron de estribo para que siglos después, en sede de la célebre Escuela de Bolonia, se le diera un alcance más general al rechazo

145 En las Institutas de JUSTINIANO, por su parte, también encontramos algunos pasajes que dan cuenta de la valía de atenerse a lo pactado o convenido primigeniamente, manifestación de coherencia contractual, en concreto conductual. Es el caso de lo señalado en relación con las 'estipulaciones condicionales', conforme a las cuales "El que ha estipulado que se le dará una cosa tal año o en tal mes, no puede pedirla regularmente hasta que hayan transcurrido todas las partes del año o del mes" (Inst. III, XXVI, 26), por cuanto si lo hace, en efecto, estaría contrariando lo acordado ex ante, en prueba, además, de patente incoherencia. 
conductual en comentario, lo que no implica restarle su inescindible conexión histórica con el Derecho romano clásico, en su ulterior formulación justinianea, dado que como acertadamente lo destacó don Luís Diez-PICAZo, “...lo que no puede negarse, ni ponerse en duda, es que la regla que estudiamos tiene en el Derecho Romano sus últimas y más profundas raíces, esto es, que, aunque haya asido formulada en el Derecho intermedio, esta formulación se produce como generalización de una serie de soluciones y de decisiones romanas"146.

\subsection{Derecho medieval}

\subsubsection{Preliminares}

Ahora bien, en lo que toca con el Derecho medieval, sin duda de marcada valía en la consolidación y afianzamiento de la cultura jurídica occidental, es de señalar anticipadamente que la temática alusiva al rechazo o inadmisión de la conducta incoherente y contradictoria, entre otras manifestaciones adicionales, tuvo un desarrollo más sistemático, e incluso más dogmático (ex cathedra), como quiera que, sin perjuicio de anidarse en supuestos concretos, propios de la examinada metodología romana, hicieron un ejercicio similar al realizado por algunos jurisconsultos del periodo clásico, registrado en el referido libro cincuenta del Digesto justinianeo ("reglas del Derecho antiguo", Tít. XVII), para lo cual extraían su esencia y la vertían en brocardos, summas, glosas, etc., ${ }^{147}$ de ordinario con un carácter más envolvente $y$, de suyo general.

${ }_{146}$ Luís Diez-PICAzo, La doctrina de los propios actos, op. cit., p. 22.

147 Como bien se ha expresado, "...los autores medievales no se limitaron a reproducir en sus obras las reglas jurídicas contenidas en el Corpus luris, sino que ellos mismos, en su glosas y comentarios, formularon nuevos aforismos o brocardos, en muchos casos resumiendo en frases lapidarias el espíritu de los textos de la Compilación de JustinIANO, o formulando de manera más concisa algunas de las reglas que esta contenía". Fernando Gómez Carbajo. Regulae luris, en Textos de derecho romano, Coordinador Rafael Domingo, Aranzadi, Pamplona, 2002, p. 302. 


\subsubsection{Escuela de los Glosadores}

Ello fue lo que aconteció, en particular, en la mencionada Escuela de los Glosadores, llamada así por el empleo habitual y prevalente de la glosa (siglos XI-XIII, D. de C.), en la que se evidenció una animadversión frente a determinadas conductas indicativas de contradicción, lo cual se hizo en desarrollo de varios brocardos, en especial el identificado con la expresión venire contra factum proprium nulli conceditur, la que no es entonces hija del Derecho romano, sino del medieval, conforme se acotó en precedencia ${ }^{148}$, tributario del legado de Roma y Constantinopla, en lo pertinente, habida cuenta que los miembros de la Escuela boloñesa de IRNERIO bebieron de las aguas romanas, muy especialmente las vertidas en el Digesto, considerado por ellos, como el hipertexto, signado por ser una mole de sapiencia, o como "depósito sapiencial"149. De ahí que alrededor de los pasajes ya examinados por nosotros de ULPIANO y CELSO, preponderantemente (1.7.25, y 8.3.11, en su orden), insignes glosadores como Azzo y Accursıo les dieron carta de ciudadanía y comenzaron a ser explicados con algún detalle, contrastándolos con aquellos actos propios que no herían de muerte la regla de la coherencia y que por tanto no estaban proscritos, para lo cual recurrieron a complejas distinciones. Como muy bien lo sintetiza MotA PINTO, con ocasión del examen histórico del venire contra factum proprium “... fue a partir de los boloñeses que el principio arribó, para no salir más". ${ }^{150}$

En lo que atañe a Azzo-Azon o Azonis-, por de pronto el primero en ocuparse del tema, es inobjetable que expresamente a él se refirió en el siglo XIII. Y lo hizo no de una, si no de tres maneras. En primer lugar a través de la expresión "VENIRE CONTRA PROPRIUM factum nulli conceditur"-parte en mayúsculas, y parte en minúsculas-; la segunda Venire contra factum proprium nulli...., y la tercera con la inclusión de un giro, mediante las palabras "non licet mihi venire

148 Cfr. Francesco Astone. Venire contra factum proprium, op. cit., p. 75, y Laura GutIerrezMasson. Actos propios y buena fe. En torno a Papiniano 3 Quasestionum D. 50, 17, 25 (sic), op. cit., p. 22.

149 Vid. Paolo Grossı. El orden jurídico medieval, Marcial Pons, Madrid, 1996, p. 164.

150 Paulo MotA PINTO. "Sobre a prohibiçao do comportamento contraditório (venire contra factum proprium) no direito civil", en Boletim da Facultade de Direito, Coimbra, 2003, op. cit., p. 278. Cfr. Francesco Astone. Venire contra factum proprium, op. cit., p. 75. 
contra factum", manantial del término venire contra factum proprium non licet, más socorrido ${ }^{151}$.

También sucede lo mismo con AccuRsıo, afamado glosador, quien a emulación de las memoradas regulae iuris consignadas en el Digesto justinianeo, signadas por su precisión y concreción (brevis rerum narratio), como se observó, acuñó la máxima: adversus factum suum quis venire potest, en función de específicos pasajes romanos consignados en el Digesto, como ya lo había hecho Azzo en su obra Brocardica Aurea, en la que se ocupó de precisar, amén que de justificar, cuando era permitido volver contra los actos propios, y cuando, por el contrario, no lo era, traduciéndose en acto ilegítimo el proceder cuestionado ${ }^{152}$.

\subsubsection{Escuela de los Comentaristas}

A su turno, en la esfera del apellidado mos italicus, juristas de la importancia y erudición del gran Bartolo DE SAXOFERRATO, y Baldo DE UBALDIS, ambos militantes de la reputada Escuela de los Comentaristas -o 'posglosadores', denominación poco feliz-, también examinaron esta temática, desarrollándola algo más, como era característico de los comentarios, nervio de la escuela y, de ordinario, objeto de mayor y refinado análisis ${ }^{153}$. Por eso se estimó, especialmente por el primero -y brillante magister y lucerna iuris- que resultaba inadmisible volver contra los actos propios, consignando ciertas excepciones orientadas a su validación (contra legem). En este sentido, comentando el texto del Digesto 1.7.25, Bartolo anotó: Pater contra emancipationem e se factam et diuturnitatem temporis robatorum venire non potest. Nota quod quis contra factum suum venire non potest"154. Y Baldo, a su vez, acudió a diversas locuciones y frases para reiterar la misma idea enderezada al rechazo a la contradicción (regla más general), también con

151 Azonis. Brocardica aurea. D. Azonis Bononiensis Antiquorum luris Consultorum, Neapolis, 1568, pp. 33 y 34.

152 Accursio, Factum suum, D.1.7.25, en Corpus iuris civilis iustinianei, cum comentariis Accursi, T. I (Digestum Vetus), 1627.

153 Cfr. Federico PRocchI. L'Exeptio doli generalis e il devieto di venire contra factum proprium, op. cit., p. 90.

154 Bartolo De Saxoferrato. In primam veteris partem. Vid. Enrico Deli'Aquila. La correteza nel diritto privato, op. cit., p. 112. 
excepciones, para lo cual se evaluaba si se trataba de actos contra legem, preater legem, ipso jure, etc. ${ }^{155}$.

\subsubsection{Escuela de los Canonistas}

Del mismo modo, en lo que a la fértil Escuela de los Canonistas se refiere, es útil memorar que sus representantes igualmente se preocuparon por el reproche conciente y deliberado de la contradicción comportamental, tanto más cuanto una de las notas que estereotiparon a esta escuela jurídica en el medioevo, estribó en el respeto por la palabra empeñada, por la regularidad y por la sublimación de la buena $\mathrm{fe}^{156}$. De ahí que en algunos textos de la época se expresara que “... nemo potest venire contra factum suum", expresión ésta a menudo empleada por la doctrina contemporánea, en ocasiones con una ligera variable (nemo potest venire contra factum proprium) ${ }^{157}$.

\subsubsection{Derecho histórico español}

Antes de culminar este somera recorrido medieval, resulta de la mayor trascendencia mencionar un texto de las Siete Partidas (Siglo XIII), que no es muy conocido, ni menos difundido por los estudiosos de la regla del venire, aun cuando en esta temática reviste acentuada importancia, habida cuenta que se ocupa de la admisión e inadmisión de la contradicción, refiriéndose a ella textualmente por su nombre, lo que no deja de tener especial significado. Al respecto, inspirada en el comentado pasaje de CELso, inmerso en el Digesto justinianeo (D.8.3.11),

155 Vid. BALDo Ubaldi. Digesti veteris partem Commentaria, L. XXVI, Venetiis, M.D. LXXVII, p. 70.

156 Cfr. Federico PROCCHI, autor que explicita cómo "Un juicio adverso respecto al comportamiento contradictorio estuvo presente en la tradición del derecho canónico, al igual que sirvió como razón inspiradora de máximas de alcance general". L'Exeptio doli generalis e il devieto di venire contra factum proprium, op. cit., p. 88.

157 Ostiense, In secundum Decretalium librum Commentaria, cit, Enrico Dell’Aquila. La correteza en el diritto privato, op. cit., p. 115. Vid. Anderson ScHReIBER. A prohibiçao de comportamento contradictório, Tutela da confiança e venire contra factum proprium, op. cit., p. 27, Antonio Menezes Cordero. Tratado de direito civil portugues, T. I, op. cit., p. 277, y María Fernanda EKDAHL E. La doctrina de los actos propios. El deber jurídico de no contrariar conductas propias pasadas, op. cit., p. 130. 
la Partida Tercera, Título 31, Ley 10, reza: "Los señores de los edificios, e de las heredades, pueden poner cada uno de ellos, servidumbre a su edificio o a su heredad. Pero si muchos fueren señores de un edificio, o de una heredad, a que quieran poner servidumbre, todos la deben otorgar cuando la ponen. E si por ventura la otorgasen algunos, e non todos, aquellos que la pusieron non la pueden después contrastar, que la non haya aquel a quien la otorgaron. Mas los otros que la non quisieron otorgar, bien la pueden contradecir cada uno de ellos también por la su parte como por la de los otros que no la otorgaron".

\subsection{Derecho moderno}

\subsubsection{Preliminares}

Examinados los rasgos más definitorios de la regla que examinamos en el apellidado Derecho medieval, luce aconsejable pasarle revista en la etapa conocida con la expresión moderna, más para facilitar un análisis didáctico, que por entender que las anteriores, stricto sensu, no exhibieron rasgos modernos, pues es una realidad incontrastable que la 'modernidad', bien comprendida, se ha enseñoreado en diversos estadios de la historia de la humanidad, y no solamente a partir del siglo $\mathrm{XVI}$, como vanamente algunos lo han pretendido. Nada más expresivo de este parecer, es cierto, que el título y el contenido de una de las obras del recordado profesor de la Universidad de Bolonia, Andrea PaDovanI: Modernitá degli antichii ${ }^{158}$. De ahí que con esta salvedad la empleemos, con el propósito de arropar hitos de especial significado, tales como la floración de las denominadas Escuelas humanista y clásica de Derecho natural, al igual que el Derecho previo a la revolución francesa, muy ligado a ésta, de suerte que el breve estudio de lo acontecido en el proceso codificador del siglo XIX, se realizará en el marco de la apellidada 'Edad contemporánea', también por razones pedagógicas, o si prefiere esquemáticas, denominación esta tampoco exenta de críticas.

$\overline{158}$ Andrea Padovanı. Modernitá degli antiqui, Bononia University Press, Bolonia, 2006. 


\subsubsection{Escuelas Humanista y Clásica del Derecho Natural}

A diferencia de lo que sucedió con las escuelas medievales, signadas por su proximidad a los textos romanos justinianeos objeto de sistemáticas glosas y comentarios, muy especialmente respecto de los Glosadores, los militantes de la Escuela Humanista, de un lado, y los de las Escuela Clásica del Derecho Natural, del otro, no siguieron tan estrechamente el legado romano, menos el aportado por Glosadores y Comentaristas, ${ }^{159}$ a quienes en el llamado esplendor renacentista se les cuestionó acerba y desconsideradamente, de tal suerte que se puede aludir a una especie de rompimiento no sólo ideológico, sino también metodológico y teleológico ${ }^{160}$. De hecho, se abogaba por una lectura más pura del Derecho romano clásico, por manera que su visión histórica trascendió el Derecho justinianeo, en sí mismo considerado, remontándose a la antigüedad ${ }^{161}$, con un espíritu más crítico, abierto y racionalista, en general, como fue característico del siglo XVI'162, y del 'humanismo jurídico', in globo ${ }^{163}$. Ello explica que, a la sazón, no

159 Como lo enfatiza el profesor Pablo KoSCHAKER, aludiendo al valor conferido a la compilación justinianea por las escuelas medievales, en especial por la escuela de los Glosadores, según se expresó, "...como libro autoritario y casi sagrado, fue, valga la expresión, secuestrado por los juristas e interpretado con ciega sumisión a la autoridad que de él irradiaba y con criterio típicamente medieval. Para los humanistas, en cambio, el corpus iuris no fue otra cosa que una manifestación del antiguo espíritu de Roma, no una colección de mandatos y prohibiciones que postulaban vigencia inmediata y que debían ser interpretados con un sentido actual y vivo...Para éstos, el corpus iuris fue simplemente una fuente del conocimiento del Derecho romano histórico..... Europa y el derecho romano, Revista de Derecho Privado, Madrid, 1955, pp. 167 y 168.

160 Vid. Domenico MAfel. Gli inizi dell'umanesimo giuridico, Giuffrè, Milano, 1964, p. 81 y ss., y Mario Ascheri. Introduzione storica al diritto moderno y contemporaneo, Giapichelli Editore, Torino, 2003, p. 57.

161 Cfr. Carlo Augusto CANnATA. Lineamenti di storia della giurisprudenza europea, Giappichelli Editore, Torino, 1976, p. 22. Cfr. Franz WIEACKER. Historia del derecho privado de la edad moderna, Aguilar, Madrid, 1957, pp. 122 y 123, texto en el que se anota que el "...giro crítico del humanismo hacia las fuentes", suscitó "... un nuevo descubrimiento de la antigüedad y el propósito de un sistema cerrado basado en el descubrimiento de la legitimidad espiritual del Derecho".

162 . Vid Vincenzo Piano Mortari. La scienza giuridica del siglo XVI. Aspetti della scuola culta, Catania, 1966, p. 47, y ss., quien anota que en esta centuria era muy común "...repensar críticamente y en plena libertad", propio de una época "... de viva revolución interior".

163 Vid. Francesco CARPINTERo, quien recuerda que "EI 'humanismo jurídico', nacido en la primera mitad del siglo XVI, representó....una orientación opuesta a la del mos italicus....porque, en definitiva, sus representantes no hicieron otra cosa que remozar con las Humanidades el contenido de la jurisprudencia". "Mos italicus, mos gallicus y el humanismo racionalista. Una 
tuviera análoga cabida el argumento de autoridad, tan presente en las escuelas medievales de los Glosadores y Comentaristas, primordialmente en la última de ellos, después en franca crisis ${ }^{164}$, de lo que se siguió una mayor libertad y apertura en la construcción del pensamiento jurídico, incluida la categoría del contrato y su fuerza vinculante, la cual, cuando se exageró y sobredimensionó, es cierto, le restó vigencia y aplicación al venire contra factum proprium, lo anticipamos.

En esta renovación -y ajuste- de la ciencia del Derecho del siglo XVI, juegan un papel destacados juristas del palmarés de Alciato en Italia, de ZASIUS -O ZASIO- en Alemania, de BUDE y posteriormente CUJAs en Francia (Escuela de los Humanistas) ${ }^{165}$, sin perjuicio de la existencia de otros más que mencionaremos luego, por cuanto su aporte se inscribirá en siglos venideros, y en Escuelas aledañas, en concreto en la Escuela Clásica del Derecho Natural -entre otras denominaciones más-.

Lo propio aconteció con juristas que, concluida la Edad media, en los albores del Derecho moderno, seguían ligados a Escuelas de origen medieval que, per se, no desaparecieron de inmediato con el advenimiento - del mal llamadorenacimiento del siglo XVI, v.gr: la denominada Escuela de los Comentaristas en Italia, también apellidada por algunos Escuela de los 'Bartolistas'166, en la cual también se examinó la regla venire contra factum proprium, expresamente $(\mathrm{DECIO})^{167}$.

contribución a la metodología jurídica”, en lus Commune, Vittorio KLostermann, Frankfurt, 1977, pp. 109 y 111.

164 Vid. Jean Gaudement. Les naissances du droit, Montchrestien, Paris, 1997, p. 332, quien recuerda que autores del prestigio de ALCIATO, ZASIUS y BUDE, abogaban por una aproximación diversa al derecho, no fundada en la autoritas, de por sí, motivo por el cual consideraban que "la verdad en derecho proviene de los testimonios, no de la autoridad de los doctores. El estudio de los textos es primero".

165 Ulrico Zasius. Opera omnia: Responsorum iuris sive consiliorum duos complectens libros... Consilium II, T. VI, Francofurti, M.D.LXXXX, p. 9. Vid. Helmut CoIng. Derecho privado europeo, T. I, Fundación Cultural del Notariado, Madrid, 1996, p. 216, especialmente en torno al aporte de ZASIUS, referente a la "... prohibición del venire contra factum proprium”.

166 Vid. Alejandro Guzman BrIto. "Juristas de los siglos XVI y XVII", en Juristas Universales, Rafael Domingo, Editor, Vol. II, Marcial Pons, Madrid, 2004, p. 78.

167 Es el caso del milanés Filippo Descio -o DeCIL-, nacido en 1454, distinguido académico italiano quien se ocupó en su célebre obra, en diversos apartes, entre otros en el Consilium 
Ahora bien, en los predios de la celebérrima Escuela Clásica del Derecho Natural, sin perjuicio de otras denominaciones (Escuela de Derecho natural, Escuela lusnaturalista, etc.), es aconsejable recrear, a manera de preámbulo, el pensamiento de Grocio y Puffendorf (Siglo XVII), habida cuenta que sus aportes fueron determinantes en este estadio de la humanidad, y también de la ciencia jurídica.

Para el primero, quien inició “...el camino hacia la declaración general del consensualismo en sede contractual que aparecerá ya fijado, de forma definitiva, por los autores que lo siguen"168, "...la madre del derecho natural es la misma naturaleza humana, la cual, aunque de nada necesitáramos, nos inclinaría a desear la sociedad mutua; y la madre del derecho civil es la misma obligación nacida del consentimiento"169, concepción que después le servirá de apoyatura a PUFFENDORF, quien realzará de los contratantes "... la fidelidad inviolable que debe tener su palabra”"170, pilares sobre los cuales se edificará el contrato en la edad moderna, particularmente en el valor asignado a la voluntad (consensualismo) y en la fuerza que de ella emana (poder vinculante para sus celebrantes) ${ }^{171}$, decisivos en el movimiento codificador del siglo XIX, como se apreciará, explicación anticipada del precario valor otorgado al cambio comportamental, una vez celebrado el contrato.

\subsubsection{Contribuciones de Domat y Pothier}

Expresado en forma sucinta lo que antecede, importa detenernos en el pensamiento de DOMAт y PотHIER, prácticamente inexplorado en la temática que

CCCCXLV, del venire contra factum proprium. Consiliorum, Sive, Tomus Secundus, Venetiis, MDLXXV, p. 105.

168 María del Carmen Gete Alonso. Estructura y función del tipo contractual, Bosch, Barcelona, 1979, p. 117.

169 Hugo Grocio. Del derecho de la guerra y de la paz, T. I, Reus, Madrid, 1925, № 16, p. 15.

170 Samuel Puffendorf. Le droit de la nature et des gens, ou systeme général de la moral, de la jurisprudence et de la politique, Paris, 1771, Lib. III, Chap. IV, Nº 2.

171 Desde una de las perspectivas anteriormente indicadas, don Luís DiEz-PICAZo expresa que en el marco de la Escuela de Derecho Natural, se "...llegó a la conclusión de que el fundamento racional de la creación de las obligaciones se encuentra en la libre voluntad de los contratantes". Fundamentos de derecho civil patrimonial, Vol. I, op. cit., p. 136. 
nos ocupa, no por ello exento de singular relevancia, como se constatará, más de la que prima facie pudiera parecer, so pretexto de que ambos exponentes, en efecto, ejercieron una notable influencia en el proceso de codificación del Derecho francés de comienzos del siglo XIX, en el que la regla venire contra factum proprium -y sus equivalentes- no fue tenida en cuenta y, por consiguiente, no fue materia de reflexión prelegislativa, y menos legislativa, según lo hemos pincelado.

Efectivamente: también en el siglo XVII, Jean DomAT, con motivo de la estructuración de su Traité des lois, incorporado en su memorable obra: Les loix civiles dans leur ordre naturel, tuvo ocasión de ocuparse de la ratio de la coherencia en sede contractual, que como hemos podido evidenciar a lo largo de este escrito es uno de los campos más propicios y abonados para la proyección plena de la institución materia de nuestro escrutinio. Y lo hizo, a partir de recrear los más preclaros y nobles sentimientos del ser humano, esos que ni aún en el campo del Derecho, en apariencia frío y lejano, pero en realidad a la mano y al servicio de la comunidad, pueden ocultarse o mimetizarse. Muy por el contrario, hay que humanizarlo cada vez más y conectarlo con sus genuinas vivencias y necesidades, que son terrenas, y no entelequias o de puro helio. Por eso, tan ilustre iusnaturalista, permeado por su amor a Dios y a los demás, en consonancia con la esencia de los evangelios - para nada oculta-, puso de manifiesto que "En todos los compromisos de una persona con otra....se debe recíprocamente demandar" el cumplimiento del precepto, conforme con el cual "no debe hacerse a los otros aquello que no deseamos que los otros nos hagan", de lo que se desprende que "...las reglas que proclaman dar a cada uno lo que le pertenece, de no perjudicar a otra persona, de guardar siempre fidelidad y sinceridad, son una respuesta del amor mutuo"172.

El texto precedente, con razón, es una muestra de inequívoca y auténtica coherencia comportamental, pues si se reclama una determinada actuación o comportamiento a un cocontratante, es porque correlativamente se está dispuesto a dispensarle el mismo trato a él, a riesgo de que si no lo hace se torne incoherente $y$, de paso, contradictorio, con todo lo que ello supone.

$\overline{172}$ Jean DomAT. Les loix civiles dans leur ordre naturel, Cap. V, T. I, Paris, M.DCC.LXXI. 
Lo mismo sucedió con otro de los grandes exponentes del Derecho histórico francés, ya mencionado: R. J. PотHIER, quien sintonizado con DomAT, en lo cardinal, expresó en el siglo XVIII en su aplaudido Tratado de las obligaciones, que "En el fuero interno, se debe mirar como contrario a esta buena fe, todo lo que se separa, por poco que sea, de la sinceridad más exacta y más escrupulosa: el simple disimulo acerca de lo que concierne a la cosa que ha sido objeto de negocio, y que la parte con quien yo contraté tenía interés en conocer, es contrario a esa buena fe; puesto que, si tenemos mandado el amar a nuestro prójimo como a nosotros mismos, menos podremos ocultarle nada que no hubiéramos querido que se nos ocultase, caso de encontrarnos en su lugar"173, idea ésta refrendada en su no menos conocido Tratado del contrato de compra y venta ${ }^{174}$.

En este orden de ideas, bien examinados los textos de estos dos consagrados juristas galos, se hace evidente que la coherencia comportamental hace presencia en cada uno de ellos, así no se manifieste literalmente, y así no se recree, expresis verbis, la regla venire contra factum proprium. Acudir a la buena fe, como soporte del reproche de actuar en contravía del respeto mutuo que se deben los cocontratantes, y de hacer aquello que no quisiera que le hicieren, es revelador del mensaje ético y jurídico de sus autores, confesamente identificados, amén que convencidos de la importancia de la sinceridad, la fidelidad, el respeto mutuo, la igualdad, la equidad, entre otros valores más, arropados por la buena fe, en general.

173 R.J. Pothier. Tratado de las obligaciones, Heliasta, Buenos Aires, 1978, p. 28.

174 Múltiples, ciertamente, son los pasajes del tratado en comentario en los que PotHiER se refiere a este tema. Basta, simplemente, referir a dos de ellos, de suyo elocuentes, a cuyo tenor: "... la justicia y la equidad con respecto a tales contratos ["los contratos en que versan intereses recíprocos"] consiste en la igualdad, y cuanto tiende á disminuirla es opuesto á la equidad... desde el momento en que el uno conoce mejor que el otro la cosa de que se trata, le lleva una ventaja en orden al contrato, sabe mejor que el otro lo que va á hacer, y la igualdad desaparece". Y el segundo, alusivo al estado de la "...cosa vendida", conforme al cual, "Así como el vendedor es enteramente libre para vender ó dejar de vender, así debe dejar al comprador en perfecta libertad para comprar ó dejar de comprar, aún por el justo precio, si este no le conviene. Luego es una injusticia el tenderle un lazo ocultándole un vicio de la cosa para obligarle á que la compre; pues no lo habría verificado de haber sabido el vicio". Tratado del contrato de compra y venta, Imprenta y Litografía de J. Roger, Barcelona, 1841, pp. 122 y ss. 
Tanto habrá sido el admirable celo al respecto, que PothIER, por vía de diciente ejemplo, no vaciló en aseverar que "... la equidad, desde el punto de vista comercial, consiste en la igualdad, y así desde el momento en que esta igualdad se siente herida y que uno de los contratantes da más que no recibe, el contrato es vicioso", lectura que, apelando al espíritu que caracterizó a estos dos juristas, nos permite entrever que, con dichos elementos de juicio, no podrían aplaudir la sorpresa, la contradicción, el cambio inopinado y lesivo de comportamiento, precisamente por no estar a tono con aquello que el mismo contratante voluble esperaría respecto a él, en el entendido que la coherencia es de doble vía, como también los referidos valores de la sinceridad, la fidelidad, el respeto mutuo, la igualdad y la equidad, exaltados por ellos, una y otra vez en sus pletóricas obras.

¿Acaso podría pretextarse una auténtica igualdad, cuando un contratante, comportándose de modo diferente al observado por el otro, ese sí leal, sincero, equitativo, respetuoso de la palabra empeñada, fiel, fraterno, en fin coherente, quiebra su confianza y altera la atmósfera y el buen clima contractual? Sinceramente nosotros creemos que no, en cuyo caso tales señales y consideraciones realizadas por DomAт y PotHiER, de gran valor, lo reiteramos, sirven de apoyatura para afirmar que ellas son indicativas de su rechazo a la incoherencia y a la contradicción conductual, a flor de piel corroborado en virtud de la regla de oro por ellos expresada de hacer aquello que no desearía le fuere hecho, muestra de irrefragable y galopante incongruencia. De ahí que si se reclama coherencia, es porque se brinda coherencia o se está en condiciones de brindarla; eso es mutualidad, rectamente entendida, a la que a menudo acudió Domat. Por lo tanto, de inobservarse este proceder, como se recibió más de lo que se dio, parafraseando a POTHER, el contrato se tornaría 'vicioso', en un sentido amplio, queriendo significar con ello que en tales condiciones no podría ser fuente de beneficio para aquél que, transgrediendo la regla o el deber de coherencia, vulnera la confianza legítima y racional del cocontratante que de buena fe $-\mathrm{y}$ no de ingenuo- no esperaba un cambio relevante en el comportamiento registrado con antelación (constantia).

En esta misma dirección, en el plano hermenéutico, el profesor belga JeanFrançois Romain, en su interesante estudio crítico acerca de la buena fe, a la vera del pensamiento de Domat y POTHIER, meridianamente expresa que "El imperativo del respeto mutuo, que demanda específicamente la buena fe, responde a una 
exigencia de coherencia racional o razonable: es coherente tratar a otro de la misma manera en que nosotros quisiéramos que nos trataran; al contrario, sería incoherente imponer a otro un comportamiento y causarle un perjuicio que nosotros no quisiéramos que se nos impusiera", a lo que agrega "Habría una contradicción, en el orden racional, tanto en el plano de la ética como en el del derecho, cuando un sujeto se comporta de una cierta manera respecto al otro, sin admitir que ese otro pueda hacer lo mismo. Ello sería violar el principio ético y jurídico de no contradicción y no respetar una coherencia elemental"175.

\subsubsection{Aporte de J. SchACHER}

En el otoño del siglo XVII, por último, hay que mencionar que irrumpe una de las contribuciones más resonantes de toda la historia jurídica, en cuanto a la regla del venire contra factum proprium se refiere, atinente al señero aporte de Johan Christoph SCHACHER, sin duda la primera obra dedicada a esta temática, in extenso, por lo menos de acuerdo con la información disponible hasta la fecha. Se trata, efectivamente, de un trabajo intitulado Disputatio juridica, de impugnatione facti proprii, cuyo capítulo I, lo denomina el autor Impugnatione facti proprii, Regulariter illicita; el capítulo II Impugnatione facti proprii quoad jus personarum; el III Impugnatione facti proprii ex jure rerum quoad actus inter vivos; el capítulo V Impugnatione facti proprii in ultimis voluntatibus, y el último capítulo (VII), para no extendernos más, Impugnatione facti proprii principis ${ }^{176}$, tratamiento este que confirma la amplitud, así como la sustantividad del estudio en referencia, al que se le reservaron 112 folios.

\footnotetext{
175 Jean-François Romain, Théorie critique du principe général de bonne foi en droit privé, op. cit., pp. 110, 111 y 113, autor que adicionalmente manifiesta que en consideración a lo afirmado, "El principio de buena fe es inseparable del principio del respeto mutuo", idea ésta presente en DoмAт у PотHIER, quienes entendieron cabalmente "...la máxima del respeto mutuo, conforme con la cual se impone tratar al otro como nosotros quisiéramos que nos trataran", clara "...expresión de una regla de coherencia, sobrentendidas la igualdad formal y la reciprocidad entre los sujetos de derecho".

176 Johan Christoph SCHACHER, Disputatio juridica, de impugnatione facti proprii, MDC LXXXVIII, pp. 5 y ss.
} 


\subsubsection{Síntesis}

Ya para concluir esta etapa de la historia, vale la pena mencionar, en términos muy generales, que al hilo - de buena parte- de las ideas humanistas, racionalistas, y iusnaturalistas, según el caso, fue madurando la idea de la vigencia generalizada y de la fuerza vinculante atribuida a los acuerdos de voluntad, en particular al contrato, como arquetípica figura jurídica, hija de un proceso volitivo encaminado al respeto de lo pactado, como coordenada de la autonomía reconocida a los particulares (lectura voluntarista), más conocido luego como reconocimiento al dogma de la autonomía de la voluntad privada, tan en boga en el derecho prerevolucionario, revolucionario y posrevolucionario francés, en el que se haría célebre la equívoca y absoluta expresión de FollLe, de acuerdo con la cual "Quien dice contractual dice justo", entre otras razones porque la justicia no campea en la incoherencia y en la contradicción comportamentales, ni es compatible con la erosión de la confianza legítima y racional en sede contractual; todo lo contrario, es cruda injusticia, como ya se ha esbozado y se esbozará de nuevo. Tiene entonces razón el profesor de la Universidad de Córdoba, Argentina, Carlos Gustavo VAlLESPINOS, cuando aludiendo a la "Escuela del Derecho Natural", indica que "El pensamiento jurídico de ese período de la historia giró entonces en torno al valor del acuerdo de voluntades, pues de él surgirían obligaciones lícitas sin importar mayormente si eran justas"177, aspecto este último que en la actualidad reviste especial valía, pues de poco vale la voluntad, sino se hace acompañar igualmente de comportamientos leales, honorables, coherentes, solidarios y probos, es decir 'justos' (justicia contractual). Hoy por hoy, entonces, no todo reside en la voluntas, pues la fides, en efecto, vuelve ha ocupar un sitial de privilegio. De ahí que una voluntad indecente, alejada de la eticidad y de la buena fe, no sea de recibo. De hecho, desde la perspectiva del solidarismo contractual moderado, tan en boga en algunas latitudes, V.gr: Francia, se pone de presente que dicha “...ética contractual se expresa concretamente, entre otras, por las ideas de altruismo, de decencia, de coherencia, de proporcionalidad y de cooperación....."178.

177 Carlos Gustavo VALLESPINOS. El contrato por adhesión a condiciones generales, Universidad, Buenos Aires, 1984, p. 88.

178 D. MAZEAUD. Solidarisme contractuel et réalisation du contrat, op. cit., p. 59. 


\subsection{Derecho contemporáneo}

\subsubsection{Preliminares}

En consonancia con lo manifestado al momento de ocuparnos de la Edad moderna, seguidamente nos concentraremos en el desarrollo histórico de la regla del venire contra factum proprium, y de algunas de sus manifestaciones primordiales, en especial de la denominada doctrina de los actos propios, el que será en este periodo radicalmente cambiante, pues de su olvido o abandono, prácticamente, virará a su resurgimiento y ulterior afianzamiento, a la par que a su creciente expansión, metamorfosis para nada gratuita, habida consideración de que estará muy ligada a las nuevas concepciones imperantes en materia contractual, muy a tono con el papel contemporáneo atribuido a la buena fe y a la protección equilibrada de la confianza legítima, todo enmarcado en una redimensionada y enriquecida 'justicia contractual'. Y lo haremos esquemática y brevemente, en aras de la anunciada y deseable concisión. Para ello, efectuaremos entonces un excursus general a partir de la Revolución Francesa, para luego hacer puntuales comentarios de la codificación del Derecho civil; la Escuela de la Exégesis; el Código Civil español; la Escuela Pandectista; el Código Civil Alemán; la dogmática y la jurisprudencia del siglo XX y una panorámica del siglo XXI, inmerso en lo que algunos han llamado la "edad global", sucedánea de otras edades: la moderna y contemporánea ${ }^{179}$.

\subsubsection{Revolución francesa}

En lo que dice relación con la revolución francesa, conocidos son sus postulados primigenios, y su ideario característico encaminado a exaltar la libertad, la igualdad y la fraternidad. Como conocida, igualmente, la Declaración de los Derechos del Hombre y del Ciudadano de 1789, en particular su artículo II, a

179 Vid. Juan Pablo Pampillo, Hacia un nuevo lus Commune americano, Universidad Javeriana, Escuela Libre de Derecho de México y Grupo Editorial Ibáñez, Bogotá, 2012, p. 32, profesor mexicano que agrega que "...puede advertirse que durante el siglo XX se produjo el agotamiento de la modernidad, más específicamente, la crisis de la modernidad contemporánea", detonante del "....advenimiento de una nueva....época a la que se denominará como 'edad global '. 
cuyo tenor: "La finalidad de toda asociación política es la conservación de los derechos naturales e imprescriptibles del hombre. Esos derechos son la libertad, la propiedad, la seguridad y la resistencia a la opresión"180.

En desarrollo de su 'techo ideológico', se acentúa el individualismo, y la voluntad adquiere un protagónico papel, hasta el punto que se entenderá que en torno a ella, a manera de dogma, girará buena parte del ideario revolucionario. Ideas como la de sublimar el carácter absoluto de la propiedad, y la adquisición y preservación de los derechos de contenido patrimonial, serán fundamentales, motivo por el cual se traducirán en su manifiesto, en consonancia con el régimen liberal que se estructuró y luego difundió, con claras repercusiones en el campo social, político, económico y jurídico, claro está.

Célebre, efectivamente, es el binomio conformado por las expresiones laissez faire, laissez passer: dejar hacer, dejar pasar, propias del sistema liberal, a la par que individualista en comento, en el que la autonomía de la voluntad, se reitera, fue un bastión en el que descansaba buena parte de la ideología de la época ${ }^{181}$.

180 El artículo IV, de la misma declaración, impera que "La libertad consiste en poder hacer todo aquello que no cause perjuicio a los demás. El ejercicio de los derechos naturales de cada hombre, no tiene otros límites que los que garantizan a los demás miembros de la sociedad el disfrute de los mismos derechos. Estos límites sólo pueden ser determinados por la ley". Vid. Henri Regnault, Manuel d'histoirie du droit français, Sirey, Paris, 1947, p. 289 y ss.

Es de señalar que el art. 8 del proyecto de Declaración presentado en el mes de febrero del mismo 1789, que finalmente no se acogió (26 de agosto), referente a la materia contractual, rezaba que "Todo hombre es libre de realizar los contratos que estime conveniente; y todo contrato libre es obligatorio para las dos partes, siempre y cuando no sea contrario a las buenas costumbres, no esconda ningún dolo de los contratantes y no ocasione ninguna lesión de los derechos del otro", precepto que era de una claridad especial, y que quizá hubiera marcado otro rumbo en el tema que examinamos, concretamente en lo que atañe a su última parte, de suyo más tuitiva y directa, incluso, que los artículos 1101 y 1134 del Código Civil francés vigente, que a la letra dicen: "El contrato es una convención por la cual una o varias personas se obligan frente a una u otras a dar, hacer o no hacer alguna cosa" (art. 1101). $Y$ "Las convenciones legalmente formadas tienen fuerza de ley entre quienes la celebraron. Ellas no pueden ser revocadas más que por su consentimiento mutuo, o por las causas que la ley autoriza. Ellas deben ser ejecutadas de buena fe" (1134). Lo mismo sucede con el contenido del art. IV de la Declaración en cita, más elocuente que el texto del propio Código.

181 Expresa el profesor chileno Alejandro GuzMAn BRITo, discípulo de Don Álvaro D'ORs, que el programa liberal del momento, puede sintetizarse así: “...en lo político, la división de los poderes, la representación popular....y el establecimiento legal de un catálogo de libertades 
Tanto que, con ocasión de la factura del Código Civil de Napoleón del año 1804, esta concepción quedó diáfanamente tatuada, erigiéndose en uno de sus rasgos prototípicos $^{182}$.

\subsubsection{La codificación y el Derecho civil francés}

En ese específico entorno irrumpe pues le code civil, enlazado con ideas de estirpe jusnaturalista y racionalista, que a la sazón sirvieron de estribo para la gestación del movimiento codificador y, por tanto, la adopción del código como granado instrumento de cohesión y unidad. Sobre el particular, claramente expresa el profesor Eugenio LLAMAS PoMBo, que "La confluencia del pensamiento ilustrado con la escuela racionalista provoca la introducción del Derecho natural como Derecho positivo de los pueblos, a través de la Codificación. Así, junto a las leyes naturales...., se piensa que existe también un orden jurídico natural, susceptible de conocimiento racional, y que ha de ser incorporado necesariamente como Derecho positivo, mediante una nueva legislación: la de los códigos, que resuelve en forma clara, breve, cierta y precisa, y en unas pocas leyes, el mayor número posible de problemas, mediante un estilo conciso y abstracto. Incluso, según el pensamiento ilustrado, esas Leyes....han de carecer de tecnicismos jurídicos y ser comprensibles por todos los ciudadanos (VoltaIRE, Rousseau)"183.

públicas; en lo social, la abolición de los estamentos y sus efectos y su reemplazo por las clases sociales de base económica....; en lo económico, la libertad interna e internacional de industria (laissez faire) y de comercio (laissez passer), con libertad de precios; en lo jurídico, la unificación del sujeto de derecho en la persona sin más, la abolición de las vinculaciones de la propiedad y la libertad de su circulación, la libertad de testar...., y la libertad de contratación; en lo ético, el reconocimiento de una esfera moral de autonomía que es, por ende, independiente de toda intervención externa....". La codificación civil en iberoamérica. Siglos XIX y XX, Editorial Jurídica de Chile, Santiago, 2000, pp. 88 y 89.

182 Según lo avala el profesor José MeLICH-ORsinI, “... los filósofos ius naturalistas de los siglos XVI a XVIII desarrollaron la tesis individualista, que supone a los hombres independientes unos de otros y cuya absoluta libertad recíproca solo puede ser limitada por su propia voluntad... A esta doctrina filosófica y política le correspondió en el terreno económico la doctrina del liberalismo económico...Esta doctrina favoreció aún más la tesis de la libertad de contratación. Bajo la influencia de esta ideología se elaboró el Código [de] Napoleón, para el cual el contrato consiste esencialmente en el acuerdo de voluntades...". Doctrina general del contrato, Jurídica Venezolana, Caracas, 1985, p. 29.

183 Eugenio Llamas Pombo, Orientaciones sobre el concepto y el método del derecho civil, Universidad Javeriana, Bogotá, 2009, pp. 57 y 58. 
Por consiguiente, una de las ideas dominantes que inspiraron la redacción del Código Civil, fue la de reconocer a la voluntad de los particulares una singular significación, al igual que una fuerza dinámica y vinculante al contrato, llamado a ser respetado y celosamente acatado por los contratantes ${ }^{184}$. Ello explica que, en un contexto amplio, mutatis mutandis, se le haya dado el status de 'ley' interpartes (art. 1134 C.C).

En este orden de ideas, resulta entonces palmario que la voluntad, de un lado, y el contrato, del otro, en particular la fuerza vinculante a él reconocidas, se constituyeron en ejes del Código Civil francés, y a su turno, de buena parte de los códigos decimonónicos, que en este aspecto lo siguieron muy de cerca, circunstancia ésta que, en la praxis, inhibió la convergencia, a la par que la aplicación de mecanismos de índole tuitiva, enderezados a proteger a una de las partes que, frente a concretas situaciones fácticas, podría resultar lesionada (remedios). Así sucedió, por décadas, con el abuso del derecho, y con figuras como la lesión, la imprevisión contractual, y el venire contra factum proprium, en cualquiera de sus manifestaciones o dimensiones, etc., hoy cabalmente recepcionadas y aprestigiadas.

Si las partes habían reflexivamente celebrado un contrato, fruto de la concurrencia de sus voluntades coincidentes (consentimiento), no era de recibo que, a posteriori, se obstaculizare el ejercicio pleno e irrestricto de los derechos de él emanados, salvo de cara a regladas hipótesis, en sí mismas ajenas a la incoherencia, a la contradicción y a la incongruencia comportamentales. De ahí que, en puridad, dicha atmósfera no fue propicia para que la regla del venire tuviera acogida o simpatía plena, ora en la órbita legislativa, ora en la judicial, y doctrinal, menos en esta última, como se observará, aun cuando hay que registrar, por su importancia, que hubiera podido ser todo lo contrario. Al fin y al cabo, el trinomio

184 “...los redactores del Código civil” francés, lo anotaron Henri LeÓn y Jean MAZEAUd, “...de la revolución conservaron las ideas individualistas y la preocupación de proteger la libertad individual.... Imbuidos de las doctrinas del derecho natural, concedieron a la voluntad de las partes, que anhelaban todopoderosa, la preeminencia en el ámbito de los contratos (principio de la autonomía de la voluntad)". Lecciones de derecho civil, Parte primera, Vol. I, E.J.E.A, Buenos Aires, 1959, p. 72. Cfr. Jean-Louis GAZZANIGA. Introduction historique au droit des obligations, Presses Universitaires de France, Paris, 1992, p. 185, doctrinante galo que con relación a la que denomina 'edad de oro del contrato', aludiendo a la concepción del Código Civil napoleónico, señaló que "El individuo es todo, y su voluntad es soberana". 
libertad, igualdad y fraternidad, bien interpretado, hubiera podido ser el robusto fundamento de su admisión, a fortiori si se le agrega el ingrediente de la buena fe, inmerso en el citado artículo 1134, expressis verbis, así como las ecuánimes y agudas reflexiones de sus artífices directos alrededor de la equidad, la conciencia y el corazón de los hombres ${ }^{185}$. Todos estos valores, postulados y análisis, al unísono, sirven y servían, holgadamente, para tan noble propósito protector, de tal suerte que pudo más la lectura individualista a ultranza, que la esencia libertaria, igualitaria, fraterna, equitativa y fiduciaria en mención, sin perjuicio del penetrante aporte que, de antiguo, en cabeza de ULPIANo, había efectuado el sapiente Derecho romano, en concreto a través del escrutinio axiológico de esos tres adamantinos "preceptos del Derecho" (Tria iuris preacepta), inalteradamente vigentes: honeste vivire; alterum non laedere y suum cuique tribuere (vivir honestamente, no dañar al prójimo y dar a cada uno lo suyo) (D.1.1.10,1).

¿Acaso hay libertad, cuando se estimula -o por lo menos no se combate-la entronización de prácticas que desdibujan la ratio del pacto, acuerdo, convenio o contrato? ¿Será que habrá libertad cuando en su nombre se mancillan los derechos legítimos de una parte que creyó y confió en otro? Eso no es libertad, sino arbitrariedad, su antítesis.

¿Acaso hay igualdad, cuando uno de los celebrantes del contrato obró de buena fe, se comportó coherente y lealmente y el otro lo asaltó en ella, y fue

185 No es fortuito que Félix Bigot-PREAmEneu, uno de sus renombrados redactores, justificara la adopción del título destinado a los contratos (Tít. III, Libro Tercero), poniendo de manifiesto que "Las obligaciones convencionales se crean y se extinguen cada día y cada instante. Mas tal es el orden admirable de la providencia, que para arreglar todas estas relaciones no debemos hacer más sino conformarnos á los principios que se hallan a un tiempo en el entendimiento y corazón de los hombres. En ello, en la equidad, en la conciencia es donde los romanos han hallado ese cuerpo de doctrina que hace honor á ese pueblo e inmortaliza su legislación....Se entenderían pues mal las disposiciones del código civil relativas á los contratos, si se las mirase de otro modo que como reglas elementales de equidad, cuyas ramificaciones se hallan en las leyes romanas. En estas hay el desarrollo de la ciencia de lo justo e injusto, allí deben acudir todos los que intentan instruirse, todos los que deseen adelantar en este campo, todos los que están encargados de la ejecución de las leyes de que consta el código francés". "Exposición de los motivos en que se funda el título de los contratos y obligaciones convencionales en general", en Curso de legislación formado por los mejores informes y discursos leídos y pronunciados al tiempo de discutirse el Código de Napoleón, T. II, Barcelona, Imprenta y Litografía de J. Roger, 1841, pp. 203 y ss. 
desleal e incoherente? La igualdad entraña simetría, y allí hay todo lo contrario: inarmonía, asimetría y desigualdad.

¿Acaso hay fraternidad, cuando un contratante, inopinadamente, cambia de comportamiento, sin importar la suerte de su congénere, pretendiendo sacar provecho de su incoherencia conductual? La fraternidad es refractaria al egoísmo, a la individualidad exacerbada, a la insolidaridad, pues solidarios y cooperantes deben ser los asociados, y los que lo hacen en virtud de un contrato, no pueden ser ajenos a la solidaridad y a la cooperación. Correspondencia y hermandad, no son adornos, ni entelequias, ni calidades extrañas -o esotéricas- en sede negocial.

¿Acaso, seria y fundadamente, puede enarbolarse la bandera de la buena fe para amparar al incoherente, al contradictorio, al incongruente, a quien altera el curso normal -y esperado- de un contrato en el tiempo (factum novum)?

¿Acaso puede hablarse con responsabilidad de equidad cuando una nueva conducta o comportamiento, de suyo inesperado, trastoca la realidad y altera la cosmovisión negocial de una de las partes que, por fuerza del cambio experimentado, sufrirá daños y perjuicios injustos, a la vez que una profunda frustración?

Paradójico, en consonancia con lo plasmado en líneas anteriores, resulta ser que, no obstante contar con las aquilatadas coordenadas para haber conservado y estimulado el rechazo a la contradicción y la incoherencia en sede del Derecho revolucionario francés y de la propia codificación napoleónica, la referida regla hubiera sido soslayada, mejor sepultada en el olvido, bien consciente, bien inconscientemente ${ }^{186}$. Con menos elementos de juicio, en el marco del Derecho histórico francés, DOMAт y POTHIER sí le dieron un tratamiento enteramente diverso a esta misma fenomenología, como se examinó, lo cual es digno de encomio y renovado aplauso.

186 Cfr. Anderson SchrelBer A prohibiçao de comportamento contradictório. Tutela da confianca e venire contra factum proprium, op. cit., p. 31 y Paulo MotA PINTO, Sobre a prohibiçao do comportamento contraditório (venire contra factum proprium) no direito civil, op. cit., p. 289. 


\section{Probablemente como lo expresa el profesor Hernán CORRAL TALCIANI, "EI} movimiento codificador, aunque siguió los postulados de la Escuela lusracionalista, no recogió expresamente la formulación del principio, quizás por su desconfianza hacia el poder de los jueces y la libertad de las reglas que les proporcionan las reglas excesivamente genéricas o discrecionales"187, a lo que cabría agregar

187 Hernán Corral T. La raíz histórica del adagio 'venire contra factum proprium non valet', op. cit., p. 28. En sentido análogo, el profesor argentino Rodolfo VIGo expresa que "El gran escenario jurídico olvidado por la teoría decimonónica ha sido el judicial". Constitucionalización y judicialización del derecho, Universidad Javeriana y Grupo Editorial Ibañez, Bogotá, 2012, p. 139.

Extraño, de igual manera, es el hecho de que en el siglo XIX y parte del XX se haya alentado esta idea del temor a la hermenéutica judicial, a sabiendas del significado de su ministerio, amplia, magistral y confesamente defendido por PORTALIS, uno de los más célebres redactores del Código Civil Francés. Memorable, al respecto, es su Discurso Preliminar del Proyecto de Código Civil, en el que in extenso expresó que "Como quiera que sea, las leyes positivas jamás podrán reemplazar completamente el uso de la razón natural en los quehaceres de la vida. Las necesidades de la sociedad son tan varias, la comunicación de los hombres tan activa, sus intereses tan múltiples y sus relaciones tan extendidas, que resulta imposible para el legislador regularlo todo". "Incluso en las materias que atraen particularmente su atención se le escapan infinidad de detalles, o bien son demasiado discutidos y fluctuantes para poder convertirse en objeto de un texto legal". "Por otra parte, ¿Cómo encadenar la acción del tiempo? ¿Cómo oponerse al curso de los acontecimientos o a la declinación de las costumbres? ¿Cómo conocer y calcular de antemano lo que sólo la experiencia nos pueda revelar? ¿Puede extenderse la previsión a objetos que el pensamiento no puede alcanzar?" "Por completo que pueda parecer un código, no bien queda concluido, mil cuestiones en él no previstas asaltan al magistrado. Pues las leyes, una vez redactadas, permanecen tal como han sido escritas; los hombres, al contrario, no reposan jamás; viven en constante actividad, y ese movimiento que nunca se detiene, y cuyos efectos son diversamente modificados por las circunstancias, a cada instante produce alguna combinación nueva algún hecho, algún resultado nuevo".

"Multitud de cosas, por consiguiente, han de quedar libradas al imperio de los usos, a la discusión de los hombres instruidos, al arbitrio de los jueces". "La misión de la ley es fijar a grandes rasgos las máximas generales del derecho, establecer los principios fecundos en consecuencias y no descender al detalle de las cuestiones que pueden surgir en cada materia". "Es al magistrado y al jurisconsulto, penetrados del espíritu general de las leyes, a quienes toca dirigir su aplicación". "De ahí que en todas las naciones civilizadas se vea formarse siempre, junto al santuario de las leyes y bajo la vigilancia del legislador, un depósito de aforismos, de decisiones, de doctrina que diariamente se depuran por la práctica y el choque de los debates judiciales, que acrecienta sin cesar, por obra de todos, los conocimientos adquiridos, y que, en todo momento, ha sido considerado como un verdadero suplemento de la legislación".

"A quienes profesan la jurisprudencia se les reprocha el haber multiplicado las sutilezas, las complicaciones (de cuestiones, controversias, y resoluciones) y los comentarios. Este reproche puede ser fundado. Pero, ¿en qué ciencia no se está expuesto a merecerlo? ¿Debe acusarse a una clase particular de hombres de lo que no es más que una enfermedad general del espíritu? Hay tiempos en que se está condenado a la ignorancia por la falta de libros, y otros en los que resulta difícil instruirse porque abundan demasiado". 
"Si en algún ámbito puede perdonarse la intemperancia en comentar y discutir es en la jurisprudencia. No se vacilará en creerlo, si se reflexiona en los innumerables hilos que llegan a los ciudadanos, sobre el desarrollo y la progresión sucesiva de las materias de que el magistrado y el juriconsulto están obligados a ocuparse, sobre el curso de los acontecimientos y las circunstancias que de tantas maneras modifican las relaciones sociales, sobre la acción y la reacción continua, en fin, de todas las pasiones y los diversos intereses. Quien vitupera las sutilezas y los comentarios, se convierte, en una causa propia, en el comentarista más sutil y fastidioso".

"Sin duda sería deseable que todas las materias pudieran ser reguladas por leyes. Pero, a falta de textos precisos sobre cada una, una costumbre antigua, constante y firmemente asentada, una no interrumpida sucesión de sentencias semejantes, una opinión o una máxima admitida hacen las veces de la ley. Y, cuando no se cuenta con nada establecido o conocido, cuando se trata de un hecho absolutamente nuevo, hay que remontarse a los principios de derecho natural, pues, si la previsión del legislador es limitada, la naturaleza es infinita y late en cuanto pueda interesar a los hombres". "Todo esto supone compilaciones, colecciones, tratados, numerosos volúmenes, en fin, investigaciones y disertaciones". "Pero, incluso el código más sencillo, ¿estaría al alcance de todos los sectores sociales? ¿No estarían perpetuamente ocupadas las pasiones en deformar su verdadero sentido? ¿No se precisa cierta experiencia para aplicar sabiamente las leyes? ¿Cuál, es por lo demás, la nación a la que le haya bastado durante largo tiempo leyes simples y poco numerosas?" "Sería un error, pues pensar en la existencia de un cuerpo de leyes que hubiera proveído por anticipado a todos los casos posibles y que, sin embargo, estuviese al alcance del vulgo". "En el estado de nuestras sociedades, harta fortuna es que la jurisprudencia constituya una ciencia que pueda atraer el talento, lisongear al amor propio y despertar la emulación. Por todo ello, una clase entera de hombres se dedica a tal ciencia, y esta clase consagrada al estudio de las leyes, ofrece consejos y defensores a los ciudadanos que no pueden dirigirse y defenderse por sí mismos, y se convierte en algo así como el seminario de la magistratura".

"Harta fortuna es que halla compilaciones y una continuada tradición de usos, de máximas y reglas, porque es en cierto modo, necesario juzgar hoy como se ha juzgado ayer, y que no haya otras variaciones, en los juicios públicos, sino las que aportan el progreso de las luces y la fuerza de las circunstancias". "Harta fortuna es que la necesidad en que se halla el juez de instruirse, de investigar, de profundizar las cuestiones que se le someten, no le permita olvidar que, si bien existen cosas libradas al arbitrio de su razón, no existe ninguna que lo esté a su mero capricho o voluntad". "Cuando la ley es clara, es preciso seguirla; cuando es oscura es preciso profundizar sus disposiciones. A falta de ley, hay que recurrir a la costumbre o equidad. La equidad es el retorno a la ley natural, ante el silencio, la contradicción o la oscuridad de las leyes positivas".

"Forzar al magistrado a recurrir al legislador, sería admitir el más funesto de los principios, sería poner de nuevo en vigencia entre nosotros la desastrosa legislación de los rescriptos; pues, cuando interviene el legislador para pronunciarse en los asuntos nacidos y vivamente agitados entre los particulares, no está más al abrigo de arrebatos que los tribunales. Se debe temer menos el arbitraje reglado, tímido y circunspecto de un magistrado, que pude ser reformado y está sometido a la acción por prevaricación, que el arbitraje absoluto de un poder independiente que no responde ante nadie". "Hay una ciencia para los legisladores, como hay otra para los magistrados, y una no se parece a la otra. La sabiduría del legislador consiste en encontrar, en cada materia, los principios más favorables al bien común; la del magistrado es poner estos principios en acción, ramificarlos, desarrollarlos mediante una aplicación sabia y razonada, a las hipótesis particulares; estudiar el espíritu de la ley, cuando 
la mencionada intangibilidad contractual, con sujeción a la cual lo convenido, convenido está, de tal manera que hay que cumplirlo sea cuál sea su costo. Al fin y al cabo, se decía -y dice aún por algunos- nadie obligó a nadie a contratar. Además, conforme se ha expresado, dicha concepción es indicativa y garante de seguridad jurídica ${ }^{188}$.

Dicho cuadro, sin embargo, no cambió con la apellidada Escuela de la Exégesis. Por el contrario, se acentuó, como quiera que sus militantes, aferrados al texto, y a los postulados en referencia, los radicalizaron aún más, quienes no aceptaron que fueran objeto de sereno e individual escrutinio judicial, y que el juez, como sí lo había admitido admirablemente PORTALIS, pudiera tener un campo de actuación de importancia, según las circunstancias ${ }^{189}$. Como lo recuerda VAN CaEnegem, un caracterizado exponente de esta escuela: Ch. AubrY, “...sostenía que

la letra mata, y no exponerse a ser una y otra vez esclavo y rebelde, desobedeciéndola por espíritu de servidumbre". "Los códigos de los pueblos se pueden hacer con el tiempo, pero hablando con precisión no acaban de hacerse jamás".

188 En esta dirección, el profesor Denis MAZEAUD, indica que "para abordar la cuestión del rol de la confianza legítima en nuestro sistema jurídico, es conveniente...revelar que es un sentimiento de desconfianza que inspira manifiestamente este concepto en los juristas franceses clásicos. La doctrina clásica, conectada con la libertad y la seguridad, en el campo del derecho francés de los contratos, no ve con buenos ojos la introducción de ese concepto....La mayoría de autores....se muestran, en efecto, extremadamente reservados, no solamente con relación a la idea de acoger esta regla comportamental, sino también de atribuirle un papel significativo en nuestro derecho contractual", sin perjuicio que para este autor ella se constituye en "...un concepto particularmente edificante". La confiance légitime et l'estoppel. Rapport francaise, Societé de Législation Comparée, Paris, 2007, p. 246. Cfr. B. FAUVARQUE-Cosson, señala que hay autores que entienden "...en el derecho francés, que no posee doctrinas específicas, no se puede acoger en su seno ni conceptos ni reglas flexibles, imprecisas, marcadas de subjetividad, tales como la confianza legítima...., o la coherencia contractual". La confiance légitime et l'estoppel, Rapport général, ibidem, p. 41.

189 Vid. Julien Bonnecase. L'ecole de l'exégése en droit civil, E. de Boccard, Editeur, Paris, 1924, p. 150, quien memora como, en desarrollo de la omnipotencia asignada a la ley por los militantes de esta escuela, en particular por MOURLon, "...el magistrado debe deponer su razón ante la razón de la ley, porque él está instituido para juzgar según ella y no para juzgarla ...En jurisprudencia no hay, no puede haber razón más razonable, equidad más equitativa, que la razón o que la equidad de la ley “. Cfr. Ricardo L. LoRENZETTI, Razonamiento judicial, Lima: Grijley, 1998, p. 209, y Eduardo García De EnTERRía, quien observa que de acuerdo con el pensamiento revolucionario galo, "...todo el Derecho debe encerrarse en las leyes, los jueces deben limitarse a inquirir de la ley la solución debida, fuera de la ley no hay criterios jurídicamente válidos. En otros términos: la Revolución Francesa ha conducido a lo que derechamente llamamos positivismo jurídico o legalista. Esta concepción del Derecho y, sobre todo, este mecanismo de ordenación y regulación social rigió pacíficamente en 
era misión de los profesores de Derecho 'protestar contra cualquier innovación tendente a sustituir la voluntad del legislador por otra distinta', revelando así una aversión...a todas las novitates"190.

No es de extrañar entonces que en esta escuela imperara una visión prevalentemente legalista, a fuer que dogmática, en la que el culto a la ley fue la nota reveladora de su ideología. Por eso, agudamente, el profesor Ch. PERELMAN no vacila en aseverar que "En esta perspectiva los juristas de la Escuela de la exégesis se consagraban a su tarea de tratar de limitar el papel del juez al establecimiento de los hechos y a la subsunción de los mismos bajo los términos de ley", de lo que se desprende que "...el papel del juez le obliga siempre que sea posible, y se entiende que lo es en la mayor parte de los casos, a emitir su juicio conforme a la ley, sin tener que preocuparse por el carácter justo, razonable o aceptable de la solución propuesta. Como servidor de la ley, no tiene que buscar fuera de ella otras reglas que la guíen: el es el portavoz de la ley...."191.

\subsubsection{La codificación y el Derecho civil italiano}

Alguna parte de lo señalado en líneas anteriores, en lo pertinente, resulta predicable del Derecho italiano, específicamente en lo que concierne a su derecho decimonónico, habida cuenta de la aproximación -que no identidad entre el Código Civil italiano de 1865, y el Código de Napoleón-, ${ }^{192}$ situación que no puede hacerse extensiva al siglo XX, a partir del advenimiento del Código Civil italiano de 1942, y de sus puntuales modificaciones e interpretaciones, gracias al viraje registrado.

Europa una vez instaurada la codificación, concluida a lo largo del siglo XIX". La democracia y el lugar de la ley", en Derecho, la ley y el Juez. Dos estudios, Madrid: Civitas, 1997, p. 44.

190 R.C. Van Caenegem. Pasado y futuro del derecho europeo. Dos milenios de unidad y diversidad, Thomson-Civitas, Madrid, 2003, p. 79.

191 Ch. Perelman. La lógica jurídica y la nueva retórica, Civitas, Madrid, 1979, p.p. 40 y 57. Acerca del positivismo jurídico, su aplicación y su evolución, véase a Paolo CoMANDUCCI, M. Angeles Ahumada y Daniel González LagIer, Positivismo jurídico y neoconstitucionalismo, Fundación Coloquio Jurídico Europeo, Madrid, 2009.

192 Vid. Carlos Augusto CANNATA, quien anota que para la época "El sistema de la legislación privatistica de Italia unitaria deriva innegablemente de la codificación francesa". Lineamenti di storia della giurisprudenza europea, op. cit, p. 147. 
Así, sólo para referir a un aspecto concreto, en el Derecho italiano antes de la promulgación del afamado Código Civil de 1942, había conciencia en la doctrina de que si bien es cierto, en principio, "Cada quien puede usar su derecho, como mejor le plazca....", según lo recuerda el profesor N. CovielLo, “... si los varios derechos de los hombres asociados entre sí son por su naturaleza o por la ley exactamente limitados, no hay duda en que el ejercicio del derecho por parte de uno no puede acarrear una lesión al derecho de otro....porque muy frecuentemente acontece que un derecho se lesiona precisamente por el ejercicio de otro derecho", ${ }^{193}$ ecuánime postura que, en general, contrastaba con la asumida durante un apreciable número de lustros en Francia, más refractaria a la limitación del ejercicio de los derechos, a raíz del referido dogma de la autonomía de la voluntad, en concreto a los alcances conferidos, como tuvimos ocasión de mencionar, y claro está y a concepciones aún más antiguas, en las que "...el derecho de crédito era concebido como poder fiero y absoluto", según lo relata de DE MARTINO ${ }^{194}$.

Ya en vigencia del Código del cuarenta y dos, mayor consciencia se adquirió alrededor de que los derechos, en su ejercicio, no son omnímodos, de tal suerte que conocen límites objetivos que no pueden ser soslayados. Es así como el artículo 833, en lo aplicable, prescribe que "El propietario no puede realizar actos que no tengan otra finalidad que la de perjudicar o producir molestias a otros", norma que si bien no puede erigirse en la adopción generalizada -y ex lege-del abuso del derecho, si es meridiana en evidenciar que el ejercicio de los derechos en referencia es limitado, la que en tal virtud debe ser articulada con el artículo 1375 , sin duda de mayor espectro, con sujeción al cual: "El contrato deberá ser

193 Nicolás Coviello. Doctrina general de derecho civil, Unión Tipográfica Editorial HispanoAmericana, México, 1938, pp. 525 y 526.

No huelga mencionar que el artículo 147 del Proyecto Franco-Italiano de las obligaciones, con un carácter más panorámico, puso de relieve que "Cada acto o hecho que manifiestamente exceda la intención del autor, por objeto o por circunstancias en la que es considerado el ejercicio normal de su derecho, no es protegido por la ley y provoca eventualmente la responsabilidad del autor".

Acerca del concepto y alcance de los derechos subjetivos con anterioridad del Código Civil de 1942, Vid. Giovanni Pugliese. Actio e diritto subietivo, Giuffrè, Milano, 1939, Roberto De Ruggiero. Instituciones de derecho civil, Reus, T.I, Madrid, 1979, p. 206.

194 Francesco De Martino. Individualismo y derecho romano privado, op. cit, p. 79. 
ejecutado de acuerdo con la buena fe" ${ }^{195}$. Y es justamente en el marco de la buena fe que se tiene establecido que de ella emanan diáfanos deberes, v.gr: el de cooperación, bona fides en la que autores de la nombradía del profesor BETTI, expressis verbis, incluyeron la regla del venire contra factum proprium. Ello explica que el catedrático de la Universidad de Roma, a la sazón, expresara que "La buena fe, en fin, es considerada en cuanto a que lleva a descubrir un abuso de derecho o conduce a prevenir el ir contra el propio acto, estableciendo una serie de limitaciones, conforme a una exigencia de coherencia en el comportamiento antecedente y en el subsiguiente....Esto es lo que sucede en los supuestos de abuso de derecho y también en el caso del venire contra factum proprium. En tales casos, la ley, aplicando la exigencia de la corrección debida entre las partes, establece un límite al ejercicio del derecho...."196.

Así las cosas, al amparo de la buena fe, en la segunda parte del siglo $\mathrm{XX}$, se albergó el venire contra factum proprium de modo muy general y algo episódico ${ }^{197}$, y en lo transcurrido del siglo XXI, de manera más sistemática, amén de orgánica y frecuente, todo como corolario de la anunciada revitalización o reverdecimiento de la bona fides en Italia -y en Francia-, según a espacio nos ocupamos del tema (Cap. I, 2.3). Por ello en la presente centuria, retomando el término medieval italiano (venire contra factum proprium), varias obras se han editado, dedicadas privativamente a esta temática, hecho que corrobora su actual y creciente importancia dogmática y jurisprudencial, más de la que se la había conferido en el siglo anterior, inclusive ${ }^{198}$.

195 Vid. Virgilio GIorgiannı. L'abuso del diritto nella teoria delle norma giuridica, Milano, Giuffrè, 1963, pp. 206 y ss.

196 Emilio BetTI. Teoría general de las obligaciones, T. I, op. cit, p. 100.

197 Vid. Giovanni Cattaneo, "Buona fede obbiettiva e abuso del diritto", op. cit, pp. 621 y ss.

198 Véase, entre varios, a Paolo Gallo, Contratto e buona fede, op. cit. p. 787; Francesco Astone, Venire contra factum proprium, op. cit; Fiorenzo FestI, Il devieto di venire contra il fatto proprio, op. cit, y a Federico PROCCHI, L'Exeptio doli generalis e il devieto di venire contra factum proprium, op. cit. 


\subsubsection{La codificación y el Derecho civil español}

No aconteció lo mismo, empero, con el Código Civil español de 1889, sobre todo con su hermenéutica, habida consideración que la doctrina del acto propio, felizmente, encontró franca acogida, tanto en la teoría, como en la jurisprudencia, pese a compartir elementos comunes -en lo pertinente- con la codificación francesa, en sede contractual ${ }^{199}$. De hecho España, lo expresamos sin ambages, es uno de los países pioneros en este campo de la recepción de la regla, mucho antes que lo hicieran otros que, en principio, hubieran podido darle cabida anticipada, v.gr: Italia y Francia, precisamente por sus antecedentes históricos. De ahí que sea referente obligado para su cabal escrutinio, el que a todas luces se tornaría incompleto si no se tuvieran muy en cuenta sus fértiles aportes, bien en la órbita doctrinal, bien en la jurisprudencial. En uno y en otro, es la realidad, el Derecho español ha sido fecundo, amén que visionario, coherente, y respetuoso de los derechos ajenos.

Varias razones, es cierto, sirven de apoyo y explicación de su acogimiento temprano, entre otras las siguientes, las que registraremos sucintamente:

En primer lugar, porque en el seno del Derecho histórico español, las afamadas Siete Partidas, uno de los cuerpos jurídicos de mayor relevancia en la cultura jurídica occidental, plasmó en el siglo XIII un precepto muy similar al

199 Como lo memora el profesor Rodolfo VIGO, "El paradigma dogmático-legalista se constituyó en Europa continental en el siglo XIX básicamente a instancias de la escuela exegética, la escuela histórica y el primer lhering; y entre sus diferentes postulados característicos destaquemos....los siguientes: 1. La sinonimia medular entre derecho y ley, remitiendo la Constitución al mundo no jurídico de lo político; 2. La tajante separación entre creación y aplicación del derecho: aquella, librada a la voluntad perfecta del legislador, y ésta confiada a una razón judicial aséptica, que mediante un elemental mecanismo de subsunción repetía sin dificultades la ley para el caso; y 3 . El valor jurídico decisivo y central del modelo era la "seguridad jurídica", en cuanto saber a qué atenerse jurídicamente o contar con la respuesta previsible y anticipada para cada problema jurídico. Para ese paradigma no había espacio ni necesidad de razonamiento justificatorio, pues la decisión creadora del legislador se justificaba en sí misma y era incontrolable, y luego venía el irrelevante silogismo formal judicial de rigurosidad teórica" Constitucionalización y judicialización del derecho, op. cit, p. 137.

Vid. Francisco Tomas y Valiente, Manual de historia del derecho Español, Tecnos, Madrid, 1992, p. 552. 
pasaje incorporado en el Digesto justinianeo, de autoría de CELSO (D.8.3.11), que por su importancia reproducimos de nuevo, indicativo, in casu, de su rechazo a la contradicción. Nos referimos a la Partida Tercera, Título 31, Ley 10, con arreglo a la cual: "Los señores de los edificios, e de las heredades, pueden poner cada uno de ellos, servidumbre a su edificio o a su heredad. Pero si muchos fueren señores de un edificio, o de una heredad, a que quieran poner servidumbre, todos la deben otorgar cuando la ponen. E si por ventura la otorgasen algunos, e non todos, aquellos que la pusieron non la pueden después contrastar, que la non haya aquel a quien la otorgaron. Mas los otros que la non quisieron otorgar, bien la pueden contradecir cada uno de ellos también por la su parte como por la de los otros que no la otorgaron".

En segundo lugar, por cuanto de antiguo sus exponentes se ocuparon expresamente de la regla venire contra factum proprium, la que no pasó entonces desapercibida, o ignorada. Prueba de ello son las aportaciones de don Melchor Peláez ${ }^{200}$ y de Joannis Del CAstillo SotomayoR ${ }^{201}$, divulgadas en 1620 y en 1726, respectivamente, al igual que las de Joannis GutiéRREZ ${ }^{202}$, Antonni GomeZz| ${ }^{203}$ y Bartolomé Agustín RodRíguez, también difundidas, en su orden, en 1730, 1761 y 1775 , motivo por el cual para los juristas españoles en mención, a la par que para otros más de la época, el venire y su correlativo rechazo, en general, estaba aceptado en el campo autoral español. En este sentido, por vía de diciente ilustración, para el último de los citados autores, "A ninguno le es permitido decir contra su hecho propio, aunque por derecho no sea válido (1): por esto no puede el padre contradecir la emancipación de la hija después de muerta; y en caso de que para ello tuviera razón, debió hacerlo en vida, sin consentir que viviese emancipada hasta la muerte"204.

\footnotetext{
200 Melchor PelÁEz. Tractatus maioratuum et meliorationum Hispaniae, T. II, 1620, p. 179.

201 Joannis Del Castillo Sotomayor. Repertorium generale rerum notabiliorum, Coloniae, M.DCCXXVI, p. 47.

202 Joannis GutiéRREZ. Operum. Tractatus tripartitus de juramento confirmatorio, Tomus Sextus, M.DCC.XXX, p. 3.

203 Antonni GomezzI. Ad leges tauri commentarium absolutissimum, Lugduni, M. DCCLXI, p. 420.

204 A. Bartolomé Rodríguez. Digesto teórico-práctico, o Recopilación de los derechos común, real y canónico por los libros y títulos del Digesto, T. I, Madrid, MCCCLXXV, p. 92.
} 
En tercer lugar, porque en algunos de los artículos de su estructurado Código Civil de 1889, igualmente hay evidencia de la inviabilidad de volver sobre el acto propio, en muestra elocuente de la idea de no tolerar, generalizadamente, la contradicción y la incoherencia comportamental, todo en consonancia con lo consagrado en las mencionadas Siete Partidas. Así sucede, ad exemplum, con el artículo 597, que a la letra expresa: "Para imponer una servidumbre sobre un fundo indiviso se necesita el consentimiento de todos los copropietarios. La concesión hecha solamente por algunos, quedará en suspenso hasta tanto que la otorgue el último de todos los partícipes o comuneros. Pero la concesión hecha por uno de los copropietarios separadamente de los otros obliga al concedente y a sus sucesores, aunque lo sean a título particular, a no impedir el ejercicio del derecho concedido".

Como se observa, el quid de esta norma estriba en su parte final, habida consideración que, no obstante no ser plenamente eficaz la cesión parcial en las descritas condiciones ("en suspenso"), la cesión individual efectuada por uno de los copropietarios impide que, ex post, se obstaculice el ejercicio de un derecho ya concedido, en muestra del respeto al acto propio, ex ante materializado: la concesión en cuestión, el cual se extiende también a sus sucesores. Gráfico, en grado superlativo, es el Dr. Francisco ORTEGA LORCA, de acuerdo con el cual, comentando esta norma, "Lo esencial es que se llegue a reunir la suma de todos los acuerdos parciales, produciendo cada uno de estos contra sus autores, y antes de conseguirse la suma total, obligaciones para en lo sucesivo, que no pueden olvidarse ni infringirse. Si llegara a obtenerse el consentimiento unánime de los restantes, quien o quienes otorgaron su aprobación primeramente, no podrán volverse atrás, 'han soltado prenda', como vulgarmente se dice, y les es imposible legalmente recogerla" 205 .

Lo mismo sucede, como se ha interpretado en algunas latitudes, sobre todo en el Derecho francés a la luz del artículo 1178 del C.C. $-y$ colombiano art, 1538 C.C.-, con el contenido del artículo 1119 del Código Civil español, que dispone que "Se tendrá por cumplida la condición cuando el obligado impidiese

$\overline{205}^{2}$ Francisco Ortega Lorca. Quintus Mucius Scaevola. Código Civil, T. X, Reus, Madrid, 1947, p. 772 . 
voluntariamente su cumplimiento", toda vez que sería a todas luces incoherente, mejor aún contradictorio, que el deudor sub conditione, luego de crear confianza legítima en su acreedor (factum proprium), en el sentido de que si se cumple determinado "...sucedo futuro o incierto", tendrá lugar "...la adquisición de los derechos" consentida (arts. 1113 y 1114, C.C.), proceda inconsultamente a impedir el cumplimiento de la condición (factum novum), en franco desafío de lo asentido previamente-, norma alrededor de la cual ya hicimos un comentario en este capítulo (5.2), y lo haremos nuevamente en el último-.

En cuarto lugar, por cuanto la jurisprudencia del Tribunal Supremo, mucho antes que otros tribunales en la esfera internacional, acogió el venire contra factum proprium, en concreto la doctrina de los actos propios como una de sus arquetípicas manifestaciones. Y lo hizo en el siglo XIX, en particular en el año de 1864, incluso antes del advenimiento del Código Civil vigente, por lo menos de conformidad con el datum y la información judicial de la que hoy disponemos. En aquella memorable ocasión, el Supremo, con motivo de una pretendida 'nulidad y rescisión de una partición de herencia', efectivamente expresó -el 28 de mayo-que tales “....acciones de nulidad y rescisión propuestas alternativamente por el demandante no eran procedentes: la primera porque él no podía ir contra sus propios actos solemnemente reconocidos y, la segunda, porque, además de no haberla deducido en tiempo, no ha probado la lesión enormísima en la que la apoyaba".

Centenares de sentencias, en el marco del Código Civil de 1889, se han producido luego de este primer fallo del Tribunal Supremo, en clara demostración del arraigo de esta doctrina en sede judicial, siendo esta una de las notas más salientes del Derecho español, en general, en donde el llamado 'Derecho pretoriano' ha ejercido una notable y anticipada influencia, en razón de que no nos cansamos de tributarle un categórico reconocimiento a la jurisprudencia española, puesto que difícilmente se aprecia en el concierto mundial tanta actividad y escrutinio en esta materia. No en vano, bien lo recordó don Luís Diez-PICAZo en el año 1963, que "La doctrina de los actos propios es una institución que posee, en el Derecho Privado Español, una sobresaliente importancia práctica. Mas de doscientas sentencias del T.S. lo atestiguan de una manera irrecusable"206, número

$\overline{206}$ Luís Diez-PICAZO, La doctrina de los propios actos, op. cit., p. 15. 
que a la fecha, huelgan prolijas estadísticas, ha aumentado considerablemente en estos últimos cincuenta años, confirmando nuestra apreciación anterior, en el sentido de cómo España ha contribuido decididamente a la maduración y difusión de la doctrina de los actos propios, aun cuando siempre serán bienvenidos nuevos y frondosos estudios, puesto que aún hay mucho por evaluar, agregar, ajustar, replantear y seguramente corregir.

En quinto lugar, porque así se añoren más y nuevas contribuciones por parte de la doctrina española, lo cierto es que, de vieja data, el interés de algunos autores por el estudio de la doctrina en comento, se remonta un siglo ${ }^{207}$, prácticamente. Es el caso del escrito de don Carlos L. DE HARO, del año 1913, un año después del señero aporte académico de E. RIEZLER en Alemania (Venire contra factum proprium), del que nos ocuparemos a continuación, titulado Los 'actos propios' en la Jurisprudencia del Tribunal Supremo, el cual fue publicado en la naciente Revista de Derecho Privado (año I, Núm. 1) ${ }^{208}$. A dicho escrito introductorio, otros lo siguieron, sobresaliendo tres trabajos en la década del cincuenta, y uno emblemático en la década del sesenta. Tales trabajos de la mitad del siglo pasado, en su orden, fueron el ilustrativo y valioso estudio del profesor José PuIG BRUTAU, titulado La doctrina de los actos propios, publicado en el año 1951, junto a otros estudios de su autoría ${ }^{209}$. Y los restantes, inscritos más en el terreno del Derecho público, de Laureano LóPEz Rodo, rotulado Presupuestos subjetivos

207 En esta dirección, el propio profesor Diez-PICAZo, luego de reconocer abiertamente el papel protagónico de la jurisprudencia española en esta temática, expresó que "Es casi inadmisible, por esto, la escasa atención que la doctrina civilista de nuestro país ha dedicado al tema". La doctrina de los propios actos, op. cit., p. 15.

208 Carlos De HARO. “Los 'actos propios' en la Jurisprudencia del Tribunal Supremo”, en Revista de Derecho Privado, Madrid, 1913, pp. 17 y ss.

209 José Puig Brutau. "La doctrina de los actos propios", en Estudios de derecho comparado, Ariel, Barcelona, 1951, pp. 97 y ss. En el año 1950, en la Nueva Enciclopedia Jurídica, el mismo autor había publicado un artículo más breve con el nombre de "Actos propios", Seix, Barcelona, 1950, p. 348 y ss. El influjo de este autor trascendió el Derecho español, de suerte que en el año 1957, en uno de los primeros escritos alusivos al tema en comento en América Latina, se le siguió de cerca. Vid. Isabel. M. Pizza De LunA. "La doctrina de los actos propios y su aplicación en las legislaciones modernas", en Estudios jurídicos en memoria de Eduardo J. Couture, Facultad de Derecho y Ciencias Sociales, Montevideo, 1957, pp. 557 y ss. 
para la aplicación del principio que prohíbe ir contra los propios actos (1952) ${ }^{210}$, y de Eduardo García De EnTERRIA, identificado con el nombre de La doctrina de los actos propios y el sistema de lesividad (1956) ${ }^{211}$.

Y en la década del sesenta, por su parte, el enjundioso libro del profesor Luís Diez-PICAZo, un oráculo en esta materia, tan cabalmente concebido y escrito, que aún conserva plena vigencia y actualidad suma: $L a$ doctrina de los propios actos ${ }^{212}$. Otros ensayos y escritos específicos, aun cuando no en demasía, igualmente vieron la luz en las décadas restantes del siglo $X X$, y en lo corrido del $X X{ }^{213}$.

En sexto lugar, por cuanto en el año 1974, se sustituyó el contenido del artículo 7 del Código Civil de 1889, a fin de darle cabida a una norma que en buena hora se ocupara del ejercicio de los derechos y del abuso del derecho, básicamente, con sujeción a los siguientes términos: "1. Los derechos deberán

210 Laureano LóPEZ Rodo. "Presupuestos subjetivos para la aplicación del principio que prohíbe ir contra los propios actos", en Revista de Administración Pública, Madrid, 1952, pp. 11 y ss.

211 Eduardo García De Enterría. "La doctrina de los actos propios y el sistema de lesividad", en Revista de Administración Pública, Madrid, 1955, pp. 70 y ss.

212 Luís Diez-Pıcazo. La doctrina de los propios actos, op. cit., publicación acerca de la cual tuvimos oportunidad de manifestar en la presentación que de su monografía La doctrina del enriquecimiento sin causa, honrosamente hiciéramos, que se trata de una "...obra señera, única en su campo, que antes de marchitarse por el paso de los lustros, día tras día se reverdece. Mutatis mutandis, es como el retrato de Dorian GRAY, imperturbablemente joven". Carlos Ignacio JARAMILLO, Bogotá, Universidad Javeriana, Depalma, y Grupo Editorial Ibañez, Bogotá, 2011, p. 18. De esta misma obra, el profesor Emilio BETTI, en la década del sesenta, manifestó elogiosamente que "Frente al escaso interés que nuestros civilistas demuestran, en general, hacia el estudio del Derecho comparado, merece una honrosa mención el reciente libro del colega Luis Diez-PICAZO y PONCE DE LeÓN: La doctrina de los propios actos....". Reflexiones sobre la noción de negocio jurídico, op. cit., p. 40.

213 Sin pretender una enumeración exhaustiva, vale la pena mencionar, igualmente en la década del sesenta, el conocido libro del profesor José Luís De Los Mozos. El principio de la buena $f e$, en el que su autor se ocupa de esta doctrina, en forma somera, Bosch, Barcelona, 1965, p. 209. Y más ampliamente el interesante y ulterior estudio del profesor José María MIQUEL GonZALES, Acto propio, op. cit., continuación de otro trabajo suyo: "Actos propios", publicado en 1983, en Cuadernos Cívitas de Jurisprudencia Civil, Número 1, Madrid, pp. 77 y ss. Y ya en esta centuria, el trabajo del profesor Carlos RogeL VIDE, titulado "La doctrina de los propios actos en la última jurisprudencia civil española", Segunda Parte, en La doctrina de los actos propios, en coautoría del Dr. Marcelo López MESA, Reus y B de F, Buenos Aires, 2005, pp. 205 y ss., y M. Nelida TUR FAUNDEZ. La prohibición de ir contra los actos propios y el retraso desleal, Aranzadi y Thomson Reuter, Pamplona, 2011. 
ejercitarse conforme a las exigencias de la buena fe. 2. La ley no ampara el abuso del derecho o el ejercicio antisocial del mismo. Todo acto u omisión que por la intención de su autor, por su objeto o por las circunstancias en que se realice sobrepase manifiestamente los límites normales del ejercicio de un derecho, con daño para tercero, dará lugar a la correspondiente indemnización y a la adopción de las medidas judiciales o administrativas que impidan la persistencia en el abuso".

Es de observar que al amparo de esta nueva normativa, la temática de la buena fe ha adquirido en territorio español singular valía, acelerando el proceso de su especial y amplio reconocimiento por parte de la jurisprudencia y la doctrina, toda vez que se ha reconocido que "... fue la positivización de la buena fe como cláusula general en el art. 7 del CC (1974) -siguiendo a los modelos alemán y suizo-lo que le otorgó un impulso decisivo para la asociación con las orientaciones jurídicas más avanzadas del derecho privado europeo. De esta manera aumentó el empleo fructífero de la buena fe por la ciencia jurídica española". ${ }^{214}$

Dicha norma jurídica también ha servido para darle aún mayor sustento a la doctrina de los actos propios, entendida como inequívoco límite al ejercicio de los derechos subjetivos, laborío asignado a la buena fe, de modo general, y a otras de sus manifestaciones, de modo particular ${ }^{215}$. Igualmente ha servido para

${ }_{214}$ Christian ECKL. "Algunas observaciones alemanas acerca de la buena fe en el derecho contractual español", en Bases de un derecho contractual europeo, Tirant lo blanch, Valencia, 2003, pp. 41 y 42.

Del mismo modo, vale la pena recrear, como recientemente lo manifestó el Tribunal Supremo Español, que " La buena fe ha sido interpretada como principio general o como cláusula abierta, aunque en definitiva debe considerarse como principio positivizado que impone deberes a los titulares de los derechos. En el art. 7.1 CC se recoge uno de los aspectos principales de las consecuencias de la buena fe...." (Sentencia del 12 de diciembre de 2011, 8594).

215 Como lo menciona don José Luís LACRUz BERDEJo, con ocasión de la temática relativa al 'ejercicio de los derechos', en concreto a la buena fe y al artículo 7 en mención, "Desde siempre se ha entendido que el derecho subjetivo ha de ejercitarse con la posible moderación y prudencia; en particular cuando choca con intereses ajenos. Actualmente el art. 7.1. Cc. dice que los derechos deberán ejercitarse conforme a las exigencias de la buena fe. La buena fe sólo puede predicarse de la actitud de uno en relación con otro (y viceversa): significa que este otro, según la estimación habitual de la gente, puede esperar determinada conducta del uno, o determinadas consecuencias de su conducta...En la 
que en el plano doctrinal, algunos autores, con ocasión de su examen, se hayan ocupado de subrayar las notas más salientes del acto propio ${ }^{216}$.

En séptimo y último lugar, para no extendernos más, porque en el año 1978, se profirió la nueva Constitución española, al amparo de la cual la doctrina de los actos propios adquirió raigambre y resonancia constitucional, habida cuenta que diversas normas suyas le sirven de apoyatura para dicho efecto, aspecto para nada intrascendente, en nuestro entender, merced al carácter envolvente asignado a la carta fundamental, no sólo en sede del Derecho constitucional, sino en general. El preámbulo de la Constitución es pródigo en valores y postulados que cumplen dicha misión. Es el caso de su encabezado, cuando realza la justicia, la libertad, la seguridad y la promoción del bien de quienes integran la nación, según el cual "La Nación Española, deseando establecer la justicia, la libertad y la seguridad y promover el bien de cuantos la integran...." Lo propio acontece con el primer apartado u ordinal, que reza que se garantiza "...la convivencia democrática dentro de la Constitución y de las Leyes conforme a un orden económico y social justo", al igual que su artículo 1, el que dispone: "España se constituye en un Estado social y democrático de Derecho, que propugna como valores superiores de su ordenamiento jurídico la libertad, la justicia, la igualdad y el pluralismo político", y el art. 9, numeral 3, que expresa “La Constitución garantiza el principio de legalidad, la jerarquía normativa, la publicidad de las normas, la irretroactividad de las disposiciones sancionadoras no favorables o restrictivas de derechos individuales, la seguridad jurídica, la responsabilidad y la interdicción de la arbitrariedad de los poderes públicos".

Lo anterior explica, consecuentemente, que el Tribunal Constitucional Español, en lo de su competencia, se haya ocupado en varias ocasiones de la doctrina de los actos propios, con mención especial a la regla venire contra factum proprium, y al deber de coherencia comportamental ${ }^{217}$.

jurisprudencia, la aplicación más señalada de tal exigencia es la llamada 'doctrina de los actos propios'..... Elementos de derecho civil, op. cit., cit, pp. 58 y 59.

216 En adición a los autores ya citados, véase el reciente comentario de la autora Clara I. AsúA González. Artículo 7. Código Civil Comentado, op. cit., pp. 90 y ss.

217 El Tribunal Constitucional, en sentencia del 21 de abril de 1988, señaló que “...la llamada doctrina de los actos propios o regla que decreta la inadmisibilidad del venire contra 


\subsubsection{La codificación y el Derecho civil alemán. Expansión generalizada de la regla venire contra factum proprium.}

A diferencia del Código Civil francés, el Código Civil alemán, edificado en las postrimerías de la Escuela Pandectista (1896), y de los demás códigos de los siglos $X X$ y XXI, registra un cambio significativo, puesto que el aludido individualismo galo se modificó por una cosmovisión más social y, por ende, solidaria y tuitiva, encaminada a la tutela sostenida de los derechos legítimos, más allá de rígidas concepciones de naturaleza puramente voluntarística ${ }^{218}$, contrarrestadas con las llamadas 'gotas de aceite social' de la época de BISMARCK y gracias a los aportes 'cooperativos' de Otto Von GieRKE, acrecentadas años después en pleno vigor del Código Civil (BGB), vigente desde el primero de enero de $1900^{219}$. Bien expresa R. Zimmerman que "Los padres del BGB vieron en la protección de la parte económicamente más débil un importante objetivo político y enfatizaron la necesidad de sensibilidad social. De todo ello se encuentran manifestaciones en el Código. Una de ellas son, desde luego, las famosas 'cláusulas generales', como los artículos 138, 226, 242 y 826 BGB que, con el tiempo, han demostrado ser

factum proprium, surgida originariamente en el ámbito del Derecho privado, significa la vinculación del autor de una declaración de voluntad generalmente de carácter tácito en el sentido objetivo de la misma y la imposibilidad de adoptar después un comportamiento contradictorio, lo que encuentra su fundamento último en la protección que objetivamente requiere la confianza que fundadamente se puede haber depositado en el comportamiento ajeno y la regla de la buena fe que impone el deber de coherencia en el comportamiento y limita por ello el ejercicio de los derechos subjetivos. Quiere ello decir...que tal doctrina puede ser aplicable a las relaciones jurídicas regidas por el Derecho administrativo y por el Derecho público en general....", obviamente“...con las necesarias matizaciones, que no la desvíen de los principios rectores que constituyen su fundamento último, que son, como acabamos de recordar, la protección de la confianza y la protección de la buena fe".

218 Cfr. Erich Molitor y Hans Schlosser. Perfiles de la nueva historia del derecho privado, Bosch, Barcelona, 1975, pp. 100 y 101. Al respecto, Hans PLANITZ corrobora que en sintonía con el cambio legislativo de comienzos del siglo XX, "...se van formando instituciones jurídicas de neto matiz social". Principios de derecho privado germánico, Bosch, Barcelona, 1957, p. 5.

219 Si bien es cierto que en la prestigiosa Escuela Pandectista comenzó a fraguarse el Código Civil alemán, el que tardó varios años en consolidarse, en ella no se registró un definido interés por rescatar y perfilar la regla del venire contra factum proprium, a diferencia de lo sucedido en punto a la exceptio doli generalis, según lo atestigua Federico $\mathrm{P}_{\mathrm{ROCCH}}$, quien expresa cómo al contrario de lo sucedido con la exceptio en mención, "....el principio de no contradicción fue casi totalmente ignorado por los manuales de Pandectas", afirmación que justifica el título asignado al desarrollo de este tema: "El silencio de la pandectista". L'Exeptio doli generalis e il devieto di venire contra factum proprium, op. cit., p. 92. 
instrumentos muy flexibles, que han permitido aplicar algo más que unas cuantas gotas de aceite social en la fábrica del BGB"220.

Y es justamente en armonía con lo prescrito por el citado artículo 242 del $B G B$, atinente a la buena fe, que la doctrina y la jurisprudencia alemanas, y luego la suiza, la austriaca, y otras más, encontrarán, en lo pertinente, el marco general en el cual inscribirían -e inscriben- la regla del venire contra factum proprium, en un auténtico renacimiento de este potente remedio conductual, llamado a conjurar sus desviaciones, en sí mismo preexistente como se anotó a espacio, desde hacía varias centurias, aunque marchitado o por lo menos en profunda hibernación. Dicho artículo es del siguiente tenor: "El deudor está obligado a efectuar la prestación como exigen la fidelidad y la buena fe en atención a los usos del tráfico".

Tal vez el primero en ocuparse del tema en Alemania, indiscutiblemente cuna de la nueva morfología de la regla en comentario, fue Erwin RIEZLER, a quien hay que rendirle explícito y reiterado reconocimiento por su excelso aporte a la ciencia del Derecho germano y universal, en general, autor de la renombrada obra que lleva por título, justamente, el asignado a la misma: Venire contra factum proprium, publicada en Leipzig ${ }^{221}$, que en esta materia ha marcado la pauta, por la amplitud de sus fuentes, por su dilatado espectro (Derecho romano, medieval, inglés y alemán), por su manifiesta riqueza histórica, y por su deseo de dotarla de cierto cuerpo y unidad histórica, sin renunciar al examen de los diversos supuestos en los que nítidamente se manifiesta, pero no en forma por completo aislada y arbitraria.

Se trata, efectivamente, de una fiable brújula que, por decenios, ha guiado a la dogmática y a la jurisprudencia; una de esas investigaciones inmortales que, por su enjundia, trascendieron y seguirán trascendiendo, y que sirvieron para que

220 Reinhard Zimmermann. El nuevo derecho alemán de obligaciones. Un análisis desde la historia y el derecho comparado, Bosch, Barcelona, 2008, pp. 188 y 189.

221 Erwin RIEZLER, Venire contra factum proprium. Studien im römischen, englischen und deutschen civilrecht, Leipzig, 1912. 
otros estudios continuaran con su examen ${ }^{222}$, éste que sigue siendo aún necesario, toda vez que la tarea no ha terminado, por más logros que se hayan alcanzado en la materia. No en vano, varias veces lo hemos advertido, es una institución en construcción, si se quiere en tránsito a la adultez -que no a la senectud-, aunque no por ello carente de lozanía, vigor, esplendor y pertinencia.

Así las cosas, la doctrina y la jurisprudencia alemanas, con fundamento en el mencionado trabajo monográfico de E. RIEZLER, han proseguido con el detenido análisis del venire y de sus diversas manifestaciones (GriESBECK, LARENZ, CANARIS, Siebert, Wieling, FLUmE, etc.), lo que explica su profusión y el interés registrado en otras latitudes, más allá del nomen asignado a la institución que, salvo puntuales excepciones, no tiene contemplaciones con la contradicción, la incoherencia, y la incongruencia lesivas. Es el caso de Inglaterra, Suiza, Austria, Holanda, Bélgica, Hungría, España, Portugal, Italia, Francia, Japón, Australia, Estados Unidos, Canadá, Brasil, Argentina, Uruguay, Chile, Colombia, Puerto Rico, Bolivia y Perú, sólo para aludir a algunas naciones del orbe que comulgan con el mismo ideario ${ }^{223}$, positiva actitud que corre pareja con el interés mostrado por algunas legislaciones nacionales e internacionales de acogerlo en su seno preceptivo, al igual que por la principialística del siglo XXI, en muestra del sitial en el que se encuentra hoy (UnIDRoIT, Principios del Derecho Europeo de Contratos, Anteproyecto de Código Europeo de Contratos, Marco Común de Referencia, etc.).

\subsection{Compendio general}

En compendio, la historia de la regla del venire contra factum proprium es rica, y no obedece, únicamente, a estadios muy anteriores, v.gr: al Derecho romano clásico, ni tampoco a muy recientes, propios de la llamada 'edad global' (nuevo milenio), de tal suerte que a través de los siglos se ha decantado, y sigue aun

222 Acerca del contenido y alcance de la obra de E. RIEZLER, con provecho, puede verse a Don Luís Diez-Picazo. La doctrina de los propios actos, op. cit., p. 87 y ss.; Antonio Menezes CordeIRo, Tratado de direito civil portugues, op. cit., p. 279 y ss., y a Fiorenzo Festı. II devieto di 'venire contro il fatto proprio', op. cit., p. 32 y ss.

223 Véase, igualmente con utilidad, la obra intitulada La confiance légitime et l'estoppel, Societé de Législation Comparée, Paris, 2007, en la que se consignan estudios que abarcan buena parte de los citados países. 
decantándose. Y también es accidentada, habida cuenta que ha tenido momentos de consolidación y auge, pero también de olvido y desinterés manifiestos y, de paso, de tozuda incomprensión radicada en cabeza de algunos que, en un plano crítico, abogan por su abandono, debilitamiento o su inaplicación ${ }^{224}$. No hay en ella, pues, un continuus, sin perjuicio que todo hace presagiar que lo habrá, puesto que tiene presente y un futuro, a nuestro juicio realmente prometedor, como lo tienen los institutos que se asientan en la buena fe y que son protagonistas de la apellidada justicia contractual, a que hemos aludido en ocasiones, obviamente con toda la cautela y cuidado, a fin de no socavar sus estructuras.

\section{NATURALEZA JURÍDICA, CALIFICACIÓN Y CONFIGURACIÓN DE LA DENOMINADA 'DOCTRINA DE LOS ACTOS PROPIOS'. CARÁCTER ASIGNADO AL BROCARDO VENIRE CONTRA FACTUM PROPRIUM}

\subsection{Preliminares}

Seguidamente, también de modo general, importa auscultar uno de los temas más polémicos y controvertidos que, sobre la doctrina de los actos propios, y figuras similares, existe en la doctrina, y en menor lugar en la jurisprudencia internacional. Nos referimos, en concreto, a la temática de su naturaleza jurídica, en particular si en puridad se puede considerar como un prototípico 'principio general', a la par que a su calificación y configuración, estos últimos temas más pacíficos que el primero, de suyo importante, aunque no por eso ayunos de valía. Por ello, en el mismo orden descrito, los examinaremos a continuación, como quiera que al respecto se aprecia un cierto grado de confusión por parte de sectores autorales y judiciales, que contribuye a su oscurecimiento y a que se

\footnotetext{
224 Vid. Eduardo GANDULFo R. "La aplicación del principio venire contra factum proprium non valet. Un caso de vulgarismo jurídico", en Revista Chilena de Derecho. Vol. 32 No 2. pp. 364 y ss.; Alberto LYON PUELMA. "Crítica a la doctrina del acto propio: ¿sanción de la incoherencia o del dolo o la mala fe?", en Venire contra factum proprium, Universidad de los Andes, Santiago de Chile, 2010, pp. 59 y ss.; Rómulo Morales HerviAs. "La doctrina de los actos propios entre el negocio jurídico y el contrato. Historia de una importación impracticable e injusta", en Jurisprudencia civil patrimonial. Análisis y crítica jurisprudencial, Lima, 2006, p. 111 y ss., y Silvia Calmes. Du principe de protection de la confiance légitime en droit allemand, communautaire et français, op. cit., pp. 482 y ss., y 545 y ss.
} 
desdibuje su real conexión con la buena fe, según se advirtió, de veras estrecha, este sí un inequívoco principio general, con todo lo que de ello se sigue.

\subsection{Naturaleza juRídica}

Un sector de la doctrina y de la jurisprudencia, de vieja data, ciertamente le otorgan al sujeto temático materia de nuestro análisis, el elevado status de 'principio general del Derecho', muchos de ellos, movidos más por la creencia de que sólo los principios de este abolengo, en rigor, tienen asegurado un rol trascendente, de suerte que si lo apellidan de modo diverso, perdería linaje, o incluso sonoridad, apreciación de buena fe, reforzada por el hecho de que si le asignan otro status podría pensarse que se le estaría restando robustez y entidad, realidad que contrastaría con la relevancia por ellos asignada a la figura sub examine, generando una especie de contradicción, pues por un lado realzarían sin ambages su utilidad y trascendencia y, por el otro, le atribuirían una condición de menor jerarquía, vale decir que, por esa vía, estarían promoviendo una capitis diminutio. $Y$ otros que, por motivos más mecánicos, sin una verdadera reflexión $\mathrm{y}$ análisis de fondo, repiten por doquier lo que numerosos doctrinantes y jueces anotan, sin dejar de reconocer, claro está, el grupo -más minoritario- de autores que está convencido de cómo él encuadra en dicha categoría, y quienes con una argumentación más general -y no muy elaborada o desarrollada-se adscriben a dicha postura.

Por nuestra parte, reconociendo que este tema es susceptible de profundos análisis jusfilosóficos, más propios de otra investigación, a lo que se suma la polémica existente en torno a su real pertinencia y proyección en la ciencia jurídica $^{225}$, no pensamos que, en estrictez, pueda dársele tal denominación o

${ }_{225}$ En este sentido, ha expresado el profesor Luís PRIETO SANCHIS que "Tal vez los principios sean uno de los últimos y más vistosos artificios fabricados por los juristas, capaces de servir por igual a malabarismos conceptuales que a propósitos ideológicos, de valer lo mismo para estimular una cierta racionalidad argumentativa que para encubrir las más disparatadas operaciones hermenéuticas...Ni en lenguaje del legislador, ni en el de los jueces, ni en el de la teoría del Derecho existe un empleo mínimamente uniforme de la expresión 'principio', hasta el punto de que, recordando la terminología de Hart, cabe decir que aquí la 'zona de penumbra' resulta más amplia que el 'núcleo de certeza'. Ley, principios y derechos, Dykinson, Madrid, 1998, pp. 47 y 48. 
carácter, que no es solamente semántica, sino que entraña relevantes corolarios en sede jurídica, por lo menos sin reservas, y puntuales salvedades ${ }^{226}$. No es fortuito que el reputado profesor italiano, Guido ALPA, en su obra sobre 'Los principios generales', haga un llamado especial de 'atención' encaminado a no asimilar, automáticamente, principio, regla, noción fundamental u otro enunciado similar, porque "no todas las fórmulas que se presentan como principios [generales] son verdaderamente tales; no todos los principios tienen la misma relevancia; no todos los principios son usados del mismo modo" 227.

Tampoco es intrascendente que esta misma idea que compartimos, según se advirtió en el párrafo precedente, haya sido expresada por el profesor Manuel AlbalADEJO G., quien tras advertir que los principios generales deben "...ser entendidos en sus justos límites", en guarda de no distorsionarlos, concluyó que "...no siempre las reglas jurídicas son fórmulas breves que recogen un principio general, sino que, a veces, con ellas se expresan ideas que son bien orientaciones en algún tema jurídico, bien simplificaciones de doctrina, etc." ${ }^{228}$, que es justamente lo que acontece con la apellidada doctrina de los actos propios o, mejor aún, con la conocida expresión latina "venire contra factum proprium non valet -o nulli conceditur o nemo potest venire contra factum proprium-, un fiable vehículo que permite explicitar una arraigada conclusión jurídica: el rechazo frontal a la incoherencia, a la contradicción, al súbito y lesivo cambio comportamental, con daño ajeno. Por eso se afirma que 'nadie puede venir contra sus actos propios', o que 'a nadie le está permitido desconocer sus propios actos' o que no es admisible 'volver contra sus propios actos', naturalmente con las excepciones de rigor, pues no tiene un carácter absoluto y tampoco forzoso, per se, lo que explica incluso su radio de acción más limitado, mejor aún subsidiario, como se apreciará.

226 Cfr. Mariana Bernal Fandiño. El deber de coherencia en el derecho colombiano de los contratos. op. cit., pp. 238 y 239.

227 Guido AlPA, II principi generali. Giuffrè. Milano. 1993, p. 7. Similar preocupación, a la sazón, había expresado ya el profesor José CASTAN TOBEÑAS al señalar que en ocasiones se estrechan "... dichos principios, confundiéndolos con los aforismos o reglas de Derecho..., o reduciéndolos a una serie, mayor o menor, de dogmas estereotipados que haya podido catalogar la doctrina científica o la jurisprudencia de los Tribunales". Derecho civil español, común y foral, T. I, Reus, Madrid, 1984, p. 496.

228 Manuel Albaladejo G. Derecho civil, T. I, Bosch, Barcelona, 1980, p. 124. 
Es pues común que, bajo el supuesto o aparente ropaje de los principios generales realmente se cobije una regla, máxima, canon, directriz, coordenada, brocardo, adagio, o una idea jurídica cardinal, pero no universal y presente en "... la conciencia colectiva", como lo memora el profesor Guillermo VALDECASAS ${ }^{229}$. Al fin y al cabo, el Derecho está abarrotado de ellas, y no todas se inscriben en el marco de los citados principios generales, de suyo más reducidos y exigentes en su configuración, razón por la cual ellos no pueden “...confundirse o identificarse con los axiomas, aforismos, apotegmas, sin perjuicio de que puedan contener un verdadero principio", tal y como lo tiene establecido autorizada doctrina española, de la mano del doctrinante Puig BRUTAU ${ }^{230}$.

De lo contrario, in complexu, gobernarían toda o prácticamente la vida en sociedad, y sabido es que ello no es así, menos en un sistema codificado o legislado, en el que la ley, revestida de imperium y de carácter general, impera, naturalmente en asocio de la constitución. Bien prescribe el artículo 4 del Código Civil Colombiano, ad exemplum, que "El carácter general de la ley es mandar, prohibir, permitir o castigar" (se destaca), y que "La Constitución es norma de normas" (art. 4. Constitución Política).

Y decimos que, a nuestro juicio el instituto de los 'actos propios' no es un arquetípico principio general -o de textura abierta, indeterminado o en blanco, o una cláusula también general-, naturalmente respetando la postura adversa, habida cuenta que su radio de acción, como se anticipó tangencialmente, y se expondrá más detenidamente al momento de pasarle revista a sus características, realmente es acotado y, por ende, restringido, no por ello insustancial, incoloro, o falto de significación, la que le sobra, en grado superlativo ('por sus frutos los reconocereis'). De allí que una de sus notas típicas sea la de constituir un instituto de aplicación subsidiaria, o residual, rectamente entendido, se itera, lo que

229 Guillermo VALDECASAS, "Los principios generales del derecho en el nuevo título preliminar", en Anuario de Derecho Civil, serie 1, número 2, Madrid, p. 333.

230 José Puig Brutau, Introducción al derecho civil, Bosch, Barcelona, 1981, p. 221. Sobre este mismo particular, el profesor Ch. PeRELMAN observa que "No todas las reglas recogidas en el Título 50 del Digesto (De diversis regulis iuris antiqui) enuncian principios generales del derecho. Algunas de ellas formulan simples máximas". La lógica jurídica y la nueva retórica, op. cit, p, 117. 


\section{explica su proyección más recortada, a diferencia de lo que tiene lugar en punto} tocante con los inequívocos y arquetípicos principios de la mencionada cobertura (generalidad), v.gr: el de la buena fe, cada vez más arraigado y extendido, que le sirve de inescindible estribo y que de alguna manera lo determina, a lo que se agrega que ellos suelen ser más definidos, perfilados y delimitados, rasgos que, con frecuencia, se echan de menos por parte de la propia doctrina que, con sinceridad, reconoce esta vicisitud, hecho que exige un mayor esmero y precisión ${ }^{231}$.

$\overline{231}$ Vid. Eduardo GARCÍA DE ENTERRÍA, quien como otros doctrinantes, reconoce que esta figura luce "....inespecífica”, y se caracteriza por su “...grosera imprecisión", expresiones, sobre todo la última que, más allá de todos la compartan por ser algo exagerada o excesiva, así la entendemos, es indicativa de que sus perfiles y su estructura están aún en construcción, por más que se hayan alcanzado relevantes avances, en especial en los últimos lustros, como en efecto ha acontecido, por manera que el laborío reciente de la doctrina y de la jurisprudencia amerita un reconocimiento especial, pues cada vez refinarán mejor la doctrina en cuestión, lo que suele tardar, de suerte que hay que tener paciencia, pues ni el Derecho es flor de un día, ni tampoco todo se construyó en el mismo tiempo. "La doctrina de los actos propios y el sistema de lesividad". En RAP. Madrid. 1956, p. 71.

No es ese propiamente el caso de la buena fe, del abuso del derecho, etc., los que cuentan con fronteras más diáfanas y reconocidas, sin perjuicio de aceradas discusiones, sobre todo respecto al abuso en referencia, entre otros motivos por cuanto han sido objeto de sistemático análisis, tanto en el siglo XX, como en el XXI. Este mismo criterio, años más tarde, fue explicitado por el profesor Díez-PICAzo en la década de los sesenta, el que no vaciló en reconocer que, “....si somos sinceros, tendremos que confesar que pocas reglas de derecho poseen una vaguedad y una falta de concreción tan grandes, hasta el punto de que es posible decir que su aplicación o inaplicación se fundan, la mayor parte de las veces, en convicciones intuitivamente formadas. Esta vaguedad y esta falta de concreción conducen, inevitablemente, a la confusión y a la inseguridad". La doctrina de los propios actos, op. cit., p. 13, docta obra en la que Don Luís había consignado un fallo del Tribunal Supremo de 1960, en el que se explicitó cómo en la judicatura era común apelar a "...tan manoseado valor de los actos propios" (Op. cit., p. 16).

Parecer similar ha expresado el autor chileno, Eduardo GANDULFo R., quien opina, críticamente, que dicho "...principio carece de contornos definidos o precisos", lo que comprueba que su "...tesis expansiva está mal diseñada de base". "La aplicación del principio venire contra factum proprium non valet. Un caso de vulgarismo jurídico", op. cit., p. 365.

En términos menos críticos, pero realistas, el Profesor español Carlos RogeL VIDE, también reconoce que "la doctrina de los propios actos, enmarcada dentro de la buena fe, tiene, en ocasiones....perfiles y fronteras poco definidas en relación con otras manifestaciones de la misma....". La doctrina de los actos propios, obra conjunta realizada, en lo pertinente, con el Dr. Marcelo LóPEz MESA, op. cit., p. 206, opinión que, en rigor, es correcta, precisamente porque como señalamos es una doctrina que, con sustantividad, se ha proyectado en la ciencia jurídica en forma lozana, pues más allá de sus orígenes y perfiles remotos, como se examinó, fue en el siglo XX cuando comenzó a adquirir fisonomía y autogobierno, hasta el punto que en algunas naciones, v.gr: Italia, ha sido en este siglo cuando la doctrina más se ha ocupado del tema. Por ello, antes de traducirse esta observación en crítica, debe 
Desde esta perspectiva, derechamente, nos identificamos con el distinguido profesor peruano, Manuel de la Puente y LaValle, quien expresa que, "Dicen algunos que se trata de un principio general de derecho, o sea principios determinados por abstracción de las normas que componen el derecho positivo... Parece difícil conceder a la doctrina de los actos propios la naturaleza de principio general de derecho. Tanto la corriente positivista, que entiende que los principios generales del derecho son aquellos que informan las soluciones concretas del derecho positivo, sirviéndole de fundamento, como la corriente naturalista, que les concede el carácter de criterios de valoración que, constituyendo el fundamento del orden jurídico, tienen una función genética respecto de las normas singulares, reconocen que lo verdaderamente importante es destacar que los principios generales constituyen normas jurídicas básicas de la organización social que revelan el sistema en que reposa la sociedad, no admitiendo excepciones"232. Y también con el autor argentino, Alejandro BoRDA, cuando haciendo hincapié en el carácter excepcional del instituto comentado rechaza la idea de que "...la inadmisibilidad de la conducta contradictoria importa un verdadero principio de derecho", pues en realidad "... no constituye un principio sino una regla de derecho", porque a) resume el sentido de una institución; b) admite excepciones (basta tener en cuenta la posibilidad de revocar testamentos, donaciones o mandatos, que demuestran actitudes contradictorias pero legítimas): c) la expresión admite un principio superior del cual deriva: el principio general de la buena fe; d) como consecuencia de lo sostenido precedentemente, la regla que sanciona

aceptarse su carácter aún provisional, en algunos aspectos, lo que antes de ser negativo, no sólo es sincero, sino que le garantiza un mejor y sostenido futuro, por cuanto no está agotada la materia. Como ya dijimos, está aún en construcción. De ahí que concite tanto interés actual, a diferencia de figuras, casi marmóreas, que ya no despiertan verdadera inquietud y vívido entusiasmo, pues todo, o casi todo está dicho. Por eso preferimos la pasión, si se quiere el frenesí científico, a la pasividad pura, a la rigidez doctrinal, en donde mucho se presenta como un dogma, en sí mismo inamovible.

232 Manuel De la puente y Lavalle. "La Doctrina de los actos propios", en Estudios de Derecho Civil, Obligaciones y contratos, Libro Homenaje a Fernando Hinestrosa, Universidad Externado de Colombia. Bogotá, T. I, 2003, p. 354. En similar sentido, el autor Juan M. Dobson manifiesta que, “...la designación de 'principio general del derecho' puede llevar a equívocos", por lo que más adelante concluye en su obra que la doctrina de los actos propios, denominación que estima "... apropiada", "....no puede señalarse que constituya un "principio general del derecho' ", máxime “...que la regla de los propios actos es una derivación del principio general del derecho de la buena fe, del cual constituye una aplicación". El abuso de la personalidad jurídica, op. cit., p. 280. 
la inadmisibilidad de la conducta contradictoria abarca una menor cantidad de situaciones que las que comprende el principio general de buena fe"233.

Otro tanto sucede con el lúcido y convincente parecer del profesor DízZPICAZO, pues con su reconocida autoridad no vacila en aseverar que, desde ningún punto de vista, dicha regla puede asimilarse a un principio general, lo que se comprueba, a su juicio, a través del escrutinio de buena parte de la jurisprudencia española, entre otros argumentos y consideraciones más. Por ello indica que "Las sentencias de nuestro Tribunal Supremo han insistido reiteradamente en que la regla, conforme a la cual 'nadie puede válidamente ir contra sus propios actos', tiene en nuestro ordenamiento jurídico categoría de principio general de Derecho. Esta afirmación jurisprudencial, que nunca ha sido demostrada, ni siquiera razonada o fundamentada, exige una revisión a fondo. Ante todo, fracasa en seguida el intento de asegurar la generalidad de la doctrina de los propios actos. Hay, dentro del ordenamiento jurídico, una serie de hipótesis en las cuales una actuación contraria a la conducta anterior del sujeto se encuentra no sólo permitida, sino aun protegida jurídicamente....", motivo que induce al mismo autor a preguntarse a continuación, en desarrollo de tal realidad, "¿qué generalidad puede atribuirse [entonces] a la doctrina de los propios actos?, ¿cómo puede hablarse de un verdadero principio general de Derecho?"234.

233 Alejandro BORDA, La teoría de los actos propios, op. cit., pp. 63 y 64. En igual dirección los autores peruanos Mario CASTILLO FREYRE y Rita SABROSO MNAYA, luego de haber efectuado diversas disquisiciones al respecto, afirman que la consideración de principio general registra inconvenientes, pues en el ordenamiento peruano “... existen una serie de supuestos en los cuales una actuación contraria a la conducta anterior del sujeto se encuentra no sólo permitida, sino aún protegida jurídicamente", motivo por el cual "...la máxima según la cual 'nadie puede venir contra sus propios actos' es una regla de Derecho...que deriva del principio general de la buena fe". Por consiguiente, concluyen manifestando que "... ha quedado claro que el venire contra factum proprium es una regla de Derecho (en tanto admite excepciones) que es expresión de un principio general de Derecho a saber: el principio general de la buena fe". La teoría de los actos propios, op. cit., pp. 67 y ss. Cfr. Inés Pardo De Carvallo. "La doctrina de los actos propios", en Revista de Derecho de la Universidad Católica de Valparaíso, XIV, 1992, p. 54, y René ORTIZ CABalleRo, La doctrina de los actos propios en el derecho civil peruano, op. cit., p. 270 y 271.

Luís Díez-Picazo, La doctrina de los propios actos, op. cit., p. 128, y 129. A la misma conclusión, años más tarde, arribó el mismo autor con motivo del examen de la temática del enriquecimiento sin causa, al señalar, en lo aplicable, que "Si por principio jurídico entendemos la idea o ideas que sirven de base a una regulación legal y que pueden permitir el ensanchamiento del campo de aplicación de ésta, creo que es lícito hablar de un principio jurídico de interdicción del enriquecimiento injusto o sin causa. No me parece por la dosis 
Abundando en consideraciones, es preciso tener en cuenta que, como se ha pincelado en otros apartes, la doctrina de los actos propios, genética y funcionalmente, está inexorablemente ligada al principio general de la buena fe, tanto que se estima -en justicia y en rigor jurídico- que es una derivación, emanación suya, cuando menos, conforme se puso de presente a espacio, razón por la cual es aconsejable no asignarle una naturaleza tan autónoma e independiente, que pierda contacto directo -y hasta paternal- con la bona fides, ese sí, un indiscutido principio general del Derecho, el que le sirve de manantial, en el que abreva y encuentra sus orígenes, esos que no se pueden traicionar ${ }^{235}$.

Por eso, atomizar los principios generales puede resultar inconveniente, a fortiori cuando su enunciación (principio general) pudiera originar una lectura equívoca, enderezada a motivar su generalizada aplicación, a sabiendas de que, no obstante su significación y su talante justiciero, es residual o subsidiario, y que no es un tonicus magicus. Por esta vía expansionista, todo, o mucho, por lo menos, se erigiría en principio general, perdiendo el carácter informador y lumínico

de excepcionalidad que antes hemos encontrado; porque es difícil considerarlo como una regla que informe de nuestro ordenamiento jurídico y porque, como más adelante veremos, algunas de sus aplicaciones prácticas encajan mal en los moldes de nuestra legislación y de nuestros códigos. Tampoco hay especial dificultad en admitirlo como principio si por tal se entiende en el sentido de la tópica o de la nueva retórica un locus..., aunque no sea por sí mismo principio del Derecho, como ocurre con la máxima venire contra factum proprium nulli conceditur....". La doctrina del enriquecimiento sin causa, op. cit., p 74 y 75.

235 En esta misma orientación, confirmando el rechazo precedentemente expuesto, el profesor DíEZ-PICAZo enseña que "...se comprende que la inadmisibilidad de 'venire contra factum proprium', que no es sostenible como un autónomo principio general de Derecho, sea fácilmente viable como derivación necesaria e inmediata de un principio general universalmente reconocido: el principio que impone un deber de proceder lealmente en las relaciones de derecho (buena fe)". La doctrina de los propios actos, op. cit., p. 133. Cfr. Luís Díez-PICAzo y Antonio Gullon B., al afirmar que "La inadmisibilidad del venire contra factum proprium, si bien no es sostenible como un autónomo principio general de Derecho, es fácilmente viable como derivación necesaria e inmediata de un principio general universalmente reconocido: el de la buena fe, que impone un deber de proceder lealmente en las relaciones de Derecho. La buena fe exige un comportamiento coherente con la confianza suscitada por los actos de su autor". Sistema de derecho civil, Vol. I, p. 440; María del Carmen Gete Alonso. La buena fe, op. cit., p. 893; Mario Castillo FreYRe y Rita Sabroso MinaYa. La doctrina de los actos propios, op. cit., p. 78; Bernadette Minvielle y Alberto Reyes OeHninger. La doctrina de los actos propios (perspectiva procesal civil), op. cit., p. 291, y Alesandro P. ScARso. Venire contra factum proprium e responsabilitá, en Responsabilitá civile e previdence, op. cit., p. 534, y Franceso Astone, Venire contra factum proprium, op. cit., p. 222. 
que los caracteriza, mejor 'solar', para emplear de nuevo una descriptiva forma de referirse a la buena fe.

Su fuerza arrolladora, espíritu bienhechor y linaje, en resumidas cuentas, no se altera o resquebraja si se utiliza una expresión diversa, y su aplicación en sede judicial o extrajudicial, no se erosiona si se le confiere otro tratamiento, más acorde con su perfil y genuina caracterización. No se olvide que su verdadera potencia reside en la propia lógica (coherencia), y el Derecho, ante todo, es eso: lógica, por manera que, in concreto, las soluciones jurídicas deben atender esta coordenada, de imperativa observancia, así no esté escrita, y tatuada en el ordenamiento positivo, de manera individual. Su valía no emerge de la letra, o de la previsión del legislador, pues trasciende la literalidad, como quiera que implicitud no es sinónimo de debilidad, o de inferioridad. Hoy no todo cabe, ni puede ser engastado en los principios generales, ${ }^{236}$ se reitera, pero aun así, en gracia de discusión, la doctrina de los actos propios está indisolublemente ligada a un principio general: el de la buena fe, como se ha esbozado y se expresará a continuación, lo que significa que, por esta vía, in casu, encontraría franca y paterna aplicación, con mayor razón cuando la buena fe ha recibido carta de ciudadanía en códigos y constituciones, no sólo de carácter decimonónico, sino del siglo $X X$ y XXI, en prueba adamantina de su valía y linaje. Lo propio en relación con los proyectos de códigos existentes en el espacio europeo, ya referidos en otros apartes.

De igual modo, importa recordar que con independencia de las expresiones nadie o a nadie, con la que se encabeza esta regla (a nadie le estará permitido volver sobre sus propios actos), lo cierto es que no puede tomarse literalmente, habida cuenta que, en rigor, hay diversas hipótesis en las cuales es lícito, a fuer que permitido el factum novum, es decir volver sobre el acto propio primigenio, confirmándose entonces que con rotundidad no se puede rechazar la incoherencia o la contradicción, de existir, pues habrá casos en que esté tolerada, cuando la

${ }^{236}$ Es que aún en el propio marco de los principios generales se hacen distinciones y matizaciones, como tiene lugar con "los principios, valores o derechos fundamentales constitucionales". Sonia Esperanza RodRíGuEz BoENTE, Los principios generales del derecho. Universidad Santiago de Compostela. 2008, p. 134. 
escolte la legalidad y muy especialmente la razonabilidad ${ }^{237}$. De ahí el alcance relativo, que no absoluto de la regla venire contra factum proprium, como lo hemos esbozado, y lo examinaremos más en detalle en capítulo ulterior, lo que no es óbice para refrendar su potencia ética, a la par que su fuerza y aceptación en el campo del Derecho. Con todo, en sintonía con lo indicado en precedencia, no creemos que se pueda entonces, sin salvedades y matizaciones, dotar de validez general y absoluta a la regla venire contra factum proprium, o al apellidado principio de no contradicción, o al principio de coherencia, entre otros más. ${ }^{238}$

En compendio, por las razones antedichas, no consideramos de recibo asignarle la morfología de principio general a la llamada doctrina de los actos propios, así algunos lo hagan, entre otras denominaciones próximas, pues no encuadra en la estructura y signos que, en estricto sentido, le son característicos

237 En esta misma orientación, Dimitri HoutcIEFF expresa que "El derecho permite la modificación del comportamiento en el marco de lo razonable". Le principe de cohérence en matiére contractuelle, op. cit., p. 67. Y Hobinavalona RAMPARANY-RAVOLOLOMIARANA igualmente menciona que en concretos supuestos “....existen 'contradicciones legítimas', en cuyo caso la incoherencia debe ser sancionada únicamente cuando perjudica a otro con ocasión de la operación contractual". Le raisonnable en droit des contrats, op. cit., p. 301. Cfr. Denis Mazeaud. La confiance légitime et l'estoppel, op. cit., p. 248, y Atilio Aníbal Alterini y Roberto López Cabana, Actos propios y responsabilidad civil, en Responsabilidad civil, Diké, Medellín, 1995, pp. 38 y ss.

238 Cfr. Paulo MotA PINTO, quien luego de indagar "si se podrá, en un plano dogmático, afirmarse un principio general de prohibición de un comportamiento contradictorio en el derecho privado?", expresó que "los autores son prácticamente unánimes en negar un principio general tal, y dicha negativa es claramente razonable... No existe, pues, una regla general de coherencia del comportamiento de los sujetos jurídicos privados, jurídicamente exigible", Sobre a proibicao do comportamento contradictório (Venire contra factum proprium) no direito civil, op. cit., pp. 275 y 276. Vid. Antonio Menezes Cordeiro. Tratado de direito civil portugues, op. cit., T. I, p. 277, y Alesandro P. ScARso. Venire contra factum proprium e responsabilitá, op. cit., p. 520 y ss.

A esta misma conclusión, arribó la jurisprudencia belga, específicamente en sentencia de la Corte de Casación del 17 de mayo de 1990, en la cual “....rechazó conferir el status de principio general de derecho 'formal' a esta noción (rechtsverwerking)", modalidad especial del venire contra factum proprium, ligada a la buena fe, muy socorrida en Bélgica y Holanda. Bénédicte FAuVARQUe-Cosson. La confiance légitime et l'estoppel, op. cit., p. 24. Vid. Sophie StIJNS. "La 'rechtsverwerking': fin d'une attente (dé) rasisonnable? Consideration á propos de l'arrete de la Court de Casation du 17 mai 1990", en Journal des Tribunaux, Bruxelles, 1990, p. 685 y ss. Al respecto, manifestó que “...la existencia de un principio general de derecho concerniente a la rechtsverwerking es rechazado por la Corte de Casación". 
a ellos ${ }^{239}$. No en balde, como se señaló, el hecho de que no derive de una norma específica o de que no esté disciplinado por el ordenamiento legal, no significa que deba otorgársele tal naturaleza, en sí misma restrictiva, como quiera que entre principio general de Derecho y coordenada, axioma, aforismo, principio jurídico, regla, etc., media una apreciable diferencia, en ningún caso de poca monta, sin que por ello pierda vigencia, valía y acendrada utilidad, máxime cuando en rigor, también como se destacó, dicha doctrina es emanación directa de un principio que, por su espectro y proyección, sí es general: el de la buena fe, un ejemplo esclarecido y paradigmático. Por eso para nosotros, prevalentemente,

239 Como ya lo pusimos de presente, un inmenso número de autores, se limitan a señalar, sin justificar, que la doctrina de los actos propios es un principio general de Derecho, denominación que en naciones como Argentina, ha hecho verdadera carrera, sin perjuicio de que algunos, ciertamente pocos, procuran justificar la toma de posición en el sentido apuntado. Es el caso del autor argentino Luís María VIVES, quien entiende que "La 'doctrina de los actos propios' es un principio general del derecho....ya que si consideramos que los principios generales son 'grandes criterios normativos coercibles de la conducta intersubjetiva que provienen de la idea de justicia o que se obtienen por generalizaciones progresivas y cada vez más amplias del entero ordenamiento positivo, inclusive del derecho internacional y del derecho público, cuya finalidad es orientar y fundamentar la interpretación del derecho e integrar el mismo' no parece que pueda caber duda en afirmar que la doctrina del venire contra factum proprium non valet tipifica plenamente un principio general del derecho autónomo", idea que apoya en el hecho de considerar que esta regla "...no deriva de la buena fe, sino que la recepciona y la integra como un elemento más de la fattispecie". La doctrina de los actos propios, en La Ley. Buenos Aires, 1987-B. pp. 946 y ss. Cfr. Simón S. SAFonTÁs, "Doctrina de los propios actos. Jus. No 5. Buenos Aires. 1964. pp. 29 y 30.

Por su parte, el profesor peruano, Juan EsPINOzA E., pone de relieve que no comparte la posición que niega el carácter de principio general a este instituto, pues "...el hecho que un principio, entendido como modelo (jurídico o dogmático) de carácter críptico o sumario, dote de contenido a los enunciados jurídicos no hace que, forzosamente, sea universal ni mayoritario. Es cierto que existen principios que tienen un ámbito de aplicación más general que otros. Sin embargo, con el alto grado de especialización que están adquiriendo distintas y nuevas disciplinas jurídicas se van generando principios con un alcance más delimitado. Los principios, como tales, evidentemente tienen excepciones en su aplicación. Incluso pueden ser además residuales....." "Interpretación del negocio jurídico", en Obligaciones y contratos en el derecho contemporáneo. Universidad de la Sabana. Diké Biblioteca Jurídica. Medellín. 2010, p. 228. Tesitura que, aun cuando respetable, no podemos compartir, pues razonando de ese modo, valdría la pena indagar, qué no encuadraría en el concepto -que no es de látex- de principio general. Habría, como lo dice el autor, que admitir en esta clasificación dilatada, aún aquello que sea 'residual', como en efecto, por excelencia, lo es la doctrina de los actos propios, como se observará a espacio y, por ende, de aplicación limitada, acotada y sujeta a precisos límites, hasta el punto que hay un protocolo muy riguroso que deberá observarse para ello, todo lo cual conspira contra la anunciada generalidad, y contra el supuesto carácter de 'modelo', que no tiene la doctrina de los actos propios, per se. Otro tanto tendrá lugar en tratándose del estoppel, de la verwirkung, de la rechtsverwerking, etc. 
tiene rango de regla (regulae iuris), expresión que preferimos entre el amplio haz existente, ${ }^{240}$ aun cuando también adherimos a la de 'principio jurídico', que no 'principio general', que no son idénticos.

No huelga mencionar, ya para terminar, que esta discusión no tiene la misma incidencia en el Derecho británico, pues como lo recuerda el profesor ZIMMERMANN, en tratándose de la buena fe, "las cosas son distintas en Inglaterra, donde no existe un principio general cuyo contenido sea que las partes de un contrato deban ajustar su conducta a los mandatos de la buena fe"241, hecho que sube de tono en relación con la regla del venire contra factum proprium, pues si la bona fides no la encuadran en un principio general, menos lo harán respecto al venire, y a sus diversas manifestaciones, lo que "...no significa que el derecho contractual inglés no sea 'inherntly equitable'", y que no rechace la contradicción, la incoherencia o el quiebre de la apariencia. Prueba de ello lo constituyen el estoppel y los laches -objeto de puntual referencia en el Capítulo IV-.

\subsection{CALIFICACIÓN JURÍDICA}

A la vista de las consideraciones que anteceden, en aras de su cabal calificación, preferimos pues emplear, como se anticipó, otras expresiones menos reveladoras, tales como la de doctrina, canon, instituto, principio jurídico, institución, figura, regla -pero con una connotación más dúctil-, coordenada, idea fundamental y aún la de 'idea-fuerza', a la que alude el profesor JosSERAND, circunscrita a otra manifestación jurídica: el factum proprium, siempre en un sentido lato, aun cuando si se trata de preferencias, optamos por la expresión regla, según lo mencionamos, por encarnar mejor su auténtico significado ${ }^{242}$,

${ }^{240}$ En este mismo sentido, la autora peruana Cecilia O'NEILL DE LA FUENTE, expresa: “Mientras que la buena fe es un principio general del Derecho, la doctrina de los actos propios toma la forma de una regla de Derecho". "El cielo de los conceptos jurídicos versus la solución de problemas prácticos a propósito de la doctrina de los actos propios", op. cit., p. 48.

241 Reinhard Zimmermann. "Rasgos fundamentales de un derecho europeo", en Estudios de derecho privado, Civitas, Madrid, 2000, pp. 155 y 156.

242 Abogamos entonces por la escisión de principio general de derecho y regla, o regla jurídica -o aún principio jurídico-, pues entendemos que no son iguales, por más que de ordinario se les confunda, pues como lo atestiguan Manuel Atienza y Juan Ruiz MANERo, "la diferencia estriba en que los principios configuran el caso de forma abierta, mientras que las reglas 
estructura, alcance y aplicación, lo que no denota infravalorarla o relativizarla, conforme se anticipó ${ }^{243}$.

Sin embargo, insistimos que la expresión 'principio jurídico' -que no general de derecho-, puede resultar igualmente de recibo. No se nos escapa, en efecto, que en el año 1913, don Carlos L. De HaRo, con ocasión del estudio de la expresión "Nadie puede ir contra sus propios actos", lo traemos a colación de nuevo, manifestó que tal "regla... es simplemente un principio cardinal en materia de obligaciones". ${ }^{244}$

Del mismo modo, desde una perspectiva histórica, lo mencionamos desde ya, la regla venire contra factum proprium, en asocio de otras expresiones más indicativas del mismo significado, hundía sus raíces en un brocado medieval, que no romano propiamente dicho, estructurado con propósitos muy diversos al asignado a los modernos principios generales de derecho, stricto sensu, no por ello menos importantes, sin embargo, como quiera que eran “....representaciones breves, ágiles, llenas de verdad jurídica”, llamadas a reproducir “...definiciones

lo hacen en forma cerrada. Con ello queremos decir que mientras que en las reglas las propiedades que conforman el caso constituyen un conjunto finito y cerrado, en los principios no puede formularse una lista cerrada de las mismas....El tipo de indeterminación que aqueja a los principios es, pues, más radical que el de las reglas....". Las piezas del derecho. Teoría de los enunciados jurídicos, Ariel, Barcelona, 1996, p. 9. En esta misma orientación, el citado profesor PeRELMAN acierta al reconocer que son "... diferentes por naturaleza de los principios generales del derecho, las máximas", que "...representan puntos de vista que la tradición jurídica ha tenido siempre en cuenta y que proporcionan argumentos que la nueva metodología no puede descuidar....". La lógica jurídica y la nueva retórica, op. cit, p. 118.

${ }^{243}$ El hecho de que se aluda a una regla, canon u otra similar, no es, per se, una capitis diminutio, como ya lo mencionamos, pues como lo acotó con su característica precisión el célebre profesor español, don Federico De CASTRo y BRAVo, "En bastantes ocasiones han sido...., el medio para que se reconozca un verdadero principio jurídico". Derecho civil de España. T. I. Civitas. Madrid. 1984, p. 434.

244 A juicio de PaUlo, "Es regla la que describe brevemente cómo es una cosa. No que el derecho derive de la regla, sino que ésta se abstrae del derecho existente. Así, pues, mediante la regla se transmite una breve descripción de las cosas...." (D. 50, 17, 1). Por su parte, siglos más tarde, en las Siete Partidas se expresó que "...regla es la ley dictada brevemente con palabras generales, que demuestra ayna la cosa sobre que fabla" (P. 7, 34 , Delas reglas del derecho).

Carlos L. De HaRo, Los actos propios en la jurisprudencia del Tribunal Supremo, op. cit., p. 17. 
concisas, fórmulas de derecho exacto, en las cuales se encerraba la sustancia de una doctrina o de un precepto al estilo lapidario" ${ }^{245}$, tal y como aconteció con el venire, en sí elocuente, atrapante y hasta musical ${ }^{246}$.

Como lo hemos precisado de antemano en los primeros apartes de este escrito, preferentemente, utilizaremos la denominación de doctrina de los actos propios, merced a su arraigado uso general, bien por parte de la jurisprudencia, bien por la doctrina. Incluso, en el campo supranacional y supralegal, según se indicará, en la Convención de Viena en materia de compraventa de mercaderías y en los principios de UnIDROIT (2010) y en el Anteproyecto de Código Civil Argentino (año 2012), se alude al acto propio -o conducta propia, como acontece en el referido anteproyecto, art. 1067), de suerte que hemos preferido preservarla, aun sabiendo que no comunica, con total facilidad, elocuencia y claridad, el mensaje deseado, como tampoco lo hacen otras expresiones similares.

De igual modo, como observamos en precedencia, el mismo concepto que revela la expresión doctrina de los actos propios (o de los propios actos) se amuebla, por ser su manifestación, en un número significativo de expresiones latinas, entre otras las siguientes que, de ordinario, fungen como sinónimas o,

${ }_{245}$ Salvatore Rıcсовоno, "Brocardica”, en Nuovo Digesto Italiano, 1957, p. 584.

Como lo puntualiza el profesor brasilero, Miguel REALE, "Actualmente...se reconoce que hay brocardos que han perdido su vigencia, pero que otros actúan ciertamente como ideas directrices que el jurista no puede despreciar apriorísticamente. Se procede a un análisis riguroso de las antiguas máximas y, mientras se observa que algunas de ellas impidieron por largo tiempo la adecuada comprensión de ciertos hechos jurídicos, otras, en cambio, representan directrices de innegable valor práctico cuando son empleadas adecuadamente". Introducción al derecho, Ediciones Pirámide, Madrid, 1982, p. 151. Para Jaime Mans Puigarnau, a su vez, los brocardos eran "....genuina manifestación de las reglas jurídicas de la Edad Media, dentro del cuadro general de los glosadores y posglosadores". En este sentido, continúa el autor, "el género más típico de la Edad Media en relación con las reglas de derecho, lo constituyen los brocardos (brocarda o brocadica)". Los principios generales del derecho. Repertorio de reglas, máximas y aforismos jurídicos, Bosch, Barcelona, 1969, p. XXXV.

246 Cfr. Antonio Menezes Cordeiro, Direito civil portugues. Parte general, op. cit., p. 278. Bien expresa entonces lan HENRIQUEZ HERRERA que "... la regla es un enunciado de razonabilidad práctica, válido normativamente en sí mismo en atención a su propio contenido", de lo que extrae "...como elementos característicos de la regla, en primer término su brevedad. En segundo término.... su elocuencia, es decir la capacidad de expresa con claridad el contenido de lo dicho o afirmado". "Las ragulae iuris como fuente del derecho civil chileno", en IV Jornadas de Derecho Civil, Universidad de los Andes, Santiago de Chile, p. 6. 
por lo menos, equivalentes -o muy próximas-, como ya lo hemos dicho: venire contra factum proprium non valet, nemo licet adversus sua facta venire, venire contra factum proprium nulla conceditur, adversus factum suum quis venire potest, nemo potest mutare consilium suum in alterius injuriam, nemo potest venire contra factum proprium, etc.

Así las cosas, no existe una calificación o un nomen único para expresar el propósito de impedir el ejercicio de un derecho atentatorio de actuaciones precedentes (conducta vinculante) constitutivas de confianza legítima (limitación al ejercicio de un derecho subjetivo), toda vez que a través de la historia, al mismo tiempo que en el Derecho comparado, se han tejido diversas expresiones, unas más precisas que otras, todas indicativas de dicho cometido bienhechor, lo cual ha tenido lugar tanto en el civil law, como en el common law, en clara muestra de su 'universalidad', en sentido amplio, que no de generalidad, como se expresó.

En síntesis, optamos por asignarle al otrora brocardo venire contra factum proprium el carácter de regla jurídica, ajena a la generalidad y al arraigo de la comunidad toda, en la inteligencia que, sin soslayar su valor y su profunda connotación ética y también jurídica, no se está en presencia de un genuino y caracterizado principio general, por antonomasia refractario a las excepciones y a la subsidiariedad, notas que signan al venire y que le dictan diáfanos límites ${ }^{247}$.

247 Bien expresó el profesor José CAstan Tobeñas que en los aforismos o brocardos “...se contienen reglas que son verdaderas en la generalidad de los casos, pero que, como todas las reglas, sufren determinadas excepciones. No bastan para resolver cualquier cuestión de derecho". Derecho civil español común y foral, op. cit., p. 501.

No sobra mencionar que, en adición a lo anterior, los brocardos en determinadas y puntuales ocasiones se tornaron luego en principios generales, aun cuando ello, se aclara, era excepcional, merced a que la nómina de principios solía y suele ser limitada, al paso que aquellos son numerosos. Por eso es por lo que el profesor de la Universidad Bolivariana de Medellín, Hernán VALENCIA RESTREPO, con su característica precisión, expresa que "Eventualmente un aforismo puede ser el vehículo de expresión de un principio. Con todo, entre lo uno y lo otro no media un vínculo o relación de necesidad, sino de simple contingencia.". Nomoárquica, principialística jurídica o filosofía y ciencia de los principios generales de derecho, Temis, Bogotá, 2005, p. 383. 


\subsection{Configuración Y EnCUADRAmiento JuRidico}

Resta indicar que la regulae en mención, recreada a través de diversas expresiones latinas, se expresa en forma típicamente negativa, y no en positivo: 'nadie puede ir contra sus propios actos', o "no se puede volver contra sus propios actos", o "no es permitido ir en contra de los actos propios", aun cuando es cierto que modernas posturas del instituto identificado mediante el brocardo 'venire contra factum proprium', se enuncian de modo disímil, a partir de considerar que se trata de un deber, específicamente de uno de los llamados deberes secundarios, instrumentales, auxiliares o especiales de conducta que reafirman cómo a lo largo de la relación negocial, y aún antes, las partes deberán observar un debito, que es continuo, que no se agota en un solo acto, tratándose de los contratos de duración, preferentemente, según se expresó en otro aparte. Es el caso del llamado 'deber de coherencia', tan en boga en algunas latitudes, conforme se ha resaltado, el que no sugiere un enunciado negativo, ni tampoco se erige en prohibición, como sucede con relación a aquél ${ }^{24}$.

Sin embargo, el mencionado brocardo es muy conocido y divulgado, por manera que, desde la perspectiva indicada, comúnmente se le asocia más con una prohibición, con una veda o restricción, o “...con un no hacer, con una abstención -no ir contra los propios actos-“, lo que ha dado pábulo para afirmar, a contrario sensu, que "...la conducta positiva -ir contra los actos propios- es estigmatizada como antijurídica"249. He allí por qué entonces se le considera un enunciado negativo -e incluso de tipo prohibitivo: "prohibición de ir contra los propios actos'- que, rectamente entendido, alternativamente, ha permitido su migración ulterior a uno positivo: la coherencia, catalogada como prototípico deber o debito; como actuación que debe ser desplegada invariablemente en el cosmos jurídico (opus), como un presupuesto de la vida en sociedad, como un

\footnotetext{
${ }^{248}$ Como lo recuerda D. HoutciefF, en esta materia impera “... un principio de 'coherencia', no una exigencia de 'no contradicción' “. Le principe de cohérence en matiére contractuelle, op. cit., p. 41. Vid. Francesco Astone, Venire contra factum proprium, op. cit., p. 165.
}

249 Luís Díez-Picazo, La doctrina de los propios actos, op. cit., p. 184. 
factor de cohesión social, entre otras razones por cuanto coherencia, lo memora Astone, es “...sinónimo de cohesión”250.

Por último, en lo que se refiere a su encuadramiento, hay que refrendar que el venire contra factum proprium, a la vez que sus distintas modalidades, entre ellas la doctrina de los actos propios, encuadra cabalmente en una de las limitaciones al ejercicio de los derechos, ya examinadas, pues su cometido neurálgico es evitar que se propague la incoherencia en el tejido negocial, y que campee impunemente la contradicción comportamental, hecho que recrea el concepto de límite o valladar.

\section{EXPANSIÓN Y ALCANCE DE LA DOCTRINA. GENERALIZADA PROYECCIÓN DISCIPLINAR, ESPECIALMENTE EN EL ÁMBITO PRECONTRACTUAL Y CONTRACTUAL}

En un todo de acuerdo con lo que hemos señalado hasta este numeral, no resulta difícil entender que el espectro de la regla objeto de análisis, realmente es muy amplio, como quiera que se incardina en diversas disciplinas y ramas del Derecho, en inequívoca demostración de su marcada relevancia y acentuada penetración, cada vez mayor, merced a su vocación típicamente remedial, vale decir a su genuino rol protector -y en ocasiones correctivo y restaurador-, el que no sólo mira en una dirección, sino en todas, en general, pues está presente, erguida, como lo están las trascendentes figuras e instituciones, allí donde se requiera esa mano firme y tendida, dispuesta a evitar un perjuicio -o su ensanchamiento-, a raíz de una conducta que, coloreada de incoherencia y salpicada de contradicción, socave la confianza previa y legítimamente generada (lesión), suficiente para que despliegue sus efectos bienhechores o terapéuticos, en un sentido más figurado, pero indicativo de su grandilocuente misión, en el obvio entendido de que se verifiquen sus presupuestos genéticos.

$\overline{250}$ F. Astone. Venire contra factum proprium, op. cit., p. 38. 
Es así cómo, de acuerdo con la tradicional división del Derecho -hoy en revisión porque no siempre sus fronteras lucen diáfanas- ${ }^{251}$, ella cohabita tanto en el público, como en el privado, de tal suerte que, si bien es cierto en éste último ocupa un sitial preferencial, sobre todo en la esfera contractual, tampoco es menos cierto que irradia al Derecho público, por vía de ilustración, al administrativo, al procesal, al laboral ${ }^{252}$, al notarial, al tributario-o fiscal-253, al penal y, en los últimos lustros, al constitucional moderno, el que se ha servido de robusto fundamento y a su turno, recta via, se ha beneficiado de su recepción, como igualmente ha sucedido con institutos tales como la buena fe, el abuso del derecho, el Derecho del consumo, entre otros más ${ }^{254}$.

Ya hemos observado que en el seno del Derecho administrativo, por vía de ejemplificación, la doctrina de los actos propios tiene amplia y sostenida cabida, habida cuenta que la administración, en sí misma considerada, puede lesionar derechos ajenos, cuando inopinada o sorpresivamente muda de conducta, en quiebre de la referida confianza legítimo-racional, en cuyo caso los postulados que se enseñorean en el Derecho privado, no tienen por qué inaplicarse en sede administrativa, como si gozara de un privilegio irritante -o exorbitanteencaminado a tolerársele la incoherencia o la contradicción. Ya hemos señalado que no hay y no puede haber feudos que impidan el ingreso presto de este tipo de doctrinas tutelares, manifestación del principio rector de la buena fe, que todo lo abraza y envuelve, bien concebido ${ }^{255}$. Muy por el contrario, si de esmero se trata,

251 Cfr. Pietro Perlingieri. El derecho civil en la legalidad constitucional, Dykinson, Madrid, 2008, p. 146.

252 Vid. Ramón Rivas Guzman. "La doctrina de los actos propios y el reglamento interno de la empresa", en Contratos, Editorial Jurídica de Chile, Santiago, 1991, p. 191 y ss.

253 Vid. José María Rovira Burgada. "El principio de los actos propios en materia fiscal", en Revista de la Administración Pública, Instituto de Estudios Políticos, Madrid, 1951, pp. 259 y ss.

254 Vid. Fernando FueYo LANERI. "La doctrina de los actos propios", en Instituciones de derecho civil moderno, Editorial Jurídica de Chile, 1990, p. 313, quien anota que "la doctrina de los actos propios está de tal modo enraizada en el Derecho....que no es patrimonio exclusivo del Derecho Privado. Antes bien, tiene reconocimientos y aplicaciones concretas en las siguientes materias: mercantil, laboral, penal, notarial y contencioso administrativo, entre otras". Cfr. Fiorenzo FestI, II divieto de 'venire contro il fatto proprio', op. cit., p. 2. y ss.

255 Categórico, no podría se de otra manera, es el profesor Jesús GonZÁlEs PÉREZ, al indicar en su conocida obra sobre la buena fe "Que la doctrina de los actos propios tiene aplicación 
es de esperar que el Estado respete celosa y solícitamente los intereses y los derechos de la comunidad, su razón de ser, sin distinciones, ni discriminaciones.

Lo mismo tiene lugar en el Derecho procesal, como quiera que el proceso, con prioridad, requiere una cosmovisión acorde con los derechos en conflicto: colectivos o individuales, y con las sacras garantías que, sin descanso, debe proveer. Al igual que en sede contractual, demandante y demandado se deben lealtad, respeto, probidad, corrección, honorabilidad y coherencia. Al fin y al cabo, hablar de buena fe en el proceso, no es ni ingenuidad, ni un estorbo, ni menos un oxímoron. Todo lo contrario; es reclamar un proceso más justo, caballeril y transparente, que no se convierta en un tinglado, en donde pulule la deslealtad, la incorrección, la desconfianza, la desfachatez, las artimañas y, en fin, un escenario en donde se fermenten las más sórdidas y siniestras prácticas. Es natural entonces que la dogmática especializada exprese que "La doctrina de los propios actos es de plena aplicación no sólo en el ámbito de las relaciones privadas sino también en el marco del proceso, siendo precisamente en este ámbito donde surge la figura anglosajona del 'estoppel' que impide al litigante formular alegaciones en contradicción con el sentido objetivo de su anterior conducta, configurándose

en el ámbito de las relaciones jurídico-administrativas parece incuestionable. También aquí constituye un supuesto de lesión a la confianza legítima de las partes venire contra factum proprium". El principio general de la buena fe en el derecho administrativo, Civitas, Madrid, 1983, p. 119. Cfr. Laureano LóPEz Rodo. Presupuestos subjetivos para la aplicación del principio que prohibe ir contra los actos propios, op. cit., p. 11 y ss.

Por su parte, en el Derecho colombiano, acontece lo mismo, según lo tiene establecido la doctrina y la jurisprudencia del ramo (Consejo de Estado). Vid, especialmente, a Gaspar CABAllero S. "La doctrina de los actos propios en el derecho administrativo", en Derecho constitucional y administrativo en la Constitución Política de Colombia, Bogotá. Universidad del Rosario y Diké, Bogotá, 1997, pp. 129 y ss., quien con gran realismo y acierto anota que "Si la doctrina de los actos propios, que impide a las personas contrariar sus conductas pasadas, ha encontrado amplio eco en el derecho privado, no se ve por qué pueda desecharse su aplicación en el escenario del derecho administrativo. En la administración pública se pueden encontrar con relativa frecuencia conductas contradictorias, que implican una infracción al deber de fidelidad a la palabra dada, máxime cuando ésta emana de actos y conductas de órganos estatales.....". Cfr. María José VIANA CLEVES. El principio de confianza legítima en el derecho administrativo colombiano, Universidad Externado de Colombia, Bogotá, 2007, p. 80, quien se ocupa de la 'prohibición de venire contra factum proprium' en la esfera administrativa. Lo mismo hace Gabriel Valbuena HeRnández, La defraudación de la confianza legítima. Aproximación crítica desde la teoría de la responsabilidad del Estado, Universidad Externado de Colombia, Bogotá, 2008, p. 117 y ss. 
como una de las reglas del fair play procesal que entra en juego en el proceso y nunca fuera de él"256.

En este mismo sentido, como se pondrá de presente en capítulo posterior, la jurisprudencia colombiana ha sido especialmente proclive a aplicar esta doctrina en sede procesal, con asidero en artículos como el 71 del Código de Procedimiento Civil, a cuyo tenor las partes y sus apoderados deben "proceder con lealtad y buena fe en todos sus actos", al igual que en la propia carta política de 1991. Los pronunciamientos pertinentes datan de 1993, con providencias garantistas que se refieren al asentimiento tácito y la improcedencia de volver contra los propios actos, en el campo casacional ${ }^{257}$.

256 Joan Pıco I Junor, La buena fe procesal, Universidad Javeriana, Depalma, y Grupo Ibáñez, Bogotá, 2011, p. 89.

No yerran tampoco los profesores argentinos Jorge W. PEYRANO y Julio O. CHIAPPINI, al refrendar que “...la doctrina de los 'propios actos' no es otra cosa que la expresión de la exigencia jurídica de que concurran 'comportamientos coherentes', exigencia sociológicamente explicable porque sólo un obrar coherente permite un cierto grado de previsión respecto del obrar del prójimo sin la cual la convivencia se tornaría difícil y, precisamente, es en el terreno del proceso civil donde la 'incoherencia' puede devenir particularmente nefasta. Habida cuenta, entonces, que al fin y al cabo lo que persigue la doctrina de los 'propios actos' es reprimir y desalentar la incoherencia en los comportamientos cargados de sentido jurídico, se nos ocurre positivo aprovechar sus postulados para erradicar las conductas procesales incoherentes....la ampliación del 'venire contra factum' involucra de alguna manera la ampliación del horizonte ético y el ingreso de una porción del derecho de Equidad, aporte del que se encuentra bastante huérfano el Derecho Procesal....", aunque no por ello se constituye, concluyeron los procesalistas de la hermana nación del sur del continente americano, en "...una absoluta rareza las decisiones judiciales fundadas en la obligatoriedad de adoptar comportamientos jurídicos coherentes". "La doctrina de los propios actos en el ámbito del procedimiento civil", en Jurisprudencia Argentina, IV, Buenos Aires, 1985, pp. 818 y 819. Cfr. Edgardo AlBERTI. Doctrina de los actos propios, La Ley, Buenos Aires, 1986, p. XXX y XXXVl; Osvaldo A. GozalnI. La conducta en el proceso. La doctrina del acto propio, Librería Editora Platense, La Plata, 1988, p. 183 y ss., y José Luis AMADEO, "Los actos propios en el procedimiento", en Jurisprudencia Argentina, IV, p. 1051 y ss. Bien expresan para concluir este aparte Bernadette MinVIELLE y Alberto ReYES OEHNINGER, que "La coherencia en el comportamiento que configura en rigor el marco en el cual debe insertarse el mismo....es exigible a todos los sujetos intervinientes en el proceso". La doctrina de los actos propios (perspectiva procesal civil). Cfr. Cristián BoETSCH GILlet. La buena fe contractual, op. cit., p. 72.

257 Cfr., entre otras, Sala de Casación Civil. Sentencia del 7 de septiembre de 1993. Exp. N ${ }^{\circ}$ 3475. También la sentencia del 22 de noviembre de 2005. Exp. № 1100131030181994 1325. 
Especial referencia también hay que realizar con relación al arbitraje internacional ${ }^{258}$, y con la actividad judicial, por cuanto en los últimos años, en prueba de la expansión de la teoría del acto propio, y de exigencia de la necesaria coherencia que, sin distinción, se debe observar en todas las actuaciones (debitum generalis), ella se está aplicando en la esfera de las actuaciones judiciales, no sin alguna reserva ${ }^{259}$.

Ahora bien, en la órbita del dinámico Derecho privado, como se ha puesto ya de relieve, la regla del venire contra factum proprium, y sus diversas aplicaciones, una de ellas la doctrina de los actos propios, es quizá donde mayor acogida ha tenido, no sólo por la convicción, agudeza y fervor con que la doctrina y la jurisprudencia han procedido a esculpirla, sino también por el número variopinto

258 Vid. Antoine Martin. L'Estoppel en droit international public, A. Pedone. 1979; Emmanuel GaILLARD. "L'interdiction de se contredire au detriment d'autri comme principe général du droit du comerce international. Le principe de l'estoppel dans quelques sentences arbitrales récentes", en Revue de L'arbitrage, Paris, 1985, No 2, p. 241 y ss. Igualmente, con provecho, puede verse el escrito del profesor Bernardo M. CREMADES, en el que aborda la temática de los actos propios en sede de la buena fe. "La buena fe en el arbitraje internacional, en Revista Internacional de Arbitraje, Universidad Sergio Arboleda y Legis, No 15, Bogotá, 2011, p. 13 y ss.

259 Este es uno de los temas que, por fuera del dominio temático de este escrito, suscita aguda polémica, por más seguidores que tenga la tesis positiva, sostenida, con sujeción a la arquitectura del acto propio, por la Corte Constitucional Colombiana, quien desarrollando la máxima venire contra factum proprium, considera que si la misma "...se predica de la actividad del Estado en general, y se extiende también a las acciones de los particulares, donde -en principio- la autonomía privada prima sobre el deber de coherencia, no existe un principio de razón suficiente por el cual un comportamiento semejante no sea exigible también a la actividad judicial". C-836/01.

Al respecto, es de mencionar que la doctrina argentina está muy dividida, y con razón, por cuanto el tema realmente es polémico, no tanto, empero, como para no poder aplicar, en lo pertinente, la esencia de la doctrina en cita, habida cuenta que la actividad de juzgar, sacrosanta, es cierto, conoce límites, motivo por el cual de cara a puntuales circunstancias sus decisiones anteriores no pueden ser una especie de 'ruleta rusa', que posibilite seguirse aleatoria o arbitrariamente. Motivos de coherencia, seguridad jurídica, confianza legítima y estabilidad, entre otros más, sirven de apoyo para entender que el factum proprium judicial, no puede ser soslayado, per se, y ninguna secuela, obviamente con excepciones, necesarias para no generalizar, y menos para encadenar la jurisprudencia, o tornarla pétrea y de espaldas a la realidad social. Una cosa, sin embargo, no supone la otra, lo que aconseja que la mutación o cambio obedezca a reales y potísimas razones que lo sustenten, las que deben ser expresadas con suficiencia y claridad, con el fin de no sorprender a los justiciables y, en general, al foro. Vid. Javier TAMAYO JARAmILLO y Carlos Ignacio JaRAMILLO J. El precedente judicial en Colombia. Papel y valor asignados a la jurisprudencia, Universidad Javeriana y Grupo Editorial Ibañez, Bogotá, 2011, pp. 257 y ss. 
de disciplinas o temáticas en él inmersas. Prácticamente todo el Derecho civil, ora patrimonial, ora de naturaleza personal, está gobernado por ella, en el que se proyecta con solvencia y fluidez. No sólo es el elocuente caso del Derecho de las obligaciones y los contratos, en el que ab antique ha ocupado un escaño preferencial, sino también en múltiples áreas, v.gr: en el Derecho de la responsabilidad civil -o Derecho de daños- ${ }^{260}$, en los Derechos reales, en el Derecho de familia ${ }^{261}$ y en el Derecho hereditario. $Y$ lo mismo acontece en el

260 Como decíamos, la doctrina argentina no es pacífica en lo que atañe a la aplicación del venire contra factum proprium a las decisiones judiciales. A favor de la tesis en comento, que en principio -e in abstracto- nos parece de recibo, toda vez que no hay actividad jurídica inmune a tan penetrante regla, y la de los jueces igualmente lo es, se encuentran buena parte de los autores que del tema expresamente se ocupan. Vid. Isidoro EISNER. "La doctrina de los propios actos compromete también el obrar del tribunal (venire contra factum proprium non valet)", en La Ley, T. 1987-C, p. 820 y ss., y M. LóPEZ MEZA. La doctrina de los actos propios, op. cit., 142 y ss., entre otros más. En contra, vid. Alejandro BordA. La teoría de los actos propios, op. cit., p. 148 y ss.

Aun cuando esta temática ameritaría un estudio sustantivo, amén que articulado, dada su amplitud y significado, en esta ocasión debemos limitarnos a manifestar que por diversas razones la regla del venire contra factum proprium y la responsabilidad civil, guardan una estrecha relación, no sólo porque en estrictez se exige para que ella se torne relevante la floración de una lesión, o la posibilidad de evitarla, lo que estaría en armonía con las nuevas funciones de la misma, sino también por cuanto algunas de sus figuras más características no son ajenas al venire, a juicio de un autorizado sector, prevalentemente alemán (LARENZ, SCHMIDT, FICHER, etc.), no unánime. Es el caso de la denominada culpa de la víctima, o la colpa del danneggiato, como se le conoce en el Derecho italiano. Al respecto, según lo manifiesta el profesor Giovanni CATTANEO, al amparo de un importante sector autoral "...el concurso de la víctima constituiría una aplicación del principio de la buena fe objetiva y más específicamente de la prohibición, derivada del tal principio, de venire contra factum proprium. Parece en efecto contradictorio, además de contrario a la buena fe, el comportamiento de la víctima que, después de haber culposamente contribuido a ocasionar el daño, pretendiese obtener del agente del daño el resarcimiento íntegro". "II concurso di colpa del danneggiato", en Rivista di Diritto Civile, Roma, II, 1967, p. 475. Cfr. Nicola DI PRIsco. Concorso di colpa e responsabilitá civile, Dott, Napoli, 1973, pp. 200 y 201. Igual referencia y análisis crítico es realizado por el agudo profesor don José María LEón al momento de ocuparse de los fundamentos de la culpa de la víctima, uno de ellos, en opinión a la que no adhiere: "La prohibición de actuar 'contra factum proprium', pues “....ya es bastante dudoso que el principio de buena fe sea aplicable entre dos sujetos que en el momento de producirse el daño no estaban vinculados por una previa relación obligatoria, ni tan siquiera en situación precontractual. De otra parte, se trataría de 'proteger la confianza' de un sujeto, el autor del ilícito, no merecedor de una especial tutela jurídica....En nuestro caso, sin embargo, parece fuera de toda duda que la idea de que la confianza no juega para nada como justificación de la exoneración (parcial) del responsable". La culpa de la víctima (Compensación de culpas), Universidad de Salamanca, s/f, p. 66 y ss.

261 En el caso colombiano, la vinculación entre responsabilidad civil y venire contra factum proprium, se hizo patente en la sentencia de la Sala de Casación Civil de la Corte Suprema de Justicia, fechada del 24 de enero de 2011, en la cuál se puso de presente que una de las consecuencias de la trasgresión del acto propio, es la indemnización de los perjuicios 
Derecho mercantil, en concreto en el Derecho societario, marcario, bancario, de seguros, etc., en los que la regla brilla con luz propia.

No es posible, por lo tanto, circunscribir la doctrina del acto propio a una temática o segmento del Derecho, por más que se haya desarrollado en unos casos más que en otros, tal y como tiene lugar en el Derecho de obligaciones y contratos, según lo pusimos de presente, ni tampoco, a su turno, es posible entender que hay subtemas ajenos a su cubrimiento, como si existieran territorios de inmunidad, o 'repúblicas independientes' a donde esta doctrina le estaría vedado ingresar, v.gr: en el campo negocial, específicamente en el contrato de seguro, como algunos lo han pretendido ${ }^{262}$, puesto que no puede haber negocios jurídicos privilegiados en los que sin dique y barreras sí se tolere la contradicción, la incoherencia, el resquebrajamiento de la confianza legítima, tanto más que, de antiguo, se ha señalado que, por antonomasia, el seguro es de uberrima bona fides, con todo lo que ello entraña, para nada insustancial. Así lo ha entendido, por lo demás, copiosa jurisprudencia de diversas latitudes.

Tal generalidad, por consiguiente, sirve de explicación para que no se entienda el venire como una mera regla individual de una específica temática, por relevante que sea, como tiene lugar en tratándose de la disciplina contractual conforme se manifestó, pletórica en sí misma considerada, sino como un principio jurídico que,

que, con dicho comportamiento, se pueden generar (Exp. Nº110013103025200100457 01).

En el terreno del Derecho de familia, a diferencia de lo que prima facie pareciera, la regla del venire más recientemente ha contado con franca acogida, pues como lo recrea Federico $\mathrm{PROCCH}$, "En el ámbito del derecho de familia el principio de no contradicción reviste una particular importancia para la reglamentación de un caso concreto de gran actualidad: el de la inseminación artificial heteróloga....". L'Exeptio doli generalis e il devieto di venire contra factum proprium, op. cit., p. 116. Cfr. Fausto CAGGIA. "Fecondazione eterologa e azione di disconoscimento di paternitá intentata del marito", en Diritto e procedura civile, p. 284.

262 Luís Alberto Botero G., "La teoría de los actos propios y su inaplicabilidad en el contrato de seguro", en Revista del Instituto Antioqueño de la Responsabilidad Civil y del Estado, Medellín, 2010, pp. 113 y ss. En contra, entre numerosos autores, y jurisprudencia internacional, Rubén Stiglitz. Derecho de seguros, La Ley, T. II, Buenos Aires, 2004; Eduardo BERCofF. "Doctrina de los actos propios y contrato de seguro", en La Ley, 1994E, 1182, p. 1 y ss.; Marcelo LóPEZ MESA, La doctrina de los actos propios, op. cit., p. 165, y Carlos Ignacio JARAmILLO J. Derecho de seguros, T. II, Universidad Javeriana y Temis, Bogotá, 2011, pp. 625 y ss., y La prescripción en el contrato de seguro, Universidad Javeriana y Temis, Bogotá, 2012, pp. 190 y ss., y 226 y ss. 
inicialmente, irradia o penetra todos los rincones del Derecho, no exento de su fuerza, cobertura y luminosidad, la que es generalizada, así obviamente campeen límites. Ella atrapa a buena parte de las disciplinas jurídicas, en mayor o menor medida, hecho que quizá explique, desde una amplia perspectiva, que un sector autoral la catalogue de principio general del Derecho, y no de regla jurídica, así no compartamos esta lectura, como ya se puntualizó a espacio, o de principio de coherencia, como igualmente se observó.

Dicho alcance es el responsable que, día tras día, más se acuda a ella, en orden buscar una respuesta y solución equilibrada y justiciera a conductas que, por sus connotaciones, lucen atentatorias de caros principios jurídicos, en especial de la buena fe, de tanta significación y expansión en los tiempos que corren, en particular el deber de coherencia, emanación suya. Y al mismo tiempo, la razón por la cual con mayor atención e interés se estudie imanada figura que, en el pasado, incluso no muy remoto, careció de análisis especial y sistemático, sobre todo por diversos sectores de la doctrina, conforme se pinceló en líneas precedentes, situación que, por fortuna, hoy no es la misma, ni por asomo. Ya no hay pues tanta orfandad, tanta soledad, tanto vacío, tanta inequidad, así falte un camino por recorrer.

No obstante lo anterior, también como se pondrá de presente en su oportunidad, el hecho por el cual el espectro de este instituto jurídico sea amplio, a la par que omnicomprensivo de un apreciable número de disciplinas o materias que se engastan en la summa divisio del Derecho tradicional, no significa que su radio de acción, por general, sea absoluto y que, en tal virtud, proceda en todos y cada uno de los supuestos en los que se invoque, porque naturalmente tiene límites y por cuanto está sujeto a restricciones, a la vez que a la verificación de precisos presupuestos (genéticos y funcionales), como quiera que no es de aplicación mecánica, forzosa, ciega u obligatoria, en todas y cada una de las hipótesis de aparente o virtual incoherencia, según se comprobará detenidamente en el capítulo tercero.

La circunstancia de que su cobertura sea entonces dilatada, y de que sus efectos sean bienhechores, a lo que se agrega su creciente aplicación, no equivale entonces a afirmar a que proceda siempre, en razón de su procedencia es 
circunstancial, amén que residual, lo que quiere decir que, in casu, será menester escrutar su viabilidad que, no es automática, ni menos mágica, se reitera, toda vez que no se abre paso, ipso jure, menos por el sólo hecho de invocar su existencia y plausibles efectos jurídicos, así sea en la expresiva lengua latina: venire contra factum proprium non valet, merced a su anunciada 'musicalidad' y personalidad ${ }^{263}$.

Una cosa es generalidad y amplitud, y otra muy disímil es totalidad, de lo que se sigue que la doctrina de los actos propios no sea de aplicación irrestricta, incondicional o absoluta, siendo pues procedente la cautela y la mesura, tanto dogmática, como judicial, a fin de no distorsionar su real extensión, de suyo acotada, y con el propósito de evitar que se aplique inconsultamente a todos los supuestos posibles, como si fuera una especie de compuesto milagroso, que obviamente no lo es, así sea de extraordinaria utilidad y de talante justiciero, insistimos en ello ${ }^{264}$.

Por nuestra parte, sabedores de la relevancia y utilidad de la regla en mención y de la proyección que alcanzará en lo porvenir, haremos más énfasis en la relación contractual, pues ese el campo temático de esta monografía, al que entonces nos debemos circunscribir, tanto más cuanto es la disciplina en donde mayor aplicación ha tenido, y seguramente seguirá teniendo, un campo abonado para su desenvolvimiento fluido y progresivo. No en vano, el contrato, el tejido contractual, en sí mismo considerado, es quizá donde el comportamiento y la conducta de los celebrantes adquiere especial resonancia y tonalidad, muy especialmente en

${ }_{263}$ La jurisprudencia colombiana, sin perjuicio de retomarla de nuevo después, ha tenido ocasión de señalar al respecto que "... si bien es evidente la necesidad de que las partes observen aquellas líneas de comportamiento, que no contraríen los derroteros ya trazados en sus conductas, ni, menos, minen su credibilidad en el desarrollo precontractual o contractual con desorientaciones perniciosas; a pesar de tan noble propósito, se decía, surge incontestable, de todas maneras, que la observancia irrestricta de sus propios actos no aparece como un deber u obligación absolutos, dado que existen hipótesis en las que ante situaciones similares ó con respecto a actos desplegados con anterioridad por la misma persona, que sirven de apalancamiento para su actuar en el inmediato futuro, le está deferida la posibilidad de apartarse de los mismos. Por consiguiente, no se trata en casos tales, de viabilizar los cambios inesperados, sorpresivos y contradictorios; ni de imponer, irrestricta e irreflexivamente, la observancia permanente e inmodificable de lo actuado". (Corte Suprema de Justicia. Sala de Casación Civil. Sentencia del 24 de enero de 2011).

264 Vid. Luís MoISSET DE ESPANÉs. “La teoría de los 'propios actos' y la doctrina y jurisprudencia nacionales", publicado en La Ley. 198 A A-152, p. 2. 
los negocios jurídicos de duración, esos que no se agotan de inmediato, como acontece con los denominados negocios de ejecución inmediata, por oposición a los de tracto o ejecución sucesiva, escalonados, entre otras denominaciones más, llamadas a relievar que se desdoblan en el tiempo, en cuyo caso la valoración conductual revestirá gran importancia, como quiera que habrá materia prima para ello, no sólo en la fase contractual y poscontractual, sino en la precontractual, de tanta significación, hecho que corrobora su enriquecido examen, amén que amplio espectro, pues será plurifásico, ejercicio guiado por la institución de la buena fe, candil que, in complexu, iluminará todas la referidas fases, así no exista, incluso, aún la relación contractual, propiamente dicha.

A este respecto, como lo ilustra Don Mariano Alonso Pérez en su refinado y profundo escrito, "Con razón se señala que la buena fe precontractual significa comportamiento leal en las relaciones sociales, causa justificativa de la confianza y, al mismo tiempo, exigencia imprescindible en la conducta preparatoria del negocio. Las partes tienen la obligación de comportarse según la buena fe en el sentido de que a ellas incumbe la carga de una lealtad recíproca de conducta socialmente valorable y exigible" 265 . Y es en ese contexto que la doctrina francesa, por vía de ejemplo, entiende que el venire contra factum proprium expresamente tiene cabida en esta fase preparatoria a previa, fundamentalmente por el significado que a lo largo de la misma reviste el factum proprium.

Elocuente, en este último sentido, también es el autor suizo Nicolas KUONEN, cuando expresa alrededor de la referida protección de la confianza, que "Cuando se crea una relación de confianza entre los hombres, conviene protegerla y evitar que se rompa de manera arbitraria. El sentimiento de justicia exige a aquel que

265 Mariano Alonso Pérez. "La responsabilidad precontractual”, en Revista de Derecho Crítico Inmobiliario, Madrid, 1971, p. 889. Ya Don Mariano, igualmente, había manifestado que "No es frecuente en el tráfico económico de nuestros días que el contrato se genere instantáneamente. El consentimiento raras veces se forma en el acto. Más bien suele ser la culminación de una serie de situaciones previas: conversaciones, tanteos, exploraciones, negociaciones preliminares; en definitiva, el término o resultado de un iter lento y a menudo costoso" (pp. 859 y 860). Vid, igualmente, el ilustrativo estudio del profesor Ricardo DE ÁNGEL YAGÜEZ, titulado "Lealtad en el período precontractual", en Realidades y tendencias del derecho en el siglo XXI. Derecho privado, T. IV, Vol. I, Universidad Javeriana y Editorial Temis, Bogotá, 2010, p. 151 y ss., y también, in extenso, la monografía de Dimitri HoutciefF. Le principe de cohérence en matiére contractuelle, op. cit., p. 580 y ss., y. 614 y ss. 
quebrantó la confianza suscitada en otro que no puede sentirse libre de defraudarla sin incurrir en ninguna sanción. De manera más general, la equidad impone al que crea una apariencia y obra de una manera que le es contraria (venire contra factum proprium), que sea tenido por responsable del perjuicio que ha causado a aquellos que han confiado en él. En materia precontractual, el régimen de la culpa in contrahendo debe asegurar que el que legítimamente ha creído en la conclusión de un contrato válido sea protegido....."266.

266 N. Kounen, La responsabilité précontractuelle, Schulthess, 2007, p. 141. 



\section{CAPÍtulo II \\ DELIMITACIÓN DE LA DOCTRINA DE LOS ACTOS PROPIOS RESPECTO DE ALGUNAS FIGURAS AFINES}

Según es conocido, por más que en la esfera racional anhelemos la exactitud, la absoluta precisión, lo realmente inequívoco y, de suyo, certero y paladino, ello no siempre se alcanza en algunas disciplinas y zonas del actuar humano, conforme tiene lugar en el Derecho, por regla ajeno a las fórmulas matemáticas y a los trazados lineales y absolutos, casi cartesianos. Es así como la ciencia del Derecho no se puede reducir a 'blanco' o 'negro', al simétrico resultado uno más uno, o a la descomposición del agua, en su célebre representación: $\mathrm{H}_{2} \mathrm{O}$. No en vano, la referencia a leyes inmutables como la de la gravedad, o la conocida relación $P i$ $(3,1416)$, no se puede trasladar a la scientia iuris. Bien decía el maestro JosSERAND, replicando a Louis LIARD que estimaba cómo....el jurista es un geómetra", que no se puede reducir el Derecho a "un departamento de matemáticas", como quiera que es un "... producto social, que es la ciencia social por excelencia, y la primera de todas, por su urgencia, por su poder de coacción; es la regla social obligatoria, regla cambiante en numerosos y sucesivos aspectos, en donde el poder de adaptación es infinito"1.

Como es la usanza en materia jurídica, es necesario, en guarda de la debida individualización de una figura, instituto o institución, delimitar cabalmente sus contornos -o por lo menos procurarlo-, con el fin de no confundirla con otras que, de una u otra manera, pudieren aproximársele o asemejársele. Esta labor es tanto más relevante en tratándose de la apellidada doctrina de los actos propios -entre otros calificativos más que expresan análoga idea-, como quiera que, per se, uno de sus rasgos característicos, según se acotó en su oportunidad, finca en

Louis Josserand. "Relativité et abus des droits", en Evolutions et actualités, Sirey Paris, 1936, p. 72. 
su relativa indefinición; en la dificultad de establecer, con claridad meridiana o muy aproximada, su identidad plena, en el entendido que es una regla jurídica algo más arenosa o porosa que otras que convergen en el ordenamiento, dueñas de una mayor definición de índole tipológica, y de un pasado más arraigado e incidente.

De ahí, anticipadamente, la valía de realizar su delimitación, no obstante admitir, desde ya, la dificultad de este constructivo ejercicio, como se anticipó, no tanta, empero, como para no reconocer que, por su etiología, morfología, estructuración, significado, alcances, efectos, características y presupuestos, posee carta de ciudadanía y, de contera, es titular de un ADN jurídico diverso y, en concreto, de marcadores genéticos singulares que, en sí mismos, reclaman autogobierno y correlativa autonomía, así no en todos los casos afloren de bulto. Desde esta perspectiva, su color sanguíneo, en apariencia, podrá asemejarse al de otros institutos, pero su sangre será propia, así los demás igualmente "tiñan de rojo", como expresa la tonada popular. Lo mismo, mutatis mutandis, tiene lugar en relación con su aroma, de suyo revelador, puesto que lo impregna con una fragancia definida y, en tal virtud, auténtica y perceptible por el olfato iuris, obviamente cuando se encuentra desarrollado.

En pocas palabras, dificultad sí (difficultas), pero no imposibilidad (impossibilitas) de escisión y, por consiguiente, de tipificación jurídica, así finalmente desfallezcamos en el intento, pues en honor a la realidad la tarea propuesta es espinosa, aun cuando ello finalmente no importa; el Derecho es un entramado de retos, así sean muy superiores a nuestras limitadas capacidades, pues suele acontecer que la íntima convicción no es tan poderosa como lo es la demostración erga omnes. Es así como lo evidente para unos, no necesariamente lo es para todos, sin soslayar, incluso, la presencia del claro oscuro y la de múltiples colores presentes en la paleta de los pintores.

Lo manifestado en precedencia, con todo, no se opone a que, con el trascurso del tiempo, gracias a los aportes venideros de la doctrina y de la jurisprudencia, cada vez se hará más ostensible su precisión y consecuente diferenciación, pues no puede desconocerse que su arquitectura, rectamente entendida, no ha concluido aún, como ha sucedido con las grandes catedrales que, por siglos, se han construido cautelosa y paulatinamente, pero que sólo al final se constata su 
verdadera forma y majestuosidad. Ese es pues uno de sus más elevados desafíos, y a fe que sus futuros artífices lo asumirán con responsabilidad y solvencia, como ha tenido lugar en tratándose de otras figuras e instituciones. Felizmente, el Derecho ni se gestó en un día, como se suele decir de la memorable Roma, ni tampoco es flor de 24 horas. Todo es, al fin y al cabo, decantación natural que, como sucede con ciertos vinos, sólo se decantan con el paso del tiempo.

En este orden de ideas, sin perjuicio de que se pudiera realizar una más exhaustiva diferenciación con diversas instituciones o figuras afines al instituto materia de nuestras reflexiones, lo que desventuradamente nos desviaría del plan inicialmente trazado, creemos conveniente tener en cuenta las siguientes, como quiera que, aun cuando poseen vasos comunicantes y dialogan entre sí, acusan disimilitudes dignas de ser tomadas en consideración, tanto más cuanto se erigen en detonantes de su sustantividad y, por tanto, de su carácter autonómico o por lo menos matizado y diferenciado. Ellas son el negocio jurídico, en general, y las declaraciones de voluntad, en particular, la renuncia de derechos, la buena fe, la excepción de dolo -exceptio doli generalis-, el abuso del derecho, la propia culpa o torpeza, y el estoppel y la verwirkung -asimilada por algunos al retraso desleal-, fundamentalmente, pues se reitera que hay otras (la preclusión y la incongruencia procesales, etc.), aunque estimamos que las mencionadas son las de mayor abolengo sustancial, y con las que más a menudo son confundidas o inescindiblemente asociadas.

Es de anticipar, por su significado, que nos detendremos en unas diferencias más que en otras, pues son las que revisten mayor dificultad, y las que, en nuestro entender, ameritan mayor claridad, así prima facie pareciera lo contrario. Es el caso, principalmente, de la exceptio doli y del abuso del derecho, hecho que justifica su tratamiento más detenido, a fortiori si lo que pretendemos con este estudio, decididamente, es contribuir a que la doctrina de los actos propios, que se ha dicho es inespecífica y, en veces, inacabada, se torne más exacta, perfilada y definida, tarea no exenta de acentuada dificultad, según se expresó, entre otras razones porque tanto el abuso del derecho, como la exceptio doli generalis, por ser "...fórmulas amplias e indeterminadas (...) se revelan sustancialmente ambiguas"2.

Giovanni Cattaneo. Buona fede obbiettiva e abuso del diritto, op. cit., p. 659. 
Algo similar sucede, no obstante su milenario desarrollo e indiscutida trascendencia axiológica y jurídica, con la buena fe, más aún cuando en ella, hasta saciarse, han bebido -y siguen bebiendo- buena parte de los remedios materia de análisis, lo que hace que en ocasiones terminemos caminando en un especie de círculo, sin quererlo, merced a su magnetismo avasallador, la que naturalmente debe tener límites, así nos cueste creerlo a quienes tanto la sublimamos y encumbramos. He ahí pincelado el agudo problema que, francamente, ab origine, escolta a estos folios; una dificultad mayúscula, nada menos que de identidad que, no por ello, debe desalentar. Muy por el contrario, debe ser acicate y estímulo para el jurista perseverante, ese que, como algunos han rotulado a BoLivar, puede ser llamado el "hombre de las dificultades", y a fe que esta delimitación, más allá de la retórica, o de argumentos de autoridad o simplemente reforzados o aún efectistas, en la intimidad del autor, cuando este dialoga consigo mismo, con humildad, desprovisto de arrebatos, vanidades y de malsano excepticismo, está abarrotada de ellas, lo que se hace patente en la medida en que se exploran más. ¡Qué consuelo!

Finalmente, otras diferencias serán estudiadas de modo muy sucinto y esquemático, en atención a que, in extenso, serán materia de análisis ulterior, v.gr: el estoppel y la verwirkung. Bastarán pues algunas referencias concretas, en obsequio a la concisión, e igualmente en aras de hacer una presentación temática de conjunto y de facilitar, correlativamente, un mejor entendimiento de la doctrina de los actos propios, en asocio de otros institutos próximos o hermanados por elementos comunes, con la confianza de que ello pueda ser así, aunque el camino sabemos que es escarpado. Iniciemos pues su examen.

\section{EL NEGOCIO JURÍDICO, EN GENERAL, Y LA DECLARACIÓN DE VOLUNTAD, EN PARTICULAR}

El negocio jurídico, por excelencia, ha estado estrechamente ligado a la voluntas, a la intentio, al querer, en una sola expresión, al inequívoco deseo de desencadenar un determinado efecto, así la motivación primigenia sea de índole práctica: v. gr: la satisfacción de una específica necesidad, más allá de que deliberadamente se anhele la generación de una arquetípica consecuencia jurídica (fin práctico del negocio jurídico). 
Así irrumpió, otrora, en la esfera de la historia del Derecho, en especial en sede de la afamada Escuela Pandectista alemana, signada por su abstracción y conceptualismo ${ }^{3}$. Por eso, como lo recuerda el profesor Francesco Galgano, recientemente fallecido, "...la definición más difundida de negocio jurídico, debida a la ciencia del derecho civil alemán del siglo XIX", es aquella que lo concibe, por ser de su "esencia", como "...una manifestación o declaración de voluntad, explícita o resultante de un comportamiento concluyente, dirigida a producir efectos jurídicos, que el ordenamiento realiza 'en cuanto queridos"'”.

En sentido similar, dándole paso a una lectura de contenido más pragmático, sin restarle vigencia estrictamente jurídica, Don Federico DE CASTRO, después de concebir el negocio jurídico como "...supuesto de hecho", explicita que este es "la declaración o acuerdo de voluntades, con que los particulares se proponen conseguir un resultado, que el Derecho estima digno de su especial tutela, sea en base sólo a dicha declaración o acuerdo, sea complementado con otros hechos o actos", de tal manera que para este afamado autor la declaración de voluntad "...ha de seguir siendo estimada como el fundamento del negocio jurídico"

Otro tanto acontece, de una u otra forma, al entenderlo como concreta manifestación de autonomía privada, a partir del reconocimiento en cabeza de los particulares, de autorregular sus propios y legítimos intereses, obviamente con las connaturales limitaciones inherentes a su ejercicio, con el fin de evitar se torne lesivo, amén de invasor. Cómo lo realza don Luís DíEz-PICAzo, en el campo patrimonial, "El negocio jurídico es un acto de autonomía privada que reglamenta

\footnotetext{
Vid. Gerhard Wesenberg y Gunter Wesener. Historia del derecho privado moderno en Alemania y en Europa, Lex Nova, Valladolid, 1998, p. 288. Cfr. José Luís De Los Mozos, quien recuerda cómo “... la teoría general del negocio jurídico queda formada en la primera mitad del siglo XIX, por obra del Pandectismo, presentándose como la expresión dogmática del reconocimiento de la autonomía privada..... El negocio jurídico, Montecorvo, Madrid, 1987, p. 20.

4 -Francesco Galgano. El negocio jurídico, Tiran lo blanch, Valencia, 1992, p. 27, autor que, no obstante reconocer que "La verdad es que nuestros civilistas hablan en la actualidad de negocio jurídico más por costumbre lingüística que por convicción conceptual", concluye que cuando se alude a "... acto negocial no se quiere expresar más que la presencia de un acto de voluntad...." (op. cit., p. 37). Cfr. Helmut CoIng. Derecho privado europeo, Vol. II, Fundación Cultural del Notariado, Madrid, 1996, pp. 343 y ss.
}

5 Federico De Castro y Bravo. El negocio jurídico, Civitas, Madrid, 1985, p. 34. 
para sus autores una determinada relación o una determinada situación jurídica. El efecto inmediato de todo negocio jurídico consiste en constituir, modificar o extinguir entre las partes una relación o una situación jurídica y establecer la regla de conducta o el precepto por el cual deben regirse los recíprocos derechos y obligaciones que en virtud de esta relación recaen sobre las partes"6.

Desde esta perspectiva, si bien es cierto que en la hora de ahora no es de recibo sobredimensionar la importancia de la voluntad negocial, hasta el punto de hacer de ella un dogma como aconteció en el pasado, en concreto en el siglo $\mathrm{XIX}$ y en parte del $\mathrm{XX}$, hoy por hoy revaluada, como es bien sabido, tampoco es menos cierto que sigue revistiendo relevancia, pues por más que esté limitada o atenuada, en función de las transformaciones experimentadas en la centuria que antecede, de suyo refrendadas en lo corrido de la presente, sigue altiva y, sobre todo vigente. En esta dirección el profesor de la Universidad de Nápoles, Luigi CARIOTA FERRARA, puso de manifiesto en su momento que en la actualidad “... no puede verse reconocido el imperio absoluto de la voluntad... Pero innegablemente la voluntad sigue siendo elemento esencial del negocio jurídico. Indudablemente el principio de voluntad se limita, pero no se excluye, por los de responsabilidad y de confianza"7.

Los mismo tiene lugar en lo tocante con el contrato, una de las más caracterizadas aplicaciones del negocio jurídico, pues independientemente de los necesarios ajustes y matizaciones realizadas en su órbita en los últimos decenios -no tantos como para socavarlo-, sigue enseñoreándose en la ciencia del Derecho como un prototípico acuerdo volitivo. Por ello es por lo que en el contrato moderno dicha convergencia de voluntades, resulta aún toral, hasta el

Luís Díez-Picazo, Fundamentos de derecho civil patrimonial. Introducción y teoría del contrato, Thomson-Civitas, Pamplona, 2007, p. 92.

Luigi Cariota Ferrara. El negocio jurídico, Aguilar, Madrid, 1956, p. 58, autor que en consonancia con lo afirmado en precedencia, señala que "...es muy justa y legítima la definición que pone de relieve, como esencial del negocio jurídico, la manifestación de voluntad. Incluso caído el dogma de la voluntad, el negocio jurídico es para nosotros "manifestación de voluntad dirigida a un fin práctico'". 
punto por el cual autores como Vincenzo Roppo, estiman que modernamente, aún, "La voluntad de las partes es el fundamento y sustancia del contrato".

De lo expuesto, en compendio, se evidencia que la médula del negocio jurídico, muy especialmente del contrato, estriba en la voluntad y reflejamente en la protección de la confianza, la que rectamente entendida se torna inescindible de aquél, toda vez que se traduce en la atmósfera en la que se teje y debe desenvolver la relación negocial, por lo menos en un plano ideal, de suerte que cuando se contamina, de paso, se quebranta la fides, en una de sus más genuinas expresiones, sin perjuicio del quiebre del objetivo que, en lo teleológico, condujo a las partes, o por lo menos a una de ellas a contratar. Como aguda e ilustrativamente lo respondió el distinguido Maestro, Don Mariano Alonso PérEZ, luego de indagar "¿En qué consiste la buena fe exigida en el tráfico jurídico....? Está en el mismo proceder negocial, en cuanto las partes están obligadas recíprocamente a guardarse lealtad, desengañarse de errores, huir de reticencias; en definitiva, cada contratante debe hablar con claridad y poner en conocimiento de la contraria las situaciones reales reconocibles, huyendo del fraude que pueda llevar a falsas determinaciones volitivas. Quien defrauda la confianza y viola la honorabilidad de las negociaciones, incumple el artículo 1258 del C.C.; en definitiva, un precepto jurídico obligatorio normativamente"9.

\footnotetext{
Vincenzo Roppo. op. cit. p. 36. Cfr. Massimo BIANCA, quien observa cómo, desde un ángulo subjetivo, se "...identifica al contrato como acto de decisión de las partes, y más precisamente como acuerdo... el acuerdo es una manifestación de voluntad, y como tal debe ser entendida. Ello no quiere decir acogimiento del llamado dogma de la autonomía de la voluntad....". Diritto civile. II contratto, Giuffrè, Milano, 1987, p. 5.
}

En sentido similar, el ilustre profesor Mariano Alonso PÉREZ, refrenda que “...todo contrato supone acuerdo, concurrencia de voluntades y el consentimiento, eje del contrato, no es otra cosa que una fusión de voluntades declaradas". Anotaciones y concordancias al Derecho español en torno a la obra de Vittorino PIETROBOn. El error en la doctrina del negocio jurídico, op. cit., p. 178.

Para Don Luís DíEz-PICAZo, por su parte, refiriendo a la “...concepción moderna del contrato", este "...es todo acuerdo de voluntades por medio del cual los interesados se obligan. El contrato así concebido se convertirá en la institución central, en la piedra angular, no sólo del Derecho Civil, sino de todo el ordenamiento jurídico". Fundamentos de derecho civil patrimonial, Vol. I, p. 137.

9 Mariano Alonso Pérez. "Traducción y extensas anotaciones y concordancias al Derecho español" en torno a la obra de Vittorino PIETROBON. El error en la doctrina del negocio jurídico, op. cit., p. 159. 
Ahora bien, tratándose del factum proprium, en rigor, su sistema nervioso no reside en la voluntas, propiamente dicha, en esa expresión de voluntad que signa al negocio jurídico y que en sede contractual se patentiza en el acuerdo de voluntades, su corazón, como se indicó.

Bien observadas las cosas, cuando aflora la contradicción; cuando se vulnera el deber de coherencia comportamental, con todo lo que ello entraña, no se está propiamente en el terreno de las voliciones, ni en la esfera teleológica asignada al negocio en referencia: la creación, modificación o extinción de relaciones patrimoniales, si de contratos se trata. No hay allí una "... manifestación de voluntad directa y reflexivamente encaminada a producir efectos jurídicos", ${ }^{10} \mathrm{ni}$ tampoco conciencia de estar celebrando un negocio de tal estirpe.

No en vano, el acto propio, la actuación sinuosa y oscilante del voluble, no encuadra en el haz finalístico del negocio jurídico, in concreto del contrato. Muy por el contrario, aflora un comportamiento que, aun cuando lícito formalmente, ni es plausible, ni altruista, ni ético, ni bienhechor, ni está en sintonía con la buena fe objetiva, blanco de la contradicción originada en una actitud insolidaria, a la vez que constitutiva de incorrección e improbidad, entre otros calificativos más, todos indicativos del divorcio reinante entre el ser y el deber ser, ese que hemos llamado 'buen gobierno contractual', relativo a las mejores prácticas negociales (asepsia negocial), en el asunto que nos ocupa de no defraudar la confianza legítima suscitada por el mismo sujeto que, sorpresivamente, luego la rasga y quebranta. He ahí pincelada la profunda diferencia existente en la manifestación volitiva, enmarcada en un negocio jurídico, dueño de una finalidad jurídico-práctica determinada, y el acto propio, detonante de una contradicción o incoherencia en el comportamiento contractual, ayuno de una intencionalidad edificante y de la nota de autorregulación de intereses dignos de tutela y protección, de tal modo que nada que los erosione, injustificada o inconsultamente, debe contar con el exequatur del ordenamiento jurídico, en particular de los jueces.

10 Guillermo y Eduardo OspinA. Teoría general de los actos o negocios jurídicos, Temis, Bogotá, 1980, p. 18. 
Al fin y al cabo, lo expresa correctamente don Luis Díz-Picazo, “...en el 'factum proprium' lo que el ordenamiento jurídico valora, para hacer depender de ello un efecto jurídico, no es una voluntad negocial que los actos revelen, sino el sentido objetivo que estos actos poseen. No se decreta la inadmisibilidad de la conducta contradictoria para vedar un cambio de voluntad, sino para vedar una consecuencia que es objetivamente inconciliable con la buena fe. Esto es: cualquiera que haya sido la voluntad que lo haya presidido o impulsado, estos actos han suscitado en el círculo de los interesados una confianza fundada respecto a lo que significan como actitud del sujeto dentro de la relación jurídica"11.

En estas circunstancias, no es ni necesario, ni tampoco aconsejable acudir a la arquitectura del negocio jurídico, específicamente a su cometido (crear, modificar o extinguir), para explicar la regla del venire contra factum proprium, ni ninguna de sus expresiones individuales, v.gr: la doctrina de los actos propios, la verwirkung, etc., como quiera que son muy disímiles genética y funcionalmente, hecho éste que, a juicio de la doctrina especializada, en forma acertada, ha suscitado serias reservas respecto a la jurisprudencia reiterada y tradicional del Tribunal Supremo, encaminada a considerar que los actos propios "...han de ser expresivos del consentimiento con el fin de crear, modificar o extinguir algún derecho" (Sentencia del 24 de febrero de 1960, entre otras más) ${ }^{12}$.

11 Luís Díez-PICAzo. La doctrina de los propios actos, op. cit., p. 163, folio éste en el cual culmina su exposición alrededor de este punto, afirmando que "El acto es, por decirlo así, una 'promesa' de una futura conducta coherente con él. La persona queda imposibilitada para contrariar sus actos, no porque haya quedado vinculada por una voluntad negocial declarada a través de ellos, sino porque debe responder de las consecuencias de la confianza suscitada". Ya líneas atrás, don Luís igualmente había señalado, en forma categórica, que "...en el venire contra factum el efecto se produce de un modo objetivo, en el cual para nada se tiene en cuenta la verdadera voluntad del autor de los actos. Se protege la confianza que estos suscitan en terceros....La eficacia de los actos concluyentes se mantiene por razón de haber mediado consentimiento, mientras que cuando se impide que una persona vaya contra sus propios actos, se deja por completo de lado toda doctrina de la declaración de voluntad para imponer directamente un efecto jurídico". Cfr. José PUIG BRUTAU, La doctrina de los actos propios, op. cit., p. 126 y ss., con especial referencia a los actos concluyentes (facta concludentia) que distingue nítidamente del venire contra factum proprium. Bien dice al respecto que "...cuando un tribunal impide que un litigante vaya contra sus propios actos, deje por completo de la lado toda la doctrina de la declaración de voluntad".

12 Cfr. Nélida TuR FAúnDEZ. La prohibición de ir contra los actos propios y el retraso desleal, op. cit., p. 42, quien indica como "Se hace necesario delimitar la doctrina de los actos propios de otras figuras con las que habitualmente es confundida, como ocurre especialmente con la figura del negocio jurídico. Resulta, en efecto, muy frecuente en nuestra doctrina 


\section{Desde esta perspectiva, le asiste plena razón al distinguido profesor José María MıQUeL, cuando ocupándose del mismo tema, después de escrutar diversos}

y en nuestra jurisprudencia que se produzca una identificación entre la inadmisibilidad de desligarse de un negocio jurídico y la prohibición de ir contra los propios actos. El tal caso, no es necesario acudir a la doctrina de los actos propios para explicar la vinculación del sujeto a la conducta anterior, sino que basta con aplicar la doctrina de los efectos del consentimiento o de la declaración de voluntad".

Como lo memora el profesor Carlos RogeL VIDE, “...ya desde finales del siglo XIX, el Tribunal Supremo ha venido diciendo que los actos a que este principio -el de los actos propios-se refiere son aquellos que, como expresión del consentimiento, se realizan con el fin de crear, modificar o extinguir algún derecho. La afirmación precedente, en efecto, procede de la STS del 10.3.1890 y está reiterada -con iguales o parecidos términos- por otras posteriores. $\mathrm{La}$ esencia del principio de que nadie puede ir válidamente contra sus propios actos está en la existencia de actos que se realizan con el fin de crear, modificar o extinguir algún derecho, no siendo actos propios vinculantes los que no entrañen manifiestamente el propósito de contraer una obligación...." "La doctrina de los propios actos en la última jurisprudencia civil española", en La doctrina de los actos propios, coautoría, Marcelo LóPEZ MESA, Reus, B de F, Buenos Aires, 2005, pp. 224 y 225.

En dirección análoga, la Dra. Clara I. Assua GonzÁlez, reafirma de la doctrina de los actos propios que, "En términos generales, esta doctrina gira en torno a la idea de que debe protegerse la legítima confianza en la coherencia de una conducta. La real virtualidad de semejante concreción de la buena fe debe situarse fuera de los actos negociales.... Hoy ha de insistirse en que semejante concepción carece de sentido y debe ser superada. Tal y como gráficamente se ha dicho, ha de diferenciarse entre mecanismos no formales que susciten confianza fundada en una conducta y la fuerza vinculante del negocio jurídico unilateral o bilateral. El campo de la doctrina de los actos propios corresponde al primer ámbito no al segundo y debería realizarse un esfuerzo jurisprudencial por sentarlo". "Comentario, artículo 7", en Código Civil Comentado, Vol. I, Dirigido por Ana CaÑIZares Laso, Pedro de Pablo Contreras, Javier Orduña Moreno y Rosario Valpuesta Fernández. Thomson Reuters, Pamplona, 2011, pp. 92 y ss.

Es de anotar, sin embargo, que el Tribunal Constitucional español, en Sentencia del 28 de abril de 1988, delimitó cabalmente ambas figuras, al puntualizar que la diferenciación de "...los facta concludentia y los actos propios, concibiendo aquéllos como sede o expresión del consentimiento negocial, y observando éstos, como propone un autorizado sector de la doctrina científica, fuera del tema de las declaraciones de voluntad expresas o tácitas, situándolo, sin carácter negocial alguno, en la perspectiva de los principios de la buena fe y de la confianza, instituyendo el deber de producirse coherentemente y admitiendo que si una conducta suscita la confianza, debe recusarse el ejercicio de los derechos opuestos a la confianza creada".

Otro tanto se expresó, con rotundidad, por parte del Tribunal Supremo en sentencia del 19 de junio de 2003, aunque se han proferido otras sentencias que insisten en el planteamiento cuestionado. En dicha ocasión el Supremo, refriéndose a "La regla jurídica según la cual no puede venirse contra los propios actos", indicó que el "...centro de gravedad" de la misma, "...no reside en la voluntad de su autor, sino en la confianza generada en terceros, ni se trata en tal regla de ver una manifestación del valor de una declaración de voluntad negocial manifestada por hechos o actos concluyentes. No es la regla una derivación de la doctrina del negocio jurídico, sino que tiene una sustantividad propia, asentada en el principio de la buena fe" (RJ 2003, 5652). 
pronunciamientos del Supremo, expresa que "...si se dice que los actos propios contra los que no se puede ir son los que se realizan con el fin de crear, modificar o extinguir algún derecho, hay que explicar qué diferencia existe entre tal acto y un negocio jurídico. O dicho de otra forma, hay que explicar si la doctrina del negocio jurídico, posterior en nuestra jurisprudencia a la de los actos propios, cubre o no a esta última. La jurisprudencia de nuestro Tribunal Supremo contiene numerosas declaraciones semejantes a las de esta sentencia... Esto quiere decir que la sentencia que comentamos continúa una línea de declaraciones jurisprudenciales en las que parece que la doctrina de los propios actos no se diferencia de la teoría del negocio jurídico. Es explicable que nuestro Tribunal Supremo utilizara tal doctrina de los propios actos para la misma finalidad que la teoría del negocio jurídico, porque ésta no se recibe en nuestra doctrina hasta los años veinte de este siglo. Ahora bien, después de que tal teoría ha sido recibida totalmente en nuestra doctrina y en nuestra jurisprudencia, parece que deberían ser diferenciadas, reservando la doctrina de los propios actos para aquellos supuestos en los que se ha creado una confianza que merece ser protegida sin que exista un negocio jurídico o una declaración de voluntad unilateral que incida en la relación negocial”"13.

Así las cosas, en el factum proprium la protección y salvaguarda de la confianza se erigirá en su epicentro, en su piedra de toque, mientras que con relación al negocio jurídico tal protección no es la savia, ni su basamento, el que estará constituido por una voluntas, no in abstracto, esto es querer por querer, simplemente, sino in concreto, en aras de crear, modificar o extinguir relaciones jurídicas, norte muy disímil al atribuido al acto propio. Vuelve a tener razón el profesor MIQUeL al momento de expresar que "Una declaración de voluntad negocial obliga desde el mismo momento de su perfección, la doctrina de los actos propios como sistema que protege la confianza en la coherencia de la conducta, precisamente exige como decisivo que la confianza haya surgido efectivamente y sea comprobable por su inversión; requiere además que la coherencia sea exigible conforme a la buena fe de modo que no pueda tolerarse la frustración de la confianza suscitada ... Hay que destacar además que la exigencia de que

José María Miquel Gonzales. "Comentario, Sentencia del 25 de enero de 1983", en Cuadernos Civitas de Jurisprudencia Civil, 1, enero/marzo de 1983, pp. 78 y 79. 
el declarante tenga conciencia de que efectúa una declaración de voluntad, para que estemos ante un negocio jurídico, elimina la posibilidad de explicar la doctrina de los actos propios bajo esquemas negociales. El acto propio contra el que no se puede ir no requiere tal condición ni es por sí solo, insisto, el supuesto de hecho que impide la contradicción"14.

A tono con lo expresado, es claro entonces que la tarea hermenéutica a cargo del juzgador será distinta tratándose de la identificación de un factum proprium y la interpretación del contrato, propiamente dicha. En el primer caso, se centrará en determinar si medió una contradicción o apartamiento conductual relevante entre un comportamiento y otro (anterior y ulterior, respectivamente), para lo cual examinará el grado de confianza suscitado (prius) y su real quebrantamiento (posterius). En el segundo, prevalentemente, se circunscribirá a establecer la común intención de los contratantes, hasta donde ello sea razonablemente posible, laborío más de índole subjetiva, por lo demás, lo cual evidencia que el norte en ambas hipótesis es rigurosamente diferente, así para concluir que campeó una contradicción o incoherencia inadmisibles sea menester escrutar y, por ende, interpretar y valorar la conducta posterior a la celebración del negocio jurídico ${ }^{15}$, pero sin que sea procedente mezclarlos.

En el acto propio, en consecuencia, lo definitorio no será la presencia de una voluntad libre y reflexivamente expresada, sino la constatación de la quiebra de la consabida confianza legítima, centro de gravedad de la misión del juez cuando de esterilizar conductas incoherentes se trate, quien no deberá distraerse en escrutar si en tales circunstancias intervino la voluntad del agente y, por tanto,

14 José María Miquel Gonzales. Acto propio, op. cit., p. 205. Cfr. Jacinto Gil Rodríguez. "Comentario a la Sentencia del 20 de noviembre de 2001", en Cuadernos Cívitas de Jurisprudencia Civil, No 60, pp. 907 y 908, en el que se escinde con precisión el acto propio y el negocio jurídico, y Miguel Pascual Liaño. "Jurisprudencia Civil Comentada". Código Civil, T. I, Comares, Granada, 2009, p. 91, quien entiende que la asimilación en mención es una "...confusión entre actos propios y declaraciones negociales de voluntad", y a su juicio una "....concepción equivocada".

15 Vid. Federico PRocchI. L'exceptio doli generalis e il divieto di venire contra factum proprium, op. cit., p. 124. Lo señalado no se opone a que, en rigor, la hermenéutica tenga cabida en la determinación o comprobación de una contradicción o incoherencia, pues es una quaesti facti, obviamente con connotaciones jurídicas de orden sustancial, susceptible, en tal virtud, de ser develada a partir de la valoración conductual. 
se configuró un prístino acto negocial, puesto que como ha sido expresado con rotundidad, "...la teoría de los actos propios no toma en cuenta la verdadera voluntad o, mejor, prescinde de ella, y se afana en proteger la confianza objetiva suscitada en un tercero". 16

Es de señalar que esta diferenciación cuenta con el favor de la generalidad de la doctrina comparada. Es el caso, ad exemplum, de la doctrina portuguesa, de acuerdo con la cual la temática en referencia "...está fuera del dominio del negocio jurídico". Esa es la opinión de Paulo MotA PINTO, autor que rechaza "... una teoría general para encuadrar el venire contra factum proprium, la que le negaría autonomía a este instituto", no entendiendo correcto efectuar ningún "...encuadramiento negocial, ni vinculación con la autonomía privada, a través del negocio jurídico", así se pretenda ampliar sus fronteras, a la par que cobijar cualquier tipo de declaración: expresas y aún las tácitas ${ }^{17}$. $Y$ también de la italiana, y de la española, como se evidenció. En esta dirección Salvatore PATTI, con ocasión del examen de la verwirkung, explicitación especial del venire contra factum proprium, pone de presente que "su originalidad está en la producción de un efecto jurídico independientemente de un acto negocial" de un sujeto, pues lo decisivo es "...su comportamiento, su actuar (en el cual se encuadra también su no actuar), el que ha originado la confianza de su cocontratante"18.

No sucede lo mismo, empero, con la tesis defendida por el profesor Hans Josef Wieling, quien seguramente como lo explica Antonio Menezez Cordeiro, aludiendo a este autor alemán, "Siendo el factum proprium un acto voluntario ...

16 Alejandro Borda. La teoría de los actos propios, op. cit., p. 122, autor que igualmente hace gran énfasis en distinguir las declaraciones tácitas de voluntad y el acto propio, como también lo hace la doctrina dominante, a la que adherimos por las mismas razones esgrimidas anteriormente. Vid. Luís DíEz-PICAZo. La doctrina de los propios actos, op. cit., p. 150, en la que se indica que tal equiparación "...es hoy unánimemente rechazada. Ha podido tener valor mientras no ha existido la teoría de la declaración tácita de voluntad, como construcción jurídica autónoma, mas hoy, admitida esta construcción, es a ella a la que hay que acudir para explicar el efecto vinculante de una conducta cuando es tomada como 'expresión del consentimiento'.... Los actos concluyentes no pertenecen a la verdadera doctrina de los actos propios"

17 Paulo Mota Pinto. "Sobre a proibiçao do comportamento contradictório (Venire contra factum proprium) no direito civil", op. cit., p. 307.

18 Salvatore PATTI, Verwirkung, en Dig. Disc. Priv, sez. civ, XIX, Torino, 1999, p. 726. 
era inevitable que aparecieran teorías que defendiesen, en relación con el venire, la violación de situaciones de tipo negocial", posición severamente cuestionada por coterráneos suyos, como acontece con los doctrinantes CANARIS y FLUME, según lo reconoce el mismo WIELING, quienes entienden que no es de recibo “... fingir una declaración" en estos supuestos, conforme tiene lugar en la renuncia, por vía de ilustración.

Es cierto que "aún permanece oscura la aplicación práctica del venire contra factum proprium, en particular su encuadramiento dogmático", como bien lo expresa el profesor WIELING ${ }^{19}$, pero de ello no se desprende, apodícticamente, que para darle claridad al instituto en comento debe entonces acudirse a la figura del negocio jurídico. Esa, en nuestro entender, tampoco es la mejor solución, pues antes que esclarecer el venire, termina a la postre por eclipsarlo más, pues no sólo

19 Hans Joseph WIELING. "Venire contra factum proprium e colpa verso se stesso", en Rass. dir.civ, 1994, p. 411 y 412.

Más interesante y original es el análisis que WIELING efectúa en torno a las cargas (oneri), por oposición a las obligaciones, stricto sensu, pues pretende justificar que la lesión de la carga, su inejecución objetiva, se traduce y es tratado como un venire contra factum proprium, a pretexto del "abandono negocial" que en la praxis se produce, aun cuando no por ello indefectiblemente exacto, pues aunque el venire sirve de explicación para sustentar la validez de la carga -o incumbencia- del acreedor. v.gr: del asegurado en relación con la evitación del siniestro y con su mitigación, según el caso (Cfr. Fernando Sánchez Calero. Ley de contrato de seguro, Aranzadi, Pamplona, 1998, p. 270), no creemos que la determinación que éste finalmente adopte, que se pregona que es en su propio y exclusivo interés, revista la naturaleza de inequívoco negocio jurídico, en estrictez. Será una "...elección que corresponde al sujeto en el supuesto de la carga", hija de la "...libertad en que se encuentra", conforme lo recrea José GonZÁlez GARCía ("Notas para un concepto de carga", $R G L J, 1986$, p. 192), pero no un negocio jurídico, así indirectamente el resultado obtenido (opus), sea reflejo del querer del acreedor, pues se entiende por parte de un sector de la doctrina que "...la carga no implica una facultad, sino que constituye una conducta que opera como presupuesto para poder ejercitar la facultad" (Antonio CABANILLAS SÁNCHEZ. LaS cargas del acreedor en el derecho civil y en el mercantil, Montecorvo, Madrid, 1988, p. 60). Con todo, si fuera un adamantino negocio jurídico, en gracia de discusión, el basamento de la protección conferida al deudor en tal hipótesis, no estribaría en el carácter de acto negocial de la elección en cita, sino que con la misma se estaría conculcando la confianza legítima en él suscitada, quebrantada cuando el acreedor, no obstante haber adoptado una conducta de suyo ilustrativa y reveladora de lo pretendido, ex post ejerce su derecho olvidando su comportamiento previo, hecho que tiene asignadas claras secuelas en el campo de las cargas: la pérdida de su derecho, o la disminución de su quantum, conforme las circunstancias, a raíz de que se entenderá violentado el postulado de la buena fe. Vid. Carlos Ignacio JARAMILLO J. "Obligaciones, cargas y deberes de conducta del tomadorasegurado en el contrato de seguro", en Derecho de seguros, Universidad Javeriana y Editorial Temis, Bogotá, 2012, pp. 231 y ss. 
es conveniente perfilar sus rasgos y reclamar una lectura autonómica y armónica, como lo hemos afirmado, sino evitar caer en la tentación de emplear categorías tan genéricas -amén que elásticas- en las que se pierda su sustantividad y, de contera, su ser y, de paso, su espíritu, sin perjuicio de que, en puridad, tampoco se advierte la verificación de todos y cada uno de sus presupuestos y su caracterización.

No desconocemos que en ocasiones el factum proprium, mejor el factum novum, diseccionado, pueda contener rasgos volitivos e, incluso, en ciertas hipótesis, irrumpir al mundo conductual por la voluntas del voluble, hecho que, al margen de su ilicitud -o antijuricidad-puntual, aunada a otras secuelas legales, no autoriza su adscripción al negocio jurídico, menos con carta de naturaleza generalizada, tanto más cuanto que por esa escarpada vía se estaría deslegitimando tan aprestigiada categoría iuris, pues el venire, de ordinario, es manantial de inequidad, de afrenta contra caros e impolutos intereses dignos de tuición, lo que explica su frontal rechazo, nada menos que su inadmisión en la esfera jurídica (inadmisión del ejercicio del derecho pretendido).

Expresado de otro modo, innecesariamente, se estaría enturbiando la figura del negocio jurídico, por antonomasia bienhechora, a la vez que de insoslayable utilidad y función social, y no un vehículo aterciopelado para que transite la sorpresa, la incoherencia, la contradicción, la inarmonía, la desazón y la desesperanza. Sería tanto como hacerle a priori, mutatis mutandis, apología al 'anti-negocio' y no al negocio jurídico, expresión esta última que, ab initio, encierra valores de especial valía, incluidos los éticos.

Antes de concluir, huelga mencionar, acorde con lo que hemos venido manifestando en líneas que anteceden, que en desarrollo de las claras diferencias existentes entre el negocio jurídico -al mismo tiempo que de la declaración de voluntad- y la doctrina de los actos propios, no puede confundirse esta con situaciones inherentes al desenvolvimiento de aquél, por vía de ejemplo, su incumplimiento o inejecución, con el argumento que las reglas pacta sunt servanda y venire contra factum proprium son simétricas, como quiera que si bien es coherente cumplir con lo acordado primigeniamente, no por ello se asimilan. La primera atiende más bien a la fuerza obligatoria, ínsita en los contratos, 
y la segunda propende por evitar que conductas huérfanas de coherencia, constitutivas de un grado de confianza considerable se erijan en lesivas de caros intereses de una de las partes del acuerdo negocial ${ }^{20}$.

Por último, lo expresado en relación con el negocio jurídico, en general, es predicable de las apellidadas declaraciones tácitas de voluntad, como se anotó tangencialmente, habida cuenta de la afinidad argumental reinante, lo que nos exime de hacer nuevas disquisiciones a las ya realizadas, a las que entonces nos remitimos, porque en todo caso son expresiones de la voluntad, variando, eso sí, su forma o modalidad de exteriorizarla, pues no sólo la palabra, la explicitud, en sí mismas, tienen cabida en la escena jurídica. Bien expresó Don Florencio García Y GoYenA en pleno siglo XIX que "...la manifestación por hechos es más elocuente y enérgica que la palabra" (art. 1019 del Proyecto de Código Civil de $1851)^{21}$.

\section{LA RENUNCIA}

Aun cuando en estricto sentido la temática de la renuncia, ora expresa, ora tácita, podría quedar cobijada en el estudio realizado en el numeral anterior,

20 No desacierta el profesor argentino Alejandro BoRDA, cuando en abono de la separación de las referidas hipótesis, observa que "... muchas veces se recurre equivocadamente a la teoría de los actos propios cuando la cuestión pasa por un simple incumplimiento contractual que podrá dar origen a una acción en donde se reclame el estricto cumplimiento del contrato o su resolución y donde ninguna incidencia tiene el comportamiento contradictorio. Lo verdaderamente importante es que no se ha cumplido debidamente con lo establecido en el contrato". La teoría de los actos propios, op. cit., p. 129. Cfr. Anderson Schreiber. A proibiçao de compotamento contraditório, op. cit, p. 231. Lo mismo tiene lugar, en obsequio a la concreción, con la ineficacia del negocio jurídico, en general, gobernada por coordenadas autónomas, de vieja data, a la par que disímiles, tanto en lo etiológico, como en lo patológico.

21 Véase por todos, en adición a lo planteado por nosotros, a José PUIG BRUTAU. La doctrina de los actos propios, op. cit., p. 126. Sin embargo, es de puntualizar que, aun cuando no con la frecuencia de antes, aún se percibe cierta confusión en el Tribunal Supremo Español al respecto, se reitera, en la medida en que en sentencia del 29 de enero de 2007, manifestó de nuevo que son presupuestos del acto propio: “...c) que el acto sea concluyente e indubitado, por ser expresión de un consentimiento dirigido a crear, modificar o extinguir algún derecho generando una situación desacorde con la posterior conducta del sujeto", asimilación que igualmente ha suscitado reservas, la que a su vez se ha hecho en otras sentencias de la presente centuria. Vid. Nélida TuR FAUNDEZ. La prohibición de ir contra los actos propios y el retraso desleal, op. cit., p. 45. 
reservado para el negocio jurídico, en general, y para las declaraciones de voluntad, en particular, resulta de la mayor importancia hacer un análisis individual de la misma, dado que es muy frecuente que se asimile o confunda con el factum proprium, en cualquiera de sus manifestaciones, sobre todo con relación a la figura de la verwirkung, como se anotará.

Por lo tanto, grosso modo, le pasaremos revista a las notas más salientes de la institución de la renuncia, ciertamente polémica, a fuer que objeto de agudas y maduras reflexiones por parte de la doctrina y la jurisprudencia, no de ahora, sino desde hace un apreciable número de lustros.

Efectivamente, hay una gran tentación, en general, de pretender encuadrar el acto propio en una renuncia, así sea de índole tácita, en atención a que ante precisas circunstancias, en materia de secuelas conductuales, se puede creer que el efecto inmanente a la incoherencia o contradicción: la inadmisión -o rechazo- del ejercicio de un derecho, obedece a una renuncia previa del mismo, la cual se desprende de puntuales actuaciones radicadas en cabeza de su titular, supuestamente indicativas de ello (acto de claudicación).

En dichas circunstancias, se tiene establecido entonces que se ha renunciado al derecho, de suyo posible en un plano abstracto, de tal suerte que si se quiere ejercer a posteriori, podría válidamente pretextarse su imposibilidad, por sustracción de materia, siendo, desde esta perspectiva, virtualmente argumentable la mencionada renuncia.

Empero, si se hace una auscultación más detenida y de mayor espectro, al mismo tiempo que se atiende a la realidad jurídica, in complexu, esta conclusión, aparentemente acompañada de alguna lógica, se pierde de raíz, pues allí sólo se insinúa la apariencia nada más, lo que explica que haya sido catalogada de "gravemente equivocada"22, y causante de "hipertrofia del negocio jurídico"23, lo anticipamos.

22 SCHREIBER. A proibiçao de compotamento contraditório, op. cit., p. 171.

23 Federico $\mathrm{PROCCH}$. L'exceptio doli generalis e il divieto di venire contra factum proprium, op. cit., p. 102. 
Es así como la renuncia, en puridad, puede concebirse como una genuina manifestación de carácter volitivo, llamada a trascender en la esfera del Derecho, particularmente en sede patrimonial. En ella media un acto abdicativo, con arreglo al cual se produce una especie de desprendimiento de un derecho previo, esto es adquirido ex ante.

Conforme lo expresó don Jerónimo GonZÁlES, puede entenderse por renuncia "...la voluntaria dejación o abandono de una situación, facultad, ventaja o expectativa tuteladas por el ordenamiento jurídico"24.

Otro tanto hizo, décadas después, la profesora María del Carmen GetE ALonso, al precisar que "La renuncia es el acto jurídico unilateral, llevado a cabo por el titular del derecho, mediante el que una persona se desprende voluntariamente (hace dejación) de su derecho de manera irrevocable"25, al igual que el profesor Paolo GALLo, en el siglo XXI, al indicar que "...la renuncia constituye un acto de naturaleza negocial, preponderantemente unilateral" ${ }^{\prime 26}$.

En este orden de ideas, sin perjuicio de que pudiéramos seguir profundizando en torno a la renuncia, a su naturaleza y características centrales, lo cierto es que

24 Jerónimo GonzÁles y MARTínez, "La renuncia en el derecho inmobiliario", en Revista Crítica de Derecho Inmobiliario, T. VIII, Madrid, 1931, p. 36. En sentido similar, haciendo hincapié en el elemento voluntario, don Demófilo DE BuEN anotó que "La esencia de la renuncia es que la voluntad del renunciante se refiere sólo al desapoderamiento de un derecho, no a su reconstrucción en otro". "Renuncia de derecho", en Enciclopedia Jurídica Española, T. XXVII, Francisco Seix, Barcelona, p. 245. Y lo mismo hizo luego don Manuel AlbaLADEJo, al conceptuar que "Renuncia de un derecho es el acto por el que el titular hace dejación voluntaria del mismo. Así, no se trata de que lo transmite a otra persona, sino que simplemente se desprende de él". Derecho civil, T. I, Vol. I, Bosch, Barcelona 1985, p. 27.

25 María del Carmen Gete Alonso. "El derecho subjetivo y la relación jurídica”, en Manual de derecho civil, Marcial Pons, Madrid, 1995, p. 431. En igual sentido se expresó ulteriormente la misma autora, al indicar que "La renuncia, como acto abdicativo de un derecho o facultad es siempre un acto voluntario que puede manifestarse en forma expresa o tácita....", "Comentarios a la Sentencia de 13 de julio de 1995", en Cuadernos Civitas de Jurisprudencia Civil, No 40, Madrid, 1996, p. 90.

26 Paolo Gallo. Contratto e buona fede, op. cit, p. 797. Para el doctrinante L. Cariota Ferrara, a su turno, la renuncia es un "... negocio jurídico por el que se hace dejación de un derecho con la consiguiente extinción del mismo”. El negocio jurídico, op. cit., p. 112. Cfr. Salvatore PATTI. Profili della toleranza nel diritto privato, Dott, Napoli, 1978, pp. 51 y ss., y Luca NANNI. La buona fede contrattuale, Cedam, Milano, 1988, p. 576. 
ella reviste la naturaleza de acto negocial, motivo por el cual la dejación de un derecho, amén de volitiva (expresa o tácita), es definida, en razón de que importa su fenecimiento o extinción, notas que no se acompasan con la doctrina de los actos propios, rectamente entendida.

Y decimos que no se acompasan o avienen, habida cuenta que el venire, el factum proprium, en lo individual, como se observó en precedencia, no tiene una naturaleza típicamente volitiva, ni obedece, en tal virtud, a un inequívoco e invariable acto ex voluntate de uno de los cocontratantes en el campo contractual. Su columna vertebral descansa en la protección de la confianza legítima, en cuyo caso no es necesario escrutar si la actuación es voluntaria, fruto de una declaración de este linaje, por cuanto es suficiente con que sea objetivamente incoherente, a la par que violatoria de la indicada confianza; ese es su eje, y también el modus operandi que la caracteriza y tipifica.

No desconocemos que puede haber puntos en común entre ambas figuras, y que quizá por ello algunos las han confundido o entremezclado, aun cuando no tan estrechos y caracterizados como para que pierdan sustantividad y se amalgamen, según lo recrea el doctrinante PUIG BRUTAU, al afirmar que "...la regla de que nadie puede ir contra sus propios actos...no se trata de un caso de renuncia de derechos, aunque es muy común la confusión de ambos conceptos. Cuando se trata de un caso de verdadera renuncia, aunque sea manifestada en forma tácita o esté implícita en ciertos actos o en determinada conducta, nos encontramos ante una declaración o manifestación de voluntad del titular del derecho renunciado. Esta delimitación de conceptos es muy importante"27.

Por su parte, don Luís DíEZ-PICAZo es enfático en aseverar que "... .actos propios y renuncia tácita son conceptos no sólo inconfundibles, sino incluso inconciliables,

27 J. Puig Brutau. La doctrina de los actos propios, op. cit., p. 102. Cfr. Alejandro Borda. La teoría de los actos propios, op. cit., p. 133, autor que agrega otra diferencia concreta, a cuyo tenor "La renuncia tácita tiene efectos erga omnes, la regla venire contra factum los tiene inter partes". 
pues donde haya actos propios no podrá hablarse de renuncia y, al revés, donde haya una renuncia tácita no podrá hablarse de actos propios" 28 .

Del mismo modo, en lo que atañe a sus efectos, como se anticipó, tampoco se constata una total armonía entre estas dos instituciones, porque en tratándose de una renuncia válida, como se evidenció, tiene lugar la dejación o pérdida de un derecho subjetivo, la que es irreversible o definitiva (abdicación), al paso que con relación al acto propio la secuela de su materialización no es propiamente la desaparición o abdicación plena y para siempre del derecho en cita, por lo menos en forma unánime y generalizada. Como se recordará se discute en los círculos doctrinales y jurisprudenciales, efectivamente, si la inadmisibilidad de su ejercicio es perenne o no lo es, aspecto en el que no hay pleno acuerdo, aun cuando la tesis dominante no es la de su pérdida, in radice, según se reiterará en su momento (Cap. III) ${ }^{29}$, luego desde este ángulo tampoco hay una absoluta coincidencia entre renuncia y factum proprium. ${ }^{30}$

28 Luís Diez Picazo. La doctrina de los propios actos, op. cit., p. 163. Cfr. Ludwig EnNeCERus, quien aludiendo al venire, afirma que "Es importante su delimitación con respecto a la renuncia. Puede haber venire contra factum proprium cuando el acreedor no conocía su derecho, pero había de exigírsele este conocimiento". Por ello, el profesor de la Universidad de Marburg, culmina su exposición aseverando que el referido venire “....no se apoya, como la renuncia, sobre una voluntad de abandono de derecho". Derecho civil. Parte general, op. cit., p. 495. Cfr. Isabel M. PIZZA De LunA. La doctrina de los actos propios y su aplicación en las legislaciones modernas, op. cit., p. 558 y 559.

29 Véase por todos, anticipadamente, a Franz WIEACKER. El principio general de la buena fe, op. cit., p. 91 y ss.

30 Cfr. Nélida Tur FaUndez, quien además anota, con razón, que aparte de que “... en la renuncia los actos deben suponer una voluntad negocial, en los actos propios lo que se valora es que los actos revelan el sentido objetivo que éstos poseen", es paladino cómo "...los efectos de los actos propios y de la renuncia son completamente diferentes. La renuncia tiene como efecto la pérdida o extinción total de un poder jurídico, de un derecho subjetivo, de una facultad. El efecto de los actos propios es, en cambio, la inadmisibilidad del ejercicio del derecho en un determinado litigio y en unas determinadas circunstancias". La prohibición de ir contra los actos propios y el retraso desleal, op. cit., p. 46.

Cosa enteramente distinta es que en el ámbito específico reservado al acto de la renuncia, pueda ser de aplicación la doctrina del acto propio, como sucede, en general, con todos los contratos. Por eso es por lo que J. Ignacio CANo MARTíneZ, cuando se ocupa de examinar "La doctrina de los actos propios: su significado en materia de renuncia", precisa que "la doctrina de los actos propios, aplicada a la renuncia, sirve para declarar ineficaz toda pretensión de invalidación o revocación de aquélla cuando al hacerla se vulnera un legítimo interés de tercero, nacido de una situación objetiva de fiducia, creada merced a la renuncia misma....Quien... ha creado una fiducia, objetivamente apreciada, no puede argumentar 
No sobra mencionar, a fin de continuar con el estudio de la siguiente diferenciación, que lo indicado respecto al factum proprium, se hace extensivo a otras figuras sintonizadas con el venire contra factum proprium, en particular con la verwirkung, o retraso desleal para muchos, como también es denominado, signada por la inactividad o inercia de un cocontratante que, en función de su comportamiento a lo largo de la relación negocial, suscita la confianza en el otro de que no ejercerá su derecho, de tal manera que cuando lo hace, a posteriori, aflorará la sorpresa y el desconcierto, imponiéndose entonces la tesis de que en estas condiciones dicho ejercicio se torna inadmisible y contrario a la buena fe, con prescindencia, incluso, de los términos de prescripción ordinarios, hecho este último que ha generado acerada controversia, según se expresará en detalle al momento de desarrollar esta institución, sin duda arraigada en el Derecho comparado, conocida en otras latitudes con el nombre de laches (common law), y no en todos los casos bien delimitada por la jurisprudencia, justamente por la confusión que se suele presentar entre renuncia y verwirkung.

Tal confusión, conforme se expresó, es fruto de creer que la aludida inactividad es constitutiva o entraña una típica renuncia de un derecho, concepción que de ser cierta, en puridad, nada tendría que ver con el retraso desleal, porque lo renunciado, renunciado permanecerá, no siendo necesario indagar ni acerca de la incoherencia comportamental registrada a la sazón, ni tampoco de la confianza legítima otrora suscitada. Sería un tema de renuncia, lisa y llanamente y nada más, lo que exige su correlativa escisión, porque de lo contrario resultaría frustránea la pretensión de darle fisonomía propia a este instituto, la que efectivamente tiene una, toda vez que no puede dejarse de lado que la regla del venire contra factum proprium, por excelencia, es subsidiaria y no puede aplicarse en todos los supuestos, por manera que si fuera acertado aplicar la figura de la renuncia -que no lo es-, mal podría dársele cabida al venire, o A una de sus aplicaciones.

Al este respecto, importa memorar con el profesor Antoni VAQUER A., que "La renuncia es una causa de extinción del derecho. $Y$ si el derecho se ha extinguido, no viene a cuento valorar si su ejercicio contradice o no los postulados de la propio". La renuncia a los derechos, Bosch, Barcelona, 1986, pp. 122 y 123. 
buena fe, porque tal ejercicio ya no es posible: igual como los muertos no andan, los derechos extinguidos no son susceptibles de ejercicio". De ahí que redondee su opinión expresando que "La delimitación entre renuncia y Verwirkung se fundamenta en el carácter negocial de la primera y no negocial de la segunda. La Verwirkung es una consecuencia que se deriva de un comportamiento que se reputa contrario a las exigencias del principio de la buena fe; por lo tanto es ajena a la voluntad del titular del derecho y no puede construirse a partir de la búsqueda de una hipotética declaración de voluntad"31.

Análogo parecer es el manifestado por un sector de la doctrina y la jurisprudencia alemana, italiana y argentina. En esta dirección, entre otras más, importa traer a colación el punto de vista del profesor emérito de la Universidad de Bonn, Werner FLUME, con arreglo al cual "La Verwirkung es una consecuencia jurídica, que se produce ex lege 'como efecto jurídico involuntario de una conducta'. Con razón... se contrapone la Verwirkung a la 'renuncia tácita', que es una verdadera declaración de voluntad en el sentido de configuración de autonomía privada", autor que, ad baculum, apoya su juicio en lo sentenciado por "...el Bundesgerichtshof en BGH 25, 51 y ss.", el que afirmó “... .acertadamente”, que "En el concepto jurídico de Verwirkung se sitúa en primera línea la conducta del titular. Con la Verwirkung se declara inadmisible el retraso desleal en el ejercicio de derechos frente al obligado. Esto quiere decir que la conducta del titular debe enjuiciarse desde puntos de vista objetivos....Para una valoración objetiva semejante, que sólo debe estar orientada por la buena fe, no puede importar la

31 Antoni Vaquer Aloy. "El retraso desleal en el ejercicio de los derechos. La recepción de la doctrina de la verwikung en la jurisprudencia española", en Revista de Derecho Patrimonial, 1999, p. 123. En consideración a lo señalado, el autor en comento también expresa dos folios después, en síntesis, "Que renuncia tácita y Verwirkung son figuras independientes", de lo que desprende que no "...es admisible resolver un mismo caso con fundamento a la vez en que se ha producido renuncia tácita y Verwirkung. Porque...son simultáneamente incompatibles: si se entiende que ha habido renuncia tácita, el derecho se ha extinguido, luego no puede ser ya objeto de ejercicio de ninguna manera, ni con retraso desleal ni de acuerdo o en contra del principio de la buena fe. Por ello, parece oportuno separar claramente sus respectivos ámbitos y evitar sistemáticamente acudir a artificiosas interpretaciones del comportamiento del titular del derecho de las que acaben por fingirse declaraciones de voluntad con carácter renunciativo..." (Op. cit., p. 125). 
declaración de voluntad subjetiva del titular. En esto se manifiesta la diferencia jurídica entre la Verwirkung y la renuncia tácita"32.

La citada doctrina italiana, a su vez mayoritaria, modernamente se inclina por la separación de ambos institutos. Es el caso de Francesco AstonE, quien adhiere expresamente a la anunciada distinción, dado que en su criterio "La renuncia tácita es un fenómeno totalmente diverso de la Verwirkung, en el cual no está en juego la voluntad del titular de disponer de su derecho, por cuanto lo que se tendrá en cuenta es su comportamiento, objetivamente considerado, y la confianza que suscita en la contraparte" ${ }^{33}$.

Y la Argentina, a su turno, es igualmente conclusiva al respecto, al inclinarse por la indicada y neta diferenciación, así en la judicatura en ocasiones se confundan, movida más por los efectos y por el prurito de evitar la conculcación de derechos legítimos, que por su etiología y desenvolvimiento. Elocuentes son las reflexiones realizadas por los profesores Augusto MoRello y Rubén STIGLITZ, quienes entienden que "La diferencia esencial consiste en que la renuncia denota un acto que requiere una manifestación exterior, que tiene como fin el abandono o abdicación de un derecho propio a favor de otro, en cambio la doctrina del acto propio se traduce en una decisión jurisdiccional que declara la inatendibilidad de una pretensión, o sea del ejercicio de un derecho, en tanto exhibe una contradicción con el sentido que, objetivamente y de buena fe, se atribuye a una conducta precedente y propia. Al cabo la diferencia esencial está dada en la circunstancia de que la renuncia se manifiesta a través de un acto positivo de la voluntad que atiende a la extinción de un derecho a través de su abandono, lo

32 Werner Flume. El negocio jurídico, op. cit., pp. 158 y 159. Cfr. Andreas Von Tuhr. Derecho civil. Teoría general del derecho civil alemán, Vol. II, Depalma, Buenos Aires, 1947, p. 298, al indicar "Que la abstención del ejercicio de un derecho no constituye renuncia...", y Gustav BoeHmer. El derecho a través de la jurisprudencia. Bosch, Barcelona, 1959, p. 245, al reseñar que en materia de la verwirkung "...únicamente es decisiva la objetiva situación de hecho que justifica que lo admita la otra parte”.

33 Francesco Astone. "Ritardo nell'esercizio del credito, Verwirkung e buona fede", en Riv. dir. civ., 2005, II, p. 622. Cfr. Salvatore PATTI, quien reitera que "...en la verwirkung no es necesario que el comportamiento del titular del derecho sea producto de una voluntad constitutiva de renuncia". Verwirkung, op. cit., p. 730. En contra Filippo RANIERI. Rinuncia tacita e verwirkung. Tutela dell'affidamento e decadenza de un diritto, Dott, Padova, 1971, pp. 65 y ss. 
que traduce una forma de ejercicio de un derecho, aun cuando consista en su abdicación. A su turno, la doctrina del acto propio obsta al ejercicio de un derecho, limita su desenvolvimiento en el proceso, con fundamento en la incompatibilidad entre la conducta impedida y la que le precede en el tiempo"34.

En consecuencia, si hemos de inscribir la verwirkung en el marco del venire contra factum proprium, o en el terreno de la abusividad -para otros-, es porque estamos convencidos cómo es de recibo centrar la atención en la floración de conductas objetivas (aún de naturaleza omisiva) que, por sus connotaciones, pueden despertar una determinada confianza digna de ser escoltada y, por ende, tutelada. Será pues preciso hablar de contradicción, de incoherencia, de inarmonía, de incompatibilidad, de incongruencia y de defraudación de la confianza, como piedra angular, tanto desde una perspectiva jurídica, como práctica.

\section{LA BUENA FE}

Aludir a la buena fe resulta imperativo en el tema central que nos ocupa y en innúmeros institutos inmersos en la ciencia del Derecho, en general, si no es que debemos decir que en todos y cada de uno de ellos, ora directa, ora indirectamente, se pasea con donosura y sostenibilidad. De allí que frecuentemente digamos que es un postulado solar, puesto que irradia la totalidad del orbe iuris, tanto más en los tiempos que corren, en los que la buena fe ha adquirido aún más fuerza, hasta el punto de que su expansión, empleo y revitalización son paladinas, a lo que se agrega su constitucionalización en algunas naciones, como testimonio de su vitalidad y abolengo. De hecho, hoy se reclama para ella un status que trascienda el rol de principio general de derecho, para traducirse en principio constitucional, migración que, al margen de lo puramente retórico, ciertamente no es de poca monta, según se ha revelado. ${ }^{35}$

34 Augusto Morello y Rubén Stiglitz. "La teoría del acto propio", op. cit., pp. 62 y ss. Cfr. Roque J. CaIvano. "Silencio, doctrina de los actos propios y renuncia tácita", en La Ley, T. 1996C197, p. 3 y ss., y Alejandro BordA. La teoría de los actos propios, op. cit., p. 133 y ss.

35 En este sentido, la Corte Constitucional colombiana, en Sentencia C-426 de 1997, refiriéndose a la buena fe como "...un principio cumbre del derecho", expresó que él "...ha pasado de ser un principio general del derecho para convertirse en un postulado 
No es nuestro propósito, menos en este espacio, pasarle revista a la temática de la buena fe, entre otras razones por cuanto de ella hicimos algunas referencias y reflexiones previas, que aconsejan que no las reproduzcamos, ni que tampoco las ampliemos (Cap. I).

Basta simplemente reafirmar que, en sede del estudio del acto propio, mejor aún del venire contra factum proprium, la buena fe ocupa un rol protagónico, casi a manera de monólogo, evidenciándose, renglón tras renglón de estas páginas, su linaje y su irrefragable carácter ecuménico. Tal vez por ello, si algún título sucedáneo del empleado por nosotros en este escrito fuera a utilizarse, el de la buena fe negocial no sería totalmente incorrecto. Por ello, resulta inescindible aludir a la bona fides cuando se desarrolla la regla venire contra factum proprium, al igual que cualquiera de sus manifestaciones, todas impregnadas de su polen, ese que se produce en los estambres de las flores cultivadas en los jardines de la lealtad, de la probidad, de la corrección, de la honestidad, de la sinceridad, de la regularidad, de la coherencia, de la decencia, de la transparencia y de la ética ${ }^{36}$.

En este orden de ideas, poco entonces podríamos agregar, en el entendido de cómo en el más estricto de los sentidos, buena fe y venire contra factum proprium están tan articulados, que una pretensión a ultranza, abiertamente separatista, creemos que traicionaría la genética y las leyes de la vida misma, por cuanto su ADN es igual al de ella. No en vano, en la intimidad, con genuina humildad no deseamos innovar en este campo, de tal manera que la condición

constitucional... Este trascendental principio exige de los particulares y de las autoridades ceñirse en sus actuaciones a una conducta honesta, leal y acorde con el comportamiento que puede esperarse de una persona correcta (vir bonus). La buena fe supone la existencia de una relación entre personas y se refiere fundamentalmente a la confianza, seguridad y credibilidad que otorga la palabra dada". De igual modo, en sentencia T-099 de 2009, la misma Corte recordó que, "[...] cada una de las normas que componen el ordenamiento jurídico debe ser interpretada a la luz del principio de la buena fe, de tal suerte que las disposiciones normativas que regulen el ejercicio de derechos y el cumplimiento de deberes legales, debe siempre ser entendida en el sentido más congruente con el comportamiento leal, fiel y honesto que se deben los sujetos intervinientes en la misma. En pocas palabras, la buena fe incorpora el valor ético de la confianza".

36 Recordemos con los profesores MorelLo y STIGLITZ, en lo pertinente, que "...el principio de buena fe domina, avanza, e invade toda la problemática del venire contra proprium factum". Teoría del acto propio, op. cit., p. 67. 
de conservacionista la asumimos con convicción, responsabilidad y profundo respeto por lo que la buena fe significa e implica.

Más osado y tal vez creativo, a juicio de algunos, sería abogar por separar de raíz lo que creemos que es inseparable, acudiendo a expedientes y caminos artificiosos, a fuer que empedrados por la dificultad y por la necedad. Buena fe y venire, ab initio, forman parte de un mismo bosque, por manera que talarlo sería un atentado con todo lo que ello supondría. No seremos nosotros entonces leñadores de la bona fides, y de paso sus verdugos, al pretender lesionar su ser, y arrancarle de sus entrañas uno de sus hijos más preciados: el venire contra factum proprium

Y si ello es así, como efectivamente creemos que es, mal haríamos en enlistar copiosas diferencias entre una y otro, máxime cuando en apartes que anteceden nos esforzamos por defender esta idea, la que sigue aún vigente Cap I), y refrendada por la communis opinio, a la par que por la mejor doctrina, esa que no entiende el afán por separarlo todo, por independizarlo todo, por divorciarlo todo, como si la escisión y la atomización fueran de imperativa convergencia en sede jurídica. Todo lo contrario: la unidad, rectamente entendida, es una coordenada de la ciencia del Derecho contemporáneo, y una racional aspiración.

Si hemos incluido en este numeral a la buena fe, no es para practicarle una autopsia, o una cirugía encaminada a su separación, como si el venire fuera una suerte de cuerpo extraño que debe ser removido, y ubicado en otra cavidad. Justamente es para reafirmar, ex proffeso, su estrecha y férrea vinculación, mejor familiaridad.

Lo anterior, sin embargo, no se opone a que puedan efectuarse algunas precisiones, pues una cosa es que entre ambas instituciones existan inquebrantables vasos comunicantes, y una genética absolutamente común, y otra que sean invariablemente idénticas, a manera de clones.

En esta orientación, la buena fe es el trapecio en el que se ejercita el plexo del venire contra factum proprium; ella es el báculo que le sirve de apoyatura a la doctrina de los actos propios, entre otras aplicaciones más. 
La buena fe es un dispensador, de tal manera que el venire será emanación suya, sin que por ello sean dos gotas de agua, absolutamente iguales. Si lo fueran, en estricto rigor, sólo habría necesidad de hablar de la buena fe y sabido es que es menester descender al acto propio, entre otras manifestaciones suyas, en atención al principio de la especificidad. Cada regla en su lugar, sin que se atente contra la familiaridad en referencia. Eso es lo cardinal, motivo por el cual buscar afanosamente situarlas en categorías divergentes y, de contera, autonómicas, a nuestro juicio es contra natura, y una tarea baldía.

Mejor entonces tejer en el telar de la bona fides, la prenda llamada a arropar al venire contra factum proprium y a todas sus resonantes y concretas manifestaciones, así ellas tengan un radio de acción más puntual. Al fin y al cabo, la buena fe es también un principio general de derecho, y ellas no lo son, dado que su aplicación es más específica y subsidiaria, lo que no les resta su progenie, en ningún caso, como tampoco lo hace el hecho de que aquella se presuma, legal y constitucionalmente, y de que pueda ser considerada un genus (Cap. I).

Quizá podrá haber otras matizaciones y sutiles entendimientos en relación con las inmediatamente aludidas, pero ninguna de una fuerza arrolladora que, in toto, arrase con la comunión existente entre ambas reglas, hipótesis de trabajo completamente diferente respecto a las que gobiernan a las otras figuras que hemos analizado en este capítulo, y que seguiremos analizando a continuación, puesto que, objetivamente lo ameritan, en aras de la precisión, que no del preciosismo, o del 'repentismo' jurídicos.

\section{LA EXCEPCIÓN DE DOLO (EXCEPTIO DOLI GENERALIS)}

\subsection{Generalidades}

Corresponde ahora pasarle revista a las diferencias reinantes entre la doctrina de los actos propios y la institución comúnmente conocida con la denominación de excepción de dolo, también identificada en lengua latina con el socorrido nomen de exceptio doli, en los últimos años objeto de un renovado y entusiasta escrutinio, como ya se mencionó en otros apartes de este estudio, hasta el 
punto que como se reiterará, es tan amplia esta institución en la actualidad, en aquellos países en los que se admite, que a juicio de un sector doctrinal bien podría fungir de gran género, en cuyo caso el venire contra factum proprium y todas sus aplicaciones (doctrina de los actos propios, estoppel y verwirkung), el abuso del derecho, el tu quoque, entre otras derivaciones más -incluso la buena fe para otros-, quedarían inmersas en esta categoría macro, lo que justifica el empleo consciente de la locución exceptio doli generalis, justamente para aludir a su irradiación de carácter general ${ }^{37}$.

Para efectos del cumplimiento de dicha tarea, en forma preliminar, importa revelar que ella resulta de la mayor pertinencia, dado que es aconsejable deslindar cabalmente ambas figuras, pues en apariencia, y sólo en apariencia, se itera, no parece que existiera mucha controversia en ello, hasta el punto de que la primera y posible reacción de algunos lectores, será la de asentir en que son tan disímiles, que incluso el autor hubiera podido prescindir de esta escisión tipológica, merced a sus diferencias 'siderales', evidenciadas a partir de la simple conexión semántica con el dolo, hecho que, como se observará, es el percutor de muchas confusiones en la materia, a nuestro modesto juicio innecesaria, justamente por el arraigo que en la cultura jurídica tiene esta expresión, no sólo en ámbito civil y comercial, sino también en el penal. Tanto es así, se anticipa, que un amplio sector de la ciencia jurídica contemporánea conserva el rótulo en comento, pero vaciándolo de contenido real, como quiera que en los tiempos

\footnotetext{
Tal es la vocación arropadora de la buena fe, que hay autores que no vacilan en ensanchar su alcance y acentuar su generalidad, hasta el punto que en ella engloban el abuso del derecho y la exceptio doli generalis, por entenderlas como derivación suya, lectura que en sentido lato se encuentra en armonía con el carácter cósmico asignado a la bona fides, el que en nuestro entender requiere concreción, v.gr: en el factum proprium cuando de erradicar la incoherencia y el quebranto de la confianza legítima se trata. Así sucede con lo expresado por el profesor de la Universidad de Bolonia, Massimo FRANZONI, quien manifiesta que "muchos de los casos resueltos por los jueces, en aplicación implícita o explícita del abuso del derecho o de la exceptio doli generalis, no podrían explicarse si no es con recurso a la existencia de la cláusula normativa general de lealtad y de buena fe, cuyo fundamento consiste en la exigencia de solidaridad en la relación obligatoria.... Así pues, las diversas expresiones no son otra cosa que la misma representación de la cláusula de buena fe...El abuso del derecho y la exceptio doli generalis no son otra cosa que modos alternativos para designar un comportamiento incorrecto de unos sujetos, o de una parte contractual, cuya relevancia puede incidir, asimismo, en la fase de ejecución de la relación". "La buena fe y la equidad como fuentes de integración del contrato", en Estudios sobre el contrato en general, Ara Editores, Lima, 2003, pp. 666 y 667.
} 
que corren, en estrictez, no se exige la inequívoca presencia de un dolo para la configuración y puesta en marcha de la denominada exceptio doli -a pesar de su denominación, insistimos en ello-, tal y como de hecho sucedió en una época en el propio Derecho romano.

Lo cierto, por consiguiente, es que por el desarrollo reciente que se le ha dado a esta institución, de suyo extraordinario, amén de dinámico, y por la íntima conexión existente con la regla venire contra factum proprium, conviene ocuparnos con relativo detalle de la renovada -o reinventada-exceptio doli, particularmente de la exceptio doli generalis, hoy por hoy, para muchos, un concepto tan envolvente que figuras como el venire contra factum proprium, y claro está, la doctrina de los propios actos, como manifestación suya, quedarían englobados en ella, se insiste en esta idea, dada su vocación generalizadora, muy propia de la temática referida al ejercicio inadmisible de un derecho, de suyo muy global y abarcadora de diversas manifestaciones individuales.

En este último sentido, anticipadamente, luce conveniente expresar, de la mano del erudito profesor F. WIEACKER, que "Un tipo totalmente distinto de actuación judicial es el representado por el campo fundamental de la exceptio doli, que se corresponde en su totalidad con la rúbrica de SIEBERT, sobre 'Inadmisibilidad de una conducta contraria a la buena fe'. Conservamos la antigua expresión forense, aunque naturalmente debemos ver en la exceptio doli-siguiendo las nuevas doctrinas- una concepción anticuada de la excepción de inadmisibilidad del ejercicio del derecho" 38 .

\subsection{Precisión terminológica}

Como se ha podido corroborar, el tema que ocupa nuestra atención no es un tema simple, y menos uno que desde la orilla semántica, pueda resolverse de improviso, a pretexto de creer que está indisolublemente ligado con el dolo, reconociendo, en todo caso, que flaco favor se le hace a la precisión con la

\footnotetext{
Franz WIEACKER. El principio general de la buena fe, op. cit., p. 59.
} 
preservación de esta singular -y vidriosa- terminología ${ }^{39}$, por más que en vano se le quiera purificar, a lo que agregamos que, en su origen mismo, es más doctrinal y pretoriana que legislativa, el que realmente no se ha examinado en muchas naciones -o se ha hecho someramente-, situación que dificulta su análisis, con mayor razón cuando no es pacífico y podría no estar en estricta consonancia con la arquitectura iuris de algunos regímenes que han optado por la conservación de otras categorías construidas paulatinamente, v.gr.: la regla venire contra factum proprium o las figuras similares, a partir del desarrollo sistémico del postulado iluminante de la buena fe, en principio suficiente para la erradicación o esterilización de conductas volubles o sinuosas que, por quebrantar la confianza legítima -ajena-otrora depositada a raíz de una determinada actuación, no están llamadas a regir y a desplegar plenos efectos en derecho, según lo demanda la justicia y la ética contractual.

39 Stricto sensu, sin perjuicio de retomar este punto luego, no creemos que sea aconsejable y menos esclarecedor acudir a la locución dolo, pues es probable que a raíz de ello, tan complejo tema se oscurezca o enrarezca. Sólo recuérdese que el dolo supone, en sede jurídica la intencionalidad, la realización de maniobras o maquinaciones para la obtención de un provecho o resultado específico. Elocuentes, en su orden, son las nociones de los jurisconsultos SERVIO y LABEÓN, según las cuales el dolo malo es "cierta maquinación para engañar a otro, de simular una cosa y hacer otra", o “...toda malicia, engaño o maquinación para valerse de la ignorancia de otro, engañarle o defraudarle" (D. 4, 3, 1.2). Bien memora el profesor de la Universidad de Catania, Biondo Bıond, que en el Derecho romano "La esencia del dolo residía en el engaño, en el fraude, en la intención maligna de dañar a otro". Corso di instituzioni di diritto romano, Editoriale Siciliana Tipografica, Catania, 1929, p. 205.

En similar sentido, siglos después, el artículo 1269 del Código Civil español, estatuyó que "Hay dolo cuando, con palabras o maquinaciones insidiosas de parte de uno de los contratantes, es inducido el otro a celebrar un contrato que, sin ellas, no hubiera hecho". Y el artículo 63 del Código Civil colombiano, último inciso, a su turno dispone que "El dolo consiste en la intención positiva de inferir injuria a la persona o propiedad del otro". No es pues de poca monta el alcance jurídico que se le asigna al dolo, en general, aunado al significado corriente del vocablo: "Engaño, fraude, simulación" (Diccionario de la Lengua Española).

Así sucede, a primera vista, por vía de ilustración, cuando el mencionado profesor WIEACKER expresa que "El venire contra factum proprium es dolus praesens", afirmación que sin matices, explicaciones o atemperaciones, resultaría desmedida, aun cuando hay que manifestar que, a renglón seguido de la misma, tan egregio doctrinante, por fortuna atempera o aclara su idea al señalar -la mencionamos en forma completa- que "El venire contra factum proprium es dolus praesens. No presupone necesariamente el que, de mala fe o con negligencia culpable, se cree una expectativa en la otra parte.....Más simplemente: el principio del venire es una aplicación del principio de la 'confianza en el tráfico jurídico' y no una específica prohibición de la mala fe y de la mentira". El principio general de la buena fe, op. cit., p. 61. 


\subsection{ETIOLOGÍA, FINALIDADES, CLASIFICACIÓN Y AFIANZAMIENTO ULTERIOR DE LA EXCEPTIO DOLI}

La exceptio doli, ligada primigeniamente al dolo malo (dolus malus), ya delineado en apartes anteriores, aflora como justiciero mecanismo enderezado a contrarrestar, por su significación y alcance, una serie de comportamientos lesivos, susceptibles de ser cuestionados en desarrollo de la apellidada acción de dolo malo, aun cuando dotada de ulterior amplitud, muy especialmente para proteger la bona fides, en forma más cabal y efectiva.

Fue el mismo jurisperito PAULO, quien en el siglo III de nuestra era, manifestare acerca de la excepción de dolo malo, que "El pretor propuso esta excepción a fin de que a nadie pueda favorecer el propio dolo malo, por valerse del derecho civil contra la justicia natural” (D. 44, 4,1.1), a lo que agregó ULPIANO, en la misma centuria, que "Es evidente que esta excepción fue propuesta por la misma causa que lo fue la acción de dolo malo" (D. 44,4,2) ${ }^{40}$.

La exceptio doli, ab initio, de acuerdo con la tipología procesal romana, fue un remedio perpetuo, dado que no era meramente temporal (exceptio perpetuae), a la vez que personal (in personam), en atención a que, a diferencia de las exeptiones in rem, aquella se formulaba en contra de precisos demandantes ${ }^{41}$.

$40 \quad$ A juicio de Matteo MARRRONE, “...debe ser en la primera mitad del siglo I a.C que el pretor introduce establemente en su edicto la cláusula que permitía la excepción de dolo malo". Instituzioni di diritto romano, Palumbo, Firenze, 2006, p. 152. Con todo, esta institución fue evolucionando en el tiempo para tornarse más tuitiva, prueba de lo cual será la amplitud que adquirirá en el Derecho romano clásico tardío. Originariamente, lo revela el profesor Pedro BONFANTE, este remedio se introdujo “.... al final de la República, cuando el incremento del comercio y la disminución de la fides, aumentó el número de los negocios dolosos....". Instituciones de derecho romano, op. cit., p. 96. Cfr. Francesco VenOstA. "Note sull'exceptio doli generalis", en Banca, borsa tit. cred., 1989, II, Paul OuRliAc y J. De MALAFosse, Derecho romano y francés histórico. Derecho de obligaciones, Bosch, Barcelona, 1960, p. 223, y Martha Lucía Neme V. La buena fe en el derecho romano, op. cit., p. p 92 y 93.

41 Cfr. J. Arias Ramos y J. A. Arias Ramos Bonet. Derecho romano, T. I, Editorial Revista de Derecho Romano, Madrid, 1986, p. 196. En las Institutas de Gayo, se expresa que "Las excepciones se dividen en perentorias y dilatorias. Son perentorias las que son perpetuas y no se pueden evitar, como por ejemplo la de miedo, la de dolo malo...." (Inst, IV, 120). 
Ella perseguía, fundamentalmente, paralizar la acción promovida por el actor, todo en consonancia con el propósito de atenuar el rigor inherente al ius civile, respecto del cual el rechazo abierto y sistemático de algunas actuaciones erosivas de la buena fe no siempre fue la regla observada, lo que precipitó la decidida -y aplaudida- actuación del pretor (iure praetorio), impregnado por la aequitas, lato sensu ${ }^{42}$, toda vez que como lo advierte Andrea TORRENTE, para dimensionar "...el significado y entender la sucesiva evolución de la exceptio doli generalis seu praesentis, es oportuno subrayar que la exceptio doli, en general, constituye un medio procesal muy eficaz adoptado por el pretor para corregir el ius civile y asegurar el reconocimiento y la tutela de los intereses, relaciones, etc., que resultaban irrelevantes o contrarios al ius civile"43.

Por su valía, en sintonía con la romanística dominante, resulta aconsejable aludir a dos tipos de exceptio doli, en consideración a que su proyección, ámbito de actuación e incidencia en el Derecho romano, no fueron simétricas: la specialis, por oposición a la generalis, esta última muy socorrida en Roma y en estadios ulteriores, incluido el que nos cobija, así hoy tenga una connotación

42 En opinión del profesor Juan IGLESIAS, el dolo “...es tomado en cuenta por el ius civile pero sólo con referencia a los iudicia bona fides....Dada la insuficiencia de tales remedios, hacia finales de la República crea el Pretor otros más seguros y convenientes: la actio doli y la exceptio doli..... Derecho romano, Ariel, Barcelona, 1999, p. 114.

43 Andrea TorRente. "Eccezione di dolo", en Enciclopedia del Diritto, Giuffrè, Milano, p. 218. En sentido similar, Vincenzo ARANGIo RuIz no duda en aseverar que "El juego constante de la actio y de la exceptio doli, el mecanismo de la in integrum restitutio y de las stipulationes pretoria, actuaron siempre en el mismo sentido: fueron todos ellos medios tuitivos contra las consecuencias injustas e inicuas a las que podría conducir la aplicación estricta del derecho civil". Historia del derecho romano, Reus, Madrid, 1994, p. 202, argumento que igualmente emplea Biondo BIONDI, para sostener que, en tales condiciones, la exceptio doli tuvo en el derecho romano clásico una "... función importantísima, en cuanto fue el medio preciso para remover algunas inequidades del ius civile." Corso di istituzioni di diritto romano, op. cit., p. 206, opinión igualmente compartida por Eduardo VolTERRA, cuando indica que gracias a la exceptio doli se comprende que "...el pretor pasara a tener un medio de extraordinaria eficacia”. Instituciones de derecho romano, op. cit., p. 201. Vid. Emilio BETTI. Instituzioni di diritto romano, Vol. I, Dott, Padova, 1947, p. 309.

Tan era relevante el rol del pretor en dicha época, contrastado con el jus civile, que como lo memora el profesor Jean MACQUERON, "Haciendo insertar la excepción de dolo en la fórmula, el demandado obtenía su absolución si podía probar...la comisión del dolo. El deudor que ha contratado bajo el imperio del dolo podía de esta manera rechazar su ejecución: el contrato afectado de dolo, aun cuando válido 'jure civile', era cobijado por una suerte de nulidad pretoriana: la excepción paralizaba sus efectos". Historie des obligations. Le droit romain, Association Auguste Dumas, Aix-En-Provence, 1975, p. 229. 
un tanto diversa. Es así como su diferenciación dependía, fundamentalmente, de un aspecto temporal -o cronológico-. Si se refería a un hecho precedente a la iniciación del juicio -dolo pasado-, se decía que era praeteritus y, de suyo, specialis, y si concernía a la iniciación del juicio mismo, era praesens -dolo presente- $y$, de contera, generalis ${ }^{44}$. Pasado y presente, fueron pues los tiempos tomados en consideración para efectos de la tipificación de una u otra modalidad.

Al respecto, refrendando el mencionado binomio, el profesor Vittorio SCIALOJA, indica que se distinguen "...dos tipos de exceptiones doli: una fundada sobre el dolo precedente, sobre el dolo que acompañó el acto, exceptio doli specialis; y otra, la exceptio doli generalis, que se tiene precisamente cuando el actor que en el momento de surgir su derecho no estaba en dolo, ha sido constituido en dolo en el momento en que intenta la acción, después de saber que el demandado podía eludir con una excepción su demanda. También aquí, el dolo que se hace valer no es dolo inherente a la relación inicial, sino dolo nacido con posterioridad por las relaciones procesales" 4 .

En dirección similar, el romanista M. TALAMANCA, haciendo énfasis en la protección de la bona fides, destaca que "Al dolo como vicio de la voluntad se refería únicamente la exceptio doli specialis, que hacía valer el dolus praeteritus. En la exceptio doli generalis, por el contrario, el comportamiento doloso no consistía tanto en un engaño como en un contenido contrario a la bona fides -es decir al genérico deber de comportarse según los cánones de la corrección-al momento en que se intentaba la acción, independientemente de cualquier actividad o reticencia encaminada a engañar a la contraparte..."46.

44 "El adjetivo praeteritus", lo enseña VoLTERRA, "en oposición a praesens, se refiere al momento en que se inicia el juicio". Instituciones de derecho romano privado, op. cit., p. 201. Por ello se puede hablar de un "...dolo en la conducta actual en el ejercicio de un derecho (neque fiat), no necesariamente intencionado", a voces de María Victoria SAnsón R., en armonía con lo opinado por M. BRUTTI (la problemática del dolo processuale nell'experienza romana)."La buena fe en ejercicio de los derechos y en el cumplimiento de las obligaciones desde la perspectiva del derecho romano privado", en II ruolo della buona fede oggettiva nell'esperienza giuridica storica e contemporanea, Vol. III, CEDAM, Padova, 2003, p. 335.

45 Vittorio SIALOJA. Procedimiento civil romano. Ejercicio y defensa de los derechos, E.J.E.A, Buenos Aires, 1954, p. 45.

46 Mario Talamanca. Instituzioni di diritto romano, Giuffrè, Milano, 1990, p. 239. Cfr. Andrea TORRENTE. Eccezione di dolo, op. cit., p. 218, autor que ratificando la diversidad de 
En el marco de los iudicia bonae fidei, tal era la significación intrínseca de la tutela efectiva de la buena fe, como coordenada orientadora de los mismos, que el iudex, motu proprio, debía examinar en detalle las circunstancias llamadas a definir la suerte del proceso, motivo por el cual se le asignaban amplias facultades para el cumplimiento de tan plausible cometido. Ello explica que ".. en todos estos juicios de buena fe el juez tenía un amplio margen de arbitrio”, igualmente predicable de los contratos respectivos, "puesto que tanto el nacimiento (...) como su contenido y alcance debía enjuiciarse según la buena fe, debía por ello el juez ex officio considerar, aún sin indicaciones expresas en la fórmula, un eventual dolo de ambas partes. La exceptio doli era por tanto inherente a los bona fides iudicia..."47.

\subsection{Alcance de La exceptio doli generalis}

Ahora bien, en lo que atañe al alcance de la exceptio doli generalis, tema de crucial valor, se ha bosquejado que fue objeto de notoria evolución, como también lo fue el concepto de dolo, en armonía con la consabida vocación protectora

cometidos, indica que tan serán distintas una y otra tipologías, que "El dolus praesens tiene un significado totalmente diverso, comprensivo de cualquier circunstancia, inclusive sobrevenida, en virtud de la cual la persistencia de actor en la demanda directa de reconocimiento de la pretensión....resulta contraria a la bona fides". En análogo sentido, el autor A. De Cossio y Del CoRRAL, en su clásica monografía sobre el dolo, luego de manifestar que en desarrollo de la exceptio doli se dotó a la "bona fides' de protección más eficaz.... arbitrando un instrumento jurídico del mayor relieve para la solución equitativa de los problemas de derecho....", anotó que dicha excepción "...tiende a evitar que se produzcan consecuencias contrarias a la 'bona fides' “. El dolo en el derecho civil, Granada, 2005, p. 119 y 120. Cfr. Paola Lambrinı. Dolo generale e regole di correttezza, Cedam, Padova, 2010, pp. 7 y 38.

47 Andreas WACKE. "La 'exceptio doli' en el derecho romano clásico y la 'verwirkung' en el derecho alemán moderno", en Derecho romano de obligaciones, Homenaje a José Luís Murga Gener, Centro de Estudios Ramón Areces, Madrid, 1994, p 978. Cfr. P. Jörs y W. KUNKEL, Derecho romano privado, Labor, 1937, p. 238, autores que confirman cómo era “...obligatorio para el juez en los 'iudicia bonae fide' tener en cuenta de oficio todos los hechos que pudieren influir sobre el nacimiento o la existencia de la obligación, como por ejemplo, el dolo de una de las partes en perjuicio de la otra....." Cfr. G. LEPOINTE y R. MonieR. Les obligations en droit romain et dans l'ancien droit français, Institut de Droit Romain de L'Université de Paris, Paris, 1954, p. 171, y Federico Fernández De Buján, confirmando que en punto a las "....acciones de buena fe....el juez antes de pronunciar la sentencia debe averiguar, a través de la actividad probatoria....el quidquid, es decir lo que el deudor demandado deba al acreedor demandante por la causa expresada en la acción". Sistema contractual romano, Dykinson, Madrid, 2007, p. 37. 
de la buena fe, en cuyo caso no podía proteger únicamente al demandado, en consideración al protervo engaño o de la malévola intención de defraudar, a través del ardid y de la maquinación aleve.

Expresado en otras palabras, si el auténtico propósito de estas instituciones, en especial la exceptio doli, admirable creación de la jurisprudencia-como la llamó A. TRABUCCHI- ${ }^{48}$, fue el de ofrecer una real y equitativa salvaguardia de los intereses del demandado en juicio, era necesario ampliar su radio de acción, con el objeto de que el dolo, en su acepción más cruda, no fuera la única manera de darle sustento a la excepción en cita. Por eso, en la práctica, la figura fue ensanchada y, en esa medida, se le dio carta de naturaleza a la apellidada exceptio doli generalis, apropiada para contrarrestar el dolo praesens -o praesentis-, según se señaló, no ligado, indefectiblemente, con la fría e inequívoca intención de perjudicar (dolus malus), conforme otrora se revelaba con toda rotundidad, puesto que como lo puso de presente A. DE Cossio y CoRRAL, a través de esta excepción, calificada de "generosa aplicación, hasta el extremo de hacernos pensar en la posibilidad de un dolo objetivo completamente ajeno a la voluntad del actor, es decir, que a los efectos de la excepción de dolo parece ser que lo decisivo no es tanto la intención dañosa y antijurídica, como evitar que se produzcan consecuencias que objetivamente estén en pugna con la buena fe considerada como norma vinculante de conducta"49. Tuvo lugar entonces un proceso de transformación gradual en lo tocante con la atadura que, ex ante, tenía la figura con el dolus malus, lo que permitió su ulterior ampliación y generalización.

A la misma conclusión arriba la generalidad de la doctrina especializada, la que confirma que el Derecho romano no se limitó a preservar la estrecha noción de dolo, por cuanto la amplificó, bien con miras a darle pábulo a otros supuestos

48 Alberto Trabucchi. // dolo, Dott, Milano, 1937, p. 343. En dirección similar, confirmando el amplio rol asignado al pretor, Francesco DE MARTINo indica que "En las acciones de derecho estricto, el pretor interviene contra las consecuencias inicuas de una aplicación rígida del ius civile con la exceptio doli, cuya eficacia cada día es más amplia....el juez tenía poderes suficientemente amplios como para rechazar cualquier pretensión que, por fundada que estuviese en el derecho civil, implicara una injusticia dentro de la práctica de la equidad pretoria". Individualismo y derecho romano privado, Universidad Externado de Colombia, Bogotá, 1978, p. 81.

49 A. De Cossío y Corral. El dolo en el derecho civil, op. cit., p. 120. 
de origen diverso que estuvieran más a tono con una nueva visión del dolus, bien en aras de contemplar diferentes hipótesis constitutivas de quebrantamiento objetivo de la bona fides, ajenas a la intencionalidad propiamente dicha. Es en esta última dirección que apuntan J. ARIAS RAmos y J. ARIAS RAMOS Bonet, al afirmar que "Esta excepción tuvo tal amplitud de aplicación, que su inserción en la fórmula daba pie al iudex para tomar en consideración todo matiz de conducta contrario a la lealtad de proceder (bona fides) del demandante, ya se haya dado en las relaciones jurídicas que sirven de fundamento a la demanda, ya en el hecho mismo de demandar, e incluso, según algunos, apreciando la lesión a la bona fides de un modo objetivo, prescindiendo de si el autor haya tenido o no conciencia de ello"50.

\subsection{ProYección, CONSOLIDACIÓn INTERNACIONAL DE LA EXCEPTIO DOLI GENERALIS Y DIFERENCIACIÓN GLOBAL CON LA DOCTRINA DE LOS ACTOS PROPIOS}

Como era de esperar, la exceptio doli no nació y murió en el Derecho romano, en razón de que pervivió, con ajustes, a lo largo de numerosas centurias y épocas, hasta llegar al siglo XXI, revitalizada y enriquecida por lo demás, en muestra inequívoca de la fuerza y de la dinámica que conserva la buena fe, bastión del Derecho en todos los tiempos, incluido el presente, en el que se evidencia su creciente proyección, sin que por ello medie unanimidad, en atención a que,

$\overline{50}$ J. Arias Ramos y J. Arias Ramos Bonet. Derecho romano, op. cit., p. 196.

Corroborando la amplitud de la exceptio doli, en el sentido indicado, véase a G. LEPOINTE y R. MonieR. Les obligations en droit romain et dans l'ancien droit francais, op. cit., p. 170; Mario TALAMANCA. Instituzioni di diritto romano, op. cit., p. 239; Eduardo VolTERRA. Instituciones de derecho romano, op. cit., p. 201; P. JöRs y W. KUNKEL, Derecho romano privado, op. cit., p. 370; Vincenzo ARANGIo-RuIz, Instituciones de derecho romano, Depalma, Buenos Aires, 1973, p. 117; María Victoria Sansón R. La buena fe en ejercicio de los derechos y en el cumplimiento de las obligaciones desde la perspectiva del derecho romano privado, op. cit., p. 335; Martha Lucía Neme Villareal. La buena fe en el derecho romano, op. cit., p. 181, y Alberto TRABUCCHI, I/ dolo, op. cit., p. 340.

Es de precisar que, en opinión de un sector de la doctrina, “...tampoco la clásica actio doli exigía siempre una intención de dañar. A veces bastaba un ulterior quebrantamiento objetivo de la palabra dada...; prácticamente la actio de dolo llegó a ser una acción general de equidad. Andreas WACKE. La 'exceptio doli' en el derecho romano clásico y la 'verwirkung' en el derecho alemán moderno, op. cit., pp. 984 y 985, parecer que se acompasa, en lo pertinente, con el del profesor V. SCIALOJA, de acuerdo con el cual “... los romanos se servían de este elemento intencional con criterios bastante amplios y a menudo incluso con cierto artificio". Procedimiento civil romano, op. cit., pp. 43 y 44. 
por momentos, se ha dudado de su admisibilidad en concretos regímenes, o se han sembrado dudas alrededor de su procedencia actual o de su verdadera autonomía, o incluso, no se ha estudiado aún en diversos círculos doctrinales y jurisprudenciales, tal y como tiene lugar, por regla, en Latinoamérica, en la que se ha dado mayor atención a la protección de la buena fe, in genere, y al abuso del derecho y a la doctrina de los actos propios, in concreto, según el caso.

Efectivamente, tanto en Alemania-y en Suiza-, como en Italia, prevalentemente, se ha admitido la viabilidad de la exceptio doli generalis, no sólo desde una perspectiva dogmática, sino jurisprudencial, desde luego con algunas reservas y dudas, unas más profundas que otras (Italia), aun cuando la constante es la admisibilidad de la misma, más bien con variables, ora porque se entiende que puede pervivir autónomamente al lado de otras figuras, v.gr: el abuso de derecho o el venire contra factum proprium, sin confundirse, ora porque se estime que pueden articularse, o también emplearse en forma alternativa, o intercambiable ${ }^{51}$.

Elocuente, en grado sumo, es el hecho de que en Alemania, en donde ha gozado la exceptio doli generalis de aceptación generalizada a lo largo de su historia (antes y después de la codificación civil) ${ }^{52}$, con motivo de la redacción del Código Civil (BGB), vigente a partir del año 1900, sus redactores advirtieron que entendían que la figura en examen era innecesaria, y también peligrosa, aunque hubiera contado con el favor de la doctrina y la jurisprudencia en el pasado (siglos XIX y anteriores). "Innecesaria en la medida en que había posibilitado a los juristas romanos simplemente una interpretación amplia de los negocios jurídicos formales y de las acciones de derecho estricto surgidas de ello; dado que el juez actual no está ya sometido en la interpretación a ninguna restricción (...) Peligrosa sería la exceptio según la exposición de motivos del BGB, porque su admisión conduciría a que el 'sentimiento subjetivo del juez se colocara en el lugar de la precisa norma jurídica de modo altamente censurable, y se borraran las fronteras entre el Derecho y la Moral". Empero, tal fue la reacción de la

51 Acerca de estas y otras opciones y combinaciones, véase a Gianluca FALCO, La buona fede e l'abuso del diritto, op. cit, p. 224, y Giovanni Meruzzı. L'exeptio doli. Del diritto civile al diritto commerciale, CEDAM, Padova, 2005, p. 458.

52 Vid. Filippo Ranieri. "Eccezione di dolo generale", en Dig. Disc. Priv. Sez.civ, VIII, Torino, 1991, p. 316. 
doctrina y de la jurisprudencia alemanas, que no se atendió la observación de los redactores en comentario, toda vez que "... poco después de la entrada en vigor del BGB, algunos autores sostuvieron que la exc. Doli, a pesar de su rechazo por el legislador, mantenía de todos modos su acendrado vigor. La jurisprudencia siguió esta opinión e inició el camino hacia la consagración como regla consuetudinaria en la exc. de dolo, o de la objeción del ejercicio inadmisible del derecho, que ha fundamentado innumerables sentencias. Desde entonces el término exc. doli, como apenas ninguna otra locución latina, es familiar incluso para los autores del derecho vigente" 53 .

Lo cierto es que como lo tiene discernido un moderno sector de la doctrina, así puedan existir "algunos puntos de contacto" entre todas estas figuras, en especial respecto al abuso del derecho y la exceptio doli generalis, como ciertamente existen, la jurisprudencia italiana, ad exemplum, ha encontrado que median "diferencias apreciables", las cuales no son "marginales", como lo relata Aldo A. DOLMETTA ${ }^{54}$, parecer respaldado recientemente por S. VIARO, quien manifiesta en esta dirección, en torno a "...la prohibición del abuso del derecho y la exceptio doli generalis (...) que se trata de una fórmula de contenido diferente y, sobre todo, que una y otra obran en planos bien distintos", razón por la cual aboga por su escisión y no por su fusión, entre otros motivos por " ... utilidad práctica y por dignidad científica", hecho que en su entender invita a "... .ulteriores reflexiones con miras a una definición más puntual y segura" ${ }^{5}$, opinión a la que adherimos sin hesitación, primordialmente por el celo y por el respeto reclamado en función de las estructuras unitarias y tipos en mención, dueños de una historia diversa, así como distinta, en lo pertinente, es su configuración y sus secuelas individuales.

53 Andreas W WCKE. La 'exceptio doli' en el derecho romano clásico y la 'verwirkung' en el derecho alemán moderno, op. cit., p. 979.

54 Aldo A. DolmetTA. “Exceptio doli generalis”, en Banca, Borsa e Titoli di Credito, Giuffrè, Vol. LI, Milano, 1998, p. 157.

55 Silvia VIARO. "Abuso del diritto ed eccezione di dolo generale", en L'eccezione di dolo generale. App. licazioni giurisprudenciali, Cedam, Padova, 2006, pp. 2 y 3. Cfr. Daniele BERARDI. "Eccezione di dolo generale, apertura di credito e credito documentario", en L'eccezione di dolo generale. App. licazioni giurisprudenciali, CEDAM, Padova, 2006, p. 243. Cfr. Filippo RanierI. Eccezione di dolo generale, op. cit., p. 326, y PellizzI, Voz "Exceptio doli", Enciclopedia del Diritto, p. 1077, cit, Francesco VENOSTA, Note sull'exceptio doli generalis, op. cit., p. 530, al señalar que no se justifica claramente la bipartición, porque "...la exceptio doli cubre perfectamente gran parte de casos de abuso del derecho". 
La expresión 'dignidad científica' resulta entonces acentuadamente sugestiva, a fuer que reveladora.

Otra cosa bien diferente es que todos y cada uno de estos supuestos remediales como lo hemos esbozado (remedios iuris), tengan puntos en común, y que de una u otra manera estén hermanados por un mismo propósito y, por ende, en sentido lato, se inscriban en un mismo objetivo misional: el ejercicio inadmisible -o intolerable- de ciertos derechos, según se dijo, sin que ello atente contra su identidad. Atinadamente afirma G. Meruzzı que "La buena fe, el abuso de derecho y exceptio doli son expresiones de la misma exigencia de racionalización de la relación jurídica y de selección de los intereses dignos de tutela en relación con el ejercicio de los derechos formalmente atribuidos por el ordenamiento" 56 , aspecto éste que a menudo es olvidado por quienes todo lo quieren reducir a una estrecha y artificial categoría sin historia, mejor aún en contra de la historia, y sin bases sólidas y decantadas o, en su defecto, a una promiscuidad institucional, en la que dé lo mismo remediar una vicisitud o patología por intermedio de cualquiera de ellas, con el sorprendente argumento por el cual son intercambiables, modulares o fungibles, y de que poco importa cual se emplee finalmente, como si la ciencia del Derecho fuera un 'bazar', en donde todo se intercambia y adquiere sin otros miramientos. Al fin y al cabo debe tenerse presente que los remedios, por más generales que sean, de ordinario no sirven para conjurar una determinada y singular patología; ellos tienen una concreta misión y, por tanto, un objetivo específico, a la par que especializado, motivo por el cual la especialidad, y no la generalidad, por regla, debe ser el criterio llamado a regir su particular aplicación, aun cuando, prima facie, parezca que varias instituciones pueden servir para el mismo propósito, pero en realidad no en un mismo plano.

Ahora bien, fuera de Alemania y de Italia, en línea de principio, la exceptio doli generalis no ha sido abordada en forma sistemática, aun cuando en España, Suiza y Portugal, un sector autoral se ha ocupado de ella. No ha sucedido lo mismo en Francia y en Bélgica, en donde se le han dedicado mayor atención al

56 Giovanni Meruzzı, L'exeptio doli, op. cit., p. 458. Análogamente, en lo que tiene que ver con la diferenciación entre exceptio doli generalis y abuso del derecho, el profesor F. WIEACKER culmina su reflexión expresando que es "...recomendable dar al abuso del derecho un puesto institucional independiente entre los problemas fundamentales de Derecho privado". 
abuso del derecho ${ }^{57}$ y al estoppel, a la vez que a la confianza legítima y al deber de coherencia. Lo mismo ha tenido lugar, según se anticipó, en Latinoamérica, aunque hay que señalar que en Brasil y en Perú, conceptualmente, se han aproximado a ella ${ }^{58}$, a la vez que en Argentina, así sea para aseverar que no se aplica, ni tiene cabida en su ordenamiento ${ }^{59}$.

Es así como en España, por vía de ejemplificación -sin perjuicio que la jurisprudencia y la doctrina abordan con esmero y detenimiento la temática de la buena fe, del venire contra factum proprium y del abuso del derecho-, A. del Cossio y Del CorRal, ya hace algunas décadas, se detuvo en el estudio de la exceptio doli en su reconocida obra sobre el Dolo en el derecho civil, admitiendo su procedencia en el Derecho español, “....no sólo de la exceptio doli specialis, sino también, en toda su amplitud, de la exceptio doli generalis (...) En tal sentido, se nos ofrece la excepción, como fundada en un concepto objetivo, al que ordinariamente acompaña, aunque no siempre es necesario que sea así, una voluntad dolosa por parte del actor (...) La excepción es general, y en tal sentido debe utilizarse cuando falte un precepto positivo concreto que disponga la improcedencia de la acción; y es legal, en el sentido de que su función no es dejar sin eficacia a las normas positivas del ordenamiento jurídico"60.

Lo mismo ha hecho Don Luís DíEz-PICAzo en diversas oportunidades, destacando las reflexiones efectuadas en su archiconocida y aplaudida obra sobre La doctrina de los propios actos, como en el memorable prólogo que realizara a la no menos conocida monografía de F. WIEACKER, titulada El principio general de la buena fe. En este último trabajo, con algunas necesarias puntualizaciones, manifestó que "Cuestionan los autores hasta qué punto puede afirmarse la existencia de la excepción de dolo en el Derecho actual, una vez desaparecido el formalismo estricto característico del Derecho romano y por lo tanto desaparecida

57 Cfr. Andrea Torrente, Eccezione di dolo, op. cit., p. 219, autor que corrobora que la problemática de los límites al ejercicio de los derechos subjetivos es "... absorbida por el abuso del derecho".

58 Vid. Anderson Schreiber. A pohibiçao de comportamento contraditório, op. cit., p. 176.

59 Alejandro Borda. La teoría de los actos propios, op. cit., p. 126.

60 A. De Cossio y Corral. El dolo en el derecho civil, op. cit., p. 203. 
con él la razón que justificara, se piensa, su nacimiento y extensión. A nuestro juicio no puede decirse que subsista, propiamente hablando, la exceptio doli del Derecho romano. Sin embargo, resulta obvio que el reconocimiento de la buena fe como un límite del ejercicio de los derechos subjetivos obliga a reconocer en el sujeto del derecho subjetivo ejercitado en contra de los dictados de la buena fe, unos medios de defensa per exceptionem que llevan a enervar, repeler o detener la pretensión del titular del derecho y que a estos medios se les puede llamar genéricamente exceptio doli"k1.

Con todo, es de resaltar que la postura asumida por el profesor Luis Rojo AJURIA, no es favorable a la exceptio doli, ni tampoco, grosso modo, a la ampliación del espectro del dolo en el Derecho español, en guarda de admitir la incardinación de supuestos más generales, en contra de su "...carácter limitado y preciso", lo que explica que señale que "Nosotros nos inclinamos por una postura más tradicional", pues la referida amplificación a otras hipótesis, sería "...fuente de inseguridad jurídica, pero más lo sería la confusión indiscriminada en el cajón de sastre del dolo", tema este "...que, en cierta medida, conecta con la actitud de los ordenamientos jurídicos modernos ante la tradicional exceptio doli generalis". Por ello, concluye el autor, que no cree que "...los artículos 1269 y 1270 CC

${ }_{61}$ Luís Díez-PICAzo. Prólogo a la obra de F. WieACKer, El principio de la buena fe, op. cit., p. 20 y 21.

En el campo del Derecho administrativo español, por su parte, este instituto también se ha dicho que tiene plena cabida, pues a juicio del profesor Jesús GonZÁlez Pérez, "Si la exceptio doli generalis ha constituido un supuesto de aplicación del principio general de la buena fe...., no existe razón alguna para que no se considere aplicable en el ámbito del proceso administrativo". El principio general de la buena fe en el derecho administrativo, op. cit., p. 143.

Ya don Federico De CASTRo y Bravo, con motivo del examen que hizo alrededor del dolo, puso de relieve en su memorable obra sobre El negocio jurídico, que "En el derecho común y en derecho moderno se facilita la ampliación del calificativo del dolo al perder la 'actio doli' su carácter infamante y generalizarse la utilización del principio de la buena fe", op. cit, 1985, p. 149.

Por su parte, el profesor Antonio CABANILLAS, con motivo del examen de la oponibilidad de excepciones en el marco de la "delegación de deuda", refiere en diversas oportunidades a la exceptio doli generalis, indicando que "...es un instrumento corrector de las consecuencias injustas que se derivan del carácter puro de la delegación, cuando el delegatario ha actuado maliciosamente", todo "...en consonancia con el Derecho romano y el Derecho común....". "La delegación de deuda", en Estudios de obligaciones en Homenaje al profesor Mariano Alonso Pérez, T. I, La Ley, Madrid, 2006, pp. 266 y 267. 
tuviesen ese significado y, desde luego, que sean equiparables a la exceptio doli generalis", por lo que "... .descarta una aproximación a un concepto general del dolo en el Derecho civil"62.

Acreditada entonces la amplitud de la exceptio doli generalis, tanto en el Derecho romano clásico, al igual que durante otros estadios históricos, incluido el Derecho contemporáneo, se tiene establecido que ella funge de género, o de fuente inspiradora de otras instituciones (buena fe, venire contra factum proprium, abuso de derecho, etc.), no sólo por ser anterior a ellas -o algunas de ellas-, sino también por cuanto en la praxis, de una u otra forma, comulgan con un mismo propósito global: servir de remedio panorámico para conjurar el ejercicio de un derecho cuando se torne lesivo -o amenazante- de caros intereses objeto de tuición, motivo por el cual resulta siendo inadmisible, finalmente. Por eso algunos la han considerado, en un plano reactivo, a la vez que muy gráfico, como un "contraderecho", el que, por su carácter absorbente y por su vigor, “....debe ser incuestionablemente examinada de oficio y, en caso necesario, incluso puesta en evidencia mediante el derecho de interrogación judicial"63.

Desde esta perspectiva, es diáfano que, más allá de las dificultades connaturales de perfilar matemáticamente las divergencias reinantes entre las instituciones a las cuales hemos venido refiriéndonos en precedencia, no puede, ni deben confundirse o amalgamarse, a pretexto de inscribirse en un ideario común, o de traducirse en un comodín. De allí que sea necesario escindir, en lo pertinente, la exceptio doli generalis, el venire contra factum proprium y el abuso del derecho, así ello no siempre resulte tan simple. Empero, el esfuerzo, en aras de claridad conceptual y del respeto a las arquitecturas y perfiles propios, a las claras lo amerita, obviamente sin desconocer una que otra tendencia fusionista pura, ayuna de sólida y convincente fundamentación, pero cargada de facilismo y carente de contorno y sentido histórico.

\footnotetext{
62 Luís Rojo Ajuria. El dolo en los contratos, Civitas, Madrid, 1994, pp. 250- 253 y 298.

63 F. WIEACKER. El principio general de la buena fe, op. cit., pp. 88 y 89, catedrático que, expressis verbis, emplea el aludido término "contraderecho".

Vid. Francesco Venosta, Note sull'exceptio doli generalis, quien considera cómo "El venire contra factum proprium es la hipótesis más característica del supuesto de hecho que justifica la exceptio doli", op. cit., p. 528.
} 
Por eso, luego de reiterar las diferencias tipológicas entre estos institutos, muy especialmente de la exceptio doli, el venire contra factum proprium y el abuso del derecho, las que se estiman que "....no son de poco espesor", la doctrina moderna reclama "...su tratamiento en paralelo", precisamente por sus "... peculiares condiciones operativas" ${ }^{4}$, lo que no significa que no se relacionen entre sí, pues resulta de la mayor importancia entender que todas ellas están conectadas a través de estrechos vasos comunicantes, hasta el punto de que podríamos decir que pertenecen a una misma familia remedial (remedios específicos para una problemática global), sin perder su autonomía y, por ende, su individualidad. Al fin y al cabo, proximidad, no supone identidad plena, ni incluso relación estrictamente gemelar.

De hecho, como tangencialmente ya lo habíamos puesto de presente, buena parte de la dogmática contemporánea le asigna a la exceptio doli generalis el carácter de género, y a las otras figuras aledañas el de especie, tal y como tiene lugar específicamente con el venire contra factum proprium, regla de la que emana la doctrina de los actos propios, como se sabe, circunstancia que avala el referido carácter autonómico, aunque es de mencionar que no faltan los que aprecian esta realidad de modo diverso, es decir, quienes entienden que el abuso del derecho, como prueba de su escalada prematura, es el genus, lo que no se acompasa ni con la historia, ni con la evolución de una y otra figura, ni menos con el vasto campo asignado a aquella, al margen de su lectura terminológica, materia de oportuno ajuste, en nuestro entender.

Lo mismo sucede respecto del venire contra factum, como quiera que no falta la peculiar postura, a cuyo tenor la exceptio doli es una especie del gran género venire contra factum proprium ${ }^{65}$, como singular igualmente lo es la tesitura que se inclina, de un lado, por asignarle a la exceptio doli generalis el rol de género

64 Sara Todesco. Per una ricostruzione teorico-generale del concetto di abuso del diritto, op. cit., pp. 43 y 44, autora italiana que, aludiendo a la exceptio doli y al abuso, admite la "... complementariedad entre estos dos institutos", los que no tienen por qué excluirse. Otra cosa diferente es la aplicación de uno y otro, o de todos, en general, como quiera que, por su sustantividad y tipificación -así sea social-, no pueden hacerse a la vez, pues su vocación remedial se tornaría frustránea, contribuyendo a la perplejidad y a la confusión, en su momento.

65 Filipo RANIERI. Eccezione di dolo generale, op. cit., p. 316. 
y también de especie y, del otro, por encuadrar en el aludido género al venire contra factum prorpium, en compañía de la regla nemo auditur turpitudinem suam allegans ${ }^{66}$.

Otra postura, ya para culminar esta descripción panorámica, de suyo muy diversa, es aquella que se encamina a atribuirle a la exceptio doli un carácter defensivo o reactivo, por manera que funge de secuela derivada de "...infringir deslealmente la buena fe" 67 , o es el corolario de la "...reacción contra la pretensión abusiva...., función que es cabalmente llevada a cabo por la exceptio doli generalis" 68 , asumiendo un papel envolvente y general, pues se predica de diversas instituciones: el abuso del derecho, la verwirkung -en particular-, etc.

Baste pues de nuevo traer a colación al profesor Alfonso Del Cossio, para corroborar la indicada inclusión de figuras específicas en el marco de la mencionada excepción, a juicio de quien son “...diversos supuestos en que puede ser utilizada la exceptio doli. Ella puede permitirnos extender el derecho de retención a supuestos no previstos por la ley; impedir la actuación contra los propios actos (...) hacer ineficaz el acto emulatorio y reducir a los límites debidos el ejercicio anormal de cualquier derecho" ${ }^{\prime 9}$.

${ }_{66}$ Sobre el particular anota Federico PROCCHI que "la exceptio doli generalis, debe entenderse como genus en su acepción más amplia y omnicomprensiva...., proponiendo adoptar la siguiente y específica tripartición: venire contra factum proprium, en sentido estricto...; el principio del nemo auditur turpitudinem suam allegans, y la exceptio doli generalis en sentido estricto". L'exceptio doli generalis e il divieto di venire contra factum proprium, op. cit., pp. 100 y 101.

67 Gustavo BoEHMER. El derecho a través de la jurisprudencia, op. cit., p. 268, autor que efectúa la señalada anotación en torno a la verwirkung, en concreto.

68 Francesco VenostA. Nota sulla'exceptio doli generalis, op. cit., p. 531, quien agrega, en esta misma dirección, que "...el éxito de la exceptio doli generalis consiste exclusivamente en el rechazo de la pretensión abusiva".

69 Alfonso De Cossío y Corral. El dolo en el derecho civil, op. cit., p. 149. Vid. Luís Díez-PICAzo, puesto que como se señaló en precedencia, tan distinguido autor entiende que cuando se habla de buena fe como límite al ejercicio de los derechos subjetivos, es probable asignarle el calificativo genérico de "exceptio doli" a sus "...medios de defensa". Prólogo, monografía de F. WIEACKER, op. cit., p. 21. Por su parte, Andreas WACKE, avala que "En los negocios inter vivos la regla venire contra factum proprium nemini licet constituye uno de los primeros campos de aplicación de la exc. doli", op. cit., p. 987.

También procede de la misma manera, pero desde la orilla del Derecho romano, María Victoria SANSón R., al puntualizar que "Los juristas romanos se valieron de distintos 
Sin embargo, bien miradas las cosas, reconociendo que la expresión exceptio doli generalis, luego de su proceso de purificación histórica, se ha abierto paso en diversas latitudes (siglos $\mathrm{XX}$ y $\mathrm{XXI}$ ), muy especialmente entendida como expresión de los límites al ejercicio de los derechos subjetivos, en concreto como la inadmisibilidad de actuaciones contrarias a la buena fe, en su concepción más dilatada, pensamos que en el plano terminológico, por su pasado y por esa fuerza arrolladora que en la conciencia popular y en la de varios sectores de profesores y abogados aún ejerce el dolo (dolus malus), no debe ser preservada, así se hagan todas las salvedades de rigor que luzcan aconsejables y que aun cuando sean más que pertinentes y válidas, son impotentes para transmitir una idea clara, exacta y decantada de la misma, que es lo que se persigue en el campo lingüístico.

Otro tanto, en el ámbito sustancial, creemos que sucede con la figura, pues aun admitiendo su procedencia en diferentes ordenamientos jurídicos $y$ la conveniencia de su recepción, no podemos adherir a quienes desdibujando institutos jurídicos, muchos de ellos inveterados, con nombre y apellido propios, se inclinan por confundirlos o someterlos a su dominio. Una y otra cosa se nos antoja inconsulta, por cuanto pese a los puntos de contacto entre ellos existentes, no deben ser fusionados o equiparados in toto, y tampoco pueden ser sustituidos o degradados, merced a su carácter individual, a su talante y a su coloración jurídica. Hacerlo, además, sería borrar el camino recorrido hasta el momento, traicionando el pasado, del cual se nutre el presente, en gran medida, el que de ordinario tiene una deuda irredimible con el ayer, en el que comenzó a tejerse.

principios jurídicos para hacer valer....la exceptio doli: 1) Venire contra factum proprium nemini licet....2) Prohibición de enriquecimiento injustificado....3) Dolo facit qui petit quod redditurus est.... En los casos examinados de aplicación de la exceptio doli... se limita el ejercicio de derechos". La buena fe en ejercicio de los derechos y en el cumplimiento de las obligaciones desde la perspectiva del derecho romano privado, op. cit., p. 335 y ss.

De la lectura de un pasaje de ULPIANO consignado en el Digesto justinianeo, ubicado en el Título IV del Libro 44, atinente a la "...excepción del dolo malo....", se comprueba que hipótesis hoy arropadas con el manto del venire contra factum proprium, en su real esencia, a la sazón, eran gobernadas por la exceptio en cuestión. Dicho texto establecía que “... se ha dicho que si un acreedor hubiera cobrado intereses futuros y reclama la cantidad prestada, a pesar de ello, antes de haber transcurrido el plazo cuyos intereses cobró, podrá ser rechazada por la excepción de dolo, pues puede decirse que obra con dolo, ya que, al cobrar los intereses, se entiende que ha aplazado la reclamación para después del plazo de los intereses pagados, y que ha convenido no reclamar entretanto" (D. 44, 4, 2.6, Ulp.). 
Por ello, si de categorías genéricas se trata, debe acudirse más que a la exceptio doli generalis a una limitación al ejercicio de los derechos subjetivos, v.gr: a la buena fe, al abuso del derecho, al venire contra factum proprium, entre otras figuras e instituciones llamadas, en concreto, a remediar cualquier quebranto $o$ desbordamiento.

\subsection{DiFERENCIAS MÁs ESPECÍFICAS}

A la vista de las consideraciones que anteceden, tanto de jure condendo, como de jure condito, la exceptio doli generalis no debe ser asimilada a la regla venire contra factum proprium y, de contera, a la doctrina de los actos propios, en particular, por diversas razones más específicas que resumimos seguidamente, sin pretender por ello agotarlas:

A) Por cuanto no es irrefragable que la exceptio doli generalis sea una institución universal, y que en tal virtud sea de acogida plena en todos y cada uno de los regímenes jurídicos, pues visto está que en un apreciable número de naciones no cuenta con explícita recepción y que, incluso, ella no ha sido materia siquiera de escrutinio. Es más, si bien es cierto que en la actualidad goza del favor de un amplio sector de la doctrina y de la jurisprudencia en países como Alemania e Italia, tampoco es menos cierto que hay autorizadas opiniones que se oponen a ella, por variopintas razones.

Muy por el contrario, la regla venire contra factum proprium, a la vez que sus manifestaciones individuales, de vieja data ha tenido mejor fortuna y una mayor aceptación jurisprudencial y dogmática -y últimamente normativa-, hasta el punto que es más seguida tanto en el sistema del civil law, como del common law (estoppel, en sentido amplio) ${ }^{70}$.

\footnotetext{
${ }_{70}$ Vuelve a tener razón el profesor Díez-PICAzo cuando puso de presente en la década de los sesenta, que "...mientras la 'exceptio doli' es, entre nosotros, poco menos que una curiosidad erudita, la doctrina de los actos propios es, lo hemos dicho ya varias veces, un instrumento de perfiles muy acusados en la vida forense". La doctrina de los propios actos, op. cit., p. 168. Cfr. Alejandro BorDA, quien aclara que "la exceptio doli no ha sido incorporada en nuestro ordenamiento positivo, ni tampoco ha sido construida doctrinaria ni jurisprudencialmente. Distinto es el caso de la teoría de los actos propios, como ya lo hemos visto". La teoría de los actos propios, op. cit., p. 126.
} 
B) Porque si se supera la discusión anterior y se admite -en gracia de ellaque la exceptio doli generalis es un arquetípico genus, de un lado, y del otro, que la regla del venire es una de sus diversas especies, debe establecerse entre ellas las diferencias que reinan entre género y especie, tanto más cuanto en este caso la exceptio se entendería, más allá de su rótulo, indicativo de otro significado jurídico muy diverso, como limitación al ejercicio de los derechos subjetivos -o si se prefiere como inadmisibilidad del ejercicio de los derechos-.

C) En caso por el cual no sea de recibo la mencionada caracterización y correlativa escisión, vale decir que ambas figuras no están en un mismo plano jerárquico, se imponen diferencias específicas, entre otras las que a continuación se mencionan:

a) La exceptio doli, aun cuando para la generalidad de autores reviste un carácter objetivo, sobre todo en punto tocante con la denominada exceptio doli specialis, para otro sector podría cimentarse en una concepción más subjetiva, en la que consideraciones inherentes a la intencionalidad tendrían cabida, directa o indirectamente, y bien se sabe que en tratándose de la doctrina de los actos propios, conforme se esbozó en su momento -y se ratificará en el Cap. III-, dicha lectura no es procedente, habida cuenta de su temperamento objetivo, refractario al dolo y a la culpa, por vía de ilustración ${ }^{71}$. En esta dirección Don Luís DíEZ-PICAZO expresa que “... para poder identificar la doctrina de los propios actos con la 'exceptio doli' sería menester dar de esta última un concepto objetivo, por completo independiente del dolo del actor, lo que nos es absolutamente pacífico en la doctrina"72. Por lo tanto, para quienes adhieren a la lectura subjetiva en referencia, la disimilitud de este instituto (la exceptio doli) con el venire contra

71 Como bien lo ilustra F. PROCCHI, idea que refrendamos de nuevo, "La doctrina se muestra prácticamente unánime al considerar que la prohibición del venire contra factum proprium opera objetivamente, con prescindencia de cualquier consideración en términos de culpa en el comportamiento observado por el titular del ejercicio del propio derecho". L'exceptio doli generalis e il divieto di venire contra factum proprium, op. cit., pp. 103 y 104.

72 Luís Díez-Picazo. La doctrina de los propios actos, op. cit., p. 168. Cfr. Anderson Schreiber. A prohibiçao de comportamento contradictório, op. cit., p. 179, para quien la exceptio doli, aparece vinculada, en algún grado, a la noción de dolo, lo que no ocurre en el venire contra factum proprium". Cfr. Alejandro BordA. La teoría de los actos propios, op. cit., p. 125. 
factum proprium, afloraría al rompe, dado su carácter objetivo, según se historió precedentemente.

b) La exceptio doli, por su proyección más general, hace hincapié en la inadmisión de determinados derechos subjetivos, pero no en función del surgimiento de una contradicción o quebranto del deber de coherencia, en ambos casos con fractura paladina de la confianza legítima previamente inculcada, nervio de la doctrina de los actos propios. De allí que como el norte específico de esta doctrina estribe en la preservación de la citada confianza, entre otros cometidos más (apariencia, seguridad jurídica, solidaridad, etc.), la figura apropiada y, por ende, aplicable, resulta ser esta última y no aquella, so pena de alterar su tarea y su auténtica misión, a lo que se agrega que de proceder de otro modo se vulneraría su identidad ${ }^{73}$. Al fin y al cabo, hay que respetar en la ciencia del Derecho, al igual que en otras ciencias, que los remedios dispuestos para combatir específicas situaciones no pueden usarse indiscriminadamente, pues para cada una existe una composición y dosis particular. Es por ello que el profesor brasileño Anderson SCHREIBER no duda en aseverar que "El venire contra factum proprium tiene un contenido relativamente determinado, orientado a reprimir un comportamiento contradictorio apto para generar legítima confianza en otro (...) La exceptio doli tiene, a su vez, contenido difuso, albergando una serie de numerosas hipótesis" ${ }^{\prime \prime}$.

c) La exceptio doli, en sentido más amplio, encuadra en el mecanismo procesal de las excepciones ${ }^{75}$, en cuyo caso, en sede judicial, es menester que las formule

73 Vid. F. PROCCHI, L'exceptio doli generalis e il divieto di venire contra factum proprium, op. cit., pp. 101, y Joao BAPTISTA MACHADO, Tutela da confiança e venire contra factum proprium, op. cit., p. 419.

74 Anderson Schreiber. A prohibiçao de comportamento contraditório, op. cit., p. 179.

75 En efecto, como su propio nombre lo indica, la exceptio doli corresponde a una excepción, en el sentido procesal del término. Al respecto, no sobra memorar que una excepción es, de acuerdo con un difundido criterio doctrinal, "... una especial manera de ejercitar el derecho de contradicción o defensa en general que le corresponde a todo demandado, y que consiste en oponerse a la demanda para atacar las razones de la pretensión del demandante, mediante razones propias de hecho, que persigan destruirla o modificarla o aplazar sus efectos..." (Hernando Devis Echandía, Compendio de derecho procesal. Teoría general del proceso. Diké. Medellín. 1993, p. 244). Otra útil noción es la delineada por Francesco CARNELUTTI, para quien “... la excepción es una razón especial de la oposición del demandado a la pretensión del demandante, manifestada en forma activa y, por tanto, 
el demandado, al paso que la doctrina de los actos propios, en general, obedece a una arquitectura no necesariamente idéntica, puesto que, en primer lugar, según tuvimos ocasión de mencionar -y lo haremos de nuevo-, puede ser objeto de aplicación ex officio por el juzgador (Cap. III). Y en segundo lugar, dado que en un momento determinado, puede ser enarbolada o referida no por el demandado, quien tiene a cargo la formulación de excepciones, sino por el demandante, luego de que aquél haga uso de ellas, en desarrollo del derecho de oposición, mejor aún de defensa, lato sensu, el que no se agota en cabeza del demandado, en atención a que el proceso, por antonomasia, es dinámico, de suerte que el debido proceso, como garantía de estirpe constitucional y legal, no se agota de cara a un extremo de la litis, o relación litigiosa, la que no es -ni puede ser- unilateral ${ }^{76}$.

una contrarazón frente a la razón de la pretensión del demandante..." (Sistema de derecho procesal civil, Tomo I, Buenos Aires, E.J.E.A, Núm. 126).

Una de las descripciones más comprensivas de la excepción, por su parte, es la realizada por el procesalista Eduardo COUTURE, para quien "En su más amplio significado, la excepción es el poder jurídico de que se halla investido el demandado, que le habilita para oponerse a la acción promovida contra él. En este primer sentido, la excepción es, en cierto modo, la acción del demandado. Era este el alcance del texto clásico 'reus in exceptione'. (...) Una segunda acepción del vocablo alude a su carácter material o sustancial. Se habla así, por ejemplo, de excepción de pago, de compensación, de nulidad. Debe destacarse también en este sentido, que tales excepciones solo aluden a la pretensión del demandado y no a la efectividad de su derecho. Mediante ellas, el demandado pretende que se le libere de la pretensión del actor, en razón de que el pago, la compensación, la nulidad hacen inexistente la obligación. (...) "En un tercer sentido, excepción es la denominación dada a ciertos tipos específicos de defensas procesales, no sustanciales, dilatorias, perentorias o mixtas, mediante las cuales el demandado puede reclamar del juez su absolución de la demanda o la liberación de la carga procesal de contestarla..." Fundamentos de Derecho Procesal, Depalma. Buenos Aires. 1958. pp. 89 y 90. Vid. Jaime GuASP. Derecho procesal civil, T. I. Instituto de Estudios Políticos, Madrid, 1968, pp. 236 y ss.

76 Vid. Luís Díez-PICAzo, quien anota con relación al aspecto funcional de las instituciones en referencia que, "la inadmisibilidad del 'venire contra factum' puede proponerse por vía de réplica, precisamente para desvirtuar la defensa del demandado, o como dúplica para paralizar una pretensión o una alegación del actor formuladas al replicar. La inadmisibilidad del 'venire contra factum' puede funcionar incluso como fundamento de la demanda, para rechazar preventivamente una posible alegación del demandado". La doctrina de los propios actos, op. cit., p. 168. Vid. Nélida TUR FAÚNDEZ. La prohibición de ir contra los actos propios y el retraso desleal, op. cit., p. 51, y Alejandro BordA. La teoría de los actos propios, op. cit., p. 125, doctrinante que, compartiendo lo explicitado por Don Luís DíEz-PICAZo, indica que "La regla que sanciona la inadmisibilidad de volver contra los propios actos escapa a ese sentido tan estricto, y se constituye no sólo en una excepción en sentido amplio -como medio de defensa- sino que puede ser opuesto por vía de réplica -para desvirtuar las defensas esgrimidas-, o de dúplica -para frenar las alegaciones expuestas en la réplica-, como así también para fundar una acción..... Finalmente, el también autor argentino Marcelo LóPEZ MESA, desde un ángulo procesal, coincide al afirmar que el acto propio "no configura una excepción en sentido estricto, sino una defensa amplia, abarcadora, hábil para frustrar la 


\section{ABUSO DEL DERECHO}

\subsection{Generalidades}

El abuso del derecho -o de derecho-, en consonancia con lo señalado en precedencia, es justamente una de esas figuras que, por ser tan generales, pero a su turno tan inespecíficas y hasta porosas, tiene un radio de acción amplio, el que se dilata y contrae con facilidad, no siempre en forma conveniente y regular, toda vez que se estira tanto que, en ocasiones, termina por invadir otros predios que, en tal virtud, podrían quedar inmersos en una especie de limbo jurídico, a pretexto de la referida generalidad, en lo que juega un papel preponderante el entusiasmo de la doctrina y de alguna jurisprudencia consistente en aplicar la teoría del abuso en forma más o menos indiscriminada, olvidando que por más global y arropadora que parezca, tiene límites, hasta el punto que como lo recordaba con tino Don Federico De CASTRo y Bravo, así en apariencia su advertencia pudiere sobrar, que naturalmente no sobra, algunos "... abusan del abuso del derecho"77, parecer compartido por los profesores argentinos Atilio A. AlteRINI y Roberto M. LóPEZ CABANA, quienes concluyendo su panorámico estudio acerca del abuso en mención, hacen una “... recomendación final en tema tan arduo", consistente en "... insistir en la purificación del concepto, evitando el abuso de la teoría del abuso, como forma idónea de evitar su desprestigio. Su uso promiscuo, indiscriminado -abusivo, en definitiva-, la ha puesto en trance de ser convertida en una baratija"78.

Expresado de otro modo, con el fin de preservar la genuina arquitectura de determinadas y precisas instituciones, incluida la del abuso del derecho,

pretensión desleal. Ello, obvio es, sin perjuicio de su posibilidad de invocación de oficio, en los casos en que ella proceda". La doctrina de los actos propios, op. cit., p. 150.

77 Federico de Castro y Bravo. Derecho civil de España. Temas de derecho civil, ThomsonCivitas, 2000, p. 139.

78 Atilio A. Alterinı y Roberto López Cabana. Responsabilidad civil, Diké, Medellín, 1995, p. 34. Cfr. Mariano Yzquierdo Tolsada. Sistema de responsabilidad civil contractual y extracontractual, Dykinson, Madrid, 2001, p. 118, al afirmar que en este terreno ha de procederse con cautela, porque el "abuso del abuso puede hacer peligrar la virtualidad de la figura". Cfr. María CostANZA. "Brevi note per non abusare del'abuso del diritto", in Giur. it, 2001, p. 2444. 
es aconsejable aplicar restrictiva y mesuradamente figuras como la que nos ocupa, pues si se hace en forma tan lata, y con tanta largueza, se corre el riesgo inevitable de borrar sus fronteras, en oportunidades centenarias o milenarias, en grave desmedro de su auténtica morfología, su teleología y su etiología ${ }^{79}$, al igual que de desnaturalizar las propias, de hecho no del todo demarcadas con diafanidad. Autores como el profesor Javier TAMAYO JARAMILLO manifiestan que "La figura del abuso del derecho es francamente inasible" 80 , y otros que, en pleno siglo XXI, como Sara TODESCo, se esfuerzan por perfilarla mejor y también por su reconstrucción ${ }^{81}$, quizá por aquello de que doctrinantes más tradicionales, a la sazón, pregonaron su abierta inutilidad ${ }^{82}$.

Hay pues que proceder con cautela, dejando de lado pretensiones invasivas o maximalistas, y también épicas. ${ }^{83} \mathrm{Al}$ fin y al cabo, el Derecho no puede ser

79 La jurisprudencia argentina, por su parte, comparte análoga conclusión, según lo compendia la profesora Aída KemelmaJer De CARLUCCI en su estudio acerca del tema, al indicar que la "...Corte Federal tiene dicho que 'cuando se trata de privar de efectos a una cláusula contractual, la teoría del abuso del derecho debe utilizarse restrictivamente y solamente cuando el antifuncionalismo aparezca manifiesto, patente, flagrante'; en seguimiento de esta doctrina judicial, se afirma reiteradamente que la teoría 'debe ser aplicada con criterio restrictivo', 'por tratarse de una remedio excepcional". "Principios y tendencias en torno al abuso del derecho en Argentina", en Revista de Derecho Privado Comunitario, RubinzalCulzoni, Santa Fé, pp. 217 y 218. Cfr. Alfredo Orgaz. La ilicitud, Lerner, Córdoba, 1974, p. 102 , quien advierte que "dentro del planteamiento tradicional del problema, los supuestos de ejercicio abusivo son, necesariamente, de carácter excepcional y, por tanto, no deben ser legislados con prodigalidad ni vaguedad, sino, al contrario, con estrictez y precisión".

80 Javier Tamayo Jaramillo. Tratado de la responsabilidad civil, T. I, Legis, Bogotá, 2009, p. 588.

81 Sara Todesco. Per una ricostruzione teorico-generale del concetto di abuso del diritto, op. cit. De igual modo, cumple mencionar que autores del prestigio de Pietro RESCIGNo mencionan y examinan los alcances de la "crisis del principio". L'abuso del diritto, II Mulino, Bologna, 1998, p. 131 y ss., opinión compartida por el profesor chileno Pablo RodRíGUEZ GrEZ, quien entiende que es extremo “...extender el 'abuso del derecho' más allá de todo límite prudente, sin advertir que se debilita gravemente el 'derecho subjetivo' ", siendo entonces admisible "... una crítica descarnada a esta....teoría, desnudando sus inconsistencias, debilidades, contradicciones y fijando sus límites". El abuso del derecho y el abuso circunstancial, Editorial Jurídica de Chile, Santiago, 1997, pp. 7 y 8.

82 F. Santoro Passarelli., op. cit, p. 77. En torno a esta evolución, hasta nuestros días, véase con provecho a Gerardo BROGGNI, "L'abus de droit et le principe de la bonne foi. Aspects historiques et comparatifs", en Studi di diritto romano e storia del diritto, Jovene Editore, Milano, 2007, p. 151 y ss.

83 Al respecto, no se equivoca el profesor Carlos LASARTE ÁlVAREZ, cuando haciendo un llamado a la mesura, precisa que el abuso del derecho, así tenga "...valor general de principio", no 
reducido a moldes de tal amplitud que aspiren albergarlo todo, socavando la personalidad y el ADN de instituciones que tienen vida propia y carta de naturaleza, con mayor razón tratándose del abuso del derecho, el que en rigor no despuntó hace un apreciable número de decenios, según lo tiene establecido la communis opinio, obviamente sin desconocer algunos de sus embrionarios antecedentes que podrían remontarse a otros estadios de la historia jurídica ${ }^{84}$, lo que reafirma la necesidad de abogar por una responsable pluralidad institucional, en la que converjan diversos institutos, dueños de sustantividad y autogobierno, muchos de ellos llamados a cumplir, in genere, una misma o similar misión, así sea por senderos diferentes, unos más escarpados que otros. Bien expresa la máxima que "las cosas que son difíciles no por ello son peores" (Qua difficilia sunt, non statim sunt deteriora)

De lo contrario, el abuso del derecho sería omnímodo, a fuerque omnipresente; todo quedaría allí en una especie de 'cajón de sastre', sobrando por completo este capítulo, entre otros motivos por cuanto habría que rotular diversamente esta monografía, a la par que otras que llevan el mismo o similar título, en cuyo caso sólo podríamos identificarla con el epígrafe de abuso del derecho, pretensión absorbente que se nos antoja a todas luces impropia, con un eco de abusividad, rayano en el absolutismo y en la tiranía conceptuales. Es en esta dirección que el Tribunal Supremo español, en sentencia del 7 de febrero de 1964, precisó acertadamente que "...el principio general prohibitivo del abuso del Derecho es de índole excepcional y de alcance restrictivo", lo que exige una conveniente demarcación, pues nada más simple que decir, para evitar estas disquisiciones, y mayores inconvenientes, que estamos presenciando un ensanchamiento de este instituto, hasta el punto que todo queda por él cobijado y dominado, y que su reino es prácticamente infinito, a fuer de eterno. Por esta vía, amén de incorrecta, cómoda, muy propia de otras épocas en las que imperaba el facilismo y el rampante pragmatismo, v.gr: en el apellidado Derecho vulgar (Derecho romano posclásico), todas las grandes y enriquecedoras discusiones jurídicas, quedarían

es "...una arma mágica", que todo lo puede. Principios de derecho civil, Parte general y derecho de la persona, T. I, Trivium, Madrid, 1992, p. 167

84 Luís Niel Puig. "Abuso del derecho", en Responsabilidad por daños en el tercer milenio, Abeledo Perrot, Buenos Aires, 1997, p. 1075. Vid. G. BROGGNI, L'abus de droit et le principe de la bonne foi. Aspects historiques et comparatifs, op. cit., p. 151 y ss. 
reducidas a polvo, a la nada, esto es, en el caso que nos ocupa, todo quedaría envuelto en el abuso del derecho, sin debate, ni fórmula de juicio.

En adición a lo anterior, resulta de la mayor significación tener muy presente la especialidad y también la especificidad del venire contra factum proprium, a la vez que de la doctrina de los actos propios, una de sus manifestaciones más dicientes, porque bien es sabido que las figuras especiales están llamadas a primar sobre las generales, todo en desarrollo de la conocida regla, a cuyo tenor lo especial prima sobre lo general, lo que quiere significar que frente a la incoherencia comportamental, a la defraudación de la confianza con ocasión de la contradicción, entre otras caracterizaciones, es la doctrina de los actos propios y no el abuso del derecho, la que se debe aplicar, privativamente, por lo menos en línea de principio, salvo que las circunstancias especiales así lo impongan, pues es posible, in abstracto, que en un asunto determinado haga presencia el abuso, frente a lo cual fungirá de mero detonante de la contradicción y correlativamente del quiebre de la confianza, quid del venire. Ello obedece, precisamente, a que es un instituto de naturaleza singular, motivo por el cual se debe aplicar de preferencia al abuso del derecho, más general, y en ningún caso su fuente generatriz, desde luego cuando resulte aplicable, pues bien se sabe que la procedencia de este tipo de remedios es limitada y sujeta a precisas oportunidades; bien vale la pena recordar que tratándose del venire y, de paso, de la doctrina de los actos propios, ad exemplum, es menester respetar su residualidad, cabalmente entendida.

Según como acontece en la medicina, si la referencia a ella se torna admisible, pueden existir varios procedimientos y fármacos que directa e indirectamente sirvan para aliviar una dolencia. Así, no se puede pretender curar un dolor de una mano con la amputación de la misma, aunque teóricamente produzca el mismo efecto supresor, o paliarlo con morfina, cuando de suyo no sea muy intenso. Por eso un procedimiento especializado mitigará mejor la aflicción. Es lo que también sucede en este plano ejemplificativo con las prendas de vestir, puesto que una talla más amplia, sin duda, puede servir para cubrir el cuerpo, pero jamás será igual de cómoda y recomendable que una prenda que se ajuste bien a él. Se trata entonces, en pocas palabras, de usar figuras hechas a la medida, esto es, figuras que respondan adecuadamente a cada situación particular y que han sido estructuradas, ex proffeso, específicamente para tal fin. No en balde, cada institución tiene su propia horma. 
En compendio, tal y como sucede con todas las instituciones jurídicas, la figura del abuso del derecho, no es la excepción, reviste claros y precisos límites. Al fin y al cabo, paradójica pero elocuentemente, ella nació para que los particulares y el Estado los respetaran. Por ello es por lo que tales límites o linderos, ab initio, están marcados con tinte fluorescente, merced a la existencia de otras figuras que, en forma especial o especializada, se ocupan de responder a problemáticas jurídicas concretas frente a las cuales son esas figuras especializadas, y no el abuso del derecho, las que están llamadas a aplicarse, de preferencia.

Ya para concluir, expresamos que le asiste toda la razón al profesor argentino Alejandro BoRDA, cuando en su detenido estudio acerca de este tema, lo introduce anotando que "En algunas oportunidades la teoría de los actos propios ha sido confundida con el llamado abuso del derecho, y ello puede deberse a que ambas figuras reconocen un tronco común en el principio general de la buena fe (...) Nosotros pensamos que el abuso del derecho es diferente de la teoría de los actos propios. Esta no deriva de aquél, sino que ambos derivan del principio general de la buena fe", motivo por el cual el mencionado autor entiende que aplicar incorrectamente tales figuras es inconsulto, en consideración a que son distintas y cada una atiende a criterios diversos. De ahí que incluso en el caso contrario al examinado por nosotros, o sea cuando se aplica a un concreto supuesto de hecho, propio de la teoría del abuso del derecho, no dude en aseverar que, por esa vía, "...el abuso del derecho desaparecería fundiéndose en la teoría de los actos propios" ${ }^{\prime}$. No es entonces fortuito, mutatis mutandis, que el pasaje bíblico enseñe que "Den al César lo que es del César, y a Dios lo que es de Dios" (MATEO, 22, 15-21).

\subsection{Algunas notas elocuentes y características del abuso del derecho}

Expresado lo que antecede, importa seguidamente esbozar algunas notas elocuentes y características de la figura del abuso del derecho, o de derecho como otros la denominan, según se anticipó ${ }^{86}$, al mismo tiempo que algunas de

\footnotetext{
${ }_{85}$ Alejandro Borda. La teoría de los actos propios, op. cit., pp. 120 y 121.

86 Vid. Gustavo Ordoqui Castilla. Abuso de derecho, Ediciones del Foro, Montevideo, 2009. Existe una segunda edición, Universidad Javeriana y Grupo Editorial Ibáñez, Bogotá, 2010.
} 
las que, a nuestro juicio, podrían erigirse en diferencias específicas, laborío en todo caso asaz complejo, justamente por las razones antedichas que atañen a su generalidad, de suyo atrapante por momentos, lo que torna aún más difícil tal empeño, a lo que se agrega el hecho incontestable de que de cara a la llamada institución de la verwirkung o retraso desleal, entre otras denominaciones más, la doctrina dominante y un amplio sector de la jurisprudencia la conciben como una modalidad especial del abuso del derecho, postura que, por general o absoluta, con independencia de su real pertinencia individual, como se examinará en su oportunidad, no debería llevarse más allá de la referida verwirkung, como quiera que retornaríamos al mismo problema ya descrito: un círculo vicioso, en el que el abuso lo sería todo: el día y la noche, sin que ello se oponga a que ante precisas y demarcadas situaciones, en sí mismas especiales, claro está, se pueda concluir que en el factum proprium hizo presencia el abuso del derecho, que es cosa diferente, porque apodícticamente no puede decirse que en ningún asunto puede converger, así el énfasis termine haciéndose en la incoherencia y en la contradicción, como se mencionó. Quizá los habrá tan evidentes, que resulte inviable negar su ostensible paternidad (estructuración propia), o su influjo (causalidad), máxime cuando el abuso goce de inequívoco resguardo legal, como tiene lugar en España (art. 7, C.C.), Alemania (art. 242), Suiza (art. 2, Código Civil de las Obligaciones), Portugal (art. 334, C.C.) Grecia (art. 281, C.C.), Argentina (art. 1071, C.C.), Perú (art. 2, Título preliminar, C.C.), Paraguay (art. 272, C.C.), Brasil (art. 187), etc., o según acontece en Colombia, que además de estar disciplinado por el artículo 830 del Código de Comercio, tiene status constitucional (art. 95) ${ }^{87}$.

En efecto, el abuso del derecho, en sí mismo considerado, vale decir acotado, funge como arquetípico límite del ejercicio de los derechos subjetivos, como bien se ha dicho, al igual que tiene lugar con la buena fe, entre otros ejemplos o modalidades más, circunstancia que, en ocasiones, ha conducido a que se amplifique su radio de acción, como se resaltará luego, o que se confunda, así sea de modo indirecto, con la bona fides. Esa, en primer término, es su ubicación cabal y la explicación inmediata de su cometido funcional, habida cuenta que persigue

87 Es así como el aludido artículo 95 de la citada carta política dispone que, "El ejercicio de los derechos y libertades reconocidos en esta Constitución implica responsabilidades. Toda persona está obligada a cumplir la Constitución y las leyes. Son deberes de la persona y del ciudadano: 1. Respetar los derechos ajenos y no abusar de los propios...". 
traducirse en valladar para los asociados y, claro está, para los cocontratantes - o futuros cocontratantes- en el campo del Derecho de los contratos, en aras de evitar injustificados perjuicios e intolerables disfunciones y frustraciones, motivo por el cual se tiene establecido que el ejercicio de los derechos subjetivos no es irrestricto u omnímodo, en razón de que está sujeto a limitaciones, bien de carácter subjetivo, bien de carácter objetivo, según el caso. Por eso es por lo que el autor Luís MARTínez CALCERRADA no duda en aseverar que la mala fe y el abuso del derecho, en concreto, actúan “...como cortapisas o controles impuestos a los titulares de los derechos subjetivos que en el aprovechamiento de su contenido no pueden traspasar (...) Vienen, pues, a representar fronteras de tal suerte, que todo lo que en ese aprovechamiento se sitúa dentro de las mismas estará tutelado por la ley, mientras lo que la rebase o 'sobrepase' quedará bajo el estigma de la condena o juicio de reproche"88.

En segundo término, en lo que se refiere a la descripción y significado del instituto en cuestión, cumple puntualizar que hay abuso de derecho, lato sensu, cuando "...su titular goza de un margen de libertad en el uso que deja abierta la vía a un mal uso, que es lo que se llama abuso (...) sólo concebible, en lógica, con esta condición: que el mal uso no se confunda desde el primer momento con la ausencia de derecho", conforme lo explicita el profesor de la Universidad Católica de Lovaina, Jean DABIN ${ }^{89}$.

En este orden de ideas, en las postrimerías del siglo XIX y en los albores del $\mathrm{XX}$, cuando de esta temática comenzaba la jurisprudencia y la doctrina a

88 Luís Martínez CalCERRADA. La buena fe y el abuso del derecho. Su respectiva caracterización como límite en el ejercicio de los derechos, Revista de Derecho Privado, Madrid, p. 451. Cfr. Ricardo De Ángel YágüEZ, quien reseña con acierto que “...el abuso del derecho debe inscribirse dentro de la doctrina de los límites del derecho subjetivo, expresión que da la idea de que si el derecho es una situación de poder que el ordenamiento jurídico atribuye o concede a la persona, es evidente que ese poder tiene que estar de algún modo limitado, pues sin límites sería justificada la absoluta arbitrariedad", a lo que agrega, también con precisión, que "Dentro de esos límites están también la buena fe y el principio de que "nadie puede ir contra sus propios actos'". "Abuso del derecho”, en Enciclopedia Jurídica Básica, Civitas, Madrid, 1995, p. 43.

89 Jean DABIN. El derecho subjetivo, Editorial Revista de Derecho Privado, Madrid, 1955, p. 335. 
ocuparse con algún interés ${ }^{90}$, autores como R. SALEILLES expresaban que "Hay abuso del derecho en el ejercicio anormal del mismo, ejercicio contrario al destino económico y social del derecho, ejercicio reprobado por la conciencia pública y excesiva consecuencia, pues todo derecho desde el punto de vista social es relativo" 91 , en palmario contraste, a la vez que respuesta a la máxima latina qui iure suo utitur neminem laedit (el que usa de su derecho a nadie perjudica), revaluada en su conjunto, al igual que la ulteriormente consignada en las Partidas: Non faze tuerto a otro quien usa de su derecho" (L. 14, tít. 34, Part. VII) ${ }^{92}$.

En lo referente a su configuración, alcances generales y elementos tipificadores, célebre es la Sentencia del Tribunal Supremo Español del 14 de febrero de 1944, cuyo Magistrado Ponente fue Don José CASTÁN ToBEÑAs, con arreglo a la cual, in extenso, "El clásico axioma qui iure suo utitur neminem laedit quiere decir que el ejercicio es lícito cuando, merced a él, se lesionan simples intereses de terceras personas y, por consiguiente, en tesis general, no hay obligación de indemnizar los daños causados con ocasión de tal ejercicio, más no debe darse a esta máxima un alcance demasiado literal y absoluto, que lo pondría en pugna con las exigencias éticas del Derecho (...) la doctrina moderna, en trance de revisar y, en cuanto sea necesario, rectificar los conceptos jurídicos, impulsada por las nuevas necesidades de la vida práctica y por una sana tendencia a la humanización del Derecho civil, ha elaborado la teoría llamada del abuso del derecho, sancionada ya en los más recientes ordenamientos legislativos, que consideran ilícito el ejercicio de los derechos cuando sea abusivo; y si bien existen discrepancias,

90 Vid. Henri y León MAZEAUd y André Tunc. Tratado teórico y práctico de la responsabilidad civil, T. I, Vol. I, EJEA, Buenos Aires, 1977, p. 107, distinguidos doctrinantes que recuerdan que en Francia "...la aparición en la jurisprudencia de la teoría del abuso del derecho es casi contemporánea del Código civil francés; pero tan sólo luego de los últimos años del siglo XIX los tribunales hacen aplicación diaria de ella".

91 Raymond SALEILLES. Etudes sur la theorie générale de l'obligation d'aprés le premier projet du Code Civil allemand, $N^{\circ} 310$, Paris.

92 No está de más recordar que esta máxima, en asocio de otras muy próximas (neminem laedit, nemo dammum facit qui suo jure utitur), pese a su aparente rotundidad, fue reinterpretada modernamente, en consideración a que como lo reseñan A. CoLIN y $\mathrm{H}$. CAPITANT, "Durante mucho tiempo, la tesis de la irresponsabilidad ha parecido innegable. Se la consideraba como consagrada por un adagio tradicional.... Sin embargo, hubiera bastado con leer atentamente los textos para convencerse que jamás han tenido el alcance absoluto que se les ha atribuido". Curso elemental de derecho civil, T. III, Reus, Madrid, 1960, p. 806. 
teóricas y positivas, en orden a importantes puntos, entre ellos la construcción sistemática de la teoría en cuestión (...) es lo cierto e innegable, de todos modos, que tales dudas o divergencias no pueden borrar la conformidad sustancial del pensamiento jurídico moderno en torno a la idea de que los derechos subjetivos, aparte de sus límites legales, con frecuencia defectuosamente precisados, tienen otros de orden moral, teleológico y social, y que incurre en responsabilidad el que, obrando al amparo de una legalidad externa y de un aparente ejercicio de su derecho, traspasa, en realidad, los linderos impuestos al mismo por la equidad y buena fe, con daño para terceros o para la sociedad...".

Dicha sentencia, se señala con frecuencia, en asocio de otras más, en compañía de legislación especial preexistente (Ley española del 13 de abril de 1956, atinente a "Arrendamientos Urbanos", preservada en lo esencial por la Ley del 11 de julio de 1964), fue muy tenida en cuenta al momento de que el legislador español se ocupara de este límite funcional en el artículo $7^{\circ}$, párrafo $2^{\circ}$, del Código Civil, a cuyo tenor: "La ley no ampara el abuso del derecho o el ejercicio antisocial del mismo. Todo acto u omisión que por la intención de su autor, por su objeto o por las circunstancias en que se realice sobrepase manifiestamente los límites normales del ejercicio de un derecho, con daños para terceros, dará lugar a la correspondiente indemnización y a la adopción de las medidas judiciales o administrativas que impidan la persistencia en el abuso"93.

93 En sentencia del 23 de junio de 2000, la Corte Suprema de Justicia colombiana, por su parte, recordó que "...hace un buen número de lustros, incluso mucho antes de que expresamente lo hiciera la legislación colombiana (art. 830, C de Co.), la jurisprudencia y la doctrina patrias...admitieron que los derechos subjetivos-aún los más sagrados, no son de carácter absoluto, sino relativo, de suerte que su ejercicio está limitado, mejor condicionado -entre varios factores- por el entorno o contexto social. No en vano, todo individuo, por el sólo hecho de vivir en sociedad, tiene derechos, pero también deberes que observar, aun de cara al uso de aquéllos, lo que excluye, in radice, la arbitrariedad, su empleo abusivo... En las páginas de la historia, como vívido testimonio de una etapa superada, ha quedado tatuado el concepto meramente individualista del ejercicio de los derechos, hoy cobijados por un criterio más acorde con las exigencias del tráfico societario, muy ajenas a ese empleo-a veces- desafiante de marras, fundado en consideraciones más egoístas, propias de la interiorización de los derechos, sin contextualizarlos con los radicados en cabeza de los demás (colectividad), no por ajenos condenados a la degradación o el atropello, pues in abstracto, están situados en pie de igualdad (simetría jerárquica)". Por eso su "... desviación o distorsión, sea porque se ejerce con la fría intención de causar daño, o porque no existe un interés actual y propio, o porque se desarrolla con evidente imprudencia o negligencia, entre otros criterios más que la doctrina profusamente ha prohijado... supone necesariamente un reproche de la ley, a la vez que de los operadores jurídicos...., pues 
Es claro entonces que a la luz de la mencionada descripción ex lege, tanto el criterio de anormalidad, como el de ejercicio antisocial del derecho, aunado a la extralimitación y, aunque discutida, a la irrogación de un perjuicio, empleados por la doctrina y la jurisprudencia en el pasado, son clave de bóveda para la tipificación y virtualidad jurídica de la abusividad en cita, lo cual es refrendado plenamente por el profesor Vicente L. Montés en su estudio sobre el artículo $7^{\circ}$ del Código Civil español, al señalar que “...el centro de gravedad se sitúa para la apreciación del abuso o el ejercicio antisocial del derecho, en la idea de 'extralimitación'. Y la consecuencia de la extralimitación, con daño para tercero, es en el abuso el presupuesto de responsabilidad, como afirma el precepto que se comenta al atribuir al sujeto autor del acto el deber de indemnizar". Tal "... extralimitación la refiere el precepto a que el ejercicio sobrepase los límites 'normales' (...) Por ello (...) parece que la idea de extralimitación equivale a ejercicio 'anormal', deducido conforme a un criterio objetivo" 94 .

En este mismo sentido, enfatizando en el aspecto concerniente a la vulneración o traspaso de los límites ordinarios o normales inherentes a los derechos subjetivos, evidentemente de acentuada relevancia en esta temática en el Derecho comparado, los doctrinantes italianos Umberto BRECCIA, Lina BIGLIAZZI GeRI, Ugo NATOLI y Francesco BusnelLI, sin apartarse del criterio finalístico, resaltan que "...el comportamiento definido como abusivo no sería, más, ni menos, que la

lo que provoca la censura...es su deformación o desbordamiento, que viene a infirmar el derecho mismo".

94 Vicente L. Montés, en Comentarios a las reformas del código civil, Tecnos, Madrid, 1977, pp. 394 y 395. En este mismo sentido, prácticamente en forma literal, José Manuel MARTín BeRnAL, expresó en su monografía que "...el centro de gravedad se sitúa para la apreciación del abuso o del ejercicio antisocial del derecho, en la idea de 'extralimitación'...y es precisamente la consecuencia de la extralimitación, con daño para tercero en el abuso, el presupuesto de la responsabilidad que suponga y configure el deber de indemnizarlo". El abuso del derecho, Montecorvo, Madrid, 1982, p. 233.

En similar dirección expresa el doctrinante Carlos DE LA VEGA BenAYAs en torno al "abuso o ejercicio antisocial", que "Ambos conllevan la nota de extralimitación manifiesta de los límites normales del ejercicio de un derecho.... El abuso se concreta, se objetiva, en el exceso o traspaso manifiesto de los límites normales del ejercicio de un derecho". Teoría, aplicación y eficacia en las normas del Código Civil, Cívitas, Madrid, 1976, pp. 268 y 270. Gustavo ORDOQUI, a su vez, aludiendo a los "...presupuestos para constatar el ejercicio abusivo de un derecho", indica que uno de ellos atañe a que "El derecho subjetivo se ejerce en forma irregular, antisocial o inmoral”, en cuyo caso el "...ejercicio es ilícito pues se aparta de la buena fe, de la moral o lo socialmente admisible". El abuso de derecho, op. cit., p. 100. 
superación de los límites formales del derecho propio (...) De suerte que habría de reconocerse la presencia de un verdadero abuso cuando quiera que una actividad -no obstante presentarse aparente y exteriormente como conforme al contenido formal del derecho- no está acompañada de la congruencia sustancial del acto con los fines del derecho mismo, y sea por ello el resultado de un traspaso de los límites (incluso) internos o por el contrario una cierta clase de límites externos, todo sin perjuicio de la ilicitud del acto en todos los casos" 95 .

Finalmente, impregnado por el auge del Derecho constitucional moderno, en particular por la denominada constitucionalización del Derecho, en general, un sector autoral proclama que la esencia del abuso del derecho reside en la principialística y en la axiología inmersas en la Constitución, razón por la cual se afirma, en sede de una lectura bastante amplia, que hoy "Los criterios para caracterizar el acto abusivo deben ser los valores y principios constitucionales. Habrá ejercicio anormal, irregular o abusivo de un derecho cuando éste sea contrario a los valores y principios constitucionales: buena fe, solidaridad, etc." ${ }^{\prime 2}$.

95 Umberto Breccia, Lina Bigliazzi Geri, Ugo Natoli y Francesco Busnelli. Derecho civil. Normas, sujetos y relación jurídica, T. I, Vol. I, Universidad Externado de Colombia, Bogotá, 1992, pp. 480 y 481.

El artículo 1071 del Código Civil argentino, objeto de reforma en el año 1968, incorpora el referido criterio teleológico, así como el atinente al desbordamiento de puntuales límites, con el fin de que el acto se pueda considerar abusivo, artículo que reza, en su segundo inciso, que "La ley no ampara el ejercicio abusivo de los derechos. Se considerará tal al que contraríe los fines que aquella tuvo en mira al reconocerlos o al que exceda los límites impuestos por la buena fe, la moral y las buenas costumbres".

El artículo 281 del Código Civil griego, a su vez, impera que "El ejercicio de un derecho está prohibido si sobrepasa manifiestamente los límites impuestos por la buena fe o las buenas costumbres, o con el fin social o económico de dicho derecho". Por su parte, el artículo 334 del Código portugués, en términos similares al griego, expresa que "Es ilegítimo el ejercicio de un derecho cuando el titular excede manifiestamente los límites impuestos por la buena fe, las buenas costumbres, o por la finalidad social y económica del derecho". Y a su turno, el artículo 187 del reciente Código Civil brasilero de 2002, prescribe que" También comete acto ilícito el titular de un derecho que en su ejercicio excede manifiestamente los límites impuestos por su fin económico o social, por la buena fe y por las buenas costumbres".

96 Ernesto Rengifo García. Del abuso del derecho al abuso de la posición dominante, Universidad Externado de Colombia, Bogotá, 2002, p. 73, autor que sigue de cerca en este materia a los doctrinantes Manuel Atienza y Juan Ruiz MANero, llícitos atípicos, Madrid, Trotta, 2000, p. 34 y ss. 


\subsection{Principales diferencias}

Ahora bien, en el terreno de las disimilitudes, una vez delineados los aspectos más salientes del abuso de derecho, necesarios para una cabal escisión tipológica, se observa que las hay tanto con la regla del venire contra factum proprium, in globo, como con la figura de la doctrina de los actos propios, individualmente considerada $^{97}$, entre otras matizaciones y caracterizaciones más, sin perjuicio de que este campo de las diferencias con el abuso del derecho, como se anotó, es un campo minado, pues al momento de concretarlas la tarea realmente no es tan simple como pareciera, pues al rompe, cuando se habla de si en realidad son idénticas - 0 análogas- la respuesta inmediata que de nosotros aflora, de ordinario, es que son distintas, así estén coloreadas por la buena fe, respuesta que brota, en general, de la idea en blanco y negro que tenemos de una y de otras y hasta del propio olfato jurídico, de ese 'ojo clínico' que, guardadas las proporciones, se le atribuye a los profesionales de la medicina y que podríamos extender a los abogados para los efectos en referencia. Obviamente, empero, hay quienes las asimilan y otros que las confunden ${ }^{98}$.

El problema se patentiza entonces al momento de concretar las disimilitudes, porque en concreto ya no son tan robustas, ni tan numerosas, toda vez que en la medida en que uno trata de asentarlas, algunas que en apariencia eran más claras se difuminan o por lo menos se mimetizan; en ese tránsito de la mente al papel, efectivamente, se pierde contundencia y especificidad, sin que se menoscabe la convicción, a lo que se agrega la dificultad naciente del tratamiento

${ }_{97}$ Cfr. Mariana Bernal Fandiño. El deber de coherencia en el derecho colombiano de los contratos. op. cit., p. 179.

98 Vid. Fausto CAGGIA. Fecondazione eterologa e azione di disconoscimento di paternitá intentatata del marito: un'ipotesi di abuso del diritto, autor que expresa que "el venire contra factum proprium... constituye una hipótesis de abuso del derecho...", op. cit., p. 36. Véase a Gianluca FALCO, quien hace la misma referencia y remisión. La buona fede e l'abuso del diritto, op. cit., p. 207. En este mismo sentido, el doctrinante portugués Paulo MotTA PINTO, nos recuerda que "En la doctrina portuguesa, la prohibición del venire contra factum proprium suele ubicarse en el ámbito del abuso del derecho", en atención a que “...el instrumento con mayor virtualidad para fundamentar legalmente la prohibición del venire contra factum proprium es el instituto del abuso del derecho consagrado en el artículo 334 del Código Civil". Sobre a proibiçao do comportamento contraditório (venire contra factum proprium) no direito civil, op. cit., pp. 291 y 312. Cfr. A. Menezes Cordeiro, Da boa fé no direito civil, op. cit., p. 742 y ss. 
heterogéneo conferido al abuso del derecho por algún sector doctrinal, en atención a que hay múltiples criterios virtualmente tipificadores de variada casta, no todos pertinentes, es cierto, y también un afán envolvente, el que se hace evidente en el deseo de que el abuso todo lo abarque, sobre todo a partir de concepciones neoconstitucionales.

Una de ellas, quizá sobresaliente, sin embargo, se impone a partir de la catalogación subjetiva del abuso del derecho, tesitura de índole más clásica en el Derecho comparado, encaminada a resaltar que hay abuso del derecho, en su concepción más arraigada, en tanto en cuanto medie intención de afectar intereses ajenos, por manera que si esta intentio asimilada a un animus nocendi no hace presencia o no existe, no se configurará y, por tanto, no se entenderá aplicable por ausencia de uno de sus presupuestos genéticos, en esta lectura uno de los de mayor prosapia, al que luego se le agregó, a manera de matización, la exigencia de la falta de un interés individual ${ }^{99}$, aun cuando en el fondo, en opinión de un sector autoral, esta ausencia de interés denota cierto grado de intencionalidad. Tan relevante fue en su momento dicha intencionalidad, que se consideró "... la pieza maestra del sistema"100.

99 Vid. José Luís PARdo López. "El uso, abuso y no uso de los derechos subjetivos", en Revista de Derecho Privado, T. XLVIII, Madrid, 1964, p. 9, autor que expresa que en la teoría subjetiva "Se dice que hay abuso del derecho cuando se ejercita... con la intención de dañar y sin verdadero interés individual para ejercitarlo". Otro tanto, en lo pertinente, había puesto de relieve el doctrinante Juan B. JORDANO BAREA, en cuyo parecer, para que se consolide el abuso, adicionalmente se exige que medie "Inmoralidad o antisocialidad de ese daño, manifestada en forma subjetiva (cuando el derecho se actúa con la intención de perjudicar o, sencillamente, sin un fin serio y legítimo". "Dictamen sobre abuso de derecho y fraude a la ley", en Anuario de Derecho Civil, Madrid, p. 962. A juicio de René Demogue, el referido interés debía ser "...serio y lícito", en cuyo caso, de verificarse su presencia, la actuación no era constitutiva de un abuso de derecho. Traité des obligations en général, T. IV, Paris, Librairie Arthur Rousseau, p. 682.

Ya en su momento, el profesor G. RIPERT, en su célebre obra La régle morale dans les obligations civiles, con ocasión del estudio de los "Actos ejecutados con la intención de perjudicar", puntualizó que, "Para encontrar hipótesis reales de abuso del derecho, es necesario que el acto ejecutado sea en sí mismo irreprochable. Inscrito en el ejercicio normal y habitual del derecho, el sería admitido indubitablemente si no estuviera viciado por el espíritu que lo inspira. Ese espíritu de maldad se descubre fácilmente por el resultado del acto.... La inutilidad del acto, si ella no proviene de un error de cálculo, evidencia que la maldad era la única razón de la acción", L.G.D.J, Paris, 1949, p. 171.

100 Jacqueline Marson, L'abus de droit, Librairie Arthur Rousseau, Paris, 1935, p. 140. 
Como lo memora la profesora María del Carmen Gete Alonso, "A tenor de la concepción subjetiva el elemento generador y delimitador del abuso del derecho viene fijado por la intención del sujeto que lo ejercita. Es la intención de dañar, sin obtener con el ejercicio un beneficio propio, su fundamento"101, intención de dañar que, de acuerdo con el doctrinante L. JosserAND, “... representa, tradicionalmente, la forma típica, el alimento normal del abuso de los derechos. Esta función del concepto del abuso es de tal manera importante y necesaria", continua el profesor francés que tanta atención le brindó a esta temática, "... que algunos autores le han atribuido un valor exclusivo, viendo en la intención de dañar, más o menos ampliamente comprendida, el único criterio, el único síntoma enunciador y constitutivo del abuso"102.

En cambio, según tendremos oportunidad de acreditar a espacio, este requerimiento de tipo subjetivo, por cierto de difícil o ímproba acreditación sistemática, no es demandado en la doctrina de los actos propios, en donde se toma en cuenta, en lo cardinal, es la floración de la contradicción o incoherencia, acompañada de la lesión de la confianza legítima otrora suscitada, pero no la

101 María del Carmen Gete Alonso. "Comentarios al Código Civil y Compilaciones Forales, Artículo 7", Editorial Revista de Derecho Privado, T. I, Vol. 1, Madrid, 1992, p. 904.

Por su parte, los autores Georges RIPERT y Jean BOULANGER, luego de haber realizado críticas a esta institución, y de haber realzado la confusión que alrededor de ella suele existir, manifestaron, a modo de colofón, que "La intención de dañar no puede ser tolerada en la sociedad. La jurisprudencia hace frecuentes aplicaciones de esta idea y es en este caso en que se debe hablar verdaderamente de abuso de derecho". Tratado de derecho civil-según el Tratado de Planiol-, T. I, Parte general, La Ley, Buenos Aires, 1963, p. 477.

En sentencia del Tribunal Supremo español del 27 de octubre de 1964, efectivamente, se realzó que en esta materia "...lo único que hay que tener en cuenta es si la parte actora ha procedido con intención de dañar, traspasando los límites de la moral y de la equidad".

102 Louis JosserAnd. El espíritu de los derechos y su relatividad, op. cit., p. 289, mención que el autor contrasta con la afirmación según la cual no se puede "...considerar la intención de dañar como un bloque indivisible", lo que justifica que, en su entender, si bien la "...falta de interés legítimo", es el "...criterio que ha encontrado una acogida más favorable en la doctrina y ante los autores más eminentes...", el último y verdadero criterio del abuso, es el que deriva del desvío del derecho, con relación a su función social, ya sea económica o moral, egoísta o desinteresada". Por todo ello cree que la "...la teoría del abuso...es a la vez subjetiva y objetiva según el ángulo desde el cual se considere" (Op. cit., pp. 295, 306 y 325), y que por tanto el "...criterio puramente intencional tiende a ser sustituido por un criterio funcional, obtenido del espíritu del derecho, de la función que le es atribuida", anotación esta última plasmada en otro ensayo de su autoría. Relativité et abus des droits, op. cit., p. 74. 
intención de dañar, más allá de que exista en un momento determinado, aunque no a manera de presupuesto sine qua non, puesto que puede o no mediar, sin que por ello deje de ser aplicable, en línea de principio rector, el venire contra factum. Es pues objetiva, por excelencia, pues la mira está puesta en el corolario obtenido: la sorpresa o desazón producido a raíz de la contradicción o incoherencia comportamentales, ya mencionadas.

Desde esta perspectiva, la subjetividad estaría presente en el abuso, a modo de "alimento natural", y ausente en los actos propios, o por lo menos no sería de forzosa cabida, ya que en estos campea una visión medularmente objetiva, como es de usanza por parte de la doctrina y jurisprudencia comparadas ${ }^{103}$.

Con todo, hay que poner de manifiesto que la visión subjetiva en mención, por restrictiva, en forma apreciable, ha sido blanco de críticas y severas recriminaciones, pues se ha dicho que no está en consonancia con la esencia del abuso del derecho y menos con su finalidad de servir de remedio o límite al ejercicio disfuncional o antisocial de los derechos, entre otras observaciones. Además, se ha subrayado la dificultad de escrutar conciencias, tarea para nada exenta de acentuada dificultad. Por ello “... pretender que la intención de dañar sea el criterio único determinante de la concepción del abuso del derecho, claramente lo ha subrayado el estudioso profesor colombiano Jorge SANTOS Ballesteros, “... no representa otra cosa que una precaución sostenida por aquellos que sienten hacia los denominados derechos del hombre una adoración absoluta y que ven en las prerrogativas limitadas una injerencia del orden social que atenta contra la seguridad jurídica (...) la intención de dañar no es el único móvil que orienta la voluntad humana (...) y que puede comprometer la responsabilidad civil de una persona"104.

103 En esta orilla conceptual, la Dra. Laura GutIERREZ-MASSON, se permite “...sugerir la posible frontera entre el acto propio y otra figura arraigada en el principio de la buena fe cual es el abuso del derecho, que implica siempre el ejercicio de un derecho con la única finalidad de perjudicar a otro". Actos propios y buena fe, en torno a Papiniano 3 Quaestionum D. 50, 17, 25, op. cit., p. 275.

104 Jorge Santos Ballesteros. Instituciones de responsabilidad civil, Universidad Javeriana, Bogotá, 2006, p. 72. 
Probablemente por ello legislaciones como la española, al instante de ocuparse de las coordenadas llamadas a informar "... el ejercicio abusivo del derecho o el ejercicio antisocial del mismo", estima que son tres: a) "la intención de su autor", b) "por su objeto", y c) "por las circunstancias en que se realice" (art. 7, Código Civil), concepción que en opinión de Don Manuel ALBALADEJO G ${ }^{105}$, significa que "...el Código civil ha venido a recoger la (...) orientación jurisprudencial que admitía tanto el criterio subjetivo como el objetivo para configurar el abuso", actitud ésta llamada por algunos "ecléctica", de algún modo delineada por el profesor JOSSERAND, como se indicón ${ }^{106}$.

De esta manera, si bien es cierto que la anunciada intención no es hoy el eje de la institución, como antes lo era, tampoco es menos cierto que es uno de los diversos detonantes del abuso, realmente significativo, de tal suerte que tampoco puede soslayarse in toto su incidencia potencial, así medien otros criterios, igualmente relevantes.

Otra de las diferencias reinantes entre una y otra figura, se centra en el concepto de normalidad, a la vez que en el de extralimitación, precedentemente esbozados, los cuales, como se apreció, son neurálgicos en sede del abuso de derecho. Sin anormalidad, entendida como lo hace claramente Don Ricardo DE ÁNGEL, “... en el sentido de un ejercicio contrario al 'destino económico-social del derecho subjetivo', deduciéndolo del espíritu de la institución”, no puede hablarse propiamente de tal. De hecho, desde comienzos de la centuria anterior, se está hablando del "... carácter anormal del acto ejecutado" respecto al abuso del derecho, como lo memora RIPERT ${ }^{107}$.

105 Manuel Albaladejo García. Derecho civil. Introducción y parte general, T. I, op. cit., p. 40.

106 María del Carmen Gete Alonso. Comentarios al Código Civil, op. cit., p. 906. Vid. Gustavo ORDOQUI, quien de la mano de JosserAND, opina que, "En realidad, no existe oposición entre los subjetivistas y objetivistas, sino que son enfoques que perfectamente se pueden complementar". El abuso de derecho, op. cit., p. 62. En esta dirección, el doctrinante colombiano Jorge Suescún Melo, observa que"...el titular de un derecho puede, con torcida intención o sin ella, ejercitarlo de manera excesiva, inoportuna o innecesaria, desviando así su finalidad última, con lo cual incurre, en todos esos eventos, en típico ejercicio abusivo de ese derecho". Derecho privado, Estudios de derecho civil y comercial contemporáneo, T. II, Legis, Bogotá, 2003, p. 239.

107 Georges RIPERT. La régle morale dans les obligations civiles, op. cit., p. 139. 
Lo mismo tiene lugar en punto a la referida extralimitación o desbordamiento, habida cuenta que si no se sobrepasan ciertos límites, en puridad, no se entenderá configurado ningún abuso, pues no se habrán alterado las pautas de la normalidad, o de la regularidad y, por lo tanto, no podrá pretextarse que el ejercicio del derecho sobrepasó un "... determinado círculo"108.

En cambio, en la doctrina de los actos propios, esencialmente objetiva, lo que se toma en consideración, primordialmente, es la floración de una conducta contraria a otra asumida con antelación -contradicción comportamental-, que en su momento, por su fuerza intrínseca, despertó cierto grado de confianza legítima en otro sujeto, en el ámbito contractual, específicamente en el cocontratante u otro extremo de la relación negocial. De ahí que, en estrictez, cuando se alude al factum proprium, no sea menester hacer hincapié en los elementos definitorios del abuso ya examinados: anormalidad y extralimitación, en lo fundamental, puesto que allí hay que apropiarse de otro lenguaje más específico y preciso, amén de técnico: la contradicción, la incoherencia, la incongruencia comportamentales, la sorpresa, el desconcierto, la erosión de la confianza inculcada, etc. Es más, el bien jurídico tutelado en ambos supuestos (venire y abuso) no es simétrico; obsérvese que en tratándose de los actos propios este está determinado básicamente por la citada confianza, y para otros en la apariencia, en la coherencia, en la seguridad jurídica o en la misma razonabilidad, aspectos que, de manera directa y, de suyo frontal, no ocupan el mismo papel en el iter abusivo, o por lo menos, en gracia de discusión, no en forma preferente o absorbente.

De hecho, cuando se piensa en anormalidad, y en extralimitación, es porque de algún modo es menester hacer una especie de examen topográfico -o anatómico-, en guarda de precisar la exacta ubicación comportamental, para saber si el ejercicio del Derecho se acompasó con los límites existentes o los sobrepasó -o desplazó, conforme lo pone de presente el artículo $7^{\circ}$ del Código Civil español ya mencionado, numeral segundo, según el cual habrá indemnización cuando el acto u omisión "...sobrepase manifiestamente los límites normales del ejercicio de un derecho", entre otros regímenes jurídicos más (Portugal, Grecia, Argentina,

$\overline{108}$ René SAVATIER. Traité de la responsabilité civile, L.G.D.J, Paris, T. I, 1939, p. 52. 
Brasil, etc. $)^{109}$, auscultación que no resulta forzosa en la doctrina de los actos propios, en la que se evalúa si medió o no incoherencia o contradicción, indagación que está sujeta a un escrutinio diverso y, sobre todo, llamada a investigar objetivos bien diferentes.

Dicho de otro modo, en los actos propios no se efectúa un juicio de desplazamiento ostensible de cara al ejercicio en comento, pues el escrutinio se hace en función de aspectos harto diversos, como se anotó: la contradicción, la incoherencia, la irrazonabilidad, etc. Además, en esta doctrina no cabe hablar con propiedad y en el más estricto sentido de típicos grados: contradicción o incoherencia manifiesta, así obviamente deban existir; si son relevantes e influyentes, que es otra cosa, será menester aplicar los correctivos de rigor, por cuanto a diferencia del abuso, en donde tiene cabida cierto margen de tolerancia o permisividad, por regla el ordenamiento jurídico es refractario a la sorpresa, a la falta de coherencia y a la contradicción. De ahí que, en puridad, se evalúe si la hubo o no, lo que explica su acendrada objetividad, ajena a los juicios de normalidad, tolerancia, exceso, etc.

Otro tanto, en el plano de las disimilitudes centrales, conviene subrayar en punto a la temática atinente a la finalidad, vale decir a la lectura teleológica del ejercicio de los derechos, pues sabido es que, de ordinario, se suele hacer hincapié en la finalidad del acto, en orden a que cuando ella se desdibuja o desatiende, podrá hablarse válidamente de abusividad, habida cuenta que como lo recalca el profesor Ricardo De ÁNGEL, “....incurre en abuso del derecho el titular del mismo que lo ejercita de forma contraria a su finalidad" ${ }^{\prime 10}$.

En el acto propio, por lo menos de manera frontal, el foco es otro: la confianza quebrantada o mancillada, sin necesidad, a priori, de examinar si hubo apartamiento, desviación o distorsión de la finalidad en mención, así la haya habido, colateralmente. La mira, en realidad, está puesta en otra parte. En el

109 En la sentencia del 23 de junio de 2000, la Corte Suprema de Justicia colombiana, sintonizada con estas ideas, señaló del abuso del derecho que lo que provoca su "... censura, ora legal, ora judicial, es su deformación o desbordamiento".

110 Ricardo De Ángel Yáguëz. Abuso del derecho, op. cit., p. 43. 
acto propio hay una inescindible vinculación con el pasado, así sea reciente, in concreto, con lo creado y recreado en cabeza del cocontratante (factum proprium); en el abuso no, por lo menos de modo forzoso. Aquí no se propende por respetar una situación ex ante, v.gr: el reconocimiento de un determinado derecho; no es pues la sorpresa o el desconcierto lo que suscita la reacción del derecho: es su ejercicio en contravía de su finalidad genuina, entre otras exigencias lo que amerita censura y, de paso, su procedencia o aplicación.

Tiene entonces razón el Dr. Dimitri HoutCIEFF, cuando afirma en torno a la diferenciación con el abuso del derecho, que "El principio de coherencia, y el deber que de él deriva, se distinguen netamente del abuso del derecho....el examen de la jurisprudencia ha mostrado que el juez se contenta con un examen del comportamiento del acreedor, sin que sea necesario recurrir a la sicología del deudor....No se trata aquí de demostrar que el derecho ha sido ejercido contrariamente a su fin, o con la intención de perjudicar al deudor, pero sí de estigmatizar una incoherencia en el comportamiento del acreedor. La sola demostración de esta contradicción, si ella ha inducido una modificación perjudicial de la posición jurídica del deudor, permitirá la aplicación del principio de la coherencia”"111.

¿Será pues que el juicio de contradicción o coherencia, per se, es suficiente para poder responder sin hesitación si hubo o no un abuso de derecho; si la línea de la normalidad en realidad se alteró o superó "...manifiestamente", o si la finalidad del acto se desatendió? Seguramente no, más allá de uno que otro elemento común, lo que altera la base autonómica y tipológica, desde luego en el entendido de que se adopte una idea precisa y acotada del abuso del derecho, pues si se aboga por una lectura absorbente y totalitaria, nos preguntamos, ¿qué no quedaría bajo su dominio? Ello sería tanto como auspiciar el fenecimiento de numerosas y útiles figuras, práctica funeraria que no puede contar con nuestro concurso, ni aceptación. Muy por el contrario, cuenta con nuestro indeclinable y consciente rechazo, pues del abuso no se puede abusar, conforme se anotó en los prolegómenos de este aparte o numeral, por más que se le considere principio general de derecho, o 'concepto válvula', o cláusula general, o se le asignen propiedades elásticas; ni aun siendo de látex sería dable fomentar su

111 Dimitri Houtcleff. Le principe de cohérence en matiére contractuelle, op. cit., pp. 712 y 713. 
omnipresencia y su generalidad, en guarda de abogar por el marchitamiento de otros institutos dignos de preservación, así pareciere más cómodo buscar categorías únicas, aunque en el camino quedaren tendidos los cadáveres de figuras como el acto propio, o su regla matriz (venire contra factum proprium).

Semejante 'genocidio', por más que sea avalado por audaces y aparentemente novísimas doctrinas, no puede quedar incólume e impune. Al fin y al cabo, acudiendo a una expresión de la ciencia médica, preferimos estar a la 'penúltima moda', a lo que se agrega que nos inclinamos por la ortodoxia y no por la heterodoxia cruda y de ocasión.

Lo anterior no se opone, en línea de principio rector, a que el abuso del derecho, de una u otra manera, atendidas las sapientes circunstancias del caso, pueda conjugarse con los elementos prototípicos del factum proprium, en cuyo caso la confianza legítima otrora suscitada en un cocontratante o sujeto de derecho, en general, puede verse quebrantada por diversas disfunciones, una de ellas el acto abusivo. Expresado en otras palabras, es probable que respecto a precisas hipótesis, la concebida confianza pueda verse eclipsada por la combinación de diversas conductas irregulares y lesivas, incluida la abusividad conductual, de tal suerte que en el resultado final el abuso del derecho tenga clara incidencia causal, situación muy diferente a la precedentemente planteada, dado que en este último supuesto se respetarían ambas arquitecturas: la del abuso en comento, y la del acto propio, sin que mediara absorción o marchitamiento alguno. Es lo que sucede, por vía de ejemplificación, con el instituto del retraso desleal (o verwirkung, para otros), tal y como se analizará en su lugar.

Obsérvese pues como una y otra institución (el abuso del derecho y el acto propio), dueñas de una anatomía y una teleología no propiamente gemelas, se estructuran con arreglo a elementos individuales, así ambas se inscriban en una misma categoría, esto es en la de los límites del ejercicio de los derechos subjetivos, a lo que adiciona la clara incidencia que en ambas ejerce la buena fe, lo cual no altera su identidad, pero tampoco borra sus distancias ${ }^{112}$.

112 Tiene razón la Dra. Clara I. Assua GonzÁLEz, cuando afirma “...que mientras todos los casos resueltos por nuestra jurisprudencia como de abuso de derecho son de contravención del 
En síntesis, si bien es cierto que el abuso del derecho y el acto propio comulgan con ciertos elementos comunes, y que persiguen erradicar conductas indeseadas o lesivas de caros intereses, dignos de tutela y salvaguarda jurídica, tampoco es menos cierto que militan puntuales divergencias que aconsejan el respeto de su individualidad y, si se quiere, de su personalidad y corporalidad, figuradamente entendidas, justamente por hacer énfasis y acento en puntos cardinales distintos, y en zonas autonómicas especiales. Ello explica que apunten a lugares disímiles, así estén hermanadas por un denominador común: ser una y otra limitaciones al ejercicio de los derechos subjetivos, se reitera, aun cuando no se nos escapa que, para algunos, el abuso del derecho se enseñorea sistemáticamente en la regla venire contra factum proprium, la que estiman que es una modalidad especial de abusividad, o una concreción suya, tesis que, aun cuando respetable, no cuenta con nuestra adhesión, por lo manifestado con antelación. Sin embargo, desde la perspectiva sub examine, aun siendo así, sólo en gracia de discusión, es de destacar que en tal supuesto conservan su entidad y no se fusionan o confunden, aunque el abuso del derecho sirva para explicar la prohibición del venire contra factum proprium ${ }^{113}$.

No se altera lo aseverado en líneas anteriores, finalmente, por el hecho de que se acuda al abuso del derecho para tratar de encontrar abrigo para el acto propio, en aquellos países que, expresamente, lo han consagrado en su legislación e, incluso, en su Constitución. Si bien resulta comprensible que para dotar de mayor solidez, firmeza y seguridad jurídica a la doctrina de los actos propios se recurra a tal expediente, tampoco es menos cierto que dicho proceder es técnicamente impropio, por lo ya analizado, e innecesario, además, como quiera que es en la buena fe, como lo examinamos a espacio, en donde ella encuentra su manantial genuino, en cuyo caso sobra tal procedimiento, para nada plausible y menos técnico u ortodoxo. Por ello es por lo que en nuestro entender, ni aun existiendo

imperativo de buena fe, algún grupo de supuestos de vulneración de la buena fe (actos propios que no impliquen retraso desleal) encaja peor en los perfiles de una conducta abusiva", a lo que agrega que "...en una ordenación lógica de la cuestión, el abuso de derecho cuando menos habría de considerarse un subgrupo dentro de los supuestos de vulneración de la buena fe en el ejercicio de los derechos". "Comentario, artículo 7", op. cit., pp. 90 y 91.

113 Vid. Paulo Mota PInTo. Sobra a proibiçao do comportamento contraditório (Venire contra factum proprium) no direito civil, op. cit., pp. 313 y ss. 
norma explícita en torno al abuso del derecho, per se, es conveniente engastar la doctrina del venire contra factum proprium -ni ninguna de sus modalidades-, en la figura del abuso, ora de origen legal, o constitucional, como tiene lugar en Colombia (art. 95, Constitución Política de 1991), así medie la mencionada inclinación, entre otras razones porque la buena fe, a su vez, es también de estirpe constitucional, amén de general en el Derecho colombiano (art. 83, Constitución Política).

\subsection{OtRAS DIFERENCIAS PUNTUALES DE ORIGEN JURISPRUDENCIAL Y DOCTRINAL}

Otras diferencias, por de pronto menos universales y algunas más polémicas, dicen relación con ciertos aspectos que, con arreglo a diversas tendencias y tesis, se suman a la defensa de la identidad del venire contra factum proprium, y con él, claro está, la de la doctrina de los actos propios, más allá de que campee la unanimidad o la plena aceptación e, incluso, la conformidad del lector, como quiera que, independiente de ello, las citamos para mayor abundamiento e información, en forma muy sucinta, entre otras razones, por cuanto de ellas nos hemos ocupado más en detalle, en el lugar pertinente (Cap. III). Por lo tanto, cumple un examen más descriptivo, que detallado.

\subsubsection{Procedencia de oficio}

En efecto, un sector defiende la idea de que el abuso debe ser alegado expresamente, al paso que ello no tiene lugar en tratándose de la doctrina de los actos propios, signados por la posibilidad de que, ex officio, la autoridad competente se pronuncie y, por ende, decida aplicarla, con total independencia de que haya o no mediado petición de parte o de interesado en su pronunciamiento. En este sentido el autor Francisco RIVERo HERNÁNDEZ, precisa que en relación con el abuso del derecho hay “...necesidad de alegación de parte”, fundándose en una sentencia del Tribunal Supremo español, del 31 de marzo de 1981, reiterada el 14 de julio de 1984, a cuyo tenor: "el abuso del derecho, por no pertenecer al ámbito de los actos contrarios a las normas, sino al ejercicio de los derechos, en armonía con sus límites, y el principio de buena es materia dispositiva que procesalmente ha de actuarse bien como excepción y remedio al perjuicio que se cause en materias no reguladas por otras normas..., por lo que debe ser actuada 
por la parte y manifestarse y revelarse de modo patente y claro/S. 29 nov. 1969) según el principio de contradicción y audiatur et altera pars" 114.

Empero, en punto tocante con la doctrina de los actos propios, aun cuando del tema nos ocuparemos con mayor amplitud, digamos abreviadamente que la tesis predominante es aquella que reclama su aplicación de oficio, a la que adherimos. En esta dirección, entre varios, don Luís Dízz-PICAZo, luego de indagar si “Puede el carácter contradictorio de una pretensión ser tenido en cuenta de oficio por el juez como ratio decidendi del litigio, o es preciso que haya sido previamente alegado por la parte?", concluye aseverando, se recuerda, que "...solicitada por el demandado la desestimación de la pretensión, cualquiera que haya sido el fundamento invocado, el juez puede, de oficio, fundar esta desestimación en el carácter contradictorio de la demanda, aunque este problema no haya sido abordado por las partes"115.

\subsubsection{Caracterización como principio general}

De igual modo, la communis opinio se inclina por asignarle al abuso del derecho el carácter de principio general de la ciencia jurídica, mientras que un grupo autoral, en el cual nos incluimos sin reservas, estima que ni el venire contra factum proprium, ni el acto propio, como una de sus manifestaciones particulares, en rigor, reviste dicha calidad, justamente por su arraigada excepcionalidad, de una parte y, de la otra, por su indiscutida condición residual o subsidiaria, hecho que exige prudencia y suma cautela en su aplicación, ajena a la generalidad.

El profesor Carlos LASARTE A., ad exemplum, expresa que en realidad “...la prohibición del abuso del derecho constituye un principio general del Derecho que

114 Francisco Rivero Hernández. Comentarios al Código Civil, op. cit., p. 243. En contra, Antonio Menezes Cordero. Tratado de direito civil portugués. Parte general, T. I, Almedina, 2000, p. 247.

115 Luís Díez-Picazo. La doctrina de los propios actos, op. cit., pp. 250 y 251. En contra, o por lo menos afirmando que "...resulta difícil -o a lo sumo arriesgado- afirmar tajantemente que el juez puede aplicar de oficio la doctrina de los actos propios", se expresa la Dra. M. Nélida TUR FAÚNDEZ. La prohibición de ir contra los actos propios y el retraso desleal, op. cit., p. 55. 
(...) tiene capacidad expansiva en el conjunto del ordenamiento jurídico. Por tanto, queda claro que la ilegitimidad del abuso del derecho tiene carácter general..."116

Por su parte, el profesor Manuel De La Puente y Lavalle, entre otros autores más, como se expresará en su oportunidad, es enfático al señalar que "Dicen algunos que se trata de un principio general de derecho, o sea principios determinados por la abstracción de las normas que componen el derecho positivo (...) Parece difícil conceder a la doctrina de los actos propios la naturaleza de principio general de derecho"117.

\subsubsection{La equidad como fundamento cardinal}

Aun cuando la equidad, de antiguo, tiene reservado en el Derecho un sitial preferencial, hasta el punto de que sirve de apoyatura para sostener y darle soporte a un apreciable número de instituciones y figuras de estirpe jurídica (Derecho público y privado), lo cierto es que la jurisprudencia ha recurrido a ella, recta via, a fin de explicar y fundamentar el abuso del derecho, pero no en forma agregada, corroborante o complementaria, sino directa y principal, amén de autónoma.

Es así como el Tribuna Supremo español, en diversas ocasiones, ha abrevado en la equidad para los fines señalados, particularmente en sentencia del 22 de octubre de 1988, cuando indicó que "....siendo el abuso de derecho una institución de equidad para la salvaguardia de los intereses que todavía no alcanzaron protección jurídica, se precisa para su estimación...." Otro tanto aconteció, sólo para traer a colación un pronunciamiento más, con la sentencia del 11 de mayo de 1990, en la que se sentenció que "...el abuso del derecho, como ponen de manifiesto, entre otras, las Ss. De 28 de dic. 1967 y 5 junio 1972, tiene su causa fundamentadora en la equidad para la salvaguardia de los intereses que todavía

116 Carlos Lasarte Álvarez. Principios de derecho civil, op. cit., p. 167. Cfr. Gustavo Ordoqui, al indicar que "...el abuso de derecho no sólo es un principio general del derecho sino que responde a una 'Teoría General del Derecho' y no a materias o sectores del derecho aislados". El abuso de derecho, op. cit., p. 78.

117 Manuel De La Puente y Lavalle. La doctrina de los actos propios, en Estudios de derecho civil, op. cit., p. 354. Cfr. María del Carmen Gete Alonso. "Comentarios al Código Civil y Compilaciones Forales, Artículo 7", op. cit., p. 895. 
no alcanzan protección jurídica como derivada de un mandato legal destinado a los órganos jurisdiccionales...".

Ahora bien, tratándose de los actos propios, no sería de recibo erradicar o desvincular de plano a la equidad, pues no se nos escapa que, a la postre, dado su amplio espectro y su genuino sentido, todo o prácticamente todo lo cobija, incluida la esfera contractual. No en vano, desde tiempos inmemoriales, ella ha ejercido un papel protagónico, y aún lo sigue cumpliendo, no obstante la dificultad que en oportunidades existe para precisar su concepto y su alcance, no siempre muy concreto, sino inespecífico y hasta volátil, que no intrascendente o anodino; todo lo contrario. Por eso, antes que propender por su inaplicación a la doctrina que nos ocupa, lo cierto es que en el campo de su fundamentación, otros fundamentos lucen más aplicables, justamente por revelar mejor la quintaesencia del factum proprium. Nos referimos, prevalentemente, a la coherencia, eje del acto propio, y de su matriz, la regla venire contra factum proprium, todo sin perjuicio del rol decisivo que ocupan la confianza, la seguridad jurídica, la buena fe, en general, entre otros.

En suma, sin soslayar la relevancia de la equidad en esta y en otras materias más, no parece entonces muy preciso asignarle el calificativo de 'causa fundamentadora' al acto propio, como lo hizo expresamente el Tribunal Supremo respecto al abuso del derecho, que es justamente el aspecto que queremos resaltar; nada más.

\subsubsection{Asignación de específicos efectos y prerrogativas}

Como se ha señalado, el ámbito del abuso del derecho es muy amplio, pues ha dejado de ser estudiado con fruición única o preferentemente en el campo de la responsabilidad civil -o del Derecho de daños-, con el propósito de examinarlo desde una perspectiva más dilatada, de tal suerte que en la hora de ahora, sin discusión, trasciende el Derecho privado, en concreto la referida responsabilidad, para anidarse en todas las disciplinas, o en la mayoría de ellas. Por eso, además de calificarse por muchos como principio general, según se observó, concepción que podría ser objeto de discusión, se estima que es "...un tema propio de la teoría general del derecho y más específicamente, de los principios generales del 
derecho en la medida en que el ejercicio abusivo está relacionado con los límites internos de los derechos subjetivos y esto es propia y precisamente objeto de delimitación por parte de los principios que informan un ordenamiento jurídico"”118.

No obstante lo anterior, es diáfano que tal abuso sigue teniendo importancia en la responsabilidad civil, en atención a la posibilidad de que un daño sea corolario o consecuencia directa del mismo (ejercicio abusivo), con total prescindencia de que concurran la culpa o el dolo ${ }^{119}$, en cuyo caso será menester compensarlo o repararlo, dejando a salvo otras opciones, en atención a que ella conserva "... su genuina finalidad reparadora”, como muy bien lo ha expresado el profesor LLAMAS Ромво $^{120}$, sin desconocer la singular valía que actualmente $-\mathrm{y}$ en buena horatiene la prevención, rectamente entendida y proyectada. Por eso legisladores como el español, con toda precisión, expresan que "La ley no ampara el abuso del derecho o el ejercicio antisocial del mismo. Todo acto u omisión (...) que sobrepase manifiestamente los límites normales del ejercicio de un derecho, con daño para tercero, dará lugar a la correspondiente indemnización ..." (art. $7^{\circ}$,

118 Ernesto Rengifo G. Del abuso del derecho al abuso de la posición dominante, op. cit., p. 59. Cfr. Atilio Anibal Alterini y Roberto M. López Cabana. Abuso del derecho, op. cit., pp. 33 y 34 , quienes expresan que "Con independencia de un acogimiento por las leyes la teoría del abuso del derecho tiene vigencia generalizada....En la doctrina moderna, la significación asignable a la teoría del abuso del derecho ha ido creciendo. Tradicionalmente ha sido analizada como un aspecto de la responsabilidad civil, pero esa concepción estrecha viene siendo ensanchada. El ejercicio abusivo concierne a los límites internos de los derechos subjetivos, y la determinación de ese perímetro atañe a los 'principios generales' o aún al 'espíritu del sistema jurídico' por lo cual en la actualidad se le considera -con razón- un tema propio de la teoría general del derecho". Cfr. Ludwig ENNECCERUs, al manifestar que "La prohibición del abuso se refiere a los derechos de toda clase y, por regla general, incluso a aquellos que se basan en otras leyes que no son el C.C., pues no cabe suponer que esas leyes pretenden excluir un principio general que tiene un fundamento moral". Derecho civil. Parte general, Vol. II, Bosch, Barcelona, p. 1082.

119 Vid. Jorge MoSSET ITURRASPE, distinguido profesor que señala que el criterio para determinar cuando un acto luce abusivo, "... atiende a los resultados, a las consecuencias, y prescinde entonces de factores subjetivos: culpa y dolo". Responsabilidad por daños, T. IV, RubinzalCulzoni, Santa Fé, 1999, p. 129. Ya en el año 1944, en sentencia del 19 de octubre la Corte Suprema de Justicia colombiana expresó que "...la falta imputable a título de dolo o culpa grave no es un elemento indispensable para la adecuada caracterización del abuso del derecho".

120 -Eugenio Llamas Pombo. "La tutela inhibitoria del daño (la otra manifestación del derecho de daños)", en La responsabilidad profesional patrimonial y el seguro de la responsabilidad civil, Asociación Colombiana de Derecho de Seguros, ACOLDESE, Bogotá, 2005, p. 432. Cfr. Ricardo De Ángel YAGÜEZ. Algunas previsiones sobre el futuro de la responsabilidad civil (Con especial referencia a la reparación del daño), Civitas, Madrid, 1996, pp. 230 y ss. 
C.C.), o como el colombiano, el que en el artículo 830 del Código de Comercio del año 1971 dispone que "El que abuse de sus derechos estará obligado a indemnizar los perjuicios que cause", o el peruano, puesto que en el artículo 924 del Código Civil de 1984, ordena que "Aquél que sufre o está amenazado de un daño porque otro se excede o abusa en el ejercicio de un derecho, puede exigir que se restituya al estado anterior o que se adopten las medidas del caso, sin perjuicio de la indemnización por los daños irrogados".

En este orden de ideas, se tiene establecido que el ejercicio abusivo de un derecho tiene claras connotaciones en sede indemnizatoria, por traducirse en un criterio de atribución de responsabilidad, en sentido amplio, dado que como lo recuerda Luis Martínez CalcerRada, "La responsabilidad del ejerciente abusivo, lleva consigo la reparación del daño causado mediante la consiguiente indemnización. Es, pues, el efecto normal que la ley establece a toda conducta productora de un daño para otro, hasta el punto que clásicamente, la condena del abuso perseguía esta carga indemnizatoria para el causante del daño"121, secuela que no es idéntica respecto al acto propio, toda vez que la reparación en comentario, no está enlistada en los efectos o secuelas forzosos de la trasgresión de la regla venire contra factum proprium non valet, o del deber de coherencia o de no ir contra los actos propios, entre otras denominaciones.

No se desconoce que uno de los presupuestos del factum proprium descansa en la floración de un perjuicio, de una típica lesión a un interés jurídicamente tutelado por el ordenamiento, como corolario del quebranto a la confianza legítima suscitada por un sujeto respecto a otro; simplemente se pone en evidencia que su reparación, en el común de los casos, no se traduce “... en entregar al perjudicado una cantidad de dinero que equivalga al daño causado y que en esa medida lo compense", en cuyo caso “...la obligación del autor del daño frente al perjudicado es una obligación pecuniaria....", como bien lo recuerda Don Luis DíEZ-PICAZO ${ }^{122}$.

\footnotetext{
121 Luís Martínez Calcerrada. La buena fe y el abuso del derecho, op. cit., p. 450.

122 Luís Díez-Pıcazo. Fundamentos del derecho civil patrimonial. La responsabilidad civil extracontractual, T. V, Civitas y Thomson Reuters, Pamplona, 2010, p. 501.
} 
Por consiguiente, los efectos directos en uno y en otro caso, en estrictez, son diversos. En el abuso del derecho, de ordinario, se persigue la reparación, desde luego, in casu, dejando a salvo otros correctivos, al paso que en el acto propio lo que se busca, im promptu, es remediar la vulneración en referencia, a través de la limitación al ejercicio de un derecho, concretamente la inadmisión, rechazo, inaplicación o dejación de la nueva conducta (posterius), en sí misma contraria a la anterior, detonante de la referida confianza legítima, por ello eclipsada. Obviamente cada caso será el regente de la situación particular, motivo por el cual lo anteriormente señalado se erige en regla general, de tal suerte que podrá haber hipótesis en las cuales la reparación del daño a través de una indemnización pecuniaria, seguramente, pueda tener cabida en el factum proprium, aun cuando esa no es la secuela habitual o corriente, según se expresó y expresará de nuevo (Cap. III) ${ }^{123}$.

\section{LA PROPIA CULPA O TORPEZA}

La communis opinio, igualmente es conteste en abogar por la separación neta de la apellidada 'propia culpa o torpeza', entre otras denominaciones más, y la figura del venire contra factum proprium, en cualquiera de sus manifestaciones y extensiones, así presenten, es cierto, algunos rasgos similares, no tantos, sin embargo, como para que se tolere su asimilación o su fundición en un solo corpus.

En efecto, de antiguo se tiene establecido que no es de recibo alegar u obtener provecho de la propia culpa, o de la torpeza humana, habida cuenta que si el sujeto, de una u otra manera, participó en el resultado que ex post cuestiona, o del cual pretende derivar provecho, entre otras hipótesis más, podría pretextarse con éxito que no le asiste razón y que se impone un rechazo frontal, toda vez que su actuación ex ante, lato sensu, no puede quedar impune y, de contera, salir avante su pretensión, pues de hacerlo se estaría estimulando, de un modo u otro, la realización de conductas previas de carácter espurio o por lo menos ayunas de fundamentación y diligencia, muchas veces coloreadas por la astucia y el oportunismo ${ }^{124}$.

123 Vid. Alejandro Borda. La teoría de los actos propios, op. cit., p. 156.

124 Como se ha señalado por la Corte Constitucional colombiana, “...de antiguo se ha aceptado, además como una regla que constituye la antítesis de la bona fides, la prohibición de 
Mutatis mutandis, de no actuarse con firmeza, en la dirección indicada, se estaría premiando la culpa o la torpeza -y hasta la desfachatez-, inhibidoras, per se, del derecho a reclamar con éxito. Nemo auditur propriam turpitudinem allegans es la gráfica sentencia latina, en asocio de otra muy próxima, con análogo significado: Non auditur propriam allegans turpitudinem, ambas indicativas de que no se le dará audiencia a quien alegare una culpa o torpeza propias.

Lo que en últimas se pretende en la esfera jurídica es que quien eleve una reclamación, o aspire a un resultado determinado, debe estar 'libre de pecado', por llamarlo de este modo, vale decir, recurriendo a otro símil, debe tener las 'manos limpias' (clean hands), por manera que si lo tiene: el pecado, o no tiene las manos limpias, no puede obtener lo pretendido, en este caso, por la mediación previa de una culpa o una torpeza, las que se erigen en un hecho impeditivo, propiamente dicho, de tal suerte que ellas serán la ratio decidendi de la negativa en comentario ${ }^{125}$.

Por eso se afirma que este tipo de alegaciones, fundadas en una culpa o torpeza precedentes en cabeza del actor, están emparentadas con el venire contra factum proprium, en términos generales, porque en últimas lo que se exhibe es una falta de congruencia: por un lado se actúa culposa o torpemente y, por el

pretender aprovecharse del propio error, dolo o de la culpa de quien por su desidia, incuria o abandono resulta afectado. Dicha regla, materializada en el aforismo nemo auditur proprian turpitudinem allegans, ha tenido incluso, una incorporación expresa en nuestro ordenamiento sustantivo civil de acuerdo con el postulado general de la "improcedencia por aprovechamiento en culpa y en dolo propio".... Recordemos que, nadie puede presentarse a la justicia para pedir protección si ella tiene como fundamento la negligencia, mala fe o dolo que ha cometido. Así, los Tribunales deben negar toda súplica cuya fuente es la incuria, el dolo o mala fe en que se ha incurrido, de acuerdo con la máxima nemo auditur suam turpitudniem allegans, pues ello, según advierten los autores es contrario al orden jurídico y al principio que prohíbe abusar de los propios derechos (Art. 95 C.N.)..." (Corte Constitucional. Sentencia T-213 de 2008).

La Corte Suprema de Justicia colombiana, igualmente se ha ocupado del tema. Así en sentencia del 5 de febrero de 2008 (Exp 19001-31-10-001-2001-00460-01), afirmó que "...está vedado a las partes auspiciar o permitir con su silencio que el proceso quede sembrado de vicios, para luego intentar valerse de ellos. Entonces, el apotegma nemo propiam turpitudinem allegans potest, por su universalidad y su fuerza ética también está llamado a gobernar la conducta de las partes en el proceso...".

125 Al inicio del capítulo IV haremos una sucinta referencia a la figura conocida como las manos limpias (clean hands). 
otro, a posteriori, se reclama, a veces hasta con ardor, olvidando lo acaecido antes (prius), lo que denota cierta ironía.

Múltiples son las aplicaciones de esta regla, sobre todo en la órbita contractual, v.gr: en la petición o declaratoria de nulidad ${ }^{126}$, y en la imprevisión y correlativa revisión contractual, indirecta o reflejamente (cláusula rebus sic stantibus, o teoría de la imprevisión, etc.), aun cuando no bajo el alero de la doctrina de los actos propios, de suyo diversa, como se reveló en líneas anteriores, y se resaltará de nuevo.

Al fin y al cabo, pese a el mencionado entronque, son dos instituciones dueñas de autogobierno y sustantividad, pero cimentadas en realidades enteramente disímiles. La regla Nemo auditur propriam turpitudinem allegans, efectivamente, se asienta en la culpabilidad o en la torpeza observada por el agente reclamante, de tal manera que media un reproche culpabilístico por no haberse comportado en su momento en forma diligente y acuciosa, lo que entraña un corolario que consecuentemente le será enrostrado, aunque lo haya puesto expresamente de presente antes ${ }^{127}$.

${ }_{126}$ Sobre su fundamento, vid. Jesús Delgado Echeverría y María Ángeles Parra Lucán. Las nulidades de los contratos, Dykinson, Madrid, 2005, p. 298 y ss.

${ }^{127}$ Esta caracterización, además de haber sido realizada en sede civil, se ha hecho también en el escenario constitucional. Es el caso del Derecho colombiano, en el cual su Corte Constitucional igualmente expresó que el asunto por ella escrutado "... se fundamenta en el principio general del derecho, según el cual, "Nadie puede obtener provecho de su propia culpa" (Nemo auditur propriam turpitudinem allegans).... No hay duda de que quien alega su propia culpa para derivar de ella algún beneficio, falta a la buena fe entendida como la ausencia de dolo, la conciencia de que el comportamiento que se observa es conforme al derecho, y los fines que persigue están amparados por éste. Ahora bien: el artículo 83 de la Carta del 91, impone la buena fe como pauta de conducta debida, en todas las actuaciones, tanto de las autoridades públicas como de los particulares. Y los artículos 1525 y 1744 del Código Civil, tan anteriores en el tiempo a nuestra Constitución actual, constituyen sin embargo cabal desarrollo de ese principio al impedir -el primero- la repetición de lo que se ha pagado "por un objeto o causa ilícita a sabiendas", y el segundo al privar de la acción de nulidad al incapaz, a sus herederos o cesionarios, si aquél empleó dolo para inducir al acto o contrato. Ejemplar es también, en esa misma dirección, el artículo 156 del mismo estatuto, que impide al cónyuge culpable, invocar como causal de divorcio aquélla en que él mismo ha incurrido. Tales disposiciones, justo es anotarlo, eran reductibles inclusive a 
Por su parte, la regla venire contra factum proprium, como tantas veces lo hemos manifestado, reside en la floración de una conducta desestabilizadora, amén de sorpresiva que erosiona la confianza previamente generada, a raíz de comportamientos anteriores, revestidos de entidad y pertinencia, sin que para la evaluación en cita sea menester efectuar consideraciones de estirpe subjetivo, en concreto de tipo culpabilísta, por completo extrañas al juicio de valor requerido para este efecto. Otro tanto tiene lugar de cara a la buena fe, stricto sensu. De ahí que esta operación sea netamente objetiva, referida a lo conductual, únicamente, y a su impacto en el círculo de intereses del cocontratante, dejando de lado lecturas encaminadas a ponderar la participación del reclamante en el pasado, y su grado de diligencia.

En este sentido, como ilustrativamente lo recrea don Luís DíEz-PICAZO, “... aun reconociendo una cierta vecindad entre este principio, conforme al cual 'turpitudinem suam allegans non auditur' y la doctrina de los actos propios, no parece admisible confundirlos. De común tienen ambos el que ambos pueden suponer una imposibilidad o un impedimento de orden jurídico, para que el negocio irregular sea declarado ineficaz. Sin embargo, si observamos atentamente ambos supuestos, nos daremos cuenta de que funcionan de un modo distinto. En el primer caso se toma en consideración la culpabilidad del sujeto en la irregularidad del negocio y se le priva totalmente de poder impugnarlo. El sujeto no puede impugnar el negocio, ni ha podido nunca, porque nunca le ha sido concedido tal poder. En cambio, en el 'venire contra factum' lo que se toma en consideración no es la participación del sujeto en la formación del negocio ineficaz, sino la conducta que posteriormente ha observado frente a este negocio" 128 .

\footnotetext{
la Carta anterior que, no obstante, no consagraba explícitamente el deber de actuar de buena fe".

"Pues bien: de esas y otras disposiciones del ordenamiento colombiano, es posible inducir la regla "nemo auditur..." que, como tal, hace parte de nuestro derecho positivo y, específicamente, de nuestro derecho legislado. Por tanto, el juez que la aplica no hace otra cosa que actuar, al caso singular, un producto de la primera y principal fuente del derecho en Colombia: la legislación." (Sentencia T-547 de 2007. Exp. T-1604996).

128 Luís Diez-Picazo. La doctrina de los propios actos, op. cit., p. 204, autor que cierra su exposición señalando que "La diferencia entre la imposibilidad de alegar la propia torpeza y la imposibilidad de venir contra los propios actos es aún más profunda. La inadmisibilidad del 'venire contra factum' tiene su fundamento, según hemos visto, en las exigencias de la buena fe y de la regularidad del tráfico, que impiden los cambios radicales de actitud....
} 
En suma, en uno y en otro caso, los insumos que deberán ser valorados y analizados por el juzgador, por vía de ejemplo, serán divergentes, así como el énfasis y aproximación judicial que se harán: en el venire, se preocupará del advenimiento de una incoherencia susceptible de eclipsar, objetivamente, la confianza legítima generada con antelación, en guarda de evitar la irrupción de un perjuicio. Aquí la censura consistirá en el cambio comportamental que engendró sorpresa y desazón, y que quebrantó los cánones de la buena fe. $Y$ en el nemo auditur el iudex se volcará a confirmar la presencia de una culpa y torpeza relevantes, reveladoras, en sí, de una participación -o coparticipación-en el resultado que ulteriormente se cuestiona, o peticiona. En este segundo supuesto el reproche no girará alrededor del quebranto de la confianza legítima, sino en la gestación de una culpa o una torpeza incidentes y, de suyo, contaminantes.

\section{EL ESTOPPEL Y LA VERWIRKUNG}

\subsection{Preliminares}

Ya para culminar con las primordiales instituciones que deben ser diferenciadas, o por lo menos que se aconseja diferenciar del acto propio, en sí mismo considerado, cumple referirnos someramente al estoppel, de un lado y, del otro, a la verwirkung.

Y decimos que en forma somera, teniendo en cuenta que una y otra serán materia de detenido análisis en capítulos subsiguientes, razón por la cual no pretendemos anticipar su escrutinio. Simplemente pincelaremos algunas de sus puntuales caracterizaciones, no sin antes advertir que, como acontece con la buena fe, aun cuando en menor medida, los puentes que las unen a la doctrina de los actos propios, son de acero puro, fundamentalmente porque todas ellas:

\footnotetext{
En cambio, cuando se decreta que no sea oído el que alega su propia torpeza, no se trata de proteger la buena fe, ni la seguridad del tráfico jurídico frente a cambios radicales de actitud, sino que, en realidad, se aplica una sanción a un acto irregular. En un caso nos hallamos frente a una norma con una finalidad eminentemente protectora, mientras que en el otro la norma es esencialmente sancionadora". Cfr. Anderson SchreIBER. A proibiçao de compotamento contraditório, pp. 174 y ss., y Dimitri HoutcIEFF. Le principe de cohérence en matiére contractuelle, op. cit., pp. 745 y 746.
} 
el acto propio, el estoppel y la verwirkung, entre otras más, son emanaciones de la regla venire contra factum proprium. Ello explica, anticipadamente, el por qué no se encontrarán categóricas e irreconciliables divergencias. De allí que prefiramos emplear los vocablos matizaciones o particularizaciones para ilustrar mejor su estrecha cercanía, hasta tal punto, incluso, que sin horadar su esencia, hubiéramos podido no ocuparnos de las mismas, sin que se atentara contra su morfología, amén que libre y sostenido desarrollo.

Aclarado lo anterior, refrendemos que tanto el estoppel, como la verwirkung, se anidan en una estructura más general que sirve de continente, puesto que una y otra son derivaciones de la regla en mención, reactiva a la contradicción, a la incoherencia y, sobre todo, a la erosión de la confianza legítima suscitada con anticipación a raíz del advenimiento de uno o varios comportamientos llamados a construirla, a la vez que a alimentarla a lo largo del iter ad contractum. Por eso ambas se erigen, desde su área de influencia, en paladines suyos, habida cuenta que su consigna, en su esencia, es la misma: evitar que la referida confianza se agriete, pero si efectivamente se agrieta dotar al ordenamiento de fiables herramientas que impidan que el vulnerador, ese que la resquebrajó con su comportamiento ulterior, no pueda válidamente ejercer su derecho, en desmedro de otro, v.gr: su cocontrante, tratándose de una relación negocial, puesto que su ejercicio conoce límites, en la medida en que no son, no pueden ser ni absolutos, ni lesivos, como se ha reiterado en precedencia.

Ya en el terreno de las matizaciones, y de las puntuales particularizaciones -o diferencias más funcionales-, reiteremos que estas dos instituciones no son idénticas o simétricas a la doctrina de los actos propios, así sean irradiación directa del venire contra factum proprium, e indirecta o general de la bona fides. Al fin y al cabo, como lo expresa SACco en relación con la verwirkung, ella es un "segundo tronco" obtenido de la raíz de la "... prohibición de contradecirse"129.

Anticipemos entonces algunas de estas diferencias menores o particularizaciones, dado que, en detalle, esta temática tiene en el Capítulo IV reservado un desarrollo esquemático, amén de descriptivo, en el que nos

$\overline{129}$ Rodolfo SACco, Il fatto, l'atto, ill negozio, op. cit., p. 234. 
ocuparemos de su concreta diferenciación, no tanta, empero, como para entender que son figuras radicalmente diversas, situadas en vértices enteramente diferentes, como se anotó en líneas anteriores.

\subsection{EL ESTOPPEL}

El estoppel, lo anticipamos, es una institución que se concibió más como un instrumento de índole procesal, como un remedio judicial, consideración que en la actualidad no ha desaparecido, así se haya extendido desde el Derecho anglosajón a otros dominios, o latitudes, ora en la esfera del Derecho internacional, ora en el Derecho francés, y en menor medida en Italia. La doctrina de los actos propios, sin soslayar su proyección en el proceso, si ha tenido y sigue teniendo una indiscutida raigambre sustancial, a fuer que dogmática, incluso en el campo extraprocesal, hecho que marca una puntual caracterización.

En el estoppel, así como acontece en el common law, en general, la apariencia ocupa un papel definitorio, mucho más que en tratándose del acto propio, en el que sin soslayar su recepción, no puede ocultarse la fuerza que hoy reviste la confianza legítima, piedra angular de la misma, a juicio de la communis opinio.

En el estoppel, militan numerosas modalidades individuales, en sí mismas diferenciadas de la figura genéricamente concebida. Es el caso del estoppel by record, del estoppel by deed, del stoppel by facts in pais, del stoppel by representation, del stoppel by delay - o laches-, entre otros, gamas o atomizaciones que en punto al acto propio no son comunes, doctrina en la que campea unicidad, y en la que no median dichas ramificaciones, conforme se examinará en detalle, más adelante.

El estoppel, en consideración a su carácter procesal antedicho, se estima por un sector muy representativo de la doctrina anglosajona que es un típico medio defensivo, en cuyo caso no procedería de oficio. En cambio, el acto propio, si puede serlo, como se realza mayoritariamente, y como lo atestigua la propia jurisprudencia continental, en procura de darle un alcance aún más tuitivo. 


\subsection{LA VERWIRKUNG}

Ahora bien, en lo que dice relación con la verwirkung, tan en boga en los Derechos de origen germánico directo, igualmente se aprecian puntuales matizaciones, aunque tampoco tan categóricas que, in radice, tornen refractario este mecanismo respecto a la regla venire contra factum proprium, y en particular a la doctrina de los actos propios, pues todas condenan la incoherencia y la contradicción. Algunas de ellas, materia de más cuidadoso análisis en el referido Capítulo IV de este texto, son las que seguidamente se esbozan, con el fin de no reproducirlas íntegramente, lo que claramente no sería aconsejable.

La verwirkung, de origen medularmente pretoriano, se afianzó para conjurar diversas disfunciones coyunturales, de ordinario ligadas con la problemática ocasionada a raíz de la primera guerra mundial, y también de la segunda, sobre todo en el campo económico y financiero (Derecho de obligaciones y contratos), al paso que la doctrina de los actos propios, no sólo de sustrato jurisprudencial, sino doctrinal en su gestación, no ha estado ligada frontalmente a la fenomenología en comentario, sino que ha obedecido a la intención de dotar al ordenamiento de un remedio más estable, al tiempo que desconectado de puntuales acontecimientos, por reveladores que sean de necesidades apremiantes.

La verwirkung, de conformidad con un amplio sector autoral, se ha estimado que es una manifestación especial del abuso del derecho, de tal suerte que su diferenciación neta con él, no podría tener lugar, por lo menos a la luz de esta concepción doctrinal. En la doctrina de los actos propios, como se corroboró en este capítulo, es menester hacer la escisión, en atención a que su finalidad, estructura y alcance son disímiles, stricto sensu.

En la verwirkung, es la regla, la inacción referida al ejercicio de un derecho, se traduce en el comportamiento que desencadena sus efectos protectores, en procura de salvaguardar la confianza legítima derivada de ella. Como se comprobará, para la generalidad de autores dicha inacción será medular, además de característica en la verwirkung, al paso que en la doctrina de los actos propios, a menudo, el comportamiento lesivo y ex novo, suele residir en una acción, más que en una omisión, inejercicio, o abstención. Por ello en aquella el transcurso 
del tiempo comúnmente tiene mayor incidencia, desde luego con puntuales excepciones, en todo caso no muy numerosas, hasta el punto que para algunos doctrinantes la verwirkung es una especie de prescripción de facto, sin confundirla con la de jure, sin embargo, como se señalará.

Lo cierto es que en el venire, el acento estará en la contradicción e incoherencia, y en la verwirkung, en la que igualmente ocuparán un sitial especial, el transcurso del tiempo, a menudo relativamente prolongado, será capital, en la que la incongruencia comportamental súbita, no tendrá análoga incidencia ${ }^{130}$.

130 Cfr. Antoni Vaquer Aloy. El retraso desleal en el ejercicio de los derechos. La recepción de la doctrina de la verwirkung en la jurisprudencia española, op. cit., p. 107. En este mismo sentido, la Corte Suprema de Justicia de Colombia, en sentencia del 28 de abril de 2011, precisó en torno a la verwirkung, que, "pese a exigir una conducta actual contradictoria con la anterior, tampoco se confunde con el venire contra factum proprium, porque éste, de suyo no presupone, ni se basa en la ausencia de ejercicio del derecho durante un período relevante, sino un acto dicotómico opuesto a la buena fe y a la confianza legítima". 

Capítulo III

\section{PRESUPUESTOS, CARACTERES Y EFECTOS DE LA DOCTRINA DE LOS ACTOS PROPIOS}

\section{PRESUPUESTOS DE LA DOCTRINA DE LOS ACTOS PROPIOS}

Son varios los presupuestos o requisitos que debe observar la regla en cuestión, para que devenga aplicable, y por ende, vinculante y también eficaz en el ámbito jurídico, los que han sido tejidos por la doctrina y la jurisprudencia internacionales, como quiera que no son de factura legal o normativa, circunstancia que, explica, de una u otra manera, que no exista en este punto unanimidad, o simetría plena, y que medie alguna controversia, propia también de la 'lozanía' de la misma -independientemente de sus remotos y casuísticos antecedentes-y del hecho de que, en puridad, ella continúa en construcción o, si se prefiere, es objeto de decantación o remozamiento, lo que aconseja proceder con cautela en esta materia, a fin de no radicalizar posiciones que, aun cuando en el común de los casos, pueden lucir consistentes y pinceladas por la lógica, como en efecto en su mayoría lo están, no revisten fuerza preceptiva (lege lata), lo que aconseja no hacer apología a ultranza de tales presupuestos, tanto más cuanto que en función del casus, en esta materia de tanta significación, pueden ser matizados a relativizados. Con dicha limitación, sin embargo, examinaremos las exigencias más socorridas, sin perjuicio de una que otra anotación especial, explicativa de nuestra adhesión o cordial discrepancia, conforme a las circunstancias'1.

Como lo tiene establecido la jurisprudencia de la Corte Suprema de Justicia colombiana, “...oportuno resulta asentar que si bien jurisprudencia y la doctrina no son concordantes en cuanto a los requisitos establecidos para considerar si, en estrictez, procede la teoría de los actos propios, la mayoría converge en señalar los siguientes como tales: i) una conducta relevante que genere en la otra persona un grado de confianza legítima sobre la realización o concreción, en el futuro, de unas consecuencias en particular; ii) que, con posterioridad, emerja otra conducta (quizás una pretensión) que contradiga con evidente y objetiva incoherencia, los antecedentes plantados; iii) que la nueva situación presentada tenga trascendencia en lo jurídico y la virtualidad para afectar lo existente; $y$, iv) que haya identidad entre quienes resultaron involucrados en uno y otro episodio" (Sentencia del 24 de enero de 2011). 
En tal virtud, grosso modo, la cabal aplicación de la doctrina de los actos propios exige que exista, como mínimo: a) una conducta o comportamiento relevante que, por sus connotaciones, previamente, infunda, despierte o suscite una confianza legítima en el otro cocontrante; b) que irrumpa en el cosmos factual una actuación que, a posteriori, contraríe o menoscabe dicha confianza primigenia que objetivamente se ha mancillado -o pretendido mancillar- en consideración a una falta de coherencia respecto de una o varias conductas anteriores (acto propio); c) que exista identidad de los sujetos (emisor y receptor), y d) que haga presencia un perjuicio real o potencial. Seguidamente, de manera general, les pasaremos entonces revista a dichos presupuestos.

\subsection{LA EXISTENCIA DE UNA CONDUCTA RELEVANTE, INEQUíVOCA Y OBJETIVA}

En primer lugar, así resulte elemental, es necesario que en el cosmos se materialice una conducta, comportamiento o actuación, con connotaciones jurídicas, en la temática que nos ocupa, en sede contractual (en sentido muy lato), con el fin de cobijar, incluso, la fase de su formación (iter ad contractum), propiamente dicha, conforme lo hemos anotado en precedencia, sobre todo en la parte final del capítulo anterior.

Sin una conducta originaria, primigenia o inicial, sin que medie un actuar determinado, con vocación de trascendencia jurídica, no se podría aludir a un arquetípico factum proprium, esto es, a un hecho propio, desencadenante de efectos en derecho, en razón de que, por su fuerza intrínseca, se traducirá en percutor de concretas secuelas, habida cuenta que como lo confirma el profesor Andreas VON THUR "La consecuencia jurídica del factum consiste siempre en una modificación del mundo jurídico....Todo hecho que produce efectos jurídicos de cualquier clase se denomina hecho jurídicamente relevante, o dotado de eficacia jurídica, o, sin más, jurídico, en contraposición con la masa de hechos que son irrelevantes para el derecho"2.

Andreas Von ThuR. Derecho civil. Teoría general del derecho civil alemán. Los hechos jurídicos, op. cit., pp. 5 y 7. 
Desde esta perspectiva, sin perjuicio de alguna aclaración, se puede entender que el factum proprium, in abstracto, se inscribe en el marco del hecho jurídico, pues como bien lo recrea Don Manuel AlbalADEJo, "En la infinita variedad de los hechos, unos son jurídicamente relevantes y otros no. Aquéllos se denominan hechos jurídicos. Estos se llaman simplemente hechos o bien hechos no jurídicos. Por relevancia jurídica entendemos el dar lugar a consecuencias o efectos jurídicos. Por tanto, desde el punto de vista de un determinado derecho positivo, un hecho es jurídico cuando aquél le liga unas consecuencias, o no lo es o cesa de serlo, cuando para tal Derecho, carece de ellas, o éste le priva de las que antes tenía....Podemos en resumen, definir el hecho jurídico como todo acontecimiento o estado -en general todo suceso o falta del mismo (ya que también hay hechos negativos)-al que por su sola realización, o juntamente con otros, liga el Derecho objetivo a la producción de un efecto....."3.

No obstante lo anterior, cumple manifestar que el factum proprium, en sí mismo, no es un hecho jurídico natural, como podría ser la erupción de un volcán, la caída de un rayo, etc. ${ }^{4}$, sino un actus hominis (acto del hombre) con virtualidad jurídica ${ }^{5}$, en particular con incidencia en la órbita precontractual y contractual, a raíz de la gestación o advenimiento de confianza en cabeza de uno de los celebrantes del acuerdo negocial, efecto cardinal y visible en tratándose de la regla del venire contra factum proprium y de sus manifestaciones, una de ellas la doctrina de los actos propios $^{6}$, en la que la referida confianza se traduce

3 Manuel Albaladejo. El negocio jurídico, Bosch, Barcelona, 1958, pp. 5 y 6 . Vid. Vittorio Scialoja. Negozi giuridici. Soc. Ed del "Foro Italiano", Roma, 1938, pp. 22 y ss.

4 El profesor F. GALGANO, al respecto, anota que "Hecho jurídico puede ser un acontecimiento natural, totalmente independiente de la intervención del hombre....También un hecho humano puede ser un hecho jurídico". "El crepúsculo del negocio jurídico", en Teoría general del negocio jurídico, 4 estudios fundamentales, Ara Editores, Lima, 2001, pp. 79 y 80.

5 Cfr. Fernando FueYo LANERI, a juicio de quien "El acto propio parte o nace esencialmente de una conducta humana". La doctrina de los actos propios, op. cit., p. 311.

6 Conviene aclarar, por su significación, que de la circunstancia de enmarcar el factum proprium en un hecho jurídico humano, no se sigue que, a su turno, se torne en un típico acto o negocio jurídico, signado por un elemento de carácter volitivo, toda vez que tal asimilación generalizada no es de recibo en el asunto sub examine, pues habrá numerosos casos en los que no haga inequívoca presencia, stricto sensu. Justamente ya tuvimos ocasión de distinguir, con toda precisión, la regla del venire y el negocio jurídico en el capítulo anterior, haciendo hincapié en el papel que en ella ocupa la evidencia de una contradicción, percutor del quiebre de la confianza legítima en su momento suscitada. En esta misma dirección, el 
en su ratio protectionis, y en la explicación causal de la relevancia asignada al comportamiento o conducta inicial (factum proprium) ${ }^{7}$.

Es en ese específico contexto e inteligencia, ex proffeso, que se emplea la expresión conducta relevante, con el propósito de no otorgarle cabida únicamente a las mutaciones o cambios que impliquen creación, modificación o extinción de relaciones jurídicas, como muchas veces lo ha exigido la jurisprudencia española sin un sólido fundamento, en este aspecto ni conteste, ni uniforme, por cuanto algunos han expresado que ha sido oscilante y en oportunidades errática, precisamente por tratar de conectar el acto propio con las declaraciones de voluntad, según tuvimos oportunidad de comprobar en el capítulo anterior ${ }^{8}$.

Se exige entonces, así delimitada, que dicha conducta originaria -o precedente- llevada cabo por uno de los cocontratantes -futuro cocontratante-, se torne relevante, es decir que, por ser determinada, amén que específica, tenga la idoneidad suficiente para suscitar -o despertar- en uno de los extremos de la relación negocial, su destinatario, la confianza o creencia de que, en el futuro, no habrá sorpresas o cambios súbitos en la esfera comportamental y jurídica por parte suya (buena fe constancia), quien merced a su comportamiento, en

autor Anderson SCHREIBER es diáfano al señalar que "El factum proprium no consiste en un acto jurídico, en sentido tradicional; produce efectos jurídicos por fuerza de la necesidad de tutelar la confianza legítima. A prohibiçao de comportamento contradictório. Tutela da confiança e venire contra factum proprium, op. cit., p. 134. Cfr. Fernando FuEYo LANERI. La doctrina de los actos propios, op. cit., p. 312, quien anota que "El acto propio no requiere -en su esencia- de una voluntad con intención de producir efecto jurídico, cosa que, a la inversa, es de esencia del acto jurídico".

7 El doctrinante argentino Alejandro BORDA, en otro de sus escritos sobre la materia, aclarando el alcance de la expresión 'relevancia', corrobora que el acto "... debe tener una relevancia que le permita suscitar la confianza de un tercero". "La teoría de los actos propios. Un análisis desde la doctrina argentina", en Venire contra factum proprium, Universidad de los Andes, Santiago, 2010, p. 44.

8 Numerosas son las Sentencias del Tribunal Supremo en las que se asocia relevancia y declaraciones de voluntad, lo reiteramos. Así, sólo por vía de referencia, en sentencia del 6 de abril de 2006, el Supremo sentenció con relación a ésta que “...es preciso que los actos envuelvan verdaderas declaraciones de voluntad en orden a crear, modificar o extinguir una relación de derecho". Por su parte, en sentencias anteriores, el mismo Tribunal había acogido este planteamiento. Es el caso de la sentencia del 24 de abril de 2001, conforme a la cual "...los actos propios, para vincular a su autor, han de ser inequívocos y definitivos, en el sentido de crear, establecer y fijar o modificar una determinada relación jurídica, con lo que produce estado". 
concreto a la conducta o conductas observadas en su oportunidad, generó un preciso entendimiento, en sí mismo suficiente y pertinente para actuar o para no actuar, según el caso, como quiera que los pasos que dicho destinatario dará, inexorablemente, tendrán como manantial la actuación inicial ajena, obligado punto de referencia.

Manifestado de otro modo, se requiere pues que medie una conducta calificada, en sí misma capaz de influir en la otra parte, puesto que de lo contrario no podría invocarse la doctrina o teoría del acto propio, habida consideración que no toda actuación, individual o pluralmente considerada, per se, tiene la idoneidad suficiente para incidir en el otro cocontrante. De allí que, bien entendida, se exija que se sea 'relevante', 'idónea', 'pertinente', lo que quiere significar que los actos anodinos, intrascendentes o estériles, como tales ayunos de fuerza y eficacia jurídica, no serán tomados en cuenta, justamente por no reflejar una actitud con vocación definida, en condiciones de razonabilidad comportamental.

Por eso es por lo que no se puede invocar, con éxito, la floración de una conducta cualquiera, dado que se requiere que sea pertinente y, que por ende, esté llamada a tener incidencia. En caso contrario, por más que materialmente se pueda identificar una concreta actuación de uno de los celebrantes del contrato, si no está revestida de idoneidad, mal podría acudirse a la doctrina en comento, pretextando el surgimiento de un estado de confianza digno de tutela, porque ella no irrumpe por generación espontánea, ni a partir de todas y cada de las actuaciones, como si fuera mecánica.

Al fin y al cabo, el concepto jurídico de factum proprium, está reservado a algunas conductas, titulares de cierta personalidad y talante, lo que exigirá, en cada asunto, un cuidadoso juicio de valor, a fortiori, cuando la diligencia y actitud de quien invoca la sorpresa y el resquebrajamiento virtual de la confianza suscitada, ciertamente no son las debidas, puesto que el cocontratante no puede ser un mero espectador, como si de él nada se pudiere esperar en el desenvolvimiento de la relación negocial. No se equivocó el profesor de la Universidad de Roma, Emilio BETTI, cuando analizando el comportamiento concluyente, en función del venire contra factum proprium, observó en el año 1962 que "En estos comportamientos, bien puede faltar al interesado una voluntad destinada a las consecuencias 
vinculantes de su comportamiento; pero el hecho de deberlas conocer y prever tiene lugar -según la evaluación judicial y jurídica- en la conciencia efectiva. En caso de que el interesado hubiera obviado procurarse tal conocimiento, peor para él. El comportamiento concluyente, en cuanto justifica deducciones, según las apreciaciones sociales, y en cuanto provoca expectativas legítimas en otros, también es imputado a su autor por una razón de autoresponsabilidad, es decir por una necesidad que la ética social y la ley ponen a su cargo; una necesidad que lo hace experimentar las consecuencias perjudiciales de su propia inercia o negligencia, sin posibilidad de transferirlas a otros (es válido, entendido en ese sentido, el dictamen quod quis ex culpa sus damnum sentit, non intellegitur damnum sentire)"9.

En suma, conforme lo subraya el profesor Luís DíEz-PICAzo, con su acostumbrado acierto, "No pueden tomarse en cuenta como actos propios aquellos a los cuales el ordenamiento jurídico no confiere trascendencia (v.gr., meras opiniones, manifestaciones incidentales, etc.).No pueden tomarse como actos propios las opiniones sustentadas en una conversación privada, las declaraciones testificales, las simples expresiones de un deseo o de un proyecto" 10 .

Acorde con lo señalado en precedencia, también se tiene establecido que la referida conducta o actuación, indefectiblemente debe ser inequívoca, o sea desprovista de variadas lecturas o interpretaciones, en cuyo caso reinaría la hesitación y la socavante duda. Por eso la equivocidad, no es bienvenida en esta materia, puesto que como acertadamente lo memoró el Tribunal Supremo

9 Emilio BETTI. "Reflexiones sobre la noción de negocio jurídico", en Teoría general del negocio jurídico, 4 Estudios fundamentales, ARA Editores, Lima, 2001, pp. 40 y 41.

10 Luís Díez-Picazo, La doctrina de los propios actos, autor que un folio más adelante, redondea su planteamiento indicando que "...unos actos sólo pueden ser tomados en cuenta como conducta vinculante, cuando expresan objetivamente una actitud actual frente a una situación jurídica, pero no cuando son simple manifestación de un propósito o perspectiva de un cambio futuro", op. cit., pp. 197 y 198. En sentido similar, el Dr. M. LóPEz MESA, puntualiza sobre la relevancia que ella no puede invocarse cuando se está frente a "...declaraciones carentes de seriedad o efectuadas en broma-iocandi causae- o con las declaraciones con fines pedagógicos, como las afirmaciones que hace un profesor en medio de una clase, con el fin de enseñar algún principio a sus alumnos. Este tipo de declaraciones, obviamente, no obligan a quien las profiere". La doctrina de los actos propios, op. cit., p. 118. 
Español, en Sentencia del 6 de octubre de 2006, "La doctrina de los propios actos tiene su fundamento en la protección de la confianza y en el principio de la buena fe, pero ello exige que los actos propios sean inequívocos, en el sentido de crear, definir, fijar, esclarecer, modificar o extinguir una determinada situación que afecta jurídicamente a su autor, para lo cual es insoslayable el carácter concluyente e indubitado, con plena significación inequívoca, de modo que entre la conducta anterior y la pretensión actual exista una incompatibilidad o contradicción, con el sentido que, de buena fe, hubiera de atribuirse a la conducta anterior.... por lo que no es de aplicación cuando los precedentes fácticos que se invocan tienen carácter ambiguo o inconcreto o carecen de trascendencia para producir el cambio jurídico y, aún menos, cuando el cambio de actitud obedece a una reacción ante nuevos hechos o actos".

Tal conducta, en orden a cobijar a uno o varios comportamientos (cadena comportamental), obviamente debe ser anterior o previa al despunte del acto incoherente o contradictorio, motivo por el cual se alude a una conducta primigenia o ex ante, a fin de diferenciarla con la gestación de la actuación voluble, en sí misma ulterior. Ello explica que haya dos momentos cruciales, mejor aún, dos conductas decisivas: la primera, a partir de la cual se crea y constituye confianza, amén de seguridad (atmosfera adecuada), y la segunda, a manera de posterius, constitutiva de contradicción e incoherencia, detonante del resquebrajamiento de la confianza alcanzada con anterioridad, y a su vez de la sorpresa y perplejidad generadas por el cambio o viraje comportamental.

Esta conducta primigenia, in complexu, bien puede estar integrada por la sumatoria de diversos y sucesivos comportamientos, y no sólo por uno de ellos, invariablemente, puesto que la pluralidad en referencia, bien puede tener cabida, sin que por ello se altere el factum proprium. De hecho, en innúmeras ocasiones es lo que tiene lugar con relación a los apellidados negocios jurídicos de duración, ya aludidos por nosotros, y lo que explica el afianzamiento de la mencionada confianza a partir de la reiteración y, de paso, la extrañeza originada en su posterior contravención.

Por último, expresamos que además de idónea y, de contera, vinculante, la conducta -o plexo conductual-debe ser valorada desde un ángulo esencialmente 
objetivo, carente de toda coloración subjetiva, vale decir que la intentio de que quien la ejecuta (actor o emisor), no desempeña un rol especial, toda vez que lo decisivo, más allá de que exista intencionalidad, es el hecho concreto de la confianza suscitada en el destinatario a raíz de la citada conducta inicial, detonante de la protección que brinda el ordenamiento, en particular el poder judicial; ella es la brújula que debe guiar la tutela conferida, el centro de gravedad de cualquier decisión, pues la ratio de este instituto, por antonomasia, es tuitiva, de tal suerte que debe evaluarse la repercusión emergente de la conducta primigenia observada por el cocontrante, al margen de otras consideraciones que, a la postre, antes que salvaguardar los intereses de aquél, terminarían por conculcarlos.

Desviar la atención en este aspecto, es perder el rumbo, a la par que contrariar el auténtico espíritu protector de la doctrina de los actos propios y, por tanto, beneficiar al victimario, en contravía de la víctima o damnificado, quien incluso- podría ampararse en su propia culpa, o en la esterilidad negocial de una disposición contractual por el estructurada (predispuesta), etc. Es lo que sucede cuando enfáticamente, sin medir las consecuencias de ello, se pone de presente que es requisito sine que non del acto propio que la conducta desplegada sea estrictamente eficaz, so pena de que no devenga aplicable la doctrina en cuestión. De ahí que prefiramos aludir a una conducta relevante, en los términos prefijados, y no a una conducta inexorablemente eficaz, entre otras razones por cuanto por esa vía, en apariencia consecuente, se estaría subordinando la protección del ordenamiento, v.gr: la judicial, al hecho de que el acto del cocontratante -o futuro cocontratante- devenga eficaz, exigencia que sólo beneficiaría al voluble, quien podría argüir, en forma insólita, mejor aún rayana en la desfachatez, que el ejercicio contradictorio de su derecho no se afecta porque su actuar no fue eficaz, así haya despertado objetivamente, de buena fe, la confianza en la dosis requerida para que se le brinde especial protección.

Expresado de otro modo, hacer hincapié a rajatabla en este requisito, el que por lo demás no es ex lege, sino de ordinario ex cathedra, es paradójicamente despejar el camino para que, frente a precisas circunstancias, reine la incoherencia conductual y la más ignominiosa desprotección o abandono de los derechos y prerrogativas de uno de los extremos de la relación jurídico-negocial, a quien no se le puede exigir actuaciones heroicas o refinadas disquisiciones que, a la postre, 
terminen por alterar el curso racional de los acontecimientos. $Y$ lo que es peor, arar el terreno para que campee la impunidad comportamental, en contravía de caros postulados y de elementales principios de justicia contractual. Summum ius summa injuria, nos lo recuerda la máxima, en prueba de que el equilibrio y la prudencia que debe imperar en el escrutinio de los presupuestos del acto propio, puesto que radicalizando su examen, así sea sin quererlo, pueden lesionarse derechos ajenos, y mancillarse, in toto, la confianza que otro, en su oportunidad, claramente generó.

Por lo tanto, si la protección de la confianza legítima, con razón, ha adquirido en los tiempos que corren tanta fuerza, no es conveniente buscar caminos que conduzcan a un resultado que abiertamente riña con este ideario, con argumentos netamente formales, a sabiendas que se conculcó con rotundidad la confianza en mención, al mismo tiempo que la buena fe ${ }^{11}$.

Que un acto entonces pueda considerarse inválido, de por sí, no autorizará entonces a que se alegue la improcedencia irremediable de la doctrina de los actos propios, so capa de que no fue eficaz, puesto que habrá casos en que, no obstante ello, la apariencia del acto, sumada a la confianza que despertó determinada actuación, deberán valorarse con cautela, a fin de no perder de vista su genuino objetivo, motivo por el cual si ella se consolidó es porque en principio la actuación no fue estéril, circunstancia que inicialmente amerita su salvaguarda, toda vez que como lo expresa el autor Federico BERRo, en línea con lo indicado, "Es preciso que la conducta produzca efectos aunque en definitiva resulte inválida. Muchos actos que luego son declarados inválidos, tienen, por un determinado periodo eficacia”. Y tan 'eficacia' tuvo en gracia de discusión de

11 Recordaba cabalmente el Profesor Ricardo LORENZETTI, en la reciente presentación del Anteproyecto de Código Unificado Argentino, quien fungió como Presidente de la Comisión redactora, que el Derecho Privado contemporáneo no debe privilegiar exacerbados tecnicismos o desuetas complejidades. Muy por el contrario, aquél es un Derecho que, por excelencia, debe acercar la justicia al ciudadano, facilitando el ejercicio racional de sus derechos. De ahí que se abogue por interpretaciones que, en lugar de tecnificar más a la ciencia jurídica, estimulen una mayor humanización y una aproximación al ciudadano común. En el concreto ámbito que nos ocupa, ello implica entonces reconocer que interpretaciones como las que exigen a ultranza la plena e invariable eficacia jurídica del factum proprium, no sólo no son aconsejables, sino que son acendradamente formalistas y, en ocasiones, artificiosas (Presentación oficial, 27 de marzo de 2012). 
este enfoque, que uno de los cocontratantes confió y correlativamente creyó en el otro, más allá del resultado final ${ }^{12}$.

En sintonía con lo anterior, Don Luís DíEZ- PICAZO, indagando sobre la presencia de un error predicable la conducta inicial de uno de los celebrantes del contrato: el que despertó en el otro confianza y seguridad, concluyó que, "Si de lo que se trata es de proteger la confianza que la actitud adoptada mediante la propia conducta ha podido suscitar en los terceros, esta protección de la confianza debe ser independiente de cualquier posible error sufrido [...] La idea es la misma que juega en el llamado principio de auto responsabilidad: irrelevancia del error y sanción del causante del vicio negocial, para proteger a los terceros que confiaron en la validez de la declaración", autor que previamente había recordado que "[...] cuando alguien es culpable de la ilicitud o de la irregularidad del negocio, no sólo carece de acción para pedir la ineficacia, sino que carece de acción para pedir el cumplimiento del negocio"13.

\subsection{EL SURGIMIENTO DE UNA CONDUCTA ULTERIOR DE CARÁCTER CONTRADICTORIO}

En segundo término, es menester que irrumpa en el cosmos factual, a posteriori, una actuación que erosione la confianza primigenia suscitada (mutare), la cual, objetivamente, fue objeto de quebrantamiento en atención a la ausencia de coherencia de cara a una o varias conductas anteriores (conductas sucesivas).

Se demanda, en consecuencia, el surgimiento de una actuación posterior y autónoma -o sustantiva- que, comparada con la precedente, luzca contradictoria o incoherente, quid de la doctrina en comento, refractaria a este tipo de cambios que, por sus connotaciones, socava legítimos intereses, así lo pretendido por el sujeto voluble intrínseca e insularmente, sea lícito in abstracto, aun cuando inadmisible por chocar frontalmente con actos suyos anteriores que, como anotó,

12 Como bien lo observa la autora M. Nelida TUR FAUnDEZ, "En principio, este presupuesto no podría ser considerado como tal si entendemos que el fundamento de la doctrina de los actos propios es el principio de buena fe objetiva, y la confianza suscitada por la apariencia que genera la conducta". La prohibición de ir contra los actos propios y el retraso desleal, op. cit., p. 37.

13 Luís Diez-PıcAzo. La doctrina de los propios actos, op. cit., pp. 204 y 210. 
tuvieron la fuerza e idoneidad suficientes para engendrar confianza, y para generar seguridad, a la vez que cierta apariencia o estado determinado, lo que amerita que esta atmósfera, en principio, no sea alterada por nuevas conductas (buena fe constancia).

Desde esta última perspectiva, si bien el ejercicio del derecho por parte del voluble puede llegar a estimarse lícito, in abstracto, dado que se hace al amparo de una facultad virtualmente conferida por el ordenamiento, en particular derivada de la posición que ocupa en la relación contractual, cuando él se ejerce contrariando los límites de la buena fe, de la coherencia y de la racionalidad negocial, su conducta se torna vulneratoria del ordenamiento y, por esa vía, antijurídica y también injusta. ${ }^{14} \mathrm{Al}$ fin y al cabo, se habrá conculcado el principio de la no contradicción, en general, y en concreto el deber jurídico de coherencia, en sí mismo vinculante, a lo que se agrega la preterición de la buena fe, in globo.

Debe haber entonces, como mínimo, dos conductas objeto de análisis: una primera, manantial de la confianza legítima suscitada, a la par que constitutiva de un estado de regularidad comportamental, y una segunda, de suyo posterior en el tiempo, contraria a la anterior, en sí misma generadora de perplejidad, sorpresa y, muy especialmente, de una lesión a derechos y prerrogativas ajenas,

14 "Es antijurídica, o contraria a derecho", lo memora L. ENNECERUs, "toda conducta humana que contradice como un todo al ordenamiento jurídico... El juicio de valor de la antijuridicidad puede referirse a dos momentos distintos del supuesto de hecho del acto. Los mandatos y prohibiciones del ordenamiento descansan sobre una valoración de los intereses (materiales o ideales) y de los conflictos que entre éstos se producen. Partiendo de la idea de que el derecho proporciona un ordenamiento racional a la vida en comunidad, aquella valoración será un requisito lógico para que la ley ordene producir un determinado estado de cosas, o sea 'hacer algo' (mandato), o no producir un determinado estado, 'omitir algo' (prohibición) ". Derecho civil. Parte general, Vol. II, op. cit, p. 854.

En el tema que detiene nuestra atención, en positivo, será menester cumplir con el deber de coherencia en comento, y en negativo, abstenerse de contrariar los actos propios y, por ende, de lesionar la confianza inculcada con antelación, vale decir que podrá aludirse, pari passu, tanto a un mandato, como a una prohibición, en sentido amplio.

Por su parte, y también en sentido lato, podrá decirse que la conducta calificada en referencia, igualmente es injusta, pues el perjuicio o el daño injusto experimentado, se ha dicho, "... .indica la lesión de un interés jurídicamente tutelado", en nuestro caso la confianza legítima y racional despertada en el cocontratante, en tal virtud materia de especial y sostenida protección. Massimo BIANCA. Diritto civile. La responsabilitá, Giuffre, Milano, 1994, p. 587. 
situados en la órbita de los intereses jurídicos radicados en cabeza de uno de los cocontratantes, en sentido lato, con el fin de cobijar las fases precontractual, contractual y poscontractual, como se ha subrayado.

Así las cosas, el sobresalto, el viraje, el cambio comportamental registrado por el voluble, gravita alrededor de una o varias conductas precedentes que, por su relevancia intrínseca, generaron indiscutidos efectos en Derecho: la confianza legitima de uno de los celebrantes del contrato, tejida en el telar de la relación contractual con los hilos suministrados por las partes contratantes, titulares de la materia prima con arreglo a la cual se construyó el edificio negocial, ese que a raíz del sismo conductual se agrietó sensiblemente, y dejó de ser habitable, por expresarlo de esta manera.

Es el pasado, de ordinario, el punto de referencia para realizar la comparación o cotejo entre dos extremos: el antes y el después, entre lo acontecido ex ante y lo sucedido ex post, de tal manera que cuando se realiza el parangón, se hace tomando como venero uno o varios comportamientos que hunden sus raíces en lo pretérito, en ese ayer contractual, caracterizado por un específico entendimiento y por una determinada creencia, materia de subsiguiente alteración, digna, por regla, de ser rechazada, en tanto y en cuanto se verifiquen los presupuestos de la doctrina de los actos propios ${ }^{15}$.

El término acto propio, alude a algo que le pertenece a un sujeto, en este caso su pasado, en concreto la conducta o haz de conductas suyas que, en sede jurídica, generaron confianza, estado que reclama especial protección, como lo

15 Si bien es cierto no se requiere que transcurran décadas, lustros, o varios años entre una y otra conducta, lo cierto es que si debe transcurrir un término razonable susceptible de suscitar confianza, nervio de la protección brindada. Sin embargo, en cada caso particular corresponderá hacer la evaluación correspondiente. Quizá por ello el profesor Vittorino Pietrobon, expresa que "... podemos ver en la confianza el principio encaminado a tutelar un estado de fiducia en un hecho jurídico presente o pasado, no en un hecho o conducta futura". El error en la declaración del negocio jurídico, op. cit., p. 247. De igual manera, según lo confirma F. AstonE, "La coherencia de la persona implica 'constante fidelidad a una línea de conducta estable....." Por ello, indica el autor que es necesario resaltar "... la relevancia del elemento temporal, en relación con el comportamiento de la persona; la coherencia es valorada 'en el tiempo', o sea en fracciones temporales no irrelevantes". Venire contra factum proprium, op. cit., p. 41. 
hemos reiterado una y otra vez. De igual modo, el término contra, eslabón de la expresión 'venire contra factum proprium', es indicativo de que preexiste una realidad ontológica y jurídica, digna de respeto y acatamiento ${ }^{16}$. De ahí que, desde esta perspectiva, el pasado, lo acontecido, lo realizado precedentemente termine por atar, justamente por revestir relevancia e incidencia, como se anotó. Aquí no cabe entonces esa expresión popular, u otra similar, a cuyo tenor lo pasado, pasado está, pues lo hecho, hecho está, y el Derecho no puede desconocer esa realidad, máxime cuando se desplegaron efectos que exigen tutela, nada menos que una confianza que, por legítima y racional, demanda atención. El pasado, a su manera, siempre está presente.

En el espejo del ayer, en tal virtud, se reflejarán los actos que, por propios, no podrán ser desafiados en la actualidad o en el futuro, y sin que se impongan concretas secuelas, encaminadas a la inadmisión del ejercicio de los derechos por parte del sujeto que vanamente pretende borrar su pasado, del que es reo, como lo somos todos los mortales, a quienes se nos demanda coherencia, antítesis de la contradicción y la volubilidad, lo que nos impide, en un apreciable número de asuntos, desandar lo recorrido. Bien expresó Pablo VI que "No desprecies el recuerdo del camino recorrido. Ello no retrasa vuestra carrera, sino que la dirige; el que olvida el punto de partida pierde fácilmente la meta".

En esta temática, importa aclararlo, no tiene cabida aquella regla hermenéutica a cuyo tenor lo posterior prima sobre la anterior, mejor aún que, en un plano normativo, la ley posterior deroga la anterior (Lex posterior derogat legi priori), o que las disposiciones posteriores derogan las anteriores (Posteriora proribus derogant), que extrapolado a la esfera contractual, podría significar que lo efectuado con posterioridad a la celebración del acuerdo negocial, mutatis mutandis, debe imperar, perdiendo todo efecto vinculante lo efectuado con antelación (acto propio). Dicho de otro modo, desde esta perspectiva, podría pretender validarse el cambio registrado en función de la posibilidad y, por ende, legitimidad de

16 Bien observa Alejandro P. ScARso, que "El acento sobre la naturaleza 'contradictoria', 'contrastante', 'incoherente', 'incompatible' de la conducta indica que la prohibición del venire contra factum proprium envuelve una relación formal entre el comportamiento precedente y uno sucesivo. Los prefijos 'contra' e 'in' concretan la relación formal, evidenciando que la relación entre dichos comportamientos es una relación de negación". Venire contra factum proprium e responsabilitá, op. cit., p. 522. 
modificar lo acordado o actuado de consuno, dándole cabida al comportamiento o comportamientos ulteriores, sin ninguna secuela, entendimiento que a todas luces devendría errado, pues justamente lo actuado con anterioridad, constitutivo de un determinado estado de cosas: la confianza suscitada, ata, liga o vincula, y no podría ser entonces alterado por la vía de la derogación o modificación, no sólo porque sería unilateral, sino también porque lesionaría caros intereses de parte, que no pueden soslayarse y menos desprotegerse jurídicamente. En esta temática, pues, no resultan predicables tales regulae, dueñas de un significado y alcance disímiles, probándose una vez más que no se pueden enarbolar con un carácter absoluto, a fortiori cuando lo nuevo, lo transformado no siempre está llamado aplicarse sin fórmula de juicio, a pretexto, simple y llanamente, que es un posterius.

En general, suele apellidarse a este segundo presupuesto, de modo muy conciso-aun cuando muy amplio-, como la 'pretensión contradictoria,', queriendo con ello denotar el advenimiento de una conducta posterior objetivamente incompatible con una previa, ambas emanadas de la misma parte, en momentos distintos y con finalidades propias que, entre sí, abiertamente colisionan, a fortiori, cuando se esgrime o se acude a ella (la ulterior).

17 Recuerda el profesor chileno, Fernando FUEYO LANERI, que esta figura está condicionada a la existencia de "un acto posterior constitutivo de una pretensión jurídica", lo que significa que debe haber "... una nueva conducta o un nuevo acto.....: importa ejercer una pretensión jurídica por parte del mismo sujeto anterior....Tratándose de la pretensión, bueno es aclarar que no es sólo una pretensión considerada procesalmente y que involucra esencialmente un acto de reclamo ante un órgano que ejerce jurisdicción...Sin embargo, desde el punto de vista del 'venire cum factum proprium', la pretensión comprende no sólo declaraciones sino que, aún más, y de modo importante, conductas...Al referirnos a la teoría de los propios actos tomamos un concepto más amplio de lo que se entiende por pretensión......" La doctrina de los actos propios, op. cit., p. 315.

En sentido similar, se había pronunciado Don Luís DiEz-PICAZO, al expresar que "La regla, conforme a la cual nadie puede venir contra sus propios actos, significa..., que una pretensión contradictoria con la propia conducta es inatendible y ha de ser, si se traduce en una actuación judicial, desestimada. La inadmisibilidad de 'venire contra factum' no impide, pues, de una manera general, los cambios de parecer de una persona dentro de una situación jurídica. Veda únicamente aquellas 'pretensiones' que son contradictorias con el sentido objetivo de una conducta anterior. Que 'venire contra factum' viene a ser un límite a la pretensión, creo que es un extremo claro si se examina atentamente la jurisprudencia de nuestro Tribunal Supremo". La doctrina de los propios actos, op. cit., p. 217. 
No obstante lo anterior, como se ha expresado, hay que entender la expresión pretensión en un sentido que trasciende el marco estricto del Derecho procesal, como quiera que no se pretende restringir al proceso, a la litis propiamente dicha, el desenvolvimiento y la aplicación de la doctrina de los actos propios, como reacción al ejercicio de un derecho por parte del voluble o promotor del factum novum. Cabe entonces abogar por un entendimiento amplio del referido vocablo, en aras de no propiciar una lectura reduccionista ${ }^{18}$.

Por consiguiente, en función de la anunciada incompatibilidad conductual, es que se impone el rechazo del actuar incoherente, por manera que la pretensión esgrimida, lato sensu, el designio del sujeto voluble se torna inaceptable, amén de inadmisible, tanto en lo sustancial, como en lo procesal, según el caso, siendo entonces conducente desestimar su formulación e impedir que desplieguen sus efectos, in abstracto procedentes, pero in concreto perniciosos y huérfanos de equidad y razonabilidad. He ahí, en apretada síntesis, la razón de la secuela dimanante de un acto vacío de coherencia, y desconectado del postulado de la buena fe.

A emulación de lo precisado en punto tocante con el presupuesto que antecede, en lo pertinente, se requiere que la actuación incoherente, además de sorpresiva, sea inequívoca o paladina, con el objeto de que no se anide ninguna vacilación o duda. Por eso ha de ser meridianamente clara, en guarda de que la contradicción sea patente, y no ilusoria, borrosa, especulativa, o implícita, lo que no significa que deba ser un cambio estridente, explosivo, 'brutal' o grávido de espectacularidad, toda vez que el mismo, así sea aún tranquilo, puede ser decisivo (mutare), siempre y cuando sea inequívoco, que es lo que en rigor se requiere en esta particular esfera ${ }^{19}$. De otro modo, la regla venire contra factum propium, no tendría porque abrirse paso, ni tampoco censurarse el cambio de

18 En esta dirección, en forma análoga, la Dra. Nelida TUR FAUNDEZ anota que "La referencia a 'situación litigiosa' no implica necesariamente que se produzca en el seno de un proceso, sino que la expresión ha de entenderse en el sentido de que exista conflicto de intereses. Existirá dicho conflicto cuando sobre un objeto idéntico varias personas ocupan posiciones y mantienen posturas incompatibles". La prohibición de ir contra los actos propios y el retraso desleal, op. cit., p. 36.

19 Vid. H. Hobinavalona Ramparany-Ravololomiarana, Le raisonnable en droit des contrats, op. cit., pp. 301 y 304; Dimitri HoutcIEFF, Le principe de cohérence en matiére contractuelle, 
actuación, precisamente por sustracción de materia, así de simple, puesto que sin contradicción o incoherencia, no habría razón de aplicar ningún remedio, menos el que, por definición, supone una inarmonía o disfunción entre una actuación y otra: un prius y un posterius, como hemos puesto de manifiesto.

Por último, para no extendernos en demasía, vale la pena registrar que la contradicción, desde un punto de vista temporal, puede ser instantánea, es decir aflorar al mismo tiempo, sin solución de continuidad. Es el caso, muy socorrido por cierto, de la petición formulada por un cocontratante en el sentido de reclamar simultáneamente el cumplimiento -o ejecución- del contrato, y a su turno la resolución del mismo, amparada por el incumplimiento, pretensiones que entre sí riñen abiertamente, por ser opuestas y por minar la coherencia: o lo uno o lo otro, pero no las dos a la vez. Por ello se alude a la referida instantaneidad. Y también puede ser discontinua y escindible, en atención a que puede materializarse luego de haber creado un estado determinado: la confianza legítima y racional, vulnerándose entonces el acto propio, de suyo precedente en el tempus, hipótesis ésta que es la más común.

\subsection{IDENTIDAD DE SUJetos}

En tercer lugar, en el ámbito contractual, se requiere que entre los sujetos pertinentes haya identidad, vale decir entre las partes contratantes, una como actora (emisora o responsable de la actuación relevante) y otra como receptora (destinataria) respecto a las conductas o comportamientos adoptados.

Lo que se quiere significar con esta particular exigencia, por regla, es que medie simetría entre los sujetos que intervienen en el circuito negocial, es decir que el actor -o emisor- de las actuaciones con virtualidad jurídica, sea el mismo, tanto en relación con la primigenia o inicial, como en la subsecuente o ulterior, esta última constitutiva de un cambio o transmutación comportamental y, por tanto, indicativa de incoherencia o contradicción, de cara a la que, con antelación, a las claras, suscitó confianza y seguridad en cabeza de su destinatario.

op. cit, p. 966, y Mariana Bernal Fandiño. El deber de coherencia en el derecho colombiano de los contratos, op. cit, p. 206. 
Así las cosas, lo que se pretende es que la conducta constitutiva de un factum proprium, sea del mismo sujeto que a posteriori realiza el factum novum, percutor de la incoherencia y, de paso, de la vulneración de la confianza legítima en él radicada previamente.

En caso contrario, cuando abiertamente se interrumpe la señalada cadena o articulación, no podrá acudirse a la doctrina de los actos propios, pues se quebraría uno de sus presupuestos genéticos, de suyo signado por la más elemental lógica, puesto que si la actuación posterior no es realizada por el mismo sujeto que otrora generó la supraindicada confianza, mal podría hacerse algún reproche o censura, justamente por cuanto no se podría aludir, en estrictez, a desconocimiento de un acto propio (venire contra factum proprium), toda vez que la institución que nos ocupa supone un ejercicio hermenéutico enderezado a ponderar conductas o actuaciones y establecer si ellas se repelen por ausencia de coherencia intrínseca, valoración que exige entonces un parangón, una comparación de actuaciones de unos mismos emisores y receptores, sobre todo con relación al voluble, responsable de la contradicción y dueño tanto de una como de la otra.

De nuevo la expresión contra ('venire contra factum'), acompañada del vocablo propio (proprium), indican que en esta figura -o remedio-media un lazo personal de índole interna, referido al sujeto que, actuado sin solución de continuidad, se vuelve contra un acto suyo, anterior. Lo mismo acontece respecto al otro cocontratante, pues la floración de la confianza y su quebrantamiento ulterior, deben cobijarlo, con el fin de que brinde la protección necesaria.

La incoherencia en mención, en suma, implica pues que ella se predique de un mismo sujeto contractual (persona natural o jurídica). No mediando identidad intrínseca y extrínseca, en tal virtud, no habrá contradicción predicable, por falta de un dominus unicus, al mismo tiempo que por inexistencia de contradicción, propiamente dicha, la que presupone coincidencia ontológica y también jurídica.

Como lo manifiesta L. López Rodo, en términos generales, “...está absolutamente fuera de dudas que tiene el carácter de autor de un acto 'propio' la misma persona o sujeto de derecho que realiza el acto subsiguiente y contradictorio. Por lo tanto, si frente a un acto que hoy realiza o intenta realizar un 
determinado sujeto individual o colectivo, nos encontramos con que ese mismo sujeto realizó con anterioridad otro acto de significación contrapuesta, podremos decir que hemos tropezado con un 'acto propio', porque evidentemente merece esta calificación frente a su autor"20.

Esta es, a grandes rasgos, la regla básica que, en la jurisprudencia y en la doctrina campea, regla que, a juicio de un sector autoral, admite puntuales excepciones, motivo por el cual no le reconocen al presupuesto sub examine un carácter absoluto, pese a que el analizado con anterioridad es "...el supuesto más común; pero, pensando un poco, pueden visualizarse sin dificultad varios casos en que la doctrina puede aplicarse con un solo sujeto en común entre dos relaciones... Con todo se trata de supuestos excepcionales..." ${ }^{21}$, que no pueden extenderse en demasía, pues se distorsionaría la regla en referencia, que tiene asidero y lógica, como se mencionó.

Así sucede, por vía de ejemplo, en el campo del contrato de seguro, en donde es común encontrar, debidamente delimitados, dos contratantes propiamente dichos, quienes asumen el específico y delimitado rol de partes: el tomador, y el asegurador, no siéndolo el asegurado, ni el beneficiario, independientemente que puedan coincidir estas calidades en un mismo sujeto, en particular en el tomador, único cocontratante de la entidad aseguradora, stricto sensu. Puede darse entonces el caso de que el referido tomador-que en Colombia es la ".... persona que, obrando por cuenta propia o ajena, traslada los riesgos", art. 1036-, sea el que contrate, y sea, por lo tanto, en quien se depositó primigenia y preliminarmente la confianza, y otro el beneficiario, que es el titular de la prestación, y respecto del cual se gestó o incidió la actuación

20 L. López Rodo. Presupuestos subjetivos para la aplicación del principio que prohíbe ir contra los actos propios, op. cit., pp. 14 y 16, consideración ésta que en tratándose de la administración no siempre se proyecta igual, como lo reconoce el autor, dado que "...la palabra Administración tiene el significado genérico de 'conjunto de sujetos colectivos que ejercen la función administrativa'".

21 Marcelo López MeSA. La doctrina de los actos propios, op. cit., p. 122 y 124 . En sentido similar, el profesor Juan M. DoBson, expresa que no se “... precisa la presencia de un mismo recipiendario de la manifestación de voluntad en cada caso, sino que el contexto debe ser idéntico; para lo cual se requiere que la conducta anterior pueda ser interpretada en el sentido de afectar los intereses del litigante actual". El abuso de la personalidad jurídica, op. cit., p. 279. 
voluble, afectándose su derecho crediticio, hipótesis que habilita la aplicación de la doctrina de los actos propios, pues mal se haría en impedirla, en el entendido que es una práctica común, a la vez que absolutamente legal la escisión de las calidades mencionadas, conforme a las circunstancias, ora convencionales, ora legales (seguro de la responsabilidad civil, seguro sobre la vida -riesgo de muerte-, etc.). Pretextar lo contrario, sería tanto como estimular la inequidad; tolerar el quebranto de la buena fe, con todo lo que ello implica, y sembrar el abuso.

En el Derecho español, entre otros más, ocurre lo mismo, toda vez que como lo enseña con claridad Don Joaquín GARRIGUES, "Mientras en los demás contratos hay dos partes contratantes, sea en nombre propio, sea como representantes de otro, y esas partes contratantes, o sus representados son las que adquieren los derechos y las obligaciones derivados del contrato, la peculiaridad del seguro consiste en que el círculo personal del contrato se extiende a personas que no son contratantes ni representados por los contratantes. Quiebra aquí el principio de relatividad personal de contrato...Vulgarmente se habla de asegurado para contraponerlo a asegurador. Pero no debe entenderse a la manera como se contraponen el comprador y el vendedor, el arrendador y el arrendatario....En el contrato de seguro las cosas ocurren de distinta manera. El contratante con el asegurador asume siempre los derechos y las obligaciones del contrato. El contratante con el asegurador asume las obligaciones, pero puede no asumir los derechos....En definitiva, frente a la compañía aseguradora pueden estar una sola persona, o dos o tres personas distintas a las cuáles habrá que definir: asegurado será aquél cuyos bienes o cuya persona está expuesta a un riesgo; contratante del seguro será el suscriptor del contrato, que asume las obligaciones frente al asegurador, y beneficiario será aquel que tiene derecho a la prestación....”22.

Por último, a fin de obviar equívocos, es aconsejable no confundir la unidad de personas con identidad de sujetos, puesto que en puridad, no significan siempre lo mismo. Es probable que, no obstante en la cadena comportamental haber participado varias personas distintas, pueda aludirse a una unidad o identidad de

22 Joaquín Garrigues. Contrato de seguro, Aguirre, Madrid, 1982, pp. 68 y ss. Cfr. Fernando SÁnchez Calero. Ley de contrato de seguro, Comentarios a la ley 50/1980, de 8 de octubre, $y$ a sus modificaciones, op. cit., pp. 150 y ss. 
sujeto, a quien podrá finalmente imputársele la mutación y, por tanto, inadmitírsele el ejercicio de un determinado derecho (sujeto activo). ${ }^{23}$

\subsection{EXISTENCIA DE UN PERJUICIO REAL O POTENCIAL}

Ya para concluir ese aparte, debemos referirnos brevemente a la exigencia de un perjuicio, lesión o alteración, no con el objeto, recta via, de que sea reparado patrimonialmente, sino como presupuesto para que en la praxis devenga aplicable la doctrina del acto propio, a raíz de la floración de una conducta que, por sus connotaciones, se torna lesiva de caros intereses jurídicos: la confianza legítima y racional, el más sobresaliente de ellos. Al fin y al cabo, derechamente, este remedio no persigue el resarcimiento de los daños y los perjuicios ocasionados por el factum novum, así hagan presencia, según lo hemos anotado, pues ese no es su auténtico y prístino cometido, sin perjuicio de la convergencia de objetivos auxiliares o complementarios, in casu. Ello no quiere decir, en tal virtud, que sea procedente referir a la viabilidad de la doctrina sub examine, sin hacer referencia alguna a un perjuicio, ora real, ora potencial ${ }^{24}$, en cuyo caso estaríamos en el

${ }_{23}$ Así lo confirma Don Luís DiEz-PICAZo, en opinión de quien es procedente que "...sean personas distintas la que observó el comportamiento y la que posteriormente pretendió, pero que los actos sean jurídicamente imputables a un solo sujeto, caso en el cual existe diversidad de personas, pero una identidad de sujeto. En este punto, “... hay dos cuestiones importantes que conviene analizar: sucesión y representación. Estas dos cuestiones pueden anunciarse así: el causahabiente no pude ir contra los actos de su causante; el representado no puede ir contra los actos del representante. La doctrina de los propios actos, op. cit., p. 232.

Esta exigencia, por igual, tiene cabida tratándose de la verwikung, y para otros del retraso desleal, según lo señalaremos en el Cap. IV.

24 Según se pondrá nuevamente de presente, el propósito medular de la doctrina de los actos propios, es evitar o mitigar la irrogación de un perjuicio derivado del comportamiento contradictorio o incoherente del sujeto voluble, en cuyo caso tiene mucho sentido que se contemple como inequívoco límite al ejercicio de un derecho subjetivo. Así las cosas, como se decía, su objetivo no es resarcitorio, en rigor, sino mejor preventivo o de evitación. Por esa razón, es dable exigir, la existencia de un perjuicio, ora real, ora potencial, desde luego en sentido lato, sin que sea preciso, en tal virtud, que cumpla inexorablemente con los requisitos del daño indemnizable, propiamente dicho, toda vez que, se itera, el propósito no es el de indemnizar, sino evitar o mitigar el daño, hasta donde ello sea posible. Por eso es por lo que se afirma que basta con que el perjuicio sea meramente potencial; una amenaza de afectación, de lesión o alteración es pues suficiente para que sea procedente la inadmisión o rechazo del ejercicio de un derecho, pues se trata de la afectación, in potentia, de un interés jurídico digno de tutela; no más, temática esta que será de nuevo 
terreno de la evitación del mismo, de tanta significación en la actualidad, en la

examinada en el Cap. IV, con ocasión del estudio de la verwirkung, en un todo de acuerdo con la mejor doctrina y jurisprudencia.

Ahora bien, no sobra puntualizar que esta distinción entre daño, in genere, y daño indemnizable, in concreto, es en general de recibo, así existan importantes voces disidentes. Ciertamente, una cosa es la irrogación fenomenológica del daño o alteración y, otra muy diferente, es que a ese daño se sumen los requisitos que lo hacen indemnizable. Puesto en otros términos, en el mundo de lo físico e, inclusive, de lo jurídico, nada impide que se hable, de una parte, del daño en sí mismo considerado y, de la otra, del daño indemnizable, como aquel daño simple, al que se suman los requisitos de la reparación. Esta distinción ha sido acogida por la jurisprudencia y la doctrina, que se ha referido, de antaño, al daño como un fenómeno individual y ha advertido que a ese daño se deben sumar ciertos requisitos para su indemnización.

Así, por vía de ejemplo, el profesor Adriano De CupIs afirma que “... La vida diaria ofrece al observador más distraído el espectáculo de una serie múltiple y heterogénea de daños. Daño no significa más que nocimiento o perjuicio, es decir, aminoración o alteración de una situación favorable. Las fuerzas de la naturaleza, actuadas por el hombre, al par que pueden crear o incrementar una situación favorable, pueden también destruirla o limitarla. El concepto de daño se presenta, bajo este aspecto, sumamente amplio (...) determinar bajo qué condiciones el daño produce efectos jurídicos, es indudablemente una de las más graves tareas del legislador. Lo que no ofrece duda, es que en ningún tiempo y en ningún país, el derecho ha sentido la necesidad de reaccionar ante cualquier daño. De manera constante, puede observarse la exigencia de establecer un criterio de discriminación, adecuado para distinguir el daño, como hecho jurídico, del daño como simple fenómeno del orden físico, aunque aquel siempre se haya configurado como una especie de éste...". El daño. Bosch. Barcelona. 1977. pp. 81-83). Nótese cómo se diferencia, de una parte, al daño y, de la otra, al daño indemnizable, que es lo que justamente se hace en este requisito de la doctrina: se requiere del daño real o potencial, que es el que se pretende evitar, pero, por lo demás, no es imprescindible que en ese daño concurran los requisitos de su indemnización, toda vez que el propósito no es el de reparación, per se. Al fin y al cabo, hay daños que no son indemnizables, como el necesario.

La misma distinción fue acogida por la jurisprudencia, en particular por la colombiana, que sostuvo que “... El daño, entendido en sentido clásico, o sea, la lesión, detrimento o menoscabo de un derecho, interés o, incluso, un valor tutelado por el ordenamiento jurídico, es el primer elemento o presupuesto de la responsabilidad civil..." (Corte Suprema de Justicia. Sala de Casación Civil. Sentencia del 24 de agosto de 2009. Exp. 1054-01). Lo propio acontece con la opinión del profesor Javier TAMAYO JARAMILLO, para quien “... El daño, para que sea indemnizable, debe tener ciertas características. No basta que se produzca un perjuicio patrimonial o moral en cabeza de alguien para que este pueda demandar reparación. La acción está subordinada al lleno de algunos requisitos. Esas limitaciones están determinadas no sólo en consideración al perjuicio mismo, sino a la calidad jurídica de las personas que lo sufren..." Tratado de responsabilidad civil., op. cit., pp. 326 y ss. 
que prevención ocupa un destacado pape ${ }^{25}$, incluso en la órbita del venire contra factum proprium ${ }^{26}$.

No en vano, buena parte de su futuro reside en esta lectura preventiva, el que en nuestro entender luce esperanzador, además que plenamente acorde con su genuino cometido protector y anticipativo, el cual es aún más trascendente que el resarcitorio, stricto sensu. De ahí se deriva la valía de dotar al ordenamiento, en particular a sus agentes: los jueces, especialmente, de herramientas fiables que inhiban la materialización -o repetición- de conductas atentatorias de las buenas prácticas cívicas, al tiempo que negociales en lo que al entorno negocial se refiere, en un todo de acuerdo con las coordenadas y estándares jurídicos aplicables (buena fe, razonabilidad, etc.).

Por ello es por lo que, en línea de principio, refrendado la valía y, sobre todo, el futuro del venire en el Derecho comparado, podría estimularse su empleo en forma sostenida (tutela inhibitoria), habida cuenta que potenciar su utilización en el campo de la prevención, en efecto, resultaría de singular importancia ${ }^{27}$. He ahí,

25 No se equivoca el profesor Eugenio LlamAs PomBo, cuando acertadamente manifiesta que "...el derecho civil no puede conformarse con la mera respuesta reparadora frente al daño y renunciar a la prevención del mismo. Pretender que permanezca impasible ante la inminencia de un daño, de su agravación o su repetición es tanto como crear y justificar un derecho a perjudicar". La tutela inhibitoria del daño. La otra manifestación del derecho de daños, en La responsabilidad profesional y patrimonial y el seguro de la responsabilidad civil, op. cit., p. 427. Ni tampoco el profesor argentino Daniel PIZARRo, al reconocer "... la enorme importancia económica y jurídica de los remedios preventivos, como función irrenunciable del derecho de daños. Siempre que sea razonablemente posible, debería ser mejor para todos prevenir que curar". El daño moral, Depalma-Hammurabi, Buenos Aires, 2004, p. 470.

26 Cfr. Anderson Schreiber, quien teniendo en cuenta la posibilidad de que se evite un daño a través de la aplicación de este remedio, puntualiza que "...la prohibición de un comportamiento contradictorio tiene también un carácter primordialmente preventivo... En el ámbito del derecho civil, entre otras medidas, se tiene establecida una importancia cada vez mayor de los instrumentos de prevención de los daños, y el nemo potest venire contra factum proprium se sintoniza con esta tendencia". A prohibiçao de comportamento contradictório. Tutela da confiança e venire contra factum proprium, op. cit., p. 164.

27 Vid. Alessandra BeLleLLI, quien reconoce la tendencia creciente... a darle espacio a la aplicación de la tutela inhibitoria, incluso fuera de las hipótesis típicas legislativamente previstas", así como la indubitable "...naturaleza preventiva del remedio" emergente de la misma, el que por excelencia mira al futuro. "L'inibitoria como strumento generale di tutela contro l'illecito, en Rivista di Diritto Civile, Padova, 2004, N 1, pp. 607, y ss. En sentido similar, la profesora Mariana BeRnAL F., indica que “... el propósito último de las medidas 
grosso modo, un insoslayable reto para esta figura en el porvenir, en especial en el ámbito del contrato, en orden a asegurar la justicia contractual, dotando de mecanismos útiles y céleres a los cocontratantes que, en procura de la evitación de perjuicios, estarían habilitados para demandar del juez un pronunciamiento oportuno al respecto.

El menoscabo o quiebre de la confianza legítima (ratio protectionis del venire contra factum proprium), su vulneración frontal, engendra pues unas puntuales secuelas, una de ellas, la gestación de un perjuicio, lesión o alteración de un interés digno de tutela en algunos supuestos, o la inequívoca amenaza de que se geste, no siempre de contenido patrimonial, de tal suerte que una u otra hipótesis, el nocimiento será punto de referencia: real o potencial, a fin de que el sujeto llamado a escrutar el haz conductual (conducta pretérita y posterior), evalúe su entidad y virtualidad, con el objeto de neutralizarlo o de evitar su ocurrencia, a través del rechazo de la pretensión por parte del sujeto activo (voluble), mejor aún de la inadmisión del ejercicio de un derecho (lato sensu), el cual puede ser a todas luces contraproducente, amén que lesivo de caros intereses del sujeto pasivo, titular de la confianza resquebrajada -o rota- ${ }^{28}$. Por ello, mutatis mutandis, en este caso podemos hablar de un perjuicio consistente en "...la lesión de la confianza", a emulación de lo que, en sentido amplio, acontece en otras esferas ${ }^{29}$.

o mecanismos enderezados a detener el ejercicio de la pretensión contradictoria es evitar que con tal comportamiento se causen daños a uno de los contratantes, derivados de la lesión o menoscabo de sus bienes o intereses como consecuencia de la vulneración de la confianza que había depositado en el mantenimiento de la conducta inicial del otro contratante. En ese sentido, cabría la posibilidad de considerar dentro de las medidas encaminadas a enervar el ejercicio de una pretensión contradictoria, en un sentido amplio, aquellos mecanismos que en el derecho comparado se han desarrollado para prevenir la causación de daños. Tal es el caso de la figura inglesa de la injuction o del mecanismo que la doctrina del derecho de daños español e italiano, así como argentino y brasilero, conocen como la tutela inhibitoria del daño...". El deber de coherencia en el derecho colombiano de los contratos, op. cit., p. 341.

28 Cfr. Anderson ScHREIBER, quien indica que “...la aplicación del principio de la prohibición del comportamiento contradictorio se justifica ante la presencia de un daño, o de una amenaza de un daño a otro". A prohibiçao de comportamento contradictório. Tutela da confiança e venire contra factum proprium, op. cit., p. 247; Joao BAPTISTA MACHADO, Tutela da confiança e venire contra factum proprium, op. cit., p. 365, y Fiorenzo FESTI. I/ divieto di venire contra factum proprium, op. cit., p. 107.

29 Vid. María Rosaria MARella y Luca Cruciani, "II danno contrattuale", en II nuovo contratto, Zanichelli, Bologna, 2010, pp. 1152 y ss. 
Si el factum novum, es anodino, ayuno de toda virtualidad jurídica, en rigor, no podrá hablarse del advenimiento de un perjuicio cierto o potencial, base de la actuación del juez, aún ex officio, entre otros motivos por cuanto si no se altera, lesiona o afecta un interés jurídico, en el supuesto sub examine: la confianza (ratio protectionis), no habrá nada que rechazar, censurar o inadmitir ${ }^{30}$. Es justamente con estribo en dicho perjuicio, corolario del quebranto de la confianza previamente suscitada, que se impone la protección de los derechos y prerrogativas del sujeto pasivo, lesionado desde dicha perspectiva, así sea necesario aludir, en algunas circunstancias, a un daño con connotaciones especiales, pero en todo caso con la entidad suficiente para que amerite la condigna reacción del ordenamiento. No en vano, el venire contra factum proprium, es un remedio, un instrumento llamado a conjurar una alteración comportamental nociva, a fuer que objetiva, que de otra manera no requeriría o plantearía un correlativo rechazo, pues sin lesión o alteración de una situación jurídica preexistente -in actus o in potentia-, no habrá piso para justificar la actuación del iudex, ora preventiva, ora correctiva o remedial. Al fin y al cabo, como lo recuerda Înigo DE LA MAZA G., "... no toda confianza debe protegerse....sólo recibe protección jurídica, quien la merece"31, idea refrendada por la Dra. RAMPARANY-RAVOLOLOMIARANA, quien expresa que "... la incoherencia debe ser sancionada únicamente cuando ella ha perjudicado a otro con motivo de la operación contractual"32.

30 Bien expresa el profesor G. ORDOQUI, en concordancia con el nervio del concepto contemporáneo del perjuicio: el interés jurídicamente protegido, que "Los bienes no se tutelan en sí ni por sí sino en la medida en que su alteración afecte un interés...Superar la identificación del daño con la lesión de un derecho subjetivo y admitir que el mismo surge de la afectación de un interés, supuso superar una visión positivista, legalista..... Por ello “...debe considerarse el significado del término interés en sentido amplio, abarcativo de todo lo que se refiere a valores, ventajas o posibilidades de disposición, reflejadas en aspectos personales y patrimoniales". Derecho de daños, La Ley, Montevideo, T.I, 2012, p. 219. En análoga dirección, el doctrinante Eduardo ZANNONI, reconoce que "El daño lesiona un interés y por ende priva al sujeto de esa facultad de actuar...La lesión de ese interés -cualquiera sea éste- produce, en concreto un perjuicio". El daño en la responsabilidad civil, Astrea, Buenos Aires, 1982, p. 15.

31 Iñigo De La Maza GazmuRI. Los límites del deber precontractual de información, op. cit., p. 315.

32 H. Ramparany-Ravololomiarana, Le raisonnable en droit des contrats, op. cit., p. 301. Cfr. D. HoutciefF, Le principe de cohérence en matiére contractuelle, op. cit., p. 746. Como bien lo memora el profesor Domenico BARBERO, con carácter más general, "Si el agresor no existe no sería tampoco del caso pensar en protegerse", de tal suerte que si no se agrede la confianza en cuestión, mal se haría en abogar por un remedio tuitivo. Sistema del derecho privado, EJEA, Buenos Aires, T.I, 1967, p. 170, en cuyo caso no se podría evidenciar, in 
Es en este último sentido que hablamos de la presencia o de la amenaza de un daño -o perjuicio-, entendido en un sentido amplio, a fin de no sacrificar supuestos especiales dignos de tutela, esto es como la lesión, alteración o menoscabo de un interés jurídico digno de protección, pues como sintéticamente lo corrobora el profesor G. ALPA, “...daño es la lesión de un interés protegido y se agota en esto" 33 . Tiene razón entonces el profesor chileno Gastón SALINAS UGARTE, al referirse a la "concepción amplia" del daño en los siguientes términos: “...el concepto jurídico de daño no difiere del concepto común y corriente de éste y corresponde: a la disminución o privación de una ventaja. El daño, entonces, es concebido como la lesión de un simple interés, donde este viene a ser [siguiendo a DE CuPIS], 'la posibilidad de que una necesidad experimentada por uno o varios sujetos determinados venga satisfecha por un bien'. La frustración de esa posibilidad, sea por la destrucción del bien o por cualquier otra causa, es lo que constituye daño. Es decir...., daño es la lesión de cualquier interés que le corresponda legítimamente a una persona". ${ }^{34}$

En síntesis, evitar la irrupción de un perjuicio; obviar que este siga reiterándose y extendiéndose, o aminorar su impacto, entre otras posibilidades más, es el

actus, "...una posición de favor, de preeminencia", como lo menciona el profesor de la Universidad de Roma Giuseppe BRANCA, en orden a que cabalmente se pueda aludir a un “...interés protegido". Instituciones de derecho privado, Porrúa, México, 1978, p. 15.

33 Guido ALPA, autor que, in complexu, expresa que “...daño no es ya, en la conciencia social, ni en la praxis jurisprudencial, ni en las propias intervenciones legislativas, un simple detrimento del patrimonio de la víctima del ilícito: daño es la lesión de un interés protegido y se agota en eso". Nuevo tratado de responsabilidad civil, Juristas Editores, Lima, 2006, p. 773. En orientación análoga, el profesor Jorge MossEt ITURRASPE puntualiza que "... habrá daño cuando se lesione un derecho subjetivo o una facultad". Responsabilidad por daños, T.I, op. cit, p. 253. Lo mismo hacen, en su esencia, los profesores Geneviéve VINEY y Patrice Jourdain, al indicar que "El perjuicio es la lesión de un interés". Traité de droit civil. Les conditions de la responsabilité, L.G.D.J., Paris, 2006, p. 15.

Por su parte, Renato Scognamiglio, estima que “... el daño coincide en todo caso con la lesión de un interés o con la alteración in peius del bien idóneo para satisfacer aquél o con la pérdida o disponibilidad o del goce de un bien que por lo demás permanece inalterado, como ocurre en supuestos de sustracción de la posesión de una cosa. "Risarcimento del danno", en Novissimo Digesto Italiano. Vol. XVI. Torino. 1969. p. 7.

34 Gastón SALINAS UGARTE, autor que bien reconoce que esta postura, cabalmente entendida, "...no significa entender que la lesión de cualquier interés deba considerarse daño. Por lo mismo, el concepto amplio de daño también tiene un elemento jurídico..... Por eso "Daño es toda lesión o menoscabo que sufre una persona en un interés legítimo propio". op. cit, T.l, pp. 304 y ss. 
propósito neurálgico de la aplicación de la doctrina del acto propio ${ }^{35}$, como quiera que a raíz del advenimiento de una o de varias conductas contradictorias, rayanas en la incoherencia, se altera la confianza legítima y racional otrora depositada en un sujeto, v.gr: el cocontratante, alteración que además de lesionar un interés jurídico pasible de tuición, nada menos que la confianza, que la fides misma, frustra la expectativa negocial, detonante de la celebración del contrato y base de su desenvolvimiento.

El referido resarcimiento, en rigor, no será entonces el norte del factum proprium, así se procure por otra senda conjurarlo, mediante la radical condena de la incoherencia, acompañada de la mencionada inadmisión del ejercicio del derecho (remedio preventivo). Empero, conforme a las circunstancias, por una vía diferente, el perjudicado, el asaltado en su buena fe, el que ha sido defraudado en la confianza depositada en su oportunidad y, por ende, lesionado, naturalmente podrá perseguir el resarcimiento cabal y pleno de todos y cada uno de los daños ocasionados, en desarrollo del arraigado principio del neminem laedere, obviamente en el entendido de que se reúnan todos los requisitos para que el perjuicio irrogado devenga indemnizable.

\section{PRINCIPALES CARACTERÍSTICAS DE LA DOCTRINA DE LOS ACTOS PROPIOS}

\subsection{Preliminares}

La doctrina de los actos propios, sin perjuicio de que cada día se decanta y se arraiga más en el concierto internacional, ya es dueña de características, signos característicos o simplemente rasgos propios que, en su conjunto, se aúnan con el inequívoco propósito de perfilarla y dotarla de personalidad, a la vez que de una anatomía especial, llamada a proyectarla y hacerla conocer

\footnotetext{
35 A este respecto, la Sala de Casación Civil de la Corte Suprema de Justicia colombiana, tuvo ocasión de afirmar de la doctrina del acto propio que su “... fin, esencial es evitar que con ese cambio de actitud, con esa rectificación se genere un perjuicio a quien despertó alguna expectativa válida por la conducta desplegada anteriormente, es, en otras palabras, dejar incólume la confianza fundada en ese antecedente..." (Corte Suprema de Justicia. Sala de Casación Civil. Sentencia del 24 de enero de 2011).
} 
mejor, no en su silueta, sino en su integralidad. Dichos rasgos, en lo esencial, resultan igualmente predicables de la regla 'venire contra factum proprium non valet', más allá de puntuales matices y algunas especificidades, conforme se indicará más adelante, con ocasión de su análisis en el enriquecido Derecho comparado, de ninguna manera lo suficientemente sustanciales para sustraerlas de un propósito común y unívoco: rechazar la incoherencia, la contradicción y la incongruencia ilegítimas.

Por lo tanto, nos ocuparemos de algunas de estas características, por de pronto las más salientes, sin que nuestro deseo estribe en la exhaustividad.

\subsection{ORIGEN Y DESARROLLO DOGMÁtICO, PRETORIANO Y RECIENTEMENTE NORMATIVO}

En armonía con lo manifestado en diversas ocasiones por nosotros, hay que memorar que lo que hoy denominamos como doctrina de los actos propios, es el corolario de su embrionaria aplicación, primigeniamente, a puntuales casos o hipótesis, como aconteció en el Derecho romano clásico, según lo pusimos de presente también en su momento (procedimiento casuístico, Cap. I), y después, en el Derecho medieval adquirió más fisonomía y corpus dogmático (venire contra factum proprium non valet), y así, con el transcurso de los siglos, se convirtió en lo que es ahora, gracias al aporte del binomio doctrina, y jurisprudencia, es decir a la contribución del docto Derecho de juristas y a la doctrina de los jueces, sobre todo en los siglos XX y XXI, no así del legislador local -o aún global-, quien no lo ha regulado, ni desarrollado aún, por lo menos expresa y definidamente (salvo uno que otro caso puntual y aislado que mencionaremos luego, Cap. V), lo que explica que, en puridad, sea hija de la academia, rectamente entendida y de la judicatura, paternidad para nada despreciable.

Ya llegará el momento, no muy lejano por cierto, en que el legislador, sabedor de sus múltiples bondades, le dará plena cabida normativa, con un carácter general, impulsado por la mejor doctrina y por la jurisprudencia, según ha tenido lugar en innúmeras ocasiones y en diferentes ámbitos del Derecho. Al fin y al cabo, desde esta perspectiva, la misión de una y otra es más preparatoria, a manera de una especie de laboratorio iuris, en el que por un prolongado espacio de tiempo se corroboró su pertinencia y efectividad. 
Así, por lo demás, ha acontecido en otras latitudes, especialmente con el estoppel, con la verwirkung, y con la rechtsverwerking, según se señalará, como quiera que su génesis, esencialmente, ha sido jurisprudencial, con el respaldo y acompañamiento de la doctrina, en general, como aconteció, en lo pertinente, y con las limitaciones de la época, con el referido Derecho romano clásico, obra de jurisprudentes (jurisprudencia clásica).

Lo anterior no quiere decir, conviene aclararlo de antemano, que en las diversas codificaciones no existan preceptos individuales que, in claris, evidencien el repudio a la contradicción, a la incoherencia, a la inconsonancia comportamentales, pues los hay, en muestra de la importancia de la regularidad, la constancia y de la coherencia en la vida jurídica y en la cívica. Otra cosa es que no exista un tratamiento específico, una categoría legis destinada, sistemáticamente, a exigir tal comportamiento o a reprochar el contrario, el que no por ello está tolerado, entre otras razones por la aplicación del postulado de la buena fe, como se señaló, su fuente generatriz y primaria.

Por consiguiente, no ha sido el telar del legislador el responsable de su tejido y consecuente aparición y posterior desarrollo, circunstancia que, si bien le da cierta movilidad, como ocultarlo, también genera alguna indefinición e incertidumbre, al mismo tiempo que no evita o zanja algunas discusiones que, en la doctrina y en la jurisprudencia, no han podido ser resueltas aún, pues no puede desconocerse el carácter de unidad y de uniformidad que imprime la ley, una de sus más típicas bondades, a la par que sólidos argumentos que militan en pro del Derecho escrito, frente al consuetudinario o jurisprudencial. De ahí que no pueda soslayarse el status brindado por el Derecho escrito, en particular por una legislación más envolvente, preferiblemente por un código encaminado a buscar la unidad y la cohesión del sistema jurídico correspondiente, así la codificación, desventuradamente, esté atravesando por dificultades serias en los tiempos que corren, atribuibles a la fenomenología de la 'descodificación', en gran medida, hecho que nos hace anhelar la recodificación del Derecho, cada vez más necesaria, así sea con arreglo en otras pautas y esquemas ${ }^{36}$.

36 Vid. Natalino IRTI. La edad de la descodificación, Bosch. Barcelona, 1992; Eugenio LLAmAS Pомво. Orientaciones sobre el concepto y el método del derecho civil, op. cit., pp. 110 y ss., y Fernando HINESTROSA. "Codificación y dispersión normativa", en Realidades y tendencias 
Además, la ausencia preceptiva o normativa, origina que, de algún modo, la figura en examen, específicamente su aplicación, quede como al arbitrio del hermeneuta, hecho que, en la praxis, ha conducido a que, en no pocas oportunidades, no se aplique o se aplique incorrectamente, a lo que es necesario agregar, en honor a la realidad, que ello tiene lugar, en parte, por su falta de conocimiento o divulgación, justificándose entonces todos los esfuerzos que se hagan con este confesado propósito informativo, de veras plausible. Bien decía Don Andrés Belto, el sabio 'codificador de América', autor del Código Civil Chileno -adoptado en Colombia y Ecuador-, que "conocimiento es poder". Y a fe que tenía, y sigue tendiendo la razón.

No obstante lo anterior, hay que reconocer que, aun cuando su explicitación o reconocimiento ex lege seguramente aparejaría beneficios, como lo creemos nosotros, no puede soslayarse el papel fundamental desempeñado por doctrina y jurisprudencia, artífices de todo lo que se ha construido hasta el presente, sin duda relevante, no sólo en la esfera del Derecho privado, sino en otras disciplinas de amplio espectro, v.gr: el Derecho constitucional y administrativo. Un reconocimiento anticipado y sin ambages, en tal virtud, amerita tan encomiable laborío, más allá de que, como es natural, aún falte camino por transitar, pues como repetidamente lo hemos dicho la figura sub examine está en plena maduración, luego de haber llegado a la mayoridad. Está pues en su primavera iuris.

De igual manera, hay que señalar que, en este campo, el eco jurisprudencial y doctrinal ha comenzado a rendir sus frutos, pues como suele suceder con numerosas figuras, materia de primigenio escrutinio académico y judicial, el legislador se está interesando en la doctrina de los actos propios, en particular, o en el venire contra factum proprium, en general, según se advirtió. Prueba de ello, lo constituye la Convención de Viena en materia de compraventa internacional, ratificada por un elevado número de naciones, e incorporada a los derechos internos correspondientes, por vía de ejemplo en España y en Colombia ${ }^{37}$, así

del derecho en el siglo XXI, T. IV, Universidad Javeriana y Editorial Temis, Bogotá, 2010, pp. 3 y ss.

37 En España, la adhesión se produjo el 2 de mayo de 1972 (BOE- 1980-11884). Y en Colombia, mediante la Ley 406/97. 
como la principialítisca contractual existente en la actualidad, v.gr: en tratándose de los conocidos principios de Unidroit, en su última versión de 2010, tal y como a espacio lo desarrollaremos en este estudio al momento de analizar la recepción normativa de la doctrina del factum proprium, toda vez que lo han elevado a regla especial (Cap. V) ${ }^{38}$.

Otro tanto sucede en punto a varios anteproyectos de ley que, ex professo la arropan en su corpus, v.gr: los anteproyectos de códigos civiles de las Repúblicas de Argentina y Perú, ambos de la presente centuria, como igualmente se resaltará.

\subsection{Proyección eXtrajudicial Y JUdicial}

Si bien la usanza es que la doctrina de los actos propios, concretamente lo que atañe a su posible aplicación, se ventile en el marco de un proceso judicial, incluido el arbitral, claro está, nada obsta que, en sede extrajudicial, se ausculte su conducencia, y se deriven puntuales consecuencias. Otra cosa distinta es que quien puede inaplicar el derecho subjetivo del voluble o del versátil, la denominada 'pretensión contradictoria', normalmente sea un juez -o un árbitro-, obviamente con auctoritas e imperium.

Efectivamente, la regla general en esta materia es que la doctrina en cuestión se examine en sede judicial, por manera que la señalada 'pretensión' deberá formularse en las oportunidades procesales pertinentes, con miras a que el juez, en su momento, o sea en la sentencia, desate la controversia sometida a su consideración, para lo cual deberá atender la argumentación esgrimida por uno y otro sujetos en torno a la aplicabilidad de la doctrina de los actos propios, en particular por la irrupción indeseada de la incoherencia comportamental. Empero, habrá hipótesis en las cuales el intérprete no sea un típico juez, pero

\footnotetext{
Anticipemos, con la venia del lector, el contenido del elocuente art. 1.8 de los principios de Unidroit, según el cual: Artículo 1.8 "(Comportamiento contradictorio. Venire contra factum proprium).Una parte no puede actuar en contradicción a un entendimiento que ella ha suscitado en su contraparte y conforme al cual esta última ha actuado razonablemente en consecuencia y en su desventaja". Otro tanto sucede con el denominado 'Marco común de referencia', artículo I-1:103 (2), el que reza que "...resulta contrario a la buena fe que una parte actúe de forma inconsecuente con sus previas declaraciones o conductas, en perjuicio de la otra parte que ha confiado en ellas".
} 
si un funcionario administrativo dotado de determinados poderes, por vía de ilustración de policía administrativa (órganos de control y vigilancia), los defensores -o Ombudsman- de los clientes (defensor del cliente, del asegurado, etc.), en desarrollo de las funciones conferidas en algunas naciones, entre otros más ${ }^{39}$.

En el campo de la dogmática, por muchos lustros, se sostuvo que, en rigor, la aplicación y cabida de la doctrina del acto propio se limitaba al proceso, como escenario calificado, según algunos aún lo hacen, y como tiene lugar en tratándose del estoppel, en el Derecho anglosajón, conforme se examinará más adelante (Cap. IV). Sin embargo, con gran realismo y sindéresis, otro sector autoral, hoy mayoritario, entiende todo lo contrario, es decir que en una y otra hipótesis resulta de recibo ${ }^{40}$, más allá de su frecuencia, que es un tema en sí mismo disímil, tesis que cuenta con nuestra explícita adhesión, pues en los tiempos que corren, y aún en anteriores, no se comprende o comprendía la razón de prohijar una postura tan reduccionista, a sabiendas que la ratio del instituto en comento, estriba en la inadmisión del acto incongruente y, de paso, contradictorio, cualquiera que sea su sede, o entorno. Lo que es contrario a la buena fe, a la coherencia, a la confianza, a la apariencia, esencialmente, no puede germinar, haya o no un litigio. Por eso, entonces, no debe dársele pábulo a la incoherencia, a la contradicción, así aflore en la periferia del proceso, o con prescindencia del mismo, el que es posible, incluso, que jamás se incube o inicie.

Otra cosa diversa es si la coherencia, en el plano del proceso, cuando este es promovido, debe o no hacer presencia a lo largo del mismo, encontrando

39 La Corte Constitucional colombiana, en sentencia del 10 de mayo de 2002, en este mismo sentido, expresó que "El respeto al acto propio, que tradicionalmente ha estado atado a la prohibición de revocatorias unilaterales, es un concepto ético del derecho, que tribunales y juristas deben tener en cuenta, por el alto valor que con él se defiende, pero se predica también de operadores jurídicos como lo son para este caso, las Fuerzas Militares, en una de sus dependencias, al interpretar las normas que pretenden aplicarle al demandante".

Al amparo del artículo 116 de la Constitución Política colombiana, se tiene establecido que "Excepcionalmente la ley podrá atribuir función jurisdiccional en materias precisas a determinadas autoridades administrativas".

40 Cfr. Fernando FueYo LANERI, quien observa, con razón, que la “...pretensión puede ser tanto judicial como extrajudicial, puesto que puede plantearse no sólo en un procedimiento judicial sino también como oposición a un requerimiento promovido al margen de un pleito". La doctrina de los actos propios, op. cit., p. 315. 
afirmativa la respuesta, pues las partes deben comportarse de la mejor forma posible en sede judicial, o sea en forma leal, considerada, solidaria y proba. Tanto que su conducta, como es más que comprensible, debe ser escrutada, amén que valorada por el juez - de quien también se espera coherencia-, quien de acuerdo con la ciencia procesal moderna, deberá darle especial y cumplida consideración, pues no puede convertirse en cómplice de la misma, así sea en forma tácita, lo que refrenda la importancia que el juzgador responsable hoy tiene, desde luego aún más que la tenía cuando era 'boca de la ley', únicamente, etapa hoy felizmente superada ${ }^{41}$.

\subsection{Carácter esencialmente objetivo de LA Conducta objeto de VALORACIÓN}

Conforme tangencialmente se ha podido advertir en líneas anteriores, específicamente con motivo de la alusión a algunas opiniones doctrinales, se tiene definido, es la regla, que la conducta primigenia, es decir la que suscita confianza y seguridad preliminar en el destinatario o receptor de la misma (factum proprium), en asocio con la ulterior o ulteriores (factum novum), debe ser auscultada objetivamente, con total prescindencia de consideraciones de índole interna o subjetiva, que no son de recibo en este cotejo. De ahí que sea objetivo, como quiera que lo que importa, en realidad, es que aflore y que se haga cognoscible la contradicción, detonante de la defraudación de la confianza, sobrando entonces análisis de otra estirpe, v.gr: de índole volitiva, culpabilística, etc.

Lo relevante, efectivamente, es que la actuación del cocontratante respectivo sea lo suficientemente determinante, tanto que, por su fuerza, dinámica, poder persuasivo y alcance, haya influido en el juicio y en la correspondiente, a fuer que correlativa actuación del otro extremo de la relación jurídico-negocial, según el

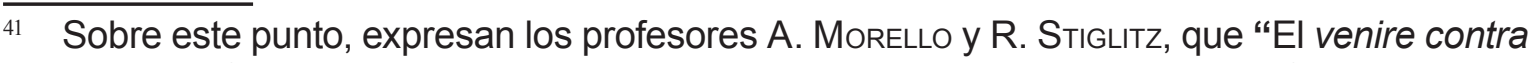
proprium factum no opera, por consiguiente, nada más que en la ancha esfera negocial o cuando se abusa de una quietud, tolerancia o cortesía incompatibles con la conservación y vigilancia activa debidas por el acreedor para que no se extingan o caduquen derechos que la parte beneficiada razonablemente pudo entender que no serían activados. Se reproduce igualmente dentro de sus propias configuraciones, en los actos del proceso en donde también es imprescindible tener en cuenta si lo que se va actuando se corresponde con las reglas admitidas sobre lo que es recto y honesto o erosionan las consecuencias que son conformes a la buena fe", La teoría del acto propio, op. cit., p. 73. 
caso, bien por acción, bien por inacción, así ella resulte equivocada. Ello explica que se estime que dicha conducta deba ser vinculante de cara al receptor o destinatario de la misma (sujeto pasivo), pues esa es la justificación que le sirve de apoyatura al instituto en cita, el que persigue, precisamente, en guarda de la buena fe, que la parte que confió, que depositó su confianza en la otra, no se perjudique por ello, no se vea lesionada por creer o confiar, como corresponde en tratándose de las relaciones del tráfico inmersas en una sociedad civilizada, también como ya se advirtió por nosotros.

Partir de la presunción contraria sería invertir los valores y el curso ético y jurídico de los acontecimientos, a la vez que sembrar y cosechar el caos, y la anarquía iuris. ¿Qué sería del Derecho y de la convivencia humana, si siempre, esto es sin excepción de ninguna especie, como ya lo expresamos en términos similares, se partiera del presupuesto de que en toda actividad interviene la maldad, el engaño, el abuso, la perversidad, la codicia, entre otras disfunciones de los seres vivos?

Lo diciente, por lo tanto, estriba en ubicarse en la posición del destinatario, en sede de la apariencia creada, según el caso, y no en la del emisor o actor, con el fin de valorar el impacto derivado de la conducta llamada a inculcar la referida confianza, detonante, a su turno, de la actuación del destinatario que, de otro modo, no se hubiera materializado, a la vez que objeto de celosa salvaguarda, una vez aflore el ulterior proceder a cargo del voluble, de ese sujeto que, no obstante haber sido depositario de la fides de otro, terminó contrariando su acto o actos propios de factura anterior (venire contra factum proprium), suscitando sorpresa, desazón y perplejidad por tan pendular actuación ${ }^{42}$.

42 Conforme lo puntualiza acertadamente el autor Rubén H. CompaGnUcCl, en “...la doctrina que analizamos lo que importa es lo que los actos revelan por el sentido objetivo que poseen, es esa representación en sentido vulgar que otorga el comportamiento del sujeto", La doctrina de los propios actos y la declaración tácita de voluntad, op. cit., p. 2. Por eso, indica la doctrinante Ana I. PIAGGI, que "Como se ha encargado de precisarlo la doctrina, la inadmisibilidad del 'venire... se produce objetivamente, con prescindencia del grado de conciencia o conocimiento que haya tenido el agente al actuar. Cualquiera que fuere la voluntad que haya presidido o impulsado esos actos, ellos han suscitado en el círculo de los interesados una confianza fundada, respecto a los que significan como actitud del sujeto dentro de la relación jurídica. Consecuentemente el sujeto debe responder por las consecuencias de la confianza suscitada. En otros términos, no interesa que pueda imputársele al sujeto dolo o culpa por su proceder, lo decisivo es la desarmonía objetiva 
Es pues esa situación jurídica, la que deberá ser tomada muy en cuenta, con un carácter absolutamente objetivo, pues a partir de ella, se desencadenaron actos llamados a trascender en el cosmos jurídico y, de ordinario, en el terreno patrimonial, no exento de serias repercusiones -no por materiales ayunas de relevancia, sin importar, realmente, si el actor o el emisor, como se prefiera, actúo deliberadamente, o sin intención, como también se precisará. Al fin y al cabo, es el hecho externo mencionado el que debe orientar cualquier decisión del juzgador, o del llamado a evaluarlo, sin adentrarse en otras consideraciones, a la postre situadas en otro plano. Lo esencial es la confianza infundida, sentir que el camino trazado por el cocontratante, virtual o aparentemente, es el correcto, así después aflore el consabido desengaño y el más profundo desconcierto, en cuyo caso se resquebrajarían la confianza y, por reflejo, la apariencia creadas, como hemos dicho tantas veces, dignas de eficiente y cumplida tutela.

La brújula, en compendio, debe apuntar a la gestación de un hecho netamente objetivo: el alumbramiento de la incoherencia, activador de alteración de la confianza en mención, sin detenerse en otro tipo de consideraciones subjetivas que podrían extraviar el rumbo del hermeneuta o del sujeto que tiene la elevada responsabilidad de salvaguardar la justicia contractual, y en concreto proteger las situaciones creadas en el marco de la buena fe: la indicada confianza, otrora despertada en el sujeto pasivo del acto propio, ese que creyó en su cocontratante, y que se desengañó luego del mismo, por haber quebrantado la regla de oro de la regularidad comportamental (buena fe constancia), y por haberse tomado por asalto la relación contractual, en sentido figurado.

\subsection{No SE EXIGE QUE LA CONDUCTA DEL SUJETO ACTIVO SEA INTENCIONAL O CULPOSA}

A tono con la característica anterior, íntimamente ligada con la presente, es de señalar que no es imperativo que la conducta originaria sea intencional o premeditada y, por tanto, realizada con animus nocendi, pues simplemente basta con la creación de una situación jurídica objetiva (apariencia o 'representación' iuris), sin que resulte menester que se anide la intención, el frío designio de dañar,

con el estándar de conducta concretado". Reflexiones sobre dos principios basilares del derecho: la buena fe y los actos propios, op. cit. 
o menoscabar intereses ajenos, de suerte que, a diferencia de lo que suele expresarse en el foro por algunos, cuando se evidencia el factum proprium, no se está partiendo del inequívoco supuesto de que se materializó la mala fe, o que esta sea sinónima del acto propio o incoherente, pues sin ella, ciertamente, se puede predicar la consolidación de la figura, conforme a las circunstancias, claro está.

Por eso no es necesario rasgarse las vestiduras para afirmar que, ab initio, se rechaza su aplicación porque no puede tolerarse que se entienda o insinúe que se actuó con mala fe, calificación que, en sede jurídica, amerita gran prudencia, y que no puede, con ligereza, pregonarse de toda actuación, por las connotaciones que de ella fluyen. Baste con decir, por no ser idéntico, que no se actuó con sujeción a los cánones de la buena fe, giro que no indica lo mismo, es decir comportarse de mala fe, así parezca lo contrario, o se crea que es un problema de simple semántica, el que va mucho más allá.

Lo que resulta de interés, amén que determinante, como lo hemos dicho, es la gestación de una conducta, en sí misma incausal y objetiva, desde una perspectiva jurídica. Por eso tampoco se requiere que sea producto de la culpa, de un actuar manifiestamente negligente o caprichoso que denote la más grosera falta de diligencia, o quebranto de puntuales deberes de conducta. Ni por supuesto tampoco es menester el advenimiento del dolo, como se esbozó, ni que se asome al balcón judicial la mala fe, o una conducta rayana en el engaño, en el fraude o en un propósito torticero. Desde este ángulo, no es entonces apodíctico que cuando no se observa o actúa de buena fe, en sentido genuino del término, de inmediato se consolida la mala fe, la que requiere algo más, según se esbozó. Este no es problema de coloración: o es blanco, o es negro, ni de antípodas: siempre buena fe, o siempre mala fe; es más una respuesta a la consideración de un 'estándar de conducta' (efecto espejo).

Ello explica que cuando se invoca la aplicación del principio jurídico en cuestión, y se subraya la significación de la actuación coherente, no se está haciendo un juicio de valor en el campo penal, o disciplinario, en el que convergen delitos, faltas graves y gravísimas, etc., ni siquiera en el civil o comercial, pues cuando objetivamente se verifica el quiebre de esta doctrina, ello es suficiente, no 
siendo necesario poner al cocontrantante en la picota, o ensañarse con él, o de escrutar en lo más recóndito de su ser, de su psiquis si se comportó intencional o descuidadamente.

De igual modo, no es menester emplear expresiones desobligantes; basta simplemente señalar que no se obró de acuerdo con la buena fe, con los estándares que protegen la confianza legitima, sobrando el juicio de mala fe, de intencionalidad, salvo que realmente la haya, máxime cuando en el tráfico jurídico, sobre todo en la esfera empresarial en la que es tan común la predisposición contractual, de ordinario, no se enseñorean ni el dolo, ni se actúa a sabiendas, fría y calculadamente, ni deseando dañar, per se, a todos los consumidores. En muchos casos es un problema de interpretación, y de actitud algo más que comercial y racional (ventajosa), pero sin los ribetes de una rampante y ostensible defraudación negocial, obviamente con excepciones, no tantas, sin embargo, como para asentar la regla contraria, de suyo injusta, intrínsecamente. ${ }^{43}$

En este sentido, en síntesis, como lo enfatiza el profesor Franz WiACKER, el principio general de la buena fe. "No presupone necesariamente el que, de mala fe o con negligencia culpable, se cree una expectativa en la otra parte"44.

43 Sobre este particular, el profesor Sergio MuÑOz LAVERDE, anota con acierto que "...existen conductas que descartan la buena fe que, sin embargo, no son dolosas, malintencionadas o deshonestas". "El principio de buena fe y su incidencia en la interpretación del contrato. Nulidad de las cláusulas abusivas en el derecho colombiano", op. cit, p. 214.

44 Franz WIEACKER. El principio general de la buena fe, op. cit., p. 61. Como lo afirma Manuel De La Puente y LaValle, "No interesa, en cambio, que el sujeto piense o no quedar vinculado por su actuar, pues el efecto vinculante de la conducta deriva de su sentido objetivo, sin que la intención juegue un papel relevante". La doctrina de los actos propios, op. cit., p. 355. Comparte análogo criterio Fernando FueYo LANERI, cuando indica que la conducta a la que se alude a través del principio venire contra factum proprium, “...es objetivamente contradictoria con una anterior". Por eso, además, "El acto propio no requiere -en su esenciade una voluntad con intención de producir efecto jurídico, cosa que, a la inversa, es de la esencia del acto jurídico". La doctrina de los actos propios, op. cit., p. 309. Lo propio, con énfasis en el tema de la culpa, pone de relieve el autor Alessandro P. SCARSo, quien indica que para su aplicación se "... prescinde de una conducta culposa". Venire contra factum proprium e responsabilitá, op. cit., p. 522. Vid. Rodolfo SAcco. II fatto, l'atto, il negozio, op. cit., p. 254 


\subsection{LA CONDUCTA CONTRADICTORIA, FORMALMENTE, SE INSCRIBE EN EL MARCO DEL EJERCICIO DE UN DERECHO SUBJETIVO LÍCITO O CON APARIENCIA DE LICITUD}

Uno de los aspectos salientes de la doctrina de los actos propios, finca en el hecho, algo singular, de la legitimidad o pertinencia jurídicas de la pretensión contradictoria' (o conducta contradictoria), la que, en línea de principio, suele ser lícita, y no espuria, o ilegal, considerada in abstracto, o por lo menos así se revela prima facie ${ }^{45}$.

Quiere significar lo anterior, que así luzca prima facie jurídica la argumentación ulterior del voluble o versátil, del sujeto pendular, nos referimos a esa parte que, a posteriori, inesperadamente cambió de norte, no resultará de buen suceso su formulación, así aparentemente el Derecho, su aplicación, esté de su parte y lo favorezca, fría y desarticuladamente evaluada la situación pertinente, evaluación que, en puridad, no debe hacerse, so pena de alterar el genuino significado de la buena fe, de ese deber de comportarse las partes, sin distingo, en forma leal, proba, correcta y considerad $a^{46}$. Por ello el juzgador no debe desatender el

45 A juicio de los profesores Augusto Morello y Rubén STIGLITZ, en otro escrito de su autoría, "La doctrina del acto propio importa una limitación o restricción al ejercicio de una pretensión. Se trata de un impedimento de "hacer valer el derecho que en otro caso podría ejercitar". "Inaplicabilidad de la doctrina del acto propio a la declaración viciada por falta de libertad y por violencia", en La Ley 10/08/2004. Buenos Aires, 2004, p. 2.

Por su parte, el doctrinante Alejandro BoRDA, acertadamente pone de manifiesto que "...la pretensión importa el ejercicio de un derecho subjetivo digno de protección pero en otro contexto. En efecto, ese derecho subjetivo esgrimido en la pretensión sería lícito si es que no hubiera existido una primera conducta. Lo que ocurre es que tomando como base a esta conducta vinculante resulta inadmisible ejercer un derecho subjetivo que, aunque válido, es contradictorio del propio comportamiento". La teoría de los actos propios, op. cit., p. 76. Cfr. Giovanni Cattaneo, Buona fede obbietiva e abuso del diritto, op. cit., p. 641.

En sentido similar se expresa el autor italiano, Luca NANNI, cuando pone de manifiesto que, si se "...niega a un sujeto la tutela jurídica prevista en una norma general a causa de un comportamiento...., no es porque sea ilícito o incorrecto, sino porque se ha suscitado una confianza" que debe ser protegida. La buona fede contrattuale, op. cit., p. 549.

46 Según lo expresó la Corte Constitucional colombiana en las postrimerías del siglo anterior, con motivo del examen del artículo 83 de la Carta Política, atinente a la buena fe, este es un "principio constitucional, que sanciona, entonces, como inadmisible toda pretensión lícita, pero objetivamente contradictoria, con respecto al mismo comportamiento efectuado por el sujeto" (Sentencia, T. 295/99). Y ya en las puertas del siglo XXI, analizando de nuevo el alcance del mencionado artículo 83 de la Constitución y su relación con "...la máxima latina venire contra factum proprium", puntualizó que tal "principio constitucional garantiza a las 
espectro comportamental en su justa dimensión, o sea en función de todo el plexo conductual, y no de una sola actuación que, analizada insularmente, conduce a resultados parciales $\mathrm{y}$, por ende, inadmisibles. No en vano la interpretación del contrato, ab antique, debe ser contextual, amén que sistemática, con miras e evitar que se dejen de lado eslabones relevantes que, in globo, reflejen la realidad contractual -toda-, la que no puede circunscribirse a un momento único, como si la relación jurídica que se desdobla en el tiempo, se pudiera segmentar y luego entronizar en compartimentos estancos.

Quedarse en el acto contradictorio, y darle pábulo, solo por aquello que se torne virtualmente lícito, desconectadamente considerado, es como no superar el umbral hermenéutico, y rendirle culto a un momentum de la relación, dueña de diversas fases y estadios, que no están llamados a ser soslayados, máxime cuando el iudex, a la postre, interpreta conductas, actuaciones, actos y procederes, no sólo en el campo del contrato -que no es totalmente anónimo-, sino también en el proceso, en donde las partes en litigio, por igual, deben comportarse leal y correctamente a lo largo de todo el juicio, tanto entre sí, como en relación con el juzgador y, claro está, con la administración de justicia, en general, que también demanda corrección, respeto y transparencia, según se advirtió.

Al fin y al cabo, según se ha mencionado, y como se expondrá en breve de modo más detallado, la buena fe, dentro de sus múltiples tareas, tiene asignada la de servir de límite o valladar al ejercicio de un derecho subjetivo lícito, pero en franca contradicción con la conducta precedente de su titular. De allí que, en concreto, la secuela de la incoherencia, de no respetar el acto propio, apareje que un derecho, aunque preexistente y virtual o aparentemente válido, no se pueda ejercitar con éxito, so pena de quebrantar el orden jurídico y la justicia, en nuestro caso la contractual.

Por lo tanto, una vez hecha la ponderación conductual, siempre tan conveniente en esta temática, una vez pesadas todas las conductas, así se concluya que la

personas que ni el Estado, ni los particulares, van a sorprenderlos con actuaciones que, analizadas aisladamente tengan fundamento jurídico, pero que al compararlas, resulten contradictorias. En estos casos, la actuación posterior es contraria al principio de la buena fe...." (Sentencia. C-836/01). 
posterior, objeto de contradicción ('pretensión contradictoria), está aparentemente avenida o conforme a derecho, no por ello debe primar, por cuanto ello no es lo determinante, ni conducente, y menos lo equilibrado, como quiera que la valoración debe hacerse in complexu, como se acotó, y no en forma desvertebrada y aislada, en cuyo caso no puede quedar impune el acto pendular, si es constitutivo de una lesión a un interés jurídico digno de tutela (la confianza). Hacerlo, ni más, ni menos, sería como ahogar la justicia, en provecho de la legalidad, de una postura tan formal que, de aplicarse, se inscribiría en el vacío axiológico. ¿Cómo entonces erosionar la equidad, con arreglo a la aplicación de normas o institutos que, en otras condiciones, se tornarían por completo válidas y pertinentes, pero no en las circunstancias presentes? Licitud abstracta, en tal virtud, no es patente de corso para defraudar la confianza legítima y para desestimar el derecho ajeno, en prueba de un rancio y extremo individualismo hoy superado, que abogaba por el ejercicio absoluto de los derechos, con prescindencia de otras consideraciones.

Es el caso, por lo demás examinado con algún detalle por la doctrina internacional, de la prescripción extintiva, un instituto que, no obstante sus peculiaridades y tensiones de diverso talante que se suscitan a su alrededor, ha sido milenariamente aceptado, formando parte inescindible e indiscutida de nuestra cultura jurídica, pues pese a su reconocida cabida, su ejercicio, en sí mismo considerado, no es irrestricto, ni puede arrasar el pasado, en particular la conducta o conductas pretéritas que infundieron confianza, pues median limitaciones como las que emergen, precisamente, del acto propio, cuando se torna incoherente con tales actuaciones previas a cargo de su titular ('ejercicio inadmisible del derecho'). Es cierto que el sujeto activo del venire contra factum proprium, demandado en sede judicial puede en principio formular la excepción de prescripción extintiva, arquetípica defensa jurídica, cuando las circunstancias temporales lo ameriten (transcurso del lapso establecido ex lege), aun cuando no en todos y cada uno de los casos, como si lo andado extraproceso, en el marco de la relación negocial, pudiera desandarlo sin el más mínimo inconveniente y escrúpulo, en especial cuando ha sembrado y consecuentemente ha retoñado confianza en cabeza del demandante, su cocontratante a la sazón ${ }^{47}$.

47 Vid. Gustav Boenmer. El derecho a través de la jurisprudencia, op. cit., pp. 270 y ss.; Filippo RANIERI. "Exceptio temporaris e replicatio doli nel diritto dell'europa continentale", 
En resumen, lo fundamental para el ejercicio racional de un derecho, en efecto, no sólo es tenerlo, o contar con él, sino cómo y cuándo se ejerce. La excepción de prescripción, en el ejemplo traído a colación, conoce límites, cuando aflora la incoherencia, la contradicción, cuando se desdibuja la confianza legítima, cuando se desatiende la prohibición de venire contra factum proprium ${ }^{48}$. No todo lo que brilla, es oro, no todo lo que se afirma como valedero, así en apariencia sea así, tiene vocación de prosperidad, a lo que se agrega que los derechos, ello es capital, no son, ni pueden ser absolutos, una idea que, en la hora de ahora, luce indiscutida, así en el pasado, por cierto no muy lejano, se pensara lo contrario, merced a una lectura individualista del Derecho, hoy por fortuna superada, según se expresó, pues como bien lo recrea GORPHE, "Un derecho no es absoluto...el hecho de que uno sea titular de un derecho no lo dispensa de tener una voluntad honesta... hay deberes hacia los demás que ningún derecho permite violar"49.

Tal será entonces la proyección del acto propio, tanto en sede extrajudicial, como judicial, que la tendencia más arraigada en la actualidad es la que pregona que debe aplicarse ex officio, así no haya sido formulada o explicitada esta doctrina, sana y racional posibilidad de la que nos ocuparemos con algún detalle, en este mismo capítulo y numeral.

Una será entonces la realidad in abstracto y otra muy distinta, in concreto, cuando el derecho se ejercita, generándose entonces, in casu, una actuación antijurídica por la consabida erosión de la confianza legítima y racional inculcada.

\subsection{NO TODAS LAS CONDUCTAS INCOHERENTES O CONTRADICTORIAS QUEDAN} FORZOSAMENTE COBIJADAS POR LA DOCTRINA DE LOS ACTOS PROPIOS

en Rivista de Diritto Civile, Padova, Cedam, 1971, pp. 256 y ss., y Carlos Ignacio JaramiLlo. La prescripción en el contrato de seguro, op. cit., pp. 226 y ss.

48 Vid. K. LAREnZ, Derecho de obligaciones. Editorial Revista de Derecho Privado. T. I, op. cit., p. 151., a Rubén H. CompagnucCl en otro trabajo suyo, su libro: Manual de Obligaciones. Buenos Aires. 1997, p. 569, y a Martha Lucía Neme V. Venire contra factum proprium, prohibición de obrar contra los actos propios y protección de la confianza legítima, op. cit., p. 19.

49 F. Gorphe, Le principe de bone foi. Paris. 1928, p. 101. cit. Delia Matilde FerreIRA. La buena fe, op. cit., p. 221. 
Conforme lo hemos mencionado sucintamente en otros apartes, resulta de la mayor importancia reiterar, ahora en forma más sistemática, que no todas y cada una de las conductas que entrañan contradicción, incoherencia, inconsonancia, incongruencia, entre otras manifestaciones análogas caracterizadas por su falta de regularidad y constancia comportamental, están llamadas a ser cobijadas por la doctrina de los actos propios.

Cierto es que, en principio, no es de buen recibo que aflore una de ellas en la esfera del Derecho, en el tema que nos ocupa en el contrato. Es más, en un plano más general, incluso, la incoherencia es censurada y no es admitida, por regla, según pudimos observar al momento de examinar sus diversos fundamentos, aún más allá de la dimensión jurídica (Cap. I), como quiera que el espectro del arraigado principio de no contradicción, es muy amplio. Sin embargo, hay que tener en cuenta que sólo un segmento de las mismas, respecto al universo de la incoherencia, aun cuando importante, es considerado como antijurídico y, por ende, lesivo de derechos y prerrogativas dignos de protección.

Por ello es por lo que en esta materia no caben generalizaciones, toda vez que si bien muchas de tales incoherencias lesionan caros intereses jurídicos en la órbita contractual, tampoco puede afirmarse que cada vez que ella se asoma inevitablemente se erosiona la confianza legítima y consecuentemente se impone la aplicación del remedio que emerge de la doctrina de los actos propios.

Aun cuando es relativamente común hacer dicha asociación, y propender porque los efectos inherentes al venire contra factum proprium, en particular al acto propio de ordinario tengan cabida, en rigor ello no es admisible, justamente por la citada generalización. Muchas de tales contradicciones, no serán anodinas, y por eso vulnerarán la supraindicada confianza legítima suscitada en uno de los cocontratantes, pauta medular para efectos de determinar la incidencia y pertinencia de la incoherencia, aunque habrá otras huérfanas de secuelas, habida cuenta que en este campo, como en otros más, no se puede dogmatizar y establecer consecuencias uniformes para todos y cada uno de los supuestos, a fortiori cuando será menester examinar cada asunto en concreto, antes de ir improvisando conclusiones, muy seguramente aventuradas, a la vez que ayunas del respaldo necesario que fluye del casus, según tendremos oportunidad de 
constatar en el espacio reservado a una de las características que más en detalle se ocupará de este signo revelador de la doctrina en comento.

Así las cosas, hay que proceder con prudencia en esta temática, con el propósito de no estigmatizar, per se, incoherencias que, independientemente de que se traduzcan en un quiebre formal del principio de contradicción, no tienen la suficiente entidad para ocasionar los consabidos efectos de la inobservancia del factum proprium, reservados para algunas, pero no para la totalidad.

Es más, en el campo del Derecho, se suele aludir a "contradicciones legítimas"50, dando a entender que no sólo no están censuradas, sino que expresamente están autorizadas o "legitimadas", aún por el propio ordenamiento legal, o también por determinadas "circunstancias o condiciones", como ya lo mencionamos en otro aparte, ${ }^{51}$ lo que corrobora que la citada estigmatización general resulta equívoca, amén de contraevidente, en atención a que hay supuestos que, ministerio legis, han sido tolerados y en ocasiones auspiciados -indirectamente- por el legislador, quien no sólo no censura el cambio comportamental o la volubilidad,

50 Denis MAZEAUD, explícitamente alude a esta expresión. Les contradictions légitimes au détriment d'autre, al igual que $\mathrm{H}$. Hobinavalona RAMPARANY-RAVOLOLOMIARANA, Le raisonnable en droit des contrats, op. cit., p. 301. Por su parte, Dimitri HoutcIEFF, también reconoce que "El derecho permite la modificación de un comportamiento en el marco de lo razonable" (Le principe de cohérence en matiére contractuelle), al mismo tiempo que la Dra. María Fernanda EDKAL E., quien anota que "...hay ocasiones en que el legislador legitima la conducta contradictoria". La doctrina de los actos propios, op. cit., p. 37. En una sola palabra, hay conductas que no obstante ser contradictorias, o ayunas de coherencia, en un plano formal, no son antijurídicas y por tanto inadmisibles, desde luego cuando media exequatur legislativo.

En esta dirección, pero con carácter más general, el profesor DíEZ-PICAZO, analizando el "carácter injusto del daño", anota que "...existen daños que el ordenamiento jurídico no repele, que algunas veces tolera..... Fundamentos del derecho civil patrimonial, T. V, op. cit, p. 300.

51 Sobre este particular, la Corte Suprema de Justicia de Colombia, en sentencia del 24 de enero de 2011, indicó que "Ciertamente, existen condiciones o circunstancias que aconsejan e, inclusive, imponen, la variación de comportamientos precedentes. Hay hipótesis en donde es el propio ordenamiento el que autoriza apartarse de la proyección generada a partir de los actos realizados antecedentemente, por lo que, sin duda, variar de conducta y sustraerse o distanciarse de las líneas demarcadas durante un período suficiente para haber generado en el cocontratante algún grado de confianza o la creación de expectativas, no resulta dañino ni deviene atentatorio de la teoría que se comenta...". 
sino que lo autoriza explícitamente, sin secuela alguna ${ }^{52}$. Es el caso prototípico de la revocación del testamento, cuántas veces lo estime el testador procedente; o la revocación de la designación del beneficiario en el seguro sobre la vida; o la retractación de la oferta hasta antes que ella sea aceptada -en algunos regímenes-; o la pertinencia de revocar el mandato; la opción de acudir al jus variandi en la resolución de los contratos por incumplimiento, en determinadas legislaciones; la de corregir oportunamente la demanda, y la de ejercer, en algunas naciones, el derecho de arrepentimiento en el marco del Derecho del consumo, no obstante haberse manifestado por el consumidor inicialmente su asentimiento, etc. ${ }^{53}$

En este último sentido, los profesores A. AlteRIN y R. López CABANA, aludiendo a las "Conductas contradictorias legitimadas en el Código Civil" argentino, manifiestan que"...el Derecho positivo legitima la conducta contradictoria cuando autoriza al oferente a retractarse de la oferta antes de que sea aceptada por el destinatario (art. 1150; $1^{a}$ parte, Cód. Civ.); o impone que la fuerza vinculante de la conducta previa dependa de ciertas formalidades (arts. 974 y ss. y 1145, Cód. Civ.); o permite el arrepentimiento en caso de haber seña penitencial (art. 1202, Cód. Civ.); o concede -mediante pacto comisorio- la acción de resolución a quien optó previamente por la de cumplimiento (art. 1204, Cod. Civil y art. 216, Código de Comercio); o establece la revocabilidad como esencial al testamento (art. 3824, Cód. Civil)"54.

52 Sin perjuicio de que lo hemos memorado, y que lo memoraremos de nuevo, importa traer a colación de nuevo, el pasaje de PAPINIANo, muy ilustrativo a este respecto, a cuyo tenor: "Algunas veces, el pretor no rechaza al que muda de parecer, y no se desprecia la opinión del que varía en ella" (D. 37, 6.8).

53 Sobre este mismo particular, en relación con el Derecho español, la Dra. Clara I. AssuA GoNZÁLEZ, recuerda que “....no se han considerado contradictorios: el cambio de calificación de la responsabilidad civil -de extracontractual en una instancia a extracontractual en la siguiente para acogerse al plazo de prescripción más largo- (STS 29 noviembre 2005 [RJ 2005, 36]; instar judicialmente la resolución por incumplimiento del agente tras haber realizado requerimiento notarial de resolución por transcurso del término de vigencia del contrato de agencia (STS 13 de junio 2000 [RJ 2000, 5732]); la pretensión de una de las partes distinta de la contenida en una oferta de transacción rechazada por la otra parte (STS 17 junio 2008, 4698]) ". "Art. 7". Código Civil comentado, op. cit, p. 95.

54 A. Alterini y R. López Cabana. Actos propios y responsabilidad civil, op. cit., p. 39. En análoga dirección, la autora chilena María Fernanda EKDAHL, concuerda en que "... hay ocasiones en que el legislador legitima la conducta contradictoria”, v.gr: "...en el caso de la oferta (art. 99 del Código de Comercio), donde antes de ser ésta aceptada por el destinatario es 
En conclusión, si bien lo deseable es que en las relaciones interpersonales no irrumpa la incoherencia, la contradicción, el cambio súbito comportamental, en la práctica no pueden reprocharse todas y cada de estas fenomenologías, menos en el campo del Derecho, en el que será necesario analizar cuidadosamente la tipología correspondiente, en aras de establecer su procedencia -o su improcedencia-, habida consideración que existen puntuales supuestos en que ella es admitida, o por lo menos no es fustigada, a priori, lo que no quiere significar, de ninguna manera, que ello sirva de acicate para que, por esa vía, se atenúe o desdibuje la condena frontal de aquellas contradicciones, que no son del todo infrecuentes, llamadas a socavar la buena fe contractual y correlativamente la consabida confianza legítima, fiable pauta de medición del impacto e incidencia causal de la incoherencia o la contradicción.

Expresado de otro modo, el hecho de que la ley en casos muy concretos, entienda que es posible volver sobre los actos propios, esto es desandar lo andado, lisa y llanamente, por ningún motivo significa que esté restándole fuerza y gravedad al quebranto de la bona fides, de la señalada confianza legítima, de la apariencia, de la seguridad jurídica, entre otros valores y principios más. Muy por el contrario, es la confirmación de cara a precisas hipótesis, de suyo limitadas y reguladas restrictivamente, el cambio comportamental no reviste la trascendencia necesaria para esterilizar el ejercicio de un derecho, dejando a salvo las demás, a fin de que puedan ser examinadas en cada caso en particular, sin anticipar la respuesta. Tanto es así, que desde tiempos inmemoriales, el Derecho romano cuestionó específicas incoherencias en sede jurídica, como se recordará, al igual que el Derecho contemporáneo, incluida la codificación, ofrece diáfanos ejemplos demostrativos de que el legislador, pese a la admisión residual de algunos supuestos, no conviene con la floración de la incoherencia o la contradicción, en general, y en las distintas áreas del Derecho, en lo individual, una de ellas la reservada al Derecho de los contratos, en el que el respeto y

perfectamente posible que el oferente se retracte; de igual modo en el caso del testamento (art. 999 del Código Civil), institución esencialmente revocable; otro tanto en la donación, que cuando se entiende por causa de muerte es por naturaleza revocable (art. 1136 del Código Civil); la donación entre vivos, que por excepción podrá revocarse mientras no haya sido aceptada y notificada la aceptación al donante (art. 1412 del Código Civil), o bien en caso de ingratitud del donatario (art. 1428 del Código Civil)". La doctrina de los actos propios, op. cit., p. 32. 
sublimación de postulados como el de la buena fe, entre otros más, corroboran con creces este aserto.

\subsection{Carácter subsidiario de la doctrina de los actos PROPIOS}

La doctrina de los actos propios, ciertamente, no es irrestricta, ni tampoco es de aplicación automática o generalizada, según se ahondará en el tema más adelante, ni es -ni podría ser-absoluta, pues no sólo conoce claros y necesarios límites, sino que tiene cabida en defecto de instituciones especiales o particulares que, por su especificidad, están llamadas a regir, de antiguo o precedentemente, en desarrollo del propósito genético, a la par que funcional que les asiste. De ahí que se diga que sea de aplicación subsidiaria, o residual, expresiones que no tienen el cometido de relativizar o diezmar su importancia, puesto que lo que persigue es resaltar la primacía jurídica y natural de otras figuras que, in concreto, tienen vida propia, y que gobiernan la actuación incoherente de modo especial, bien tolerándola, bien censurándola o impidiendo que despliegue algún efecto puntual o específico ${ }^{55}$. No en balde, su ámbito no es absoluto, como se refirió, y por ello no todo lo domina, y abraza, aspecto que debe ser tenido muy en cuenta, en aras de no desdibujar su razón de ser, ni de sobredimensionar su rol, relevante en grado sumo, pero sujeto a precisas limitaciones y a un protocolo que, en pro de la misma sanidad -o salud- de este instituto, es aconsejable observar, so pena de su distorsión, y de su malformación, las que podrían llevar a su desprestigio e inaplicación relativa.

55 Como lo afirmó don Fernando FueYo LANERI, "El principio jurídico que desaprueba las conductas contradictorias con las realizadas anteriormente, tiene un carácter residual, y, por lo tanto, no es invocable cuando la ley regula una solución expresa para la conducta contradictoria, sea impidiéndola, sea permitiéndola". La doctrina de los actos propios, op. cit., p. 309. En sentido muy similar, la autora María Fernanda EKDAHL E., igualmente chilena, afirma que, "...la doctrina de los propios actos posee un carácter residual, esto es, está llamada a regir principalmente, en ausencia de solución legal expresa, en aquellos tópicos donde no hay aún pronunciamiento efectivo sobre el tema, pues es justamente en este campo donde la aplicación y vigencia de un principio general de derecho cobra su importancia más preponderante". La doctrina de los actos propios. El deber jurídico de no contrariar conductas propias pasadas, op. cit., pp. 37 y 38. Cfr. Noemi Lidia Nicolau. "La doctrina de los actos propios y la verwirkung”, en Juris., Rosario, 1976, p. 130. 
Esta característica luce pues fundamental, por cuanto sin demeritar la relevancia asignada a la misma, la que en ningún momento se pone en duda, sitúa en un justo medio su real alcance y particular injerencia en el mundo del Derecho -sustancial y procesal-. Trascendente, sí, pero con las cautelas que su aplicación exige, como quiera que no es ni omnímoda, como ya se acotó, ni tampoco ilimitada, o incluso mágica, también como se pondrá de manifiesto, circunstancia que exige prudencia y una gran cautela, a fin de no generalizar su radio de acción que, aun cuando dotado de cierta amplitud, no cobija, ni comprende todo el Derecho, como acontece en punto tocante con el axioma de la buena fe, dispensador de la fuerza a la regla en comento, aun cuando condicionada a la ausencia de un régimen determinado, ante el cual debe ceder todo su espacio, haciéndose a un lado, o dando un paso al costado ${ }^{56}$.

Y es que si el mismo postulado de la buena fe, pese a su significado, también debe ser aplicado con mesura y con racional y también prudencial entusiasmo, con mayor razón debe hacerse lo propio en tratándose de este instituto jurídico, de suyo algo inasible, como dijimos antes, aún en construcción (pero no en obra negra'), en la medida en que no está completamente perfilado. De allí la relevancia de seguir examinándolo, lo cual antes de ser negativo, es positivo, como lo advertimos, en razón de que mucho hay aún que decir de él, no siendo entonces un tema agotado, o fenecido -si es que este tipo de temas ciertamente existen en el Derecho-, y sin admitir por ello que esté en bruto, debido a que se ha avanzado progresiva y sostenidamente a su alrededor, o que su trascendencia es menor o relativa. Todo lo contrario, como lo atestigua su desarrollo, penetración y acogida, cada vez mayor en diversas naciones del orbe, se itera, más allá de cual sea su denominación.

Por consiguiente, rescatamos una idea ya esbozada con antelación, conforme a la cual no todas las conductas volubles, incoherentes o contradictorias,

56 En sentencia del 24 de enero de 2011, la Corte Suprema de Justicia colombiana, sobre este particular, puso de presente que "...la supletoriedad o subsidiariedad es una característica de la regla que se comenta, pues no opera de manera automática ni en todos los eventos, luego no es ilimitada; por ello, en las situaciones en que, hipotéticamente, hay incursión en los predios del acto propio, debe sobrevenir la confrontación del suceso en sí con la regulación normativa vigente para determinar la pertinente procedencia. Su vitalidad, entonces, se patentiza en la medida en que el asunto del que se trate no tenga una regulación legal general o especial ante la cual, por su naturaleza, el principio deba ceder....". 
objetivamente consideradas, de por sí, erosionan el equilibrio contractual y menoscaban los derechos de uno de los cocontratantes o de uno de los sujetos interesados, pues hay supuestos en que ello, no obstante tener materialización formal, no entraña limitación alguna.

Por eso, conviene no satanizar todas las conductas oscilantes, o cambiantes, pues habrá algunas lícitas, amén que protegidas por el ordenamiento jurídico, con potísimas razones, lo que explica que la formulación absoluta de la regla, conforme la cual "a nadie le está permitido volver sobre sus propios actos", si no es matizada o relativizada, se torna absoluta y, por ende, errada.

Es pues el acto propio una figura subsidiaria y, por tanto, limitada, pues como lo anota Manuel DE LA PueNTE y LAVAlLE: "Se trata de un instituto que debe ser aplicado supletoriamente" 57 , circunstancia que invita al juzgador $y$, en general, a quien tenga la autoritas respectiva, a analizar con sumo cuidado el haz de figuras que, de una u otra manera, aun conduciendo a un resultado común, tienen aplicación preferente o exclusiva, pues no todas están situadas en un mismo plano jerárquico, siendo entonces menester, indefectiblemente, acatar un determinado orden, so pena de mancillar el designio legis, la real intentio del legislador, al igual que la finalidad de las instituciones o figuras jurídicas, dueñas de un objetivo que no puede ser interferido ${ }^{58}$.

Dicho más elemental y popularmente, 'lo primero es lo primero', y por eso deberá primar lo que, ministerio legis, fue establecido o acogido ab initio, o ha sido admitido inveteradamente en el campo jurisprudencial y doctrinal, merced a su indiscutida fuerza intrínseca. En otro caso, no se aplicaría la ley, stricto sensu, por más que se quisiera acudir a una plausible institución, ayuna de autogobierno y sustantividad plena, lo que no quiere decir que esta sea una recomendación siempre fácil de acatar, porque habrá casos en donde la línea divisoria entre la

57 Manuel De La Puente y Lavalle. La doctrina de los actos propios, op. cit., p. 304.

58 Según lo expresa M. Nélida TuR FAUNDEZ, avalando este rasgo, "La doctrina de los actos propios se aplica a los casos que no encajan perfectamente en las correspondientes prescripciones legales, que siempre son, obviamente, de aplicación preferente sobre tal doctrina". La prohibición de ir contra los actos propios y el retraso desleal, op. cit., p. 52. 
figura virtualmente aplicable, y la doctrina de los actos propios, sea porosa, o muy borrosa, tal y como tiene lugar en punto al abuso del derecho.

Así las cosas, corroborando lo dicho, los profesores Anibal Tulio ALTERINI y Roberto M. López CABANA, concluyen su estudio alusivo al tema, manifestando que la 'doctrina de los propios actos', es “....un instituto de carácter residual, en virtud de que no se aplica: a) Cuando hay solución legal que regula la conducta contradictoria, sea legitimándola o prohibiéndola. b) Cuando, sin existir solución legal, hay justificaciones éticas prevalentes" 59 .

\subsection{LA TRASCENDENTE MISIÓN ASIGNADA AL JUEZ PARA LA VALORACIÓN DE LA PROCEDENCIA Y LA APLICACIÓN DE LA DOCTRINA}

Aunque su campo o radio de acción no lo constituye el proceso o el litigio, como se observó, es claro que, en sede judicial, es donde se ventilará con mayor asiduidad esta cardinal regla (venire) o, si se prefiere, la doctrina de los actos propios, como manifestación suya. Por ello será el iudex el encargado de definir, in casu, sus perfiles y su estructuración, en el entendido que se estime procedente, o de rechazar su conducencia, al amparo de los presupuestos reseñados, o de otras exigencias que luzcan necesarias, en el asunto sometido a la auscultación

59 Aníbal Alterini y Roberto M. López Cabana, Actos propios y responsabilidad civil, op. cit., p. 48 , quienes, folios antes, habían tenido ocasión de recrear esta característica, a través de una diciente comparación, conforme con la cual "...la existencia de un principio que sólo rija en ausencia de solución legal expresa no es ajena al sistema jurídico. Así, en materia de enriquecimiento sin causa, el principio que lo impide late debajo de muchas figuras que tienen concreta regulación legal. En una lúcida metáfora se ha dicho que el enriquecimiento sin causa es 'como un río subterráneo que nutre reglas precisas que revelan su existencia, pero sin salir nunca a la superficie', sin perjuicio de lo cual la actio in rem verso sólo se concede en supuestos residuales y a condición de no existir un remedio legal expreso o un impedimento para la restitución. De allí que resulte impropio acudir al principio jurídico que nos ocupa fuera o más allá de las hipótesis residuales...." Op. cit., pp. 43 y 44.

Otro tanto, en el plano comparativo, podría decirse del apellidado recurso de amparo constitucional, o acción de tutela (Colombia), toda vez que su procedencia no es liminar, inmediata o autónoma, en la medida en que es residual o subsidiario, pues su aplicación está sujeta a puntuales exigencias previas, una de ellas, precisamente, relativa al agotamiento de las vías ordinarias, en particular las previstas y dispuestas en el proceso, en sí mismo garantista, y dueño de diversas etapas encaminadas a escrutar la pertinencia de las pretensiones y defensas esgrimidas. 
del juez, quien por más amplios poderes que tenga, es cierto, debe observar prudencia y cautela, bien para no ensanchar -en demasía- su horizonte, como en veces sucede, bien para acortarlo notoriamente, hasta el punto que, sin verdadera justificación, lo torne inaplicable, o lo recorte tanto que, en el fondo, lo haga inoperante, en desmedro de los intereses de uno de los justiciables, dignos de tutela y salvaguarda, como se esbozó.

Por eso el equilibrio en esta materia, y en otras similares, en la que es necesario depositar la confianza en el Estado, en su representante que por antonomasia es el juez, es fundamental. No desconocemos que en algunos estadios de la historia se ha desconfiado de los juzgadores, y se ha querido limitar su intervención, hasta el punto de expresar que "La mejor ley es la que reduce al mínimo el arbitrio judicial; y el mejor juez es el que reduce al mínimo el suyo" (Otima est lex, quae minimum relinquit arbitrio iudici; Optimus iudex, qui minimum sibi). De hecho, en el Derecho prerevolucionario francés y en la Escuela de la Exégesis fue notoria dicha limitación, tal y como se resaltó en el Cap. I, dado que se le consideraba como 'boca de la ley', en prueba de la fuerza y valor a ella asignado (concepción legalista), idea ésta que tuvo eco en buena parte del siglo $X X$, incluso ${ }^{60}$, y que fue enarbolada ardorosamente para inhibir la procedencia de figuras justicieras, como el abuso del derecho, la lesión subjetiva, la teoría de la imprevisión -o de la cláusula rebus sic stantibus-, la objetivización -prudencial y excepcional- de la responsabilidad civil, entre otros ejemplos indicativos de los reparos al arbitrium iudice o a la ampliación de los poderes judiciales, siendo de resaltar que finalmente dichas figuras, de una u otra forma, en el siglo XXI cuentan con sólida acogida, ora normativa, ora jurisprudencial y obviamente doctrinal.

Sin embargo, tampoco podemos soslayar que en el último siglo se ha hecho aún más evidente que, con las salvaguardas necesarias, por cuanto su rol no

$\overline{60}$ Diciente, en efecto, es el siguiente pasaje del profesor Marco Aurelio RısolıA, quien examinando esta temática, alrededor de precisas máximas latinas, anotó sobre una de ellas: "dura lex sed lex, que tanto vale como ratificar la confianza en el orden jurídico que se apoya en los textos legales y desconfiar de la apreciación ampliamente conferida al exclusivo resorte del criterio judicial. Tanto esta doctrina [la del abuso del derecho] como la de la lesión que antes expusimos, conducen a un solo atajo: la extensión extraordinaria de los poderes del juez que, dotado de una y otra, resultaría el árbitro y censor infalible para determinar donde existe el derecho y dónde no existe". Soberanía y crisis del contrato, Abeledo-Perrot, Buenos Aires, 1974, p. 184. 
es omnímodo, claro está, es conveniente, mejor necesario, permitir que el iudex tenga una mayor injerencia en la aplicación del Derecho, no para que lo sustituya, o suplante al legislador, sino para que, por el contrario, pueda hacer tangible su genuino ideario, en todo aquello que abogue por la dignidad del ser humano y por el respeto de sus mínimas garantías. Al fin y al cabo, no todo puede ser previsto por la ley, ni menos desarrollado con explicitud y detalle ${ }^{61}$.

Le asiste pues la razón al profesor PUIG BRUTAU, al manifestar que “...el estudio de la función que corresponde al arbitrio judicial y el reconocimiento de su carácter verdaderamente integrador del orden jurídico, resulta indispensable para discernir y aquilatar dichos extremos; es decir, para saber con alguna consistencia en qué casos tendrá fundamento invocar frente a alguien la regla general de que no está permitido contrariar los propios actos" 62 .

Entonces para arribar a cualquier conclusión, el juzgador deberá asumir el rol de intérprete comportamental, debiendo auscultar y luego valorar cuidadosamente la conducta asumida por las partes -o sujetos correspondientes, a lo largo de las fases del contrato, en sentido lato. No en vano, es un ejercicio hermenéutico el que deberá realizarse, con el fin de aplicar o inaplicar la doctrina en referencia, lo que se corrobora plenamente de cara a la relación negocial, en cuyo caso serán de recibo, en lo pertinente, las pautas que, ministerio legis, con carácter vinculante,

${ }_{61}$ Con gran realismo, el profesor Josef ESSER, con ocasión del análisis de la misión de la ley y la atribuida a los principios, expresamente se refiere al venire contra factum proprium, y lo hace en los siguientes términos: “...los ejemplos clásicos de reducción de "pensamientos jurídicos generales' a artículos concretos de una ley, como la de la subrogación real en el patrimonio separado a los ejemplos conocidos o la del venire contra factum proprium a la 'idea contenida en el art. 162 BGB', si se sirven de esta forma demostrativa para subrayar cómo los principios en cuestión 'nacen de la ley', es sólo en aras de sistematismo. La verdad es que, en tanto que principios, son eficaces con independencia del texto legal. Su justificación les viene de la naturaleza de la cosa o de la institución respectiva, y constituyen una pieza funcionalmente necesaria de toda solución concreta que entre en ese círculo común de problemas. De ahí que, dadas las unas circunstancias análogas, sean igualmente bien conocidos en todos los sistemas jurídicos, incluso allí donde ninguna ley los 'conoce'. La necesidad, en conjunción con una armonía, no bastante estudiada aun, en las ideas de justicia formadas en el curso de la historia, da lugar, en iguales conflictos de intereses, a soluciones coincidentes -aun en ausencia de 'ley' y de todo 'concepto doctrinario'....No nos dejemos, pues, extraviar por lo exterior....".

62 J. Puig Brutau, La doctrina de los actos propios, op. cit., pp. 97 y 98. Cfr. María Fernanda EKDAHL E. La doctrina de los actos propios, op. cit., p. 27, quien igualmente reconoce que en este campo "...el rol del juez es decisivo". 
estableció el legislador, y no meramente indicativo, campo en el cual se tiene establecido que no revisten la naturaleza de consejos o meras recomendaciones ${ }^{63}$.

Así las cosas, con suma y responsable prudencia le corresponderá al juez analizar la situación de hecho y de derecho respectivas, como ya lo hemos dicho en diversos apartes de este escrito, pues tan inconveniente y lesivo es el juzgador que inyecta incoherencia, ese que, obsesiva y rimbombantemente, se cimienta en la regla latina en cita, para hacerle producir efectos en todos y cada uno de los casos (fiebre o moda judicial), como el que, de espaldas a la justicia del caso, a la equidad propiamente dicha, permite que, el voluble, el incoherente, el versátil, y el contradictorio, salgan y permanezcan inmaculados, en grave perjuicio ajeno, a pretexto de un exacerbado rigorismo que guillotina y ahoga derechos subjetivos. Nuevamente equilibrio, y más equilibrio. Ni jueces obsequiosos, esos que sentencian más con el corazón que con la razón, desconociendo las pautas y límites jurídicos; ni jueces fanáticos que, inscritos en el ius strictum, obsecadamente, se niegan a hacer justicia, con el argumento de que la doctrina no tiene asiento y desarrollo legal propio, o de que cuando se aplican este tipo de reglas se está fallando no en derecho sino en equidad, o de que la confianza que se suscitó en cabeza de uno de los cocontrantes, por vía de ejemplo, fue por falta de audacia, o perspicacia, pues en el fondo, hoy 'no se puede fiar de nadie'.

Claros entonces los límites que tiene la relevante tarea del juez, útil es memorar que, in concreto, en este campo su laborío resulta imprescindible, pues aunque es cierto que entraña riesgos, como toda obra humana, no puede desconocerse que, con las cautelas de rigor, hay que confiar en su juicio y en su sindéresis, no como un 'acto de fe', únicamente, o como muestra de resignación ciudadana, sino en función del papel que en un régimen democrático desempeña -o debe desempeñar-el juzgador, con mayor razón en tratándose del examen de la doctrina del acto propio, ayuno de desarrollo legal, pues como acertadamente lo realza don José María Miquel GonzÁlez, “...la proliferación de las cláusulas

63 Vid. Carlos Ignacio Jaramillo J. La interpretación del contrato en el derecho privado colombiano, en La Interpretación del contrato en América Latina. T. II. Grijley. Lima. 2007. 
generales, como equidad, abuso, buena fe, conduce a una potencialidad del arbitrio judicial...." ${ }^{\prime \prime}$.

En armonía con lo afirmado, habrá que acudir entonces a los jueces para efectos de solicitar la aplicación de la regla del venire contra factum proprium en sus distintas dimensiones, pues como lo recreara el propio ARISTÓTELES «Cuando están en desacuerdo los hombres recurren al juez, pues ir al juez es ir a la justicia, y el juez es la justicia animada ${ }^{65}$.

\subsection{Procedencia y APLICACIÓN DE Oficio POR PARTE DeL JUEZ}

Aun cuando lo corriente, lo que de ordinario tiene lugar en esta materia, es la alegación, pretensión, formulación o réplica, lato sensu, por parte del interesado o interesados (principio dispositivo), nos parece pertinente, a la par que acorde con el auténtico alcance jurídico-ético asignado a la doctrina de los actos propios $y$, por tanto, posible que el juzgador pueda ocuparse de ella, de oficio y no en forma rogada, en prueba de su aquilatada vigencia, y fuerza expansiva. De lo contrario, lo anticipamos, se le restaría su verdadera importancia como remedio, en particular como infranqueable límite al ejercicio de un derecho subjetivo lesivo de los intereses de un congénere, en sede contractual, de su cocontratante, con todo lo que ello implica. Al fin y al cabo, lo que está en juego es un reproche frontal no sólo a la buena fe, lo que es determinante, sino también a la falta de coherencia, de constancia y regularidad comportamentales, hechos que reclaman del juez una actitud diversa, a tono con su genuina misión tuitiva, muy ajena a ese juez pasivo, espectador y frío del pasado, hoy por hoy inadmisible, obviamente sin exagerar su tarea y sin olvidar sus límites, porque los tiene, ciertamente, como lo hemos resaltado.

64 José María Miquel GonzÁlez. Observaciones en torno a la buena fe, op. cit., p. 497.

Justificando la tarea del juez contemporáneo, en particular de cara a los denominados 'tópicos jurídicos', dentro de los cuales incluye el venire contra factum proprium, Ch. PERELMAN anota que gracias a ellos "... el juez va a disponer de una mayor libertad en la interpretación de los textos legales y en su flexibilización", lo que significa que "...esta libertad, en lugar de conducir a la arbitrariedad, aumenta los medios intelectuales que el juez dispone para la búsqueda de una solución razonable, aceptable y equitativa". La lógica jurídica y la nueva retórica, op. cit., pp. 123 y 129.

65 Aristóteles. Ética a Nicómaco, 1132, a. 
No encontramos, en tal virtud, ningún obstáculo real e insalvable, que impida que en el marco de un proceso, llegado el caso, indefectiblemente el juzgador entienda que una específica 'pretensión', concebida en sentido muy amplio, como lo hemos expresado, no pueda abrirse paso, justamente en consideración al mencionado principio y tendencia que, de otra manera, se verían eclipsados, so capa de la aplicación de uno o varios criterios 'procesales' que, en últimas, desvirtuarían la auténtica ratio del Derecho procesal contemporáneo, menos proclive, en buena hora, por la ciega e irracional defensa del inciso, del numeral, de la vía, o de la fórmula, así una de las partes inmersas en la litis no haya invocado la regla venire contra factum proprium (ius strictum). ¿Cómo aplaudir pues al funcionario que, de espaldas a la institución que detiene nuestra atención, proclama rancias fórmulas procesales, a sabiendas de que caros derechos subjetivos se mancillarán por su inacción, mientras se ocupa de hacer alarde de su aparente sabiduría? Cuánto daño, efectivamente, se genera por parte de esos jueces espectadores que, aun evidenciando un elocuente hecho constitutivo de injusticia contractual, optan por acallarlo con su silencio indiferente y con su apatía, y que prefieren que, por esa vía, naufraguen los derechos y prerrogativas de uno de los justiciables que, confiadamente, acudió a él en procura de justicia, y no de su negación.

Por ello, en la actualidad, no resulta de recibo que cuando en los estrados judiciales se pasee la incoherencia, la contradicción, la incongruencia en el comportamiento de uno de los contratantes, así sea titular de un derecho lícito, el juzgador se torne preso de la ausencia de invocación de la doctrina por parte del llamado sujeto activo, lesionado por obra del factum novum, el que no puede quedar impune. Es en ese preciso momento, en cambio, cuando el iudex, responsablemente, podrá cumplir de mejor manera su hierático oficio, y sentirse pleno, en la intimidad de su ejercicio, de haber honrado su toga. Ese día deberá sentirse realizado, por haber sido intérprete de la justicia y vocero, al mismo tiempo, del Derecho procesal moderno, ese que no se aferra irrestrictamente a fórmulas y adagios que, en el pasado, pudieron tener alguna justificación, pero que hoy por hoy no tienen análoga fuerza y pertinencia, puesto que el proceso, como ya lo expresáramos en el pasado, no puede ser como una especie de triángulo de las Bermudas, en donde se extravíen los derechos de las partes, en este caso, los del sujeto que ha sido víctima de la incoherencia, vulneratoria de la confianza otrora depositada. 
No en vano, en los tiempos que corren, quizá como en ningún otro, se ha hecho evidente, amén que necesario, que el juez abandone esa posición de neutralidad, que no puede confundirse con la imparcialidad, stricto sensu, en orden a desempeñar una tarea menos distante o divorciada de la realidad que inspira el proceso actual, un laborío más activo que, sin redundar en un malhadado 'activismo judicial', o del ejercicio desbordado del quehacer del juzgador, propio de la idea de sustitución relativa de algunos de los poderes públicos, entre otros ejemplos más, deje esa actitud de espectador que mencionabamos, o de mero observador, impotente, de la transgresión de acrisolados derechos, en contravía de un 'orden justo', como lo imperan algunas constituciones modernas, o como se desprende de los postulados que escoltan, bien entendido, un Estado Social de Derecho, uno de ellos, de suyo relevante, atinente a la 'prevalencia del derecho sustancial' frente a aspectos formales, en los que se suelen ahogar muchas prerrogativas, o en las que terminan adheridas numerosas expectativas de los justiciables, en una especie de telaraña judicial.

Proceder de oficio por parte del iudex, de cara a concretos supuestos, no es pues exótico, ni aventurado, ni menos inusual en el Derecho comparado. Muy por contrario, así existan voces inconformes, que desde luego respetamos, es una práctica relativamente corriente en algunos sistemas y naciones que, cabalmente realizada, evita la floración de tantas injusticias que, de otro modo, se enseñorearían en el cosmos jurídico y social, con graves secuelas.

Atenerse entonces, invariablemente, esto es en todos y cada uno de los casos a la alegación de parte, creemos que desvertebra la ratio cardinalis de la doctrina de los actos propios, tolerando que determinados sujetos, a contrapelo de la buena fe, y de las más elementales reglas y deberes especiales de conducta, terminen mofándose de la justicia, y de paso, del propio juzgador que, desvalido, observa como se erosionan los derechos ajenos, como se mansilla al justiciable ante sus ojos, circunstancia ésta que refrenda que en estos concretos casos es conveniente recrear la imagen de la justicia de modo algo diferente, con el propósito de despojarla de la venda a ella característica, con el fin de que pueda ver con diafanidad y, por ende, corroborar su visible quebranto. Actuar, solícitamente, es pues la consigna que en este ámbito debe imperar. 
Sobre este particular, con su proverbial claridad, explícita don Luís DíEzPıcAzo, que "...el juez puede fundar en esta causa su sentencia, aunque no haya sido alegada. ¿Puede el carácter contradictorio de una pretensión ser tenido en cuenta de oficio por el juez como 'ratio decidendi' del litigio, o es preciso que haya sido previamente alegado por la parte?...A mi juicio...no existe para ello ningún inconveniente y puede perfectamente el problema ser reconducido al principio 'lura novit curia'...." Por eso “... el juez puede, de oficio, fundar esta desestimación en el carácter contradictorio..., aunque este problema no haya sido abordado por las partes"66.

66 Luís Diez-Picazo. La doctrina de los propios actos, op. cit., pp. 250 y 251. Cfr.: Mariana BERnAL FAndiño. El deber de coherencia en el derecho colombiano de los contratos, op. cit., p. 253. Véase también a Marcelo López MESA. La doctrina de los actos propios, p. 148, autor argentino que indica que, "...por la vía del principio iura curia novit, se ha aplicado de oficio el instituto....criterio que apoyó también el despacho de las Novenas Jornadas Nacionales de Derecho Civil (Dres. Compagnucci, Goldenberg, Cazeaux, Gosende, Stiglitz, Sala, Ramírez, Tejerina, Mosset Iturraspe, Bustos, López Cabana, Ricer E Iribarne); Edgardo AlberTI, Doctrina de los actos propios, op. cit., p. - XXXII y ss.; Alejandro BordA. La teoría de los actos propios, op. cit., p. 142; Gustavo OrdoQu C. La buena fe contractual, op. cit., p. 606, y Rodrigo AlCAíno ToRREs. Comentario acerca de la naturaleza, efectos y orígenes de la regla venire contra factum proprium non valet, que impide contravenir las conductas pasadas, op. cit., p. 117, quien anota que para que se proceda de oficio "...basta que el juez constate la contradicción". Categóricos, a su turno, son los profesores argentinos PeYrano y ChIAPPINI, según los cuales “...los jueces pueden y deben invocar oficiosamente y sin retaceo alguno la doctrina de los propios actos, ora respecto de la relación sustancial, ora respecto de la relación procesal". La doctrina de los propios actos en el ámbito del procedimiento civil, op. cit., p. 819.

Es de señalar que algunos de los mencionados autores, clara y confesamente partícipes de la idea de la actuación ex officio, son contestes en señalar que para que proceda es menester que el interesado haya puesto en evidencia la contradicción o la transgresión del acto propio. Así, ad exemplum, el Dr. LóPEz MESA entiende que "Basta con que la parte haya denunciado el cambio de actitud de la contraparte para que proceda la aplicación de oficio de la regla, porque se cumple entonces la exigencia de la congruencia y no se ultrapasan las alegaciones, pretensiones y defensas introducidas por los litigantes". La doctrina de los actos propios, op. cit., p. 148. Ya había expresado lo mismo AlBeRTI, a juicio de quien "...lo necesario, en todo caso, es que la conducta precedente respecto de la cual la pretensión provocaría una contradicción inatendible por el tribunal, sea invocada y probada en sí misma". Doctrina de los actos propios, op. cit., p. XXXIII. Cfr. Osvaldo A. GozAINI, La conducta en el proceso, op. cit., p. 218. En dirección algo similar, la Dra. Clara I. Assua GonzÁlez, refiriéndose al "ejercicio de los derechos conforme a las exigencias de la buena fe", pone de presente que, "Dado que la buena fe delimita los perfiles de un derecho, poder o facultad, no ha de descartarse que su vulneración pueda, según los casos, ser apreciada de oficio; cuestión que ha de valorarse también desde la perspectiva de los límites de la congruencia (art. 218.II LECCiv) y la interdicción de la indefensión (art. 24.1 CE)", en “ Código Civil Comentado, artículo 7", op. cit., p. 91.

Empero, hay que mencionar que otros doctrinantes, en nuestro entender con argumentos convincentes, a la par que a tono con la verdadera esencia de la figura que analizamos, 
No toda la doctrina, como era de suponer, está plenamente de acuerdo con la aplicación de oficio del acto propio por parte del juez, aunque hay que reconocer que la communis opinio, en general, la admite. La Dra. M. Nélida TuR FAUndEZ, en la otra orilla, al amparo de la interpretación que ella realiza del contenido del art. 218.1 de la nueva Ley española de Enjuiciamiento Civil de 2000, arriba a una conclusión que, aun cuando no es absoluta, a fuer de categórica y terminante al respecto, sí pone en tela de juicio su aplicación ex officio, cuando concluye que “...resulta difícil -o al menos arriesgado-afirmar tajantemente que el juez puede aplicar de oficio la doctrina de los actos propios. Estamos ante una manifestación del principio general de la buena fe, que tiene el carácter de norma jurídica. $Y$ según acabamos de ver, únicamente podrá ser aplicado de oficio por el juzgador cuando su aplicación no altera lo que los litigantes han querido establecer sobre sus derechos subjetivos en juicio"67.

Con nuestro acostumbrado respeto, no podemos adherir a la postura anterior, pues no ponemos en duda la aplicación de oficio de la doctrina de los actos

sobre todo con su carácter remedial y bienhechor, se inclinan por una postura más amplia, encaminada a validar la actuación del juez cuando se percate de la presencia del quebranto incidente del factum proprium, como lo expresare don Luís DIEZ-PICAZO, citado en precedencia, y como a menudo se hace en sede judicial en diferentes latitudes. Así sucede con el Dr. BorDA, quien con rotundidad expresa que, en su opinión, "... lisa y llanamente, la conducta contradictoria puede y debe ser valorada por el tribunal, incluso aunque no haya mediado pedido de parte; y ello es así porque no se trata ni de una prueba, ni de una presunción, ni de un dato indiciario, sino de que no es admisible que se premie la conducta contradictoria, porque se violaría el principio general de la buena fe", autor que concluye su exposición, anotando que los jueces "...tienen el deber de impedir la incoherencia, los comportamientos contradictorios, la mala fe, evitando que ello se generalice en el mundo de los negocios con el irreparable perjuicio que traería aparejado en la confianza del público y el normal y desleal desenvolvimiento comercial de nuestra sociedad". La doctrina de los actos propios, op. cit., p. 142.

Análogo parecer expresan, en lo esencial, Anibal T. Alterinı y Roberto López CABANA, al puntualizar claramente que, "También afirmamos la posibilidad de la aplicación de oficio de la regla venire contra factum proprium (....). Se trata, en nuestra opinión, de una derivación de la línea de ideas que incorpora oficiosamente al proceso los standards de buena fe y el ejercicio regular de un derecho.... VENINI (....) afirma, con criterio compartible, que 'muy magra imagen daría el juez de los que realmente constituyen la esencia de su función si, apercibido de groseras violaciones de aquellos standards mencionados (buena fe, moral y buenas costumbres) aplicara el derecho tal como se pretende, habida cuenta de que no ha mediado un planteo concreto sobre tal temática". Actos propios y responsabilidad civil, op. cit., pp. 46 y 47.

67 M. Nélida TuR FAUndez. La prohibición de ir contra los actos propios y el retraso desleal, op. cit., p. 55. 
propios, como lo hemos ya advertido a lo largo de este numeral, ad baculum de doctas opiniones.

Expresa efectivamente el artículo 218, párrafo 2 de la citada Ley de Enjuiciamiento que, "El tribunal, sin apartarse de la causa de pedir acudiendo a fundamentos de hecho o de derecho distintos de los que las partes hayan querido hacer valer, resolverá conforme a las normas aplicables al caso, aunque no hayan sido acertadamente alegadas por los litigantes".

Aun cuando la misma autora reconoce que en torno al punto en el Derecho español "Entre la doctrina procesalista encontramos diferentes opiniones", 68 aspecto que, de entrada, confirma que en este campo no hay una única manera de interpretar la norma, menos en forma inequívocamente restrictiva como algunos lo hacen, no hallamos en la referida disposición un obstáculo ciertamente insuperable que inhiba al juez contemporáneo, del que a propósito hace gala tan moderna ley en el concierto internacional del Derecho procesal, de actuar de oficio, cuando las circunstancias, de suyo excepcionales, así lo aconsejen, con el objeto de no alterar postulados que están aún por encima de lo querido por las partes, quienes ya no son los titulares del proceso, privativamente hablando.

Mal puede pues seguir pregonándose que son los litigantes los monarcas absolutos de la relación procesal, y que el juez, per se, es un invitado de piedra, que debe conformarse con actuar, 'robóticamente', en atención a lo ordenado por las partes, así se esté en presencia de la más indignante y atroz injusticia. A ello no apunta ni el Derecho, en general, ni el procesal o constitucional, en particular, los que deben velar por tutelar y proteger las prerrogativas y expectativas de los justiciables, y dentro de ellos, prevalentemente, la confianza legítima que una actuación previa, digna de respeto, despertó en una de las partes de la litis. Si de coherencia se trata, tema del que tanto hemos escrito, es menester observarla, a fin de que la protección de la referida confianza no se torne teórica, o nominal.

68 Ibídem, p. 55. La Dra. M. Nélida TuR F., en sentido favorable a la tesis de la procedencia ex officio, cita a OTELls Ramos, quien entiende que es “...función propia del juez, ejercitar de oficio por el mismo, la de aplicar el Derecho del modo que considere correcto, sin quedar vinculado por las alegaciones de normas y principios jurídicos y por los razonamientos jurídicos efectuados por las partes". Derecho procesal civil, p. 450. 
No creemos, por tanto, que ese haya sido el espíritu genuino del artículo 218 de la Ley de Enjuiciamiento Civil, expedida en los albores del nuevo milenio, signado por una mayor humanización del proceso, y del contrato, con todo lo que ello envuelve, aunado a una mayor democratización de uno y otro, cabalmente entendida. De ahí que si el juzgador debe fallar "...conforme a las normas aplicables al caso", como lo expresa imperativamente el señalado precepto, deberá hacer eco de disposiciones que como el artículo 7 del C.C, preclaramente contemplan y desarrollan el postulado de la buena fe, nada menos que de cara al ejercicio de los derechos, elocuente expresión que no puede ser esterilizada por la aplicación de una lectura reduccionista, o de espaldas a la realidad de los acontecimientos, esos que deben orientar la sentencia del juez.

Lo mismo sucede tratándose de valores de estirpe constitucional, v:gr.: la seguridad jurídica (art. 17.1, Constitución española, entre otras), la que se vería socavada si se permitiera que el demandado, vulnerando la buena fe y la confianza legítima por él suscitada, resultara libre de cualquier responsabilidad, merced al argumento formal de "...no apartarse de la causa de pedir", a sabiendas de que se estaría apartando de algo superior: la justicia misma. De allí que, in complexu, deba interpretarse la mencionada norma, con el propósito de no quebrantar su recta inteligencia, que respetuosamente creemos que es otra, como tiene lugar en el Derecho comparado, ampliamente.

Más que contundente, en efecto, es la opinión del profesor F. WIEACKER, de acuerdo con la cual "...la excepción de 'ejercicio inadmisible del derecho', debe ser hoy incuestionablemente examinada de oficio, y, en caso necesario, incluso puesta en evidencia mediante el derecho a interrogación judicial"69.

Y también lo es la expresada recientemente por el profesor Joan PIco I JunOY, quien en su segunda edición de su obra sobre la buena fe procesal, alude a esta polémica, separándose del criterio de quienes no aceptan la procedencia ex officio en referencia, y lo hace en los siguientes términos que, in extenso consignamos,

69 Franz WIEACKER. El principio general de la buena fe, op. cit., p. 89. Cfr. F. Venosta. Note sull'exceptio doli generalis, op. cit., p. 535, autor italiano que anota que "...el juez debe aplicar ex officio la normativa de la buena fe, si no quiere pronunciar una sentencia injusta". 
dada su valía y también lozanía: "Además de la denuncia a instancia de parte, y debido al carácter imperativo de los arts. 11.1 LOPJ y 247 LEC, el principio de la buena fe procesal debe hacerse respetar también ex officio, y en este sentido se pronuncia la propia literalidad de las citadas normas, la doctrina y la jurisprudencia. Sin embargo, especialmente por parte de ciertos civilistas que han estudiado el alcance del art. 7.1 CC, entienden que debido a la vigencia del principio dispositivo en el proceso civil no cabe esta actuación oficiosa por cuanto es exigible la previa alegación por quien pretenda la inadmisibilidad de la conducta realizada. Como es obvio, el principio dispositivo exige que la delimitación fáctica de lo enjuiciado lo realicen las partes, esto es, impide que el conocimiento privado del juez pueda incidir sobre aquello que libremente las partes quieren someter al debate procesal. Partiendo de la corrección inicial de este planteamiento, deben efectuarse dos observaciones:

a) En primer lugar, respecto de la relación jurídico-procesal, el juez puede apreciar la actuación maliciosa de la parte en todos aquellos actos que se deriven de su propia intervención procesal sin necesidadque la parte contraria alegue nada (así, por ejemplo, en el caso ya analizado de la STS de 9 de octubre de 2007300, el juez puede apreciar de oficio la doctrina de los actos propios cuando el litigante no solicita una prueba -e incluso se opone a la misma- y después insta la nulidad de la sentencia en función de la falta de práctica de dicha prueba, y puede hacer todo ello sin necesidad de que la parte contraria formule alegación alguna sobre el particular)".

"b) Y en segundo lugar, respecto de la relación jurídico-material, el juez también podrá apreciar de oficio la actuación maliciosa de la parte cuando concurran dos requisitos: que los hechos susceptibles de calificarse como atentatorios a la buena fe hayan sido oportunamente alegados por alguna de las partes, y que esta alegación forme parte del planteamiento o enfoque jurídico de quien será beneficado por la apreciación de la mala fe, esto es, sin ser necesario que expresamente se alegue la actuación «de mala fe» de la parte contraria, si se debe deducir -de la exposición fáctica formulada en el escrito inicial de alegaciones- mediante expresiones que manifiesten dicha actuación (así, por ejemplo, afirmaciones tales como la intervención «deshonesta», «indecente», «inmoral», «desleal», «sorpresiva», «abusiva», «indigna», «fraudulenta», «contraria 
a los usos habituales del sector», «atentatoria a la confianza recíproca»-0 similares- de la parte contraria), pues sólo así se permitirá que la parte adversa pueda defenderse adecuadamente. En este caso, no es relevante que el litigante expresamente haya citado el art. 7.1 CC, 11 LOPJ o 247 LEC, para que el juez aprecie de oficio los efectos derivados de una actuación atentaroria a la buena fe en virtud de la regla iura novit curia recogida en el art. 218.1.II LEC.... Si se dan ambas circuntancias.... es válida la iniciativa oficiosa del juez civil"70.

\subsection{LA DOCTRINA DE LOS ACTOS PROPIOS NO PUEDE SER APLICADA MECÁNICA, AUTOMÁTICA E ILIMITADAMENTE}

Íntimamente vinculada con las características que anteceden, es conveniente mencionar otra nota que acompaña al factum proprium, ya pincelada por nosotros en diversos apartes de la presente monografía, pero que, en orden a darle más sustantividad y autonomía, la registramos seguidamente, con el confesado propósito de evitar algunos desafueros. Nos referimos al carácter limitado de la regla del acto propio, rasgo éste encaminado a enfatizar que, no obstante su indiscutida utilidad, la que nuevamente sublimamos, no puede ser aplicada en todos los casos, per se y mecánicamente, no sólo por la referida subsidiaridad o residualidad, sino también porque debe serlo ex abundante cautela, y $\sin$ desbordado entusiasmo y furor, el que puede ser contagioso en el sistema jurídico, en especial en la esfera judicial ${ }^{71}$.

70 Joan Pico I Junor. El principio de la buena fe procesal, Boch Editores, Barcelona, 2012, pp. 135 y 136.

71 Sobre este mismo particular, haciendo énfasis en el referido carácter alquímico, a la par que mágico, la jurisprudencia argentina ha tenido oportunidad de precisar con tino que, “.... esta teoría no es alquimia milagrosa ni puede ser al juez lo que la triaca máxima al médico (cuenta ORTEGA Y GASSET que cuando se había perdido la esperanza en salvar al paciente, el médico resolvía reunir todos los elementos medicinales conocidos en una sola pócima; a esa combinación surgida de la desesperación del médico se le llama 'triaca máxima' (Sentencia de la Corte de Mendoza de 5 de mayo de 1990, Voto de la Dra. Aída KemelmAJer de CARLUCCI).

La jurisprudencia colombiana, por su parte, igualmente resalta el cuidado que debe imperar en materia de la aplicación de la mencionada doctrina. En esta dirección, en sentencia del 24 de enero de 2011, precisó que “... si bien es evidente la necesidad de que las partes observen aquellas líneas de comportamiento, que no contraríen los derroteros ya trazados en sus conductas, ni, menos, minen su credibilidad en el desarrollo precontractual o contractual con desorientaciones perniciosas; a pesar de tan noble propósito, se decía, 
La doctrina de los actos propios, en tal virtud, no puede ser asimilada a una receta mágica, una institución mesiánica, que todo lo puede y lo conjura; una figura alquímica que, in radice, trasforma la esencia o sustrato material de las cosas o, si se prefiere, un instituto que, a emulación del Rey MIDAs, lo que por él sea tocado, de plano, se convierte en áureo. No en vano, pese a su renovada importancia, tiene límites y fronteras amplias que no pueden ser soslayadas, a pretexto de su generalizada aplicación, por justiciera que luzca y prima facie parezca la idea de llevarla a la práctica siempre, y sin restricciones.

Mesura, tacto, y suma cautela, son pues virtudes que el juzgador debe observar, pues reconociendo su singular magnetismo, la magia que la rodea, el iudex no se puede dejar envolver o seducir por sus avasalladores encantos, ante los cuales no debe rendirse, so pena de esclavizarse y, por ende, esclavizar la justicia, como quiera que, mal entendida, mal aplicada, antes que bienhechora, puede convertirse en una institución erosiva, y paradójicamente injusta. Desde esta perspectiva, merced a sus indubitables efectos alucinantes, debe imperar la prudencia y la ecuanimidad, a fin de que el juzgador no se deje guiar por los espejismos de una justicia vidriosa y sólo aparente: de galería. Hay que huirle pues a tales anzuelos envenenados, y recordar que hay límites infranqueables que la signan, y presupuestos que se deben observar, ya expresados ${ }^{72}$.

surge incontestable, de todas maneras, que la observancia irrestricta de sus propios actos no aparece como un deber u obligación absolutos, dado que existen hipótesis en las que ante situaciones similares ó con respecto a actos desplegados con anterioridad por la misma persona, que sirven de apalancamiento para su actuar en el inmediato futuro, le está deferida la posibilidad de apartarse de los mismos. Por consiguiente, no se trata en casos tales, de viabilizar los cambios inesperados, sorpresivos y contradictorios; ni de imponer, irrestricta e irreflexivamente, la observancia permanente e inmodificable de lo actuado".

72 No se equivocan los autores Jorge PeYRano y Julio CHIAPPINI, al momento de resaltar que “...los magistrados deben ser especialmente cautos cuando se trata de aplicar el venire contra factum proprium porque dicha doctrina no debe servir como puente de plata para efectuar fundamentaciones dogmáticas o facilistas....". La doctrina de los propios actos en el ámbito del procedimiento civil, op. cit., pp. 818 y ss.

En este mismo sentido, el profesor Marcelo LópEz MESA pone de presente que, "A decir verdad, nos asustan los entusiasmos, porque generalmente no son hijos de una consideración serena, de una crítica sopesada de virtudes y defectos, de un balance necesario entre el pro y el contra. Los entusiasmos respecto de ciertas ideas jurídicas han hecho que se llamara eterno a lo que, a veces, en realidad era efímero; que pasara por justo lo que es inicuo, que se convirtiera en moda una determinada idea sin merecerlo, y que pasaran al olvido otras elaboraciones sin que tampoco ello se justificara. Ello implica, lisa y llanamente, que la prohibición de variar de comportamiento no debe ser aplicada en 
En síntesis, sí a la procedencia de la doctrina de los actos propios, en sí misma vulneratoria de la buena fe y de la confianza legítima, rectamente entendidas, pero sin exageraciones, pasiones y desbordamientos, obviamente en el entendido, que igualmente reprochable es la exageración, como la inaplicación o inhibición, pues de un extremo, se pasaría al otro, ambos indeseados. Tan grave es pues aplicarla mal, como no aplicarla, cuando se torne conducente, en cuyo caso la injusticia afloraría por omisión, y no por acción, hecho que invita a la cordura y a que se realice un ponderado ejercicio de valoración individual, dado que el esmero y la cautela con la que se debe actuar, no puede extralimitarse, hasta el punto de tornarla inoperante, como se manifestó. He ahí de nuevo subrayada la elevada tarea conferida al juez en esta materia, para nada exenta de dificultades, y también la responsabilidad para los abogados de acudir a ella cuando sea menester, no siendo de recibo, ni la prodigalidad extrema, ni la avaricia o restricción suma. Que hable de nuevo el justo medio, quien tiene la palabra.

Lo mismo puede decirse cuando, sin necesidad real, se invoca en los fallos judiciales, lo cual no es muy infrecuente, pues la sentencia termina resolviendo la litis pero con fundamento en otras razones enteramente diversas, en cuyo caso se hace un uso indebido de la doctrina en cita, que no está llamada a adornar las decisiones de los jueces, por más sonora y virtualmente erudita que resulte la regla venire contra factum proprium. En esta hipótesis, se evidencia pues una distorsión de la doctrina de los actos propios, como quiera que si se refiere a ella en su corpus, en línea de principio rector, es para que incida en la ratio decidendi, y no para situarse en la periferia de la sentencia, o para traducirse en obiter dicta.

forma rígida, ni antisocial, ni mucho menos automáticamente, siempre que existiera una contradicción entre dos actos", motivo por el cual, concluye el mismo autor, que "El venire contra factum...no debe ser aplicado ilimitadamente ni con cualquier objeto. Se trata de una teoría valiosa que debe ser empleada dentro de su marco, sin retraerse ni excederlo. Y no puede utilizarse irreflexivamente, ni para cualquier cometido". La doctrina de los actos propios, op. cit., p. 172.

Finalmente, los autores Mario CAStilLo F. y Rita SABRoso M, en la misma línea, concluyen su monografía recordando que "...el venire contra factum proprium no debe ser aplicado ilimitadamente ni con cualquier objeto. Se trata de una teoría valiosa que debe ser empleada dentro de su marca, sin retraerse ni excederla. $Y$ no puede utilizarse irreflexivamente, ni para cualquier cometido, porque constituye una herramienta flexible y no un fluido que se adapte a todo continente". La teoría de los actos propios, op. cit., pp. 180 y 181. 


\subsection{LA CONDUCTA CONTRADICTORIA DEBE APRECIARSE EN CADA CASO EN PARTICULAR}

También en sintonía con la característica precedente, según lo hemos tangencialmente mencionado, brevemente expresamos que la doctrina del acto propio, en sí misma considerada, no puede aplicarse generalizadamente, sin atender las circunstancias individuales de cada caso, habida cuenta que se requiere un examen pormenorizado de lo acontecido en el litigio, o fuera de él.

Por consiguiente, la conducta que prima facie luce contradictoria, será necesario auscultarla en cada asunto, con prescindencia de análisis tan globales o generales, que no consulten el casus, fiable brújula que le servirá de apoyo al juzgador para escrutar la realidad de los acontecimientos y de las particularidades que lo rodearon, los que serán diversos, no siendo de recibo aplicaciones huérfanas de lo que ciertamente aconteció, con mayor razón cuando hay contradicciones, bien se sabe, que son legítimas, amén de autorizadas por el ordenamiento, motivo por el cual, per se, no pueden ser estigmatizadas todas y cada una de ellas, situación que exige cautela y buen juicio. ${ }^{73}$

Lo anterior explica que no se puede proceder al margen de lo que sucedió en la esfera contractual, pues cada conducta o comportamiento, figuradamente, tiene su tonalidad, a la vez que talante y personalidad propia, no pudiéndose entonces uniformar, a priori, sino contrastar con lo sucedido en sede negocial.

En este orden de ideas, será indispensable descender al caso en concreto, en aras de poder determinar si la incoherencia advertida, bien por iniciativa de parte, o ex officio por el ludex, deviene inadmisible y, por tanto, improcedente, sobre todo por quebrantar la confianza depositada con anticipación en uno de los cocontratantes, según lo tiene establecido la doctrina. Sólo así, esto es haciendo un ejercicio estrictamente individual, podrá establecerse la conducencia de la

73 Cfr. Francesco Alcaro, Lucia Bandinelli y Massimo Palazzo, quienes anotan que de cara a la buena fe y por extensión a la regla venire contra factum proprium, "... no es posible asignar un contenido prestablecido y constante", en cuyo caso deberá acudirse "... .al caso particular". Effetti del contratto, Edizione Scientifiche Italiane, Napoli, 2011, p. 403. 
doctrina en mención, de acentuada aplicación práctica, y no simplemente de raigambre teórica o dogmática.

Así las cosas, procediendo de este modo, vale decir aterrizadamente en la litis, podrá hacerse una adecuada evaluación de la presencia de las diversas conductas llamadas a tener incidencia en la praxis, lo cual, además, evita la malhadada tentación de recrear la doctrina del acto propio inútilmente, en concreto en aquellos supuestos en los que no incidirá en la decisión final. Al fin y al cabo, ella no tiene como vocación adornar la sentencia, sino servirle de báculo y de firme apoyo, como se mencionó anteriormente.

\section{EFECTOS, CONSECUENCIAS Y SECUELAS JURÍDICAS DERIVADAS DE LA APLICACIÓN DE LA DOCTRINA DE LOS ACTOS PROPIOS}

\subsection{Preliminares}

Como hemos señalado en varias ocasiones, aun cuando de manera tangencial, la transgresión de la doctrina de los actos propios, o de la regla del venire contra factum proprium, o si se prefiere el quebranto del deber jurídico de coherencia a cargo de todo sujeto de derecho, en particular de cada uno de los extremos de la relación negocial, en sede contractual, no puede quedar impune, ni tampoco generarse una especie de statu quo juris, como si efectivamente todo debiera permanecer igual, vale decir inalterado, en el entendido erróneo de que erosionar o eclipsar la confianza legítima y, de paso, socavar reglas de elemental lógica comportamental y convivencial, no trasciende el mundo del Derecho y el mundo de la ética colectiva -o de la colectividad-, y que la actuación voluble, amén que contradictoria, por regla general, son de recibo y, por ende, no ameritan reproche ético-jurídico, ni implican medidas correctivas. Nada, ciertamente, más ajeno a la realidad, al ser jurídico y social.

En efecto, casuísticamente en el Derecho romano, y con un carácter más global a lo largo de otros periodos de la historia, incluido el que detiene nuestra atención -pues ella todo lo permea-, como se confirmó en el primer capítulo, 
se ha claramente evidenciado, con mayor o menos énfasis, un rechazo a la incongruencia, a la contradicción, a la oscilación o a la incoherencia, a los comportamientos dobles, entre otras expresiones que, in casu, lesionan la confianza, la apariencia, el estado regular esperado, la seguridad jurídica, la razonabilidad y que, al materializarse una cualquiera de ellas, suscita natural sorpresa, espontánea extrañeza, y profunda perplejidad y desconcierto, ante lo cual el orden jurídico no puede permanecer indiferente, o peor aún volverse cómplice, porque su deber es tomar partido, y luchar por la justicia, por el rechazo al quebranto antijurídico de los derechos de la colectividad.

\subsection{EFECTO IMPEDITIVO O LIMITANTE DEL EJERCICIO DE UN DERECHO SUBJETIVO}

En consonancia con lo mencionado, en la actualidad hay plena conciencia de que cuando aflore, de ordinario, hay que esterilizar la contradicción relevante e incidente; erradicar la incoherencia de esa laya; ahuyentar la incongruencia y extraditar las ulteriores actuaciones que, en asocio con las realizadas otrora, detonantes de confianza o, por lo menos, no indicativas de desconfianza, o extrañeza en un marco jurídico relacional en el que imperaba la presunción de buena fe, generaron sorpresa, desconcierto, desconsuelo y desazón, todo en sentido descriptivo. Hoy pues se anhela un fair play, una asepsia jurídica, en especial en sede contractual, desprovista de agentes contaminantes que, a la postre, eclipsen el norte prístino del negocio jurídico, concebido para servir, pero no para servirse unipersonal y egoístamente.

Tal esterilización o erradicación del cosmos jurídico, igualmente en el mismo contexto, es pues tarea de quien tiene a su alcance la posibilidad de evitar la trasgresión de la buena fe, en general, y la vulneración de institutos como el de la confianza legítima, en particular, entre otros más. Tan nobilísimo laborío hunde sus raíces en el vívido propósito de hacer justicia, merced a la búsqueda y consecuente aplicación de la equidad, que es su concreción, en el asunto escrutado, bien sub judice, bien por fuera de la causa litigiosa, pues si bien es cierto que el juez es quien comúnmente funge de esterilizador de las conductas volubles y lesivas de intereses dignos de tutela, tampoco es menos cierto que a su lado, como lo mencionamos en su oportunidad, hay otros actores que, sin ser representantes institucionales con carácter permanente o pro tempore de 
la administración de justicia (juzgadores y árbitros, respectivamente), también pueden desempeñar dicho rol genérico, en orden a evitar que, airosa y arrogante, se enseñoree la incoherencia o la contradicción, cuando atenten, claro está, contra la regularidad y la estabilidad esperadas en una relación jurídica, por vía de ejemplo, la negocial (constantia).

Por consiguiente, el remedio iuris que se receta cuando irrumpe la referida patología comportamental, primordialmente es su frontal inadmisión, lato sensu, toda vez que no es procedente su tolerancia o su aceptación, ora explícita, ora implícita, en uno y otro caso con idénticos efectos perturbadores, que es lo que acontece cuando no se inaplica la pretensión -también en sentido muy amplioque enarbola el incoherente, más allá de que, in abstracto, como observamos, ella sea lícita -o aparentemente lícita-, a la par que jurídica, pero in concreto, corrosiva de caros derechos radicados en cabeza del sujeto destinatario pertinente, esto es el cocontratante en la esfera contractual.

Expresado de otra manera, la doctrina de los actos propios aboga por la preservación de los derechos de la persona, natural o jurídica que, de buena fe, ha confiado previamente en un sujeto que, a posteriori, muda su conducta primigenia, con grave perjuicio para aquél, actual o inminente, razón por la cual, in toto, se impone su improcedencia, su desestimación, su rechazo, su inatención, su esterilización, por retomar este término, o el de 'cauterización', igualmente empleado por un sector de la doctrina portuguesa ${ }^{74}$. De allí que

74 Múltiples son las expresiones que se emplean en la doctrina para referirse a la secuela emergente del quebrantamiento del deber de coherencia y la correlativa vulneración de la confianza legítima y racional. Una de ellas, por de pronto la más englobante, es la inadmisión, aunque igualmente son válidas otras más, sin perjuicio del respeto de las arquitecturas procesales que pueden cambiar en cada nación y que obviamente sería menester acatar. De hecho, algunos combinan varias de ellas (inadmisión y desestimación), tal y como sucede con Don Luís DíEz-PICAZo (cita entrante), y con la profesora argentina Noemi Lidia Nicolau, quien observa que "...la pretensión contradictoria con la propia conducta resulta inadmisible y debe ser desestimada por los tribunales". La doctrina de los actos propios y la verwirkung, op. cit., p. 127. Cfr. Bernadette Minvielle y Alberto ReYes Oehninger. "La doctrina de los actos propios (perspectiva procesal civil)", en Revista Uruguaya de Derecho Procesal, Fundación de Cultura Universitaria, No 2, Montevideo, 2000, p, 294. De igual modo, Rodrigo AlCAíno TORRES, hace énfasis en la desestimación, motivo por el cual pone de presente que "...la pretensión incompatible con una conducta anterior debe ser desestimada........Comentario acerca de la naturaleza, efectos y orígenes de la regla venire contra factum proprium non valet, que impide contravenir las conductas pasadas, 
convenga contemplar la doctrina en referencia como una arquetípica limitación al ejercicio de un derecho subjetivo, como acertadamente lo hace un sector de la dogmática ${ }^{75}$, y también de la jurisprudencia, postura que, a nuestro juicio, luce precisa, habida cuenta que, en estrictez, el derecho de formular una pretensión - siempre en sentido muy lato como lo hemos señalado en diversas ocasiones-, no es irrestricto, pues conoce límites: uno de ellos, precisamente, el de pretender obtener un beneficio a costa de los intereses, derechos o expectativas de otros. Por ello, con un visible carácter impeditivo, actúa como inequívoca limitación al ejercicio de un derecho, se reitera, pues aunque no se desconoce su existencia ontológica y jurídica, no es conducente, ni racional ejercerlo, so pena de perjudicar a quien no tiene por qué verse perjudicado, entre otras razones por cuanto así lo revela y correlativamente reclama el postulado de la buena fe, muy especialmente en su vertiente objetiva, según se señaló en precedencia. Por eso es por lo que se ha afirmado que la contradicción apareja un impedimento en el ejercicio del derecho subjetivo lícito, un deber de no poder hacer o, como gráficamente lo sugiere la doctrina anglosajona, a través del estoppel, un 'pare' o 'stop' respecto a la conducta del contratante.

op. cit., p. 123. Inés Pardo De Carvallo, a su vez, manifiesta que "la indamisibilidad de la pretensión contradictoria sería, al parecer, la sanción adecuada frente a un supuesto de contravención del deber jurídico de no contrariar conductas propias anteriores". La doctrina de los actos propios, op. cit., p. 61.

75 Es así como el profesor DíEz-PICAZo, con su conocida precisión, indica que “...es claro que la prohibición de ir contra los propios actos constituye un límite a los derechos subjetivos.... Cuando decimos que nadie puede ir contra sus propios actos, significamos que un acto de ejercicio de un derecho subjetivo o de una facultad, que contradice el sentido que, conforme a la buena fe, ha de darse a la conducta anterior del titular, constituye una extralimitación ...podemos decir que la 'pretensión contradictoria con la propia conducta' es inadmisible y ha de ser, si se traduce en una actuación judicial, desestimada. No hay en este caso un deber jurídico de tipo negativo; lo único que ocurre es que se ejercita un derecho de una manera que el ordenamiento jurídico no puede tolerar". La doctrina de los propios actos, op. cit., p. 186. Vid. Rodrigo AlCAíno ToRRES. Comentario acerca de la naturaleza, efectos y orígenes de la regla venire contra factum proprium non valet, que impide contravenir las conductas pasadas, op. cit., p. 115 y 116.

En el mismo sentido, la profesora colombiana Mariana BERNAL, igualmente con tino, expresa que "...la doctrina de los actos propios", siendo "...una manifestación de la regla "Venire contra factum proprium non valet' que implica la imposibilidad general de actuar contra los propios actos", se constituye en "...límite al ejercicio de un derecho subjetivo con el fin de obtener, en las relaciones jurídicas, un comportamiento consecuente de las personas y el respeto del principio constitucional de la buena fe". El deber de coherencia en los contratos y la regla del Venire contra factum proprium, op. cit., p. 309. 
En la órbita doctrinal, en opinión del autor Alejandro BORDA, lisa y llanamente, "...la conducta contradictoria resulta inadmisible. Esto significa que cualquier pretensión ajustada a derecho puede ser exigida al sujeto pasivo de la relación jurídica, e incluso, el sujeto activo podrá obtener una resolución judicial que así lo acuerde. Pero si esa pretensión, así esté ajustada a derecho, es contradictoria de actos anteriores, resulta inadmisible, y el sujeto pasivo podrá negarse a cumplir con el reclamo y podrá obtener una resolución judicial que desestime tal pretensión"76.

El Dr. Marcelo LóPEz MESA, por su parte, pone de presente que, "El efecto fundamental que provoca la aplicación de la doctrina es la irrelevancia de la conducta contradictoria con un acto anterior, esto es, que el acto posterior contradictorio no se tiene en cuenta, y se está a la primera manifestación"77.

A su turno, para el doctrinante Juan M. DoBson, "De la apreciación judicial de la contradicción existente entre la pretensión esgrimida en el pleito y la conducta anterior del litigante, resulta la inadmisibilidad de la pretensión actual. El efecto, entonces, de la aplicación de la doctrina de los propios actos es la 'inadmisibilidad' de una pretensión"78.

Finalmente, de acuerdo con el profesor José PUIG BRUTAU, "La regla de que nadie puede ir contra sus propios actos", o si se desea, "la doctrina de los propios actos", entre múltiples nombres más que se le puedan dar, “...ofrece la particularidad de que paraliza la actuación de una persona", que "...no puede hacer que su derecho prevalezca por encima del derecho de quien ha depositado su confianza...." en determinada apariencia, de suerte que si lo pretendiere "...ha de tropezar con un obstáculo", ese mismo que, en el common law, primordialmente,

$76 \quad$ Alejandro Borda. La teoría de los actos propios, op. cit., p. 156.

77 Marcelo López M. La doctrina de los actos propios, op. cit., p. 147, quien agrega, en otro aparte de su documentado trabajo, que "Un autor español ha dicho, con todo acierto, que antes que como una espada, la prohibición de variar de conducta debe utilizarse como un escudo, siendo la función natural de la construcción servir de barrera o excepción frente a un reclamo contradictorio a una anterior conducta del sujeto voluble" (Op. cit., p. 149).

78 J. Dobson. El abuso de la personalidad jurídica, op. cit., pp. 287 y 288 , obra en la que el mismo autor, a renglón seguido, señala que, "En otras ocasiones, los tribunales han establecido que tal conducta anterior opera por vía de impedimento: el litigante que ha propiciado un acto determinado, 'no puede posteriormente variar su postura' 
deviene del llamado estoppel, como se recreó en numerales anteriores. "Por ello, muy gráficamente, los juristas anglosajones afirman que alguien está estopped o barred, es decir impedido de hacer valer el derecho que en otro caso podría ejercitar"79 y 80 .

Para una mayor comprensión de las consecuencias, efectos o secuelas dimanantes de la aplicación de la doctrina en comentario, conviene mencionar de nuevo un elocuente ejemplo, obviamente al que no se puede circunscribir su radio de acción, únicamente, no exento, por lo demás, de puntual controversia. Nos referimos a la formulación de una defensa en el marco de un proceso, concretamente a la socorrida excepción de prescripción que, si bien formalmente pudo haber tenido lugar, en atención al transcurso del tempus pertinente, no siempre podrá ser declarada como tal por el juzgador, pues si comprueba que esta actuación defensiva en la litis, en sí misma legítima, choca paladinamente con conductas precedentes constitutivas de confianza extra-procesal, ella se torna impotente para abrirse paso, en cuyo caso así lo podrá decidir expresamente el juez en su sentencia, conforme ya se ha hecho en diversas hipótesis, tanto en el Derecho patrio como en el comparado (algunas de ellas, objeto de análisis detallado por parte nuestra en apartes posteriores de este escrito, Cap. V).

79 J. Puig Brutau. La doctrina de los actos propios, op. cit., p. 102 y 103. Anne-Sylvie CourdierCUISINIER, refiere igualmente a una paralización del comportamiento contradictorio, de cara a precisos supuestos -por la vía de la déchance-. Le solidarisme contractuel, p. 420.

80 En el terreno del Derecho administrativo, la situación expuesta no varía, justamente por la estrecha relación que, en este y en otros aspectos, más de lo que prima facie parece, muy especialmente en los últimos años en los que se ha evidenciado la aparición del fenómeno llamado la 'huida del derecho administrativo hacia el derecho civil', existe entre ambas disciplinas. Es así como el profesor español Jesús GonzÁles PéreZ, en su conocido estudio alusivo al tema de la buena fe, refiriéndose al postulado que prohíbe ir contra los actos propios, manifiesta que "...la aplicación de tal principio se traducirá en la inadmisibilidad de la pretensión contradictoria, entendiendo como pretensión 'el acto de ejercicio de un derecho subjetivo o de una situación de poder frente a otra persona' “, idea que enriquece el mismo autor, folios más adelante, cuando expresa que la consecuencia "...de la aplicación de la regla que prohíbe ir contra los actos propios será la inadmisibilidad”, razón por la cual concluye el profesor precisando que, "La prohibición de ir contra los propios actos se traducirá en la improcedencia de toda actuación contradictoria con la conducta vinculante. Si tal actuación contradictoria tiene lugar en un proceso, como pretensión de una de las partes, el órgano jurisdiccional competente deberá rechazar tal petición, por atentar contra el principio de los actos propios". El principio general de la buena fe en el derecho administrativo, op. cit., pp. 125, 138 y 140. 
En el supuesto mencionado, ello es lo toral, la conducta voluble, la actuación sorpresiva, a fuer que contradictoria de cara al conjunto de actuaciones previas observadas por el titular del acto novum, en este caso en sede judicial, no quedaría incólume y, por contera, ayuna de consecuencias jurídicas, en atención a que el juzgador, como representante del Estado y como garante de un 'orden justo', tiene el deber de evitar que la incoherencia se torne incidente y que, por reflejo, se perjudique el demandante sorprendido, motivo por el cual debe esterilizar -o paralizar- los efectos extintivos ínsitos en la excepción de prescripción formulada, declarándola improcedente, con todo lo que de ello se sigue en el plano sustancial y procesal.

Lo determinante, al margen del ejemplo empleado, es que el juez, o el funcionario investido de auctoritas o imperium, conforme a las circunstancias, evite la consumación de un perjuicio en cabeza del destinatario del cambio inopinado e inconsulto -o su extensión-, quien en línea de principio, desde luego sin generalizar, no tiene por qué correr con los avatares y corolarios de la incoherencia, siendo entonces no sólo viable la aplicación de la doctrina de los actos propios o de la regla venire contra factum proprium, o cualquiera que, con distinto nombre, ello no es basilar, conduzca al mismo resultado, pues en este campo de "... dar a cada uno su derecho" o de "...dar a cada uno lo suyo, como hace más de mil quinientos años lo anotó ULPIANO (D. 1,1.10), lo de menos es el rótulo. No en vano, es un problema de justicia, que trasciende la semántica y el purismo, lo que está en estricta consonancia con su responsable actuar, aún ex officio, según se admitió al momento de pasarle revista a las características de este justiciero instituto.

En síntesis, cuando cabalmente se aplica la doctrina de los actos propios, respetando su arquitectura, quintaesencia, presupuestos y limitaciones, debe declararse claramente, cualquiera sea el vehículo y la fraseología respectiva, la inadmisibilidad de la conducta incoherente y, por ende, la inviabilidad o improcedencia del ejercicio de un derecho subjetivo, como quiera que ella funge como diáfana limitación, según se acotó, o como frontera, valladar, barrera, veda u obstáculo insalvable que, individualmente considerado, vehemente exige observancia y pleno acatamiento, pues se ha trasgredido uno de los más adamantinos deberes a cargo de los que actúan en Derecho: la coherencia, 
princesa comportamental, e hija de la reina de las reinas jurídicas: la buena fe, igualmente mancillada, que de no corregirse diligente y oportunamente su quebranto, bien podría reclamar que, en su epitafio, se dijera: aquí yacen los restos mortales de un principio hierático que, sangrante, por obra de los hombres, fue pisoteado una vez más. Del lector, en gran medida, y de algunos que no nos lean, depende que ello no se repita, aquí y allá. Huelga memorar que uno de los mayores pecados es la inacción, la pasividad.

Vale la pena entonces memorar con el reputado civilista argentino, don Guillermo BORDA, que “....nada que sea abusivo o contrario a la buena fe, puede tener protección del derecho y de los jueces"81.

Ya para culminar esta temática, es menester tener en claro que en puntuales y concretas circunstancias, en lo pertinente, será el legislador el llamado a intervenir previamente, de cara a la materialización de una manifiesta contradicción, para señalar consecuencias diferentes al impedimento o la inadmisión de la nueva conducta. Es el caso, sólo por vía de ejemplificación, de lo consignado en el marco de las obligaciones condicionales, específicamente de lo reglado por los artículos 1178 del Código Civil francés y 1119 del Código Civil español, entre otros más, los que entienden que "Se tendrá por cumplida la condición cuando el obligado impidiese voluntariamente su cumplimiento" (artículo 1119). Nótese cómo en esta materia en particular, ante la contradicción comportamental del deudor condicional que ha aceptado el débito sujeto a un hecho futuro e incierto, pero que, posteriormente, ha evitado el cumplimiento o la configuración de ese hecho, se evidencia una censura específica, que no está referida a la directa inadmisión de su comportamiento, sino a una secuela más específica, como es dar por consumado el hecho condicional.

En efecto, esta es una típica hipótesis en la que la incoherencia del sujeto, en estricto sentido, no conduce a rechazar inmediatamente dicha incoherencia, sino a una consecuencia distinta, cual es la mutación del estado de la condición,

81 Guillermo Borda. "Proyección actual de la Ley 17. 711 en materia de responsabilidad civil en Responsabilidad por daños en el tercer milenio", en Homenaje al Profesor Doctor Atilio AnIBAL AlteRINI. Abeledo-Perrot. Buenos Aires. 1998, p. 32. 
aun cuando en el fondo, bien miradas las cosas, aún allí lo que subyace es un una patente estigmatización del comportamiento contradictorio, tanto que por la vía de impedir su cumplimiento, se genera la sanción en comentario (la condición se tendrá por cumplida), aspecto que denota, a las claras, una censura al acto contradictorio o incoherente, conforme lo pusimos de relieve en su oportunidad (Cap. I).

En este orden de ideas, si bien el rechazo o la inadmisión del comportamiento contradictorio, es la consecuencia principal y general reservada para el voluble, existirán particulares circunstancias en las que dicha consecuencia adquiere una expresión normativa diferente, toda vez que surgirán, recta via, otros efectos que, cabalmente examinados, en el fondo, son indicativos del rechazo inequívoco de la consabida incoherencia. La norma particular y el caso concreto, por consiguiente, serán los derroteros específicos llamados a orientar cada situación. Así sucederá, también, por vía de ilustración, tratándose de la hipótesis gobernada por el art. 1115 del Código Civil español, el que dispone que: "Cuando el cumplimiento de la condición depende de la exclusiva voluntad del deudor, la obligación condicional será nula" (art. 1535, Código Civil Colombiano, art. 1174, Código Civil francés y 1355, Código Civil Italiano)", nulidad que encarnará la secuela adoptada por el legislador para el supuesto sub examine (puramente potestativa; si voluero).

\subsection{Destino del derecho EJercido por El Voluble}

En lo atinente a la suerte del derecho ejercido por el voluble, hay que manifestar que si bien es cierto que la inadmisión, desestimación, limitación, inejercicio, esterilización o erradicación -en sentido figurado- en lo tocante con el ejercicio de un derecho formalmente lícito es el corolario comúnmente admitido de la doctrina del acto propio, tampoco es menos cierto que un reducido sector de la doctrina aboga por entender que, en rigor, más que inadmitirse dicho ejercicio, lo que acontece es que el derecho radicado en cabeza del sujeto activo, transgresor del acto suyo precedente desaparece, se extingue, se borra o aniquila irremediablemente, esto es en forma definitiva, no cabiendo una secuela temporal o transitoria (la paralización, inadmisión o desestimación) hasta que desaparezca la violación de la confianza inculcada, según el caso. 
Aunque en esta materia no impera entonces plena unanimidad, la tesis mayoritaria se inclina por validar la primera de las posiciones descritas, encaminada a pregonar la gestación de un hecho impeditivo u obstativo, pero no radicalmente extintivo. En este sentido se pronuncia buena parte de la doctrina alemana, como bien lo recrea el profesor F. WIEACKER, al indagar y responder si “... el párrafo 242 [del BGB] constituye una causa de extinción definitiva del derecho o fundamenta únicamente un impedimento transitorio del titular para el ejercicio del mismo. Este problema no se refiere ya a la contraposición entre excepción en sentido material y excepción en sentido procesal, sino a la que existe entre el ejercicio de un derecho y el derecho mismo. En nuestro caso ha de decirse con EndemAnn, Lehmann, Esser y Siebert que el titular no se le impide el futuro ejercicio leal de su derecho, aunque la simple de lealtad pasajera no será probablemente lo normal" 82 .

Otro tanto tiene lugar con el parecer expresado por el profesor B. CREMADES, a cuyo tenor "La doctrina de los actos propios, de construcción principalmente jurisprudencial en base a la buena fe, constituye un límite de los derechos subjetivos. No extingue el derecho, sino que solamente limita su ejercicio. Se traduce en una inejercitabilidad del derecho" ${ }^{\prime 3}$.

En el Derecho francés, algunos autores abogan por la materialización de la figura de la dechéance, stricto sensu, enderezada a habilitar la pérdida del derecho, sin perjuicio de algunas matizaciones, para que se entienda, preferiblemente, como la privación de una prerrogativa. Lo cierto es que no existe un efecto único y menos unánime de la figura en comento, de suyo polémica. Por eso autores como Dimitri HoutCIEFF, acuden a la noción especializada, en el campo procesal,

82 F. WIEACKER. El principio general de la buena fe, op. cit., p. 91, quien a su turno transcribe la siguiente opinión de SIEBERT: "La lesión contra la buena fe no es ningún motivo de desaparición del derecho, pues su existencia no se aniquila por el hecho de que se intente ejercer fuera o más allá de sus límites inmanentes".

83 B. Cremades. La buena fe en el arbitraje internacional, op. cit., p. 19. Cfr. Cecilia O'Neill DE LA FUENTE, autora que puntualiza en torno a los "Resultados de su aplicación": “¿La consecuencia es acaso que el sujeto activo de la conducta vinculante y pretensión posterior pierda su derecho? La respuesta es que no. La contradicción a la que se opone el sujeto pasivo no extingue el derecho, sino que limita su ejercicio". El cielo de los conceptos jurídicos 'versus' la solución de problemas prácticos. A propósito de la doctrina de los actos propios, op. cit., p. 51. 
de fin de non-recevoir ${ }^{34}$, una especie de rechazo o desestimación formal que impide un pronunciamiento de fondo.

A nuestro juicio, reconociendo que el punto reviste complejidad, nos inclinamos por la inadmisibilidad, en sentido muy amplio y no por la extinción, per se, medularmente por tres razones. En primer término, por cuanto lo fundamental en el venire contra factum proprium, y en sus distintas modalidades o ramificaciones, es impedir que una pretensión en sentido lato, contraria a un acto propio anterior, pueda salir avante, a sabiendas de que a través del ejercicio de un derecho, a posteriori, se está conculcando la buena fe y la confianza legítima por él inculcada en otro sujeto, en el campo contractual su cocontratante. Luego si ello se evita, es decir se impide que la actuación posterior produzca efectos en Derecho (evitación), se habrá cumplido el cometido primordial de la doctrina en mención, a manera de una especie de escudo, a lo que se agrega que ella se inscribe -y ha inscrito- en el marco de las 'limitaciones al ejercicio de un derecho subjetivo', lo que no es igual que inscribirla en el campo de la 'terminación de un derecho'.

En segundo término, porque la erradicación plena de un lícito, dada la implicación que ella apareja en el plano jurídico, de ordinario supone su consagración explícita en una norma legal, norma que en tratándose del remedio que nos ocupa, se echa de menos en el Derecho comparado, la que no se puede sobreentender, máxime si en este caso se le atribuyen connotaciones sancionatorias o extintivas. Es más; la trasgresión de la buena fe, in genere, no está acompañada inexorablemente de la pérdida o erradicación de un derecho propiamente dicho -o con apariencia de tal-, en el ordenamiento jurídico. Habrá hipótesis, como efectivamente las hay, en las que su quebranto conduce a la pérdida del derecho, pero en consideración a lo prescrito explícitamente por la ley aplicable ${ }^{85}$.

84 D. HoutciefF. Le principe de cohérence en matiére contractuelle, op. cit., p. 791.

85 Así sucede, ad exemplum, en el contrato de seguro. El artículo 1078 del Código de Comercio Colombiano, dispone que "La mala fe del asegurado o del beneficiario en la reclamación o comprobación del derecho al pago de determinado siniestro, causará la pérdida de tal derecho". 
Y en tercer término, es probable que si cesa la contradicción, si desaparece el germen nocivo que justifica la aplicación de la doctrina, pueda ser ejercido el derecho que, de haber desaparecido, no habría como volverlo a ejercer, por sustracción de materia. De ahí que como lo recordara WIEACKER, en el aparte transcrito anteriormente, "...el titular no se le impide el futuro ejercicio leal de su derecho", consideración que, por lo demás, está plenamente acorde con la idea de preservación del derecho, a fortiori, ello es fundamental, si no ha operado la cosa juzgada en torno suyo, en cuyo caso no se puede válidamente impedir que su derecho, de suyo lícito, como se anotó, a la par que sus pretensiones, se ventilen en sede judicial ex novo. De otro modo, lo que habría acontecido es lo más cercano a una expropiación del derecho, pero sin resarcimiento o indemnización.

\subsection{LA REPARACIÓN DEL PERJUICIO IRROGADO}

Como lo pusimos de relieve en el presente capítulo al momento de examinar los presupuestos de la doctrina de los actos propios, uno de los requisitos que válidamente debe reunir el acto, es un perjuicio o lesión en cabeza del sujeto pasivo del factum, perpetrado por el cocontratante voluble (sujeto activo), perjuicio que se evidencia y hace tangible a raíz de la vulneración de la confianza legítima en su momento inculcada, sin el cual la incoherencia, en sí misma considerada, pese a existir, no sería incidente y, de contera, ilegítima, habida cuenta que no en todos los casos el comportamiento volátil o contradictorio, se torna censurable, por lo menos desde una perspectiva jurídica, según lo expresamos en detalle.

También dijimos que aun cuando el cometido cardinal del acto propio, en su genuino y prístino sentido, no apunta al resarcimiento del perjuicio irrogado, propiamente dicho, sino a impedir que se ejerza con éxito un derecho subjetivo por parte del versátil o voluble (efecto impeditivo), no puede desconocerse que refleja, indirecta o secundariamente, dicho nocimiento puede ser resarcido, conforme a las circunstancias (efecto resarcitorio), en el entendido, que no todo daño, per se, es indemnizable, como quiera que para ello deberá cumplir determinadas exigencias establecidas por la ley, y recreadas por la jurisprudencia ${ }^{86}$.

86 En efecto, debemos reiterar que, si bien el auténtico cometido de la doctrina de los actos propios no es la indemnización de los perjuicios derivados de la contradicción, nada obsta 
En este orden de ideas, los requerimientos para que el daño devenga resarcible, serán autónomos y serán materia de escrutinio, cuando ello sea menester, única y exclusivamente para evaluar su efectiva procedencia, no siendo este el rasero que se aplicará para impedir el ejercicio del derecho subjetivo pretendido, pues se insiste en que son dos situaciones que, aun cuando intercomunicadas, revisten sustantividad y tienen carácter autonómico.

Puede acontecer, en gracia de discusión que en el juicio de responsabilidad, stricto sensu, se concluya por algún motivo que el daño no deviene indemnizable, pero esta conclusión, de por sí, no tiene por qué afectar retroactivamente la materialización del efecto impeditivo en referencia, que es divergente. Ello explica que el juzgador al momento de examinar la procedencia del ejercicio del derecho subjetivo en cuestión, deba centrarse en comprobar que el factum novum, en contraste con el factum proprium previo (prius), lesionó un interés jurídico digno de tutela, o que si no interviene indefectiblemente se lesionará, sin adentrarse en el balance que debe hacer el juez al que se le reclama la reparación de índole económica.

En este orden de ideas, es útil tener claro que el venire contra factum proprium, y la doctrina de los actos propios, por vía de especificación, teleológicamente no persigue ninguna reparación o resarcimiento del daño sufrido, por lo menos en forma delantera, en razón de que se encamina a impedir el ejercicio de

para que dicha consecuencia resarcitoria se imponga ex latere, de manera auxiliar, cuando, junto a la contradicción, concurran los demás elementos estructurales de la responsabilidad. En esta hipótesis, no sólo tendrán cabida los efectos primarios o principales del venire contra factum proprium non valet, sino que, además, se activará la responsabilidad civil, en su concepción tradicional. Ahora bien, como ya se dijo, para que ello sea así, es necesario que concurran los elementos o presupuestos estructurales del débito resarcitorio, los cuales, desde la óptica clásica, se resumen en la conducta activa u omisiva del agente (I), el daño (II), la relación causal (III) y el factor de atribución de responsabilidad (IV). Al respecto, a modo de elocuente ejemplo, el artículo 1902 del Código Civil español, prescribe que "El que por acción u omisión causa daño a otro, interviniendo culpa o negligencia, está obligado a reparar el daño causado". Nótese cómo dicha disposición alude a los presupuestos antes mencionados. Lo propio hace el profesor Mariano IZquIERDo TOLSADA, quien sostiene que “... para que exista responsabilidad es necesario que una acción u omisión guarde en relación con un daño una relación de causalidad. A este triángulo de requisitos vendrá a añadirse el adecuado factor de atribución, que permitirá justificar la imputación del daño a un determinado patrimonio..." Sistema de responsabilidad civil contractual y extracontractual, op. cit., p. 109. 
un derecho subjetivo lesivo de intereses ajenos. Otra cosa distinta es que, complementariamente, a modo de plus, aspire a que se le indemnice también el daño, para lo cual será indispensable que acredite, en el marco del trámite y vía pertinentes, los elementos vertebrales de la responsabilidad civil, los que no se pueden sobreentender, no bastando con la comprobación del advenimiento de incoherencia, puesto lo que ahora se exige es mucho más. Al fin y al cabo, ya no se anhela paralizar, impedir, paliar, conjurar o contrarrestar la contradicción, en concreto el ejercicio de un derecho subjetivo conculcatorio, sino a obtener una indemnización pecuniaria, la que se gobernará por los cánones que disciplinan el Derecho de daños, en general, sin que sea predicable un régimen especial emanado del venire contra factum proprium, es decir una especie de 'microcosmos' -0 sistema típicamente autónomo- ${ }^{87}$.

87 Adherimos, entonces, a la postura acogida por don Luís DíEZ PICAZO, según la cual "No cabe duda que este deber de resarcimiento existe, pero, a poco que meditemos, nos daremos cuenta que el deber de resarcimiento no sanciona específicamente la contradicción, sino en general todo acto dañoso (cfr. artículo 1092 C.C.), aunque haya sido causado en el ejercicio de un derecho, cuando éste deba ser considerado como abusivo". La doctrina de los propios actos, op. cit., p. 246.

En contra, Anderson SchreIBER, A prohibiçao de comportamento contradictório. Tutela da confiança e venire contra factum proprium, p. 166, a juicio de quien "Es cierto que el daño eventualmente causado por el venire contra factum proprium debe ser resarcido", a lo que agrega que algunos autores no reconocen un régimen exclusivo al venire, en atención a que recurren a la "... regla general de que los daños injustamente causados ameritan resarcimiento". Por eso, continúa el autor, en el "...el derecho brasilero, la configuración del venire contra factum proprium, sirve de prueba de abusividad, y por consiguiente de título de la reparación del daño causado". 
CApítulo IV

PROYECCIÓN DE LA REGLA

VENIRE CONTRA FACTUM PROPRIUM

EN EL DERECHO COMPARADO.

\section{ESPECIAL REFERENCIA AL ESTOPPEL Y A LA VERWIRKUNG}

\section{GENERALIDADES}

Una idea central, sin perjuicio del examen particular de cada una de estas figuras jurídicas, importa dejar en claro de antemano: más allá de las puntuales diferencias y matizaciones que entre ellas existan -no tantas, sin embargo, como para situarlas en vértices opuestos, o en extremos irreconciliables-, todas se encaminan a vedar las actuaciones que ex post, minen la confianza suscitada con antelación (ex ante), impidiendo el ejercicio de un derecho subjetivo, en franca contradicción con su actuar primigenio, que es el que sirve de contraste o punto de referencia comportamental.

Por lo tanto, en lo medular, se identifican con la consigna de evitar que de un acto incoherente, a la vez que contradictorio, stricto sensu, pueda obtener réditos, en contra de los intereses, prerrogativas o derechos legítimos del que depositó su confianza en el sujeto voluble o versátil -o en la situación por él alimentada-, quien sorpresiva e inopinadamente, a modo de posterius, mudó de conducta, no siendo de esperar, racionalmente, un desenlace tal (constancia y regularidad) 1 .

1 Cfr. Dimitri HoutciefF. Le principe de cohérence en matiére contractuelle, op. cit., p. 727, quien anota que, “...aún más allá de las culturas jurídicas la existencia de un principio general de proscripción de la contradicción existe”. 
Aclarado lo que antecede, cumple señalar que, en el Derecho comparado, con nombres y morfologías propias, campean diversas figuras que, en puridad, son emanación o manifestación de la centenaria regla latina venire contra factum proprium non valet, en esta materia, matriz de sus derivaciones y aplicaciones concretas, lo que no se opone a que, en lo particular, cada una revista algunas notas individuales, sin que ello implique un divorcio o una escisión plena. Al fin y al cabo, con sus individualidades, todas ellas comparten un mismo ideario esencial, y comulgan con su genuina teleología, lo que tampoco hace, obviamente, que se tornen simétricas, por cuanto perderían su unidad e individualidad, máxime si se tienen en cuenta las arquitecturas del common lawy del civil law, las que terminan pesando e influyendo, no sólo en lo sustancial, sino igualmente en lo procesal. Por ello, reconociendo sus orígenes, su específica genealogía, viven una vida autónoma, pero entrelazadas, genética y teleológicamente; integran una misma familia, lo que justifica su incardinación y su examen en esta monografía, dado que son instituciones que tienen innegables vasos comunicantes, de un lado, con la mencionada regla del venire contra factum, existente hace varias centurias $y$, de la otra, en lo pertinente, con principios superiores, como el de la buena fe.

En un sentido amplio y en tal virtud omnicomprensivo de la anunciada fenomenología, primordialmente tales figuras son la doctrina de los actos propios, el deber de coherencia, la confianza legítima, el estoppel, la verwirkung, la rechtsverwerking, el tu quoque y la doctrina de las clean hands (o de las manos limpias), de amplia cabida y proyección en los derechos español, argentino, chileno, colombiano, uruguayo, italiano, francés, anglosajón, alemán, suizo, belga, holandés y brasilero, las que, sin ser idénticas o gotas de agua, como se anticipó, si comparten una misma filosofía, a la par que genes comunes, hasta el punto que se hermanan en función de un mismo acto gestacional, que funge de pater ius: la regla del venire contra factum proprium, conforme se pinceló, lo que les asegura, en el ámbito familiar, el carácter de emanación suya, así su pasado esté más presente en unas que en otras, todo sin desconocer el rol estelar que, en ellas, ocupa la buena fe -o su equivalente-, ese postulado solar que todo lo irradia, que todo lo cobija, no sólo en el campo sustancial, sino en el procesal ${ }^{2}$.

2 Vid. S. StinJ, La 'rechtsverking': fin d'une attente (dé) raisonnable?, op. cit., pp. 685 y ss., y S. Stins et Ise SAmoY. "La confiance légitime en droit des obligations, Rapport belge", en La confiance légitime et l'estoppel, Societé de Législation Comparé, Paris, 2007, pp. 167 y ss. 


\section{Igualmente, por su significado, es menester memorar que en ocasiones el estudio de esta temática se hace directa o preferentemente en función de la regla}

En relación con la figura del llamado tu quoque, importa recordar que, en su origen semántico e histórico, su empleo se remonta a la expresión que pronunció JULIO CÉSAR frente a BRUTO -en el año 44 a. de C-: ¿Tú también?, queriendo significar con ella, la sorpresa, la desazón, y desconcierto que le generó la actitud asesina de quien consideraba cercano y leal, casi como un hijo. En el plano argumental y retórico, a menudo se utiliza para cuestionar un razonamiento o idea ayuno de coherencia y consistencia intrínseca, por reclamar con firmeza -y hasta con un dejo de cinismo- lo que previamente no ha hecho el reclamante. Célebre es el siguiente pasaje que, ad baculum, se cita para ilustrar su alcance en la órbita moral: "Son mis hechos no mis palabras, soldados, lo que quiero que secundéis; que no sólo busquéis en mí órdenes, sino también ejemplo". VALERIO CORVINO (Tito Livio, VII, 32,12).

En el campo de la ciencia jurídica, muy especialmente en sede contractual, se acude al tu quoque para evidenciar -también- la materialización de una contradicción comportamental, fruto del quiebre de la coherencia durante una de las fases de la de la relación jurídiconegocial. Como lo realza Luciano De CAmargo PenTEADo, "El tu quoque se verifica en las hipótesis en que existe un determinado comportamiento dentro del contrato que viola su contenido preceptivo....Existe una contradicción en la relación obligacional al exigirse un comportamiento por parte de un sujeto en circunstancias tales en las que él mismo dejó de cumplir" ("Figuras parcelares da boa-fé objetiva e venire contra factum proprium", en Revista de direito privado, Vol. 27, 2006, pp. 264 y ss.), o como expresara la profesora Clara I Assua GonzÁles, el tu quoque, entendido como expresión de la "...la doctrina de los propios actos", alude a la "...imposibilidad de alegar reglas jurídicas por quien no las observó". "Art. 7", Código Civil Comentado, op. cit, p. 94. Por eso su formulación “...impide a la otra parte, especialmente en la defensa, recurrir a normas jurídicas que ella misma no cumplió", como lo recuerda F. WIEACKER, quien previamente había señalado que es estos casos, de modo muy general, "....solamente la propia fidelidad jurídica puede exigir fidelidad jurídica”, en diáfana muestra de la mencionada coherencia conductual, y de paso, del quebranto del aquilatado derecho a la igualdad, pues a voces del mismo profesor alemán, “....un demandante que reclama a pesar de su propia infracción jurídica, está queriendo el tratamiento desigual de su contrincante en beneficio suyo. Con otras palabras: le exigencia de reciprocidad es un elemento de la exigencia de igualdad". El principio general de la buena fe, op. cit, p.p. 66 y ss.

En la doctrina, con frecuencia, para ilustrar un ejemplo de tu quoque se suele recurrir a la hipótesis de la petición de la resolución de un contrato por incumplimiento por parte del que previamente lo ha incumplido, lo que no resulta coherente, ni acorde con las mínimas reglas jurídicas que disciplinan la materia.

En consecuencia, tendiendo en cuenta que en esta figura campea la contradicción, y se hace tangible la ausencia de coherencia en el comportamiento por parte de uno de los extremos de la relación negocial, se ha estimado que desde esta perspectiva, más allá de la dinámica que la caracteriza en el terreno funcional, no hay razones atendibles para no englobarla, obviamente respetando su morfología, en la regla venire contra factum proprium, de indiscutida vocación envolvente de diversas hipótesis constitutivas de contradicción. En este sentido, acierta el Dr. Anderson SCHREIBER, cuando asevera que "...en el núcleo del tu quoque hay una idea de contradicción, una incoherencia todavía más específica.... Por tanto, es posible clasificar al tu quoque como una subespecie del venire contra factum proprium" (A prohibiçao de comportamento contradictório. Tutela da confiança e venire contra factum proprium, op. cit, p. 184), punto de vista compartido por el profesor portugués, 
del venire contra factum proprium, sin distingo o individualización, en razón de que, recta via, se aborda la fuente o raíz. Así sucede muy frecuentemente en Portugal y en Brasil, sin perjuicio de que un sector de la doctrina alemana hace lo propio. Sólo recuérdese el excelso y visionario aporte de RIEZLER en 1912, el que llevó por título: venire contra factum proprium, ejemplo que otros seguirán varias décadas después (DETTE, TEICHMANN, etc.). Lo mismo tiene lugar, conforme se examinó, con el Derecho italiano, muy especialmente en lo corrido del nuevo siglo, en el que ha resurgido con gran vitalidad. Por su parte, en Bélgica y en otras naciones como Holanda, se acude con frecuencia a una figura denominada rechtswerking, con alcances muy similares.

Del mismo modo, importa manifestar que no sólo el Derecho occidental es refractario a la contradicción, al comportamiento que, por incoherente, termina lesionando intereses ajenos dignos de tutela, según como se ha evidenciado a lo largo de los capítulos anteriores. En el Derecho Musulmán, por vía de diciente ejemplo, existe una institución que persigue análogo fin, denominada tanakod, muy propia del proceso ${ }^{3}$.

António Menezes CoRdeIRo, quien califica al tu quoque de "subtipo más concreto" del venire. Da boa fé no direito civil, op. cit, p. 843.

Ahora bien, en lo tocante con la apellidada figura de las manos limpias (clean hands), a su turno confirmatoria de la valía de la coherencia en el comportamiento humano, un sector de la doctrina expresa que "una figura del common law que tiene algunos rasgos en común con el deber de coherencia de los contratantes es la que se conoce como la clean hands doctrine. Según esta teoría, una parte en un proceso debe estar exenta de reproche por comportamientos legal o moralmente censurables relacionados con el tema de su pretensión. Para invocar esta teoría como medio de defensa, el demandado debe demostrar que la conducta del demandante hacia el demandado fue injusta, deliberada y que tal conducta reprochable estaba relacionada con la pretensión del demandante. Para determinar si la conducta del demandante es injusta, ésta debe afectar las relaciones de equidad entre las partes, como puede suceder en casos de fraude o mala fe en general. Así, la teoría de las manos limpias no se limita a situaciones de ilegalidad, sino que se extiende a cualquier conducta contraria a la buena fe o la equidad....". Mariana BERNAL FANDIÑO. El deber de coherencia en el derecho colombiano de los contratos, op. cit., pp. 168 y 169. Amplia referencia a este tema, de igual modo, se encuentra en el estudio del Dr. Carlos DANTE FERRARI. "La doctrina "clean hands ("manos limpias"): una respuesta jurisdiccional fundada en la buena fe y en la equidad (Acerca de su aplicación en el derecho civil argentino y en el ámbito de la responsabilidad civil), en elDial, Buenos Aires, 2010.

3 Al respecto, anota Omar M., que una de las exigencias de la validez de la acción es "... la ausencia de contradicción en el comportamiento del demandante", citado por Dimitri HOUTCIEFF, Le principe de cohérence en matiére contractuelle, op. cit., T. II, p. 726. 
Así las cosas, teniendo en cuenta la importancia que en la jurisprudencia y en la doctrina tienen dichas figuras, sobre todo el estoppel y la verwirkung, a continuación nos ocuparemos de ambas con algún detalle, máxime cuando de buena parte de las restantes nos hemos ocupado en el presente escrito, particularmente del acto propio, del deber de coherencia, y de la confianza legítima, y obviamente de la regla del venire contra factum proprium, manantial en el que beben y han bebido ellas, se reitera, con independencia de las diferencias y matizaciones reinantes, que en nuestro entender no tienen la sustantividad suficiente para desconocer su progenie, además que, por razones típicamente metodológicas, tampoco resulta aconsejable su escisión. Unas breves líneas, por su parte, destinaremos también a las manos limpias y al tu quoque, que no son más que manifestaciones del anhelo ético-jurídico de vedar el comportamiento que, a posteriori, por incoherente, se torna voluble, contradictorio, y lesivo.

Antes de iniciar el referido excursus, sin embargo, cumple reafirmar la idea por la cual la doctrina del venire contra factum proprium, en particular de los actos propios, y sus homólogas, no son figuras domésticas, lugareñas, o de proyección muy limitada o aislada en la geografía planetaria, pues con prescindencia del nomen y de su carácter autonómico, que no opuesto, se ha expresado, gozan de amplio reconocimiento y cabida en el concierto jurídico, por lo que permanece no sólo vigente, sino en franca y sostenida expansión, como también lo demuestran las novísimas investigaciones del presente milenio, y los aportes de la jurisprudencia y de la principialística internacional (proyectos y ante-proyectos de códigos civiles y de Derecho de contratos).

\section{EL ESTOPPEL}

\subsection{Cuestión PREvia}

El estoppe ${ }^{4}$, de una u otra manera, directa o indirectamente, como lo anticipábamos, está conectado con la regla venire contra factum proprium, no

$4 \quad$ Con el propósito de profundizar en el estudio del estoppel, en su real dimensión y extensión a la luz del Derecho inglés y anglosajón, en general, bien puede verse con provecho el estudio del profesor John CARTWRIGHT, intitulado "Protecting legitimate expectations and 
sólo por su origen, sino también por cuanto comulga con buena parte de sus fundamentos, sin que ello implique que hoy sean simétricos, toda vez que, aun cuando hermanados funcionalmente y, por ende, compartiendo la esencia de un mismo material genético, revisten sustantividad, y son dueños de características y rasgos propios que, en la hora de ahora, impiden una asimilación plena, así se pudiere concluir anticipadamente que, en puridad, éste hunde sus raíces en aquél. Otro tanto sucede en punto tocante con la doctrina de los actos propios, una de sus manifestaciones especiales ${ }^{5}$.

En sentido lato, bien puede entonces refrendarse que todas ellas están enlazadas por su origen, a la par que por la unidad de propósito que les asiste, como quiera que, una y otras figuras, con sus diferencias, estructura y alcances propios, persiguen la evitación de la contradicción comportamental, raíz primaria de las mismas, más allá de sus particularidades y disimilitudes, que desde luego las tienen como se observará, especialmente de cara al estoppel y a la verwirkung ${ }^{6}$.

En suma, ni identidad total, ni divorcio o desconexión absoluta, como si fueran institutos extraños, no susceptibles de un examen articulado. Muy por el contrario, ellos están llamados a conjurar el comportamiento y la conducta ayunas de coherencia y consistencia, con el fin de no erosionar derechos ajenos que,

Estoppel: english law', en Benedicte FAUVARQUE-Cosson, La confiance légitime et l'Estoppel. Droit privé comparé et européen. Societé de législation comparée. Vol. 4. 2007. Cfr. Bruce Macdougall, Consideration and Estoppel: problem and panacea. 15 Dalhouise. HeionOnline. 265. 1992.

5 El profesor Luís DiEz-PICAZo, con claridad, expone esta misma idea, al afirmar que “... algunos juristas anglosajones han relacionado únicamente el 'estoppel' con la figura romana de la 'exceptio doli', pero hoy se encuentra muy generalizada la opinión que conecta 'estoppel' y 'venire contra factum'. Exista o no esta comunidad de origen histórico, es claro, sin embargo, que una y otra institución han sufrido evoluciones independientes, amoldándose cada una de ellas a la idiosincrasia del país y a la realidad social en que han sido aplicadas, de tal manera que entre ambas figuras existen hoy divergencias.... Pero si esto es así, lo es también que acaso estas divergencias y esta disparidad pueden ser un útil complemento". La doctrina de los propios actos, op. cit., p. 64. Cfr. David SNYDER. "Comparative law in action: promissory Estoppel, the civil law and the mixed jurisdiction", Arizona Journal of International and Comparative Law, 695 (1998).

6 Vid. Mariana BeRnAL. El deber de coherencia en los contratos y la regla del venire contra factum proprium, op. cit., pp. 298 y ss. 
de otro modo, se verían conculcados. De ahí que respecto de ambos se pueda hablar, in complexu, de una verdadera "...identidad de función", como bien lo resalta ESSER ${ }^{7}$, incluido el estoppel.

Esclarecido lo que antecede, antes de iniciar el estudio formal de los principales aspectos del estoppel, forzoso es señalar que, desde una perspectiva sistémica, su proyección es diversa a la regla venire contra factum proprium -y también a la doctrina de los actos propios-, en razón de que luego de su configuración típica, amén que propia en la historia jurídica, él se anidó en el sistema anglosajón, o del common law, por oposición a ella -o ellas-, que lo hizo en el sistema continental, o civil law, en donde han permanecido hasta ahora, con matices, aun cuando hay que mencionar anticipadamente que, el estoppel, ha comenzado a ensanchar sus fronteras más allá del Derecho británico y anglo-americano, como se evidencia en la esfera del Derecho internacional, muy especialmente en el campo del arbitraje. Lo mismo ha sucedido en Francia y en Italia, en donde se reconoce que el término ha sido recepcionado por los autores encargados de cultivar las publicaciones conocidas como vocabularios jurídicos ("vocabulaire juridique", CORNU) ${ }^{8}$, y algunos otros hablan, gráficamente, de un "...estopel a la italiana" (SACCO) .

Ello explica, ab initio, que el estoppel sea esencialmente creación de la doctrina jurisprudencial británica, toda vez que fue y ha sido la jurisprudencia, por excelencia, la que se ha encargado de su estructuración, afianzamiento y maduración, mientras que la regla románica en comento, con sus principales aplicaciones directas continentales (doctrina de los actos propios, verwirkung, deber de coherencia, rechtsverwerking, etc.), fue primero obra de los juristas del Derecho medieval (Derecho de juristas), sin perjuicio de la conexión con el Derecho romano clásico, stricto sensu, concretamente en lo que atañe a la casuística ya conocida y examinada con anticipación por nosotros, la que también fue preocupación de los jurisconsultos (Derecho de abogados y profesores).

Josef EsSER. Principio y norma en la elaboración jurisprudencial del derecho privado, op. cit., p. 41.

8 Bertrand FAGES. Le comportement du contractant, op. cit., Num. 637.

9 R. SAcco. II fato, l'atto, il nogozio, op. cit., p. 247. 
Por consiguiente, habida cuenta de las singularidades de cada uno de los referidos sistemas, el estoppel es hijo o hechura de la jurisprudencia, y no de la ley, en sí misma considerada, o de la dogmática, cabalmente entendida, al paso que la regla venire contra factum proprium, tiene como manantial la actividad de los juristas, ciertamente de origen más académico y científico, sin perjuicio del apoyo preceptivo (legal y constitucional) brindado por la buena fe, entre otros principios más, y del desarrollo jurisprudencial posteriormente alcanzado, de suyo notable, pero en el marco de un sistema escrito y legislado (huella de la 'compilación', y ulteriormente de la 'codificación', stricto sensu).

En conclusión, no se puede aseverar que el estoppel y la regla venire contra factum proprium -y sus aplicaciones-son figuras iguales, y que sólo se diferencian por la lengua que las identifica o por su geografía jurídica, porque pese a su génesis, son autonómicas, así compartan, como comparten, diversos elementos estructurales que avalan su 'parentesco' ${ }^{10}$ y su 'estrecha relación'11. Sin embargo, en cada sistema jurídico, en lo pertinente, haciendo un ejercicio de comparación, fungen como instituciones próximas o equivalentes ${ }^{12}$.

\subsection{Etimología}

En lo que concierne a la etimología del vocablo estoppel, no hay unanimidad en la doctrina, habida cuenta que, en la esfera lingüística, existen diversas lecturas del mismo, en especial por los antecedentes mediatos, o los antecedentes inmediatos.

10 Cfr. Juan Vallet de Goytisolo. "Vida jurídica. Nota crítica, Doctrina de los actos propios", Luís Díez-PICAzo en Anuario de Derecho Civil. T. XVI, Fascículo I. 1963, p. 468, y Enrique BIANCHI T. y Héctor IRIBARNE P. El principio general de la buena fe y la doctrina 'venire contra factum proprium non valet', op. cit., p. 859.

11 Cfr. Simón Safontás. Doctrina de los propios actos, en JUS. No 5. 1964, p. 32, y Jorge PeYrano W. y Julio Chiappini O. La doctrina de los propios actos en el ámbito del procedimiento civil, op. cit., p. 820.

12 Cfr. Luís MoIsSET de EsPANÉs. "La teoría de los 'propios actos' y la doctrina y jurisprudencias nacionales”, en La Ley. 198A 152 y Bol. Fac. de Der. Córdoba. 1982-1983, p. 223. 
Para muchos, el origen real y primario del vocablo se encuentra en la lengua latina, puesto que "....proviene del latín stopare (estopar en castellano antiguo), que significa 'tapar', 'cerrar', y de la que se derivan el verbo inglés estoppe o stoppe y el sustantivo estoppel... ${ }^{13 "}$

Por ello, algunos doctrinantes opinan que la expresión estoppel, de textura inglesa, “...tiene la misma raíz que el castellano 'estopa”, lo que quizá explique “....el refrán español: 'No bastan estopas para tapar tantas bocas'. Por eso “...se dice que estoppel es la conclusión a que se llega... porque el acto o la conducta misma de una persona 'le tapa la boca' para alegar o hacer valer en juicio la verdad de los hechos"14.

Y para otros, ciertamente no pocos, la expresión inglesa en comento tiene como fuente directa el francés. En este sentido, "Explica LitTETON, uno de los clásicos comentaristas ingleses del common law, que del antiguo francés normando, que tanta influencia tuvo en la terminología jurídica inglesa después de la ocupación de Inglaterra por Guillermo el Conquistador, se tomó la palabra estouper o etouper, del latín stopare"15.

13 Bernadette Minivelle y Alberto Oehninger Reyes. "La doctrina de los actos propios (perspectiva procesal civil)", en Revista Uruguaya de Derecho Procesal. Fundación Cultura Universitaria. $\mathrm{N}^{\circ}$ 2. Montevideo. 2000, p. 294.

14 Phanor Eder J. Principios característicos del 'Common Law' y del derecho latinoamericano. Abeledo-Perrot. 1960, p. 92. Según lo afirma la doctrina, a la sazón, Lord CoKE acuñó una frase muy elocuente para referirse al genuino significado del estoppel, sobre el cual afirmaba que, "... el propio acto de un hombre o su aquiescencia impiden o callan su boca para allegar o pedir la verdad..." Everest y STRODDE. Law of estoppels. Londres. 1923, p. 33.

15 Oscar RABASA. El derecho angloamericano. Porrúa. México. 1982. pp. 195 y 196. Cfr. Juan M. Dobson, quien explica que "El origen del vocablo 'estoppel' se encuentra en la voz francesa 'estoupe', que significa detener (y de donde proviene la voz inglesa: 'to stop'). El abuso de la personalidad jurídica, op. cit., p. 266, y Nattan NisIMBLAT. "La cosa juzgada en la jurisprudencia constitucional colombiana y el principio del Estoppel en el derecho anglosajón”, en Revista Universitas. No 118. Universidad Javeriana. Bogotá. 2009, p. 249, doctrinante que pone de presente que este vocablo "... proviene del francés estoupail, lo que significa 'tapón'. El término está relacionado con el verbo 'estop', que proviene del francés antiguo estopper, en el sentido de detener, impedir. En inglés la palabra 'stop' significa 'detenerse', de allí también la similitud con el vocablo 'estop'. Cfr. Guillaume Weiszberg. "Actualité de la théorie de l'éstopp. el dans la jurisprudence" (fr). JurisPedia. 2007, p. 1. 
Por último, para el profesor DíEz PICAZO, acompañado en ello por el profesor Vallet De Goytisolo, la palabra "Estoppel significa, etimológicamente, estorbo, impedimento, obstáculo, detención"16, significado que, como observaremos, en el fondo, está en estricta consonancia con su ratio y real teleología.

En síntesis, más allá de la procedencia del vocablo materia de examen, lo cierto es que no es de origen inglés, en principio, sino latino, stricto sensu, como a primera vista pareciere, conforme tiene lugar con tantas otras expresiones, e incluso instituciones jurídicas. No en vano, una vez más, queda en evidencia el legado romano, no sólo aquilatado, sino extendido y con profundas raíces en la cultura occidental.

\subsection{ORIGEN}

Tal y como ya lo esbozamos, sin perjuicio que en esta temática tampoco campea el acuerdo, resulta difícil pensar que la paternidad del estoppel sea genuinamente inglesa y que no conozca, en efecto, antecedentes que expliquen su existencia y su fundamento, y que no sirvan de estribo para reconocer en la conocida regla latina venire contra factum proprium, recta via, su paternidad, o basamento histórico, aspecto este que se agrega al etimológico, inmediatamente esbozado.

Aceptar dicha procedencia británica, idea a la que anticipadamente no adherimos, sería tanto como soslayar no solamente el enriquecido legado jurídico romano, más presente de lo que se piensa, en el Derecho anglosajón, sino también la herencia del Derecho medieval en este punto, como en tantos otros más, realmente pletórica, se itera.

Desde esta perspectiva, desconectada de la tradición jurídica, amén que descontextualizada, in toto, no han faltado quienes han aseverado que, "la doctrina llamada estoppel es una institución jurídica exclusiva del sistema angloamericano

16 Luís Díez-Picazo. La doctrina de los propios actos, op. cit., p. 62, y Juan Vallet De Goytisolo. Vida jurídica. Notas críticas, op. cit., p. 468. 
de derecho, que no se encuentra en ninguno de los regímenes jurídicos derivados del derecho romano...."17, y "Que otro principio del derecho-equidad, de gran importancia práctica, y que no tiene, que yo sepa, ningún equivalente en el Derecho latinoamericano, es el Estoppel"18.

Por ello es por lo que preferimos pensar, con fundada verosimilitud, que la 'matriz' o el manantial de las manifestaciones o aplicaciones contemporáneas del rechazo a la contradicción o a la incoherencia comportamentales, reside en esta milenaria regulae iuris (venire contra factum proprium), en concreto la 'doctrina de los actos propios', el estoppel y la verwirkung, entre otras (deber de coherencia, confianza legítima, rechtsverwerking, clean hands, etc. $)^{19}$.

Así las cosas, de la mano del profesor Puig BrUtau, estimamos "... que no hace falta mucho esfuerzo para demostrar o hacer ver que esta descripción de la doctrina del estoppel, que se trata de presentar como exclusiva del sistema anglosajón, coincide con nuestro concepto de la doctrina de los actos propios. La extraña incomunicación de ideas jurídicas que existe entre el mundo anglosajón y el continental ha impedido la fácil observación de que la regla venire contra factum proprium non valet puede ser alegada indistintamente como fundamento de nuestra doctrina de los actos propios y del estoppel", opinión que luego acompaña de la siguiente conclusión, conforme a la cual "...creemos que la doctrina del

17 Oscar RABASA. El derecho angloamericano, op. cit., p. 195.

18 Phanor Eder. Principios característicos del 'Common Law'y del derecho latinoamericano, op. cit., p. 92.

19 Sobre este mismo parecer, bien precisa la profesora Mariana Bernal que "... existen conceptos que se encuentran estrechamente relacionados con la idea de la no contradicción y la regla del venire contra factum proprium non valet tales como la doctrina de la Verwirkung en el derecho alemán y suizo (A), la figura del Estoppel en el derecho anglosajón (B), el deber de coherencia (C) denominado como tal recientemente por la doctrina francesa, entre otros...." El deber de coherencia en los contratos y la regla del venire contra factum proprium, op. cit., p. 295.

Como lo expresa con rotundidad Dimitri HoutCIEFF, "La matriz de la teoría del estoppel es la idea según la cual 'nadie puede contradecirse en detrimento de otro', el venire contra factum proprium". Le principe de cohérence en matiére contractuelle, T. II, op. cit., p. 729. 
estoppel no representa una peculiaridad exclusiva del Derecho anglosajón, a pesar de que los mismos autores angloamericanos sostienen lo contrario"20.

Al fin y al cabo, como tantas veces se ha demostrado, según se anticipó, un número no despreciable de instituciones anglosajonas, hunden sus raíces en el Derecho romano clásico ${ }^{21}$, o medieval, las que se enseñorearon, por siglos, en su entorno geográfico, como que Britania, a la sazón, así sea con intermitencia, hizo parte del imperio, a lo que se suma que en territorio británico la afamada Escuela de los Glosadores, entre otras más de origen medieval, en su momento tuvo singular influjo, especialmente gracias a VACARIO (Vacarius), caracterizado militante de la afamada Escuela de Bolonia, epicentro de la cultura jurídica europea, por numerosos decenios ${ }^{22}$.

20 José Puig Brutau. La doctrina de los actos propios, op. cit., pp. 105, 106 y 114, doctrinante que, luego de reconocer "... la coincidencia entre estoppe/ y nuestro principio o regla general de que nadie puede ir contra sus propios actos", reitera que, entre ambas figuras, hay "... una identidad substancial a través de sus diversas concreciones históricas". Cfr. María Fernanda EKDAHL E. La doctrina de los actos propios, op. cit., pp. 78 y 79, y Alejandro BoRDA, quien indica con razón que, “....aparentemente, el estoppe/ nace en el medioevo, donde los juristas ingleses fueron fuertemente influidos por el derecho romano-canónico. Además, la doctrina del estoppel utiliza frecuentemente la expresión own act, que es sinónimo de “acto propio"'. La teoría de los actos propios, op. cit., p. 28.

Menos enfático es Don Luís DíEz- PICAzo, para quien el origen y la evolución histórica del estoppel, "...es un problema que permanece en la oscuridad", lo que no impide que, con apoyo en las investigaciones de Riezler, acepte que esta tesis conectora "...no sea demasiado aventurada. ...Lo que está fuera de toda duda es el parentesco ideológico". La doctrina de los propios actos, op. cit., p. 64., en donde igualmente afirma que, a favor de "...esta hipótesis, pueden alegarse razones de índole muy diversa...., en primer lugar, el hecho de que algunos juristas ingleses del Medioevo (p. ej., .BRACTON, GLANVILLE, etc.) fueron efectivamente muy influidos por la doctrina romano-canónica", motivo por el cual “...hoy se encuentra muy generalizada la opinión que conecta 'estoppel' y 'venire contra factum proprium' “(p. 64).

21 Vid. R. C. Caenegem Van. Pasado y futuro del derecho europeo. Dos milenios de unidad y diversidad. Thomsom-Civitas. Madrid. 2003, p. 52.

22 A este respecto, en su oportunidad, habíamos manifestado que, "Dada la fama y el irrestricto prestigio obtenidos por la Escuela de Bolonia, receptáculo y también vivero de un apreciable número de alumnos pertenecientes a las más diversas culturas y 'nacionalidades', quienes luego de culminar sus estudios retornaban a sus lugares de origen, para difundir ampliamente el derecho romano-justinianeo, no es difícil advertir el grado de expansión que tuvieron sus enseñanzas en el mundo civilizado, máxime cuando en aquél estadio el fenómeno cultural comenzaba a adquirir importante dimensión, no ajena, claro está, a al ciencia jurídica....No en balde, emulando el ejemplo escolar y universitario de Bolonia, en Europa se edificaron nuevas universidades al amparo del modelo boloñés....Dichas escuelas, dispersas por varios países del viejo continente, no en pocas ocasiones fueron 


\subsection{SignificADO GENERAL Y ALCANCE}

Según se esbozó, en su acepción generalizada, el término estoppel supone una limitación, una restricción, una especie de impedimento o valladar para actuar libremente, en particular en sede procesal, como se indicará, lo cual es gráficamente recreado por la continua referencia a la estopa y al hecho de 'cerrar o tapar la boca'23. En esta dirección, en forma muy simple, se concibe como el "...principio que impide a una parte alegar o probar en el proceso que un hecho es diferente de lo que aparenta según las circunstancias" ${ }^{24}$, o más explícitamente como la doctrina que tiende a "....impedir que una persona repudie sus propios actos o conducta cuando otra persona es guiado por los mismos y ha adaptado a aquéllos su modo de proceder. En tales casos la ley no admite una repudiación puesto que de lo contrario, no sería justo y equitativo"25.

lideradas por glosadores fuera de Bolonia, tal y como aconteció con VACARIO en Inglaterra (Oxford), con Piacentino en Francia (Montpellier), con Bassiano y Pillio de Medicina...". Carlos Ignacio JARAmILLo. El renacimiento de la cultura jurídica, op. cit., p. 231 y ss.

23 Vid. Carr v. London and North Western Railway y Co. (1875) LR. 10 CP. 307; Greenwood v. Martin's Bank Ltd. (1933). AC.51, HL; Hopgood v. Brown. (1955) 1 WLR 213, CA. Cfr. Keven LINDGREN. Estoppel in contract. U.N.S.W.L.J. HeinOnline. 1898. pp. 154-157.

24 Halsbury's Laws of England. Vol. 16. Londres. 1976. cit. Héctor A. MAIRAL. La doctrina de los propios actos y la administración pública. Ediciones Depalma. Buenos Aires. 1978, p. 18. Análogamente, don Luís MoISSET DE ESPANÉs, indica que el estoppel, para un mejor y claro entendimiento, se “...erige en una barrera o freno ('stop') a las pretensiones de quien reclama algo en abierta contraposición con lo que anteriormente había aceptado“. La teoría de los 'propios actos' y la doctrina y jurisprudencia nacionales, op. cit., p. 223.

A su turno, Eugene ANDERson y Natalia Holober explican que, “... un procedimiento judicial o administrativo puede ser visto como una oportunidad para adoptar la posición que más convenga. El hecho de adoptar posiciones inconsistentes en el marco de un proceso judicial, perjudica la integridad del prenotado proceso y del sistema judicial, abriendo las puertas para decisiones inconsistentes y debilitando la confianza pública en el aparato jurisdiccional. Es por eso que, durante años, se han diseñado doctrinas legales y herramientas para prevenir tales inconsistencias en el campo procesal, de tal suerte que se pueda tutelar la integridad total del sistema judicial. Tales doctrinas incluyen, sin duda, la doctrina del Estoppel en sus diversas modalidades." Eugene ANDERSON y Natalia Holober. Preventing Inconsistencies in Litigation with a Spotlight on Insurance Coverage Litigation: The Doctrines of Judicial Estoppel, Equitable Estoppel, Quasi-Estoppel, Collateral Estoppel, "MEND the Hold" "FRAUD on the Court" and Judicial and Evidentiary Admissions. 4. Insurance Law Journal. 1997-1998.

25 Ronald RuBinstein. Iniciación al derecho inglés. Bosch. Barcelona. 1956, p. 25. Cfr. Anenson, Leigh. From theory to practice; analyzing equitable Estoppel under a pluralistic model of law. 11, Lewis and Clark Law Review. 633-669, 637 (2007); AshbuRner, Principles of equity. 445 (9a Ed., Browne, Londres, 1933). Winfield, A text book of the Law of Torts, 389, (Londres, 
Muy socorrida, en el ámbito doctrinal, es la noción elaborada -a mediados de la pasada centuria- por V.A. GRIFFITH, a cuyo tenor "Estoppel es la doctrina en cuya virtud alguien que, por su manera de obrar, con palabras o mediante actos, produce en otro la creencia racional de que ciertos hechos son ciertos y el último obra sobre la base de tal creencia (belief), impidiendo al primero que pueda negar la verdad de lo que ha 'representado' con sus palabras o su conducta, cuando la negativa habría de redundar en su beneficio y en perjuicio de la otra persona" 26 .

Ahora bien, en lo que dice relación con su alcance, es menester anticipar que, en rigor, en la práctica anglosajona, el estoppel es una figura más de estirpe procesal, mejor aún una típica regla de evidencia ('rules of evidence') ${ }^{27}$ que, en línea de principio, no tiene incidencia, ni eficacia sustancial, pues se mantiene al margen de estos dominios, muy al contrario de lo que tiene lugar en tratándose de las instituciones homólogas de índole continental, según se reseñará.

Es entonces una figura que, en la praxis, se desdobla en el marco de un litigio, no siendo de recibo su acreditación extraprocesal, lo que, a juicio de la communis opinio, corrobora su naturaleza de "...simple regla de prueba" ${ }^{28}$, sin perjuicio de que un sector de la doctrina no comparte esta visión, de suyo restringida ${ }^{29}$.

1948). Michael CAmeron. Equitable estoppel: its genesis, Development and application in government contracting. Cont. L. J. HeinOnline. 19 pub.

26 Outlines of the law. Indianapolis. 1950, p. 164. cit. J. PUIG BRUTAU, La doctrina de los actos propios, op. cit., p. 111.

27 Como lo expresan, J. PeYrano y J. ChiappinI, "Dicha institución secular del Derecho inglés es un principio procesal que integra la teoría de las reglas de la prueba que se denominan 'rules of evidence'. Cfr. Simón p. SAfontÁs. Doctrina de los propios actos, op. cit., p. 33; Luís María VIVEs. Doctrina de los actos propios, op. cit., p. 946 y ss. y Osvaldo GozAINI. La doctrina del acto propio, op. cit., p. 222. Cfr. Samuel WILLINSTON. The law of contracts. II. Baker, Voorhis \& Co. New York. 1920, p. 2680; James. Introduction to English law. Londres. 1959, p. 79 y Stephen. Comentaries on the Laws of England. Londres. 1950, p. 150.

28 J. EsSER. Principio y norma en la elaboración jurisprudencial del derecho privado, op. cit., p. 43, autor que, memorando la explicación de WinfIELD en Pollock (Principles of Contract), anota que, "La regla no lo es de ley substantiva en el sentido de que no establece ningún derecho o pretensión inmediatos. Es una regla de prueba, pero capaz de tener los más graves efectos sobre los derechos substantivos de las partes".

29 Sobre este particular ha afirmado Lord DenNING que el Estoppel, "No es una regla de prueba....Es un principio de justicia y de equidad", Halburry's Laws of England, cit. MAIRAL, H. La doctrina de los propios actos y la administración pública, op. cit., p. 22, quien puntualiza que no obstante la opinión que lo cataloga como "...una institución relativa a la prueba", 
Con todo, el tema es polémico, porque de ordinario, e históricamente, se tiene establecido su carácter procesal. De hecho, a menudo se le reconoce el status de típico "remedio procesal"30.

\subsection{FUNDAMENTO ESENCIAL Y FINALIDADES PRIMORDIALES}

El fundamento cardinal del estoppel, de acuerdo con la opinión dominante, estriba en la protección de la apariencia, que tanta fuerza y vigencia tiene en este instituto, incluso con más énfasis que en otros muy próximos, en los que la confianza es su ratio capital, en esencia por el valor que sus seguidores le asignan a la representation -en un sentido amplio y corriente-, esto es a la recreación de una determinada situación o cuadro fáctico, como sucede en tratándose de una 'representación teatral', según lo atestigua un segmento de la doctrina especializada.

En esta orientación, el profesor Alejandro BORDA, pone de relieve que, "El estoppel responde a la idea de inadmisibilidad de alegar y probar hechos contradictorios con la apariencia que la misma parte (que pretende tales alegaciones y pruebas) ha creado....Como puede observarse el núcleo de la figura del Estoppel es la 'apariencia'...Por ello se hable de protección objetiva de la apariencia jurídica"31.

otro sector "...ha preferido calificarlo como una regla de derecho sustancial”. Cfr. Juan M. DoBson, autor que recuerda que "...se ha llegado a sostener que se trata en realidad de un sector del derecho de fondo, y no solamente de un instituto procesal, ya que la conducta de una persona crea a favor de otra un derecho, y este derecho no puede ser desconocido ni negado por otra (Lord Wright en Canadian and Dominion Sugar, Co Ltd V Canadian National..., 1947)". El abuso de la personalidad jurídica, op. cit., p. 267.

Otro tanto sucede con la opinión del ilustre profesor René DAVID, de conformidad con el cual "La conclusión que nos parece más exacta es la de que el estoppel adopta sus características, a la vez, de la reglamentación de las pruebas...., pero le interesa también el fondo del derecho". Les contrats en droit anglais. L.G.D.J. Paris. 1985, p. 231.

30 Rodolfo SAcco. Il fatto, l'atto, ill negozio, op. cit., p. 228.

31 A. Borda. La teoría de los actos propios, op. cit., p. 65. Cfr. Luís Díez-PICAzo, quien expresa que, "Uno de los más acusados rasgos de la idea del 'estoppel' es su relación con el principio de la protección de la apariencia jurídica. Así como la idea romanista del 'venire contra factum proprium' se basa fundamentalmente en la 'improbitas', en la contravención de la 
En un sentido próximo a la buena fe y de paso a la confianza, otros autores aluden a la reliance como pilar o fundamento del estoppel (CAUCHY-PSAUME y SoURIUX) $)^{32}$.

$Y$ en lo que atañe a sus finalidades primordiales, acorde con todo lo expresado en precedencia, puede afirmarse que el estoppel, por tratarse de una institución que comparte material genético con la regla venire contra factum proprium, persigue evitar que una persona, como corolario de la contradicción e incoherencia incurridas, perjudique a otra u otras que, en desarrollo de la precitada 'representación', lato sensu, dieron crédito a una apariencia jurídica, la que por reflejo, en otro escaño, genera confianza ${ }^{33}$.

Desde esta perspectiva tuitiva, en tal virtud, el estoppel propende por la protección de la apariencia, y por la evitación de perjuicios y beneficios, respectivamente, lo que en la esfera procesal se traduce en impedir la incardinación de pruebas llamadas a afirmar o negar, según el caso, un preciso hecho lesivo para la contraparte.

buena fe, la idea anglosajona del 'estoppel' tiene su más profunda raíz en la protección objetiva de la apariencia jurídica”.

Por su parte, J. Puig BRUtau, realza que el estoppel, en sí, es fruto de la "... aplicación de la teoría de la apariencia, o mejor dicho, de la protección dispensada a la confianza en la apariencia". La doctrina de los actos propios, op. cit., p. 107.

32 Vid. D. HoutciefF. Le principe de cohérence en matiére contractuelle, op. cit., T. II, pp. 730 y 731.

33 Eugene Anderson y Natalia Holober, incluso van más allá de la apariencia, ya que aluden a la confianza, pero colectiva y no individual, recordando que “... un procedimiento judicial o administrativo o puede ser visto como una oportunidad para adoptar la posición que más convenga. El hecho de adoptar posiciones inconsistentes en el marco de un proceso judicial, perjudica la integridad del mismo proceso y del sistema judicial, abriendo las puertas para decisiones inconsistentes y debilitando la confianza pública en el aparato jurisdiccional. Es por eso que, durante años, se han diseñado doctrinas legales y herramientas para prevenir tales inconsistencias en el campo procesal, de tal suerte que se pueda tutelar la integridad total del sistema judicial. Tales doctrinas incluyen, sin duda, la doctrina del estoppel en sus diversas modalidades". Eugene Anderson y Natalia Holober. Preventing Inconsistencies in Litigation with a Spotlight on Insurance Coverage Litigation: The Doctrines of Judicial Estoppel, Equitable Estoppel, Quasi-Estoppel, Collateral Estoppel, "MEND the Hold" "FRAUD on the Court" and Judicial and Evidentiary Admissions. 4. Insurance Law Journal. 1997-1998. Sobre este particular, Vid. Andrew ROBERTSON. "Towards a Unifying purpose of Estoppel". Monash U.L. Rev. HeinOnline. 1996. 
Finalmente, en prueba de la acerada relación existente entre estoppel y el venire contra factum proprium, en lo que a lo finalístico igualmente concierne, resulta diamantino que aquél, como manifestación de éste, se erige en arquetípico remedio para conjurar la incoherencia comportamental, objeto de frontal repudio, como igualmente tiene lugar tratándose de otras figuras hermanadas por análogo propósito, su ultima ratio. Con plena razón el autor B. FAGES, no duda en aseverar que "En derecho inglés, el primer elemento constitutivo del Estoppel reside sin vacilación en la incoherencia del comportamiento. Antes de verificar la condición de un perjuicio sufrido por la otra parte, el juez británico se funda necesariamente sobre la incompatibilidad de las actitudes sucesivamente adoptadas por el contratante" 34 .

\subsection{Tipología}

Múltiple, amén de variopinta, es la tipología del estoppel, el que por la riqueza pretoriana del sistema anglosajón, principalmente, no se reduce a un sólo tipo, lo que explica entonces su acusada diversidad. Tanta que, en rigor, su estudio detenido desbordaría nuestro cometido de analizar sus aspectos más salientes, motivo por el cual le pasaremos revista a los más característicos, guiados por un criterio meramente descriptivo, y no taxativo, o exhaustivo.

Así las cosas, en su orden, examinaremos los siguientes tipos, o clases: a) estoppel by record; b) estoppel by deed; c) estoppel by facts in pais; d) estoppel by representation; e) estoppel by delay o laches, y f) estoppel by acquiesence, insistiendo en que son más ${ }^{35}$.

34 Bertrand FAGES. Le comportament du contractant, op. cit., Num. 637.

35 En un aparte de la obra del profesor LAwSON, ya citado en precedencia, se hace una somera referencia a las diversas tipologías que admite el estoppel; así, dice el autor que en el John LaWson, él se considera como el primer caso de la norma de estoppel; se dijo, respecto de la figura, que "... el Estoppel, lo afirma COKE, se da cuando una persona es conminada, por sus propios actos o su aquiescencia, a decir la verdad, y se divide en tres tipos: 1. By matter of record. 2. By deed. 3. By conduct; en cuanto a la primera, cuando las partes y el objeto de litigio son el mismo, la decisión ejecutoriada proferida en sede judicial, es concluyente, y no permite entonces que se vuelva a litigar lo ya resuelto. Ello, como es de suponerse, en salvaguarda del interés público. En cuanto a la segunda, ésta se puede invocar cuando un sujeto que ha proferido un acto de forma solemne, pretende, posteriormente, desconocer la manifestación que ha hecho en ese acto solemne (...) en 


\subsubsection{Estoppel by record}

Grosso modo, esta modalidad o tipo de estoppel, haciendo un parangón con el ordenamiento jurídico continental, equivale a la res judicata, a la cosa juzgada, de raigambre procesal y con claros efectos reflejos sustanciales, obviamente en lo que resulte pertinente, pues la identidad no es plena; se entiende entonces que es una aproximación ${ }^{36}$.

Se dice que esta específica clase se explica en el hecho por el cual en el Derecho anglosajón, a emulación de lo acontecido con el antiguo Derecho germánico, stricto sensu, no se conocía la figura precisa de la cosa juzgada, tal y como hoy la concebimos, por manera que para evitar las secuelas negativas de una decisión que no tuviera límites espacio-temporales, se acudió al estoppel para "...impedir a una de las partes que desconociera la situación que la misma había creado o había contribuido a crear. No era la alegación de la sentencia firme lo que producía el efecto paralizador, como modernamente ocurre, sino el hecho de que su pretendido desconocimiento implicaba ir contra los propios actos representados por cuanto habían alegado o admitido las partes seguir el procedimiento" ${ }^{\prime 3}$.

el caso del Estoppel by conduct, si un sujeto, con su conducta, ha dado a entender que un determinado estado de cosas existe en la realidad, independientemente de si dicha conducta fue voluntaria o no, no puede posteriormente denegar la existencia del prenotado estado de cosas, porque, en tal caso, se podrá entonces invocar el Estoppel ..." John LAWSON. "Leading cases simplified", A collection of the leading cases of the Common Law. pp. 279-282.

36 Sobre el estoppel by record, y otras modalidades afines a ésta última, como el collateral estoppel, ha dicho la Corte Suprema de los Estados Unidos que “... la visión moderna de la cosa juzgada es similar a la doctrina del collateral Estoppel, que básicamente establece que si un asunto o controversia ha sido sometida ya a consideración en sede judicial, y ha sido dirimida mediante una decisión válidamente proferida y ejecutoriada, dicha decisión debe mantenerse incólume, en la medida en que es concluyente e impide cualquier acción subsiguiente que intenten las partes, sobre el mismo o similar asunto. En ese sentido, no serán de recibo las pretensiones de quien pretende volver a litigar el asunto, a menos que exista una causal que justifique este nuevo intento..." (Traducción propia) (Hicks v. De La Cruz (1977), 52 Ohio St. 2d 71, 74). Cfr. Sabrina Sudol. The U.N. Convention on the recognition and enforcement of foreign arbitral awards and issue preclusion: a traditional collateral estoppel determination, Universitty of Pittsburg Law Review. 65. 2004.

37 J. Puig Brutau. La doctrina de los actos propios, op. cit., p. 109 y 110. 


\subsubsection{Estoppel by deed}

El llamado estoppel by deed, íntimamente ligado con el derecho formal, con la excepcional existencia de negocios jurídicos formales o solemnes, por oposición a los consensuales o de forma libre, tiene que ver, directamente, con la declaración consignada en un documento sellado y público que, por la fuerza y alcance de un escrito de esta especificidad y linaje (deed), no puede ser luego objeto de desconocimiento por parte de su hacedor. De ahí que quien "...hace una declaración de voluntad, asume una responsabilidad y, en consecuencia, no puede discutir la veracidad de lo declarado. La prueba en contrario queda excluida" 38 , salvo que "...se trate de un documento que carezca de validez, o que encubra un negocio fraudulento" 39 .

\subsubsection{Estoppel by facts in pais}

A diferencia del estoppel by deed, este tipo es el resultado de la materialización de determinados actos que, por su idoneidad y notoriedad, crean una específica apariencia digna de tutela judicial ${ }^{40}$, la cual se proyecta en determinados campos: el posesorio y tenencial (Tenancy), el restitutorio (Bailment) y el de patentes de invención (Patents), entre otros más, muy estudiados en el Derecho inglés.

38 Alejandro Borda. La teoría de los actos propios, op. cit., p. 37.

39 S. SAFOnTÁs. Doctrina de los actos propios, op. cit., p. 34. Vid. George SPENCER Bower. The law relating Estoppel by representation. Butterworths. London. 1977. pp. 158-165.

40 Sobre este particular afirma Hilda Aguilar Grieder que “... dentro de la institución del Estoppel se distinguen claramente tres categorías generales: estoppel by fact in pais (o también denominado como estoppel by conduct), estoppel by record y estoppel by deed. Es el estoppel by conduct el que guarda una estrecha similitud con la doctrina de los actos propios. Para G.D. NoKES, la aplicación del estoppel by conduct requiere de la concurrencia de los tres requisitos siguientes: en primer lugar, es necesaria la existencia de un determinado comportamiento (expreso o implícito) por parte de una persona, que equivalga a una representación (entendida ésta en sentido coloquial) encaminada a inducir, a la persona con respecto a la cual se lleva a cabo la representación, a seguir una determinada línea de conducta. En segundo término, es preciso igualmente que dicha representación provoque que esta última persona, que desconoce el verdadero estado de cosas, lleve a cabo un determinado acto o que incurra en una omisión. Y por último, es necesario que dicho acto u omisión cause una desventaja a una persona...". La extensión de la cláusula arbitral a los componentes de un grupo de sociedades en el arbitraje comercial internacional. Universidad Santiago de Compostela. 2001, p. 196. 


\subsubsection{Estoppel by representation}

Este tipo, sin duda el más elocuente y descriptivo de la esencia de esta figura anglosajona, es considerado como "...la forma más importante y característica que el 'estoppel' reviste en el moderno Derecho inglés y, por tanto, lo que mayor interés posee para nuestro estudio", el que ha sido descrito, desde 1837, hasta nuestros días (caso Picward v. Sears ${ }^{41}$ ), en los siguientes términos: "Cuando una persona, con sus palabras o con su conducta, produce voluntariamente a otra la creencia de la existencia de un determinado estado de cosas y la induce a actuar de manera que altere su previa posición jurídica, el primero no puede alegar frente al segundo que en realidad existía un estado de cosas diferente ${ }^{\text {"42 }}$.

Como se observa, en esta especie, de suyo muy próxima a la filosofía que anima a la doctrina de los actos propios, desde luego con sus diferencias, la representación de ese estado de cosas hecha por una de las partes, deviene medular, a partir de la apariencia registrada. Por ello opera como una “... prohibición hecha a la persona que, por sus declaraciones, sus actos o su actitud, es decir por la representación que ella ha podido originar respecto de una situación dada, ha conducido a otra persona a modificar su posición en perjuicio propio y en beneficio de la primera"43.

${ }^{41}$ Otros pronunciamientos judiciales que se han referido al consabido estoppel by representation son: Ismail v. Polish Ocean Lines (1976). QB.893, CA.; Avon C.C. v. Howlett (1983) I All ER 1073, CA. Sledmore v. Dalby (1996) 72 P \& CR 196, CA.

42 Luís Díez-PICAzo. La doctrina de los propios actos, op. cit., p. 79, quien recrea otro diciente y renombrado fallo (West v. Jones, 1851), conforme al cual "Cuando una parte, con sus palabras o con su conducta, ha originado a otra una representación, induciéndola a creer en la existencia de un particular hecho o estado de hechos, y esta otra persona ha actuado confiando en tal representación, la parte que originó la representación no debe ser oída ni puede alegar que los hechos no eran como ella los había representado", doctrinante que señala, más adelante, que "Su fundamento se encuentra en la idea que cualquiera que haya podido ser la intención real de la persona, ésta debe quedar vinculada por la apariencia o impresión que el sentido objetivo de su conducta puede haber ocasionado en otra, pues un deber de diligencia social impone tener en cuenta las representaciones que nuestros actos pueden causar a los demás" (p. 80). Sobre este particular, Vid. George BOWER SPEnCER. The law relating Estoppel by representation. Butterworths. London. 1977. pp. 130-135.

43 Emmanuel GaILLARD. "L'interdiction de se contradire au détriment d'autre comme principe général de droit du comerce International. Le principe de l'éstopp. el dans quelques sentences arbitrales récentes", en Revue d'Arbitrage. Paris. 1985, p. 246. 
En este ámbito específico, algunas situaciones particulares y propias, originadas en las relaciones de representación o mandato, específicamente en la agencia, tendrán especial cabida, en las que la apariencia jurídica ocupará un sitial preferente $e^{44}$ y 45 .

\subsubsection{Estoppel by delay o Laches}

Este tipo de estoppel, muy particular y harto controvertido en el Derecho continental, tiene lugar cuando la actuación o la manifestación a cargo de una de las partes interesadas se produce con indiscutido e irrazonable retraso atribuible sólo a él, en perjuicio ajeno, en concreto de ese sujeto que por el transcurso de un lapso determinado razonablemente pudo interpretar como "... un tácito asentimiento a la situación creada y, consiguientemente, el 'inejercicio' del derecho"46.

Expresado de otro modo, en esta peculiarísima modalidad, un extremo, a posteriori, actúa con un retraso objetivo, con fundamento en el cual el otro entendió, o pudo entender, que aquél no pretendía ejercer su derecho o

${ }_{44}$ Vid. René DAVID. Les contrats en droit anglais, op. cit., pp. 230 y ss.

45 Sobre este particular afirma Erick MeDINA que el Estoppel by representation "... ha sido considerado, por algunos estudiosos del tema, como una subdivisión del Estoppel by fact in país, inclusive se ha llegado a determinar que no existen diferencias entre ellos. Dice relación con los actos que han sido ejecutados notoriamente, que provocan oposición del estoppel by fact in pais; en tanto que el hacer creer voluntariamente -a través de conductas o palabras-, la existencia de un determinado orden de cosas y que induce a actuar de una determinada manera, impide a quien ha producido dicho orden de cosas, el alegato de la inexistencia de tal estado. Es decir, que los actos ejecutados notoriamente no pueden ser contradichos por su ejecutante" Erick Medina MuÑoz. El estoppel, el verwirkung y la teoría de los actos propios (sic), en: Política y derecho Internacional [En línea], p. 40.

46 S. SAFONTÁs. Doctrina de los propios actos, op. cit., p. 34. La Corte Suprema de los Estados Unidos, por su parte, ha dicho en torno a la figura conocida como Laches que "...en algunas ocasiones esta doctrina se usa para significar que hubo un retardo de la contraparte en su forma de proceder y nada más; en algunas ocasiones se toma dicho retraso como aquiescencia; y en otras ocasiones se entiende en su justa dimensión, esto es, como una inactividad que se traduce en aquiescencia en cuanto al estado de cosas que se litiga y que, en consecuencia, impide desconocer esa aquiescencia mediante el posterior ejercicio de la acción ..." (Goldsworthy v. Brickell [1987] Ch 378, 410A-C). Cfr. Lindsay Petroleum Company v. Hurd (1873) 5 App. Cas 221, 239. 
prerrogativa, o que no estaba realmente interesado en hacerlo, en cuyo caso el silencio o la inacción termina generando efectos en Derecho, así no se haya consolidado el plazo respectivo de prescripción, el que para nosotros, en el Derecho continental, ordinariamente sigue teniendo una especial valía, tema alrededor del cual haremos varias y puntuales reflexiones en este campo cuando nos ocupemos seguidamente de la verwirkung -o retraso desleal-.

Entre tanto, expresemos nuestras reservas y correlativo distanciamiento preliminar, por lo menos con carácter general, habida cuenta que, por dicha vía, se estaría desconociendo el instituto prescriptivo, con todo lo que ello supone en el terreno obligacional (existencia y ejercicio de los derechos subjetivos) y en el de la seguridad jurídica, especialmente, por cuanto todo o prácticamente todo quedaría librado a una lectura subjetiva de cada caso, en contra de la estabilidad emergente de la existencia de términos precisos, a la vez que inequívocos y definidos con antelación ('reglas claras de juego'). Habrá ocasión entonces de volver en torno a esta temática, también conocida con la expresión 'retraso desleal', o valor jurídico del silencio, como se anotó, entre otras más, combatida por algunos en Iberoamérica, y aceptada por otros, no muchos, ciertamente, aun cuando el tema no es pacífico, hay que reconocerlo.

\subsubsection{Estoppel by acquiesence}

Por último, se encuentra el denominado estoppel by acquiesence, en virtud del cual, si un sujeto en particular, al que se le invaden o quebrantan sus derechos por la conducta desprevenida, y también honesta de otro sujeto, no objeta dicha vulneración, sacando del error al agente de la misma, no puede, a posteriori, contravenir su conducta pretérita alegando la consabida invasión, cuando, en realidad, no lo hizo oportunamente. Puesto en otros términos, y como lo explica don Luís Díez-PICAzo, el estoppel by acquiesence se da "... cuando una persona (A) está invadiendo el derecho de otra (B), en la falsa creencia de que este derecho no existe, y $\mathrm{B}$, conociendo esta creencia de $\mathrm{A}$ y sabiendo que es equivocada, se 
abstiene de desengañarle. $B$ falta a un deber de la buena fe y queda, en virtud de su conducta omisiva, 'estopped' para afirmar posteriormente su derecho..."47 y 48.

Puesto en otros términos, se ha dado aplicación al estoppel by acquiesence en aquellos casos en que un sujeto no objeta, protesta o manifiesta su inconformidad en forma oportuna respecto a la vulneración de un derecho propio, por otro sujeto que lo invoca y ejercita creyendo, honesta y desprevenidamente, que ese derecho le pertenece ${ }^{49}$.

En tal virtud, coincidimos también con el profesor Díez PICAZO, en que son varios los presupuestos que deben concurrir para que una persona $(A)$ invoque el estoppel by acquiesence frente a otra (B), a saber: “... $1^{\circ}$, A debe haber sufrido una equivocación a consecuencia de la cual está invadiendo el derecho de $B ; 2^{\circ}$, $B$ debe conocer la existencia de su propio derecho, que es incompatible con los actos de $A ; 3^{\circ}, B$ debe conocer además la creencia equivocada de $A$ de obrar rectamente; $4^{\circ}$, A debe haber realizado algún desembolso patrimonial o cualquier

47 Luís Díez-PICAzo. La doctrina de los propios actos, op. cit., p. 83. Es importante anotar que, en lo concerniente al Estoppel by acquiesence, son varias las hipótesis en que se ha dado cabida a la figura; al respecto, Vid. Berrysford v. Millward (1740), caso en el que se afirmó que "... cuando un hombre ha permitido que otro edifique sobre su terreno, conociendo el propietario el alcance y la existencia de su propio derecho e ignorándolo el edificante de buena fe, el tribunal debe obligar al propietario del suelo, que sólo ha hecho valer su derecho cuando el edificio había sido ya totalmente construido, a permitir el goce quieto y pacífico del edificante ..."; en otro caso, Ramsden v. Dyson (1866), se dijo que "... si un extraño comienza en una tierra suponiendo que es suya y el verdadero propietario, dándose cuenta de este error, se abstiene de hacer valer su derecho y le deja al edificante perseverar en su error, la equidad no puede permitir después que el propietario ejercite su derecho. Pero si un extraño edifica en terreno ajeno, conociendo que es propiedad de otro, la equidad no impide al propietario reclamar en cualquier momento su terreno...", pronunciamiento que fue reiterado en Plimcher v. Wellington Corporation (1884).

48 El estoppel by acquiesence es también conocido como el estoppel “... por silencio o inacción (Estoppel by silence or inaction); en definitiva esta figura no constituye sino una aplicación del adagio de que "quien calla cuando debería hablar, no será oído si habla cuando debía callar'..." EKDAHL, María Fernanda. La doctrina de los actos propios. El deber jurídico de no contrariar conductas propias pasadas, op. cit., p. 86.

49 Sobre este particular, Vid. Georgia v. South Carolina. 497 U. S.376 (1990); Central Pacific Railway Co. v. Alamda County 284 U.S. 462 (1932). 
otro acto con base en su creencia equivocada; $5^{\circ}, B$ debe haber alentado a realizar estos actos, por lo menos absteniéndose de afirmar su derecho ..."50.

\subsection{RASGOS CARACTERÍSTICOS Y ALGUNAS DIFERENCIAS CONCRETAS CON LA 'DOCTRINA DE LOS ACTOS PROPIOS'}

También en términos muy generales, en orden a no exceder las pretensiones panorámicas que animan el presente estudio del estoppel, cumple observar que, entre otras notas o rasgos más, bien podemos destacar los siguientes, algunos de ellos que, a su turno, examinados desde otro ángulo, se erigen -o pueden erigirse- en puntuales diferencias con la figura más genérica del venire contra factum proprium, y con la más específica, si se prefiere, de la doctrina de los actos propios.

Es de precisar, sin embargo, que estas notas no pueden ser consideradas en forma pétrea e inflexible, a la par que absoluta, como quiera que, en ocasiones, puede ser excepcionadas o, incluso, no aceptadas por un sector autoral, en atención a que no todos los temas concernientes al estoppel, son pacíficos y, por ende, objeto de acuerdo unánime.

Del mismo modo, no huelga indicar que uno u otro rasgo, ya han sido pincelados por nosotros en precedencia, circunstancia que, no impide, por razones sistemáticas, traerlos de nuevo a colación, así sea muy sumariamente.

\subsubsection{Su origen pretoriano}

En desarrollo de lo ya señalado, se tiene establecido que ha sido la jurisprudencia, propiamente dicha, la que se ha ocupado de dimensionar y dotar de contenido al estoppel en el Derecho anglosajón, a diferencia de lo acontecido en el Derecho continental, en el que la regla del venire contra factum proprium o de la doctrina de los actos propios, conforme se ha reseñado, ha sido obra de la

50 Luís DíEz-PICAZO. La doctrina de los propios actos, op. cit., p. 84; esta idea, al mismo tiempo, es recreada por Ashburner. Principles of equity. Browne. Londres. 1957. 
dogmática (Derecho de juristas), y luego de la jurisprudencia e, incluso, de la ley, ora directa, ora indirectamente, lo cual es característico de uno y otro sistema.

No obstante lo anterior, sin que ello suponga la alteración de las diferencias estructurales existentes entre el common law y el civil law -cada día menos distantes, en lo pertinente-, hay que reconocer el protagónico papel que en las naciones inscritas en este último ha ocupado la jurisprudencia, pues se ha apropiado de la doctrina del acto propio, hasta el punto que a ella se le debe buena parte de su 'renacimiento', o de su fuerza y primado, según sea la nación correspondiente, pues no en todas tiene idéntica proyección y arraigo, como se observará en su momento. De hecho, en algunas su datación es más reciente, hasta el punto que a finales del siglo XX o en lo corrido del XXI comienza a conocerse y aplicarse con regularidad en sede judicial.

\subsubsection{Su carácter procesal}

También a tono con lo mencionado en otros apartes, un importante y mayoritario bloque autoral se inclina por sublimar la naturaleza estrictamente procesal del estoppe $/{ }^{11}$, de la que derivan, en forma categórica, que su incidencia no es sustancial, de tal suerte que se ha entendido como "...una de las reglas de un 'fair play' procesal y entra en juego dentro de un proceso y nunca fuera de él. Forma parte, como decíamos, de las 'rules of evidence' y éstas pertenecen netamente al Derecho procesal" ${ }^{\prime 2}$.

Empero, como igualmente se mencionó por nosotros, esta concepción no es de recibo por todos, en razón de que existen doctrinantes y jurisprudencia que se inclinan por una lectura más omnicomprensiva, y menos rígida y excluyente, como corresponde, con el objeto de darle cabida al derecho sustancial, sin

51 RADCLIFFE-CROss destacan la figura del estoppel como una figura de estirpe netamente procesal (RADCLIFFE-CROSs. The english legal system, 324-327, (Londres, 1954); es también la posición de otros autores como CoWEN y CASTER (Essays on the law evidence, 188 y ss. (Oxford, 1956)

${ }^{52}$ Luís Díez-Picazo. La doctrina de los propios actos, op. cit., p. 67. 
duda interesado en esta problemática, muy especialmente el moderno Derecho procesal. De ahí que este criterio ha venido cambiando en los últimos tiempos.

Como tuvimos ocasión de examinar, en tratándose de los actos propios, la incidencia de esta doctrina es sustancial, a fuer que procesal, como resulta lógico. Es más, puede ser empleada judicial, pero también tiene cabida extrajudicialmente, lo que asegura una proyección mucho más amplia de la figura en referencia.

\subsubsection{Es un medio defensivo y no procede de oficio}

En el Derecho anglosajón, a diferencia de lo que tiene lugar en punto al Derecho continental, el estoppel no puede ser instrumentado a través de una acción, sino únicamente mediante una excepción, en sentido lato, o si prefiere, un 'medio de defensa'53.

Ello explica que, de antiguo, sea considerado como un arquetípico medio defensivo, o de defensa de los intereses en tensión, o en conflicto. Célebre, amén de ilustrativa en grado sumo, sobre este particular, es la opinión británica (CABABE) expresada siglo XIX, con arreglo a la cual el estoppel "es un escudo, pero no una espada" 54 , la que refleja en su exacta medida dicho carácter especial.

En armonía con este signo revelador, de vieja data se ha entendido que el estoppel no puede ser invocado a instancia de parte, habida consideración que no procede de oficio, en cuyo caso el juez debe abstenerse de invocarlo, pues estaría sustituyendo a uno de los extremos de la relación procesal, característica ésta que contrasta con lo acontecido en sede del acto propio, como quiera que la communis opinio continental admite que el juzgador, dada la importancia de conjurar la contradicción y la incoherencia, al mismo tiempo que el quebranto del postulado vertebral de la buena fe, pueda actuar ex officio.

53 Sobre este particular, Vid. Geoffrey GiBson. The Arbitrator's companion. Ed. Federation Press. Sydney. 2001, p. 114. Cababe. The principles of Estoppel. Londres. 1988, p. 119. Cfr. JowIT, The dictionary of English law. Londres. 1959, p. 737.

54 CABABE. The principles of Estoppel. Londres. 1988, p. 119; JowIT, The dictionary of English law. Londres. 1959, p. 737. 


\subsubsection{Es de doble vía y de efectos relativos}

Decimos que es de doble vía, en atención a que, según las circunstancias, puede ser invocado por ambas partes, pero no mediante una acción, como se acotó.

Puede serlo por el demandado, es la usanza, pero también por el demandante, en el evento de que sea necesario acudir a él por una específica alegación previa del demandado, todo en desarrollo del concepto prístino del derecho de defensa, el que permite se acuda a este mecanismo, de carácter defensivo.

Buena parte de la doctrina se refiere a este rasgo a través de la expresión 'reciprocidad', pero nosotros creemos que es más preciso y, sobre todo, descriptivo el término empleado: doble vía, pues hace énfasis en que, según el caso, a él pueden acudir demandante y demandado, con la advertencia ya efectuada.

De otra parte, a emulación de los efectos relativos del contrato, mutatis mutandis, el estoppel no puede ser esgrimido por terceras personas ajenas a la relación jurídico-procesal, puesto que las legitimadas para hacerlo, es la regla, son las partes, y no los terceros al litigio, según lo entiende la generalidad de la doctrina y de los jueces. A ellas, ni les perjudica, ni les favorece; simplemente les resulta inoponible, postulado que, como algunos lo reconocen, no puede sostenerse con un carácter absoluto -a rajatabla-, sino general, a la par de lo que tiene lugar con relación a la doctrina de los actos propios.

\subsubsection{Se fundamenta primordialmente en la apariencia jurídica}

Este instituto, ad baculum, se apoya de manera prevalente en la doctrina de la apariencia, muy ligada a la representación, en el Derecho anglosajón, aunque algunos refieren también a la reliance, según se anotó. Es aquella, efectivamente, la que sirve de piedra de toque para que la judicatura brinde protección y salvaguarda al que, con fundamento en ella, objetiva y razonadamente actuó de una determinada manera. Por eso se erige en el bien jurídico tutelado, por excelencia, sin perjuicio de que cuando episódicamente se alude a la confianza, 
se hace más en función de acentuar la valía de la referida apariencia, núcleo tuitivo fundamental del estoppel, según se evidencia de las referencias traídas a colación precedentemente. En cambio, sin que, in toto se pueda descalificar a priori otra lectura, en el Derecho continental, como ya observamos, es la confianza el alma de la doctrina de los actos propios; su ratio protectionis y fundamento cardinal, a lo que se agrega el significado profundo que tiene la coherencia y, correlativamente, la fuerza jurídico-ética que inviste la incoherencia, entendida como detonante de la fractura de la referida confianza, base del sistema ${ }^{55}$.

\subsubsection{Su 'irradiación’ al Derecho internacional}

Aun cuando se ha subrayado que la geografía del estoppel está referida a los países inmersos en el common law, en los últimos años se ha evidenciado que, por lo menos nominalmente, ha trascendido las fronteras originarias de este sistema.

Es así como su referencia es amplia en el campo del Derecho público internacional ${ }^{56}$, y también en el arbitraje, igualmente internacional, no solamente en el espacio europeo, sino también en el americano, hasta el punto que "la prohibición de contradecirse en detrimento de otro", ha sido elevada a "principio general derecho del comercio internacional" (lex mercatoria), aun cuando se discute si en realidad es un verdadero 'principio general', o es una regla jurídica, como firmemente lo creemos nosotros, y lo sustentamos antes en este escrito $(\text { Cap. I) })^{57}$.

55 Al respecto, señala A. Borda que, “...el estoppel (todo estoppel) responde a la idea de la apariencia jurídica, en tanto que la teoría de los propios actos tiene en mira el comportamiento coherente". La teoría de los actos propios, op. cit., p. 33.

56 Vid. Francisco GARCíA JIMÉNEZ. Los comportamientos recíprocos en el derecho internacional. A propósito de la aquiescencia, el estoppel y la confianza internacional. Dilex. 2002 y Luís Fernando Álvarez Londoño. Derecho Internacional Público, Pontificia Universidad Javeriana, Bogotá. 2007, pp. 192-197.

57 Emmanuel GaILLARD. L'interdiction de se contradire au detriment d'autrui comme principe général du droit du comerce international. Le principe de l'estoppel dans quelques sentences arbitrales récentes, op. cit., p. 242. También G. WeIZBERG, Actualité de la théorie de l'estoppel dans la jurisprudence Française, op. cit., p. 2, quien observa que "El Estoppel es frecuentemente invocado o evocado en el derecho internacional público en materia de arbitramento comercial internacional". 
Con todo, cumple expresar nuestra preocupación, toda vez que, a menudo, en el campo del Derecho público internacional y del arbitraje, el vocablo estoppel se utiliza con mucha amplitud, y sin mucho rigor, por cuanto se emplea, en ocasiones, más para referirse a la problemática de la incoherencia o de la contradicción en el comportamiento, que a los supuestos propios y típicos del estoppe ${ }^{58}$. Muy por el contrario, con el ropaje de este, se suele cubrir a la doctrina de los actos propios, stricto sensu, en una clara distorsión, puesto que no hay una inequívoca y total simetría entre estas manifestaciones o figuras, así sean próximas, como ciertamente lo son, según se indicó.

Dicho de otro modo, quizá porque en algunas naciones, como en Francia, en donde el término: 'doctrina de los actos propios', o actos propios, o venire contra factum proprium, entre otros, no se ha abierto paso firme, es que se acude a la expresión estoppel, ciertamente difundida en ciertos sectores, incluso de América Latina. He allí el motivo de la señalada inquietud que trasciende lo meramente gramatical, puesto que esta asimilación, equiparación, o laxitud conceptual, inyecta confusión y fomenta la oscuridad, quedando la sensación, por supuesto equivoca, de que el estoppel eclipsó al acto propio, o a la regla del venire contra factum proprium, de la que es emanación, conforme se indicó.

58 En este sentido, justamente, se expresó la Corte Interamericana de Derechos Humanos recientemente, al expresar que, "según la práctica internacional cuando una parte en un litigio ha adoptado una actitud determinada que redunda en beneficio propio o en deterioro de la contraria no puede luego, en virtud del principio del estoppel asumir otra conducta que sea contradictoria con la primera. Para la segunda actitud rige la regla de non concedit venire contra factum proprium". Cit., Nicolás DE PIÉROLA y Carolina LOAYSA. "Los principios generales de derecho de la buena y el estoppel y la regla del agotamiento de la jurisdicción interna en la jurisprudencia de la Corte Interamericana de Derechos Humanos", Gaceta Jurídica online, 2009, p. 3.

Ernesto De La GuARdia y Marcelo DeLPECH, in extenso, a este mismo respecto manifiestan que, "El principio de las consecuencias jurídicas de la contradicción entre la conducta o manifestaciones anteriores de un estado y sus reclamaciones eventuales en una controversia internacional ha sido reiteradas veces aplicado por las jurisprudencias nacionales y la internacional. En el derecho anglosajón es conocido con las denominaciones de preclusión o estoppel, en francés es llamado forclusion y en el mundo hispano parlante 'doctrina de los actos propios', aunque existen diferencias de matiz especialmente en el ámbito de la terminología anglosajona. Sin embargo, aunque algunos juristas no parecen conformes con su utilización, el término estoppel se ha impuesto poco a poco en la práctica internacional, sobre todo después de las conocidas decisiones de la Corte Internacional de Justicia de la Haya en los casos de las sentencia arbitral dictada por el Rey de España y del Templo de Preah Vihear". "El derecho de los tratados y la convención de Viena de 1969", La Ley. Buenos Aires. 1970, p. 372, cit, Ibídem. 


\subsubsection{Es más limitado que la 'doctrina de los actos propios'}

Aun cuando con alguna frecuencia se pone manifiesto que el estoppel “...es más amplio o abarca más supuestos que la regla de que nadie puede ir contra sus propios actos", ${ }^{9}$ tenemos la impresión de lo contrario, esto es que es más restringido que la doctrina en cuestión, no sujeta a tantas limitaciones extrínsecas, entre otras, a su carácter exclusiva o prevalentemente procesal y no sustancial; a su naturaleza defensiva que impide su formulación por la vía activa; a la correlativa imposibilidad de invocación de oficio por el iudex, por terceras personas, etc.

En adición a lo anterior, sin dejar de reconocer que existen diversas tipologías de estoppel, hecho que, prima facie, podría ser indicativo de su amplio espectro, creemos que la aplicación de la doctrina de los actos propios, a partir de una fórmula general como la que la estereotipa (transgresión de la contradicción, incongruencia o incoherencia comportamentales, o que no está permitido volver sobre los propios actos, entre otras expresiones), permite una más extendida aplicación, tal y como da cuenta la enriquecida casuística jurisprudencial existente en la materia, para nada despreciable, de lo que se colige su vasto radio de acción (numerus apertus), así no se acuda a una clasificación tipológica, circunstancia que, a nuestro juicio, se traduce en mayor libertad, pero mayor responsabilidad, con todo lo que ello supone ${ }^{60}$.

59 J. PuIg BRUTAU. La doctrina de los actos propios, op. cit., p. 114. Cfr. María Fernanda EKDAHL. La doctrina de los actos propios, op. cit., p. 80., y Alejandro BordA. La teoría de los actos propios, op. cit., p. 32.

60 Cfr. Luís María Vives. Doctrina de los actos propios, op. cit., p. 4, y Mariana BeRnAL. El deber de coherencia en los contratos y la regla del venire contra factum proprium, op. cit., p. 300, quien a partir de la acentuada significación que en el Derecho continental reviste el principio de la buena fe, anota que, "...la prohibición de contradecirse en perjuicio de otro cuenta en el derecho comparado con un campo de aplicación mucho más amplio que el del estoppel". 


\section{LA VERWIRKUNG}

\subsection{Generalidades}

Al lado del estoppel, en la temática que detiene nuestra atención, corre pareja la figura comúnmente conocida a través de la expresión alemana verwirkung, una explícita e inequívoca corroboración de la importancia que en el Derecho alemán, primordialmente, alcanzó y sigue alcanzando el escrutinio de la buena fe, en particular de la máxima latina venire contra factum proprium, materia de sistemática y detenido análisis por su dogmática, sobre todo a partir de los albores del siglo XX, pródigo en estudios acerca de la conducta contradictoria e incoherente y su incidencia en la esfera del Derecho (público y privado), en conjunción con la teoría del abuso del Derecho, conforme se observará, pues para un sector autoral son inseparables. Una de tales contribuciones, sin duda de acendrada significación, fue realizada por E. RIEZLER, autor de una de las más examinadas y afamadas obras en la materia, escrita en el año 1912, e intitulada: Venire contra factum proprium, y que sigue siendo muy consultada, así tenga más de un siglo, tal y como tuvimos ocasión de resaltar en el capítulo primero61, de la mano de otros destacados autores germanos, entre varios SieBERT, ENNECERUS, Larenz, Boehmer, Wieacker, Stauder, Wieling, Flume y Wacke.

La figura sub examine, en puridad, es obra del Derecho pretoriano ${ }^{62}$, en particular de la jurisprudencia alemana que, a partir de los estudios doctrinales de comienzos de la centuria precedente, se dio a la frecuente tarea de auscultar concretos supuestos que, con los años, permitieron que se madurara una doctrina judicial consistente que, en su momento, permeó a la dogmática la cual, en esta temática, ciertamente es abundante, tarea que los tribunales germanos acometieron alrededor del artículo 242 del Código Civil alemán (B.G.B), atinente a la buena fe, corazón de este instituto, dada la trascendencia que a ella se le

${ }_{61}$ Erwin RIEZLER. Venire contra factum proprium. Leipzig. 1912.

62 José Luís De Los Mozos. El principio de la buena fe, op. cit., p. 207. Al respecto, nos recuerdan los doctores Antoni Vaque Aloy y Núria Cucurrul SerRA, que "La doctrina de la Verwirkung se origina en Alemania a finales del siglo XIX. Su primera formulación se encuentra en la sentencia del Reichsoberhandelsgericht de 20.10.1877", en InDret, 274, Barcelona, 2005, p. 3. 
reconoce en esta esfera, como igualmente se anotará, sobre todo a partir de la primera guerra mundial. He aquí, anticipadamente, una muestra del llamado Derecho judicial, tejido en el telar de la buena fe, en el que tanto hincapié hizo WIEACKER, y que se consolidó a través de puntuales 'rupturas ético-jurídicas', motivo de aplausos, pero también de críticas, en especial fuera de Alemania ${ }^{63}$.

Es de señalar que tanto en Portugal como en Brasil, a menudo, la verwirkung se identifica a través de la expresión suppressio, la que ha adquirido en el lenguaje jurídico de ambos países concreta identidad, aun cuando el vocablo alemán (verwirkung) también se emplea ${ }^{64}$.

\subsection{TeRminología y RECEPCIÓN PRELIMINAR. VERWIRKUNG Y RETRASO DESLEAL}

Importa manifestar que la expresión alemana 'verwirkung', en sí misma considerada, es un vocablo propio, acuñado para identificar a esta institución que ha sido estimada como autónoma, por más vasos comunicantes que existan con otras análogas, como las ya referidas, y en concreto con el postulado de la buena fe, así sea su manantial ${ }^{65}$.

Sin embargo, cuando se ha pretendido su traducción a otras lenguas, no ha sido fácil encontrar su auténtico significado, lo que explica que, de ordinario, sobre todo en los últimos lustros, sea mencionada en los textos respectivos

63 Franz WIEACKER. El principio general de la buena fe, op. cit., pp. 51 y 74 y ss. Igualmente en el prólogo de esta monografía, realizado por L. Díez-Picazo, pp. 17 y ss.

64 Vid. Paulo Mota PINTO. Sobre a prohibiçao do comportamento contraditório (venire contra factum proprium) no direito civil, op. cit., p. 271; Anderson SchreIBER. A prohibiçao de comportamento contradictório. Tutela da confiança e venire contra factum proprium, op. cit., p. 185; Marcelo Colombelı I Mezzomo. "A boa-fe objetiva e seus institutos", en Jus Navegandi, Año 11, No 1212, 2006, p. 6; Pedro H. Pedrosa Nogueira. "Notas sobre preclusao e venire contra factum proprium", en Revista de processo, Vol. 168, 2009, p. 331 y ss., y Luciano DE CAmARgo PenteAdo. "Figuras parcelares da boa-fe objetiva e venire contra factum proprium", en Revista de direito privado, Vol. 27, 2006, pp. 252 y ss.

65 Es de señalar que ha sido tan difundido su empleo por la jurisprudencia y por la doctrina, que el propio legislador alemán la ha acogido expresamente. Es el caso de la Ley alemana de marcas de 1995, en la que se le da carta de ciudadanía al vocablo Verwirkung von Ansprüchen. Vid. Carlos Fernández-NovoA. Tratado sobre derecho de marcas, Marcial Pons, Madrid, 2004, p. 651. 
(en castellano, en italiano, etc.), en lengua alemana, a través de la expresión verwirkung, con el confesado propósito de evitar equívocos ${ }^{66}$, aun cuando en los últimos años, pareciera estar haciendo carrera el término 'retraso desleal' 'o

66 En el Derecho italiano, por vía de ilustración, se preserva habitualmente la expresión alemana en comentario. Es el caso de la obra del profesor Filippo RANIERI, Rinuncia tacita e verwirkung, Padova, 1971., y la de los autores Francesco AstonE. Venire contra factum proprium, op. cit., pp. 93, y Ritardo nell'esercizio del credito. Verwirkung e buona fede, op. cit., pp. 605 y ss.; Forenzo FESTI. II devieto di 'venire contro il fatto proprio', op. cit., p. 133 y ss.; Salvatore PATTI. Verwirkung, op. cit., pp. 722 y ss., y Francesco Gazzonı. Manuale di diritto privato, op. cit, p 114. Lo mismo sucede en el Derecho español, v.gr: Luís DıEz-PICAZo. La doctrina de los propios actos, op. cit., pp. 93 y ss.; Bernardo Gómez CoRRAlizA. La caducidad, Montecorvo, 1990, pp. 77 y ss.; Antoni VAQUer Aloy. El retraso desleal en el ejercicio de los derechos. La recepción de la doctrina de la verwirkung en la jurisprudencia española, op. cit., p. 90 y ss., y Ana CAÑIZARES LASO. La caducidad de los derechos y acciones, Civitas, Madrid, 2001, p. 25 y ss. Y también en el Derecho portugués. Vid. Joao BAPTISTA M. Tutela da confiança e venire contra factum proprium, op. cit., p. 419. También por parte de la jurisprudencia, como quiera que en el año 1976 el término verwirkung fue expresamente utilizado por el Tribunal Supremo (Sentencia del 24 de junio), aunque a partir de 1982, es cierto que la expresión retraso desleal es más empleada en sede jurisprudencial.

Y en el Derecho iberoamericano, acontece otro tanto. Vid. Noemi Nicolau. "La doctrina de los actos propios y la verwirkung", op. cit., p. 134; Martha Lucía NemE V. Venire contra factum proprium, prohibición de obrar contra los actos propios y protección de la confianza legítima. Tres maneras de llamar a una antigua regla emanada de la buena fe, op. cit., pp. 19 y ss.; Anderson SCHREIBER, A prohibiçao de comportamento contradictório. Tutela da confiança e venire contra factum proprium, $p$. 185 y ss. Igualmente la jurisprudencia colombiana (Sentencia del 28 de abril de 2011).

A su vez es pertinente puntualizar tratándose de obras alemanas más recientes, no se traduce al castellano el término en cuestión, pues se conserva incólume. Vid. Werner FLumE. El negocio jurídico. Fundación Cultural del Notariado. Madrid. 1998, p. 157, cuyo nomen asignado al numeral 3 de esta publicación es el de "La Verwirkung por conducta......" 


\section{atraso desleal' ${ }^{67}$ y 68 , no siempre en forma pacífica, asi alguna jurisprudencia haga la correspondiente asimilación, según se apreció en líneas anteriores.}

67 En suma, tiene plena razón la profesora Ana CAÑIZARES LASO, cuando observa que en este campo terminológico, en general, "....es mejor hablar de decaimiento de los derechos o bien mantener el término alemán que, por otra parte, es lo que últimamente viene haciendo la doctrina". La caducidad de los derechos y acciones, op. cit., p. 26.

Luís Diez-Picazo en el mencionado prólogo alude específicamente al 'retraso desleal' y entre paréntesis, al lado de este, incluye la palabra 'verwirkung', op. cit., p. 21, como lo hace a su turno el Tribunal Supremo Español. Vid, entre otras sentencias, la del 3 de diciembre de 2010. Lo propio, sólo para citar un ejemplo más, hace el profesor uruguayo, Gustavo ORDoQuI C., en su libro dedicado a la buena fe, quien expresamente, en numeral autónomo, se ocupa de este mismo tema, de la siguiente manera: 'Buena fe y el 'retraso desleal' en el ejercicio de un derecho (teoría de la verwirkung)', La buena fe contractual, op. cit., p. 234, lo cual tiene explicación, toda vez que dicho retraso es consustancial a esta institución, pues se tiene establecido que la Verwirkung, lo memora don Juan Vallet De Goytisolo, "...es un caso especial de inadmisibilidad del ejercicio de un derecho por contravención a la buena fe, o mejor de un especial abuso del derecho consistente en ejercitarlo con un retraso estimado como desleal....". Notas críticas, La doctrina de los actos propios (sic), op. cit., p. 468. Otros hablan de 'retardo desleal' (Sieber). Cfr. Rafael Resnick. (Provincia de Buenos Aires: “¿Paraíso donde las causas nunca prescriben?”, op. cit., p. 6).

68 La doctrina hace una mención en torno a la recepción jurisprudencial del retraso desleal en el ámbito civil; así resulta de interés la descripción que hace el doctor Francisco LóPEZ DE LA PEÑA, quien describe la acogida que en esta materia se ha alcanzado en sede jurisprudencial, particularmente en lo tocante con el derecho inmobiliario. Alteración de elementos comunes: consentimiento tácito. Aranzadi - Thomson Reuters [En línea]. Vid., ampliamente, a Nélida TUR FAUNDEZ. La prohibición de ir contra los actos propios y el retraso desleal, op. cit., p. 75 y ss.

Don Luís Díez-PICAzo, en su momento, también puntualizó que en el marco del Derecho español la doctrina del retraso desleal ha obtenido respaldo; para él, una de las múltiples manifestaciones del venire contra factum proprium non valet, de raigambre jurisprudencial, es aquella según la cual "... va contra sus propios actos quien ejercita tardíamente un derecho, en forma contradictoria con una situación que tácitamente ha admitido..." La doctrina de los propios actos, op. cit., p. 123. Y más recientemente, anotó que "La doctrina del 'retraso desleal' tiene cabida dentro del actual art. $7 \mathrm{CC}$. Prueba de ello es que aunque de forma esporádica aparece acogida por algunas sentencias". La prescripción extintiva, Thomson-Civitas, Pamplona, 2003, p. 89.

En fin, sobre este particular se pueden también consultar puntuales pronunciamientos del Tribunal Supremo español, de los cuales se destacan, en particular, las sentencias de 21 mayo 1982, 6 junio 1992, 4 julio 1997, 1 marzo 2001, 19 diciembre 2005, 31 enero y 5 octubre 2007. En una de las más recientes, fechada el 3 de diciembre de 2010, expresó el Supremo que "Se consideran que son características de esta situación de retraso desleal (Verwirkung) a) el transcurso del tiempo sin ejercitar el derecho; b) la omisión del ejercicio; c) creación de una confianza legítima en la otra parte de que no se ejercitará. En este sentido, la jurisprudencia de esta Sala se ha pronunciado en temas directamente relacionados con esta cuestión". 
Para algunos, en consecuencia, los términos en mención (verwirkung y retraso desleal), pueden emplearse indistintamente en la esfera jurídica, en forma conjunta o separada, y para otros, es preferible no asimilarlos, aun cuando en la praxis, a menudo, se utilizan como equivalentes, lo cual también es admitido por un sector autoral, pero con matices. Es el caso del Dr. Antoni VAQUER ALOY, a juicio de quien es frecuente que se establezca “... .una curiosa sinonimía entre retraso desleal y Verwikung, esto es, como si se tratara de lo mismo, cuando es claro que la Verwirkung es el efecto jurídico que se anuda a la existencia de un retraso desleal en ejercicio de los derechos... Hecha esta advertencia, sin embargo, no parece oportuno pecar de un exagerado purismo terminológico, por lo que puede admitirse un uso equivalente de ambas expresiones...."69.

Es importante refrendar que, como bien lo indica la jurisprudencia, a la par que la doctrina española, la figura del retraso desleal -bajo este específico nomen o denominación- no ha sido del todo extraña a la evolución del Derecho español, como quiera que, en providencias pretéritas, particularmente en un fallo fechado del 25 de enero de 1983 y proferido por el Tribunal Supremo se afirmó que "... actúa contra la buena fe el que ejercita un derecho en contradicción con su anterior conducta, en la que hizo confiar a otro (prohibición de ir contra los actos propios), $y$, especialmente, infringe el mismo principio el que ejercita su derecho tan tardíamente que la otra parte pudo efectivamente pensar que no iba a actuarlo (retraso desleal), vulnerando tanto la contradicción con los actos propios, como el retraso desleal, las normas éticas que deben informar el ejercicio del derecho, las que determinan que el ejercicio del derecho se torne inadmisible, con la consiguiente posibilidad de impugnarlo por antijurídico al amparo de la preceptiva contenida en el artículo 7.1 del Código Civil ...".

Por su parte, en fallo del 4 de marzo de 2005, la Sala III del Supremo, en la esfera administrativa, puso de relieve, en lo que a la virwirkung expresamente se refiere, que "En cuanto a la invocación de la doctrina de la verwirkung, considerando que estamos ante un supuesto claro de retraso desleal en el ejercicio del derecho, entendemos que la propietaria desconoce el alcance y significado de dicha doctrina. En definitiva, ésta no es más que una concreción

69 Antoni VAQUer Aloy. El retraso desleal en el ejercicio de los derechos, op. cit., p. 106. 
del principio general de buena fe, de protección de la confianza legítima y más concretamente de la prohibición general de venire contra factum proprium, que, ateniéndose a su formulación alemana y siguiendo ENNECERUs, podemos formular del modo siguiente: "si uno espera para ejercitar su derecho tanto tiempo que su silencio despierta en la otra parte la confianza legítima de que el derecho no será ya ejercitado, la otra parte podrá oponerse al mismo mediante la objeción de Verwirkung, siempre que el ejercicio tardío del derecho sea generalmente considerado como desleal según los principios de la buena fe que dominan la vida del tráfico" (Sentencia 2466, Sala III, Sección 6).

Finalmente, cumple advertir que, en veces, la locución verwirkung, ha sido traducida al castellano, sobre todo hace algunas décadas, como 'caducidad' ${ }^{70}$, lo cual ha sido catalogado de inexacto, stricto sensu, habida cuenta de las diferencias reinantes entre estas dos figuras, al mismo tiempo que con la prescripción, conforme se examinará, más allá de una que otra similitud, pues como cabalmente lo realza la profesora Ana CAÑIZARES LASO, refiriéndose a la verwirkung, "...este término se utiliza entre los autores, como sabemos, en un sentido muy distinto" ${ }^{11}$. También debe tenerse en cuenta que otro sector autoral, para ampliar aún más el abanico terminológico, afirma que en el campo del Derecho de patentes, "El concepto de preclusión se corresponde con la institución alemana de la 'Verwirkung' que alguien llegó a traducir gráficamente como

70 Es el caso, por vía de ejemplo, de lo acontecido con la traducción de algunas de las obras del Profesor de la Universidad de Kiel, Karl LaRenZ, puesto que en la de obligaciones, como en su parte general, el vocablo caducidad es empleado como equivalente -en nuestra lengua- de la expresión verwirkung. Derecho de obligaciones. Editorial Revista de Derecho Privado. T. I. Madrid, p. 151, y Derecho civil, Parte general. Editorial Derecho Privado. Madrid. 1978. pp. 301 y ss. Otro tanto acontece con la obra del también alemán, Heinrich Lehmann. Parte general, Revista de Derecho Privado. Madrid. 1956, p. 522 y ss. A su turno, el ilustre profesor colombiano, Fernando HiNESTROSA F. realiza la misma traducción (caducidad, Verwirkung-Ausschlussfristen). La prescripción extintiva. Universidad Externado de Colombia. Bogotá. 2006, p. 248, y la Corte Suprema de Justicia colombiana, en fallo del 23 de septiembre de 2002, Exp 6054, en el que hace una completa y documentada descripción de los fenómenos de la 'prescripción' y la 'caducidad', refiere “....al plazo de caducidad (Verwirkung) del derecho alemán)....."

71 Ana CañIzARes Laso. La caducidad de los derechos y acciones, op. cit., p. 26. 
deseficacia... En la práctica, incluso, es frecuente que se identifique 'Verwirkung' con 'retraso desleal'...."72.

Por último, no sobra manifestar de nuevo que en el Derecho anglosajón el sucedáneo de la verwirkung, mutatis mutandis, es la figura conocida con el nombre de laches, ya mencionada por nosotros con ocasión del estudio del estoppel.

\subsection{GÉnESIS}

En el marco del Derecho alemán, en el que la buena fue ha ocupado un papel estelar -y sigue ocupándolo- (art. 242, BGB), se experimentó la necesidad de seguir ahondando en las secuelas de su pretermisión, en asocio con la regla del venire contra factum proprium que censuraba, derechamente, la conducta incoherente y contradictoria.

Ello explica que en sede del llamado 'Derecho judicial', como se esbozó, se abogara por una nueva lectura de principios entronizados en normas estáticas de índole legal, mejor aún de una 'ruptura' frente a axiomas rígidos que, sin pretenderlo, por aquello de la natural y acelerada evolución de la ciencia jurídica, podrían auspiciar el abuso y, por ende, la injusticia, antítesis de un 'Derecho justo', en el que ya comenzaba a perfilarse un 'Estado Social de Derecho' -por oposición al 'Estado liberal de Derecho' o 'Estado de Derecho'-, y en el que se percibía, con una mayor sensibilidad, la tensión entre justicia y seguridad jurídica (ius aequum y ius strictum), esa que, a su manera, aún persiste y persistirá.

Por consiguiente, en guarda de situaciones muy especiales, de ordinario ligadas al excesivo, o relevante transcurso del tiempo, se consideró que el juez tenía el deber, en sintonía con la buena fe, y con la evitación de conductas objetivamente abusivas, a la par que lesivas, de impedir el ejercicio válido de derechos, así estuvieren protegidos ex lege, de ordinario por los términos de prescripción, inicialmente conferidos a favor del titular del derecho, del acreedor,

72 José A. Gómez Segade. "Preclusión de las acciones del titular de la patente por retraso desleal", en Actas de Derecho Industrial, 1999, p. 175. 
todo en sincronía con el espíritu tuitivo que, ab antique, se le reconocía -y reconoce- a la prescripción extintiva.

Expresado de otro modo, si bien formalmente el acreedor podría hacer uso pleno e íntegro de dichos plazos, instituidos en su beneficio, en cuyo caso podía tomarse hasta el último día, en la hipótesis prescriptiva aludida, tampoco es menos cierto que, si en el ínterin, no actuó, creando una sensación entera y racionalmente diferente, o alimentando una creencia o confianza legítima en el deudor, no será entonces de recibo ejercer luego su derecho, a juicio de sus defensores, máxime si se considera, de un lado, lo prolongado de ellos (en el pasado hasta de treinta años) y, del otro, que en la praxis, ellos se consideraban 'sociológicamente superados' ${ }^{\text {'3 }}$.

En este sentido, bien expresa el profesor alemán Gustav BOEHMER, introduciendo el tema de la verwirkung, que "En un terreno próximo al de las reglas que señalan la forma de los negocios jurídicos, como es el de las disposiciones que señalan requisitos de plazo, se nos ofrece el mismo impresionante espectáculo de una lucha por la equidad contra los preceptos legales de carácter formal", por lo demás muy presente en "...el instituto de Derecho pretorio de la Verwirkung que priva de vida a derechos subjetivos que, a tenor del texto literal de las reglas de Derecho, todavía deberían considerarse plenamente subsistentes por no haber transcurrido el plazo de prescripción ni haber quedado extinguidas por el transcurso del plazo de caducidad, por entender que, dadas las circunstancias del caso concreto, su ejercicio resulta abusivo y es, por ello, inadmisible". Al fin y al cabo, continúa el autor, "En este punto han intervenido de nuevo la ciencia y la jurisprudencia con el fin de ampliar y rectificar los formalistas y esquemáticos plazos de prescripción por medio de un idóneo instituto jurídico de propia creación que pueda adaptarse mejor a la situación concreta de cada caso. Tal es la llamada Verwirkung"74.

73 Es que como esquemáticamente lo expresa K. LARENZ, en la verwirkung “...el titular difiere por tanto tiempo su ejercicio que produce justificadamente en aquel contra quien se dirige el derecho la impresión de que la otra parte ya no lo ejercitará....". Derecho civil. Parte general, op. cit., p. 301.

74 Profundizando en el basamento de la verwirkung, G. BOHEMER, reseña que, "La justicia del jus aequum actúa en este caso contra la seguridad jurídica del jus strictum, imprimiendo a la ley una torsión especialmente revolucionaria, por lo que necesita protegerse escrupulosamente 
Así pues, in globo, nace esta peculiar figura de origen alemán -o un 'efecto' como la entienden algunos-, y de estirpe judicial, ampliamente divulgada y estudiada por la doctrina, e incluso exportada a otras latitudes ${ }^{75}$, en donde el 'retraso desleal', no sin algún temor, como se expresará, ha comenzado a expandirse, en quiebre de una visión probablemente más ortodoxa de la codificación y del papel que tiene asignado el juez en el sistema continental, sin duda alguna relevante, si se quiere grandilocuente, pero quizá no tanto como para 'desafiar', inconsideradamente, los términos de prescripción establecidos de modo inequívoco por la ley, y la teleología misma de esta institución, no por milenaria, llamada a ser soslayada, so pretexto de “...un nuevo Derecho Judicial" (WIAECKER), desde luego sin dejar de reconocer su fuerza intrínseca, y sus fundamentos, algunos ciertamente loables, por más que no se compartan a ultranza, o con un entusiasmo sin par. No todo lo que parece justo, in promptu, tiene que ser bendecido, o adoptado de plano, a sabiendas de que la justicia de uno, puede ser la injusticia del otro, realidad que reclama equilibrio y mesura. Ya decía HEGEL que "Lo que es razonable, es real. Y lo que es real, es razonable", y que con la 'espada de la justicia', blandida por muchos y desde diversas orillas, también se han cometido injusticias. ¿Quién en un mundo desigual e injusto, no apela a la justicia, incluso, para amparar situaciones intrínsecamente injustas? De hecho, los injustos, paradójicamente, la invocan y cínicamente la reclaman.

\subsection{Significado general, NATURALEZA Y CONFIGURACIÓN}

La verwirkung, en términos muy generales, es un mecanismo tuitivo que, al hilo de la buena fe, que sublima mayúsculamente, se encamina a limitar -o impedir- el ejercicio ulterior y contradictorio de un determinado derecho que, en caso contrario, terminaría vulnerando intereses ajenos, en razón de un retraso,

del reproche de infidelidad legal". El derecho a través de la jurisprudencia, op. cit., pp. 242 y 245.

75 Filippo RanieRI. "Le principe de l'interdiction de se contradire au detriment d'autre ou du venire contra factum proprium dans les droits allemand et suisse e sa difusion en Europe", en L'Interdiction de se contredire au détriment d'autre. Economica. Paris. 2007. pp. 25 y ss. 
dilación o atraso desleal previo por parte de su titular, producto de su inactividad o actitud silente -o pasiva- ${ }^{76}$ y 77 .

Y en términos más particulares, al amparo de lo ya señalado en líneas que anteceden, y en concordancia con lo expresado por don Luis DíEz PICAZO, in extenso, puede decirse que, 'La 'Verwirkung' es un caso especial de la inadmisibilidad del ejercicio de un derecho por contravención a la buena fe, o, si se prefiere, un caso especial de abuso de derecho, que se puede definir como el abuso de derecho consistente en un ejercicio del derecho realizado con un retraso desleal. Un derecho subjetivo o una pretensión no pueden ejercitarse 'cuando el titular no sólo no se ha preocupado durante mucho tiempo de hacerlos valer, sino que incluso ha dado lugar, con su actitud omisiva, a que el adversario de la pretensión pueda esperar objetivamente que ya no se ejercitará el derecho"78.

76 Expresan E. BIANCHI y H. IRRIBARNE, que “...en la Verwirkung lo que se reputa inadmisible es el retraso objetivamente desleal en el ejercicio del derecho, que lesiona la confianza en el tráfico jurídico". El principio general de la buena fe y la doctrina 'venire contra factum proprium non valet', op. cit., p. 858.

77 Una somera y sintética caracterización de la verwirkung es la que efectúa el Dr. Osvaldo GozAínl, quien explica que “... la institución de la verwirkung reposa en tres ideas: la del retraso en el ejercicio del derecho; la de la conducta contradictoria y la infracción de la buena fe, siendo éstas las que llevan al concluyente juicio de valor de que la conducta del titular representa un abuso del derecho. La postergación indefinida apareja, objetivamente considerada, una actitud desleal cuando se pretende obtener una ventaja, y ésta resulta intolerable a la luz de las circunstancias que precedieron al caso. Asimismo, la pasividad de mala fe, puede conseguir del adversario una sorpresa de tal entidad que le vulnere, en cierta medida, su derecho de defensa. Pero lo importante es que la persona que haya receptado los actos haya podido contar con que el derecho no sería ejercitado sobre bases objetivas y teniendo en cuenta, las circunstancias del caso. La contradicción del comportamiento se advierte en la asistematicidad que sucede a la buena fe inspirada, complementándose la triple exigencia de identidad requerida por la Verwirkung..." "Caducidad de la pretensión por retraso desleal en su ejercicio", La Ley. Buenos Aires. 1987. C-89.

78 Luís Díez Picazo. La doctrina de los propios actos, op. cit., p. 94. A su turno, años después, el mismo maestro expresó en otra de sus conocidas obras que, "La verwirkung es un caso especial de inadmisibilidad del ejercicio de un derecho por contravención de la buena fe, o si se prefiere, un caso especial de abuso de derecho, que se puede definir como el abuso del derecho consistente en un ejercicio del derecho realizado con un retraso desleal". $L a$ prescripción extintiva, op. cit., p. 85.

De la misma manera, para el profesor A. VAQUeR Aloy, “...el concepto de Verwirkung.... supone el ejercicio inadmisible de un derecho propio, que tiene lugar cuando su titular ha permanecido inactivo durante un periodo significativo sin hacer valer dicho derecho, de modo que el sujeto pasivo le ha confiado y podía confiar en que el derecho en cuestión ya no iba a ser objeto de ejercicio en el futuro. Se produce, por tanto, un retraso desleal, 
Un ejemplo real, objeto de escrutinio por la jurisprudencia alemana, seguramente contribuirá a esclarecer más el significado y alcance de la verwirkung.

En efecto, "Es aleccionador el caso de arrendamiento de un hotel, el cual fue arrendado por 20 años; el alquiler debía calcularse según la cifra de negocios, no obstante lo cual había de ascender, cuando menos, a 2.500 marcos mensualmente. El arrendador no había reclamado contra ello. Posteriormente exigió el arrendador el importe restante por todo el tiempo transcurrido. Las pretensiones por alquileres pendientes, prescriben, según el artículo 197, a los cuatro años. Por tanto, respecto a los cuatro últimos años la pretensión no había aún prescrito. El Tribunal Supremo Federal la consideró caducada por los años posteriores al tiempo en que estaba ya realizada la liquidación entre las partes, dado que el arrendatario no había ya debido contar con una reclamación posterior por esos años"79.

Y también lo es el contenido de una de las más explícitas decisiones alemanas proclives a esta institución (30 de enero de 1929), a cuyo tenor, “...desde hace tiempo está reconocido que, bajo determinadas circunstancias, el ejercicio retrasado de pretensiones puede representar una actitud que infrinja la buena fe por lo que en semejante caso debe ser privada de eficacia jurídica; una conducta semejante es conocida en la jurisprudencia y en la doctrina jurídica con el nombre de retraso desleal (...) con la expresión de Verwirkung"80.

que se erigirá en obstáculo al ejercicio del derecho". El retraso desleal en el ejercicio de los derechos, Op., cit, p. 92.

79 BGH LM, No 22, cit. Karl LARENz. Derecho civil, Parte general, op. cit., p. 303, quien recrea otro ejemplo enderezado a explicar mejor esta figura. "Un empleado ha cometido en la empresa una falta que justifica su despedido inmediato por parte del empresario. No obstante, éste lo silencia por largo tiempo y deja al empleado en su puesto de trabajo, de forma que éste llega y puede llegar a la convicción de que el empresario no pretende ya sacar consecuencias de tal evento. Tras largo tiempo, sin embargo, el empresario alega la falta anterior por un motivo insignificante, y debido a ella declara el despedido inmediato. El empleado puede oponer a ello la objeción de caducidad del derecho de despido" ( $p$. 302).

80 Cit. G. BoeHmer. El derecho a través de la jurisprudencia, op. cit., p. 263. 
Así las cosas, en aras de precisar mejor su significado y su alcance, lo fundamental en la verwirkung, estriba, por un lado, en la inactividad -o silencio, agregan algunos ${ }^{81}$ - del titular del derecho que suscita una confianza en otro sujeto que, por sus connotaciones, se torna legítima, al igual que susceptible de protección y, por el otro, en el transcurso de un término razonable ${ }^{82}$, que sin confundirse con el de la prescripción, porque es inferior a él, denote que dicho sujeto objetivamente, no está interesado en su real y efectivo ejercicio, por manera que cuando lo haga, si lo hace, se entenderá que, además de contradictorio, es lesivo y, por tanto, constitutivo de un retraso desleal e inadmisible, en acatamiento a la buena fe, en cuyo caso el juzgador, de acuerdo con las circunstancias, deberá inaplicar los términos prescriptivos y, de paso, no acudir a la institución de la prescripción extintiva, caracterizada, de ordinario, por plazos amplios o, por lo menos, relativamente amplios, con excepciones ${ }^{83}$. Por eso sus seguidores han expresado que la verwirkung "...opera con eficacia negativa: deniega la existencia

81 Vid., entre otros, a Fiorenzo FESTI. I/ devieto di venire contro il fatto proprio, op. cit., p. 133, y a Francesco Gazzon.. Manuale di diritto privato, op. cit, p. 114, quien observa que su esencia radica en el "... no ejercicio del derecho".

82 Entiende F. WIEACKER, que "La nota particular de la caducidad reside en que la conducta previa a imputar es una inactividad, del que no se puede separar el elemento de una determinada duración". El principio general de la buena fe, op. cit., p. 62.

83 Relata W. FLUME que en este tema “...se admitió en un gran número de sentencias y en los casos más diversos, que el titular de un derecho ya no podría ejercitarlo por su conducta, concretamente porque por su silencio se había 'aquietado'....Sobre la Verwirkung dice el Bundesgerichtshof en BGH 25, 51 y ss., acertadamente: "En el concepto jurídico de la Verwirkung se declara inadmisible el retraso desleal en el ejercicio de derechos frente al obligado. Esto quiere decir que la conducta del titular debe enjuiciarse desde puntos de vista objetivos. En esta medida, es decisivo que el obligado, en una valoración objetiva, pueda deducir de la conducta del titular que éste ya no quiere ejercitar más su derecho". El negocio jurídico, op. cit., pp. 157 y 158.

En sentido similar, igualmente aludiendo a decisiones judiciales alemanas, H. LEHMANN, manifiesta que, "la larga duración de algunos plazos de prescripción, y la limitación de la prescripción a las pretensiones, ha dado lugar a que en la práctica se tome en consideración también el transcurso del tiempo cuando el titular demore en contra de la buena fe el ejercicio de su derecho....En tales casos han rechazado los Tribunales el ejercicio tardío del derecho contrario a la buena fe....", aun cuando este autor también pone de presente en su obra que, "La demora del ejercicio del derecho es sólo un caso principal de aplicación de tal contradicción inadmisible consigo mismo. Sólo la demora no es suficiente. Lo decisivo es que, de acuerdo con el conjunto de las circunstancias y la peculiaridad de la relación jurídica, se haya despertado en la otra parte la confianza legítima de que el derecho ya no será ejercitado y, por consiguiente, el ejercicio posterior tendría como consecuencia un 
de un derecho al impedir que se realice a pesar de que todavía subsiste según las normas legales. Pero en ambos casos la creación judicial se apoya en el mismo fundamento ético: la apelación a un mandato legal positivo o negativo aparece como un atentado contra la buena fe (Verstoss gegen Treu und Glauben) en vista de la situación concreta de que se trate y, por tanto, como un abuso de una disposición legal fundada en una valoración sólo justificada in abstracto. En ambos casos deriva el juez su legitimación para no observar el precepto formal regular del mandato legal en blanco que contiene el artículo 242 [Código Civil, BGB, alusivo a la buena fe]"84.

Ahora bien, en lo que concierne a su naturaleza, como ya se ha delineado, la verwirkung encuadra en arquetípico límite al ejercicio de un derecho subjetivo llamado a impedir que su titular, a raíz del cambio comportamental observado, v.gr: en sede contractual, pueda obtener algún beneficio a través suyo, en franca contravía de la confianza legítima por el suscitada con antelación. De ahí que dicho ejercicio se torne en inadmisible, desde un perspectiva muy lata, que es la respuesta que en el proceso debe dar el juzgador, quien debe así declararlo, bien por solicitud de parte, o aún de oficio, como se apreciará al momento de ocuparnos de las características de este remedio, obviamente respetando la arquitectura y terminología procesal de cada ordenamiento. Por eso aludimos a

perjuicio injusto para el obligado, perjuicio que no hubiere sufrido de haberse ejercitado oportunamente el derecho". Parte general. Vol. I, op. cit., p. 522.

De igual modo G. BoEHMER, haciendo una adecuada descomposición de la institución en cita, indica que "... .en el instituto jurídico de la Verwirkung se juntan tres ideas: la del retraso en el ejercicio del derecho, la de la conducta contradictoria (venire contra factum proprium) y la de la infracción contra la buena fe ('gute Treue'). Las tres juntas llevan al concluyente juicio de valor de que la conducta del titular representa un abuso de derecho", las que por lo tanto no pueden faltar, pues ya había advertido el mismo autor que, "la simple falta de ejercicio de una pretensión o de un derecho potestativo....por sí sólo no es suficiente. Además, deben concurrir otras dos circunstancias. Por un lado el silencio del titular debe aparecer a la otra parte como expresión de la voluntad de renunciar al ejercicio del derecho, independientemente de si in concreto existe tal voluntad o incluso el mismo conocimiento de la existencia del derecho: únicamente es decisiva la objetiva situación de hecho que justifica que lo admita la otra parte. Esta, además, ha de haber ajustado su conducta a la justificada creencia de que no se ejercitará la pretensión. Si ambas cosas coinciden, aparecerá como ejercicio inadmisible del derecho, por infringir deslealmente la buena fe". El derecho a través de la jurisprudencia, op. cit., p. 260.

84 G. Boehmer. El derecho a través de la jurisprudencia, op. cit., p. 247. 
la expresión inadmisión, en sentido muy general, a fin de no desconocer otras denominaciones.

Además, rectamente entendida, la verwirkung, en consonancia con lo manifestado en el párrafo que antecede, se configura como una modalidad, o mejor aún una manifestación especial de la regla venire contra factum proprium, a su turno conectada con la buena fe, la que se traduce en su manantial y en su soporte funcional, por lo menos desde esta perspectiva. Ello explica que buena parte de la doctrina e incluso de la jurisprudencia, haga descansar a la verwirkung, en la buena fe, y particularmente en el venire contra factum proprium, sin perjuicio de la relación establecida con el abuso del derecho - por un amplio sector autoral- ${ }^{85}$.

En compendio, como ilustrativamente lo expresa la profesora CAÑIZARES LASO, "La 'Verwirkung' desde un plano dogmático es un caso especial del ejercicio inadmisible de un derecho, que dimana inmediatamente del principio de inadmisibilidad de una conducta contradictoria consigo misma, es decir del principio venire contra factum proprium. Significa que si uno espera para ejercitar sus derechos tanto tiempo que su silencio despierta en la otra parte la confianza legítima de que el derecho no será ya ejercitado, la otra parte podrá oponerse al mismo mediante la objeción de verwirkung, siempre que el ejercicio tardío del derecho sea generalmente considerado como desleal según los principios de la buena fe"86.

85 Vid. D. HoutciefF. Le principe de cohérence en matiére contractuelle, T. II, op. cit., p. 722, quien puntualiza, con precisión, que "La contradicción es aún más directamente sancionada por la aplicación del adagio non venire contra factum y por su derivado la verwirkung".

86 Ana Cañizares Laso. La caducidad de los derechos y acciones, op. cit., pp. 26 y 27, quien redondea su exposición, expresando que "La institución de la Verwirkung se liga a un problema de límite temporal al ejercicio de los derechos, basado en el principio de venire contra factum proprium en un primer plano y en definitiva por este principio basado por último en el ejercicio de los derechos de acuerdo con los dictados de la buena fe". En esta misma dirección, el Dr. Bernardo Gómez CoRRALIzA, indica de la verwirkung, que "Su fundamento está en la inadmisibilidad de la conducta contradictoria ('venire contra factum proprium') y, a mi modo de ver, también en el principio de que los derechos deben ser ejercitados conforme a las exigencias de la buena fe". La caducidad, op. cit., p. 78.

En el Derecho alemán ocurre lo mismo, pues como lo confirma A. VAQUER AloY “...buena parte de la doctrina alemana considera los supuestos de Verwirkung como un grupo especial dentro de la categoría más amplia del 'venire contra factum proprium'”. El retraso desleal 


\subsection{CASUÍSTICA Y TEMÁtICA JURISPRUdENCIAL PRIMIGENIA}

Centrados en la jurisprudencia primigenia alemana en esta materia, como se indicó de comienzos del pasado siglo (primeras décadas), se suele aludir a tres grandes temáticas en las que el 'Derecho judicial' fijó su atención cardinal, independientemente de que luego se ocupara de otras, merced a la difusión acelerada de la verwirkung en la geografía alemana, y luego en naciones vecinas, entre otras Suiza ${ }^{87}$, y después Austria y Holanda -y Bélgica, con matices- ${ }^{88}$.

Ellas fueron, en primer lugar, el contrato de mutuo, en particular la incidencia que en éste tipo negocial podían llegar a tener las normas jurídicas dictadas con ocasión de la galopante inflación registrada, a raíz de la primera guerra mundial, y luego de la revaluación acontecida (efecto contrario), al término de las cuales el acreedor, ad libitum, estaba facultado a pedir la referida revaluación de su crédito, siendo de esperar, que si lo hacía, lo hiciere dentro de un lapso racional, pues de otro modo perjudicaría al deudor que no podía esperar pacientemente a que aquél se definiera. En esta hipótesis el silencio o la inactividad del acreedor, se interpretaba como fundante -o percutor- de la creencia del deudor de que ya no se acudiría entonces a la petición de revaluación, actualización, o revalorización.

También se profirieron importantes decisiones en materias tales como en propiedad industrial (marcas y competencia desleal), en el Derecho laboral ${ }^{89}$, las que luego se extendieron, como se anotó, a diversas áreas del saber jurídico,

en el ejercicio de los derechos, op. cit., p. 107. Vid. W. FlumE. El negocio jurídico, op. cit., p. 161. Lo mismo tiene lugar en Derecho portugués, habida cuenta que como lo corrobora J. BAPTISTA M., en "En general se considera a la 'Verwirkung' como una modalidad especial de la prohibición de venire contra factum proprium". Tutela da confiança e venire contra factum proprium, op. cit., p. 421.

87 Vid. F. Ranieri. Rinuncia tacita e verwirkung, op. cit., p. 40.

88 Vid. F. RANIERI. Le principe de l'interdiction de se contradire au detriment d'autre ou du venire contra factum proprium dans les droits allemand et suisse e sa difusion en Europe, op. cit., p. 32, y 35.

89 Vid. Luís Díez-Picazo. La doctrina de los propios actos, op. cit., pp. 95 y ss.; G. BoeHmer. El derecho a través de la jurisprudencia, op. cit., p. 253 y ss.; A. BORDA. La teoría de los actos propios, op. cit., p. 43 y ss.; F. RANIERI. Rinuncia tacita e verwirkung, op. cit., pp. 31 y ss., y F. FESTI. II devieto di venire contro il fatto propio, op. cit., p. 135. 
dado que una de las notas más salientes de este instituto, conforme se observará, reside en su amplio espectro, debido a su expansión generalizada, a emulación de una especie de 'mancha de aceite', parafraseando al profesor Luis JOSSERAND, con motivo de una memorable reflexión realizada en la década de los treinta, en punto a la amplificación de la responsabilidad contractual, en general ${ }^{90}$.

Lo anterior explica que, en general, ella campee tanto en el Derecho público, como en el privado, aun cuando es de subrayar que es en el Derecho de contratos en donde mejor se acomoda, según dan cuenta los numerosos asuntos judiciales en lo que se ha ventilado la verwirkung ${ }^{91}$.

\subsection{TRASCENDENCIA DE LA BUENA FE Y DeL ABUSO DEL DERECHO}

Al igual de lo que acontece en un apreciable número de instituciones jurídicas -por no decir que en todas, directa o indirectamente-, en particular las conectadas con la penetrante regla latina, venire contra factum proprium non valet, la trascendencia, amén que incidencia de la buena fe en la verwirkung, es notable, como que se edificó, ab origine, a partir del referido artículo 242 del Código Civil alemán (B.G.B), con sujeción al cual "El deudor está obligado a efectuar la prestación como exigen la fidelidad y la buena fe en atención a los usos del tráfico".

90 L. JosserAND. "L'evolution de la responsabilité", en Evolution et actualités. Sirey. Paris. 1936, pp. 29 y ss.

91 Otro subcampo en el que la verwirkung se ha desarrollado considerablemente en la jurisprudencia alemana es el de la prescripción, figura con la cual claramente se diferencia, según se corroborará a espacio. Tanto que, incluso, se ha admitido que una pretensión, según las circunstancias, se puede ejercer así formalmente haya operado el fenómeno de la prescripción. Así lo revela el Dr. Andreas WACKE en un interesante escrito traducido al castellano por el profesor José María MıQUEL GoNZÁLEZ., conforme al cual la verwirkung "la jurisprudencia la utiliza ante todo para complementar las normas sobre la prescripción, y ciertamente en dos sentidos distintos. En un sentido puede perder su eficacia una pretensión todavía no prescrita, si el acreedor despierta (o suscita) en el deudor la confianza legítima de que no se la exigirá. En otro sentido y a la inversa puede ejercitarse una pretensión a pesar de estar ya prescrita. Si concretamente el deudor ha despertado en el acreedor la confianza de que no alegará la prescripción (por ej. En las negociaciones sobre la indemnización), entonces el acreedor puede enervar la alegación de la prescripción con la réplica de la Verwirkung". La 'exceptio doli' en el derecho romano clásico y la 'verwirkung' en el derecho alemán moderno, op. cit., p. 993". 
Por consiguiente, en este instituto, incluso con más fuerza que otros, en donde se llega a dudar de que la bona fides tenga tanta relevancia, se ha señalado que la regla en mención, aun cuando se conecta con ella, para algunos tiene vida propia; incluso se ha estimado que el 'deber de coherencia', en sí mismo, no se asienta indefectiblemente en la buena fe, por lo menos de modo directo, como ya se esbozó en el primer capítulo, en especial en el relativo a la buena fe y su conexión con el acto propio. Lo mismo acontece, en lo particular, de cara a la doctrina de los actos propios, conforme lo enseña un sector autoral que, sin revelarse contra la importancia de la buena fe, le ha dado el carácter de principio general autónomo y sustantivo, naturaleza que no compartimos, como se evidenció en su oportunidad, y que sin pretenderlo, quizá, marca su propio territorio fuera de los predios de la fides bona, por más que se ubique o pretenda situarse en su vecindario. Tanta distancia, se nos antoja inadecuada, pues como atinadamente lo realzó el profesor WIEACKER, cuando se ocupó del venire contra factum proprium, "...la buena fe (...) alumbra la totalidad del principio". ${ }^{92}$ No en vano, es 'solar': todo lo irradia. Al fin y al cabo, recordando una diciente expresión del profesor RISOLIA, "EI derecho se baña íntegro en el agua lustral de la buena $\mathrm{fe}^{\prime \prime}{ }^{3}$, la que está -y ha estado- muy presente en la verwirkung-.

En este sentido, aparte de las sentencias judiciales ya precitadas, concretamente su ratio decidendi, al mismo tiempo que de las opiniones reveladas al respecto, una de ellas incluso señalando que la aplicación de los mandatos legales referentes a la prescripción, en ciertos casos, podría considerarse un "... atentado contra la buena fe", importa señalar con FLUME que, "El principio de la Verwirkung expresa que nadie puede hacer valer un derecho o una posición jurídica cuando, dada su conducta, el ejercicio de los mismos es contrario a la buena fe y, con ello, contrario a la idea de Derecho (...) pues lo que siempre importa es si, en consideración a la conducta, el ejercicio del derecho o de una posición jurídica es contrario a la buena fe" ${ }^{\prime 4}$.

92 F. WIEACKER. El principio general de la buena fe, op. cit., pp. 60 y 61.

93 Marco Aurelio Rısolía. Soberanía y crisis del contrato, op. cit., p. 205

94 W. Flume. El negocio jurídico, op. cit., pp. 160 y 164, autor que concluye diciendo que, en este campo, "...la contravención de la buena fe es decisiva".

En esta misma orientación, destacando la fuerza del silencio y de la inactividad en la 
Ahora bien, en lo tocante con el abuso del -o de- derecho, sin perjuicio de haber manifestado en el capítulo segundo que la regla venire contra factum propium, en sentido lato, a la vez que la doctrina de los actos propios, stricto sensu, eran figuras aledañas -o afines- a él, pero no simétricas y, de contera, inmersas en una misma arquitectura jurídica, motivo por el cual antes abogamos por su correspondiente escisión y ahora lo refrendamos, cumple subrayar que, para la communis opinio, media en la verwirkung un diáfano abuso de derecho, parecer no por arraigado unánime ${ }^{95}$, pero sí acentuadamente mayoritario, como igualmente ha podido confirmarse a través de la lectura de algunas de las citas y referencias que hemos traído a colación en líneas anteriores, a las que nos remitimos en obsequio a la concisión.

Sin embargo, sólo para reiterar esta socorrida tendencia, conviene memorar con Borda, que en el terreno de la Verwirkung, "Se entiende que el ejercicio 'paralizador', que se funda en que los plazos de prescripción no han transcurrido íntegramente, importa un abuso del derecho"96, y con BOEHMER, que la unión de las ideas "....del retraso en el ejercicio de un derecho, la de la conducta contradictoria....y la de la infracción contra la 'buena fe'....llevan al concluyente juicio de valor de que la conducta del titular representa un abuso de derecho's7.

Verwirkung, y el papel que en ello desempeña la buena fe, el distinguido profesor uruguayo, G. ORDoQuI, entiende que, "El silencio, la inactividad, la no declaración, sólo pueden tener relevancia como conductas en la formación de relaciones jurídicas en casos excepcionales. El silencio tiene, en ciertos casos, relevancia por las circunstancias que lo rodean. Ocurre que, en ocasiones, la inactividad o el silencio en el ejercicio de un derecho pueden configurar un retraso desleal frente al obligado. En estos casos de inacción se puede deducir que el titular del derecho lo ha renunciado o no quiere ejercitarlo más. El titular de un derecho debe actuar de buena fe, tanto al ejercer como al no ejercer un derecho. No es actuar conforme a la buena fe el pretender ejercer un derecho cuando se había asumido una conducta que significaba inequívocamente que ello no iba a ocurrir." La buena fe contractual, op. cit., p. 234.

95 Vid. José Luís De Los Mozos. El principio de la buena fe, op. cit., p. 209, pues independientemente de haber transcrito una opinión proclive, entre varios aspectos, a la floración de un abuso de derecho, entiende que "...la teoría del abuso del derecho...." está en "... campos vecinos, como es el de la propia Verwirkung, o el de la doctrina de los actos propios".

96 A. Borda. La doctrina de los actos propios, op. cit., p. 42.

97 G. BoeHmer. El derecho a través de la jurisprudencia, op. cit., p. 268. 
Por nuestra parte, aunque el tema de suyo es alambrado por la dificultad, hay que reconocerlo, nos parece que la afirmación categórica de que en la verwirkung inexorablemente media un abuso de derecho, no todas las veces se hace reflexivamente, desde luego con notables excepciones, quizá por aquello de que, a menudo, se repite la misma idea expuesta por otros expositores, a lo que se suma que, sin mayores elucubraciones se asocia 'verwirkung' y 'retraso desleal' con abuso de derecho, no siendo necesariamente iguales, hecho que obstaculiza su delimitación jurídica, puesto que su esclarecimiento se dificulta a través de esta asimilación, la que podría conspirar contra su sustantividad, dado que si inequívocamente fuera un abuso de derecho, no habría necesidad de hablar de verwirkung, retraso desleal, etc., siendo viable aludir, únicamente, al consabido abuso, como categoría envolvente y a posteriori absorbente. De ahí que en el segundo capítulo de este escrito, con algún detenimiento, procuramos exaltar, in abstracto, el carácter autonómico de la doctrina de los actos propios, como genuina manifestación del venire contra factum proprium respecto al abuso de derecho, sin perjuicio de entender que excepcionalísimamente, con arreglo a circunstancias muy particulares, la incoherencia o la contradicción aflorarán como secuela del abuso comportamental, pero de ningún modo generalizadamente, de lo que se desprende que no es de recibo una lectura expansiva, encaminada a darle cabida al abuso en todas y cada una de las hipótesis de configuración de la verwirkung.

Lo anterior cobra aún más fuerza, si se tiene en consideración que un criterio válido, ese sí unánime, es el de que esta teoría de la verwirkung supone escrutar el caso individual, a fin de no generalizar, lo que implica que, atendidas las circunstancias individuales del mismo, en gracia de discusión, es probable que no siempre cristalicen las notas del abuso del derecho, dueño de insoslayables presupuestos genéticos que no se pueden ni suponer, ni desconocer, amén que no es dable desconocer su "... autonomía estructural", conforme lo expone cabalmente G. ORDOQUI C. en su reciente y documentada obra, con mayor razón si se considera -como bien lo refiere la profesora Aída KeMELMAJER DE CARLUCCIcitada en su texto-, que "... el abuso no se presume" ${ }^{\text {, }}$, idea muy difundida en la órbita jurídica.

98 Gustavo Ordoqui C. Abuso de derecho. Pontificia Universidad Javeriana, Colección Internacional, Bogotá, 2010, p. 101. 
Habrá pues que analizar cada situación individualmente, así se concluya eventualmente, a posteriori, que se materializó un abuso de derecho, pero en función del casus, y no de una exigencia dogmática que, en sí misma, pudiere reñir con lo acontecido en el asunto unitariamente considerado. No en vano en la verwirkung, según se anticipó y se señalará de nuevo, la floración de una contradicción, de una incoherencia -o de un haz de incoherencias-es requerida como detonante del quebranto de la confianza legítima en su momento despertada. Bien dice FLUME, refiriéndose a la verwirkung, que, "En consideración a la conducta precedente el actual ejercicio de derechos y posiciones jurídicas es un venire contra factum proprium ${ }^{99}$.

\subsection{DifERENCIAS fundamentales CON LA PRESCRIPCión}

Aun cuando este tema pueda resultar muy específico, como en efecto lo es, nos parece aconsejable despejar una duda que puede surgir luego del examen de los apartes precedentes, así como de otros que, sobre la verwirkung, se puedan auscultar, cual es sí esta institución se confunde con la prescripción, o sí guarda algún parecido o similitud con ella, a lo cual respondemos de antemano que no son iguales, así tengan rasgos familiares, habida cuenta que una y otra son autónomas, y también titulares de estructuras y objetivos muy diversos, así comportan ciertas similitudes, como sucede en materia jurídica con tantas instituciones ${ }^{100}$, aunque hay que reconocer que en esta materia en oportunidades se asocian, bien por infortunado proceder, o bien por plena conciencia, con el propósito de buscar un mejor entendimiento de la figura, tal y como tiene lugar

99 W. Flume. El negocio jurídico, op. cit., p. 161.

100 Como lo aclara don Luís Díez-PICAZO “La Verwirkung'-la doctrina alemana se ha preocupado enormemente de destacarlo- es una institución diversa de la prescripción extintiva, aunque existan entre ambas figuras conexiones muy estrechas....En trazos muy generales la función de la prescripción y la función de la 'Verwirkung', son muy semejantes. En ambos casos se trata de impedir que sean ejercitados -casi diríamos resucitados- derechos muy antiguos, abandonados por su titular durante mucho tiempo. Un ejercicio tardío del derecho aparece siempre como socialmente inconveniente. Es este inconveniente el que la prescripción viene a obviar. Pero los plazos de prescripción, heredados del derecho tradicional, no se ajustan a las necesidades de nuestro tiempo....Es precisamente este inconveniente el que trata de obviar la 'Verwirkung' ". No obstante ello, también es cierto, como lo puntualiza el autor, que "...se desprenden con toda claridad las diferencias entre prescripción y 'Verwirkung”'. La doctrina de los propios actos, op. cit., p. 97. 
cuando se alude a una prescripción de hecho -o de facto-, por oposición a una de derecho o de jure, según se apreciará, expediente éste que, aun cuando gráfico, puede suscitar alguna confusión.

Múltiples, en efecto, son las diferencias reinantes. Empero, centrando nuestra atención por ahora en algunas de ellas, más a manera ejemplificativa que exhaustiva, tarea ésta que desbordaría el propósito central de esta investigación, expresemos, al rompe, que se advierten las siguientes diferencias que describiremos muy someramente, lo cual también ocurre con la figura de la caducidad, lo aclaramos de plano ${ }^{101}$, binomio que amerita ser diferenciado entonces de la verwirkung (prescripción y caducidad):

a) En la prescripción, se ha dicho desde tiempos inmemoriales, media una inacción, una inactividad, al paso que en la verwirkung, así parezca sutil, se hace hincapié en la ausencia de ejercicio de una facultad, prerrogativa o derecho, puesto que como bien lo explica el profesor F. HINESTROSA, "la doctrina insiste en que el fundamento o presupuesto de la prescripción reside en la 'índole de la inacción del titular del derecho, mientras que en la caducidad [estimada en un sentido muy amplio], en cambio, se toma principalmente en consideración el hecho objetivo de la falta de ejercicio del derecho dentro del término fijado"102.

b) De conformidad con lo juzgado por la jurisprudencia alemana, se acude a la verwirkung, frente a precisos supuestos, en casos en los que no se evalúa frontalmente el transcurso de un término propiamente dicho, ni tampoco una inacción, v.gr: cuando se afirma en sede extrajudicial que "....no se hará valer la excepción de prescripción”, ${ }^{103}$ en cuyo caso lo que prevalentemente se indaga

101 Cfr. Ana CañIZARes Laso. La caducidad de los derechos y las acciones, op. cit., pp. 29 y 30 , quien acierta al concluir, luego de la exposición del tema, que "Se suelen establecer rasgos paralelos entre Verwirkung, prescripción y caducidad; sin embargo, sólo tienen en común la falta de ejercicio de un derecho durante un tiempo, por consiguiente ese transcurso del tiempo funciona como un hecho en los distintos supuestos de hecho de las distintas figuras". Como lo manifiesta el Dr. A. VAQUER ALoY, en el "...transcurso de un período más o menos largo de inactividad de un derecho por parte de su titular...se agotan las semejanzas entre ambas figuras". El retraso desleal en el ejercicio de los derechos, op. cit., p. 119.

102 F. Hinestrosa. La prescripción extintiva, op. cit., p. 253.

103 G. Boemmer. El derecho a través de la jurisprudencia, op. cit., p. 271. 
es este hecho conductual, contrastado con la actitud ulterior de acudir a ella con ocasión de un litigio -por parte de quien dijo que no lo haría-, aproximándose entonces, en este punto, a la doctrina de los actos propios que, con vehemencia, también rechaza esta singular conducta, precisamente por incoherente y contradictoria, al igual que huérfana de lealtad negocial ${ }^{104}$, que es lo que se destaca, recta via, en la expresión 'retraso desleal'.

c) En la prescripción, la incoherencia, el advenimiento de la contradicción comportamental, no tiene incidencia, pues lo que se examina es una inacción prolongada y sostenida, prevalentemente, con independencia del comportamiento voluble o pendular que haya podido registrar un sujeto. En la verwirkung, dicha incoherencia y sobresalto conductuales, se traducen en una de sus notas fundamentales, como se expondrá más en detalle.

d) A tono con la diferencia que antecede, se tiene establecido que el fundamento de uno y otro instituto, es divergente, dado que es la protección de la confianza legítima, en asocio de la buena fe y el respeto a la coherencia en el comportamiento, la que fundamenta la verwirkung, y en general las diversas aplicaciones de la regla venire contra factum proprium, al paso que la prescripción, por excelencia, tiene como basamento la seguridad jurídica. ${ }^{105}$

e) En la prescripción, de antiguo, tienen cabida las figuras de la 'interrupción' y de la 'suspensión' ${ }^{106}$, por completo extrañas a la verwirkung.

104 Cfr. Laudo Arbitral, 5 de marzo de 2009, entre Beneficencia del Valle, y Previsora de Seguros S.A, Cámara de Comercio de Bogotá.

105 Cfr. A. VAQUer Aloy, quien anota que "El fundamento de la verwirkun... es la contradicción con los postulados que se derivan del principio de la buena fe, del titular del derecho, que con su inactividad ha generado la confianza legítima en el sujeto pasivo de que el derecho no será ulteriormente actuado... En cuanto a la prescripción, los autores coinciden en señalar que su fundamento radica en la necesidad de dotar de seguridad jurídica a las restantes relaciones jurídicas". El retraso desleal en el ejercicio de los derechos, op. cit., p. 120.

106 Diter Medicus. Tratado de las relaciones obligatorias. Bosch. Barcelona. 1995, p. 808; Manuel AlbaladeJo. Derecho civil. T. I Vol. II. Bosch. Barcelona. 1980, p. 524; Guillermo Orozco PARDo. De la prescripción extintiva y su interrupción en el derecho civil. Comares. Granada. 1995. pp. 48, 91 y ss.; Francisco Rıccı. Derecho civil. De la prescripción. T. XII. La España Moderna. 411 y ss.; y Manuel ARgañARÁs. La prescripción extintiva. TEA. Buenos Aires. 1966, p. 323, entre otros, dado que este punto es más pacífico. 
f) En la prescripción, de antaño, es menester alegarla por parte del interesado, en la inteligencia de que requiere alegación expresa, mientras que en la verwirkung, por el contrario, cabe la declaración ex officio ${ }^{107}$. Al fin y al cabo, el juez debe tener amplios y responsables poderes para evitar que la contradicción, la incoherencia, y la abusividad, cuando hacen presencia, según el caso, queden impunes, en perjuicio ajeno.

g) En la prescripción, está una de las más relevantes y reconocidas diferencias: es la ley la que establece ex ante los plazos, en aras de la seguridad y certidumbre jurídicas; en la verwirkung, no, habida cuenta que es el juez, en atención a las circunstancias individuales de cada asunto, el que estima sí opera o no la figura, desde luego sin considerar para ello los términos de prescripción que están fluyendo -o corriendo- ${ }^{108}$, hecho que, sin duda, acusa acendrada subjetividad, y que es el detonante de fundada preocupación en cabeza de un sector autoral, no sin razón, se itera, muy especialmente por cuanto lo que persigue la prescripción (la seguridad jurídica), por otra vía se podría ver trocado, parecer éste que, desde nuestra humilde orilla académica, igualmente es el nuestro, sabiendo que el tema, ex collatione multorum, no es simple y, por ende, exento de controversia, el que exige más profundización y debate, lo que explica que lo abordaremos de nuevo en la parte final de este capítulo, no sin antes aclarar que esta anotación general se efectúa respetando las diferencias y particularidades de cada legislación y sistema, puesto que sabido es que en algunos tiene cabida la verwirkung, gracias a la jurisprudencia, o a la misma ley.

He ahí, anticipadamente, la médula de la institución en cita, pues es esta indeterminación temporal, justamente, la que cualifica la verwirkung, haciéndola operativa en la praxis judicial, pero a su turno el factor que más suscita inquietud,

107 Conforme anota H. LeHMANN, "También se diferencia la caducidad [traducción del término verwirkung] de la prescripción en que ésta da lugar a una excepción, en el sentido técnico de contraderecho, mientras que la caducidad fundamenta la objeción de ejercicio inadmisible del derecho, lo que opone una barrera intrínseca al derecho". Parte general, op. cit., p. 524.

108 Cfr. Ana CañIZARES LASO., profesora que recuerda en su obra relativa a la caducidad que "...la Verwirkung tiene como uno de sus presupuestos básicos el transcurso de un período de tiempo, cuya duración habrá de determinarse en cada caso concreto", mientras que "... el plazo de tiempo señalado por la ley es el elemento esencial para la prescripción". La caducidad de los derechos y acciones, op. cit., pp. 28 y 30. 
por su acentuado subjetivismo, el cual amerita, se anticipa, un esmero y cuidado extremos, si ha de aplicar en un momento determinado, conforme al régimen jurídico imperante, pues sabido es que no en todas las naciones ella tiene cabida, como ya lo mencionamos, v.gr: en Italia, en Argentina y en Perú, en donde ha encontrado claras reservas, y en ocasiones despertado enconadas críticas.

Entre tanto, por su significado, es muy útil para la reflexión tener en cuenta que si una de las razones de fondo para admitir la verwirkung estriba y ha estribado en la extensión de los plazos de prescripción, a menudo muy amplios, lo cual en general es cierto, conviene indagar si el llamado a modificarlos, por vía indirecta, es el juez, o si en realidad, como creemos nosotros, inicialmente es el legislador, por más importante que sea reducirlos. Si fuera de otro modo, a sabiendas de que este tópico es en extremo polémico en el Derecho comparado, sobre todo a raíz de la apellidada 'constitucionalización del Derecho"109, el poder judicial, in radice, podría sustituir al legislativo, cada vez más profundizando el llamado 'gobierno de los jueces', y el denominado 'activismo judicial', a veces tan en boga, lo cual no suscita unánimes aplausos, pues sin generalizar, reconociendo la encomiable y prudente labor realizada por la judicatura, en puntuales asuntos se generan y pueden generarse más desbordamientos. Por este sendero, y no es una exageración, buena parte la terminarían haciendo los jueces, quienes merecen todo nuestro profundo respeto, consideración y estimación -porque orgullosamente lo hemos sido-, en contra de la existencia trimembre y centenaria de los poderes públicos, concretamente de su necesaria separación y equilibrio.

$\mathrm{Ni}$ jueces 'boca de la ley', como limitadamente aconteció en buena parte de la Escuela de la Exégesis, ni jueces normativos, omnímodos y mesiánicos, como si todo lo pudieren, como si fueran los 'salvadores' de la modernidad y de su sociedad, quienes han sustituido la toga, majestuosa prenda que demanda equilibrio y contención, por la Constitución como único ropaje, no siempre bien

109 Véase, con sumo provecho, el trabajo del Profesor Eugenio Llamas PomBo, en el que hace una serie de análisis ciertamente profundos, a la vez que actuales. Orientaciones sobre el concepto y el método del derecho civil. Universidad Javeriana, Colección Internacional. $N^{\circ}$ 8. Bogotá. 2009. pp. 116 y ss. También pueden consultarse sobre este particular: Luís PRIETO SANCHís. "Neoconstitucionalismo y ponderación judicial", en Neoconstitucionalismo(s). Trotta. Madrid. 2005, pp. 123 y ss; M. FIoravanti. Los derechos fundamentales. Apuntes de historia de las Constituciones. Trotta. Madrid. 1996. 
entendida y aplicada, como si fuera mágica, y como si absorbiera y esclavizara todo el Derecho (codificado y descodificado). Jueces, sí, magos, no. BARTOLO DE SAXOFERRATO, máximo exponente de la juridicidad en la historia, a lo suyo; y MERLín, próximo al 'círculo artúrico', a lo de él.

En este sentido, no puede desconocerse que una de las tendencias contemporáneas en sede del Derecho, in globo, y en particular en el Derecho privado, es la de reducir los plazos de prescripción, tarea que, incluso, recientemente se ha hecho en terra alemana (en los albores del siglo XXI y patria originaria de la verwirkung), en donde se redujo el término general de treinta años, a tres años, en prueba inequívoca de que la reducción deviene conveniente (más allá de que cuatro o cinco años sean igualmente de recibo), ${ }^{110}$ pero bajo la regencia del legislador, en este caso, merced a la novísima reforma a su Código Civil (B.G.B, art. 195)111. Lo propio tuvo lugar en Cataluña, también en esta centuria (Código Civil, art. 121-21, Ley 29 de 2002, Primera Ley del Código).

He ahí una respuesta a la inquietud cabalmente planteada en la década de los sesenta por don Luis DíEz-PICAZO, como se indicó, quien explicaba la vigencia de la verwirkung, entre otras razones, por los términos excesivos de la prescripción, hoy, empero, objeto de ajuste en muchas latitudes, y con potísima razón, y en vías de modificación como corresponde, términos que como expresa el autor Thomas FinKENAUER, "...la jurisprudencia [alemana] pasó por alto regularmente.... por medio de la admisión de una caducidad"112, lo que reafirma el significado del supraindicado término 'Derecho judicial'.

110 Vid. Thomas Finkenauer. "El nuevo derecho de prescripción en La reforma del BGB. Modernización del derecho alemán de obligaciones", Universidad Externado de Colombia, Bogotá, 2006, p. 367 y ss.

111 Vid. Claus-Wilhelm CANARIs. La riforma del diritto tedesco delle obbligaziioni, Cedam, Milani, 2003, pp. 88 y ss., y Stefano Dele Monache, "Profilli dell'attuale normativa del codice civile tedesco in tema di prescrizione", en Rivista di Diritto Civile, Milano, 2003, pp. 179 y ss.

112 Thomas FINKENAUER. El nuevo derecho de prescripción, op. cit., p. 369, autor que pone en alerta al lector y, en general, al interesado en esta temática, por cuanto expresa que "La aceleración general no puede servir como argumento para privilegiar al deudor" (p. 370). 
Ya para culminar esta valoración preliminar, sujeta a mayores disquisiciones y análisis, por de pronto más refinados y exactos que los consignados por nosotros, sin perjuicio de una reflexión final al respecto que haremos antes de culminar este capítulo, no podemos dejar de reconocer que la examinada es una figura sugestiva, a fuer que atrapante, la que por momentos, pareciera, hace doblar la razón, para inclinarse por sus seductores encantos. Por eso mismo, con los pies más en la tierra jurídica y con desapego de lo inmediato, hay que tomar cierta distancia de ella, por lo menos en algunos entornos jurídicos, v.gr: el colombiano, así muchos sigan o puedan seguir su camino, creyendo que en la vida y en Derecho todo es relativo y flexible, y que tesituras más conservadoras, y acordes con la tradición y el respeto por las instituciones deben quedar clavadas en el ayer, pues son supuestamente diluvianas, por manera que si el costo de permitirlo 'todo', de entender que el Derecho no es derecho, en sentido literal del vocablo, sino ondulante o zigzagueante y sujeto al malhadado 'depende' (depende de), que no es lo mismo que el del caso, bien entendido, con gusto aceptamos tal calificación.

Flexibilidad sí, acartonamiento, no; dinamismo sí, elasticidad no, puesto que la ciencia del Derecho no está construida ni de látex, ni de 'plastilina', como en lo pertinente dijera el maestro DíEz-PICAZo en su más reciente estudio acerca del daño moral ${ }^{113}$. Hay instituciones y principios que, por su fuerza y capacidad lumínica, y también eticidad, no deben ser relativizados, ni menos sacrificados, pues en ellos, milenariamente, descansa nuestra ciencia jurídica, o por lo menos así lo queremos seguir creyendo que en ella importan la tradición y el respeto por lo fundamental, lo que no puede confundirse con vetustez y rigidez suma. Cambios y evolución, sí, pero no a cualquier costo, menos si la vía, expedita para ello, es suplir el poder legislativo, mejor suplantar el legislador, que tiene reservadas específicas funciones, una de ellas, ocuparse del fenómeno prescriptivo. Ese el corolario de respetar la tripartición de los poderes públicos, no por antigua, llamada a ser desatendida, pues es ella la que sigue campeando en el Derecho constitucional moderno $y$, por ende, inmersa expresa y conscientemente en las constituciones políticas más recientes, inclusive, a manera de aquilatada y justiciera garantía. El tiempo hablará.

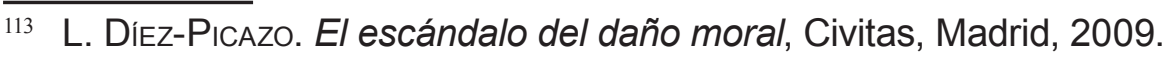


Cuán acertada resulta sobre este particular la conclusión a la que arribó el profesor LEHMANN en su oportunidad (hace más de cincuenta años), a cuyo tenor la falta de precisión entre las diferencias entre una y otra figuras "... .amenaza con destronar la prescripción, facilitando la inseguridad jurídica”"14. $Y$ hoy, muchos decenios después, en pleno siglo XXI, sigue sólo siendo eso: una amenaza, aun cuando la seguridad jurídica si se ha conculcado, desventuradamente.

Por ello su futuro dependerá, en gran medida, de la actitud que adopte el legislador de cara a los términos prescriptivos, pues si los disminuye en forma razonable, la utilidad de la verwirkung, o del retraso desleal, como factor causal y desencadenante de este remedio, será muy limitada, y sobre todo de la prudencia y esmerado tacto de los jueces, quienes no podrán acudir a ella a discreción, o por un asunto de moda, o generalizadamente. Dicho de otro modo, si se ha de acudir a ella, en procura de proteger la confianza legítima suscitada, coordenada que exige un análisis ponderado, deberá ser en condiciones tan excepcionales que justifiquen su existencia y aplicación, de suyo harto restrictiva, lo cual a veces se olvida -o se quiere olvidar-. Una, dos o tres en un millar ponen de presente el carácter no sólo residual, sino también restringido que la escolta, so pena de desnaturalizarla, gravemente.

Las normas jurídicas, en sintonía con lo expresado, así se ocupen del tema de los plazos de prescripción, no pueden ser consideradas como estorbo iuris, como algo anodino y, si lo fueran, en gracia de discusión, que no lo son, hay vías institucionales para promover su reforma, pero dentro del sistema, y no fuera de él. Tan es así que, algunos autores, sabedores de dichas reservas o cuestionamientos, han acudido a dotar de cierta formalidad e institucionalidad a esta figura, a través de la expresión 'prescripción de facto', lo que en nuestro entender no esclarece la situación en referencia, toda vez que, en puridad, la prescripción es de origen y desarrollo legal, y no judicial, en cuyo caso no hay prescripciones sino de jure, y no de facto, a lo que se agrega que, en sana lógica,

$\overline{114}$ H. Lehmann. Parte general, op. cit., p. 523. 
lo conveniente es la existencia de una prescripción(unicidad prescriptiva), y no de dos, tanto más si tienen abolengo diferente ${ }^{115}$.

Finalmente, hay casos, para no ahondar más en la materia, por las descritas razones, en las que la verwirkung tiene lugar en tratándose de derechos, facultades o prerrogativas que, por su naturaleza son imprescriptibles, lo que afianza su extensión y gran alcance, y divergencia -en este otro punto- con el instituto prescriptivo, puesto que, desde esta perspectiva, la trasciende y la acota.

\subsection{Presupuestos necesarios para su inVocación}

A la luz de las anteriores reflexiones, nótese entonces que en esencia son tres los principales requisitos o presupuestos que, al decir de un sector de la doctrina y jurisprudencia mayoritarias se deben observar para que resulte aplicable la consabida figura de la verwirkung en general, ${ }^{116}$ a saber:

115 Vid. Filippo RanierI. Le principe de l'interdiction de se contradire au detriment d'autre ou du venire contra factum proprium dans les droits allemand et suisse e sa difusion en Europe, op. cit., p. 28.

116 Al respecto, memoramos que el Tribunal Supremo Español en sentencia del 3 de diciembre de 2010, mencionó que son requisitos del "retraso desleal (Verwirkung): a) el transcurso de un periodo de tiempo sin ejercitar el derecho; b) la omisión del ejercicio; c) creación de una confianza legítima en la otra parte de que no se ejercitará".

La jurisprudencia colombiana realizó también un importante estudio en torno a esta materia. Al respecto, anotó que “... La doctrina alemana desde la sentencia pronunciada por el Reichsoberhandelsgericht el 20 octubre de 1877, admite la Verwirkung basada en la buena fe (Treu und Glauben, \$242 BGB), en cuanto "la demandada podía confiar y ha confiado en que la demandante ya no haría ejercicio de sus derechos" "sich die Beklagte darauf einrichten durfte und eingerichtet hat, die Klagerin verde vor ihren Rechten nicht mehr Gabrauch machen"; Tribunal Supremo Alemán [BGH] sentencias de 10 de junio de 1876, 13 y 16.7.2004.), ora en la seguridad del tráfico jurídico o la evitación de abusos (AusschluBfrist o Verfallfrist). Dicha figura, anota SIEBERT, consiste en la "pérdida del derecho por retardo desleal en su ejercicio, fundada en la prohibición del ejercicio abusivo del derecho" (Wolfgang Siebert, Verwirkung und Unzulassigkeit der Rechtsausubung 1 ff, 53, 1934), su extinción o efecto jurídico extintivo derivado del comportamiento desleal por contrario a la confianza legítima inspirada de buena fe en otro sujeto con la falta de ejercicio del derecho durante un período relevante que permite concluir razonablemente que no será ejercido. La Verwirkung, dice autorizada doctrina, se diferencia de la caducidad o prescripción en las cuales el simple paso del tiempo legal entraña la extinción del derecho (...).

En otros términos, la Verwirkung, efecto jurídico de una conducta desleal, encuentra por elementos estructurales, el transcurso de un tiempo menor al de prescripción o caducidad, 
a. En primer lugar, una de las partes debe, en rigor, haberse mantenido inactivo respecto del ejercicio de un derecho, durante un lapso razonable o, en su defecto, se dice, debe haber declarado o afirmado que no ejercería dicho derecho, actuando ulteriormente en contra de su deudor. Aun cuando no se requiere un tiempo específico, amén de absoluto, será menester examinar cada caso en particular, a fin de determinarlo, aunque de ordinario la jurisprudencia y la doctrina tienen establecido que debe ser relativamente 'prolongado' o por lo menos 'significativo', con el objeto de evitar aplicaciones de períodos fugaces, o tan breves que terminen abiertamente por cercenar el derecho del voluble e inactivo, esto es del sujeto que, pudiendo, no ejercitó sus derechos y prerrogativas oportunamente, y que cuando lo hizo, actúo por fuera de un período signado por la razonabilidad (imputabilidad) ${ }^{117}$.

De igual manera, es absolutamente diáfano que si bien es cierto que a priori no se puede establecer el plazo en comento, este deberá ser menor al término fijado por la ley en sede prescriptiva, dado que es precisamente en consideración a un lapso menor, que tiene aplicación la verwirkung. En caso contrario, perdería toda su razón de ser ${ }^{118}$.

la falta de ejercicio del derecho durante este período y la confianza legítima inspirada a otro sujeto en cuanto no será ejercido, por lo cual, su exigibilidad tardía es inadmisible al reputarse abusiva y contraria a la buena fe; la caducidad o prescripción, estrictamente, el no ejercicio del derecho durante el plazo legal, y la doctrina del acto propio, una conducta incompatible con la precedente, vulneradora de la confianza legítima.....(Corte Suprema de Justicia. Sala de Casación Civil. Sentencia del 28 de abril de 2011).

Es de advertir que, con arreglo a la opinión de otros distinguidos autores, se agrega uno más a la anunciada nómina. Es el caso del profesor José María MıQUEL GoNZALES, quien manifiesta que los presupuestos son cuatro: "el transcurso de un período de tiempo, la omisión del ejercicio del derecho, la confianza legítima en que el titular del derecho no lo ejercitará y la intolerabilidad de dicho ejercicio". Comentario al art. 7.1, en Comentario del Código Civil, Op. cit., pp. 53 y 54.

117 No obstante, aun cuando lo ideal es que sean plazos no tan efímeros, en algunos supuestos se han aplicado términos breves, hecho que contribuye a que en esta materia temporal se hayan valorado variados lapsos, de suyo llamativamente diversos, todos ellos tildados de 'suficientes', según el caso. De ahí que los Doctores A. VAquer Aloy, y N. Cucurull Serra recreen que hay causas en las que la justicia española estimó la suficiencia en comento a partir de "trece meses", "5 años", "16 años", "20 años", etc., lo que reafirma la subjetividad de la figura en lo que a su aplicación se refiere. "¿Solvencia recuperada en buen momento? Aplicaciones jurisprudenciales de la Verwikung en el juicio ejecutivo”, op. cit, p. 5.

118 Como lo expresa la Dra. Nélida TUR FAUNDEZ., examinando el tema del "período de tiempo" frente al retraso desleal, "Evidentemente, ese período ha de ser inferior al plazo de 
Aun cuando el sólo transcurso del tiempo resulta insuficiente para que se generen los efectos consustanciales al retraso desleal, en particular la aplicación de la verwirkung, desde una perspectiva causal (contemplada más como corolario), resulta capital entender que él, de por sí, no torna abusivo, desleal o contrario a la buena fe el comportamiento del titular del derecho, como en algunas ocasiones se pudiere pensar, dado que como bien lo aclaró el Tribunal Supremo español en sentencia del 7 de junio de 2010, "...la tardanza en el ejercicio de la acción, en cuanto supone una falta de actuación, no puede, si no es con otros elementos que lo apoyan, convertirse en aquiescencia. Esta Sala tiene declarado que quien puede ejercitar una pretensión es dueño de hacerlo o no mientras la acción se mantenga viva, así como escoger para ello el momento que estime oportuno..., pues el derecho pierde la acción para ser reclamado cuando se produce la prescripción, pero mientras no haya prescripción, el derecho permanece sin que pueda atribuirse deslealtad por un mero retraso".

b. Así mismo, se requiere que a través de la inactividad del acreedor, o de su declaración, afirmación o silencio, según las circunstancias, se haya suscitado en el deudor, inexorablemente, y en contra de la buena fe, la confianza en cuanto a que el primer sujeto, en efecto, no ejercería el derecho a su favor, de tal suerte que al hacerlo, se generará desconcierto y perplejidad. Dicha confianza, se ha dicho que deber ser calificada, rechazándose la de índole meramente interna, carente de manifestaciones objetivas y externas. De ahí que sistemáticamente se aluda a una confianza legítima o razonable, por cuanto no toda confianza, per se adquiere tal status, según tuvimos ocasión de examinar en el Cap. I.

c. Finalmente, es necesario que con su conducta posterior, aun por su inercia ${ }^{119}$, silencio u omisión, lato sensu, el sujeto acreedor haya lesionado la expectativa o confianza legítima del deudor, procurando hacer valer la prerrogativa que, ab initio, había ignorado, desestimado o descartado. Por ello, algunos autores, con buen criterio creemos nosotros, en consonancia con lo manifestado cuando

prescripción del derecho, pues en caso contrario, la figura objeto de estudio carecería de interés alguno". La prohibición de ir contra los actos propios y el retraso desleal, op. cit., p. 79.

119 Cfr. Alberto Trabucchi. Instituzioni di diritto civile, Cedam, Padova, 1974, p. 125. 
nos ocupamos de los presupuestos de la doctrina de los actos propios (Cap. III), exigen la presencia de un perjuicio o lesión a un interés jurídico, a raíz de la materialización del quebranto de la referida confianza.

En opinión del Dr. A. VAQUER, in extenso la traemos a colación por su relación con el tema, "...la misión que viene a cumplir la doctrina de la Verwirkung es la protección de la confianza legítima del sujeto pasivo de que el derecho a que se halla sometido no será ejercitado en el futuro, confianza suscitada con su comportamiento por el titular del derecho.....La doctrina española exige que el ejercicio retrasado se torne intolerable y, en concreto, 'que no sea exigible a la otra parte que soporte tan tardíamente el ejercicio del derecho', 'lo que sucederá normalmente cuando la otra parte, en virtud de la confianza suscitada, haya procedido de modo irreversible' (MıQuel GonzÁLEZ). Esta intolerabilidad del ejercicio retrasado tiene lugar cuando produce un perjuicio al sujeto pasivo. Así lo ha reconocido nuestra jurisprudencia en diversos pronunciamientos. Por una parte, se manifiesta expresamente en sentencias que niegan el retraso desleal y, por consiguiente, el efecto Verwirkung precisamente por no comportar el ejercicio retardado menoscabo alguno a la posición jurídica del sujeto pasivo. Constituye un buen ejemplo de ello la STS de 4 de julio de 1997, cuando observa que 'no se aprecia que tal ejercicio del derecho de resolución se haya realizado con patente intención de dañar al vendedor sin provecho alguno para los compradores'. Además, por otra parte, en sentencias que sí entienden que ha concurrido retraso desleal el perjuicio para el sujeto pasivo resulta evidente: se trata de compensar con el precio de unas obras recién terminadas el importe de unos honorarios devengados hasta doce años antes (STS de 21 de mayo de 1982), de aplicar una cláusula de revisión de la renta contractual 'colocando al deudor arrendatario ante la realidad de una deuda o prestación excesiva, impensada o no esperada y sumamente gravosa' (STS de 19 de junio de 1985)...o en 'aplicar un interés de demora que aumente la deuda' (SAP Vizcaya 5 de diciembre de 1995). En definitiva, pues, al sujeto pasivo el retraso en el ejercicio del derecho, tras haber confiado como consecuencia del comportamiento del titular que el derecho ya no iba a ser ejercitado, le debe reportar algún perjuicio, esto es cualquier agravamiento de su posición jurídica: una pérdida patrimonial, un aumento de responsabilidad, una pérdida o debilitamiento de sus opciones de defensa 
ante la reclamación del titular (extravío de comprobantes de pago, deterioro de documentos probatorios, etc.)"120.

Como se mencionó, es entonces claro que no existe unanimidad en torno a los presupuestos que deben concurrir para que se configure el retraso desleal, o la verwirkung; sin embargo, es también incontestable que la doctrina suele coincidir en algunos puntos estructurales, que como tal se tornan medulares, desde una perspectiva genética.

Así, el doctrinante Rafael RESNICK, afirma que “...La institución de la Verwirkung reposa sobre tres ideas: la del retraso desleal en el ejercicio del derecho; la de la conducta contradictoria y la infracción de la buena fe, siendo éstas las que llevan al concluyente juicio de valor de que la conducta del titular representa un abuso del derecho. El principio de la buena fe como límite al ejercicio de los derechos subjetivos precisa la fijación de su significado y alcance, por ello, tanto doctrina como jurisprudencia extranjera, han fijado presupuestos para que se produzca un retraso desleal:

$\left.1^{\circ}\right)$ Transcurso de un período de tiempo significativo. El cómputo del tiempo de inactividad debe iniciarse en el momento en que pudo ejercitarse el derecho (evidentemente será un plazo de tiempo menor al establecido para que opere la prescripción).

$2^{\circ}$ ) Omisión del ejercicio del derecho. El titular del derecho permanece inactivo sin hacerlo valer. No se trata de una mera pasividad sino que con su permanecer inactivo el titular debe generar la confianza legítima en el sujeto pasivo de que el derecho no se actuará en el futuro; la inactividad debe medirse en términos objetivos.

120 Antoni VAQUer Aloy. El retraso desleal en el ejercicio de los derechos, op. cit., p. 112 y 113. Cfr. A. Vaquer Aloy, y N. Cucurull Serra. "¿Solvencia recuperada en buen momento? Aplicaciones jurisprudenciales de la Verwikung en el juicio ejecutivo", op. cit, p. 7, al poner de presente que "No basta con que el ejercicio tardío del deudor repugne las exigencias de la buena fe en un plano meramente ideal, sino que debe causar un perjuicio al sujeto pasivo y de ahí su intolerabilidad". 
$3^{\circ}$ ) Confianza legítima en el no ejercicio del derecho. Tiene su fundamento en el principio jurídico en el que se establece que los derechos deberán ejercitarse conforme a las exigencias de la buena fe, y es de gran importancia para la seguridad jurídica contractual, lo que comporta que el sujeto pasivo no debe haber contribuido a la inactividad del titular del derecho.

$4^{\circ}$ ) Debe existir un perjuicio para el sujeto pasivo como consecuencia del ejercicio retrasado del derecho..."121.

Cumplidos estos presupuestos, podrá entonces el sujeto que se ha visto sorprendido, enervar u oponerse a la 'pretensión' del acreedor, en sentido lato, por su marcado carácter extemporáneo, contradictorio y lesivo.

\subsection{RASGOS CARACTERÍSTICOS}

Ahora bien, partiendo de la descripción básica expuesta en precedencia, cumple destacar, en forma somera, los rasgos más descollantes que, según el desarrollo jurisprudencial que se ha hecho de la figura, caracterizan a la verwirkung; así, siguiendo la metodología empleada en el estudio en torno al estoppel, resulta de suma importancia señalar que, de una lectura de los diversos temas abordados en numerales previos, es dable afirmar que la verwirkung se estructura en función de los elementos que se mencionan a continuación, a saber:

121 Rafael RESNICK. Provincia de Buenos Aires: ¿Paraíso donde las causas nunca prescriben? Op. cit., p. 6.

Osvaldo GozAínı, por su parte, sostiene que “...Los presupuestos de su accionar se resumen: a) Una de las partes tiene que haber mostrado durante un lapso no desdeñable una conducta que permitiera a la contraria suponer que no quería hacer uso de sus facultades procesales. b) La parte contraria tiene que haberse acomodado a la situación resultante de esa conducta. c) Para la caducidad rige el principio de la subsidiariedad. El principio general del ejercicio leal de los derechos cede ante normas especiales que posibilitan la misma solución.....".Caducidad de la pretensión por retraso desleal en su ejercicio, op. cit., C-89.

Y Don Luís DíEz-PICAZo, a su turno, menciona que "Tres son los elementos de la figura que examinamos: la omisión del ejercicio del derecho; el transcurso de un periodo de tiempo y la objetiva deslealtad e intolerabilidad del posterior ejercicio retrasado". Prólogo a la monografía de Franz WiEACKER. El principio de la buena fe, op. cit., p. 22. 


\subsubsection{Se trata de una figura de origen pretoriano}

En idéntica situación a la del estoppel, la verwirkung es una figura que se ha forjado a través de la loable y muy enriquecida labor de la jurisprudencia alemana, la cual, con fundamento en lo prescrito en el citado artículo 242 del Código Civil alemán (BGB), ha enfatizado en la necesidad de tutelar la bona fides, a la par que de mitigar y conjugar las actuaciones contradictorias y desconocedoras de las expectativas creadas en los individuos; así, ha sido notable la labor de los jueces en punto tocante con la evolución y ulterior irradiación, de la verwirkung en el ámbito nacional alemán, y aledaños.

Lo anterior no se opone, tal y como se señaló en su oportunidad, a que el legislador alemán, por vía de diciente ejemplo, se haya ocupado de darle carta de ciudadanía a la verwirkung en áreas muy concretas, como en el Derecho de patentes.

También la jurisprudencia española se ha ocupado de referir por su nombre a la verwirkung, como equivalente al retraso desleal (sentencia del 24 de junio de 1996: “...el retraso desleal, denominado por la doctrina germánica 'verwirkung' “) y también lo ha hecho en la presente centuria. Prueba de ello, sólo para aludir de nuevo a un reciente fallo, es la sentencia del 12 de diciembre de 2011 que se ocupa del "... .retraso desleal en el ejercicio del derecho", señalando que "un derecho subjetivo o una pretensión no pueden ejercitarse cuando el titular no se ha preocupado durante mucho tiempo de hacerlos valer y ha dado lugar, con su actitud omisiva, a que el adversario de la pretensión pueda esperar objetivamente que ya no se ejercitará el derecho. En el derecho alemán surge la figura de la Verwirkung en cuya virtud resulta inadmisible que el derecho se ejerza con un retraso objetivamente desleal".

\subsubsection{Es un instituto que sublima la buena fe y protege la confianza legítima}

Al conjurar las actuaciones que, de una u otra manera, contrarían la confianza o las expectativas legítimas que el actuar de un sujeto ha generado en otro, 
evitando así la sorpresa, la contradicción y la volubilidad comportamental, la verwirkung se erige en inequívoco punto de apoyo para la bona fides y, como no decirlo, para la coherencia y la confianza de los individuos; en ello media un punto común entre el estoppel, la verwirkung y la regla del venire contra factum proprium non valet, desde una perspectiva más global, como quiera que, en todos estos casos, el soporte en que se apoya la aplicación de las doctrinas es, sin duda, la buena fe, la coherencia y la confianza legítimas. No en vano se ha dicho que este es el genuino manantial del importante avance jurisprudencial que, en guarda de las anteriores principios, se ha logrado en diversas latitudes, cuestión que no es difícil de verificar si se tiene presente, ad exemplum, que en el marco de la jurisprudencia alemana, ha sido justamente el artículo 242 del BGB el que ha servido de sustento normativo para la implementación de la verwirkung. Así mismo, en el caso de la consabida doctrina de los actos propios, como en capítulos precedentes se acotó y, en el numeral siguiente se desarrollará, la bona fides y la confianza han sido su basamento, situación en la que existe identidad con el estoppel, como en su momento se refirió, con los matices derivados de la teoría de la apariencia y la reliance.

Lo anterior, empero, no quiere significar, ello es toral, que la verwirkung se confunda con la buena fe, o la confianza legítima; no: si bien se trata de figuras por demás cercanas, a fuer de hermanadas, cada una de ellas tiene identidad y caracteres propios que, como tales, las han hecho merecedoras de una denominación autónoma o especial que, con el nomen propio, no procura sino significar la naturaleza autonómica que las identifica, lo que no se opone a la cercanía en referencia.

Es de señalar que en el Derecho español, al igual que en el Derecho alemán, la norma encargada de albergar y disciplinar la buena fe, desde un ángulo general, ha sido el soporte genético-funcional de la verwirkung, o del retraso desleal, como también se la apellida por algunos, incluido el Tribunal Supremo. En esta dirección, en reciente sentencia del 12 de diciembre de 2011, se puso de presente que" La buena fe ha sido interpretada como principio general o como cláusula abierta, aunque en definitiva debe considerarse como principio positivizado que impone deberes a los titulares de los derechos. En el art. 7.1 CC se recoge uno de los 
aspectos principales de las consecuencias de la buena fe y comporta determinar lo que debe entenderse por retraso desleal en el ejercicio del derecho....."

\subsubsection{Entraña la inadmisibilidad del ejercicio de un derecho o, como lo afirma la doctrina mayoritaria, la materialización de un abuso del derecho}

Como lo indica lo posición doctrinal dominante, la verwirkung trasluce, en lo medular, la inadmisibilidad de un derecho por su ejercicio abusivo; así las cosas, es claro que los derechos, como bien lo explica el profesor L. JosserAND, deben ser ejercidos en el marco de la teleología que los informa, a la par que dentro de los límites que se les han impuesto, razón por la cual, su ejercicio contradictorio y vulneratorio de las expectativas creadas, resulta por demás reprochable, amén de inadmisible, como justamente lo hace la verwirkung en el seno del derecho alemán: allí se impide o rechaza el ejercicio de un derecho, a pesar de su primigenia admisibilidad, como quiera que, en puridad, a través del ejercicio de dicho derecho se puede llegar a vulnerar la confianza legítima de una tercera persona, por manera que, en rigor, a juicio de sus propugnadores, se trataría del ejercicio abusivo del derecho que, como tal, no es digno de recibo en la ciencia del Derecho.

Puesto en otros términos, siguiendo a la doctrina mayoritaria en esta materia, que no es en todo caso unánime, según lo hemos manifestado, es preciso destacar que, en el marco de la aplicación de la verwirkung, el trasfondo que conduce a la inadmisibilidad de la pretensión que se pretende hacer valer, no es otro diferente al de un ejercicio abusivo de los derechos, particularmente un ejercicio en el cual, a través del derecho, se vulneran las expectativas y la confianza legítima de un tercero, a la par que su buena fe.

Obviamente, como advertimos antes, esta exigencia del abuso de derecho, no es unánime, ni pacífica, por cuanto se ha señalado que hay casos en los que no media el referido abuso, en estrictez, pero opera la verwirkung, como lo pensamos nosotros, conforme lo anticipamos, como quiera que lo decisivo no es la abusividad sino lo floración de una incoherencia y correlativamente el quiebre de la confianza legítima y racionalmente incubada. 


\subsubsection{Es una figura que difiere de la prescripción}

Como in extenso se mencionó, la verwirkung es un instituto que, en muchos de sus aspectos, difiere de la prescripción, en la medida en que se caracteriza por una genuina y propia estructura, a la par que teleología, que, como tal, hace de ella una figura enteramente diversa a la de la prescripción extintiva, así comportan uno que otro elemento, diversidad, como se acotó, que se evidencia a través de múltiples de sus rasgos, ya examinados.

\subsubsection{No solamente es producto del trascurso del tiempo}

Es importante anotar que, en adición a todo lo anterior, la verwirkung no obedece exclusivamente a la inactividad del acreedor, acompañada por el trascurso del tiempo, toda vez que, partiendo de su propia teleología, se trata de una figura que se aplicará siempre que, a partir de la conducta del acreedor -consista ésta última en la inactividad, o en un acto positivo y concluyentesea razonable deducir que, en rigor, éste no intentará ejercer el derecho que, en principio, le corresponde; así, bien puede suceder que la aplicabilidad de la verwirkung en un caso en particular, esté dada por una afirmación hecha por el acreedor (en el sentido de no pretender cobrar la obligación, por vía de ejemplo) y no, como sí sucede en la prescripción, por el simple y desnudo trascurso del tiempo, desde luego acompañado de inactividad. Lo importante, en realidad, es que medie una actuación (ora comisiva, ora omisiva) de parte de dicho acreedor, en virtud de la cual pueda razonablemente el deudor confiar en que el derecho no se ejercitará, con total independencia del fenómeno prescriptivo, así se requiera que transcurra un plazo razonable, determinado por el juez, y no por el legislador, más allá de los comentarios realizados alrededor del subjetivismo que esta vía entraña.

Por consiguiente, es diáfano que en atención a lo manifestado, “...debe entenderse esa indeterminación como elemento necesario de la verwirkung porque, precisamente, en dicha indeterminación reside una de sus características 
esenciales. Debe valorarse un cierto período de tiempo en principio indeterminado conjuntamente con el ejercicio del derecho contrario a la buena fe"122.

\subsubsection{No se exige una intención inequívoca de perjudicar}

En armonía con lo examinado en diversos apartes de este escrito, se tiene establecido que, en rigor, no se exige la presencia de un confeso o paladino interés de perjudicar al cocontratante (animus nocendi), pues basta que la conducta $o$ haz de conductas sean contrarias a la buena fe, en cuyo caso se alude a que lo relevante es que la actuación devenga desleal, que no necesariamente intencional, por cuanto para su configuración no es menester realizar juicios subjetivos, sino objetivos. Bien ha dicho el Tribunal Supremo, con rotundidad, que "Es indiferente que la conducta desleal sea o no realizada para buscar el daño del perjudicado; simplemente se requiere que se haya actuado en contra de las reglas objetivas de la buena fe, de acuerdo con las normas del tráfico y con lo que el perjudicado puede esperar de la propia conducta de quien ha producido la confianza". (Sentencia del 12 de diciembre de 2011, 8594).

\subsubsection{Se trata de una institución que puede aplicarse de oficio}

Según se expresó, otro de los rasgos de mayor trascendencia en el marco de la caracterización de la verwirkung, tiene justamente que ver con la posibilidad de que sea aplicada ex officio por un juez, en ámbito de un determinado trámite procesal; así, a diferencia de lo que sucede con el estoppel en particular, esta singular figura, no requiere de la expresa alegación en el seno de dicho trámite procesal, como quiera que, si el juez puede constatar que en éste concurren los presupuestos necesarios para su aplicabilidad, procederá entonces a darle cabida para el casus, en particular, en aras de que se torne en un efectivo y tuitivo

122 Ana CAÑIZAREs LAso. La caducidad de los derechos y acciones, op. cit., p. 28.

En este mismo sentido, igualmente con claridad, el Tribunal Supremo español, en lozano fallo del 12 de diciembre de 2011, manifestó que "....la figura del retraso desleal se distingue de la prescripción porque, si bien en ambas se requiere que el derecho no se haya ejercido durante un largo tiempo, en el ejercicio retrasado se requiere, además, que la conducta sea desleal, de modo que haya creado una confianza en el deudor, de que el titular no lo ejercería..... (STS, 8594). 
mecanismo que, de otro modo, se eclipsaría o por lo menos perdería su dinámica y fuerza singular, tal y como tuvimos oportunidad de plantearlo en tratándose de la doctrina de los actos propios, con mayor detalle (Cap. III).

\subsubsection{Se aplica en función del caso particular}

En armonía con la nota que antecede, al mismo tiempo que de acuerdo con lo puesto de presente en otros apartes anteriores, se tiene definido, con razón, que no es posible fijar de antemano si la figura sub examine resulta o no procedente. De ahí que sea imperativo, a fuer que responsable, descender al caso en concreto, a fin de poder establecer las circunstancias de tiempo, modo y lugar referentes al ejercicio del derecho pretendido por su titular. Esa es la única manera fiable de verificar su conducencia, siendo pues de la mayor valía que se escrute el caso individual, brújula señera de juzgadores e intérpretes, en general ${ }^{123}$.

\subsubsection{Su aplicación, es de doble vía}

Finalmente, dada su particular estructura, resulta muy oportuno acotar que la verwirkung, al fundamentarse en la protección a la confianza suscitada en un sujeto, en cuanto a que otro no ejercitará, en contra del primero el derecho de que es titular, permite entonces su alegación, en sede procesal, tanto por la demandante, como por la persona que es convocada como demandada: bien puede suceder que, respecto de los derechos en cabeza de uno y otro sujeto, se ejecuten actos que, en sí mismos considerados, permitan razonablemente confiar en que el sujeto en particular no ejercerá el derecho de que es titular, habilitando así para que, independientemente de la calidad de demandante o de demandado de quien emplee la figura, éste se valga de ella para evitar así la incoherencia o contradicción.

123 Para A. VAQUer Aloy, a modo de conclusión en este punto, es cierto "...que de manera prácticamente unánime se considera que el retraso desleal y, por tanto, las consecuencias que de tal calificación se deducen, debe ser aplicado de oficio por Jueces y Tribunales". El retraso desleal en el ejercicio de los derechos, op. cit., p. 101. 
De este modo, superlativamente, se reafirma la significación que la verwirkung reviste, pues cualquiera que sea la posición procesal del lesionado, puede hacer uso de la misma, no siendo entonces procedente limitar su formulación a la exclusiva condición de demandante. De ahí que, en términos muy generales, se aluda -y hayamos aludido- a una 'pretensión'.

\subsection{Limitaciones, peligros y cautelas. Somero juicio de pertinencia}

Son los mismos cultores de esta institución, los que al lado de las bondades que, en su entender se imponen, quienes con honradez intelectual y con objetividad, expresan ciertas limitaciones, a la vez que peligros y cautelas, los que no pueden ser soslayados. Muy por el contrario, con miras a que su aplicación no se torne desenfrenada, y menos conculcatoria de aquilatados principios y valores, igualmente dignos de celo y tutela, deben ser tenidas en cuenta. Nada pues que aconseje la mesura, la prudencia, el buen juicio y la sindéresis, debe ser desoído, menos si están en tensión derechos y prerrogativas inscritas en la esfera contractual, fértil terreno de la verwirgung, por antonomasia, según se ha evidenciado.

A) Limitaciones, desde luego, porque por novedosa y justiciera que luzca, la figura no es omnímoda, ni irrestricta, pues conoce límites, en razón de que no es una pócima que se pueda recetar en todos los casos. Al fin y al cabo, como observamos, está sujeta a la verificación de precisas reglas y exigencias que no pueden ser soslayadas, por más que impere el vívido deseo de aplicarla, en pro de la llamada 'justicia del caso', de veras relevante, pero no ilimitada. Quebrantarlas sería constitutivo de un yerro judicial, susceptible de ser enmendado a través de los mecanismos y correctivos establecidos para el efecto, de ordinario, los recursos horizontales, y verticales.

El hecho de que no existan normas jurídicas que le den carta de naturaleza inequívoca y que fijen las reglas en comentario expressis verbis, no significa que no deban ser respetadas específicas fronteras. Por ello, con sobrada razón, el profesor LARENZ aconseja en este campo "...se han de imponer 'rigurosas 
exigencias' en cuanto a los requisitos de caducidad" [verwirkung] ${ }^{124}$, a lo que se agrega, con buen criterio, que en atención a las particularidades que la rodean, sobre todo en relación con "...la inadmisibilidad del ejercicio de un derecho no prescrito, debe ser objeto de una interpretación restrictiva”.125

B) Peligros, obviamente, porque toda obra humana, por refinada que sea, y la judicial suele serlo, es susceptible de engendrar ciertos dislates, con mayor razón cuando el basamento de la figura, se traduce en el criterio del juez, en su buen juicio, obviamente acompañado de la búsqueda del respeto por la buena fe, expresada en positivo, y de que no se abuse de los derechos ajenos, expresada en negativo.

Arbitrio judicial, bien se ha dicho una y otra vez, no es abuso judicial, a lo que se suma que la discrecionalidad, bien entendida, es refractaria al referido abuso. ${ }^{126}$

Por consiguiente, no puede desconocerse que en la esfera humana, a veces sin darnos cuenta, nos empeñamos en una causa que estimamos justa, sin reparar en que la justicia es bifronte y también de doble vía, y que el juez, no es ni del vendedor, ni del comprador; ni del arrendador, ni del arrendatario; ni del paciente, ni del médico; ni del asegurador, ni del asegurado y, en fin, de uno o de otros sujetos jurídicos; lo es de ambos, lo que demanda criterio, ecuanimidad y suma objetividad.

124 K. Larenz. Derecho civil. Parte general, op. cit., p. 303, quien agrega, igualmente con acierto, que "El acreedor de una suma de dinero no debe resultar perjudicado si difiere por largo tiempo la reclamación o la interposición de la demanda, ya sea por consideración al deudor, por 'complacencia' o sólo por su propia comodidad. En general el deudor ha de contar con el ejercicio del derecho de crédito, en tanto no haya prescrito".

125 Antoni Vaquer Aloy, y Núria Cucurull Serra. “¿Solvencia recuperada en buen momento? Aplicaciones jurisprudenciales de la Verwikung en el juicio ejecutivo", op. cit., p. 4.

126 Cfr. Alejandro NiETo, quien recuerda que "El ejercicio indebido del arbitrio es arbitrario y con él aparece la arbitrariedad", motivo por el cual no se pueden confundir "....los conceptos de arbitrio y arbitrariedad”. El arbitrio judicial, Ariel, Barcelona, 2000, p. 212. 
Este tipo de instituciones, en manos de juzgadores que, imbuidos en el 'Derecho judicial', o en el neoconstitucionalismo a ultranza ${ }^{127}$, cuando es aplicado por fanáticos, comúnmente entrañan riesgos, y peligros adicionales a los ordinarios, nos referimos a los judiciales (yerro judicial). Así sucede, como lo relatamos, de una u otra manera, en punto a la institución de los actos propios, así entre esta y ella, la verwirkung, o el retraso desleal, entre otros apellidos, existan diferencias de grado en esta materia. Baste simplemente recordar que la doctrina de los actos propios, por definición, es residual o subsidiaria, lo que implica que su aplicación, in toto, está subordinada a la inexistencia de un instituto especial o predicable del caso, mientras que la consabida verwirkung, se aplica a despecho de una figura tan particular como lo es la prescripción, aspecto que, bien examinado, no es de poca monta; es más, media una especie de insubordinación judicial de cara al término o plazo que, en concreto, ordena la propia ley observar, pero que se inobserva, hablándose incluso de que en virtud de ella, conscientemente, 'se suplantan los plazos legales'.

En compendio, sin con ello querer restarle importancia a esta figura que tanta vigencia tiene en Derechos como el alemán y suizo y más recientemente en el español, portugués y brasilero (suppressio) -aun cuando no en el italiano-, vale la pena recordar con uno de sus más caracterizados defensores, el profesor $\mathrm{G}$. BoeHMER, que "la Verwirkung es un caso típico de un jus aequum condicionado por la situación de hecho concreta en el que salta a simple vista el peligro de una

127 Sobre este particular, Vid. Rodolfo Luís VIGO. El neoconstitucionalismo y la función judicial: Límites, riesgos y perspectivas. I Congreso de la Corte Suprema de Justicia. Temis. Bogotá. 2006. Alexy De Radbruch. La injusticia extrema no es derecho. Universidad de Buenos Aires y La Ley. Buenos Aires. 2005.

Al respecto, por su elocuencia, importa recrear un pasaje del prólogo del Profesor DíEzPICAZO a la monografía de F. WIEACKER (El principio general de la buena fe), de acuerdo con el cual "La idea del principio de buena fe como una vía de introducción de un Derecho judicial, que supone una desviación o una ruptura del Derecho legal o legislado, suscita, por lo menos a mí, abundantes dudas desde el punto de vista constitucional, sobre todo cuando la constitución política se funda en el viejo principio de la división de los poderes y cuando el sistema judicial se le encomienda como tarea el aplicar y ejecutar las leyes. Por otra parte, subsiste la grave dificultad de diferenciar nítidamente ese derecho judicial que así se crea de la pura y simple 'justicia del cadí. La justicia del cadí es la pura decisión individual que es, aunque sea en el mejor sentido de la palabra, arbitraria. Como se ha dicho algunas veces, no tiene pasado y no tiene tampoco futuro", op. cit., p. 17. 
desviación del Derecho a consecuencia de una exclusión demasiado flexible del jus strictum". 128

C) Y cautelas, obviamente resultan necesarias, mejor aún indispensables, dadas las limitaciones reinantes, y los peligros que se generan a partir de la verwirkung, como ya se anotó.

Por ello, todo lo que se pueda hacer para no aplicarla a raudales, es más que bienvenido, máxime si con ello se evita, de una parte, cometer injusticias y yerros, a menudo irreparables y, de la otra, socavar una institución que, con mejoras, y ajustes, como casi todo en la vida jurídica, merece seguir viviendo. Nos referimos a la prescripción, a la que no se le puede extender una partida de defunción. Buen ejemplo es el ofrecido por el propio legislador alemán de comienzos del presente siglo, que no obstante la gloria alcanzada por el B.G.B, modificó algunas de sus disposiciones en materia de Derecho de obligaciones, una de ellas atinente, nada menos, que a los plazos de prescripción, procediendo, como corresponde en los tiempos que corren, a reducirlos en forma importante, según una acusada tendencia internacional. Lo mismo se hizo en España, concretamente en Cataluña, como se anotó, también en el año 2002.

Ese es, así lo creemos, el camino correcto y más ortodoxo, además el mismo que han emprendido otras naciones, en donde términos treintañales y veinteñales, son cosa del pasado, como también sucede en Colombia. Por nuestra parte, entonces, sólo nos resta memorar esa frase que, con alguna frecuencia se repite en la literatura española y en ciertos círculos de América Latina, según la cual,

128 G. Boenmer. El derecho a través de la jurisprudencia, op. cit., p. 269, autor que ya había expresado en su misma obra, que la verwirkung debe ser reservada para los casos en que el ejercicio retrasado del derecho aparece verdaderamente como un abuso de derecho" (p. 268). Igualmente, con provecho, puede verse a Francesco AstonE, pues expresa sus temores alrededor de la "...excesiva discrecionalidad judicial", frente a la "...certeza del derecho, la seguridad de la relación jurídica y la necesaria predictibilidad del éxito del litigio", propias de la prescripción legal. Ritardo nell'essercizio del credito. Verwirkung e buona fede, op. cit., p. 619. De hecho, como se esbozó, un amplio sector de la doctrina italiana adhiere a la idea de que la verwirkung "...difícilmente encuentra espacio en el ordenamiento..." italiano. Francesco Gazzoni. Manuale di diritto privato, Edizioni Scientifiche Italiane, Napoles, 2003, p. 114, y Pietro PerLINGIERI, Manuale di diritto civile, Edizioni Scientifiche Italiane, Napoles, 1997, p. 332, quien reitera que "...en el ordenamiento italiano no existe un instituto parangonable a la Verwirkung". 
"Los muertos que vos matáis, gozan de buena salud", y a fe que la prescripción no está ni herida de muerte, ni enferma, así la acompañe la verwirkung, o sus equivalentes. Muy por el contrario, con los cambios en referencia, pervive tonificada y revitalizada, y también 'revascularizada', para emplear un término de la ciencia galénica, indicativo de su estabilidad coronaria.

Y si ello es así, como en efecto lo es, es decir que la responsabilidad primigenia reside en el legislador, quien cada vez evidencia su mayor preocupación encaminada a reducir los términos de prescripción, en los últimos años en forma drástica, cabe preguntarse con un destacado sector de la doctrina internacional ${ }^{129}$, si se justificará entonces preservar, inalterada, la figura de la verwirkung, a sabiendas de que ella, ciertamente, hundió sus raíces en situaciones coyunturales, empujadas por una prescripción de 30 años, en el Derecho alemán, a todas luces extrema, y a su turno sinónimo de injusticias, por lo dilatada.

Expresado de otro modo, vale la pena dejar sentado un interrogante en relación con el porvenir de la verwirkung, sobre todo en aquellas naciones en las que el legislador, ex proffeso, intervino para acortar los plazos tan abultados que existían, como quiera que por la vía de una prescripción razonable, vale decir breve y suficiente, se estaría reinstitucionalizando esta temática, evitándose, ello es lo neurálgico, la transgresión de la confianza legítima, y de paso, el estímulo de figuras de hecho (prescripción de facto), las que otrora pudieron tener mayor justificación, no tanta, empero, como para olvidar que es legislador a quien en línea de principio le corresponde sentar las bases del sistema, en este caso, liderar la revitalización del instituto de la prescripción.

Baste, para terminar, traer a colación la esclarecida opinión del profesor Antonio Gullon BALlesteros, con la que comulgamos plenamente, por revelar, con diafanidad, la idea que deslizamos a lo largo de los párrafos precedentes, muy especialmente en los previos al examen de sus presupuestos, según la cual, en lo pertinente, "Aunque la doctrina de la Verwirkung ha sido admitida y aplicada por nuestro Tribunal Supremo, es muy delicada en tanto que prima facie

129 Cfr. F. FEstI. Il devieto di venire contra facto proprio, op. cit., p. 138; F. Astone. Venire contra factum proprium, op. cit., p. 96 p. Gallo, Contratto e buona fede, op. cit., p. 787. 
puede contradecir las instituciones de la prescripción y caducidad. Si el legislador señala unos plazos para el ejercicio del derecho, no parece que el titular pueda ser considerado de mala fe cuando los ejercita dentro de los mismos. Otra cosa es que añada a su conducta actos de los que la otra parte pueda inferir lógica y objetivamente que nos los ejercitará, pero entonces la Verwirkung no será más que una modalidad o subtipo de la prohibición de actuar contra los propios actos...130".

130 Antonio Gullon. “Art. 7", en Comentarios del Código Civil, Bosch, Barcelona, 2000, p. 398.

Ilustrativo, igualmente, resulta el parecer expresado por don Manuel ALBALADEJo G., cuando señaló que "Un tema quiero sólo apuntar aquí: Como el derecho prescribe por el paso del tiempo sin usarlo, es claro que, en principio, cabe usarlo hasta el final del plazo. Pero ¿puede ser abusivo o contra la buena fe su ejercicio tardío, aunque aún dentro de plazo? Que pueda ser abusivo depende de las circunstancias, pero ¿parece que, de por sí solo, no cabrá considerar abusivo el ejercicio dentro del plazo por muy tardío que sea, pues pensar otra cosa lo que fundamentaría sería solamente el acortamiento del plazo prescriptivo?". La prescripción extintiva, op. cit., p. 21.

En sentido similar, aun cuando mucho más críticos en torno a la posibilidad de inaplicar los términos de la prescripción, por el sendero de la verwirkung, el retraso desleal, el venire contra factum proprium, etc., véase a Marcelo LóPEZ MESA. La doctrina de los actos propios, op. cit.; Mario CAStillo F., y Rita Sabroso M. La teoría de los actos propios, Op, cit, p. 181; Eduardo GANDULFO R. "La aplicación del principio 'venire contra factum proprium non valet'. Un caso de vulgarismo jurídico", op. cit., p. 374, y Carlos Sото C. "Teoría de los actos propios", en Hechos de la Justicia, Lima, 2005, p. 4. 

Capítulo V

RECEPCIÓN NORMATIVA Y JURISPRUDENCIAL

DE LA DOCTRINA DE LOS ACTOS PROPIOS. VISIÓN COMPARADA

\section{PRELIMINARES Y RECEPCIÓN NORMATIVA EN EL CAMPO INTERNACIONAL}

Es preciso manifestar, delanteramente, que en el presente numeral pretendemos hacer un somero y panorámico examen de la recepción de la doctrina de los actos propios a nivel normativo y jurisprudencial, en distintos ordenamientos jurídicos iberoamericanos, como quiera que ya hicimos mención, precedentemente, a jurisprudencia inglesa, estadounidense, alemana, italiana, etc., sin perjuicio de una que otra referencia a jurisprudencia suiza y belga en torno a las figuras del estoppel, verwirkung y rechtswerking, a la que entonces nos remitimos.

En este orden de ideas, se reseñarán puntuales pasajes jurisprudenciales en los que se ha dado cabida al venire contra factum proprium, en sus diferentes manifestaciones, muy especialmente en sede de la doctrina de los actos propios, con independencia de un examen que, en ocasión ulterior, más in extenso, esperamos se pueda realizar respecto de los pronunciamientos que referenciaremos, así como de cara a otras providencias y textos legales.

En efecto, huelga reiterar que la fuerza jurídica y normativa de la doctrina en comento no estriba en disposiciones legislativas específicas, amén que especializadas, habida cuenta de que, recta via, su resonancia y evolución, por demás difundida y reconocida en diversos sistemas jurídicos del mundo, encuentra su manantial en el apellidado derecho vivo, esto es, el derecho jurisprudencial y doctrinal, a la par que en la sana lógica y en el desarrollo de ciertos principios 
jurídicos que se insuflan en la doctrina del venire contra factum proprium non valet y que han servido de faro para su desarrollo e incorporación en muchos Estados. No en vano se ha dicho que la prenombrada doctrina hunde sus raíces en la bona fides, y la coherencia, amén que en la teleología que la informa -ratio protectionis-, cual es justamente la tutela de la confianza legítima, haciendo de ella una palmaria, a fuer de ineluctable expresión de la justicia mundus, la cual transpira por sus poros, como lo anotamos en su momento.

Así las cosas, aunque en estricto rigor son escasísimas las disposiciones legislativas que, expressis verbis, se refieren a la doctrina de los actos propios, su lógica y pertinencia, a la par que su indiscutida relación con los antedichos principios cardinales de la ciencia jurídica, ha servido de férreo basamento para que la jurisprudencia y la doctrina se ocupen de su estudio y afinamiento respecto a problemas jurídicos que se enseñorean a diario en la praxis del derecho.

Justamente por eso, ha sido encomiable la labor de los jueces de ciertos Estados en punto tocante con la evolución de la doctrina de los actos propios, ora porque se han ocupado de mantener viva una figura que de antaño se ha incardinado en su ordenamiento jurídico, como es el caso del Derecho español, entorno en la que la jurisprudencia, con tino y sindéresis, ha dedicado centenares de fallos a su escrutinio, ora porque recién han tomado conciencia de la valía de la figura, o han vuelto a tomarla y, consecuentemente, han velado por su redescubrimiento, después de haber estado en hibernación. De allí que, sin quiebres, se pueda aludir, en la hora de ahora, a uno de sus mejores momentos, si se quiere a su apogeo, sobre todo en ciertos países, como se observará.

Habida cuenta de ello, en el presente capítulo nos ocuparemos de referenciar, en apretada síntesis, algunos puntuales pasajes jurisprudenciales que han desarrollado la doctrina del venire contra factum proprium en distintos sistemas jurídicos, así como el fundamento normativo que ha servido de punto de apoyo para tales pronunciamientos judiciales, principiando, como es lógico, por el ámbito supranacional, esto es, por el derecho internacional, escenario que, como se anticipó, ha estado profundamente permeado por el prenombrado brocardo, y por su esencia. 
Cumple reiterar que el prenombrado Derecho internacional no ha sido ajeno, en manera alguna, a la intensa expansión, a fuer del reverdecimiento de la doctrina en comento; corolario de ello son algunas normas que campean en el referido Derecho internacional y que reflejan los derroteros básicos del venire contra factum proprium non valet, como, ad exemplum, el artículo 45 de la Convención de Viena sobre el Derecho de los tratados celebrados entre Estados, fechada del 23 de mayo de 1969, el que textualmente reza que, “Un Estado no podrá ya alegar una causa para anular un tratado, darlo por terminado, retirarse de él o suspender su aplicación con arreglo a lo dispuesto un los artículos 46 a 50 o en los artículos 60 y 62, si, después de haber tenido conocimiento de los hechos, ese Estado: a) ha convenido expresamente en que el tratado es válido, permanece en vigor o continúa en aplicación, según el caso; o b) se ha comportado de tal manera que debe considerarse que ha dado su aquiescencia a la validez del tratado o a su continuación en vigor o en aplicación según el caso".

Lo anterior, como se podrá corroborar, no es más que una lógica aplicación de la doctrina en cuestión, como quiera que se proscribe e inadmite la conducta de un Estado que, en desconocimiento de su actuación pretérita, impetra la nulidad, terminación o suspensión de un Tratado Internacional; lo precedente no solamente vincula a múltiples Estados de la comunidad internacional, que han sido signatarios de la antedicha Convención -166 Estados en total, la inmensa mayoría de ellos, habiéndola ratificado ya-, sino que también resulta vinculante para el Reino de España, el que ratificó la Convención mediante instrumento de adhesión fechado del 2 de mayo de 1972 y suscrito por el señor Gregorio LóPEZ BRAVo, ministro de Asuntos Exteriores de España, en aquél entonces, e igualmente de Colombia, entre otros países más.

Idéntica situación se predica del artículo 29 de la Convención de las Naciones Unidas sobre Compraventa Internacional de Mercaderías (más conocida como Convención de Viena relativa a la Compraventa Internacional de Mercaderías de 1980), que dispone que "Un contrato por escrito que contenga una estipulación que exija que toda modificación o extinción por mutuo acuerdo se haga por escrito no podrá modificarse ni extinguirse por mutuo acuerdo de otra forma. No obstante, cualquiera de las partes quedará vinculada por sus propios actos y no podrá alegar esa estipulación en la medida en que la otra parte se haya basado en tales 
actos"; siendo entonces locuaz, amén que evidente e innegable, la aplicación de la doctrina en el marco de las relaciones reguladas por la prenombrada Convención.

Adicionalmente, y como si lo anterior no fuera suficiente, el artículo $7^{\circ}$ del mismo Tratado consagra el principio general de la buena fe en el comercio internacional y el Derecho internacional privado - positivizando así la fuente que ha servido de soporte para la incorporación de la doctrina en múltiples ordenamientos jurídicos locales-, a la par que el artículo 16 hace lo mismo, el que prescribe que "la oferta no podrá revocarse: a) si indica, al señalar un plazo fijo para la aceptación o de otro modo, que es irrevocable; o b) si el destinatario podía razonablemente considerar que la oferta era irrevocable y ha actuado basándose en esa oferta"). Ello, cumple destacar, no es más que una paladina consagración de la referida doctrina de los actos propios, en el ámbito de la oferta en la compraventa internacional de mercaderías. Además, cumple agregar que esta Convención resulta también vinculante para varios Estados, entre ellos España, que depositó el instrumento de adhesión a la misma, el 24 de julio de 1990.

La aplicación de la antedicha doctrina se observa también en los Principios de UnIDROIT sobre los Contratos Comerciales Internacionales, redactados por el Instituto para la Unificación del Derecho Privado -UnIDROIT-, los cuales, con elocuencia suma, consagran la consabida doctrina de los actos propios en el marco del artículo 1.8, titulado "Comportamiento contradictorio. Venire contra factum proprium", a cuyo tenor, "una parte no puede actuar en contradicción a un entendimiento que ella ha suscitado en su contraparte y conforme al cual esta última ha actuado razonablemente en consecuencia y en su desventaja".

Nótese entonces que se trata de una consagración expresa e inconcusa de la regla del venire contra factum proprium non valet, en la órbita de la contratación comercial internacional, lo que constituye meridiana evidencia de la importancia que aquella ha venido adquiriendo en el escenario local y mundial; en efecto, la consagración en comento es una muestra, por demás diciente, de que en el ámbito contractual la protección de la confianza legítima, a la vez que la tutela de la coherencia comportamental, se ha transformado en derrotero de las reglas en mención, como quiera que, en puridad, su recepción y proyección es cada vez mayor, a fuer de expresa y explícita, ora en sede jurisprudencial, ora en sede legal 
o convencional, a lo que conviene agregar que estos principios, a menudo, son invocados por las propias partes en sus negocios jurídicos, y también tenidos en cuenta por el juez, como referente de autoridad.

Sobre este particular, no sobra reiterar que la consagración de la doctrina de los actos propios en el campo de los Principios UNIDROIT, reviste una trascendencia práctica estructural, toda vez que, además de reflejar la importancia misma de la doctrina como tal, es también un antecedente basilar para que ésta última se difunda, con renovada fuerza, en el escenario contractual contemporáneo, en la medida en que, en puridad, los mencionados Principios han expandido o dilatado su ámbito de aplicación a diversos ramos del comercio internacional. Ello revela, con claridad, el Preámbulo de los mismos, el cual refleja que además de su aplicabilidad cuando ha habido acuerdo inter-partes para ello, ésta también tendrá lugar cuando se ha pactado que el contrato, en concreto, se regirá por los principios generales de derecho, la lex mercatoria o expresiones similares que denoten esta intención, así como cuando las partes no han pactado nada en torno a las normas aplicables a su acuerdo negocial internacional -lo que les atribuye un carácter subsidiario o supletivo-. Pero la cuestión atinente a su significación no termina allí, toda vez que los principios UNIDROIT pueden servir como criterio de interpretación de las convenciones de tipo internacional, amén que de la normatividad local, lo que renueva entonces su importancia en el escenario jurídico mundial y, como no decirlo, lo que refrenda también la trascendencia que, con la consagración expresa de la doctrina de los actos propios en el marco del artículo 1.8, ésta puede adquirir en sede de la contratación, en general

El referido preámbulo, a la letra dice: "(Propósito de los Principios)

Estos Principios establecen reglas generales aplicables a los contratos mercantiles internacionales. Estos Principios deberán aplicarse cuando las partes hayan acordado que su contrato se rija por ellos. Estos Principios pueden aplicarse cuando las partes hayan acordado que su contrato se rija por principios generales del derecho, la "lex mercatoria" o expresiones semejantes. Estos Principios pueden aplicarse cuando las partes no han escogido el derecho aplicable al contrato. Estos Principios pueden ser utilizados para interpretar o complementar instrumentos internacionales de derecho uniforme. Estos Principios pueden ser 
utilizados para interpretar o complementar el derecho nacional. Estos Principios pueden servir como modelo para los legisladores nacionales e internacionales".

Ahora bien, cumple también agregar que la consagración realizada por el artículo en comento, devela, sin mayor dificultad, los rasgos o caracteres de tipo general que, en lo medular, delinean las fronteras de la doctrina de los actos propios; así las cosas, nótese que la disposición permite identificar, en forma primigenia, la proscripción de la contradicción comportamental, a la par que de la vulneración de la confianza legítima de un individuo. Así mismo, es importante destacar que, al menos de la redacción misma del artículo, la aplicación de la doctrina tendrá lugar sin tener que agotar una nómina muy amplia de requisitos, como quiera que bastará, en puridad, que la conducta de un sujeto haya dado lugar a un entendimiento de otro sujeto en particular, que, con fundamento en ello, ha obrado razonablemente y en su desventaja; ello conduce entonces a una diáfana tutela de la confianza y previamente de la coherencia en general, en la medida en que, se itera, no se exige un acervo de requisitos para que la figura tenga cabida en el plano contractual.

Otro tanto se puede afirmar de los "Principios de Derecho Europeo de los Contratos", preparados por la Comisión de Derecho Europeo de los Contratos (Proyecto LANDO, denominación en homenaje al presidente de la Comisión, doctor Ole Lando), que en su artículo 2:202, relativo a la revocación de la oferta, hace una tácita referencia a una indiscutida aplicación de la doctrina de los actos propios en materia de oferta contractual, como quiera que prescribe que la revocación de la oferta no surtirá efectos “... (c) si su destinatario podía creer de manera razonable que se trataba de una oferta irrevocable y hubiera actuado en función de dicha oferta...". Nótese que allí se tutela, con carta de ciudadanía propia, la confianza legítima del destinatario de la oferta, cuando éste podía razonablemente creer que dicha oferta era irrevocable y, en consecuencia, ha actuado en consideración a su razonada creencia. Ello muestra, sin duda, que los "Principios de Derecho Europeo de los Contratos" abren un espacio importante para la regla venire contra factum proprium non valet en el marco de una puntual institución -la oferta contractual-, a pesar de no realizar una consagración expresa, lo que no empecé tenerla como incardinada y vigente, en la medida en que los Principios sí consagran, por vía global, el deber de obrar de acuerdo a la buena fe contractual, incontestable 
pilar, a fuer de asidero para la aplicación de la consabida doctrina de los actos propios (Art. 1:201)' y también el deber de colaboración o cooperación entre las partes contractuales, como norma de conducta a la que se sujetan, en forma abiertamente conveniente, los efectos del contrato (Art. 1:202) ${ }^{2}$.

Todo lo anterior evidencia, sin duda, en el plano internacional, la importancia que, como reiterativamente se ha hecho notar, ha venido ganando la tutela por la coherencia y la confianza legítima, ora desde el punto de vista general, ora desde un punto de vista particular, a través de sus manifestaciones en puntuales instituciones.

Idéntica es la situación del Anteproyecto de reforma del Código Civil francés -por citar un elocuente ejemplo en el plano internacional-, el que, en el artículo $1105-4$, alusivo a la oferta contractual, dispone que “... cuando la oferta dirigida a una persona determinada comporta el compromiso de mantenerla durante un término preciso, ni su revocación prematura, ni la incapacidad del oferente, ni su deceso impiden la formación del contrato"; sobre esta disposición en particular, de lineamientos y contornos similares a los de los del Proyecto LANDO, ha sido enfática la doctrina en cuanto a que se trata de una paladina protección de la confianza legítima. Es así como el profesor Denis MAZEAUD, observa que, “... en el fondo, en virtud de este texto, es claro que una oferta en tales circunstancias genera, en el espíritu de su destinatario, una confianza legítima de que se mantendrá....." Por ello, continúa el autor, "esta solución aporta la prueba de la penetración, cada vez más fuerte, del concepto de confianza legítima en derecho francés...”3.

Lo propio, por su parte, ya había expresado el mismo doctrinante galo con ocasión de un análisis realizado al anteproyecto en comento, en concreto a la temática de la formación del contrato, en asocio con el profesor Philippe

1 El artículo 1:201 dispone que "(1) Cada parte tiene la obligación de actuar conforme a las exigencias de la buena fe. (2) Las partes no pueden excluir este deber ni limitarlo“.

2 En virtud del artículo 1:202, "Cada parte tiene el deber de colaborar con la otra para que el contrato surta plenos efectos". Recuérdese, según lo examinamos en el Capítulo I, como el deber de cooperación puede servir de continente al deber de coherencia, rectamente entendido.

3 Denis Mauzeaud. “La confiance légitime et l'estoppel: Rapport française”, op. cit, p. 273. 
Delebecque, de acuerdo con el cual en estas “...nuevas reglas se observa el propósito de protección de la confianza legítima del beneficiario...."4.

En este mismo Anteproyecto, el artículo 1137 refleja la gran valía que en el escenario local, regional e internacional se ha dado a la protección y garantía frente a las actuaciones coherentes; así, la norma en comento dispone que, "Todas las cláusulas del contrato se interpretarán unas en relación con las otras, dándole a cada una el sentido que respete la coherencia del acto en su integridad", con lo cual se hace evidente la protección a la consabida y, en múltiples ocasiones, sublimada coherencia comportamental.

Es importante manifestar que en el examinado panorama europeo, el "Marco Común de Referencia para los Contratos Europeos" incorpora la expresa prohibición de contravenir las conductas previas, cuando a partir de ellas se ha suscitado legítima confianza en un tercero. El art. I-1: 103 (2), sobre el particular expresa que, "En particular, resulta contrario a la buena fe que una persona actúe de forma inconsecuente con sus previas declaraciones o conductas, en perjuicio de la otra parte que había confiado en ellas"

Pero esta tendencia ya descrita, no es, ni mucho menos, exclusiva del continente europeo; muy por el contrario, América Latina nos ofrece un muy diciente ejemplo sobre este particular, con el anteproyecto de Código Civil peruano, el que expresamente recepciona la doctrina de los actos propios y lo hace, nada menos, que en el título preliminar de dicho Anteproyecto, cuyo artículo VI dispone que, "A nadie le es lícito hacer valer un derecho en contradicción con una conducta anterior, cuando en razón de ella otro sujeto haya tenido motivo justificado para confiar razonablemente en que no se ejercerá tal derecho". Este pasaje, por demás explícito y categórico, habla por sí solo. Lo mismo acontece con el reciente Anteproyecto de Código Civil y de Comercio argentino de 2012, al que nos referiremos de nuevo, puesto que su artículo 1067 dispone muy claramente

4 Philippe Delebecque. "Formación del contrato (arts. 1104 a 1107)", en Del contrato, de las obligaciones y de la prescripción, Anteproyecto de reforma del Código civil francés. Universidad Externado de Colombia. Bogotá. 2006, p. 50.

5 Vid. Fauvarque-Cosson / Mazeaud and Wicker / Racine / Sautonie-Laguionie / Bujoli (eds.), Principes contractuels commun. Projet de cadre commun de référence (París, 2008). 
que "La interpretación debe proteger la confianza y la lealtad que las partes se deben recíprocamente, siendo inadmisible la contradicción con una conducta jurídicamente relevante, previa y propia del mismo sujeto...".

En fin, dentro de este acápite relativo a la experiencia internacional, es de resaltar que la jurisprudencia arbitral internacional ha hecho también explícita mención de la doctrina de los actos propios, como justamente sucedió en el Laudo arbitral que dirimía el proceso arbitral entre Duke Energy International Perú Investments N 1, LTD. y la República del Perú (Caso CIADI No. ARB/03/28, Laudo arbitral fechado del 18 de agosto de 2008); allí, en el numeral tercero del capítulo quinto, se enunció la precitada doctrina como parte del análisis jurídico realizado por el Tribunal, develando con ello la valía de la misma en el ámbito internacional ${ }^{6}$.

\section{RECEPCIÓN LEGAL Y JURISPRUDENCIAL EN EL CAMPO DE LOS ORDENAMIENTOS JURÍDICOS DE CARÁCTER NACIONAL}

En lo que atañe a los ordenamientos internos de distintos países, como se anticipó, a continuación registramos los textos legales que han servido de fundamento para el desarrollo de la doctrina sub-examine, al mismo tiempo que algunos reveladores pasajes jurisprudenciales que refrendan la trascendencia de la doctrina en referencia.

\subsection{España}

El indiscutible desarrollo de la doctrina de los actos propios en el marco del derecho español, en cuyo seno se enseñorea desde hace ya más de una centuria, ha tenido como estribo legal, en las últimas décadas, el artículo $7^{\circ}$ del Código Civil español, cuyo texto dispone que, "... los derechos deberán ejecutarse conforme a las exigencia de la buena fe". Esta disposición, como se anticipaba, ha servido de soporte para que la judicatura, en desarrollo del consabido principio de la

$6 \quad$ Tribunal de Arbitramento entre Duke Energy International Peru Investments $N^{\circ} 1, L T D$. y la República del Perú. Laudo arbitral del 18 de agosto de 2008. Caso CIADI N ARB/03/28. 
buena fe que en ella se consagra, se ocupe de afinar, desde los más generales hasta los más particulares rasgos caracterizadores de la doctrina de los actos propios, la cual ha ganado un importante espacio en el Derecho español, ejemplo en esta y en otras materias.

Otro tanto puede decirse, bien escrutado, del artículo 1258 del Código Civil, conforme lo ha subrayado un sector de la doctrina a juicio de la cual en esta norma se anidan -o se pueden anidar- los deberes secundarios o especiales de conducta, v.gr: el de coherencia, el que reza que "Los contratos se perfeccionan por el mero consentimiento, y desde entonces obligan no sólo al cumplimiento de lo expresamente pactado, sino también a todas las consecuencias que, según la naturaleza, sean conformes a la buena fe, al uso y a la ley" ${ }^{7}$.

En efecto, múltiples, mejor aún cientos de sentencias han sido proferidas en España por parte del sistema judicial, incluido en el campo casacional y, por ende, con vocación unificadora, las emanadas del Tribunal Supremo, en el que se ha asentado la siguiente doctrina fundamental, de suyo decantada una y otra vez, a través del tiempo: "Ninguna persona puede ir válidamente contra sus propios actos y ello, porque, si bien toda persona es libre de realizar o no un acto, al realizarlo y reconocer algún derecho a favor de tercero, surge una relación jurídica entre ambos que no puede después ser destruida por actos posteriores. Cada uno es libre para determinarse y actuar lícitamente en cualquier dirección, pero una vez realizado el acto, no puede sustraerse a las consecuencias del mismo, que son vinculantes para quien lo ha llevado a cabo"s.

Lo mismo puede decirse de otras normas, entre varias el artículo 1119 del Código Civil, al tenor del cual "Se tendrá por cumplida la condición cuando el obligado impidiese voluntariamente su cumplimiento", norma de la que se desprende, tal y como lo expresamos a espacio en el Capítulo I (5.2), que allí hay una censura de carácter comportamental, a raíz de la contradicción en la que incurre el deudor condicional cuando, no obstante haberse obligado sub conditione con antelación, posteriormente impide, con su conducta incoherente, el acaecimiento del "...suceso futuro o incierto", justificándose entonces ampliamente la secuela legis adoptada: tener "...por cumplida la condición”, todo en consonancia con el postulado de la buena fe, en su vertiente objetiva, conforme lo corrobora la doctrina, especialmente la francesa, que es quizá la que más se ha ocupado del tema en cuestión.

8 Doctrina jurisprudencial citada por Carlos RogeL VIDE. La doctrina de los actos propios, op. cit., p. 207. 
De igual modo, en Sentencia del 28 de noviembre, 2000, el Tribunal Supremo, puso de manifiesto que, "En efecto, la regla que veda "venire contra factum propium», nacida en el ámbito de la autonomía de la voluntad propia del Derecho privado, impone la vinculación del autor de una declaración de voluntad al sentido objetivo de la misma, tal y como puede ser entendido por los demás, impidiendo un comportamiento contradictorio. La doctrina de los actos propios tiene su fundamento último en la protección de la confianza y en el principio de la buena fe, que impone un deber de coherencia y autolimita la libertad de actuación cuando se han creado expectativas razonables (sentencias del Tribunal Constitución 73 y 198/1988 [RTC 1988, 73 y 198], auto del Tribunal Constitucional de 1 de marzo de 1993 [ RTC 1993, 77 AUTO] )".

Y es que el de España es uno de los ordenamientos jurídicos en los que la doctrina de los actos propios campea con mayor fuerza, como quiera que se trata de una latitud en la que, en realidad, se enseñorea de antaño la regla del venire contra factum proprium non valet, dando lugar a un muy fecundo desarrollo jurisprudencial cuyos inicios datan de 1864, año a partir del cual se ha mantenido ininterrumpida la loable y muy completa tarea de la judicatura en favor del afinamiento del brocardo en mención.

Así, por vía de ejemplo, en el precitado fallo del 28 de mayo de 1864, el Tribunal Supremo español sostuvo que, en el caso que se sometía a su discusión-relativo a la nulidad o rescisión de una partición de herencia-, "... las acciones de nulidady rescisión propuestas alternativamente por el demandante no eran procedentes: la primera porque él no podía ir contra sus propios actos solemnemente reconocidos y, la segunda, porque además de no haberla deducido en tiempo, no ha probado lesión enormísima en que la apoyaba ..."

En ocasión posterior, el Tribunal refrendó el anterior criterio cuando sostuvo que “... si bien es cierto que este Supremo tribunal en algunos casos, relativos a juicios voluntarios de testamentaría, ha establecido la doctrina de que nadie puede ir contra sus propios actos solemnemente reconocidos y consentidos, ha sido siempre bajo el supuesto de que tales actos hayan sido lícitos y permitidos

STS de 28 de mayo de 1864. J.C. 1864, 1, Nº 157. 
por las leyes y nunca cuando, como en el presente caso, se hallan expresa y terminantemente prohibidos bajo pena de nulidad ..."

En providencia fechada del 13 de julio de 1892, cuando conoció de un proceso relativo al reconocimiento unilateral de una deuda, el Tribunal Supremo volvió a referirse a la doctrina -sin perjuicio de otros tantos pronunciamientos sobre esta materia, proferidos en el interregno entre 1876 y 1892-, afirmando que “... el principio de que no se puede ir contra los propios actos supone que los actos que se invocan como excepción tengan significación y eficacia jurídica contrarias a la acción intentada, lo cual no aparece en la protesta que el actor formuló al entregar en la Sucursal del Banco de España las pesetas, ni al aceptar del demandado con aquella ocasión el documento privado en que éste se declaraba deudor de la mitad de la expresada suma, puesto que ni de uno ni de otro acto se desprende lógica, ni legalmente, que el actor renunciase a exigir del demandado el cumplimiento de sus obligaciones ....11.

En sentencia del 28 de noviembre de 1906, sostuvo el mismo Tribunal lo siguiente: “... si bien es de jurisprudencia que nadie puede ir válidamente contra sus propios actos, no es menos evidente que tal principio presupone una relación jurídica entre éstos y las personas a quienes afectan, y esa en ningún caso puede derivarse del sentido y alcance resultante en las diligencias y operaciones de partición y división, que sólo con los interesados se relacionan..."2.

En otro fallo de incontestable elocuencia en punto tocante con la doctrina del acto propio se dijo que “... para que el principio de que nadie puede ir contra sus propios actos sea aplicable, es preciso que aquellos obedezcan a una determinación espontánea de la voluntad de quien los realiza y al designio de crear, modificar o extinguir algún derecho, cuyo alcance y significación no cabe atribuir, al efecto de dar por reconocido el derecho y la personalidad de la parte actora

\footnotetext{
$10 \quad$ STS de 26 de mayo de 1876. J.C. 1876, I, $2^{\circ}, \mathrm{N}^{\circ} 184$.

$11 \quad$ STS de 13 de julio de 1892. J.C. 1892, III, N 18.

12 STS de 28 de noviembre de 1906. Alc. 1908.
} 
por la demandada ..."’3, posición ésta última que fue reiterada en una providencia del 14 de enero de 1932, en la que se afirmó que “... El Tribunal a quo tampoco viola en su sentencia el principio de Derecho reconocido por la jurisprudencia de que nadie puede ir válidamente contra sus propios actos, pues, según tiene declarado este Tribunal Supremo, los actos propios a que este principio se refiere, son aquellos que, como expresión del consentimiento, se realizan con el fin de crear, modificar o extinguir algún derecho, y como la Sala sentenciadora estima que la escritura de compromiso se concertó inducidos los demandantes a su otorgamiento con maquinaciones insidiosas generadoras de dolo, y éste anula el consentimiento prestado, es manifiesto que el mero otorgamiento de la escritura de referencia no puede invocarse, como lo hace el recurrente, para fundamentar el segundo de los motivos del presente recurso ..."14.

Ulteriormente, el Tribunal Supremo sostuvo que “... el principio de derecho según el cual nadie puede ir válidamente contra sus propios actos, es una regla jurídica cuya debida aplicación en cada caso concreto requiere ante todo la probada existencia de hechos de inequívoca significación obstativa o contradictoria a las acciones o excepciones posteriormente alegadas en el pleito..."15.

También de acentuada significación fue una providencia fechada del 12 de abril de 1944, en la que el mismo Tribunal aseveró que “... ni por la teoría de los actos propios pueden quedar obligados, en casos como el de autos, los que no los realizaron, ni el hecho trascendental de la sucesión, con las consecuencias que de él se derivan conforme a los artículos 659, 661, 1257 y 1258 del Código Civil, puede impedir a un legitimario impugnar por simulación los actos de su causante que cedan en peculiar perjuicio de derechos sustraídos a la disposición del testador, so pena de contrariar el espíritu de las disposiciones encaminadas a velar por la defensa de la legítima, frente a los actos ilícitos encaminados a aminorarla o a hacerla totalmente ilusoria ..."16.

13 STS de 16 de noviembre de 1923. Gac. 15, 3, 1924.

14 STS de 14 de enero de 1932. A.1932-1933.

15 STS de 7 de octubre de 1932. A.1932-1933.

16 STS de 12 de abril de 1944. A. 1944, N 535. 
Diez años después el Tribunal reiteró esta doctrina, al afirmar que "...no infringe la Sala la doctrina de los actos propios contra los cuales no puede ir válidamente quien los realiza, porque tal calificación sólo puede darse a aquellos que, como expresión del consentimiento, se llevan a efecto con el fin de crear, modificar o extinguir algún derecho, y tales finalidades no pueden atribuirse a los realizados por el demandado con el exclusivo fin de dar a conocer sus actividades mercantiles y destacar la importancia de las mismas, pero no la de producir ninguno de los efectos necesarios para la existencia de tales actos ... ’’7. También reiteró jurisprudencia pretérita cuando sostuvo que "... la virtualidad de los actos propios, en cuanto a determinar la constitución, modificación o extinción de una relación de derecho, sin posibilidad jurídica de que su autor los contradiga, requiere entre otras condiciones que el vínculo resultante del acto vaya de acuerdo con las exigencias del derecho objetivo y se trate de hacerlo valer en contra y no a favor de quien lo ha producido..."18.

En 1961, refiriéndose al requisito de eficacia para la aplicabilidad de la doctrina en comento, el Tribunal Supremo puso de presente que el actor “... invoca la eficacia de los actos propios, que para que lo sean han de existir y ser válidos, capaces para obligar, y en este caso, aparte de que esta cuestión pudiera ser nueva y como tal rechazable, negada por la Sala la realidad del contrato causal, carecen de virtualidad los actos que no desembocaron en el contrato, con lo cual queda demostrada la improcedencia del recurso ..."19.

Ya más recientemente, el Tribunal Supremo se ha ocupado de reiterar, en lo medular, sus pronunciamientos pretéritos; así ha indicado que "... actúa contra la buena fe el que ejercita un derecho en contradicción con su anterior conducta, en la que hizo confiar a otro (prohibición de ir contra los actos propios), y, especialmente, infringe el mismo principio el que ejercita su derecho tan tardíamente que la otra parte pudo efectivamente pensar que no iba a actuarlo (retraso desleal), vulnerando tanto la contradicción con los actos propios, como el retraso desleal, las normas éticas que deben informar el ejercicio del derecho, las que determinan

\footnotetext{
STS de 29 de mayo de 1954. A. 1954. № 1578.

18 STS de 13 de noviembre de 1956. A. 1956, № 3444.

$19 \quad$ STS de 6 de septiembre de 1961. № 213.
} 
que el ejercicio del derecho se torne inadmisible, con la consiguiente posibilidad de impugnarlo por antijurídico al amparo de la preceptiva contenida en el artículo 7.1 del Código Civil ..."20; agregando, en providencia posterior, que “...la esencia del principio de que nadie puede ir válidamente contra sus propios actos está en la existencia de actos que se realizan con el fin de crear, modificar o extinguir algún derecho, no siendo actos propios vinculantes, los que no entrañen manifiestamente el propósito de contraer una obligación ..." ${ }^{21}$ o, puesto en otros términos, “... el principio de que nadie puede ir contra sus propios actos sólo tiene aplicación cuando lo realizado se oponga a los actos que previamente hubiesen creado una relación o situación de derecho que no podía ser alterada unilateralmente por quien se hallaba obligado a respetarla ..."22.

Otra ilustrativa providencia fue la del 16 de septiembre de 1986, ocasión en la cual el Tribunal Supremo puso de presente en torno a la inequivocidad de la conducta que "... el mantenimiento de la discusión-entre actores y demandados-, en orden al montante de los intereses de un préstamo, impide estimar que los actores realizaron actos propios concluyentes de la aceptación -por su parte, de los intereses establecidos por el demandado-, pues, para que pueda apreciarse una conducta contraria a los actos propios, se requiere que sea inequívoca ..."23.

En 1992, el mismo Tribunal afirmó sobre la unicidad personal que “... la aplicación del principio general de derecho en virtud del cual "nadie puede ir contra sus propios actos", requiere que los actos propios contradictorios provengan de una misma persona actuando con la misma representación, por lo que esta doctrina resulta inaplicable cuando los actos se ejecutaron con distinta personalidad y representación -en el propio nombre y derecho, primero; en representación legal de un descendiente, seguidamente ..."24.

$20 \quad$ STS de 21 de mayo de 1982.

$21 \quad$ STS de 25 de enero de 1983.

$22 \quad$ STS de 16 de junio de 1984.

23 STS de 16 de septiembre de 1986.

$24 \quad$ STS de 29 de noviembre de 1992. 
También ha dicho, limitando un poco la figura -en consideración, justamente, al requisito de eficacia- que "... no puede mantenerse que la doctrina de los actos propios permite amparar al donatario de donación nula frente al donante que la ratifica o cumple de modo voluntario y después acciona pidiendo su nulidad, pues ésta es absoluta, legitima a cualquier interesado para pedirla y la acción para hacerlo es imprescriptible ..."25.

En pronunciamiento cercano -temporalmente hablando- al anterior, dijo el Tribunal que son requisitos para que opere la doctrina de los actos propios, “... primero, que el acto que se pretende combatir haya sido adoptado y verificado con plena libertad de criterio y voluntad no coartada; segundo: un nexo causal eficiente entre el acuerdo adoptado o acto realizado y su incompatibilidad con la conducta posterior; y tercero, que la acción sea concluyente e indubitada... ${ }^{266}$.

En 2001, el Tribunal, una vez más limitando el alcance de la figura, afirmó que "... la causa del contrato, aún existente, puede ser ilícita, como contraria al ordenamiento jurídico y normas que rigen la moral, y esa ilicitud produce, sin más, la nulidad absoluta del contrato según el artículo 1275, nulidad que puede, incluso, apreciarse de oficio. Cualquiera que haya sido la implicación de la actora en el proceso contractual llevado a cabo y ante la gravedad de la simulación absoluta producida, no puede prevalecer la teoría de los actos propios que vinculan al actor..."27.

Ya más recientemente, en Sentencia del 6 de octubre de 2006, señaló el Tribunal Supremo, en un elocuente recuento de la jurisprudencia más diciente en la materia, a la par que en una apretada síntesis que resume los principales derroteros del venire contra factum proprium en la actualidad, que "La doctrina de los propios actos tiene su fundamento en la protección de la confianza y en el principio de la buena fe (Sentencias de 25 de octubre [RJ 2000, 8813] y 28 de noviembre de 2000 [RJ 2000, 9244]), pues se falta a la buena fe en sentido objetivo, es decir, como

\footnotetext{
$25 \quad$ STS de 3 de marzo de 1995.

26 STS de 20 de diciembre de 1996.

27 STS de 20 de noviembre de 2001.
} 
exigencia de lealtad y honestidad en los tratos y en el ejercicio de los derechos (artículo 7.1 CC[LEG 1889, 27]) cuando se va contra la resultancia de los propios actos (Sentencias de 16 de julio [RJ 1987, 5795] y 21 de septiembre de 1987[ RJ 1987, 6186], 6 de junio de 1992 [RJ 1992, 5165],etc.), pero ello exige que los actos propios sean inequívocos, en el sentido de crear, definir, fijar, esclarecer, modificar o extinguir una determinada situación que afecta jurídicamente a su autor, para lo cual es insoslayable el carácter concluyente e indubitado, con plena significación inequívoca, de modo que entre la conducta anterior y la pretensión actual exista una incompatibilidad o contradicción, con el sentido que, de buena fe, hubiera de atribuirse a la conducta anterior (Sentencias de 9 de mayo de 2000 [ RJ 2000, 3194], 27 de febrero RJ 2001, 2615], 16 de abril [ RJ 2001, 5278] y 24 de mayo de 2001 [RJ 2001, 3379], 25 de enero de 2002 [ RJ 2002, 2302], entre otras muchas), por lo que no es de aplicación cuando los precedentes fácticos que se invocan tienen carácter ambiguo o inconcreto (Sentencias de 23 de julio de 1997 [ RJ 1997, 5808] y 9 de julio de 1999 [RJ 1999, 5967]) o carecen de trascendencia para producir el cambio jurídico ( Sentencias de 28 de enero de 2000 [RJ 2000 , 455],7 de mayo de 2001 [ RJ 2001, 7374], 25 de enero de 2002 [ RJ2002,2302]) y, aún menos, cuando el cambio de actitud obedece a una reacción ante nuevos hechos o actos"28.

En el año 2010, como prueba de la prolija actividad del Tribunal Supremo, a la vez que de la importancia de la doctrina de los actos propios en el foro, fueron numerosos los pronunciamientos del Tribunal Supremo. No obstante, en aras de la concreción, importa destacar la sentencia del 21 de diciembre de 2010, en la que se puso de presente que “...La doctrina de los actos propios no sólo vincula a la Administración, sino que también lo hace respecto de los interesados $y$ administrados, en la medida en que sus compromisos anteriores no pueden eludirse. Así, en las sentencias de la Sala $3^{3}$ del Tribunal Supremo de 13 de junio de 1983 y de 26-12-1987, se dice: "Que opuesta por el Abogado del Estado a la pretensión de la demanda la vinculación del demandante a sus propios actos, ha de ser examinada con preferencia esta cuestión múltiples veces tratada en relación con la conducta de la Administración y en menos ocasiones en consideración a la del administrado, aunque suficientes para poder contar hoy con una doctrina,

$\overline{28} \quad$ STS de 6 de octubre de 2006. 
que ha de presidir el enjuiciamiento de este caso y que entre otras cosas, tiene declarado: que el apotegma "venire contra "factum" proprium non valet" ha encontrado acogida en la jurisprudencia contencioso-administrativa.... ${ }^{29}$.

En fin, cumple destacar otros dos importantes pronunciamientos de 2012, en los que el Tribunal Supremo precisó el alcance, fundamento y presupuestos de la doctrina bajo examen. Es el caso, en primer lugar, de la sentencia del $1^{\circ} \mathrm{de}$ marzo, en la que se puso de presente que "...4. La cuestión, en consecuencia, no es si la validez y eficacia del contrato quedó al arbitrio de una de las partes, sino si alguna de las partes está legitimada para oponer la nulidad de lo pactado al cumplimiento del contrato o, pese a ello, prescindiendo de las razones por las que el ordenamiento aplica tan grave sanción a lo estipulado, debe aquietarse en aras al principio que impide actuar contra los propios actos.

45. Ciertamente, pese a que el Código Civil español carece de norma especifica que se refiera de forma expresa a la prohibición de actuar contra los propios actos, doctrina y jurisprudencia coinciden que el principio venire contra factum proprium non valet (no es lícito actuar contra los propios actos), constituye una manifestación del principio de buena fe que, como límite al ejercicio de los derechos subjetivos impone el artículo 7 del Código Civil. 46. También es cierto que un sector doctrinal propugna una aplicación amplia de la regla "nemo propriam causam turpitudinem allegare potest" que constituye una peculiar manifestación de dicho principio, de tal forma que no puede invocar la nulidad la parte que ha provocado la nulidad. 47. Ahora bien, para que sea aplicable la doctrina de los lo que es precisa la concurrencia de los siguientes requisitos:

1) Existencia de una conducta jurídicamente relevante previa y consciente de sus consecuencias. 2) Que tal conducta tenga una significación e inequívoca e incompatible con la posterior. 3) Que las expectativas defraudadas por la actuación posterior sean razonables..."30.

29 STS del 21 de diciembre de 2010 (4762/2008). Vid. también STS del 23 de diciembre de $2010(887 / 2010)$.

$30 \quad$ STS del $1^{\circ}$ de marzo de 2012 (434/2009). 
Lo propio se sostuvo en la sentencia del 8 de mayo de 2012, en la que se afirmó que “...45. Como declaramos en la sentencia 691/2011, de 18 de octubre, reproduciendo la 292/2011, de 2 de mayo, la clásica regla "venire contra factum proprium non valet", constituye una manifestación del principio de buena fe que impone un deber de coherencia y limita la libertad de actuar cuando se han creado en un tercero unas expectativas razonables, de tal forma que impide un posterior comportamiento contradictorio, para lo que es preciso que concurran los siguientes requisitos: 1) Existencia de una conducta jurídicamente relevante previa y consciente de sus consecuencias. 2) Que tal conducta tenga una significación inequívoca e incompatible con la posterior. 3) Que las expectativas defraudadas por la actuación posterior sean razonables..."31.

\subsection{Argentina}

Pasando ahora al Derecho argentino, como lo hemos afirmado repetidamente, la doctrina de los actos propios ha sido objeto de amplio examen y difusión, tanto por parte de la academia, como de la jurisprudencia, a diferencia de otras naciones en las que su desarrollo ha sido más pretoriano que doctrinal.

En el ámbito normativo, la legislación argentina, a semejanza de lo que sucede en otras latitudes, no se ocupa en particular del principio en referencia; sin embargo, el Código Civil argentino, a emulación de otras codificaciones, contiene dos disposiciones que, por desarrollar el milenario y acerado postulado de la buena fe, a la par que el instituto del abuso del derecho, han servido de manantial para la descrita labor jurisprudencial. Es así como se ha recurrido, de una parte, al artículo 1198 de la codificación civil argentina, con arreglo al cual "los contratos deben celebrarse, interpretarse y ejecutarse de buena fe y de acuerdo con lo que verosímilmente las partes entendieron o pudieron entender, obrando con cuidado y previsión...", a la par que al artículo 1071 de la misma normatividad, que prescribe que "el ejercicio regular de un derecho propio o el cumplimiento de una obligación legal no puede constituir como ilícito ningún acto. La ley no ampara el ejercicio abusivo de los derechos. Se considerará tal al que

$\overline{31}$ STS. Sentencia del 8 de mayo de 2012 (1465/2009). 
contraríe los fines que aquélla tuvo en mira al reconocerlos o al que exceda los límites impuestos por la buena fe, la moral y las buenas costumbres".

Por su significado, empero, no debemos dejar de señalar de nuevo que el Anteproyecto de Código Civil y Comercial de la Nación, redactado por la Comisión de Reformas integrada mediante el Decreto 191 de 2011 y cuyo texto fue presentado el pasado mes de marzo de 2012 a las autoridades competentes, desarrolla expresamente la figura en comento en su artículo 1067, a cuyo tenor, en lo aplicable,: "La interpretación debe proteger la confianza y la lealtad que las partes se deben recíprocamente, siendo inadmisible la contradicción con una conducta jurídicamente relevante, previa y propia del mismo sujeto ...."

Ahora bien, en lo que concierne a los pronunciamientos de la judicatura, son varias las providencias que brillan por su elocuencia y claridad en relación con el venire contra factum proprium; así, en sentencia proferida por la Corte Suprema de Justicia de la Nación, fechada del 19 de octubre de 2000, el antedicho Tribunal afirmó que "... La buena fe implica un deber de coherencia del comportamiento, que consiste en la necesidad de observar en el futuro la conducta que los actos anteriores hacían prever, reglas que gobierna tanto el ejercicio de los derechos como la ejecución de los contratos (arts. 1071 y 1198 del Código Civil) y es aplicable por igual en el campo del derecho privado y en el del derecho administrativo... "32.

Dicha providencia que se encuentra en evidente consonancia con sentencias pretéritas del mismo Tribunal, en las que éste último, en forma aún más diciente, ha sostenido que "...No es lícito hacer valer un derecho en contradicción con la anterior conducta, interpretada objetivamente según la ley, las buenas costumbres o lo buena fe (...) Así, la aceptación de una calidad en la contraparte, o una manifestación de carácter definitivo volcada en un expediente, pueden dar lugar a la invocación de la regla, ante su ulterior contradicción ...”33; en otra ocasión sostuvo también que “... Por derivación del principio cardinal de la buena fe, todo ciudadano tiene derecho al comportamiento coherente de los otros, sean estos los particulares o el propio Estado, por lo que, al habérsele notificado al recurrente

Corte Suprema de Justicia. Sentencia de 19 de octubre de 2000. Fallo 323-3035.
33 Corte Suprema de Justicia. Sentencia de 8 de septiembre de 1998. Fallo 321-2530. 
por cédula el proveído que le había requerido la agregación de ciertas copias, pudo fundadamente creer que si mediaba otro requerimiento, se mantendría el procedimiento seguido..." 34 .

Idéntica posición se esgrimió luego en providencia fechada del 29 de marzo de 1990, con sujeción al voto del doctor Carlos FAYT, quien afirmó que “... Los contratos deben celebrarse, interpretarse y ejecutarse de buena fe y de acuerdo con lo que verosímilmente las partes entendieron o pudieron entender, obrando con cuidado y previsión, principios aplicables al ámbito de los contratos administrativos. Por ser ello así, es dable exigir a las partes un comportamiento coherente, ajeno a los cambios de conducta perjudiciales y debe desestimarse toda actuación que implique un obrar incompatible con la confianza que, merced a sus actos anteriores, se ha suscitado en el otro contratante. Tales principios poseen singular importancia en la relación contractual administrativa, pues la intangibilidad del acuerdo sobre la base de la propuesta seleccionada, es la garantía insoslayable para que los oferentes no vean frustrado su derecho de participar en la licitación en la igualdad de condiciones...”35.

Ahora bien, ya descendiendo a casos o hipótesis concretas, es también muy prolija la jurisprudencia argentina, como quiera que se ha ocupado de extrapolar los derroteros básicos de la doctrina de los actos propios a situaciones fácticas muy particulares -concernientes a distintas ramas del Derecho-que han permitido una considerable irradiación de la misma a todo lo largo de la ciencia jurídica. Así, por vía de ejemplo, el Tribunal Colegiado de Responsabilidad Extracontractual de Santa Fe, afirmó en una sentencia que data de 1992, que “... Es deber de los precontratantes observar conductas diligentes que se traducen en el deber de "conservar" $y$ "custodiar" los bienes que se hubieren desplazado con motivo de las tratativas previas; en obrar con la diligencia que imponen las circunstancias (obligación de medios); en abstenerse de realizar "actos antifuncionales", entendiéndose por tales: a) los que no son idóneos para avanzar eventualmente en las negociaciones; $y$ b) los que al mismo tiempo son susceptibles de producir

34 Corte Suprema de Justicia. Sentencia de 19 de octubre de 1995. Fallo 318-2050.

35 Corte Suprema de Justicia. Sentencia de 29 de marzo de 1990. Fallo 313-376. Voto del doctor Carlos FAYT. 
perjuicios al otro precontratantes; requisitos estos que guardan relación con la teoría de los "actos propios" ..."36.

La Cámara de Apelaciones en lo Civil y Comercial de San Isidro, aplicando la regla del venire contra factum proprium non valet al ámbito del derecho de familia, sostuvo que "... es contrario a la teoría de los propios actos abandonar al cónyuge, convivir con otra persona y sentirse injuriado porque su esposa se muestra en público con otro hombre, con quien, es preciso resaltar, no convive..."37.

También se ha dicho que “... la postura del contratante que en vez de conceder a la otra parte la posibilidad de prever su postura en contra de la prórroga del contrato, dio origen a una situación de incertidumbre que no se conciliaba con el interés que había postulado a favor de la continuidad, corresponde sea encuadrada en la doctrina de los actos propios...”38; en otra ocasión a su vez se afirmó que "... La aceptación de un contrato, presidido por un régimen permanente de inestabilidad, veda reclamar en su trascurso los derechos emergentes de la estabilidad en el empleo, dado que, de otro modo, se violenta el principio que impide venir contra los propios actos..."39. También en punto tocante con el derecho contractual y su relación con el venire contra factum proprium, la jurisprudencia argentina ha manifestado que "... la nulidad de la cláusula que establece alquileres escalonados durante el plazo mínimo de vigencia del contrato de locación no queda purgada por el consentimiento de la locataria, puesto que se trata de una materia indisponible. La prohibición del venire contra factum proprium sólo rige en tanto se pretenda contradecir una conducta anterior jurídicamente relevante y plenamente eficaz, nunca para validar la transgresión a un dispositivo de orden público. No debe olvidarse que el referido principio constituye una derivación de la buena fe, y que el rechazo a la conducta contradictoria se fundamenta en la legítima expectativa que pudo despertar la conducta anterior. Mas en este caso, es por demás evidente

36 Tribunal Colegiado de Responsabilidad Extracontractual de Santa Fe. Sentencia de 19 de mayo de 1994.

37 Cámara de Apelaciones en lo Civil y Comercial de San Isidro. Sala I. Sentencia de 2 de junio de 1998. JA; 2001-II-451.

38 Corte Suprema de Justicia - Sala de Casación Civil. Sentencia de 19 de octubre de 2000. Fallos 323-3035.

39 Corte Suprema de Justicia. Sentencia de 20 de octubre de 1987. JA. 1988-I, 109. 
que la locadora, no pudo legítimamente abrigar tales expectativas, en función de la declinación por parte de la locataria de un derecho indisponible, ni puede ahora invocar un perjuicio derivado de la actual posición asumida por su contraparte, que no hubiera experimentado de todos modos de haber mantenido ésta, desde el origen de la relación locativa, su posición contraria al incremento del arriendo..."40.

Otras providencias argentinas de cardinal importancia son, por vía de ejemplo, la sentencia del 7 de agosto de 1996, en la que la Corte Suprema de Justicia de la Nación afirmó que "... No es admisible que un litigante pretenda aportar razones de derecho que contravengan su propia conducta anterior, cuando ésta ha sido adoptada de un modo formalmente relevante y jurídicamente eficaz. Así cuando una actuación voluntaria crea o reconoce algún derecho a favor de un tercero surge una relación jurídica entre éste y el agente que no puede ser arbitrariamente destruida o desconocida por actos posteriores..."14; también la sentencia del 6 de agosto de 1986, en la que sostuvo que "... Si la calidad de pasajero que revestía la víctima había sido admitida con anterioridad al juicio por la propia empresa de ferrocarriles demandada, ya que hizo saber al juzgado que había procedido a intimar el pago de la multa en concepto de infracción a los arts. 141 y 154 de la ley de ferrocarriles, ello basta para probar el extremo que aquélla pretendió desconocer al contestar la demanda, poniéndose en contradicción con sus propios actos..."42.

En el campo aseguraticio se cuenta también con puntuales pronunciamientos de la Cámara Nacional de Apelaciones en lo Comercial, que ha dicho que "...La conducta de la aseguradora que admitió los pagos de la prima por el asegurado fuera de los plazos convenidos, sin formular objeción, antes y después del siniestro, oponiendo a la hora de cumplir con sus obligaciones, un supuesto estado de mora, no se adecua al principio de buena fe que debe regir en la ejecución de los contratos, y tanto más en los de seguros que han sido caracterizados como de uberrima bona fide, ya que, la actitud de la aseguradora frente a su asegurado

40 Cámara de Apelaciones en lo Civil y Comercial de Bahía Blanca. Sentencia de 22 de febrero de 1995. KA, 1996-II. 434.

41 Corte Suprema de Justicia. Sentencia de 7 de agosto de 1996. Fallo 319-1335.

42 Corte Suprema de Justicia. Sentencia de 6 de agosto de 1986. Fallos 303-72. 
debió ser congruente con lo que le imponían sus "propios actos precedentes ....43; también ha aseverado que "... La circunstancia de que la demandada hubiese contratado seguros para amparar siniestros "por la guarda y/o depósito de vehículos a título no oneroso' en la playa de estacionamiento del Shopping explotado por ella, lleva a concluir que ella tenía un interés económico en que tales hechos no ocurrieran; por lo cual resulta contradictorio y contrario a la doctrina de los propios actos, que luego pretenda deslindar su responsabilidad en caso de robo del vehículo sosteniendo no haber asumido la custodia del mismo en vista de la gratuidad de dicho servicio ..."44.

Finalmente, para no extendernos más, se encuentra la sentencia del 16 de marzo de 2000, proferida por la Cámara Nacional de Apelaciones en lo Civil y Comercial Federal, en la que se aseveró que “...En tanto la demandada reconoció en sede administrativa, frente a los medios públicos y ante el Congreso de la Nación, su responsabilidad en los hechos, admitir su argumento en cuanto a que se debe distinguir entre la responsabilidad que le cabe frente a los usuarios en los términos del contrato de concesión y la responsabilidad civil frente a una demanda judicial para obtener los daños y perjuicios eventualmente no abonados, implicaría permitir que contradijera sus propios actos, lo cual resulta inadmisible pues, no se puede mantener una conducta incompatible con otra anterior, deliberada jurídicamente relevante y plenamente eficaz. La conducta que se asume frente a un hecho que es susceptible de generar responsabilidad es única y no contradictoria... Una de las consecuencias del deber de obrar y de ejercer los derechos de buena fe, es la exigencia de un comportamiento coherente, el cual significa que, cuando una persona, dentro de una relación jurídica, ha suscitado en otra con su conducta una confianza fundada en un determinado comportamiento futuro, según el sentido objetivamente deducido de la conducta anterior, no la debe defraudar y es inadmisible toda actuación incompatible con

43 Cámara Nacional de Apelaciones en lo Comercial. Sala C. Sentencia del 18 de diciembre de 1996.

44 Cámara Nacional de Apelaciones en lo Comercial. Sala A. Sentencia del 25 de septiembre de 1997. 
ella. La exigencia jurídica del comportamiento coherente está de esta manera estrechamente vinculada a la buena fe y a la protección de la confianza..."45.

\subsection{Colombia}

Pasando ahora al Derecho colombiano, son conocidos sus textos que se refieren a la buena fe, tanto en ámbito legal: Código Civil (art. 1603) y Código de Comercio (arts. 863 y 871), como en el constitucional: Constitución Política (art. 83), alrededor de los cuales se ha tejido la doctrina de los actos propios, a emulación de lo sucedido en el Derecho Comparado. De hecho normas decimonónicas como el mencionado artículo 1603 de la codificación civil, han sido reinterpretadas, a fin de cobijar los apellidados deberes de conducta (especiales o secundarios), emanación de la buena fe, como también ha tenido lugar en otras naciones, por vía de ejemplo España, según se anotó. Esta norma, que en realidad expresa más de lo que prima facie pareciera revelar y que ahora comienza a adquirir mayor figuración y significado, prescribe que "Los contratos deben ejecutarse de buena fe, y por consiguiente obligan no solo a lo que en ellos se expresa, sino a todas las cosas que emanan precisamente de la naturaleza de la obligación, o que por la ley pertenecen a ella"46.

45 Cámara Nacional de Apelaciones en lo Civil y Comercial Federal. Sala I. Sentencia del 16 de marzo de 2000. 2000-II-223.

46 El artículo 871 del Código de Comercio de 1971, a su turno, refrenda el mismo concepto, aun cuando de manera más diáfana, al disponer que "Los contratos deberán celebrarse y ejecutarse de buena fe y, en consecuencia, obligarán no solo a lo pactado expresamente en ellos, sino a todo lo que corresponda a la naturaleza de los mismos, según la ley, la costumbre o la equidad natural". Vid. Sergio MuÑOz LAVERDE. "El principio de buena fe y su incidencia en la interpretación del contrato. Nulidad de las cláusulas abusivas en el derecho colombiano", op. cit., p. 219, quien se ocupa de ambas normas y de su genuino alcance.

El artículo 1538 del Código Civil, igualmente es invocado como sustento de la existencia de normas que en el Derecho colombiano vedan el comportamiento contradictorio, al igual de lo que sucede en Chile, con el artículo 1481, según se aludirá de nuevo con ocasión del examen de la codificación civil chilena. Dicho artículo 1538, en lo pertinente, reza que, “....si la persona que debe prestar la asignación, se vale de medios ilícitos para que la condición no pueda cumplirse, o para que la otra persona, de cuya voluntad depende en parte su cumplimiento, no coopera a él, se tendrá por cumplida", norma de la que ya nos habíamos ocupado a espacio en el Cap. I, y en este último capítulo también, con ocasión del examen del ordenamiento español, en particular del art. 1119 del C. C. 
Ahora bien, en el campo jurisprudencial, esta regla o deber, ha sido objeto de explícito examen, si bien es cierto no de manera sistemática, tampoco es menos cierto que en los últimos años ha despertado el interés de la administración de justicia -en sus dimensiones estatal y arbitral-. Incluso, de ella se ha hecho aplicación específica, así expresamente no se le haya dado dicha denominación concreta, aun cuando en lo toral se ha arribado a análogos resultados: la abierta censura del comportamiento incoherente, incongruente, inconsonante, contradictorio y voluble.

Es así como en la justicia constitucional, en la civil, la contencioso administrativa y laboral, expressis verbis, se ha analizado y aplicado la doctrina que nos ocupa, conforme se evidenciará a continuación, no sin antes advertir que, en aras de la concreción, sólo consignaremos unos cuántos pasajes de sus sentencias, en principio los más relevantes.

En la primera de ellas, en lo más determinante del pronunciamiento traído a colación, la Corte Constitucional sentenció que, "Un tema jurídico que tiene como sustento el principio de la buena fe es el respeto al acto propio, en virtud del cual, las actuaciones de los particulares y de las autoridades públicas deberán ceñirse a los postulados de la buena fe (art. 83 C.N). Principio constitucional, que sanciona como inadmisible toda pretensión lícita, pero objetivamente contradictoria, con respecto al propio comportamiento efectuado por el sujeto. La teoría del respeto del acto propio, tiene su origen el brocardo 'venire contra factum proprium nelli conceditur' $y$, su fundamento radica en la confianza despertada en el otro sujeto de buena fe, en razón de una primera conducta realizada. Esta buena fe quedaría vulnerada, si fuese admisible aceptar y dar curso a una pretensión posterior y contradictoria....".

"Se trata de una limitación del ejercicio de derechos que, en otras circunstancias podrían ser ejercidas lícitamente; en cambio, en las circunstancias del caso, dichos derechos no pueden ejercerse por ser contradictorios respecto de una anterior conducta, esto es lo que el ordenamiento jurídico no puede tolerar, porque el ejercicio contradictorio del derecho se traduce en una extralimitación del propio derecho...." (Sentencia T-295/99) ${ }^{47}$.

$\overline{47}$ Esta misma doctrina fue acogida en la sentencia T-827/99. 
"....En la doctrina y en la jurisprudencia colombiana [continúa, la Corte], no ha sido extraño el tema del acto propio, es así como la Corte Constitucional en la T-475/92- dijo:

"La buena fe supone la existencia de una relación entre personas y se refiere fundamentalmente a la confianza, seguridad y credibilidad que otorga la palabra dada. En las gestiones ante la administración, la buena fe se presume del particular y constituye guía insustituible y parámetro de acción de la autoridad. La doctrina, por su parte, ha elaborado diversos supuestos para determinar situaciones contrarias a la buena fe. Entre ellos cabe mencionar la negación de los propios actos (venire contra factum proprium), las dilaciones injustificadas, el abuso del poder y el exceso de requisitos formales, sin pretender con esta enumeración limitar el principio a tales circunstancias. No es posible reducir la infracción de la buena fe a casos tipificados legalmente. De ahí que la aplicación de este principio suponga incorporar elementos ético-jurídicos que trascienden la ley y le dan su real significado, suscitando en muchas ocasiones la intervención judicial para calificar la actuación pública según las circunstancias jurídicas y fácticas del caso.

12. La administración y el administrado deben adoptar un comportamiento leal en el perfeccionamiento, desarrollo y extinción de las relaciones jurídicas. Este imperativo constitucional no sólo se aplica a los contratos administrativos, sino también a aquellas actuaciones unilaterales de la administración generadoras de situaciones jurídicas subjetivas o concretas para una persona. El ámbito de aplicación de la buena fe no se limita al nacimiento de la relación jurídica, sino que despliega sus efectos en el tiempo hasta su extinción.

13. El principio de la buena fe incorpora la doctrina que proscribe el "venire contra factum proprium", según la cual a nadie le es lícito venir contra sus propios actos. La buena fe implica el deber de observar en el futuro la conducta inicialmente desplegada, de cuyo cumplimiento depende en gran parte la seriedad del procedimiento administrativo, la credibilidad del Estado y el efecto vinculante de sus actos para los particulares. La revocatoria directa irregular que se manifieste en la suspensión o modificación de un acto administrativo constitutivo de situaciones jurídicas subjetivas, puede hacer patente una contradicción con el principio de buena fe y la doctrina de los actos propios, si la posterior decisión de 
la autoridad es contradictoria, irrazonable, desproporcionada y extemporánea o está basada en razones similares. Este es el caso, cuando la administración, luego de conceder una licencia de funcionamiento a una persona para el ejercicio de una determinada actividad, luego, sin justificación objetiva y razonable, procede a suspender o revocar dicha autorización, con el quebrantamiento consecuente de la confianza legítima y la prohibición de "venir contra los propios actos"48.

En fin, en un recientemente pronunciamiento, la Corte Constitucional se refirió, in extenso y de manera especial a la figura objeto de examen, recogiendo los principales pronunciamientos sobre la materia. Al respecto, afirmó que “... El artículo 83 de la Constitución Política consagra el principio de la buena fe al establecer que: "Las actuaciones de los particulares y de las autoridades públicas deberán ceñirse a los postulados de la buena fe, la cual se presumirá en todas las actuaciones que aquellos adelanten ante éstas". De lo anterior, se entiende que éste principio no sólo tiene lugar al momento del nacimiento de la relación jurídica, sino que desarrolla sus efectos en el tiempo hasta que ésta se extingue.

La jurisprudencia de la Corte Constitucional ha considerado que la buena fe:"(...) incorpora el valor ético de la confianza y significa que el hombre cree y confía que una declaración de voluntad surtirá, en un caso concreto, sus efectos usuales, es decir, los mismos que ordinaria y normalmente ha producido en casos análogos. De igual manera, la buena fe orienta el ejercicio de las facultades discrecionales de la administración pública y ayuda a colmar las lagunas del sistema jurídico".

A su vez, el principio de la buena fe proscribe el venire contra factum proprium, por lo que a nadie le es permitido ir en contra de sus propios actos; en esa medida,

48 La Corte Constitucional, en otras ocasiones, se ha ocupado de este mismo tema. Así, entre otras más, véanse las sentencias T-475/92 -ya mencionada tangencialmente-; T-578/94; T-503/99; T-295/99; C-836/01; T-961/01 y T-366/02. También en el seno de la jurisdicción constitucional, ha dicho la Corte Constitucional que existe "... la obligación (...) de preservar un comportamiento consecuente, no contradictorio frente a los particulares, surgido en un acto o acciones anteriores, incluso ilegales, salvo interés público imperioso contrario. Se trata, por tanto, que el particular debe ser protegido frente a cambios bruscos e intempestivos efectuados por las autoridades públicas (...) el Estado no puede súbitamente alterar unas reglas de juego que regulaban sus relaciones con los particulares..." 
la buena fe implica que a futuro se mantengan las conductas que en un inicio se desarrollaron, y a cuyo respeto se sujetan en gran manera "la seriedad del procedimiento, la credibilidad de las partes y el efecto vinculante de los actos."

\section{(...)}

Como otra manifestación del principio de buena fe, la Corte ha introducido el principio del respeto al acto propio. El respeto al acto propio implica el deber de llevar a cabo actuaciones coherentes en el transcurso del tiempo, de manera que:

“(..) resulta contraria al principio mencionado, toda actividad de los operadores jurídicos que, no obstante ser lícita, vaya en contravía de comportamientos precedentes que hayan gozado de la entidad suficiente para generar en los interesados la expectativa de que, en adelante, aquéllos se comportarían en consonancia con la actuación original”.

Así, en virtud del principio de respeto al acto propio, una autoridad que ha realizado una actuación que ocasiona una situación particular, concreta y definida a favor de otro, no podrá modificar de forma unilateral su decisión, ya que la confianza del administrado no surge por la convicción de la apariencia de legalidad de una actuación, "sino por la seguridad de haber obtenido una posición jurídica definida a través de un acto que creó situaciones particulares y concretas a su favor"..."49.

La Corte Suprema de Justicia, igualmente, se ha ocupado en diversas oportunidades de este instituto, bien de manera explícita y directa, bien de modo más tangencial, o hasta implícito, como se puso ya de presente, habida cuenta que, en veces, sin aludir expresamente al nomen respectivo (doctrina de los actos propios, acto propio, venire contra factum proprium, etc.), ha aplicado el mismo principio capital, y ha formulado simétrico reproche frente a la incoherencia, a

49 Corte Constitucional de Colombia. Sentencia T-923 de 2010. Cfr. T-895 de 2010; Cfr. Del mismo Tribunal, las sentencias T-521 de 2004, T-1094 de 2005 y T-1023 de 2006, respecto de las cuales la Corte hace un interesante resumen en la citada providencia T. 923 de 2010. 
la contradicción, a la inconsistencia, y a la inconstancia en la actuación jurídica, sobre todo en el pasado -no reciente-.

Importa referir, por vía de diciente ejemplo, la reciente sentencia emanada de su Sala Civil, el 9 de agosto de 2007, a cuyo tenor, luego de haber destacado que los particulares "...deben honrar sus obligaciones y, en general, asumir para con los demás una conducta leal y plegada a los mandatos de corrección socialmente exigibles...", se indicó que "...obrar de buena fe es proceder con la rectitud debida, con el respeto esperado, es la actitud correcta y desprovista de elementos de engaño, de fraude o de aprovechamiento de debilidades ajenas. Inclusive, bueno es destacarlo, desarrollo de estos parámetros es la regla que impide reclamar amparo a partir de la negligencia o descuido propios: Nemo auditur propriam turpitudinem allegans. En cabal realización de estas premisas las personas, al interaccionar con sus semejantes, adoptan conductas que fijan o marcan sendas cuya observancia, a futuro, determinan qué grado de confianza merecen o que duda generan. Los antecedentes conductuales crean situaciones jurídicas que devienen como referentes a observar frente a actuaciones presentes y futuras, de similar textura fáctica y jurídica, no pudiendo sustraerse caprichosamente de sus efectos, génesis esta de la llamada Teoría de los Actos Propios...". Por ello la actuación voluble o contradictoria, continúa afirmando la Sala Civil, "respecto de los mismos aspectos fácticos y los mismos intereses económicos, puede constituir, y suele serlo, un acto contrario a los fundamentos de la buena fe y a la coherencia jurídica exigida a cualquier contratante...”. (Exp. 00254.01).

Esta tesitura, en lo esencial, ya había sido referida en otro fallo del 2 de febrero de 2005 (Exp. 9124-02), en el que analizando el significado y alcance de la buena fe, la Corte Suprema señaló que "... dentro del ordenamiento civil patrio la noción de buena fe suele ser contemplada..." desde diversas perspectivas distintas", una de ellas, "...como una regla de conducta, es decir como la exigencia de comportarse en el tráfico jurídico con rectitud y lealtad”, en cuyo caso, "...la buena fe se vislumbra como un genuino hontanar de normas de comportamiento no formuladas positivamente pero implícitas en el ordenamiento que, por consiguiente, ante una situación dada, le imponen al sujeto una conducta determinada con miras a no agraviar los intereses jurídicos ajenos. Desde este punto de vista, la buena fe genera deberes y se califica cotejándola con un 
prototipo abstracto colocado en el contorno social de la persona. Refiriéndose a estos aspectos de la buena fe, ha dicho esta Corporación que "en tratándose de relaciones patrimoniales, la buena fe se concreta, no sólo en la convicción interna de encontrarse la persona en una situación jurídica regular, aun cuando, a la postre, así no acontezca, como sucede en la posesión, sino también, como un criterio de hermenéutica de los vínculos contractuales, amén que constituye un paradigma de conducta relativo a la forma como deben formalizarse y cumplirse las obligaciones. Todo lo anterior sin dejar de lado que reglas tales como aquellas que prohíben abusar de los derechos o actuar contrariando los actos propios, entre otras, que en la actualidad, dada su trascendencia, denotan un cariz propio, encuentran su fundamento último en la exigencia en comento.... (Sentencia del 9 de agosto de 2000, Exp. 5372)"50.

Esta doctrina jurisprudencial se ha reiterado en diversas ocasiones. De hecho, en pronunciamientos recientes la Corte Suprema de Justicia se refirió de nuevo a la doctrina del venire contra factum proprium non valet. Así, por vía de ilustración, en sentencia del 28 de abril de 2011, la Sala Civil realizó, in extenso, una ilustrativa explicación de la materia, en tratándose de situaciones relacionadas con la prescripción y la caducidad. Al respecto, afirmó que "... La doctrina alemana desde la sentencia pronunciada por el Reichsoberhandelsgericht el 20 octubre de 1877, admite la Verwirkung basada en la buena fe (Treu und Glauben, §242

50 Tal y como se indicó en líneas anteriores, la Corte Suprema de Justicia, en sede casacional, reiteradamente, se ha preocupado por la presencia de conductas procesales que, en entre sí, riñan lógica y abiertamente durante las distintas fases del proceso y de los recursos, según el caso, generando rechazo y claros reparos de su parte, así no acuda para ello, stricto sensu, a la denominación de 'doctrina de los actos propios', al principio jurídico venire contra factum proprium, etc., incluso, a la buena fe. Son numerosos los fallos en este sentido. Así, sólo por vía de ejemplificación, aun cuando en esta ocasión apoyada en la buena fe, la Sala Civil en sentencia del 10 de septiembre de 1998, luego de la evaluación de una determinada conducta, concluyó que, "Dicha actitud, además de ser inconsecuente con la conducta procesal asumida por la impugnante del proceso, evidentemente atenta contra principios de la buena fe y lealtad con que las partes deben proceder-artículo 71-1 del C. de p. C, cuya aplicación exige de éstas un comportamiento sincero y, por sobre todo, exento de actuaciones destinadas a sorprender a la contraparte con argumentos de última hora y que denotan también, sin duda alguna, deslealtad frente al juez de instancia cuya decisión se impugna, quien en su momento obró de acuerdo con lo que le mostró la actuación procesal y desde una perspectiva distinta de la que finalmente proyecta el censor" (Exp. 5023). Véase, también, las sentencias 122 del 26 de agosto de 1993 y 128 del 6 de octubre de 1995, entre varias, en las que la Corte Suprema, particularmente en la última de las citadas, alude a la floración de una "...notoria incompatibilidad" entre los cargos enrostrados a la sentencia de segunda instancia. 
BGB)...Dicha figura, anota SIEBERT, consiste en la "pérdida del derecho por retardo desleal en su ejercicio, fundada en la prohibición del ejercicio abusivo del derecho" (Wolfgang Siebert, Verwirkung und Unzulassigkeit der Rechtsausubung $1 \mathrm{ff}, 53$, 1934), su extinción o efecto jurídico extintivo derivado del comportamiento desleal por contrario a la confianza legítima inspirada de buena fe en otro sujeto con la falta de ejercicio del derecho durante un período relevante que permite concluir razonablemente que no será ejercido.

La Verwirkung, dice autorizada doctrina, se diferencia de la caducidad o prescripción en las cuales el simple paso del tiempo legal entraña la extinción del derecho. En cambio, aquélla, además requiere una conducta contraria a la buena fe y a la confianza legítima. Asimismo, pese a exigir una conducta actual contradictoria con la anterior, tampoco se confunde con el venire contra factum proprium, porque éste, de suyo no presupone, ni se basa en la ausencia de ejercicio del derecho durante un período relevante, sino un acto dicotómico opuesto a la buena fe y a la confianza legítima.

En otros términos, la Verwirkung, efecto jurídico de una conducta desleal, encuentra por elementos estructurales, el transcurso de un tiempo menor al de prescripción o caducidad, la falta de ejercicio del derecho durante este período y la confianza legítima inspirada a otro sujeto en cuanto no será ejercido, por lo cual, su exigibilidad tardía es inadmisible al reputarse abusiva y contraria a la buena fe; la caducidad o prescripción, estrictamente, el no ejercicio del derecho durante el plazo legal, y la doctrina del acto propio, una conducta incompatible con la precedente, vulneradora de la confianza legítima...."

España, reconoce el "retraso desleal" ("denominado por la doctrina germánica "Verwirkung»", Tribunal Supremo, Sala 1a, sentencia de 24.6.1996)...El Codice Civile It. (R.D. 16 marzo 1942, n. 262, Gazzetta Ufficiale, n. 79 del 4 aprile 1942), trata "Della decadenza" de los derechos que deben ejercerse dentro de un determinado término (Capítulo II, Título V, Libro VI, artículos 2964 a 2969), y la doctrina francesa, refiere a los délais préfix y déchéances ("l'un des grands mystères du droit français»..."51.

$\overline{51}$ Corte Suprema de Justicia. Sala de Casación Civil. Sentencia del 28 de abril de 2011. 
En otra ocasión, el mismo Tribunal se refirió, in extenso, a la figura bajo examen. En dicha oportunidad, el máximo Tribunal de la jurisdicción ordinaria afirmó que "... referir a la doctrina de los actos propios, es reclamar la exigencia de un comportamiento coherente; de ahí que, la concreción de una u otra conducta, según su extensión y efectos, vista en retrospectiva, permite precisar si lo cumplido estaba en la misma línea de lo que, otrora, se ejecutó. Realizado este ejercicio, si lo acaecido no correspondió a lo que en el pasado inmediato tuvo lugar; si no hay puentes comunicantes entre una y otra conducta que le mantengan en su esencia, significa que el acto propio no fue respetado y, contrariamente, el proceder desplegado contradijo su inmediato antecedente, esto es, vulneró el principio analizado.

4. Los orígenes del mismo no parecieran anidar plenamente o, por lo menos, en su verdadera dimensión en el Derecho romano; por el contrario, es usual señalar que su formulación surge en el Derecho intermedio y, de manera particular, que su elaboración fue obra de los glosadores, quienes, en todo caso, repararon en algunas soluciones o decisiones romanas. Lo cierto es que a la escuela de la Glosa, concretamente, a Azo y Accursio, los autores les atribuyen las primeras formulaciones de tal brocardo. A su vez, a BARTOLO, le asignan el fortalecimiento de tal tesis en cuanto que no es viable contradecir los actos propios, salvo cuando opera "factum contra legem"; pero, en los eventos de "secundum legem" y "praeter legem", no resulta posible. Por su parte, BALDO concluyó que no es posible contradecir los propios actos sino en tres hipótesis: i) cuando el acto "ipso iure" no obliga; ii) cuando se actúa en nombre de otro; $y$, iii) a favor de la libertad. Tratando de fortalecer la teoría en comento, refiere casos como la donación o enajenación del comerciante en fraude de sus acreedores, quien no puede revocar tales actos (....)

En el Derecho inglés, así mismo, se adoptó el equivalente a la teoría de los actos propios incorporando la figura del "Estoppel", cuyo significado etimológico alude, con algunas discrepancias entre los diferentes autores, al "estorbo, impedimento, obstáculo, detención" ó "taponar o cerrar la boca con estopa". Empero, a pesar de esas diferencias, concuerdan en que la finalidad es evitar que dentro de un proceso, la parte pueda, válidamente, contradecir su conducta anterior; no le es dable alegar y probar la falsedad de algo que ella misma ha 
acreditado. Además, se le reconoce como una creación de los tribunales y no de la legislación.

De los diferentes "estoppel" desarrollados, o sea, "estoppel of record"; "estoppel by deed"; y, "estoppel in pais o by representación", el primero de tales conceptos desarrolla el principio de la cosa juzgada; el segundo, restringe la posibilidad de contradecir lo dicho en documento solemne. Por igual, la última modalidad memorada, que es la más próxima a la teoría de los actos propios, refiere a la confianza que una persona despierta, con los actos desplegados, en otra, pero, posteriormente, altera la posición asumida previamente. Sin embargo, al "stoppel" se le reconoce una función eminentemente procesal y de carácter defensivo.

Por su parte, en el sistema alemán fue incorporada por la jurisprudencia la figura de la "Verwirkung" o "atraso desleal" y concierne con la inadmisibilidad del ejercicio de un derecho abandonado por un período significativo, desprendimiento que crea en la parte contraria la creencia objetiva de que ya no hará valer tal derecho. Situación semejante, se dice, contraviene la buena fe. No obstante, debe aparecer de manera clara la actitud desleal e intolerable para el adversario.

5. Las reseñas verificadas, con todo y las variables incorporadas en cada región o normatividad, respecto de las cuales no entra la Corte a establecer categorizaciones o ligeras generalizaciones, ponen de presente la teoría de los actos propios o "venire contra factum proprium non valet", que en definitiva conclusión, puede anunciarse que es la coherencia exigida en el comportamiento de las personas, de tal forma que lo realizado en el pasado, que ha servido, a su vez, como determinante o referente del proceder de otras o que ha alimentado, objetivamente, ciertas expectativas, no pueden ser contrariadas de manera sorpresiva, caprichosa o arbitraria, si con ello trasciende la esfera personal y genera perjuicio a los demás.

\section{(...)}

Empero, cumple resaltar que el objetivo último, no es, en verdad, salvar la contradicción del acto o impedir la incoherencia de un determinado comportamiento; 
el fin, esencial, por lo demás, es evitar que con ese cambio de actitud, con esa rectificación se genere un perjuicio a quien despertó alguna expectativa válida por la conducta desplegada anteriormente, es, en otras palabras, dejar incólume la confianza fundada en ese antecedente.

Bajo tales parámetros, oportuno resulta asentar que si bien jurisprudencia y la doctrina no son concordantes en cuanto a los requisitos establecidos para considerar si, en estrictez, procede la teoría de los actos propios, la mayoría converge en señalar los siguientes como tales: i) una conducta relevante que genere en la otra persona un grado de confianza legítima sobre la realización o concreción, en el futuro, de unas consecuencias en particular; ii) que, con posterioridad, emerja otra conducta (quizás una pretensión) que contradiga con evidente y objetiva incoherencia, los antecedentes plantados; iii) que la nueva situación presentada tenga trascendencia en lo jurídico y la virtualidad para afectar lo existente; $y, i v)$ que haya identidad entre quienes resultaron involucrados en uno y otro episodio.

6. Expuestas así las cosas, es pertinente puntualizar ahora que si bien es evidente la necesidad de que las partes observen aquellas líneas de comportamiento, que no contrarien los derroteros ya trazados en sus conductas, ni, menos, minen su credibilidad en el desarrollo precontractual o contractual con desorientaciones perniciosas; a pesar de tan noble propósito, se decía, surge incontestable, de todas maneras, que la observancia irrestricta de sus propios actos no aparece como un deber u obligación absolutos, dado que existen hipótesis en las que ante situaciones similares ó con respecto a actos desplegados con anterioridad por la misma persona, que sirven de apalancamiento para su actuar en el inmediato futuro, le está deferida la posibilidad de apartarse de los mismos. Por consiguiente, no se trata en casos tales, de viabilizar los cambios inesperados, sorpresivos y contradictorios; ni de imponer, irrestricta e irreflexivamente, la observancia permanente e inmodificable de lo actuado.

7. En efecto, la supletoriedad o subsidiariedad es una característica de la regla que se comenta, pues no opera de manera automática ni en todos los eventos, luego no es ilimitada; por ello, en las situaciones en que, hipotéticamente, hay incursión en los predios del acto propio, debe sobrevenir la confrontación del 
suceso en sí con la regulación normativa vigente para determinar la pertinente procedencia. Su vitalidad, entonces, se patentiza en la medida en que el asunto del que se trate no tenga una regulación legal general o especial ante la cual, por su naturaleza, el principio deba ceder. No siempre y de manera rotunda toda reclamación ulterior que pueda contrariar un comportamiento ya agotado debe ser concebida, necesariamente, como la trasgresión de la reseñada regla, pues, como ya se dijera, no son pocas las ocasiones en que la misma ley considera el comportamiento precedente como irrelevante para los efectos de estructurar o encajar en el aludido principio.

8. Ciertamente, existen condiciones o circunstancias que aconsejan e, inclusive, imponen, la variación de comportamientos precedentes. Hay hipótesis en donde es el propio ordenamiento el que autoriza apartarse de la proyección generada a partir de los actos realizados antecedentemente, por lo que, sin duda, variar de conducta y sustraerse o distanciarse de las líneas demarcadas durante un período suficiente para haber generado en el cocontratante algún grado de confianza o la creación de expectativas, no resulta dañino ni deviene atentatorio de la teoría que se comenta. Propicio resulta citar como ejemplos de esta última referencia, la consagración expresa de la retractación en el contrato de venta, incluso, la suposición legal de que ciertos comportamientos indicarían no querer avenirse al contrato (arts. 1858 y ss. C. C.); las donaciones revocables (arts. 125 y 1194); o la condonación de una deuda en testamento (Art. 1187 C.C.); el mismo desistimiento (art. 344 C. de P. C.); el artículo 1259 del C. de Co., con características similares al caso objeto de estudio, en donde, a pesar "de la aprobación de la cuenta", no queda prohibida o excluida la posibilidad de "impugnarla por errores de cálculo", etc. Por manera que existen eventos en que el sujeto interesado puede apartarse, válidamente, de sus actos anteriores sin que ello le ubique en el supuesto que se evalúa..."52 y 53.

52 Corte Suprema de Justicia. Sala de Casación Civil. Sentencia del 24 de enero de 2011.

53 No debemos dejar de subrayar, como providencia destacada, la sentencia del 25 de junio de 2009, en la que la Corte Suprema de Justicia hizo una amplia explicación sobre el alcance de la confianza legítima, en clara consonancia con la doctrina de los actos propios (Exp. 2005-00251). 
Nótese cómo estos pronunciamientos confirman una expansión de la doctrina de los actos propios, a la que la sostenidamente la Sala Civil ha empezado a dar un tratamiento singular y autónomo. Ello puede también colegirse de otras providencias que, en obsequio a la brevedad, no transcribimos, pero en las que se alude al carácter autonómico de la regla que prohíbe volver contra el factum proprium, tal y como sucede en la providencia del 18 de diciembre de 2009. ${ }^{54}$

$\overline{54}$ Ahora bien, la Sala de Casación Laboral de la Corte colombiana, por su parte, se refirió también a la doctrina de los actos propios, respecto de la cual afirmó, en lo medular, que “... un tema jurídico que tiene como sustento el principio de la buena fe es el del respeto al acto propio, en virtud del cual, las actuaciones de los particulares y de las autoridades públicas deberán ceñirse a los postulados de la buena fe. Principio constitucional, que sanciona entonces, como inadmisible toda pretensión lícita, pero objetivamente contradictoria, con respecto al propio comportamiento efectuado por el sujeto (...) se trata de una limitación del ejercicio del derecho que, en otras circunstancias podrían ser ejercidos lícitamente; en cambio, en las circunstancias concretas del caso, dichos derechos no pueden ejercerse por ser contradictorias respecto una de una anterior conducta, esto es lo que el ordenamiento jurídico no puede tolerar, porque el ejercicio contradictorio del derecho se traduce en una extralimitación del propio derecho. El respecto del acto propio requiere entonces de tres condiciones para que pueda ser aplicado: a. Una conducta jurídicamente anterior, relevante y eficaz (...) b. El ejercicio de una facultad o de un derecho subjetivo por la misma persona o centros de interés que crea la situación litigiosa, debido a la contradicción -atentatorio de la buena fe existente entre ambas conductas (...) c. La identidad del sujeto o centro de interés que se vinculan en ambas conductas...". Sentencia del 3 de junio de 2004. Exp. 21255.

Finalmente, tal y como se expresó, esta doctrina, gracias a su dilatado espectro, también ha permeado el Derecho Administrativo -según como se pudo constatar de la lectura de algunos apartes de algunos de los fallos de la Corte Constitucional-, en particular la jurisprudencia del Consejo de Estado. Así sucede con su sentencia del 3 de febrero de 2000 , en la que con apoyo en autorizada doctrina, anotó que, “....ante la omisión de la entidad contratante de efectuar la adjudicación en debida forma, el adjudicatario pudo hacer valer los derechos que surgieron con la aceptación de su propuesta al momento de la suscripción del contrato. Si el contrato fue firmado por el contratista sin objeción alguna, hay que entender que aceptó la forma de pago en él plasmada, vale decir, "mediante presentación de cuenta de cobro acompañada del acta de recibo de la mercancía" y que le es aplicable en consecuencia, la doctrina de los actos propios según la cual "a nadie es lícito venir contra sus propios actos", lo cual le impedía demandar posteriormente derechos contractuales que debieron ser reclamados por el contratista en la debida oportunidad. Sobre esta doctrina ha dicho el profesor Jesús González Pérez: " (.) Como dice una sentencia de 22 de abril de 1967, "la buena fe que debe presidir el tráfico jurídico en general y la seriedad del procedimiento administrativo, imponen que la doctrina de los actos propios obliga al demandante a aceptar las consecuencias vinculantes que se desprenden de sus propios actos voluntarios y perfectos jurídicamente hablando, ya que aquella declaración de voluntad contiene un designio de alcance jurídico indudable, manifestado explícitamente, tal como se desprende del texto literal de la declaración, por lo que no es dable al actor desconocer, ahora, el efecto jurídico que se desprende de aquel acto; y que, conforme con la doctrina sentada en sentencias de esta jurisdicción, como las del Tribunal Supremo de 5 de julio, 14 de noviembre y 27 de diciembre de 1963 y 19 de diciembre de 1964, no puede prosperar el recurso, cuando el recurrente se produce contra sus propios actos. $Y$ 
Es de señalar, una vez auscultado el pensamiento jurisprudencial en el ámbito de las mencionadas jurisdicciones estatales permanentes, que en la esfera arbitral los Tribunales de Arbitramento colombianos se han venido ocupando de la temática en referencia, cada vez con más frecuencia (in crescendo), en muestra del vívido interés que, en los últimos años, se ha registrado alrededor de ella, tanto en la jurisprudencia, como en la doctrina ${ }^{55}$. Así, por vía de ejemplo, en el Laudo Arbitral que dirimió la disputa entre Delta Consultores de Riesgos Ltda. vs. BBVA Seguros Ganadero, Compañía de Seguros S.A. y BBVA Seguros Ganadero, Compañía de Seguros de Vida S.A., se expresó con claridad que "... debe afirmarse que la conducta de los particulares en la ejecución de un contrato, las aceptaciones tácitas, los hechos inequívocos y otros gestos que trascienden el ámbito jurídico tienen valor significativo en el derecho privado, en especial cuando se trata de dilucidar la intención de las partes en un determinado contrato. No puede admitirse que tales verdaderas manifestaciones de voluntad se consideren inocuas o carentes de significación jurídica cuando demuestran una intención clara que se exterioriza de modo contundente en conductas con relevancia para el mundo del derecho, y no es necesario abundar en razones sobre las consecuencias que, con sobrada justificación, se le han dado en la doctrina y la jurisprudencia a las conductas de negación de los propios hechos (venire contra factum proprium). Es claro, desde antiguo, que el ordenamiento no

la de 27 de febrero de 1981 (.) dice que "constituye un principio de Derecho civil y de la Teoría general del Derecho, la inadmisión de la contradicción con una propia conducta previa, como una exigencia de fides que impone el mantenimiento de la palabra dada, la constancia en la conducta, la lealtad a lo pactado o prometido, la observancia de la buena fe, una de cuyas exigencias es la de impedir venire contra factum proprium: principios de la dogmática jurídica que han sido plenamente refrendados por la jurisprudencia:" "(Sentencia de 3 de febrero de 2000, Exp. 10399).

55 En efecto, en la jurisprudencia arbitral, sobre todo la del último lustro, se ha acudido con frecuencia a este instituto, tal y como puede observarse a través de la lectura de varios laudos. Es el caso, entre muchos más, del laudo del 17 de marzo de 2004, proferido con motivo del "...trámite arbitral entre Multiphone S.A. y Bellsouth Colombia S.A"; el del 29 de noviembre de 2005, “...en el caso Germán Alfonso Cia. Ltda. y otros vs. Dataflux S.A. de C.V. y otra"; el del 20 de octubre de 2006, orientado a "...resolver las diferencias entre Giorgio HelmsdorfF Bracoo,.... y Alberto FARJ", y otros, y el encaminado a "...dirimir en Derecho diferencias entre la Beneficencia del Valle Del Cauca E.I.C.E, parte convocante, y La Previsora S.A. Compañía De Seguros, parte convocada". 
puede prohijar la inconsistencia en el actuar, ni mucho menos premiar la carencia de sindéresis, cuando de reclamar las prestaciones de un contrato se trata..."56.

En otro Laudo Arbitral, esta vez para el Tribunal convocado por Genser General Ltda. y Laboratorios Smart S.A., contra Camilo Bernal Prieto, se afirmó que "... la doctrina de los actos propios ha tenido una larga vida en el mundo jurídico (...) en esencia, esta doctrina constituye un límite al ejercicio de un derecho subjetivo, de una potestad o de una facultad, como resultado de la aplicación del principio de la buena fe y de la exigencia natural de observar en el comportamiento jurídico una actitud consecuente, que, por otro lado, impida enervar o destruir de manera ilegítima la confianza debida entre las personas al actuar en el comercio jurídico. La teoría no pretende dar pie a una especie de congelación de las actuaciones jurídicas, según la cual nadie es libre de enmendar o rectificar una determinada postura o decisión. Esto equivaldría a sugerir la infalibilidad de la especie humana y, de paso, significaría un fuerte recorte a la libertad. La verdadera base de la doctrina de los actos propios se encuentra en las expectativas legítimas y razonables. Hay un valor digno de protección cuando una persona deriva de la conducta racional de otra, expectativas plenamente legítimas y razonables. Expectativas que, por otro lado, se conectan con la necesidad de extraer consecuencias prácticas al principio de la buena fe que es una guía central en el desenvolvimiento de las relaciones jurídicas... ${ }^{257}$.

En fin, muy recientemente se profirió otro laudo en el que, para dirimir la controversia surgida entre Occipetrol S.A. y Lukoil Overseas Colombia Ltda., el Tribunal de Arbitramento sostuvo, refiriéndose a la doctrina de los actos propios, que "...no se desconoce la valía que la precitada regla jurídica reviste en la ciencia del Derecho, muy especialmente en la ahora de ahora en la que ha adquirido particular acogida y difusión en el campo doctrinal y también jurisprudencial y en virtud de la cual] se tiene entonces establecido, en línea de principio rector, que toda persona, en consonancia con el postulado de la buena fe, debe comportarse

56 Tribunal de Arbitramento entre Delta Consultores de Riesgos Ltda. vs. BBVA Seguros Ganadero, Compañía de Seguros S.A. y BBVA Seguros Ganadero, Compañía de Seguros de Vida S.A. Laudo arbitral del 24 de octubre de 2002. Cámara de Comercio de Bogotá.

57 Tribunal de Arbitramento entre Genser General Ltda. y Laboratorios Smart S.A., vs. Camilo Bernal Prieto. Laudo arbitral de septiembre 21 de 2007. Cámara de Comercio de Bogotá. 
coherentemente, en guarda de evitar comportamientos ulteriores que, inopinada y paladinamente, contrariando actos precedentes suyos, de suyo vinculantes, afecten prerrogativas o generen un daño en cabeza ajena, así sea in potentia. De allí que se diga, de modo sucinto, pero lapidario, que a las personas no les está tolerado, por regla, contrariar sus propios actos, pues ello lesiona caros y legítimos intereses que el ordenamiento debe proteger, o salvaguardar, tornándose inadmisible el ejercicio de un derecho, en tales condiciones, circunstancia ésta que, en el ámbito judicial, exige la intervención decidida y oportuna del juez, siempre y cuando concurran los presupuestos pertinentes (...)"58.

\subsection{BrasiL}

En lo que respecta a la República Federativa de Brasil, cumple delanteramente destacar que su acogida o recepción se ha dado en múltiples ámbitos. No en vano ha servido de insoslayable valladar para impedir que las conductas contradictorias e incoherentes se abran camino en el interior de su sistema jurídico, en campos diversos como son, por vía de ejemplo, el derecho civil y el derecho administrativo. Ello obedece a que ha sido justamente la buena fe, el fundamento constitucional y legal para la aplicación del venire contra factum proprium non valet en este país del sur de continente americano.

Así las cosas, se ha partido del artículo 37 de la Constitución Nacional, para la construcción, incorporación y consolidación de la doctrina de los actos propios. También se ha recurrido al Código Civil de 2002, el cual contiene una amplia lista de disposiciones que, de una parte, reivindican la valía de la buena fe a todo lo largo del ordenamiento brasilero, y que, de la otra, han constituido el basamento para la consolidación de la doctrina en comento. Así sucede, ad exemplum, con los artículos 879, 765, 164, 1214, 1219, 1268, 1270, 689 y, muy especialmente, dos disposiciones que suelen servir de inequívoco estribo en las múltiples referencias a la doctrina de los actos propios, a saber: el artículo 113 del Código Civil brasilero, conforme al cual "Los negocios jurídicos deben ser

\footnotetext{
58 Tribunal de Arbitramento entre OBRAS CIVILES Y CONSTRUCCIONES PARA LA INDUSTRIA PETROLERA S.A. -OCCIPETROL S.A.- Y LUKOIL OVERSEAS COLOMBIA LTDA. Laudo arbitral de octubre 14 de 2009. Cámara de Comercio de Bogotá.
} 
interpretados conforme a la buena fe y a los usos del lugar de su celebración". Y el artículo 187, que prescribe que "Comete acto ilícito el titular de un derecho que, al ejercerlo, excede manifiestamente los límites impuestos según su fin económico y social y según la buena fe y las buenas costumbres"; sobre éste último artículo se ha dicho que consagra el deber de no hacer que impide el ejercicio de un derecho, cuando éste va en contradicción de una conducta pretérita o propio acto y, en consecuencia, trasgrede la buena fe de quien ha obrado con base en ese propio acto.

Ahora bien, en lo que respecta al desarrollo jurisprudencial, es fecundo el avance de la judicatura brasilera en torno a la mencionada doctrina, habida cuenta de que ha partido del imperativo respeto por la bona fides-ordenado en sede legal y constitucional, como se anticipó- para denegar los comportamientos contradictorios, aun cuando, en algunas ocasiones, no ha utilizado la específica nominación de doctrina de los actos propios o el brocardo venire contra factum proprium non valet.

Así, en providencia fechada del 2 de abril de 2004, el Tribunal Superior de Justicia sostuvo que "... del mismo modo que, en derecho civil, el comportamiento contradictorio implica la violación del principio de buena fe objetiva, es posible pensar, al menos en un primer plano, que la violación del mismo principio se da en el ámbito del proceso civil ..." 59 .

En otro pronunciamiento, el mismo Tribunal aseveró que "... la teoría de los actos propios impide que la administración pública retorne sobre sus propios pasos, perjudicando a los terceros que confiaron en la regularidad de su proceder ..." ${ }^{\prime \prime 0}$, posición que había sido ya esbozada en una providencia pretérita, fechada del 16 de octubre de $1997^{61}$ y que fue reiterada en un fallo ulterior de septiembre 20 de 2004, en el que el Tribunal Superior de Justicia, al conocer de un caso de responsabilidad por el otorgamiento de licencias, se refirió también a la

\footnotetext{
59 Tribunal Superior De Justicia. Sentencia de 2 de abril de 2009. MC 15398 RJ 2009/0051622-9,

60 Tribunal Superior de Justicia. Sentencia de 17 de abril de 1998. SP141-879.

61 Tribunal Superior de Justicia. Sentencia de 16 de octubre de 1997. SP47-015.
} 
imposibilidad en que se hallaba la administración de volver contra sus propios actos, revocando las licencias de operación y funcionamiento que había otorgado, para exonerarse así de la responsabilidad que, en ciertas hipótesis particulares, le correspondía ${ }^{62}$.

También se refirió a la citada doctrina en providencia del 3 de septiembre de 1996, en la que sostuvo que una persona que había reconocido la existencia de una promesa de compraventa no podía, a posteriori, en sede judicial, negar o controvertir dicha existencia, como quiera que con ello contradecía sus actos pretéritos $^{63}$.

Pero lo que resulta más interesante desde el punto de vista de la jurisprudencia brasilera, es el amplio desarrollo que durante los últimos años, esto es, durante 2009, se le dio a la regla del venire contra factum proprium non valet. Así, por citar los ejemplos más representativos, en una sentencia proferida por el Tribunal de Justicia de Río de Janeiro, se afirmó que en el derecho brasilero campea “... la prohibición del comportamiento contradictorio - venire contra factum propriumque, por violar el principio de la buena fe objetiva, impide el reconocimiento del eventual derecho del demandante..."64.

El mismo tribunal, esta vez en pronunciamiento fechado del 4 de septiembre de 2009, sostuvo que la proscripción del comportamiento contradictorio en el marco de un proceso judicial constituía una “... aplicación, en el derecho procesal, de la prohibición general del comportamiento contradictorio (venire contra factum proprium), instituto de corriente aplicación dado el principio de la buena fe objetivo..." (Traducción propia) ${ }^{65}$.

\footnotetext{
62 Tribunal Superior de Justicia. Sentencia de 20 de septiembre de 2004. SP60129.

63 Tribunal Superior de Justicia. Sentencia de 3 de septiembre de 1996. SP. 95539.

64 Tribunal de Justicia de Río de Janeiro. Sentencia de 28 de octubre de 2009. 004254340.2005.8.19.0001 (2009.001.55719)

65 Tribunal de Justicia de Río de Janeiro. Sentencia de 4 de septiembre de 2009. 000595741.2006.8.19.0042 (2009.001.41353)
} 
En ulterior ocasión, se retomó la misma temática, reiterando la aplicación de la doctrina de los actos propios en el ámbito del derecho procesal pero, en esta oportunidad, con fundamento en el principio de lealtad procesal (Código de Procedimiento Civil de la República Federativa de Brasil, arts. 14 y 599); así, aseveró que "... no se puede (...) adoptar un comportamiento contradictorio (prohibición del venire contra factum proprium), debido al principio de lealtad procesal..." ${ }^{\prime 6}$, posición ésta última que fue reiterada en providencia fechada del 24 de junio de $2009^{67}$.

El Tribunal de Justicia del Estado de Minas Gerais, por su parte, ha refrendado la anterior posición, también en múltiples y muy dicientes pronunciamientos, como en la sentencia del 6 de mayo de 2009 en la que dispuso que "... en virtud de la aplicación del principio de la buena fe objetiva en el campo procesal, especificamente del instituto que prohíbe el comportamiento contradictorio-venire contra factum proprium-, no se puede permitir que, en sede de apelación, se sustente una tesis diversa a la esgrimida en la contestación inicial ..."68.

En el campo del Derecho comercial, particularmente del Derecho aseguraticio, el Tribunal de Justicia de Espirito Santo ha dicho que resulta aplicable “... la teoría del venire contra factum proprium, ya adoptada por los tribunales, incluso por el TRIBUNAL SUPERIORDE JUSTICIA, y en cuya virtud se veda el comportamiento contradictorio (...) la aseguradora que recibe el valor de la prima ajustada, en el momento de efectuar el cumplimiento de sus obligaciones en el contrato, en clara violación del principio de confianza, negar el pago de la indemnización asegurada ..."69

66 Tribunal de Justicia de Río de Janeiro. Sentencia de 25 de agosto de 2009. 009493753.2007.8.19.0001 (2009.001.21710)

67 Tribunal de Justicia de Río de Janeiro. Sentencia de 24 de junio de 2009. 023650472.2007.8.19.0001 (2008.001.65106)

68 Tribunal de Justicia del Estado de Minas Gerais. Sentencia de 6 de mayo de 2009. 1.0701.06.156416-0/002(1)

69 Tribunal de Justicia de Espirito Santo. Sentencia de 28 de julio de 2009. 24089008940 
En fin, otros pronunciamientos en los que ha tenido cumplida aplicación la antedicha doctrina de los actos propios, en sede jurisprudencial, son, ad exemplum, las sentencias del 3 y el 17 de noviembre de 2009, del 22 de septiembre del mismo año, del 22 de julio de 2009 -en el que es cabal la explicación que hace el Tribunal de Justicia de Río de Janeiro de la doctrina y sus figuras afines-y del 30 de junio de 2009, todas ellas proferidas por el Tribunal de Justicia de Río de Janeiro. También la providencia del 28 de octubre de 2009 del Tribunal de Justicia del Estado de Rio Grande Do Sul, por citar algunos de los más dicientes.

\subsection{Perú}

La República del Perú también ha sido escenario para el desarrollo de la doctrina de los actos propios, como quiera que se ha realizado un o desarrollo jurisprudencial en cuya virtud se ha reivindicado la importancia de la misma, partiendo del artículo 1362 de su Código Civil, habida cuenta que éste prescribe que "los contratos deben negociarse, celebrarse y ejecutarse según las reglas de la buena fe y común intención de las partes", y, consecuentemente se erige en soporte para la descrita reivindicación y expansión de la regla del venire contra factum proprium en Perú, como quiera que ésta última, como reiterativamente se ha afirmado, es una palmaria materialización del principio de la bona fides y, por consiguiente, se abrirá paso en todo sistema en el que a su vez tenga cabida dicho principio.

Otro artículo que ha servido de sustentáculo complementario para la recepción de la doctrina, es el artículo 168, que dispone que "El acto jurídico debe ser interpretado de acuerdo con lo que se haya expresado en él y según el principio de la buena fe". Como ya se anotó, la referencia normativa a la bona fides sirve de fundamento legal para incorporar o incardinar la doctrina de los actos propios, en la medida en que ésta última es justamente una materialización del antedicho principio.

Pues bien, partiendo de los anteriores pilares normativo, los tribunales del Perú han dado aplicación a la regla del venire contra factum proprium, como lo refleja en forma palmaria la sentencia de Casación N²208-2005- de la Corte 
Suprema de Justicia de Perú, en la que ésta última explicó que "... de acuerdo con la doctrina de los actos propios, a nadie le es lícito hacer valer un derecho en contradicción con su anterior conducta, cuando ésta, interpretada objetivamente, según la ley, las buenas costumbres o la buena fe, justifica la conclusión de que no hará valer tal derecho. En ese sentido, si las partes han acordado resolver el contrato mediante la configuración de un vicio que han denominado resolutivo y no rescisivo, como dice la ley, debe primar la voluntad establecida por aquellas, no pudiendo desconocer sus propios actos..."70

En otra ocasión, la Sala de Procesos Abreviados y de Conocimiento sostuvo que "... debe el demandante asumir la consecuencia de sus actos, si los enfrentamientos que se produjeron entre las partes, por actos propios de los mismos, trascendieron el círculo íntimo y fueron de conocimiento incluso de organismos internacionales; hecho que motivó la difusión de la carta de renuncia del demandado, entre las personas e instituciones que conocieron sus diferencias, como forma de repeler el agravio que era objeto y recuperar la buena imagen de la cual gozaba ..."71.

En providencia posterior, fechada del 31 de agosto de 1999, la Corte Suprema de Justicia de Perú, afirmó que “... no es posible, permitir que un litigante actúe de manera distinta dentro de un mismo proceso, provocando una determinada conducta de la contraparte, a pesar de lo cual se le admite su proceder. Significa concederle que afecte la llamada doctrina de los actos propios, según la cual ningún litigante puede provocar con sus actos una determinada actuación del otro e intentar posteriormente conseguir beneficios con ello..."72

Otros tribunales, como el Tribunal de Defensa de la Competencia y de la Propiedad Intelectual de dicha nación, sostuvieron que “... no cabe que la denunciada pretende trasladar al denunciante sus problemas administrativos $y$

70 Corte Suprema de Justicia de Perú. Sentencia de Casación № 2208-2005. Lima.

71 Sala de Procesos Abreviados y de Conocimiento. Sentencia de 9 de octubre de 1998. Exp. 2644-98.

72 Corte Suprema de Justicia de Perú. Sentencia de 31 de agosto de 1999. Exp. 2659-99BE-S. 
la falta de control sobre las acciones de sus representantes. En todo caso, debe tenerse en cuenta que el principio de buena fe hace indispensable que en sus relaciones los sujetos observen un comportamiento coherente en sus actos, por lo que no cabe amparar un derecho que se ejercita en contradicción con la anterior conducta del propio actor. Así, resulta inadmisible que la denunciada pretenda librarse de responsabilidad por los hechos denunciados, alegando fundamentos de hecho y de derecho que contradicen sus propios actos, es decir, asumiendo una actitud que lo coloca en contradicción con su conducta anterior, como fue la de dar plena validez al Convenio y tramitar créditos en representación de sus asociados ..."73.

\subsection{C HILE}

El Derecho chileno ha sido también fértil escenario respecto a la incorporación de la doctrina de los actos propios a la praxis jurídica cotidiana, particularmente en sede jurisprudencial, como quiera que ésta última ha servido de percutor para la expansión del venire contra factum proprium a todo lo largo de su corpus jurídico y, muy especialmente, del Derecho privado y el Derecho contractual -o de los contratos-.

Justamente por eso, el cimiento normativo con arreglo en el cual se ha estructurado la doctrina en comento en el régimen chileno, primordialmente ha sido el artículo 1546 de su Código Civil, que dispone: "Los contratos deben ejecutarse de buena fe, y por consiguiente obligan no sólo a lo que en ellos se expresa, sino a todas las cosas que emanan precisamente de la naturaleza de la obligación, o que por la ley o la costumbre pertenecen a ella".

El anterior texto legal ha servido entonces para que la judicatura, en el marco de su competencia, desarrolle la regla del venire contra factum proprium non valet, no sólo en el ámbito del Derecho privado, sino también en otras ramas de la ciencia jurídica, aun cuando no con tanta fuerza como en la primera, al que

73 Tribunal de Defensa de la Competencia y de la Propiedad Intelectual. Sala de Defensa de la Competencia. Resolución N0563-2005 /TDC-INDECOPI. Exp. N 1042-2004/CPC. Mayo 18 de 2005. 
la doctrina agrega otros: los artículos 1481, 1546 y 1683, igualmente del Código Civil de $1855^{74}$.

Así, la Sala 1 de la Cámara Nacional de Apelaciones en lo Civil y lo Comercial Federal, en providencia del 20 de septiembre de 2004 , sostuvo que "... no es lícito hacer valer un derecho o pretensión en contradicción con la anterior conducta de la misma persona, y siempre que este cambio de conducta importe un perjuicio contra otro. O sea contrario a la ley, las buenas costumbres o a la buena fe. En virtud de la figura del acto propio primarán las consecuencias de la primera conducta y se rechazará la pretensión que se invoca y que implica el cambio de la conducta no aceptado..."75.

En otra ocasión, en forma por demás elocuente, sostuvo el antedicho Tribunal que "... la consecuencia de la teoría de los actos propios es la de impedir a un sujeto que realice un acto o una conducta contraria a otro acto o conducta anterior. Esta regla no funda la sanción impuesta en la ilicitud de la conducta contradictoria - pues de hecho puede no existir ilicitud alguna-, sino en que resulta inadmisible proteger un comportamiento incoherente que puede traer aparejada la vulneración de la confianza que ha podido despertarse en un tercero en virtud de un primer acto o conducta, que en doctrina se denomina conducta vinculante Ahora bien, el hecho de que la consecuencia o efecto de la conducta contradictoria es su inadmisibilidad, no importa, por cierto, presumir la mala fe del sujeto activo. En efecto, en la aplicación de la teoría el sujeto pasivo no necesita invocar o atribuir mala fe al sujeto activo, sino que le basta con demostrar la contradicción de la pretensión de este último. Por otra parte, la buena fe del sujeto pasivo, como es regla, se presume y nace naturalmente de la confianza suscitada por la conducta vinculante $y$, por ello, el sentenciador no debe prestar atención a la eventual mala fe del sujeto activo, sino a la buena fe del sujeto pasivo...."76.

74 Cfr. Cristián Boetsch Gillet. La buena fe contractual, op. cit, p. 72, normas éstas que, en lo esencial, se reproducen en el Código Civil colombiano, en cuyo caso igualmente resultarían aplicables, sobre todo las consignadas en los arts. 1538 y 1603 , en su orden, dado que el artículo 1683 sufrió en Colombia una modificación a raíz de la ley 50 de 1936 (art. 1742).

75 Cámara Nacional de Apelaciones en lo Civil y Comercial Federal. Sentencia del 20 de septiembre de 2004. 13.567/02.

76 Corte Suprema de Justicia de Chile. Rol 1492-05. 
Idéntica posición se esgrimió en otra ocasión, en la que la Corte Suprema de Chile afirmó que "... La doctrina de los actos propios prescribe que ninguna persona puede hacer valer un derecho, sea de naturaleza civil o procesal, que se configure en contradicción con una anterior conducta, de carácter jurídico, que haya realizado. Esta exigencia nace como corolario lógico del principio general de la buena fe que informa el derecho privado, que en el caso de la doctrina en comento implica que nadie puede negar para luego afirmar, o viceversa, una situación jurídica determinada, causando con ello perjuicio a un tercero Ahora bien, el ejercicio de una actividad tendiente a hacer valer un determinado derecho interrumpe el plazo de la prescripción extintiva de un derecho. Constituye un acto que genera este efecto, la acción intentada contra el tercero poseedor de la finca hipotecada y su notificación, al constituir una clara manifestación de la intención del titular del derecho de ejercer este mismo. No obsta a lo anterior el hecho de que el tercero poseedor demandado no sea efectivamente el dueño de la finca hipotecada, al haber realizado con ella un contrato de compraventa sin realizar oportunamente la inscripción del dominio en el Registro correspondiente. No puede la demandada alegar tal circunstancia, conforme a la doctrina de los actos propios y de la buena fe..."

Circunscribiéndolo al ámbito del derecho procesal, ha dicho el mismo Tribunal que "... a nadie le es lícito hacer valer un derecho civil o procesal en contradicción con su anterior conducta jurídica (sentencias ingreso Corte Suprema rol 4689-05, 2349-05, 127-05, 3437-04, entre otras). Esta doctrina, conocida como "de los actos propios", ha sido recogida en diversas disposiciones de nuestro Código Civil, como los artículos 1683, 1481, 1546 y, en su forma de expresión conocida como buena fe, informa en carácter de principio general todo el referido cuerpo de leyes. Ella permite al sentenciador ponderar la actitud lógica del actor o de su contraparte, que puede incidir en la acción misma o en un simple incidente (Raúl Diez DuARTE, "El contrato: Estructura civil y procesal", Editorial Jurídica Conosur, 1994, pág. 365 y siguientes). Así, se impide jurídicamente el que una persona afirme o niegue la existencia de un hecho determinado, en virtud de haber antes ejecutado un acto, hecho una afirmación o formulado una negativa en el sentido precisamente opuesto, pues de acuerdo a este principio, nadie puede contradecir

Corte Suprema de Justicia de Chile. Rol. 2100-0. 
lo dicho o hecho por él mismo, con perjuicio de un tercero. De esta manera, los actos propios encuadran el derecho de los litigantes, de forma que no puedan pretender que cuando han reclamado o negado la aplicación de una determinada regla en beneficio propio, puedan aprovechar instrumentalmente la calidad ya negada precedentemente, con perjuicio de los derechos de su contraparte ..."78 $y^{79}$.

En fin, en otra ocasión, también muy afirmativa, la Corte se refirió al valor o status jurídico de la doctrina de los actos propios, haciendo énfasis en el principio de la buena fe. Así, afirmó que “... la doctrina denominada de los actos propios, impone un deber jurídico de respeto y sometimiento a una situación jurídica creada anteriormente por la conducta del mismo sujeto..." ${ }^{\prime \prime}$; para luego agregar que “... los principios generales que informan en derecho, están en un estatus más alto que el de las propias normas, cumpliendo la función legitimadora del mismo. Entre otros principios figuran el ya señalado de la buena fe, que es inspirador a su vez de la doctrina denominada de los actos propios, que impone un deber

78 Corte Suprema de Justicia de Chile. Rol 4689-05

79 Se ha expandido también la doctrina al ámbito del Derecho laboral, como diáfanamente lo expone la prenombrada Corte Suprema, en un pronunciamiento fechado del 20 de diciembre de 2006, en el que sostuvo que "... de acuerdo a la Teoría de los Actos Propios, que postula que a nadie le es lícito ir contra sus propios actos anteriores que expresan su voluntad y definen su posición jurídica en una materia determinada, teoría fundada en el principio general de la buena fe, es posible concluir que hay una aceptación de la existencia de una relación de naturaleza civil con sus respectivas consecuencias, durante el largo período de tiempo señalado, por no haber formulado reclamo alguno en tal sentido (...) En la sentencia Rol 2.45005 citada, la Excma. Corte Suprema añade: "resulta útil recurrir a la denominada Teoría de los Actos Propios, basada en la noción que a nadie le es lícito ir contra sus propios actos anteriores que expresan la voluntad del sujeto y define su posición jurídica en una materia determinada y que se funda, en último término, en el principio más general de la buena fe, la que, ciertamente, tiene plena cabida en el ámbito laboral de que se trata, pues como reiteradamente lo ha decidido esta Corte, la legislación laboral no puede considerarse en forma aislada del ordenamiento jurídico general, que regula las vinculaciones que genera los sujetos del derecho y que, en el caso, se ha traducido en la aceptación por la parte demandante de la existencia de una relación de naturaleza civil con sus respectivas consecuencias, durante más de quince años, sin haber formulada reclamo alguno en tal sentido ..." Corte Suprema de Justicia de Chile. Sentencia del 20 de diciembre de 2006. Rol № 2450-2005.

80 Corte Suprema de Justicia de Chile, Rol 1750-2004, de 28/07/2004. 
jurídico de respeto y sometimiento a una situación jurídica creada anteriormente por la conducta del mismo sujeto. ${ }^{81}$

\subsection{URUGUAY}

En lo que respecta al ordenamiento jurídico uruguayo, éste tampoco se ha mantenido distante o aislado frente a la doctrina de los actos propios, habida cuenta que le ha dado cabal aplicación en múltiples oportunidades en las que la judicatura, partiendo de la consagración constitucional y legal del principio de la buena fe -cardinal orientador de la aplicación de la doctrina en el caso Uruguayo-, ha considerado procedente impedir o denegar una determinada pretensión o defensa, esgrimiendo como fundamento la proscripción de volver contra las propias acciones.

Lo anterior, como se anticipó, con base en disposiciones normativas que, como el artículo $7^{\circ}$ de la Constitución Política de Uruguay ${ }^{82}$, han servido para derivar el citado principio de buena fe. También ha sido definitivo el artículo 1291 de su Código Civil, a cuyo tenor los contratos "... deben ejecutarse de buena fe, y por consiguiente obligan, no sólo a lo que en ellos se expresa, sino a todas las consecuencias que según su naturaleza sean conforme a la equidad, al uso o a la ley".

Pues bien, partiendo de tales disposiciones, ha dicho la Suprema Corte de Justicia que "... cuando el Estado contrata con un particular, debe ajustarse a los principios generales de la contratación, es decir la buena fe y la equidad. No hay duda que posteriormente podrá modificar las condiciones contractuales, en virtud del interés colectivo; si bien en todo caso, actuando de tal modo, alterará las bases económicas del contrato, es claro que deberá indemnizar al particular. Éste, no puede verse afectado en su patrimonio, en función del interés general;

\footnotetext{
81 Ibídem.
}

82 Dispone el artículo $7^{\circ}$ de la Constitución Política de Uruguay que "Los habitantes de la República tienen derecho a ser protegidos en el goce de su vida, honor, libertad, seguridad, trabajo y propiedad. Nadie puede ser privado de estos derechos sino conforme a las leyes que se establecieron por razones de interés general". 
debe aceptar sí, la modificación, pero recibiendo la condigna reparación. En ese sentido, estudiándose la relevancia jurídica de la conducta anterior, es decir, como inciden los actos propios de la Administración, se señala que uno de los elementos que importan es precisamente, una posterior conducta contradictoria con la primera. $Y$, en el presente caso, ese elemento que se destaca o por vía del cual, la Administración lesionó el deber de coherencia que debe estar presente en el comportamiento de la misma. No es legítima esa contradicción, la que, a su vez, vulnera la seguridad jurídica; por lo que si concreta en la realidad, lo jurídico y razonable es exigir la correspondiente indemnización..." ${ }^{\text {83. }}$

En otra oportunidad, el Tribunal de lo Contencioso Administrativo, en providencia fechada del doce de diciembre de 1977, afirmó que “... la promotora de la incidencia carece, por otra parte, no sólo de legitimación sustancial, sino también adjetiva en cuanto funda su pretensión de invalidez en acto propio. $Y$ es estrictamente arreglado a Derecho expresar que si la Administración -por mediación de su representante o delegado- obró en su oportunidad con error al considerar como regular y dar trámite al recurrimiento cuestionado formalmente en la vía anulatoria, no puede en ésta ampararse en dicha circunstancia para desligarse de la confianza depositada en la regularidad de su actuar, para 'venire contra factum proprium'..." 84 .

También se refirió a la doctrina sub-examine, el Tribunal de lo Contencioso Administrativo $2^{\circ}$, mediante sentencia $188 / 92$, en la que dejó dicho que “... la doctrina de los actos propios no es otra cosa que la aplicación de los principios de la buena fe. Esta situación se presenta "cuando se pretende ejercitar algún derecho o facultad en contradicción con anteriores conductas de relevancia jurídica y que también choquen con la buena fe". Es decir, cuando se adopta una conducta diametralmente opuesta a su propia conducta anterior. Ello coincide con el principio de la buena fe..." ${ }^{\prime 85}$. Posición ésta última que fue refrendada en un pronunciamiento posterior del Tribunal de lo Contencioso Administrativo $5^{\circ}$, en el que se sostuvo que “... el órgano judicial no puede amparar pretensiones ambivalentes, contradictorias

\footnotetext{
83 Suprema Corte de Justicia. Sentencia N 157/98.

84 Tribunal de lo Contencioso Administrativo N 123. Sentencia del 12 de diciembre de 1977.

85 Tribunal de lo Contencioso Administrativo $2^{\circ}$. Sentencia 188/92.
} 
entre sí, en forma tal que resulten transgresivas de los principios de lealtad, probidad y buena fe que informan desde su raigambre constitucional (arts. 7, 72 y 332 de la Carta) y su recepción legal expresa en el nuevo ordenamiento procesal (arts. 5 y 63 de CGP) como sostiene LARENZ, hay infracción de la buena fe “... cuando el titular del derecho ha creado con sus actos una situación en la que otra parte podía confiar y después ejercita el derecho del crédito en contradicción con sus anteriores conductas ...", al igual que por el Tribunal de lo Contencioso Administrativo $7^{\circ}$, que en una providencia aseveró que "... el valor del asunto fue establecido expresamente por quien pretende hoy desconocerlo (...) contradicción que debe descalificarse de plano por ilógica e incongruente, acudiéndose al auxilio de la teoría del acto propio (venire contra factum proprium) expuesta por GeLSI (...) y que sustenta justamente en la incoherencia o incongruencia de un sujeto respecto de anteriores comportamientos, verificándose incompatibilidades por contradicción de las mismas ..." ${ }^{\prime 26}$.

Ya más recientemente, en pronunciamiento de 1999, la Suprema Corte de Justicia afirmó que "... no es legítimo, en nombre de la defensa en el proceso, variar las posiciones que se sustentan, sin que se indique un motivo razonable para ello..." $" 87$.

86 Tribunal de lo Contencioso Administrativo $7^{\circ}$. Sentencia 35/94.

87 Suprema Corte de Justicia. Sentencia 149/99.

Se cuenta también con un pronunciamiento del mismo año -sin perjuicio de algunos otros que, en la presente centuria, han desarrollado la temática- en el que el Tribunal de lo Contencioso Administrativo $3^{\circ}$ aseveró que “... la confirmatoria de la impugnada viene dada por la aplicación de la doctrina de los actos propios aplicada al ámbito del proceso civil y con abstracción del ingreso en la temática por parte del Tribunal de la real naturaleza jurídica de la Compañía de Gas. El "venire contra factum proprium non valet", significa que un acto de ejercicio de un derecho subjetivo o de una facultad que contradice el sentido que, conforme a la buena fe, ha de darse a la conducta anterior del titular, constituye una extralimitación: luego, esa pretensión contradictoria con la propia conducta resulta inadmisible y debe ser desestimada por los tribunales. Se torna inoponible la conducta de un sujeto de derecho cuando es contradictoria con otra anterior, jurídicamente válida y eficaz, emanada del mismo sujeto. La conducta asumida por la demandada en el agregado, concretada en la tácita aceptación de la naturaleza jurídica asignada doctrinariamente (...) Y consiguiente no decisión sobre su responsabilidad en el contencioso de derecho público (...) constituye a juicio de la mayoría requerida legalmente una conducta desplegada en el marco de una determinada situación jurídica, omisiva (en tanto se ciñó a la no deducción de impugnación), pero jurídicamente relevante, no errónea y eficaz, y que generó en los actores una expectativa seria de comportamiento futuro, configurándose de ese modo 


\subsection{BOLIVIA}

Bolivia no ha sido tampoco refractaria a la incorporación de puntuales manifestaciones relativas a la doctrina de los actos propios en el seno de su ordenamiento jurídico, muy particularmente del Derecho privado y administrativo, merced al arraigo con que, de antaño, se proyectado la buena fe en dicho ordenamiento, todo lo cual contrasta con una notoria omisión de una disposición relativa a la buena fe en el marco de la reciente Constitución boliviana, por demás moderna, en múltiples aspectos, aun cuando no en este asunto en particular, como si lo han hecho otras cartas políticas, recientemente.

Ello, sin embargo, no sucede igual en la codificación civil, pletórica en referencias a la bona fides en distintos aspectos, como son, por vía de ejemplo, la posesión, la prescripción, el pago y, muy especialmente, la contratación, en donde resultan elocuentes los artículos 465 y 520 del Código Civil; el primero prescribe que "En los tratos preliminares y en la formación del contrato las partes deben conducirse conforme a la buena fe, debiendo resarcir el daño que ocasionen por negligencia, imprudencia u omisión en advertir las causales que invaliden el contrato". Y el segundo dispone que "El contrato debe ser ejecutado de buena fe y obliga no sólo a lo que se ha expresado en él, sino también a todos los efectos que deriven conforme a su naturaleza, según la ley, o a falta de ésta según los usos y la equidad". Estas normas, dicientes por sí solas, han servido de asidero para la incorporación de la doctrina en la órbita Derecho boliviano, específicamente en sede jurisprudencial.

Así las cosas, en Auto supremo fechado del 20 de octubre de 1997, afirmó la Sala Civil de la Corte Suprema de Justicia de la Nación que "...Ese actuar contradictorio resulta inadecuado para el derecho, dado que de otro modo se violentaría el principio que impide venir contra los propios actos..." 88.

los requisitos para la aplicación de la doctrina del "venire contra factum" ...Tribunal de lo Contencioso Administrativo $3^{\circ}$. Sentencia 49/99.

88 Corte Suprema de Justicia - Sala de Casación Civil. Auto de 20 de octubre de 1997. 
Posteriormente, en sentencia 102 del 15 de diciembre de 2003 -también proferida por la Corte Suprema de Justicia de la Nación-, sostuvo la corporación que "... tanto la Superintendencia de Telecomunicaciones como la General, han sido contradictorias en la emisión de las Resoluciones Administrativas impugnadas, respecto a anteriores criterios vertidos por ellas mismas, incurriendo en lo que la doctrina denomina "la teoría de los propios actos". Añade que mediante R.A. 2000/0002, la Superintendencia de Telecomunicaciones dejó claramente establecida su posición en cuanto a que el Art. 142 del Decreto Reglamentario de la Ley de Telecomunicaciones (D.S. N ${ }^{\circ}$ 24132) fija principios de la estructura de tarifas que deben aplicarse y en las cuales no pueden incluirse los llamados cargos de interconexión; por su parte, dice, la Superintendencia General al emitir la R.A. $N^{\circ}$ 2000/346 ratifica lo expresado por la Superintendencia de Telecomunicaciones, en el sentido de que la estructura tarifaria no incluye en ninguna de sus partes el costo de interconexión, manifestando expresamente que "...Las relaciones del operador local, en este caso Cotas con sus abonados, se regula de acuerdo a la estructura tarifaria aprobada por la Superintendencia de Telecomunicaciones, la misma que tampoco en ninguna de sus partes incluye el costo de la interconexión con otros operadores..." ${ }^{189}$.

Relevante fue también la posición consignada en Auto Supremo $\mathrm{N}^{\circ} 162$, fechado del 8 de octubre de 2005 y proferido por la Sala Civil Primera, en el que se dijo que, "...En este sentido, la actitud de los demandantes afecta a la buena fe, a la moral, como fundamento del Derecho, y atenta, además, contra la seguridad jurídica, ya que las mismas personas que otorgan un mandato para vender un inmueble demandan posteriormente la nulidad de los actos realizados en ejercicio de ese poder. Es decir, después de otorgar voluntariamente el poder para vender, atacan o impugnan su propio acto, vulnerando las reglas precedentemente transcritas, desconociendo viejos aforismos aceptados universalmente, tales como: Nemini liceo adversus sua pacta venire, "A nadie es lícito volverse contra sus propios actos; Nemu admittitur aut auditur propian tempitudinem allegano, "A nadie se admite o se oye cuando alega su propia torpeza"..."90.

\footnotetext{
89 Corte Suprema de Justicia - Sala de Casación Civil. Sentencia de 102 del 15 de diciembre de 2003.

90 Auto Supremo N 162 del 8 de octubre de 2005.
} 
Por último, en forma más reciente, en sentencia 153 de 2008, proferida por la Sala Plena de la Corte Suprema de Justicia de la Nación, se trajo también a colación la doctrina de los actos propios, en la que se afirmó que, "...CESSA acató las diferentes resoluciones que emitió la Superintendencia en ejercicio de su función reguladora, reconociendo en todo momento la aplicación de las disposiciones de la Ley de Electricidad y sus reglamentos, por lo que, considerando la doctrina de los actos propios, no puede pretender ahora estar exenta de las obligaciones legales que le corresponden ...."19.

\subsection{Paraguay}

Para concluir con el panorámico examen de los ordenamientos jurídicos, en asocio de su contribución pretoriana. se echará un vistazo al ordenamiento paraguayo, en el cual, aun cuando no ha sido muy prolífero el desarrollo de la doctrina, se cuenta, entre otras providencias, con una somera referencia al deber de coherencia y al principio de la buena fe, en concreto con una sentencia proferida por la Primera Sala del Tribunal de Cuentas y fechada del 17 de octubre de 2005, en la que se revisa la legalidad de un acto administrativo contentivo de una serie de modificaciones al sistema tributario y en el que el antedicho Tribunal se remite a la teoría de los actos propios, justamente para sustentar su posición.

En dicha ocasión se afirmó que “... el intempestivo y hasta -caprichoso cambio de criterio es o constituye por parte de la administración tributaria un acto arbitrario, ilegal e ilegítimo. Esto es así ya que de conformidad a la "Teoría de los Actos Propios", habida cuenta la posición sustentada por la administración en su Nota S.S.E.T. / C.C. No 168 del 1 de diciembre de 1997, no le estaba permitido variar en forma intempestiva y sorpresiva el criterio de aplicación impositiva en ella sustentado y violando el principio de "no sorpresa" pretender, con el aludido cambio de criterio, percibir del administrado un impuesto que hasta ese momento el mismo fisco reconocía que no incidía sobre la firma actora. Debió de haber recurrido a la jurisdicción de este Tribunal mediante la "Acción de Lesividad" para que, mediando el respeto a las normas constitucionales del debido proceso,

$\overline{91}$ Corte Suprema de Justicia - Sala de Casación Civil. Sentencia de 153 de 2008. 
eventualmente el órgano jurisdiccional le diese la razón en su pretensión. La administración tributaria no pudo ni puede pretender desconocer su conducta anterior cuando ésta ha sido ya tenida en cuenta por el administrado, generando consecuencias en la situación del mismo. Dicho de otra forma y siguiendo lo; que enseña Federico Berro en su obra "La Relevancia Jurídica de la Conducta Anterior" al "...definir como "la regía del Derecho anglosajón que, por virtud de una presunción iuris et de jure, impide jurídicamente el que una persona afirme o niegue la existencia de un hecho determinado, en virtud de haber antes ejecutado un acto, hecho una afirmación o formulado una negativa en el sentido precisamente opuesto; pues conforme a este principio, nadie puede contradecir lo dicho o hecho por el mismo o por aquel de quien derive su derecho, de un modo aparente y ostensible, con perjuicio de un tercero que, fiado en esas apariencias, producidas intencional o negligentemente por el responsable de ellas, contrae una obligación o sufre un perjuicio en su persona o en su patrimonio". (SIC, VIDE opus citada páginas 12 y 13)..."92.

En cuanto al fundamento legal que ha servido de asidero para la incorporación de la doctrina, a emulación de lo que ha sucedido en otros ordenamientos jurídicos, en el caso paraguayo suele ser esgrimido para ello el artículo 689 de su Código Civil, el que se refiere justamente a la buena fe. Así, el precitado artículo dispone que "En el desarrollo de las negociaciones y en la formación del contrato, deben las partes comportarse de acuerdo con la buena fe". También se hace referencia a otras disposiciones como el artículo 714 , que prescribe que "... El contrato debe ser interpretado de acuerdo con la buena fe", a la par del artículo 715, en cuya virtud "Las convenciones hechas en los contratos forman para las partes una regla a la cual deben someterse como a la ley misma, y deben ser cumplidas de buena fe. Ellas obligan a lo que esté expresado, y a todas las consecuencias virtualmente comprendidas".

$\overline{92}$ Tribunal de Cuentas. Primera Sala. Sentencia Nº 76/05. Octubre 17 de 2005. 


\section{CONCLUSIONES}

La denominada 'doctrina de los actos propios', o de los propios actos, stricto sensu, no es una figura de reciente aparición, como podría pensarse prima facie, toda vez que es manifestación de una centenaria regla latina, comúnmente conocida mediante el brocardo venire contra factum proprium non valet, obra de los juristas más sobresalientes del Derecho medieval, quienes le dieron un carácter más general. Sin embargo, el Derecho romano (clásico y posclásico), casuista por excelencia, aisladamente se ocupó de concretos supuestos que revelaban un rechazo frontal a específicas conductas contradictorias, huérfanas de coherencia y razonabilidad. Instituciones como la emancipación, el establecimiento de una servidumbre por parte de algunos condóminos, la compra de un fundo ajeno, la alteración perjudicial del comportamiento anteriormente registrado y el respeto por la palabra empeñada, entre otras más, sirvieron de ejemplo del referido rechazo individual a la contradicción comportamental, al mismo tiempo que de ilustrativo antecedente en la materia.

Por consiguiente, el término venire contra factum proprium, en asocio de otros vocablos latinos que expresan análoga idea (adversus factum summ quis venire non potest; venire contra factum proprium nulli conceditur; nemo potest venire contra factum proprium; nemini liceo adversus sua facta venire, nemo potest mutare consilium suum in alterius injuriam, mutare consilium quis non potest in alterius detrimentum, proprium factum nemo impugnare potest, etc.), no se remonta al Derecho romano, como algunos lo han señalado, sino al medieval, en el que también la figura comenzó a perfilarse de mejor manera, gracias a los aportes de los Glosadores, Comentaristas y Canonistas (siglos

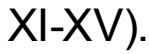


La vigencia y la correlativa aplicación de la regla latina venire contra factum proprium, pese a su raigambre histórica, no han sido constantes, por cuanto en algunos estadios del Derecho fue ignorada o simplemente inaplicada, como aconteció con otros institutos en el marco de la codificación del Derecho, en especial el francés, caracterizado por su acentuado individualismo, por el excesivo y correlativo papel conferido a la autonomía de la voluntad (dogma) y por la falta de confianza en el arbitrio de los jueces. Empero, importa manifestar que, al amparo de los postulados ideológicos de libertad, igualdad y fraternidad, otra hubiera podido ser la suerte de la regla en comentario, pues paradójicamente ellos son los que en la actualidad le sirven de sólido sustento, sin perjuicio de la existencia de otros que coadyuvan en dicha misión estructural, v.gr: la buena fe, mencionada en el artículo 1134 del Código Civil francés, expresamente. Lo propio cabe agregar respecto a los aportes de los juristas J. Domat y R.J. POTHER en este campo, que no tuvieron ulterior eco e incidencia legislativa, con las consecuencias que ello originó en la jurisprudencia y en la doctrina, no sólo en el Derecho francés, sino en buena parte de los demás Derechos europeos y americanos, sobre todo en el siglo XIX.

III

En la esfera del Derecho contemporáneo, la regla venire contra factum proprium fue recepcionada por la doctrina a finales del siglo XIX, particularmente por la alemana (RIEZLER), la que realizó fecundos aportes orientados a su escrutinio histórico, contextualización, delimitación preliminar y revitalización, seguidos de otros más de origen alemán, igualmente valiosos (Griesbeck, Larenz, Canaris, Sieber, Boehmer, Dette, Teichmann, Wieling, Flume, etc.).

Posteriormente, fue la jurisprudencia, también alemana y luego de otras naciones europeas, la encargada de su aplicación, al mismo tiempo que de fijar su alcance, sus presupuestos, límites y, en fin, gran parte de lo que hoy 
se conoce en la órbita jurídica, habida cuenta de la importancia que en esta temática ha tenido el elemento jurisprudencial. Así se evidenció en España, incluso tempranamente, y luego en América Latina con la llamada doctrina de los actos propios; en el Reino Unido, en los Estados Unidos, en Canadá y en Australia, con el estoppel; en Alemania, en Austria y en Suiza fundamentalmente con la verwirkung; en Bélgica y Holanda con la rechtsverwerking, y en Portugal y Brasil con la suppresio, figuras muy próximas entre sí, refractarias a la sorpresa, al cambio comportamental lesivo originado en la incoherencia y la contradicción, detonantes del resquebrajamiento de la confianza suscitada en otro sujeto, v.gr: el cocontratante en el ámbito contractual, en las que ha ocupado un destacado lugar.

Ello también explica, a nivel internacional, el creciente interés no sólo de la doctrina y de la jurisprudencia, sino de la propia legislación internacional y nacional, encaminado a su recepción, gobierno, aplicación y desarrollo, a lo que se agrega el hecho de que los más modernos proyectos legislativos del siglo XXI, en materia de obligaciones y contratos, expresamente se ocupan de ella, en clara muestra de su fuerza y dinámica. Es el caso de los principios sobre 'contratos comerciales internacionales', Unidroit, de los 'principios de Derecho Europeo de los Contratos', del 'Marco Común de Referencia', del 'Anteproyecto de Código Civil francés, del 'Anteproyecto de Código Civil peruano', del Anteproyecto de Código Civil y Comercial argentino', etc. Y en el campo legislativo, de la Convención de Viena sobre el 'derecho de los tratados', y la Convención, también de Viena, sobre 'compraventa internacional de mercaderías'.

\section{IV}

Aun cuando la expresión actos propios no resulta satisfactoria, a la vez que suficientemente reveladora de su significado y alcance, es el vocablo que más se emplea en la praxis doctrinal y jurisprudencial española y latinoamericana, motivo por el cual, con el objeto de no contribuir a la confusión terminológica, la mejor doctrina y la judicatura la emplean habitualmente, sin dejar de reconocer las vicisitudes apuntadas. Quizá por ello, algunos han optado por aludir a su 
raíz, esto es a la referida regla venire contra factum propium non valet, la que sin duda comunica más. Incluso, en algunos círculos autorales, cada vez se utiliza la expresión 'deber de conducta', específicamente de 'coherencia' ('deber de coherencia') que, por estar construido en forma positiva y no negativa, transmite más adecuadamente la idea que se pretende revelar: que los particulares, así como la administración, en línea de principio, tienen que observar una conducta sistemáticamente coherente. Lo mismo acontece con el término 'confianza legítima', la que se está abriendo paso en la esfera doctrinal y jurisprudencial, en especial en puntuales áreas del saber jurídico, v.gr: en el terreno de los Derechos constitucional y administrativo, sin perjuicio que hay autores que la distinguen del acto propio, así encuentren aproximaciones.

También hay que reconocer que el término estoppel, de origen latino y ulterior desarrollo en lengua y en territorio británico, es más expresivo, puesto que vincula la idea de tapar o cerrar (stopare), y de parar o detener (estoppe-stoppe), vocablos que reflejan el mensaje consustancial a esta institución, enderezada a impedir, en últimas, que produzca efectos la conducta contradictoria.

\section{V}

La doctrina de los actos propios, grosso modo, es una institución autónoma, derivada de la buena fe en su dimensión objetiva, cuyo propósito cardinal es impedir el ejercicio incoherente y contradictorio de un derecho subjetivo por parte de su titular, en contravención de la confianza legítima y racional suscitada a raíz de actuaciones precedentes dotadas de relevancia, en sí misma merecedora de tutela por parte del ordenamiento jurídico, inicialmente refractario a los cambios sorpresivos en la conducta de los particulares o de la administración.

\section{VI}

Desde otra perspectiva teleológica, la aplicación cabal y oportuna de la doctrina de los actos propios, a su turno, persigue el desdoblamiento y preservación de relaciones jurídicas transparentes y éticas, a la par que escoltadas 
por comportamientos probos y no sorpresivos que, antijurídicamente, vulneren la confianza depositada por un sujeto de derecho. De ahí su confeso carácter bienhechor, a fuer que esencialmente tuitivo, por cuanto la valía de la doctrina de los actos propios, trasciende la estricta órbita de los particulares, dado que interesa a la sociedad, ávida de coherencia y rectitud en cabeza de la ciudadanía, en general (proyección y alcance social). Por eso no es modélico el ciudadano-y, de paso, el cocontratante- voluble, versátil, contradictorio, sinuoso, inconstante, inestable, insolidario y, en fin, el que desafía el orden justo, la seguridad y los derechos ajenos, creando desconcierto, sorpresa y frustración, suficientes para que el sistema reaccione arbitrando mecanismos e instrumentos encaminados a su reproche y generalizada inadmisión.

De lo aseverado anteriormente se colige que la doctrina en cuestión, por más que se asiente en un apreciable número de elementos de carácter teórico y abstracto, reviste un innegable talante práctico, puesto que es un remedio efectivo contra la contradicción y la falta de coherencia en el comportamiento humano, comprobándose de este modo su cotidiana utilidad y su potencial para solucionar problemas reales.

\section{VII}

Cuatro son los presupuestos esenciales de la doctrina de los actos propios, aunque al respecto no existe pleno acuerdo en la jurisprudencia y la doctrina, en consideración a que el legislador no se ha ocupado de ella. En tal virtud, a nuestro juicio, primeramente se requiere la existencia de una conducta relevante, que además de inequívoca sea objetiva (factum proprium), con el objeto de que la actuación de un determinado sujeto tenga la incidencia suficiente para suscitar confianza legítima y racional en otro. En segundo lugar, se exige el advenimiento de una conducta ulterior contraria a la observada con antelación (factum novum), caracterizada por su incoherencia, contradicción o incongruencia intrínsecas, y por el quebrantamiento de la mencionada confianza. En tercer lugar, es menester que haya identidad de sujetos, es decir que el sujeto emisor de las conductas respectivas (factum proprium, y factum novum), y su destinatario (titular de la confianza), sean los mismos. $Y$ finalmente, que el cambio comportamental 
registrado genere un perjuicio, bien sea real, o potencial, materializado en la lesión de la aludida confianza, ratio protectionis del acto propio.

\section{VIII}

En la actualidad, el postulado rector de la buena fe, que tanta fuerza y dinámica adquirió en el Derecho romano, ocupa de nuevo un sitial de preferencia en la ciencia del Derecho, muy especialmente en el campo del Derecho de obligaciones y contratos, a diferencia de lo que en algunos ordenamientos aconteció, en los que había perdido su prístino brillo y su genuina función. De ahí que en naciones como Francia, Italia y Bélgica, hoy se aluda a su revitalización, reverdecimiento o despertar, entre otras expresiones indicativas de su plausible resurgimiento a finales de la centuria anterior y en lo corrido del siglo XXI, hecho de significación y materia de reconocimiento por el Derecho constitucional, en general, y por algunas de las más modernas constituciones (constitucionalización del principio). Algo similar tiene lugar tratándose de la confianza legítima, tanto en el Derecho privado, como público.

\section{IX}

La conexión entre la buena fe, y el venire contra factum, incluida la doctrina de los actos propios, es y ha sido estrecha, en consideración a que aquélla le sirve no sólo de manantial, sino también de uno de sus férreos basamentos, sin duda alguna el de mayor abolengo. Ello explica que la communis opinio se cimiente en la buena fe, ora como principio general del Derecho, ora como estándar de conducta debida, o bien como límite al ejercicio de los derechos subjetivos, entre varios enfoques, a fin de darle carta de naturaleza y plena legitimidad. Por ello, bien contextualizada dicha regla, no es de recibo su divorcio o desvinculación de la buena fe, conforme un sector minoritario lo ha pretendido. Muy por el contrario, es una de sus arquetípicas aplicaciones, como bien lo señaló la doctrina y la jurisprudencia alemanas en los albores del siglo XX, y posteriormente la española, entre otras más, motivo por el cual se ha entendido que sus vasos comunicantes son insoslayables y su comunión inmarcesible. 
En consecuencia, buena fe y doctrina de los actos propios, forman parte de una misma dimensión global, así no sean figuras simétricas, como efectivamente no lo son, lo que no conspira contra la citada conexión, y con el propósito común de rechazar la incoherencia, la contradicción, la inarmonía, la irregularidad y la correlativa alteración de la confianza legítima.

\section{$\mathbf{X}$}

El factum proprium debe ser diáfanamente diferenciado de otras figuras jurídicas afines, con el objeto de dotarlo de plena fisonomía, pese a la cercanía reinante entre ellas, circunstancia que en efecto ha dificultado su configuración autónoma, muy especialmente en relación con el abuso del derecho. Por lo tanto, importa distinguir la doctrina de los actos propios, de figuras como el negocio jurídico, en general, y la declaración de voluntad, en particular; la renuncia; la buena fe; la excepción de dolo (exceptio doli generalis); el abuso del derecho; la propia culpa o torpeza, el estoppel, la verwirkung, etc.

\section{$\mathbf{X I}$}

El acto propio, o su matriz (venire contra factum proprium), en nuestro entender, no reviste la naturaleza de un típico principio general de derecho -o 'cláusula general'-, como lo entiende un sector de la doctrina, toda vez que, por su carácter residual o subsidiario, al mismo tiempo que por su aplicación excepcional, entre otras potísimas razones más, no encuadra cabalmente en la morfología de los principios en mención, objeto de mesurada floración. Por eso, en lo que concierne a su naturaleza jurídica, tiene asignado el rango de regla (regulae iuris), o de principio jurídico, pero no general, así derive de uno que sí lo tiene: la buena fe, que es cosa enteramente diferente.

\section{XII}

Varios son los fundamentos jurídicos de la doctrina en referencia, por cuanto su peculiar estructura no aconseja prescindir de una plataforma plural. En este 
sentido, el fundamento jurídico-técnico primordial de la doctrina en referencia reside en la coherencia comportamental, la que no puede ser socavada, ni siquiera por parte del titular de un derecho legítimo que, so pretexto de su natural $u$ ordinario ejercicio, pretende conseguir un beneficio a costa de los intereses de otro que, en su oportunidad, no imaginó que luego sería sorprendido en desmedro suyo. En adición a la señalada coherencia, el acto propio igualmente descansa en la consabida buena fe (en sentido más general) y en la confianza legítima (en sentido más particular), sin perjuicio del registro de otros más (seguridad jurídica, solidaridad, razonabilidad, apariencia, etc.).

Aparte de los indicados fundamentos de carácter jurídico, es imperativo reconocer que la doctrina en comento se apoya en otros fundamentos de variada naturaleza que corroboran su arraigo y solidez: filosófica, social, evangélica y económica.

\section{XIII}

El espectro de la doctrina de los actos propios, a la par que de las demás figuras conectadas con la regla venire contra factum proprium, ciertamente es amplio y pareciera que será aún más dilatado en lo venidero, pues no solamente se proyecta en el Derecho privado, originariamente su cuna, sino también en el Derecho público, en plena expansión. Es el caso de los Derechos constitucional, internacional, administrativo, procesal, laboral y tributario, en los que día tras día adquiere mayor cabida, lo que se corrobora con su frecuente y sostenido empleo.

Algo similar acontece en relación con el mencionado Derecho privado, habida consideración que el Derecho de contratos no es el único campo fértil de aplicación de la misma, así probablemente sea el más propicio (fases precontractual, contractual y poscontractual), sino a su vez el Derecho de familia, y el de sucesiones o hereditario. Análoga observación cumple realizar respecto al arbitraje internacional, y la actividad judicial y, en general, al citado Derecho procesal, en el que de hecho reviste marcada significación (conducta procesal). 
El remedio prescrito contra la incoherencia y la contradicción comportamentales, es la inadmisión -o desestimación, inaplicación, paralización, etc.- del derecho subjetivo radicado en cabeza del sujeto voluble, razón por la cual el incoherente, así tenga un derecho o una prerrogativa legítima, no podrá ejercerlo válidamente. Por ello es por lo que se estima que el acto propio se anida en el marco de las limitaciones al ejercicio de los derechos subjetivos. De este modo, la reparación de los perjuicios irrogados, según el caso, no es el efecto connatural de esta doctrina, habida cuenta que no tiene como cometido esencial el resarcimiento de un perjuicio, porque esa no es su auténtica teleología, orientada, ordinariamente a su evitación, inhibiendo que el nuevo comportamiento (factum novum) desdibuje el acto propio (factum proprium), percutor de la confianza que amerita protección. Ese es el costo de la incoherencia y la contradicción jurídicas, en consonancia con el resquebrajamiento de la buena fe, que no pueden quedar impunes.

Ahora bien, en lo que atañe al destino del derecho subjetivo, abogamos por la posición encaminada a su preservación limitada en el mundo del Derecho, dado que no comulgamos con la tesis que pregona su irreversible pérdida o fenecimiento, posición que, por rotunda y expropiatoria, no se aviene con la patología del acto incoherente. Al fin y al cabo, lo neurálgico es la evitación de una lesión a raíz del ejercicio de un derecho lícito, pero permeado por la contradicción conductual, objeto de consecuente rechazo.

\section{XV}

Con la finalidad de tornar plenamente aplicable el remedio emergente de la doctrina de los actos propios, la doctrina y la jurisprudencia dominantes, a la que adherimos, tienen establecido que si las partes o una de ellas, no lo invocan expresamente, el juez puede, mejor aún, debe proceder de oficio, en aras de evitar los efectos adversos de la incoherencia y la contradicción en perjuicio ajeno, en el entendido que se verifiquen todos y cada uno de sus presupuestos genéticos. De este modo, se reafirma el alcance prudencial de la tarea asignada 
al juez contemporáneo, el que no puede permanecer como un simple espectador, indiferente ante la presencia de actuaciones incoherentes, erosivas de la buena fe y la confianza y, en general, de la justicia contractual.

\section{XVI}

No obstante la significación de la regla jurídica de los actos propios, no puede estimarse que no conozca límites, por cuanto es restricta, amén que acotada, a lo que se agrega que tampoco es absoluta, puesto que su aplicación está circunscrita a la verificación de precisos presupuestos y exigencias extrínsecas, de lo que se colige que no cabe mecánica, ni automáticamente. Además, se ha dicho que es un principio jurídico de índole residual o subsidiario, en atención a que sólo se aplica en defecto de una figura específica, en cuyo caso aquél no podría tener cabida, pues se vería desplazado en la esfera jerárquica.

En virtud de lo anterior, no es una figura herculina, ni menos mesiánica o alquímica, a la que se le atribuyen poderes especiales, casi mágicos o sobrenaturales, hasta el punto de que se crea que todo lo puede. De ahí que sin soslayar su importancia, se reitera, no puede procederse con desbordado entusiasmo por parte de juzgadores y actores jurídicos, pues procediendo de esta manera, de bienhechora, se pasaría a la otra orilla, olvidando que la justicia es bifronte o de doble vía, por manera que mirando sólo hacia un lado, se eclipsaría el restante, con grave quebranto de la decisión justa, norte de todo sistema jurídico. Mesura, cautela, ecuanimidad y buen juicio son entonces necesarios con tal propósito.

\section{XVII}

Aunque en el siglo XX y en el XXI la doctrina de los actos propios ha adquirido un status privilegiado en la ciencia del Derecho, no puede aseverarse que sea una figura plenamente madura y, por ende, decantada, toda vez que, sin perjuicio de reconocer los logros alcanzados, aún no está perfilada por completo, lo cual, antes que traducirse indefectiblemente en algo negativo, se erige en una oportunidad constructiva para que la ley, la jurisprudencia, y la doctrina, culminen tan elevada 
misión. He ahí uno de los más importantes retos para este siglo que comienza, el que no puede ser inferior a los anhelos de equilibrio, solidaridad, transparencia, moralidad, limpieza y cohesión socio-jurídica.

\section{XVIII}

Es de esperar que en el futuro la doctrina de los actos propios, en asocio de otras figuras hermanadas, se arraigará aún más, no sólo con la finalidad de expandir sus dominios, en claro beneficio de la scientia iuris, en particular de la justicia contractual, sino también con el objeto de amplificar su vocación preventiva, en sintonía con la tendencia de enfatizar en la prevención o evitación de los perjuicios emanados del quiebre de la confianza legítima y racional.

Por eso se convertirá, ortodoxa y oportunamente aplicada, en una de las figuras con mayor porvenir, propiciando una mejor atmósfera convivencial y una cultura negocial más respetuosa de la buena fe, muy especialmente en lo que se refiere a obrar con estricto apego a caros principios, deberes, reglas y valores, entre otros los relativos a la coherencia, la regularidad, la lealtad, la razonabilidad, el acatamiento de la palabra empeñada, la solidaridad, la eticidad y la decencia comportamentales, clave de bóveda para un mejor y más humanizado mañana contractual. En esta específica dirección, igualmente se espera que a medida en que más se difunda y aplique, se observen mejores prácticas contractuales, desincentivándose, correlativamente, la materialización de conductas signadas por la contradicción y la incoherencia, con tangibles beneficios en el futuro. 



\section{BIBLIOGRAFÍA}

AccarIAs, C. Précis de droit romain, Librairie Cotillon, Paris, T. I, 1886.

Accursio, Factum suum, D.1.7.25, en Corpus iuris civilis iustinianei, cum comentariis Accursi, T.I (Digestum Vetus), 1627.

Aguilar Grieder, Hilda. La extensión de la cláusula arbitral a los componentes de un grupo de sociedades en el arbitraje comercial internacional. Universidad Santiago de Compostela, 2001.

Albaladejo, Manuel. El negocio jurídico, Bosch, Barcelona, 1958.

- $\quad$ Derecho civil, T.I, Vol. I, Bosch, Barcelona 1985.

- $\quad$ La prescripción extintiva, Centro de Estudios, Madrid, 2004.

Albert MÁrquez, Martha. Derecho y valor. Una filosofía jurídica fenomenológica. Universidad de Córdoba, 2004.

AlbertI, Edgardo. Doctrina de los actos propios, La Ley, Buenos Aires, 1986.

AlCAíno ToRREs, Rodrigo. "Comentario acerca de la naturaleza, efectos y orígenes de la regla venire contra factum proprium non valet, que impide contravenir las conductas pasadas", en Revista de Derecho y Tribunales, AMF, № 2, 2006.

Alcaro, Francesco; Bandinelli, Lucia, y Palazzo, Massimo. Effetti del contratto, Edizione Scientifiche Italiane, Napoli, 2011. 
Alonso Pérez, Mariano. "La responsabilidad precontractual”, en Revista de Derecho Crítico Inmobiliario, Madrid, 1971.

- $\quad$ "Extensas anotaciones y concordancias al Derecho español". El error en la doctrina del negocio jurídico. Vittorino PIETROBON, Editorial Revista de Derecho Privado, Madrid, 1971.

ALPA, Guido. I/ principi generali. Giuffrè, Milano, 1993.

- Manuale di diritto privato, Cedam, Padova, 2007.

- Nuevo tratado de responsabilidad civil, Juristas Editores, Lima, 2006.

Alterinı, Atilio A. y López Cabana, Roberto. Responsabilidad civil, Diké, Medellín, 1995.

Álvarez Londoño, Luís Fernando. Derecho Internacional Público. Pontificia Universidad Javeriana, Bogotá. 2007.

AmADEO, José Luis. "Los actos propios en el procedimiento", en Jurisprudencia Argentina, T. 1992-IV.

Anderson, Eugene y Holober, Natalia, Preventing Inconsistencies in Litigation with a Spotlight on Insurance Coverage Litigation: The Doctrines of Judicial Estoppel, Equitable Estoppel, Quasi-Estoppel, Collateral Estoppel, "MEND the Hold," "FRAUD on the Court" and Judicial and Evidentiary Admissions. 4. Insurance Law Journal. 1997-1998.

ANENSON, Leigh. From theory to practice; analyzing equitable Estoppel under a pluralistic model of law. 11, Lewis and Clark Law Review. 633-669, 637 (2007).

Antolín, Mariano. Las ventajas económicas asociadas a las estructuras de confianza. Universidad de León y ACEDE, León. 2009. 
Arangio Ruiz, Vincenzo. Historia del derecho romano, Reus, Madrid, 1994.

-Instituciones de Derecho Romano, Depalma, Buenos Aires, 1973.

Argañarás, Manuel. La prescripción extintiva, TEA, Buenos Aires. 1966.

Arias Ramos, J. y Arias Ramos Bonet, J. A. Derecho romano, T.I, Revista de Derecho Romano, Madrid, 1986.

Aristóteles. Metafísica, Espasa Calpe, Madrid, 2007.

AsCHERI, Mario. Introduzione storica al diritto moderno y contemporaneo, Giappichelli Editore, Torino, 2003.

AsHBURner. Principles of equity, Browne, Londres. 1957.

Astone, Francesco. "Ritardo nell'esercizio del credito, Verwirkung e buona fede", en Riv. dir civ, 2005.

- $\quad$ Venire contra factum proprium, Jovene Editore, Napoli, 2006.

Asser-HARTKAMP. Asser's Handleiding tot de beoefening van het Nederlands burgerlijk recht, Verbintenissenrecht, deel II, Algemene leer der overeenkomsten, 11th edition, by A.S. Hartkamp, Tjeenk Willink, Deventer, 2001.

Assua González, Clara I. "Comentario, artículo 7", en Código Civil Comentado, Vol. I, Dirigido por Ana CañIzares Laso, Pedro de Pablo Contreras, Javier Orduña Moreno, y Rosario Valpuesta Fernández, Thomson Reuters, Pamplona, 2011.

AtAz LóPEZ, Joaquín. "La libertad contractual y sus límites", en Tratado de los contratos, Tirant lo blanch, Valencia, 2009. 
- "Sobre la interversión posesoria”, en Homenaje al profesor Juan Roca J., Murcia, 1989.

Atienza, Manuel y Ruiz Manero, Juan. Las piezas del derecho. Teoría de los enunciados jurídicos, Ariel, Barcelona, 1996.

- $\quad$ llícitos atípicos, Madrid, Trotta, 2000.

AYNES, Laurent. "La confiance en droit privé des contrats", en La confiance en droit privé des contrats, Dalloz, Paris, 2008.

Azonis, Brocardica aurea. D. Azonis Bononiensis Antiquorum luris Consultorum, Neapolis, 1568. ??

BAdENES Gasset, Ramón. El contrato de compraventa, T.I, Bosch Editor, Barcelona, 1995.

Ballarin HeRnÁndez, Rafael. "Reflexiones sobre la referencia del artículo 22 de la ley 49/2003, de 26 de noviembre, de arrendamientos rústicos, al artículo 34 de la ley hipotecaria", en Estudios de derecho de obligaciones, Homenaje al Profesor Mariano Alonso Pérez, La Ley, T.I, Madrid, 2006.

BARBERo, Domenico. Sistema del derecho privado, EJEA, Buenos Aires, 1967.

BARTOLO. In primam digesti veteris partem., Venezia, 1575.

BARROS BoURIE, Enrique. Tratado de responsabilidad extracontractual, Editorial Jurídica de Chile, Santiago, 2006.

BeLLeLLI, Alessandra. "L'inibitoria como strumento generale di tutela contro l'illecito, en Rivista di Diritto Civile, Padova, 2004. 
BerardI, Daniele. "Eccezione di dolo generale, aperura di credito e credito documentario", en L'eccezione di dolo generale. Applicazioni giurisprudenciali, CEDAM, Padova, 2006.

Bercoff, Eduardo. "Doctrina de los actos propios y contrato de seguro", en La Ley, 1994-E, 1182.

Bernal FandiÑo, Mariana. "El deber de coherencia en los contratos y la regla del venire contra factum proprium", en International Law, Revista Colombiana de Derecho Internacional, Pontificia Universidad Javeriana, Bogotá, 2008.

- "El solidarismo contractual: Especial referencia al derecho francés", en Vniversitas. No. 114. Julio-Diciembre, 2007.

- El deber de coherencia en el derecho colombiano de los contratos, Universidad Javeriana, Bogotá, 2012.

BERRo, Federico. La relevancia jurídica de la conducta anterior, Ediciones Jurídicas Amalio Fernández, Montevideo, 1989.

BettI, Emilio. Instituzioni di diritto romano, Vol. I, Dott, Padova, 1947.

- Istituzioni de diritto romano, Vol II, Padova Cedam, 1960.

- "Reflexiones sobre la noción de negocio jurídico", en Teoría general del negocio jurídico, 4 Estudios fundamentales, ARA Editores, Lima, 2001.

- Teoría general de las obligaciones, Editorial Revista de Derecho Privado, Madrid, 1966.

BiAnCA, Massimo. Diritto civile. I/ contratto, Giuffrè, Milano, 1987. 
- Diritto civile. La responsabilitá, Giuffrè, Milano, 1994

- $\quad$ "Técnicas de formación del contrato y tutela del contratante débil: el principio de la buena fe en el derecho privado europeo", en Tratado de la Buena Fe, T. II, La Ley, Buenos Aires, 2004

BIANCHI, Enrique T. e IRIBARNE, Héctor. "El principio general de la buena fe y la doctrina 'venire contra factum proprium non valet', en $E D$, 106-851, Buenos Aires.

Binyuang, Hsiung. The Success of Law and Economics: A Methodological Interpretation. Universidad Nacional de Taiwan, 2000.

BIond, Biondo. Corso de instituzioni di diritto romano, e Siciliana Tipografica, Catania, 1929.

BöEHMER, Gustav. El Derecho a través de la jurisprudencia. Su aplicación y creación, Barcelona, Bosch, 1952.

Boetsch Gillet, Cristián. La buena fe contractual, Editorial Jurídica de Chile, 2011.

Bigot-Preameneu, Félix, Curso de legislación formado por los mejores informes y discursos leídos y pronunciados al tiempo de discutirse el Código de Napoleón, T.II, Imprenta y Litografía de J. Roger, Barcelona, 1841.

Bonfante, Pietro. Instituciones de derecho romano, Reus, Madrid, 1979.

BonneCASE, Julien. L'ecole de l'exégése en droit civil, E. de Boccard, Editeur, Paris, 1924.

Borda, Alejandro. La teoría de los actos propios. Abeledo-Perrot. Buenos Aires. 1986. 
- "Un análisis desde la doctrina argentina”, en Venire contra factum proprium, Universidad de los Andes, Santiago, 2010.

BORDA, Guillermo. "Proyección actual de la Ley 17.711 en materia de responsabilidad civil", en Responsabilidad por daños en el tercer milenio, Homenaje al profesor Doctor Atilio Aníbal Alterini, Teoría general del derecho de daños. Responsabilidades especiales. Derecho privado y procesal: perspectiva y prospectiva / coordinada por Alberto José Bueres, Aída Kemelmajer de Carlucci. Buenos Aires, 1997.

Botero G., Luis Alberto. "La teoría de los actos propios y su inaplicabilidad en el contrato de seguro", en Revista del Instituto Antioqueño de la Responsabilidad Civil y del Estado, Medellín, 2010.

BOWER SPENCER, George. The law relating Estoppel by representation, Butterworths. London, 1977.

BranCA, Giuseppe. Instituciones de derecho privado, Porrúa, México, 1978

Breccia, Umberto, Bıgliazzi Geri, Lina. Natolı, Ugo y Busnelli, Francesco, Derecho civil. Normas, sujetos y relación jurídica, T.I, Vol. I, Universidad Externado de Colombia, Bogotá, 1992.

BRENNER, Ch. "Dos hipótesis fundamentales", en Elementos fundamentales de psicoanálisis, Buenos Aires, Libros Básicos S.C.A, 1968.

BROGGNI, Gerardo. "L'abus de droit et le principe de la bonne foi. Aspects historiques et comparatifs", en Studi di diritto romano e storia del diritto, Jovene Editore, Milano, 2007.

CABABÉ, Michael. The principles of Estoppel. Londres: W. Maxwell \& son, 1888. 
Caballero S., Gaspar. "La doctrina de los actos propios en el derecho administrativo", en Derecho constitucional y administrativo en la Constitución Política de Colombia, Bogotá. Universidad del Rosario y Diké, Bogotá, 1997.

Cabanillas Sánchez, Antonio. Las cargas del acreedor en el derecho civil y en el mercantil, Montecorvo, Madrid, 1988.

- "La delegación de deuda", en Estudios de obligaciones en Homenaje al profesor Mariano Alonso Pérez, T.I, La Ley, Madrid, 2006.

- Los deBERES DE PROTECCIÓN EN EL DERECHO CIVIL, EN EL MERCANTIL Y EN EL LABORAL. CIVITAS, MAdRID, 2000, P. 258.

Caenegem Van, R. C. Pasado y futuro del derecho europeo. Dos milenios de unidad y diversidad. Thomsom-Civitas, Madrid, 2003.

CAGGIA, Fausto. "Fecondazione eterologa e azione di disconoscimento di paternitá intentata del marito", en Diritto e procedura civile, 2010.

Caivano, Roque J. "Silencio, doctrina de los actos propios y renuncia tácita", Revista La Ley, T. 1996-C197.

CalabresI, Guido. Some Thoughts on Risk Distribution and the Law of Torts", en The Yale Law Journal. Vol. 70. 1967.

Calmes, Silvia, Du principe de protection de la confiance légitime en droit allemand, communautaire et français, Dalloz, Paris, 2001.

Cameron, Michael. Equitable estoppel: its genesis, Development and application in government contracting. Cont.L.J. HeinOnline. 19 pub.

CANARIS, Claus-Wilhelm. La riforma del diritto tedesco delle obbligaziioni, Cedam, Milano, 2003. 
Cannata, Carlo Augusto. Lineamenti di storia della giurisprudenza europea, Giappichelli Editore, Torino, 1976.

Cano Martínez, J. Ignacio. La renuncia a los derechos, Bosch, Barcelona, 1986.

CañIzares Laso, Ana. La caducidad de los derechos y acciones, Civitas, Madrid, 2001.

Cariota Ferrara, Luigi. El negocio jurídico, Aguilar, Madrid, 1956.

Carnelutti, Francesco. Sistema de derecho procesal civil. Tomo I. Buenos Aires, 1968.

Carpintero, Francesco. "Una contribución a la metodología jurídica, en lus Commune”, Vittorio Klostermann, Frankfurt, 1977.

CARTWRIGHT, John. "Protecting legitimate expectations and Estoppel: english law", en Benedicte Fauvarque-Cosson, La confiance légitime et l'Estoppel. Droit privé comparé et européen. Societé de législation comparée. Vol. 4. 2007.

Casado Candelas, M. Jesús. Una introducción al estudio del origen de la jurisprudencia romana, Universidad de Valladolid, 1994.

Castan Tobeñas, José. Derecho civil español, común y foral, T.I, Réus, Madrid, 1984.

Castillo Freyre, Mario y Sabroso Minaya, Rita. La teoría de los actos propios, Palestra, Lima, 2006.

- $\quad$ La venta de bien ajeno. Ediciones Caballero Bustamante, Lima, 2010.

Castresana, Amelia. Fides, bona fides, Tecnos, Madrid, 1991. 
Cattaneo, Giovanni, "Buona fede obbiettiva e abuso del diritto", in Riv.trim.dir.proc. civ., 1971.

_ " "Il concurso di colpa del danneggiato", en Rivista di Diritto Civile, Roma, II, 1967.

Cazorla Prieto, Luis María. El lenguaje jurídico actual. Thomson- Aranzadi, Pamplona, 2007.

Celice, B. Le principe de cohérence en matiére contractuelle, Presses Universitaires D'Aix Marseille, Faculté de Droit, Aix-En-Provence, T.I, 2001.

ChAZAL, Jean-Pascal. "Les nouveaux devoirs des contractants. Est-on allé trop loin?", en La nouvelle crise du contrat, Dalloz, Paris, 2003.

CleVES, María José. El principio de confianza legítima en el derecho administrativo colombiano, Universidad Externado de Colombia, Bogotá, 2007.

COASE, Ronald. The Nature of the Firm, en Economica, № 4, 386, noviembre, 1937.

- The Problem of Social Cost, en Journal of Law and Economics, Vol. 3. Octubre de 1960. CIUDAD EDITORIAL

CoIng, Helmut. Derecho privado europeo, Vol. II. Fundación Cultural del Notariado, Madrid, 1996.

Coleman, James Samuel. Foundations of Social Theory. Harvard University Press. Cambridge. 1990.

Coleman, Jules L., Riesgos y daños, Marcial Pons, Madrid, 2010.

Colerio, Juan Pedro. "Derecho Procesal en vísperas del Siglo XXI". Temas actuales en memoria de los profesores Isidoro EISNER y Joaquín ALi SALGADO. Ediar. Buenos Aires. 1997. 
Colin, A. y Capitant, H. Curso elemental de derecho civil, T. III, Reus, Madrid, 1960.

Colombell Mezzomo, Marcelo. "A boa-fe objetiva e seus institutos", en Jus Navegandi, Ano 11, N 1212, 2006.

Comanducci, Paolo., M. Ageles Ahumada y Daniel González Lagier, Positivismo jurídico y neoconstitucionalismo, Fundación Coloquio Jurídico Europeo, Madrid, 2009.

Compagnucci de CAso, Rubén. "La doctrina de los propios actos y la declaración tácita de voluntad”, publicado en La Ley, Buenos Aires, 1985.

- Manual de Obligaciones. Buenos Aires. 1997.

CostanzA, MariA. "Brevi note per non abusare del'abuso del diritto", in Giur. it,2001.

Cooke, P.J.; y Ougthon, D. W. The common law of obligations, London: Butterworths, 1989.

Corneluus, Benjamin A. Dagobert D. Runes, Dictionary of Philosophy, Littlefield, Adams, and Company. Totowa, NJ. New York, 1983.

CoRRAL TALCIANI, Hernán. "La raíz histórica del adagio 'venire contra factum proprium non valet"', en Venire contra factum proprium, Universidad de los Andes, Santiago, 2010.

Cossıo, Carlos. Radiografía de la teoría egológica del derecho, Depalma, Buenos Aires, 1987.

Courdier-Cuisinier, Anne-Silvie. Le solidarisme contractuel, Université de Bourgogne, Litec, 2006. 
CouturE, Eduardo. Fundamentos de Derecho Procesal, Depalma, Buenos Aires, 1958.

Coviello. Nicolás. Doctrina general de derecho civil, Unión Tipográfica Editorial Hispano-Americana, México, 1938.

Coviello, Pedro José. La confianza legítima. Tesis (Doctorado en Ciencias Jurídicas). Universidad Católica Argentina, Facultad de Derecho y Ciencias Políticas, Buenos Aires, 2003.

Cowen, Zelman y CASTER, P.B. Essays on the law evidence, Oxford: Clarendon Press, 1956.

CREMADES, Bernardo M. "La buena fe en el arbitraje internacional", en Revista Internacional de Arbitraje, Universidad Sergio Arboleda y Legis, $\mathrm{N}^{\circ} 15$, Bogotá, 2011.

Cubides Camacho, Jorge. "Los deberes de la buena fe contractual”, en Realidades y Tendencias del Derecho en el Siglo XXI, T. IV, Vol. I, Universidad Javeriana y Temis, Bogotá, 2010.

D'Angelo, Andrea. Buona fede e giustizia contrattuale, Giappicheli Editore, Torino, 2005.

D'ORs, Álvaro. Derecho privado romano, Eunsa, Pamplona, 1981.

Da Rocha, Antonio. Manuel. Da boa fé no direito civil. Almedina, Lisboa, 2001.

DABIN, Jean. El derecho subjetivo, Editorial Revista de Derecho Privado, Madrid, 1955.

Dante FerRarl, Carlos. "La doctrina de las clean hands (manos limpias): una respuesta jurisdiccional fundada en la buena fe y en la equidad". Suplemento 
de derecho de daños. http://www.eldial.com/suplementos/danos/danos.asp [En línea].

Danz, Erich. La interpretación de los negocios jurídicos, Editorial Revista de Derecho Privado, Madrid, 1955.

DAVID, René. Les contrats en droit anglais. L.G.D.J. Paris. 1985.

De Ángel YÁgüez, Ricardo. "Abuso del derecho", en Enciclopedia Jurídica Básica, Civitas, Madrid, 1995.

- Algunas previsiones sobre el futuro de la responsabilidad civil (Con especial referencia a la reparación del daño), Civitas, Madrid, 1996.

- Tratado de la responsabilidad civil, Universidad de Deusto y Civitas, Madrid, 1993.

- $\quad$ "Lealtad en el período precontractual", en Realidades y tendencias del derecho en el siglo XXI. Derecho privado, T. IV, Vol. I, Universidad Javeriana y Editorial Temis, Bogotá, 2010

De Camargo Penteado, Luciano. "Figuras parcelares da boa-fe objetiva e venire contra factum proprium", en Revista de direito privado, Vol. 27, 2006.

De Castro y Bravo, Federico. Derecho civil de España. T.l. Civitas. Madrid. 1984.

- $\quad$ El negocio jurídico, Civitas, Madrid, 1985.

De Cossio y Del BCorral, A. El dolo en el derecho civil, Granada, 2005.

De CupIS, Adriano. El daño. Bosch. Barcelona. 1977. 
De HARO, Carlos L. "Los 'actos propios' en la jurisprudencia del Tribunal Supremo, en Revista de Derecho Privado, Madrid, 1913.

De La Guardia, Ernesto y Delpech, Marcelo. El derecho de los tratados y la convención de Viena de 1969, La Ley, Buenos Aires, 1970.

De LA MAZA G., Iñigo. Los límites del deber precontractual de información, Civitas y Thomson Reuters, Pamplona, 2010.

De la Puente y Lavalle, Manuel. "La Doctrina de los actos propios, en Estudios de Derecho civil, obligaciones y contratos, Libro Homenaje a Fernando Hinestrosa. T.I, Universidad Externado de Colombia, Bogotá, 2003.

De La Rosa Díaz, Pelayo. "Reflexiones sobre la emancipatio", en Estudios jurídicos in memoriam del profesor Alfredo Calonge, Vol. I, Asociación Iberoamericana de Derecho Romano, Salamanca, 2002.

De La Vega Benayas, Carlos. Teoría, aplicación y eficacia en las normas del Código Civil, Civitas, Madrid, 1976.

De Los Mozos, José Luís. El principio de la buena fe, Bosch, Barcelona, 1965.

- El negocio jurídico, Montecorvo, Madrid, 1987.

De Martino. Francesco. Individualismo y derecho romano privado, Universidad Externado de Colombia, Bogotá, 1978.

De Piérola, Nicolás y Loaysa, Carolina. "Los principios generales de derecho de la buena y el estoppel y la regla del agotamiento de la jurisdicción interna en la jurisprudencia de la Corte Interamericana de Derechos Humanos", Gaceta Jurídica online. 2009. 
De Radbruch, Alexy. La injusticia extrema no es derecho. Universidad de Buenos Aires y La Ley. Buenos Aires. 2005.

De Ruggiero, Roberto. Instituciones de derecho civil, Reus, T.I, Madrid, 1979.

De Trazegniez G., Fernando. “Desacralizando la buena fe en el derecho", Tratado de la buena fe, T.II, La Ley, Buenos Aires, 2004.

De Vivero A., Felipe. "La protección de la confianza legítima y su aplicación a la contratación estatal", en Revista de Derecho Público. Universidad de los Andes. Bogotá, 2004.

Del Castillo Sotomayor, Joannis. Repertorium generale rerum notabiliorum, Coloniae, M.DCCXXVI.

Dele Monache, Stefano. "Profilli dell'attuale normativa del codice civile tedesco in tema di prescrizione, en Rivista di Diritto Civile, Milano, 2003.

Delebecque, Philippe. "Formación del contrato (arts. 1104 a 1107)", en Del contrato, de las obligaciones y de la prescripción, Anteproyecto de reforma del Código civil francés. Universidad Externado de Colombia. Bogotá. 2006.

Delgado Echeverría, Jesús y Parra Lucán, María Ángeles. Las nulidades de los contratos, Dykinson, Madrid, 2005.

Dell'Aquila, Enrico. La correteza en el diritto privato, Giuffrè, Milano, 1980.

Demogue, René. Traité des obligations en général, T. IV, Paris, Librairie Arthur Rousseau, 1931.

Den Butter, Frank y Mosch, Robert. Trade and Transaction Costs. Universidad de Amsterdam e Instituto Tinbergen, Amsterdam, 2003. 
Descio-o DeCIL, Filippo, Venire contra factum proprium. Consiliorum, Sive, Tomus Secundus, Venetiis, MDLXXV.

Devis Echandía. Hernando. Compendio de Derecho Procesal. Teoría General del Proceso. Diké. Medellín. 1993

Dı MARZo, Salvatore. Instituzioni di diritto romano, Giuffrè, Milano, 1946.

Dı PrIsco, Nicola. Concorso di colpa e responsabilitá civile, Dott, Napoli, 1973.

Díez-Pıcazo, Luís y Gulzon B., Antonio. Sistema de derecho civil, Vol. I, Tecnos, Madrid, 2004.

Díez PicAzo, Luís, La doctrina de los propios actos, Bosch, Barcelona, 1963

- Derecho de daños. Civitas. Madrid. 1999.

- Fundamentos de derecho civil patrimonial. Introducción y teoría del contrato, Thomson-Civitas, Pamplona, 2007.

- Fundamentos del derecho civil patrimonial. La responsabilidad civil extracontractual, T. V, Civitas y Thomson Reuters, Pamplona, 2010.

- La doctrina del enriquecimiento sin causa, Universidad Javeriana, Depalma y Grupo Editorial Ibáñez, Bogotá, 2011.

- La prescripción extintiva, Thomson-Civitas, Pamplona, 2003.

- Prólogo a la monografía de Franz WIEACKER. El principio general de la buena fe. Civitas, Madrid, 1982. 
- Prólogo a la monografía de Antonio Cabanillas Sánchez. Los deberes de protección en el derecho civil, en el mercantil y en el laboral, Civitas, Madrid, 2000.

Dobson, Juan M. El abuso de la personalidad jurídica. Depalma, Buenos Aires, 1985.

DolmettA, Aldo A. "Exceptio doli generalis", en Banca, Borsa e Titoli di Credito, Vol. LI, Giuffrè, Milano, 1998.

DOMAT, Jean. Les loix civiles dans leur ordre naturel, T. I, Paris, M.DCC.LXXI.

ECKL, Christian. "Algunas observaciones alemanas acerca de la buena fe en el derecho contractual español", en Bases de un derecho contractual europeo, Tirant lo blanch, Valencia, 2003.

Eder J., Phanor. Principios característicos del 'Common Law' y del derecho latinoamericano. Abeledo-Perrot. 1960.

EISNER, Isidoro. "La doctrina de los propios actos compromete también el obrar del tribunal ('venire contra factum proprium non valet')", publicado en La Ley, Buenos Aires, 1987-C.

EKDAHL, María Fernanda. La doctrina de los actos propios. El deber jurídico de no contrariar conductas propias pasadas. Editorial jurídica de Chile, Santiago de Chile, 1989.

Enneccerus, Ludwig. Derecho civil. Parte general, Vol. II, Bosch, Barcelona, 1950.

EsPINOZA E., Juan. “Interpretación del negocio jurídico", en Obligaciones y contratos en el derecho contemporáneo, Universidad de la Sabana, Diké Biblioteca Jurídica, Medellín, 2010. 
EsSER, Josef. Principio y norma en la elaboración jurisprudencial del derecho privado, Barcelona: Bosch, 1961.

Esteban De La Rosa, Gloria. Derecho contractual comparado, Civitas Thomson, Pamplona, 2009.

EstigarRiBia Bibier, María Laura. "La buena fe. Implicaciones actuales en las relaciones negociales", en Contratos. Teoría general, principios y tendencias, Grupo Ibáñez, Bogotá, 2011.

ETCHEVERRY, Raúl Anibal. Interpretación de los contratos atípicos, Universidad de La Sabana y Grupo Editorial Ibáñez, Bogotá, 2012.

EVEREST, Lancelot Feilding. Everest and Strode's Law of estoppels. Londres: Stevens and sons, limited, 1923.

FAGES, Bertrand. Le comportement du contractant, Presses Universitaires D'Aix Marseille, Faculté de Droit, Aix-En-Provence, 1997.

FALCo, Gianluca. La buona fede e l'abuso del diritto, Giuffrè, Milano, 2010.

Fauvarque-Cosson, Benédicte. "La confiance légitime et l'estoppel. Rapport général", en La confiance légitime el l'estoppel, Societé de Législation Comparée, Paris, 2007.

Fernández De Bujan, Federico. Sistema contractual romano, Dykinson, Madrid, 2007.

FERnÁndez-NovoA, Carlos. Tratado sobre derecho de marcas, Marcial Pons, Madrid, 2004.

FerreIRA R. Delia Matilde. La buena fe. El principio general en el derecho civil. Montecorvo. Madrid. 1984. 
FESTI, Fiorenzo. Il devieto di venire contra il fatto proprio, Giuffrè, Milano, 2007.

FINKENAUER, Thomas. El nuevo derecho de prescripción, en La reforma del BGB. Modernización del derecho alemán de obligaciones, Universidad Externado de Colombia, Bogotá, 2006.

Fioravanti, M. Los derechos fundamentales. Apuntes de historia de las Constituciones. Trotta, Madrid, 1996.

FLUME, Werner. El negocio jurídico. Fundación Cultural del Notariado. Madrid. 1998.

FRANZONI, Massimo. "La buena fe y la equidad como fuentes de integración del contrato", en Estudios sobre el contrato en general, Ara Editores, Lima, 2003.

FueYo LANERI, Fernando. "La doctrina de los actos propios", en Instituciones de derecho civil moderno, Jurídica de Chile, Santiago de Chile, 1990.

GAILLARD, Emmanuel. "Le principe de l'éstoppel dans quelques sentences arbitrales récentes", en Revue d'Arbitrage, Paris, 1985.

GALDI, Matteo. Delle servitú prediali, Unione Tipografico-Editrice Torinese, Torino, 1915.

Galgano, F. "El crepúsculo del negocio jurídico", en Teoría general del negocio jurídico, 4 estudios fundamentales, Ara Editores, Lima, 2001.

- El negocio jurídico, Tiranlo blanch, Valencia, 1992.

Gallo, Paolo. Contratto e buona fede, UTET, Torino, 2009.

GANDULFO R., Eduardo. "La aplicación del principio 'venire contra factum proproum non valet'. Un caso de vulgarismo jurídico", en Revista Chilena de Derecho, Santiago, 2005. 
García De Enterría, Eduardo. Derecho, la ley y el Juez. Dos estudios, Madrid, Civitas, 1997.

- "La doctrina de los actos propios y el sistema de lesividad", en Revista de Administración Pública, Madrid, 1955.

García GarRIDo, M.J. Derecho romano privado, Reus, Madrid, 1982.

García Jiménez. Los comportamientos recíprocos en el derecho internacional. A propósito de la aquiescencia, el estoppel y la confianza internacional. Dilex. 2002.

GARCíA MÁYnes. Eduardo. Lógica del raciocinio jurídico, Fontamara, México D.F, 1997.

GaRRIGUes, Joaquín. Contrato de seguro, Aguirre, Madrid, 1982.

Gaudement, Jean. Les naissances du droit, Montchrestien, Paris, 1997.

Gautier, Pierre-Yves. "Confiance légitime, obligation de loyauté et devoir de cohérence", en La confiance en droit privé des contrats, Dalloz, Paris, 2008.

GaZZANIGA, Jean-Louis. Introduction historique au droit des obligations, Presses Universitaires de France, Paris, 1992.

Gazzoni, Francesco. Manuale di diritto privato, Edizioni Scientifiche Italiane, Napoles, 2003.

Germanl, Anna Rita. "Environmental Law and Economics in U.S. and E.U.: A Common Ground?", en SOAS, Universidad de Londres, junio, 2004.

Gete Alonso. María del Carmen. "Comentarios al Código Civil y Compilaciones Forales, Artículo 7", Editorial Revista de Derecho Privado, T. I, Vol., 1, Madrid, 1992. 
- "El derecho subjetivo y la relación jurídica", en Manual de derecho civil, Marcial Pons, Madrid, 1995.

- Estructura y función del tipo contractual, Bosch, Barcelona, 1979.

GHESTIN, Jacques. Cause de l'engagement et validité du contrat, LGDJ, Paris, 2006.

- $\quad$ Traité de drot civil. Les obligations. Le contrat: Formation, L.G.D.J, Paris, 1988.

CARDILl, Riccardo. Bona fides. Tra storia e sistema, Giappichelli Editore, Torino, 2010.

Gibson, Geoffrey. The Arbitrator's companion. Ed. Federation Press. Sydney. 2001.

GIL Rodríguez, Jacinto. "Comentario a la Sentencia del 20 de noviembre de 2001", en Cuadernos Cívitas de Jurisprudencia Civil, No 60.

GIORGIANNI. Virgilio. L'abuso del diritto nella teoria delle norma giuridica, Milano, Giuffrè, 1963.

Gómez ACEBo. "La buena fe y la mala fe; su encuadramiento en la teoría general del derecho y su eficacia en el Código civil”, en Revista de Derecho Privado. T. XXXVI. Madrid.

Gómez Carbajo, Fernando. "Regulae luris", en Textos de derecho romano, Coordinador Rafael Domingo, Aranzadi, Pamplona, 2002.

Gómez Corraliza, Bernardo. La caducidad, Montecorvo, Madrid, 1990.

Gómez EstradA. Contratos Civiles, T.Il, Universidad del Rosario, Bogotá, 2009. 
Gómez Segade, José A. "Preclusión de las acciones del titular de la patente por retraso desleal”, en Actas de Derecho Industrial, 1999.

Gomezzı, Antonni. Ad leges tauri commentarium absolutissimum, Lugduni, M. DCCLXI.

Gonzáles Pérez, Jesús. El principio general de la buena fe en el derecho administrativo, Civitas, Madrid, 1983.

GonzÁles y MARTínez, Jerónimo. "La renuncia en el derecho inmobiliario", en Revista Crítica de Derecho Inmobiliario, T.VIII, Madrid, 1931.

GonZÁlez García, José. “Notas para un concepto de carga”, RGLJ, 1986.

GoRPHE, F. Le principe de bone foi. EDITORIAL Paris. 1928.

GozAIn, Osvaldo A. La conducta en el proceso. La doctrina del acto propio, Librería Editora Platense, La Plata, 1988.

Caducidad de la pretensión por retraso desleal en su ejercicio, La Ley. Buenos Aires. 1987.

GRIFFITH, Virgil Alexis. Outlines of the law: a comprehensive summary of the major subjects of American law. Indianápolis: Bobbs-Merrill, 1950.

Grocio, Hugo. Del derecho de la guerra y de la paz, T.I, Reus, Madrid, 1925.

Grossı, Paolo. El orden jurídico medieval, Marcial Pons, Madrid, 1996.

Grosso. Giuseppe. Le servitu prediali nel diritto romano, Giappiccheli- Editore, Torino, 1969. 
GuASP, Jaime. Derecho procesal civil. Instituto de Estudios Políticos de Madrid, 1968.

Gullon, Antonio. “Art. 7”, en Comentarios del Código Civil, Bosch, Barcelona, 2000.

Guillouard, L. Traité sur la vente et d'échange, A Pedone, Paris, 1982.

GutiÉRREZ, Joannis. Operum. Tractatus tripartitus de juramento confirmatorio, Tomus Sextus, M.DCC.XXX.

Gutierrez-Masson, Laura. "Actos propios y buena fe. En torno a Papiniano 3 Quaestionum". II ruolo della buona fede oggetiva nell'esperienza giuridica storica e contemporanea", Vol III, Cedam, Milano, 2003.

GuzMAN BRITo, Alejandro. “Juristas de los siglos XVI y XVIII”, en Juristas Universales, Rafael Domingo, Editor, Vol. II, Marcial Pons, Madrid, 2004.

- "El vocabulario de la negocialidad jurídica en el derecho romano", en Acto, negocio, contrato y causa en la tradición del derecho europeo e iberoamericano, Thomson- Aranzadi, Pamplona, 2005.

- La codificación civil en iberoamérica. Siglos XIX y XX, Editorial Jurídica de Chile, Santiago, 2000.

HARO, Carlos L. de. "Los 'actos propios' en la jurisprudencia del Tribunal Supremo", en Revista de Derecho Privado, Madrid, 1913.

HAU-SIU CHOW, Irene. How trust reduces transaction costs and enhances performance in China's businesses, en SAM Advanced Management Journal. 2008.

HenRIQUez HeRrera, lan. "Las ragulae iuris como fuente del derecho civil chileno", en IV Jornadas de Derecho Civil, Universidad de los Andes, Santiago de Chile. 
Hinestrosa F. Fernando. La prescripción extintiva, Universidad Externado de Colombia, Bogotá, 2006.

- Tratado de las obligaciones. T.I. Universidad Externado de Colombia, Bogotá, 2002.

- "Codificación y dispersión normativa", en Realidades y tendencias del derecho privado, T.IV, Universidad Javeriana y Editorial Temis, Bogotá, 2010.

HoutclefF, Dimitri. Le principe de cohérence en matiére contractuelle. Paris: Universidad de París XI. Facultad Jean Monnet-Sceaux. Doctorado en Derecho, 2000.

IglesIAS, Juan. Derecho romano, Ariel, Barcelona, 1999.

IRTI, Natalino. La edad de la descodificación, Bosch. Barcelona, 1992.

Izquierdo Tolsada, Mariano. Sistema de responsabilidad civil contractual y extracontractual. Dykinson. Madrid. 2001.

JAMES. Introduction to English law. Londres. 1959.

JAMIN, Christophe. "Le procés du solidarisme contractuel: bréve réplique", en Le solidarisme contractuel- Mythe o realité?, Economica, Paris, 2004.

JARAmILLo J., Carlos Ignacio, El renacimiento de la cultura jurídica. Temis y Pontificia Universidad Javeriana, Bogotá, 2009.

- Derecho de seguros, T.II, Universidad Javeriana y Editorial Temis, Bogotá, 2011. 
- La interpretación de los contratos atípicos y valoración de la conducta de los contratantes. Universidad de La Sabana y Grupo Editorial Ibañez, Bogotá, 2012.

- " "La interpretación del contrato en el derecho privado colombiano", en La Interpretación del contrato en América Latina. T. II. Grijley. Lima. 2007.

- Responsabilidad civil médica, Universidad Javeriana, Bogotá, 2010.

- La prescripción en el contrato de seguro, Universidad Javeriana y Editorial Temis, Bogotá, 2012.

- "Obligaciones, cargas y deberes de conducta del tomador-asegurado en el contrato de seguro", en Derecho de seguros, Universidad Javeriana y Editorial Temis, Bogotá, 2012

Jiménez García, Francisco. Los comportamientos recíprocos en el derecho internacional. A propósito de la aquiescencia, el estoppel y la confianza internacional. Madrid, Dilex, 2002.

JoRDANo BAREA, Juan B. "Dictamen sobre abuso de derecho y fraude a la ley", en Anuario de Derecho Civil, Madrid.

JöRs, P. y KUNKEL, W. Derecho romano privado, Labor, 1937.

JosseRAND, Louis, "Relativité et abus des droits", en Evolutions et actualités, Sirey Paris, 1936.

- $\quad$ El espíritu de los derechos y su relatividad, José M. Cajica. Puebla, 1946.

Jowit. The dictionary of English law. Londres, 1959.

KASER, Max. Derecho romano privado, Reus, Madrid, 1982. 
Kemelmajer De Carluccl, Aída. "Principios y tendencias en torno al abuso del derecho en Argentina", en Revista de Derecho Privado Comunitario Rubinzal-Culzoni, Santa Fé, 2008.

KENFACK, Hugues. "La consagration de la confiance comme fondement de la force obligatoire du contrat?", en La confiance en droit privé des contrats, Dalloz, Paris, 2008.

Koschaker, Pablo. Europa y el derecho romano, Editorial Revista de Derecho Privado, Madrid, 1955.

KOUNEN, Nicolas. La responsabilité précontractuelle, Schulthess, 2007.

KRAFT, J. y RAVIX, L. Corporate Governance and the Governance of Knowledge: Rethinking the Relationship in Terms of Corporate Coherence, en Economics of Innovation and New Technology. Vol. 17. No. 1-2, 2008.

LaCruz Berdejo, José Luís. Elementos de derecho civil, Librería Bosch, Barcelona, 1977.

LAmBRINI, Paola. Dolo generale e regole di correttezza, Cedam, Padova, 2010.

Larenz, Karl. Derecho de obligaciones. Editorial Revista de Derecho Privado. T.I. Madrid, 1958

- $\quad$ Fundamentos de la ética jurídica. Civitas. Madrid. 1985.

- Metodología de la ciencia del derecho, Ariel, Barcelona, 1994.

- Derecho civil, Parte general, Edición Revista de Derecho Privado, Madrid, 1978. 
Lasarte Álvarez, Carlos. Principios de derecho civil, Parte general y derecho de la persona. T. I, Trivium, Madrid, 1992.

LASERRE-Kielow, Valérie. "Contrat y morale", en Los contratos en el Derecho privado, Legis y Universidad del Rosario, Bogotá, 2007.

LaWson, John Howard. Leading cases simplified. A collection of the leading cases of the Common Law. [w.e]. 1959.

Le Tourneau, Philippe. La responsabilidad civil profesional. Legis y Republique Française. Bogotá. 2006.

Lehmann, Heinrich. Parte general, Editorial Revista de Derecho Privado. Madrid. 1956.

LEón A., José Ricardo. La categoría de la obligación 'in solidum', Publicaciones de la Universidad de Sevilla, Sevilla, 1978.

LEón, José María. La culpa de la víctima (“Compensación de culpas”), Universidad de Salamanca, S/F.

Lepointe, G. y Monier, R., Les obligations en droit romain et dans l'ancien droit français, Institut de Droit Romain de L'Université de Paris, Paris, 1954.

LINDGREN, Keven. Estoppel in contract. U.N.S.W.L.J. HeinOnline. 1898.

Llamas Pombo, Eugenio. Orientaciones sobre el concepto y el método del derecho civil. Universidad Javeriana, Colección Internacional. Nㅜ 8. Bogotá. 2009

- "Buena fe y cláusulas abusivas en la contratación con consumidores", en Tratado de la buena fe, T. II, La Ley, Buenos Aires, 2004. 
- "La tutela inhibitoria del daño (la otra manifestación del derecho de daños)", en La responsabilidad profesional patrimonial y el seguro de la responsabilidad civil, Asociación Colombiana de Derecho de Seguros, ACOLDESE, Bogotá, 2005.

Loos, Marco B. M. Right to performance. University of Amsterdam ML/T\&C. PECL. Bw [En línea]

LóPEZ de LA PeÑa, Francisco. Alteración de elementos comunes: consentimiento tácito. Aranzadi - Thomson Reuters [En línea].

López Mesa, Marcelo y Rogel Vide, Carlos. La doctrina de los actos propios. Doctrina y jurisprudencia. Reus y B de F. Buenos Aires. 2005.

LóPEZ Rodo, Laureano. "Presupuestos subjetivos para la aplicación del principio que prohíbe ir contra los propios actos", en Revista de Administración Pública, Madrid, 1952.

LóPEZ VILLEGAS, Eduardo. Derecho y argumentación, Universidad Javeriana y Grupo Editorial Ibáñez, Bogotá, 2011.

LoRenzetTI, Ricardo L. Razonamiento judicial, Lima: Grijley, 1998.

- "Esquema de una teoría sistémica del contrato", en Contratación contemporánea, Palestra y Temis, Bogotá, 2000.

Lyon Puelma, Alberto. "Crítica a la doctrina del acto propio: ¿sanción de la incoherencia o del dolo o la mala fe?", en Venire contra factum proprium, Universidad de los Andes, Santiago de Chile, 2010.

MACHADO, Joao B. "Tutela da confiança e venire contra factum proprium", Obra dispersa, Scientia luridica, 1991. 
Macdougall, Bruce. Consideration and Estoppel: problem and panacea. 15 Dalhouise. HeionOnline. 265. 1992.

McClintock, Henry Lacey. Handbook of the principles of equity. $2^{\mathrm{a}}$. Ed. St. Paul: West Pub. Co., 1948.

MACQUERON, Jean. Historie des obligations. Le droit romain, Association Auguste Dumas, Aix-En-Provence, 1975.

MAfEI, Domenico, Gli inizi dell'umanesimo giuridico, Giuffrè, Milano, 1964.

MAIRAL, Héctor A. La doctrina de los propios actos y la administración pública. Ediciones Depalma. Buenos Aires. 1978.

MAnne, Henry. Our Two Corporation Systems: Law and Economics, en Virginia Law Review, Vol. 53, № 2, marzo de 1967.

Mans Puigarnau, Jaime. Los principios generales del derecho. Repertorio de reglas, máximas y aforismos jurídicos, Bosch, Barcelona, 1969.

Marella, Maria Rosaria y Crucianl, Luca. "Il danno contrattuale", en II nuovo contratto, Zanichelli, Bologna, 2010

MARRRone, Matteo. Instituzioni di diritto romano, Palumbo, Firenze, 2006.

MARson, Jacqueline. L'abus de droit, Librairie Arthur Rousseau, Paris, 1935.

Martín Bernal, José Manuel. El abuso del derecho, Montecorvo, Madrid, 1982.

MARTin, Antoine. L'Estoppel en droit international public, A. Pedone, 1979. 
Martínez Calcerrada, Luís. "La buena fe y el abuso del derecho. Su respectiva caracterización como límite en el ejercicio de los derechos", Revista de Derecho Privado, Madrid, 1976.

MARTINS-CostA, Judith. "La buena fe objetiva y el cumplimiento de las obligaciones", en Tratado de la buena fe, T.II, La Ley, Buenos Aires, 2004.

MASnATTA, Héctor. "Teoría de la penetración y doctrina de las clean hands", en JA. 15-365. 1972.

Maturana, Humberto. La objetividad. Un argumento para obligar, Dolmen Ediciones, Bogotá, 1998 (Impresión de 2002).

Maulaurie, Philippe, Aynes, Laurent y Stoffel-Munnck, Philippe. Les obligations, Lextenso Éditions, Paris, 2011.

MAZEAUD, Denis. "La confiance légitime et l'estoppel". Rapport Française, en 'La confiance légitime et l'estoppel'. Societé de Legislation Comparé, Paris, 2007.

- "Solidarisme contractuel et réalisation du contrat", en Le solidarisme contractuel - Mythe ou réalité. Economica. Paris. 2004.

MAZEAUD, Henri y León y Tunc, André. Tratado teórico y práctico de la responsabilidad civil, T. I, Vol. I, EJEA, Buenos Aires, 1977.

Medicus, Diter. Tratado de las relaciones obligatorias. Bosch. Barcelona. 1995.

Medina Muñoz, Erick. "El estoppel, el verwirkung y la teoría de los actos propios" en Politica y derecho Internacional [En línea].

MeLICH-OrsinI, José. Doctrina general del contrato, Jurídica Venezolana, Caracas, 1985. 
Menezes Cordeiro, Antonio. Tratado de direito civil portugues. Parte general, T.I, Almedina, Lisboa, 2005.

- Da boa fé no direito Civil. Coimbra: Almedina, 2001.

MeruzzI, Giovanni. L'exeptio doli. Del diritto civile al diritto commerciale, CEDAM, 2005.

Messineo, Francesco. Le servitú, Giuffrè, Milano, 1949.

Minivelle, Bernadette y Oehninger Reyes, Alberto. "La doctrina de los actos propios (perspectiva procesal civil)", en Revista Uruguaya de Derecho Procesal. Fundación Cultura Universitaria. N² 2. Montevideo. 2000.

Miquel Gonzales, José María. "Acto propio", en Enciclopedia Jurídica Básica, T. I, Civitas, Madrid, 1995.

- “Observaciones en torno a la buena fe”, en Homenaje al profesor Juan Roca Juan, Universidad de Murcia, Murcia, 1989.

- “Comentario, Sentencia del 25 de enero de 1983”, en Cuadernos Civitas de Jurisprudencia Civil, 1, enero/marzo de 1983.

Mıquel, Joan. Historia del derecho romano, Promociones y Publicaciones Universitarias, Barcelona, 1990.

MoIsset de Espanés, Luis. "La teoría de los 'propios actos' y la doctrina y jurisprudencias nacionales”, en La Ley. 198A 152 y Bol. Fac. de Der, Córdoba, 1982-1983.

Molina Cantó, Eduardo. "Principio de no-contradicción y usos del verbo ser en Aristóteles”, en Onomazein. 7. EDITORIAL Santiago de Chile. 2002. 
Molitor, Erich y Schlosser, Hans. Perfiles de la nueva historia del derecho privado, Bosch, Barcelona, 1975.

Monsalve Caballero, Vladimiro. Responsabilidad precontractual. La ruptura injustificada de las negociaciones, Grupo Editorial Ibáñez, Bogotá, 2010.

MonTÉs, Vicente L. Comentarios a las reformas del código civil, Tecnos, Madrid, 1977.

Morales Hervias, Rómulo. "La doctrina de los actos propios entre el negocio jurídico y el contrato. Historia de una importación impracticable e injusta", en Jurisprudencia civil patrimonial. Análisis y crítica jurisprudencial, Lima, 2006.

Morello, Augusto y Stiglitz, Rubén. "La teoría del acto propio", en Dinámica del contrato. Enfoques. La Plata, Librería Editora Platense, 1985.

Inaplicabilidad de la doctrina del acto propio a la declaración viciada por falta de libertad y por violencia, en La Ley 10/08/2004, Buenos Aires, 2004.

MOSSET ITURRASPE, Jorge. Interpretación económica de los contratos, RubinzalCulzoni, Santa Fe, 1994.

- $\quad$ Responsabilidad por daños, T. IV, Rubinzal-Culzoni, Santa Fé, 1999.

Mota PINTO, Paulo. "Sobre a proibiçao do comportamento contradictório (Venire contra factum proprium) no direito civil", en Boletim da Facultade de Direito, Coimbra, 2003.

-MuÑoz LAVERDE, Sergio. "El principio de buena fe y su incidencia en la interpretación del contrato. Nulidad de las cláusulas abusivas en el derecho colombiano", en Realidades y tendencias del derecho en el siglo XXI, Universidad Javeriana y Editorial Temis, Bogotá, 2010. 
NANNI, Luca. La buona fede contrattuale, Cedam, Milano, 1988.

Neme VilLareal, Martha Lucía. "Venire contra factum proprium, prohibición de obrar contra los actos propios y protección de la confianza legítima. Tres maneras de llamar a una antigua regla de la buena fe", en Estudios de derecho civil obligaciones y contratos. Libro homenaje a Fernando HINESTROSA. T. III. Universidad Externado de Colombia, Bogotá. 2003.

- La buena fe en el derecho romano. Extensión del deber de actuar conforme a la buena fe en materia contractual, Universidad Externado de Colombia, Bogotá, 2010.

NiCOLAU, Noemi. "La doctrina de los actos propios y la verwirkung", Juris, Rosario, 1976.

Niel Puig, Luis. Abuso del derecho, en Responsabilidad por daños en el tercer milenio, Abeledo Perrot, Buenos Aires, 1997.

NIETO, Alejandro. El arbitrio judicial, Ariel, Barcelona, 2000.

Nisimblat, Nattan. "La cosa juzgada en la jurisprudencia constitucional colombiana y el principio del Estoppel en el derecho anglosajón”, en Revista Universitas. No 118. Universidad Javeriana. Bogotá. 2009.

Nolfl, Martín M. La doctrina de los propios actos como garantía de la solidaridad social, en La Ley. Buenos Aires. 1996-B.

Nоотевоом, B. Trust: forms, foundations, functions, failures and figures. Edward Elgar. Cheltenham. 2002.

O’Neill de LA Fuente, Cecilia. "El cielo de los conceptos jurídicos versus la solución de problemas prácticos a propósito de la doctrina de los actos propios", en Themis, Revista de Derecho. Lima. 2005 
Ordoqui C., Gustavo. Abuso de derecho, Pontificia Universidad Javeriana, Colección Internacional, Bogotá, 2010.

- Buena fe contractual. Ediciones del Foro y Universidad Católica del Uruguay, Montevideo, 2005.

- La buena fe contractual, Universidad Javeriana y Grupo Editorial Ibañez, Bogotá, 2012.

- Reflexiones sobre la buena fe contractual, Academia Nacional de Derecho y Ciencias Sociales de Córdoba, Anales, Córdoba. 2008.

- Derecho de daños. La ley, Montevideo, 2012.

Orgaz, Alfredo. La ilicitud, Lerner, Córdoba, 1974.

Ortega LoRCA. Francisco. Quintus Mucius Scaevola. Código Civil, T. X, Reus, Madrid, 1947.

Ortiz Caballero, René. "La doctrina de los actos propios en el derecho civil peruano", en Derecho, N 45, 1991.

Orozco PARDo, Guillermo. De la prescripción extintiva y su interrupción en el derecho civil, Comares. Granada. 1995.

OsPINA, Guillermo y Eduardo. Teoría general de los actos o negocios jurídicos, Temis, Bogotá, 1980.

Ourlac, Paul y De Malafosse, J. Derecho romano y francés histórico. Derecho de obligaciones, Bosch, Barcelona, 1960.

PAdovanı, Andrea. Modernitá degli antiqui, Bononia University Press, Bolonia, 2006. 
Pampillo, Juan Pablo. Hacia un nuevo lus Commune americano, Universidad Javeriana, Escuela Libre de Derecho de México y Grupo Editorial Ibáñez, Bogotá, 2012.

Pardo De Carvallo, Inés. "La doctrina de los actos propios", en Revista de Derecho de la Universidad Católica de Valparaíso, N XV, 1992.

PARDo López, José Luís. "El uso, abuso y no uso de los derechos subjetivos", en Revista de Derecho Privado, T. XLVIII, Madrid, 1964.

Paricio, Javier y Fernández BarReiro, A. Historia del derecho romano y su recepción europea, Centro de Estudios Ramón Areces, Madrid, 1995.

PARICIO, Javier. El legado jurídico de roma, El Faro Ediciones, Madrid, 2007.

Parra Benitez, Jorge. Estudios sobre la buena fe, Librería Jurídica Sánchez, Medellín, 2011.

Pascuau Liaño, Miguel. Jurisprudencia Civil Comentada. Código Civil, T.I, Comares, Granada, 2009.

Passarelli, Santoro. Doctrinas generales de derecho civil, Editorial Revista de Derecho Privado, Madrid, 1964.

PATTI, Salvatore. Profili della toleranza nel diritto privato, Dott, Napoli, 1978.

- "Verwirkung”, en Dig. Disc. Priv, Sez. Civ, XIX, Torino, 1999.

Pedrosa Nogueira. Pedro H. "Notas sobre preclusao e venire contra factum proprium", en Revista de processo, Vol. 168, 2009.

Peláez, Melchor. Tractatus maioratuum et meliorationum Hispaniae, T. II, 1620. 
Peluızz, G. Voz “Exceptio doli”, Enciclopedia del Diritto, Giuffré, Milano.

Perelman, Ch. La lógica jurídica y la nueva retórica, Civitas, Madrid, 1979.

Pérez Luño, Antonio-Enrique. La seguridad jurídica, Ariel, Barcelona, 1994.

Pérez Milzos, Samuel. Comentario exegético al texto griego del Nuevo Testamento, Editorial CLIE, Barcelona, 2009.

PeRLINGeRI, Pietro. Il diritto civile nella legalitá constituzionale, Editorial, Napoli, 1984.

- $\quad$ El derecho civil en la legalidad constitucional, Dykinson, Madrid, 2008.

- Manuale di diritto civile, Edizioni Scientifiche Italiane, Napoles, 1997.

Peyrano, Jorge W., y ChiappinI, Julio O. "La doctrina de los propios actos en el ámbito del procedimiento civil", en Jurisprudencia Argentina, IV, Buenos Aires, 1985.

Phanor J. Eder. Principios característicos del 'Common Law' y del derecho latinoamericano, Buenos Aires: Abeledo-Perrot, 1960.

PIAGGI, Ana I. "Reflexiones sobre dos principios basilares del derecho: la buena fe y los actos propios", en Tratado de la buena fe en el derecho, Buenos Aires: La Ley, 2004.

PIANo MortarI, Vincenzo, La scienza giuridica del siglo XVI. Aspetti della scuola culta, Catania, 1966.

PIco I Junoy, Joan. La buena fe procesal, Universidad Javeriana, Depalma, y Grupo Editorial Ibáñez, Bogotá, 2011. 
_ El principio de la buena fe procesal, Bosch, Barcelona, 2012.

Pietrobon, Vitorino. El error en la doctrina del negocio jurídico, Editorial Revista de Derecho Privado, Madrid, 1971.

Pimenta Batista P., Alexandre. "Entre o individual e o social: o problema das expectativas negociais á luz da teoria dos sistemas (A vedaçao do venire contra factum proprium)", en Revista de direito privado, Vol 24, 2005, p. 14.

Piscitello, Lucia. "Corporate diversification, coherence and economic performance, en Industrial and Corporate Change, Vol. 13 No. 5 (ICC Association) 2004.

Pizza De Luna, Isabel M. "La doctrina de los actos propios y su aplicación en las legislaciones modernas", en Estudios jurídicos en memoria de Eduardo J. Couture, Facultad de Derecho y Ciencias Sociales, Montevideo, 1957.

Planitz, Hans. Principios de derecho privado germánico, Bosch, Barcelona, 1957.

Posner, Richard, Economic Analysis of Law. Aspen Publishers. Chicago. 2011.

PotHIER, R.J., Tratado de las obligaciones, Heliasta, Buenos Aires, 1978.

- Tratado del contrato de compra y venta, Imprenta y Litografía de J. Roger, Barcelona, 1841.

Prieto Sanchis, Luis. Ley, principios y derechos, Dykinson, Madrid, 1998.

- "Neoconstitucionalismo y ponderación judicial”, en Neoconstitucionalismo(s). Trotta. Madrid. 2005.

ProcchI, Federico, "L'exceptio doli generalis e il divieto di venire contra factum proprium”, en L'eccezione di dolo generale, CEDAM, Padova, 2006. 
PufFENDORF, Samuel. Le droit de la nature et des gens, ou systeme général de la moral, de la jurisprudence et de la politique, Paris, 1771.

Pugliese, Giovanni. Actio e diritto subietivo, Giuffrè, Milano, 1939.

Puig BRUtAu, José. La doctrina de los actos propios, en Estudios de Derecho Comparado, Ariel, Barcelona, 1951.

- Introducción al derecho civil. Bosch, Barcelona, 1981.

QuiÑonez Escamez. Ana. "Buena fe y lealtad contractual", en Derecho contractual comparado, Civitas Thomson, Pamplona, 2009.

RABASA, Oscar. El derecho angloamericano. Porrúa, México, 1982.

RADCLIFFE-CRoss. The english legal system, 324-327, London, 1954.

Ramparany-RaVololomiarana, Hobinavalona. Le raisonnable en droit des contrats, LGDJ, Paris, 2009.

Ranierl, Filippo. "Eccezione di dolo generale", en Dig. Disc. Priv. Sez.civ, VIII, Torino, 1991.

- "Exceptio temporaris e replicatio doli nel diritto dell'europa continentale", en Rivista de Diritto Civile, Padova, Cedam, 1971.

- Le principe de l'interdiction de se contradire au detriment d'autre ou du venire contra factum proprium dans les droits allemand et suisse e sa difusion en Europe, en L'Interdiction de se contredire au détriment d'autrui. Economica. Paris. 2007.

-Rinuncia tacita e verwirkung. Tutela dell'affidamento e decadenza de un diritto, Dott, Padova, 1971. 
Reale, Miguel. Introducción al derecho, Ediciones Pirámide, Madrid, 1982.

RECASENS SiCHEs, Luis. "Estudios de filosofía del derecho", en Filosofía del derecho, T. I, Parte sistemática, Unión Tipográfica Editorial Hispano-Americana, México, 1946.

Regnault, Henri. Manuel d'histoirie du droit français, Sirey, Paris, 1947.

Reinoso Barbero, Fernando, Los principios generales del derecho en la jurisprudencia del Tribunal Supremo. Dikynson. Madrid. 1987.

RenGiFo GaRCiA, Ernesto. Del abuso del derecho al abuso de la posición dominante, Universidad Externado de Colombia, Bogotá, 2002.

Rescigno, Pietro, L'abuso del diritto, II Mulino, Bologna, 1998.

Rıccl, Francisco. Derecho civil. De la prescripción. T. XII. La España Moderna, S/F.

Rıccoвono, Salvatore, "Brocardica”, en Nuovo Digesto Italiano, 1957

RIEZLER, Erwin. Venire contra factum proprium. Studien im römischen, englischen und deutschen civilrecht, Leipzig, 1912.

RINALDI, Francesco. "Contratto in genere. Dovere di buona fede", en NGCC, 2005.

RIPERT, Georges. La régle morale dans les obligations civiles, L.G.D.J, Paris, 1949.

RIPERT, Georges, y BOULANGeR, Jean. Tratado de derecho civil -según el Tratado de Planiol-, T.I, Parte general, La Ley, Buenos Aires, 1963.

RisoliA, Marco Aurelio. Soberanía y crisis del contrato, Buenos Aires, AbeledoPerrot, 1974. 
RIVAS GuzMAn, Ramón. "La doctrina de los actos propios y el reglamento interno de la empresa", en Contratos, Editorial Jurídica de Chile, Santiago, 1991.

Rivero Hernández, Francisco, Comentarios al Código Civil, Madrid, 1978.

RoBertson, Andrew. "Towards a Unifying purpose of Estoppel". Monash U.L. Rev. HeinOnline. 1996.

RocA, Encarna. Derecho de daños, Tirant lo blanch, Valencia, 1998.

Rodriguez Boente, Sonia Esperanza, Los principios generales del derecho, Universidad Santiago de Compostela, 2008.

Rodríguez Grez, Pablo. El abuso del derecho y el abuso circunstancial, Editorial Jurídica de Chile, Santiago, 1997.

Rodriguez, Bartolomé. Digesto teorico-práctico, o recopilación de los derechos común, real y canónico por los libros y títulos del Digesto, T.I, Madrid, MCCCLXXV.

RoETTI, Jorge Alfredo. “Aristóteles y el principio de no contradicción”, en Anuario Filosófico. N. 32.1 Universidad de Navarra. 1999.

RogeL VIDE, Carlos. "La doctrina de los propios actos en la última jurisprudencia civil española", Segunda Parte, en La doctrina de los actos propios, en coautoría del Dr. Marcelo López MesA, Reus y B de F, Buenos Aires, 2005.

Rojo AJuRIA, Luis. El dolo en los contratos, Civitas, Madrid, 1994.

Romain, Jean-François. Théorie critique du principe général de bonne foi en droit privé, Bruylant, Bruxelles, 2000. 
Roppo, Vicenzo. I/ contratto. Giuffrè. Milano. 2000.

Rovira BuRgadA, José María. "El principio de los actos propios en materia fiscal, en Revista de la Administración Pública", Instituto de Estudios Políticos, Madrid, 1951.

RUBINSTEIN, Ronald. Iniciación al derecho inglés. Bosch. Barcelona. 1956.

RuDI, Daniel Mario. "Aporte de la Encíclica 'sollicitudo rei socialis' a la doctrina de los actos propios", en El Derecho. T. 138, Buenos Aires.

SACco, Rodolfo. “Affidamento”, en Enclopedia del diritto, Vol I, Giuffre, Milano, 1958.

- II fatto, l'atto, ill negozio, in Trattato di diritto civile, UTET, Turín, 2005.

SACCHI, Alessandro. Tratatto teorico-pratico sulle servitú prediale, Unione Tipografico-Editrice, Torino, 1902.

SAFONTÁs, Simón S. “Doctrina de los propios actos”. Jus. N 5. Buenos Aires. 1964.

SAleILlES, Raymond. Etudes sur la theorie générale de l'obligation d'aprés le premier projet du Code Civil allemand.

Salinas Ugarte, Gastón. Responsabilidad civil contractual, Abeledo-Perrot y Thomson Reuters, Santiago, T.I, 2011.

Sampson, Gary. Greater Coherence in Global Economic Policymaking: A WTO Perspective, en The WTO as an International Organization, Universidad de Chicago, Chicago, 2000.

San Mateo. El Evangelio según San Mateo, Ediciones Cristiandad, Madrid, 1975. 
Sánchez Calero, Fernando. Ley de contrato de seguro, Aranzadi, Pamplona, 1998.

- Ley de contrato de seguro, Comentarios a la ley 50/1980, de 8 de octubre, y a sus modificaciones, Aranzadi, Pamplona, 1999.

SAnsón R., María Victoria. "La buena fe en ejercicio de los derechos y en el cumplimiento de las obligaciones desde la perspectiva del derecho romano privado", en Il ruolo della buona fede oggettiva nell'esperienza giuridica storica e contemporanea, Vol. III, CEDAM, Padova, 2003.

Santoro Passarelli, F. Doctrinas generales de derecho civil, Editorial Revista de Derecho Privado, Madrid, 1964.

Santos Ballesteros, Jorge. Instituciones de responsabilidad civil, Universidad Javeriana, Bogotá, 2006.

- La responsabilidad civil. Parte general, T.I, Universidad Javeriana y Temis, Bogotá, 2012.

SANTos BRIZ, Jaime. La responsabilidad civil. Tomo I. Montecorvo. Madrid. 1993.

SaVATIer, René. Traité de la responsabilité civile, L.G.D.J, T.I, Paris, 1939.

ScARso, Alessandro P. "Venire contra factum proprium e responsabilitá", en Responsabilitá civile e previdenza, №3, 2009.

SCIAlOJA, Vittorio. Negozi giuridici. Soc. Ed del "Foro Italiano", Roma, 1938

- Procedimiento civil romano. Ejercicio y defensa de los derechos, E.J.E.A, Buenos Aires, 1954. 
SCHACHER, Johan Christoph. Disputatio juridica, de impugnatione facti proprii, MDC LXXXVIII.

Schiavone, Aldo. La invención del derecho en occidente, AH Editora, Buenos Aires, 2009.

SCHREIBER, Anderson. A prohibiçao de comportamento contradictório. Tutela da confianca e venire contra factum proprium, Renovar, Rio de Janeiro, 2007.

Schultz, Fritz. Principios del derecho romano. Civitas. Madrid. 1990.

Scognamiglio, Renato. "Risarcimento del danno", en Novissimo Digesto Italiano. Vol. XVI. Torino. 1969.

Sicchiero, Gianluca. "Linterpretazione del contratto ed il principio contra factum proprium venire potest, en Studi in onore de Cesare Massimo BIANCA, Giuffré, Milano, 2006.

SNYDER, David. Comparative law in action: promissory Estoppel, the civil law and the mixed jurisdiction. 15, Arizona Journal of International and Comparative Law, 695 (1998).

SoHm, Rodolfo. Instituciones de derecho romano privado, Antigua Librería Robredo, México, 1951.

Solarte Rodríguez, Arturo. "Buena fe contractual y deberes secundarios de conducta", en Revista Universitas. No 108. Universidad Javeriana. Bogotá. 2004.

- "Relevancia jurídica del silencio en la contratación privada", en Estudios de derecho privado, en Liber Amicorum en homenaje a César Gómez Estrada, Universidad del Rosario, Bogotá, 2009. 
Soто C., Carlos. Teoría de los actos propios, en Hechos de la Justicia, Lima, 2005.

SPENCER BOWER, George. The law relating Estoppel by representation. Butterworths. London. 1977.

Stephen. Comentaries on the Laws of England. Londres. 1950.

Stiglitz, Rubén. Contratos Civiles y comerciales. T.I. Abeledo Perrot. Buenos Aires. 1998.

- $\quad$ Derecho de seguros, La Ley, T.Il, Buenos Aires, 2004.

StIJNS, Sophie. "Consideration á propos de l'arrete de la Court de Casation du 17 mai 1990", en Journal des Tribunaux, Bruxelles, 1990.

S. Stinj et Ise SamoY. "La confiance légitime en droit des obligations, Rapport belge", en La confiance légitime et l'estoppel, Societé de Législation Comparé, Paris, 2007

Sudol, Sabrina. The U.N. Convention on the recognition and enforcement of foreign arbitral awards and issue preclusion: a traditional collateral estoppel determination, Universitty of Pittsburg Law Review. 65. 2004.

Suescún Melo, Jorge. Derecho privado. Estudios de derecho civil y comercial contemporáneo, T.II, Legis, Bogotá, 2003.

Talamanca, Mario. Instituzioni di diritto romano, Giuffre, Milano, 1990.

Tamayo Jaramillo, Javier. De la responsabilidad civil. Tomo I. Temis. Bogotá. 1999.

- Tratado de la responsabilidad civil, T.I, Legis, Bogotá, 2009. 
Tamayo Jaramillo. Javier, y Jaramillo J., Carlos Ignacio. El precedente judicial en Colombia. Papel y valor asignados a la jurisprudencia, Universidad Javeriana y Grupo Editorial Ibáñez, Bogotá, 2011.

TAmburINo, Guiseppe. Le servitú, Unione Tipografico-Editrice Torinese, Torino, 1968.

Todesco, Sara. Per una riconstruzione teorico-generale del concetti di abuso del diritto, Padova, 2008.

Tomas y Valiente, Francisco. Manual de historia del derecho Español, Tecnos, Madrid, 1992.

ToRrente, Andrea. “Eccezione di dolo”, en Enciclopedia del Diritto, Giuffrè, Milano,

TRABUCCH, Alberto. /l dolo, Dott, Milano, 1937.

- $\quad$ Instituzioni di diritto civile, Cedam, Padova, 1974

TUR FAUndez, Nelida. La prohibición de ir contra los actos propios y el retraso desleal, Aranzadi y Thomson Reuter, Pamplona, 2011.

UBALDI, Baldo. Digesti veteris partem Commentaria, L. XXVI, Venetiis, M.D. LXXVII.

Valbuena HeRnÁndez, Gabriel. La defraudación de la confianza legítima. Universidad Externado de Colombia. Bogotá. 2008.

VALDECASAS, Guillermo, "Los principios generales del derecho en el nuevo título preliminar", en Anuario de Derecho Civil, serie 1, número 2, Madrid.

Valencia Restrepo, Hernán. Nomoárquica, principialística jurídica o filosofía y ciencia de los principios generales de derecho, Temis, Bogotá, 2005. 
VALLESPINOS, Carlos Gustavo. El contrato por adhesión a condiciones generales, Universidad, Buenos Aires, 1984.

Vallet de Goytisolo, Juan. "Vida jurídica. Nota crítica, Doctrina de los actos propios", Luis Dízz-PICAZo, en Anuario de Derecho Civil. T. XVI, Fascículo I. 1963.

Valbuena Hernández, Gabriel. La defraudación de la confianza legítima. Aproximación crítica desde la teoría de la responsabilidad del Estado, Universidad Externado de Colombia, Bogotá, 2008.

Van Caenegem, R.C. Pasado y futuro del derecho europeo. Dos milenios de unidad y diversidad, Thomson-Civitas, Madrid, 2003.

VAQUeR Aloy, Antoni. "El retraso desleal en el ejercicio de los derechos. La recepción de la doctrina de la verwirkung en la jurisprudencia española", en Revista de Derecho Patrimonial, 1999.

Vaquer Aloy, Antoni y Cucurull Serra, Núria. ¿Solvencia recuperada en buen momento? Aplicaciones jurisprudenciales de la Verwikung en el juicio ejecutivo", en InDret, 274, Barcelona, 2005,

VENOSTA, Francesco. "Note sull'exceptio doli generalis", en Banca, borsa tit. cred., 1989.

Viana Cleves, María José. El principio de confianza legítima en el derecho administrativo colombiano. Universidad Externado de Colombia. Bogotá. 2007.

VIARO, Silvia. "Abuso del diritto ed ecceszione di dolo generale", en L'eccezione di dolo generale. Applicazioni giurisprudenciali, CEDAM, Padova, 2006.

VIEHWEG, Theodor. Tópica y jurisprudencia. Thomson Civitas, Pamplona, 2007. 
VIGo, Rodolfo L. "El neoconstitucionalismo y la función judicial: Límites, riesgos y perspectivas". I Congreso de la Corte Suprema de Justicia. Temis. Bogotá. 2006.

- La injusticia extrema no es derecho (De Radbruch a Alexy), Universidad de Buenos Aires y La Ley, Buenos Aires, 2005.

- Constitucionalización y judicialización del derecho, Universidad Javeriana y Grupo Editorial Ibañez, Bogotá, 2012.

VINEY, Geneviéve, y JourdaIn, Patrice. Traité de droit civil. Les conditions de la responsabilité, L.G.D.J., Paris, 2006.

VIVES, Luis María. “Doctrina de los actos propios”, La Ley, Buenos Aires, 1987-B, 946.

VolterRa, Eduardo. Instituciones de derecho privado, Civitas, Madrid, 1991.

Von Thur, Andreas. Derecho civil. Teoría general del derecho civil alemán. Los hechos jurídicos, Vol. II, Depalma, Buenos Aires, 1947.

WACKE, Andreas. "La 'exceptio doli' en el derecho romano clásico y la 'verwirkung' en el derecho alemán moderno", en Derecho romano de obligaciones, Homenaje a José Luís MuRga Gener, Centro de Estudios Ramón Areces, Madrid, 1994.

WeIszBeRg, Guillaume. "Actualité de la théorie de l'éstoppel dans la jurisprudence" (fr). JurisPedia. 2007.

Wesenberg, Gerhard y Wesener, Gunter, Historia del derecho privado moderno en Alemania y en Europa, Lex Nova, Valladolid, 1998. 
WIEACKER, Franz. Historia del derecho privado de la edad moderna, Aguilar, Madrid, 1957.

- El principio general de la buena fe, Civitas, Madrid, 1982.

WIELING, Hans Joseph. "Venire contra factum proprium e colpa verso se stesso", en Rass.dir.civ, 1994.

WiLliamson, Oliver. The Economic Institutions of Capitalism, traducción por Eduardo Suárez. Fondo de Cultura Económica. México. 1989.

- Transaction cost economics: the governance of contractual relations", en Journal of Law and Economics. N²2, 1979.

WilLinston, Samuel. The law of contracts. II. Baker, Voorhis \& Co. New York. 1920.

WiNFIELD, A text book of the Law of Torts, 389, London, 1948.

Yzquierdo Tolsada. Mariano, Sistema de responsabilidad civil contractual y extracontractual. Dykinson. Madrid. 2001.

ZANNONI, Eduardo. El daño en la responsabilidad civil, Astrea, Buenos Aires, 1982.

ZAsIus, Ulrico. Opera omnia: Responsorum iuris sive consiliorum duos complectens libros... Consilium II, T.VI, Francofurti, M.D.LXXXX.

Zimmermann, Reinhard. El nuevo derecho alemán de obligaciones. Un análisis desde la historia y el derecho comparado, Bosch, Barcelona, 2008.

- Rasgos fundamentales de un derecho europeo", en Estudios de derecho privado, Civitas, Madrid, 2000. 